The Netherlands

\title{
Trying-out. An Anatomy of Dutch Whaling and Sealing in the Nineteenth Century, 1815-1885
}

Schokkenbroek, J.C.A

\section{Citation}

Schokkenbroek, J. C. A. (2008, April 2). Trying-out. An Anatomy of Dutch Whaling and Sealing in the Nineteenth Century, 1815-1885. Retrieved from https://hdl.handle.net/1887/12669

Version:

Not Applicable (or Unknown)

License:

Licence agreement concerning inclusion of doctoral thesis in the Institutional Repository of the University of Leiden

Downloaded from: $\quad$ https://hdl.handle.net/1887/12669

Note: To cite this publication please use the final published version (if applicable). 
00 voorwerk 19-02-2008 13:57 Pagina 1

TRYING-OUT

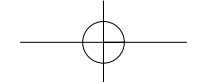


00 voorwerk 19-02-2008 13:57 Pagina 2

For Josje 


\title{
TRYING-OUT
}

An Anatomy of Dutch Whaling and Sealing

in the Nineteenth Century, 1815-1885

\author{
PROEFSCHRIFT \\ ter verkrijging van \\ de graad van Doctor aan de Universiteit Leiden, \\ op gezag van Rector Magnificus prof. mr. P.F. van der Heijden, \\ volgens besluit van het College voor Promoties \\ te verdedigen \\ op woensdag 2 april 2008 \\ klokke 16.15 uur. \\ door \\ Justus Carolus Antonius Schokkenbroek \\ Geboren te Nijmegen \\ in 1961
}

aksant

Amsterdam

2008 
Promotiecommissie:

promotores: Prof.dr. F.S. Gaastra

Prof.dr. L. Hacquebord (Rijksuniversiteit Groningen)

referent: $\quad$ Stuart M. Frank, Ph.D. (New Bedford Whaling Museum, Massachussetts, USA)

overige leden: Prof.dr. J.R. Bruijn

Prof.dr. C.A. Davids (Vrije Universiteit Amsterdam)

Dr. H.J. den Heijer

This publication has been made possible through the generosity of Fonds Directie der Oostersche Handel en Reederijen, Stichting Vaderlandsch Fonds ter Aanmoediging van 's-Lands Zeedienst, and Stichting Admiraal van Kinsbergenfonds.

A trade edition of this dissertation is published by Aksant Academic Publishers with IsBN 978-905260-283-7. 


\section{Table of Contents}

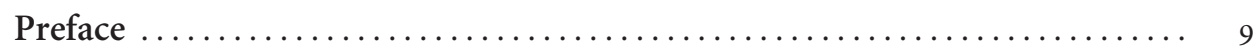

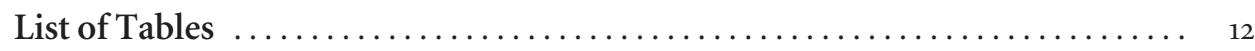

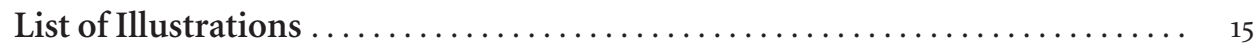

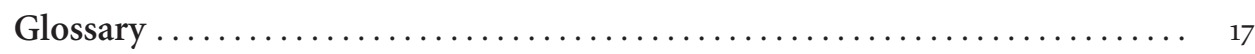

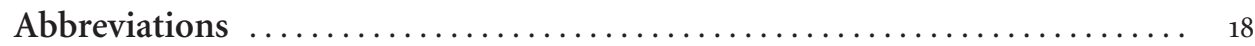

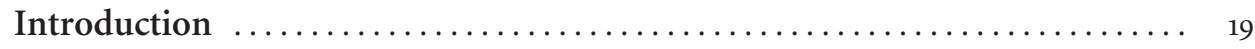

\section{Chapter 1:}

Dutch Whaling and Sealing in the Seventeenth and Eighteenth Centuries .... 26

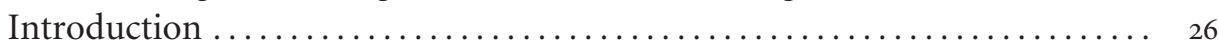

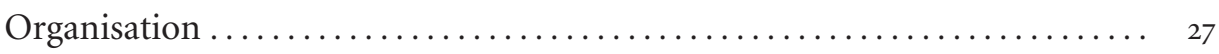

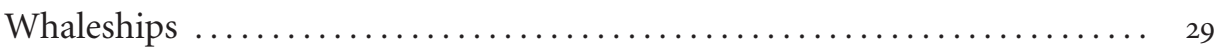

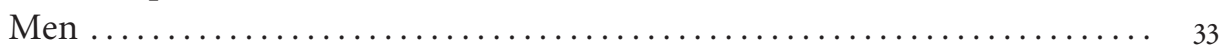

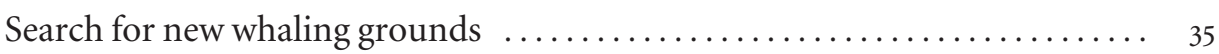

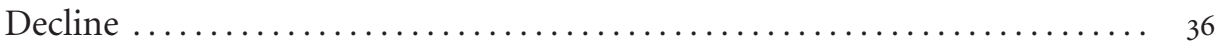

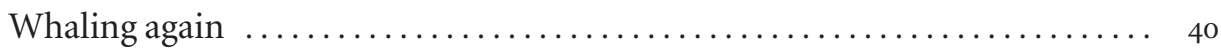

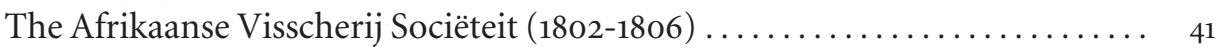

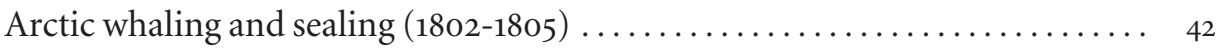

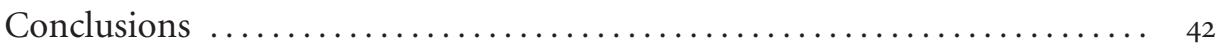

\section{Chapter 2:}

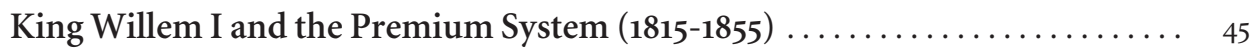

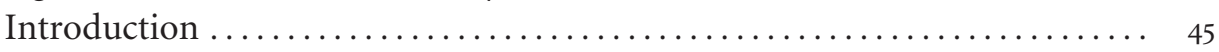

International developments in the nineteenth century $\ldots \ldots \ldots \ldots \ldots \ldots .45$

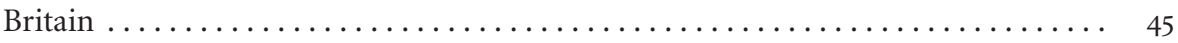

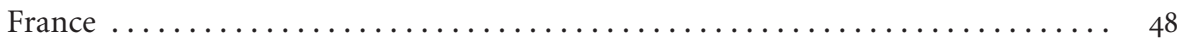

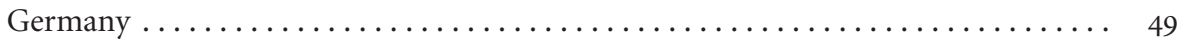

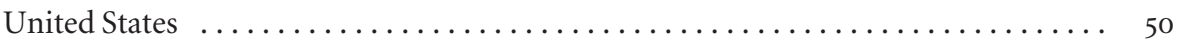

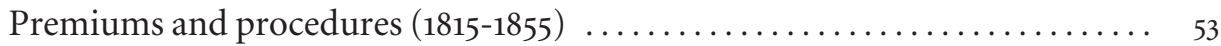

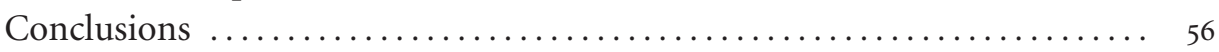




\section{Chapter 3:}

Nineteenth-Century Dutch Whaling in the South Seas (1827-1849) . . . . . 68

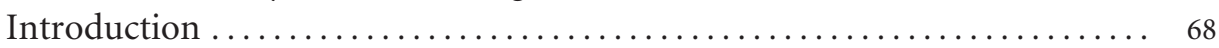

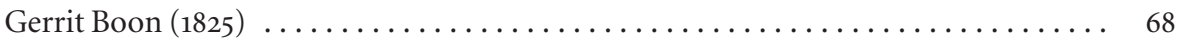

Nederlandsche Handel-Maatschappij (Dutch Trading Company, NHM) (1827-1830) . 69

Rotterdam: De Vereeniging tot Walvischvangst om de Zuid (Merchant House

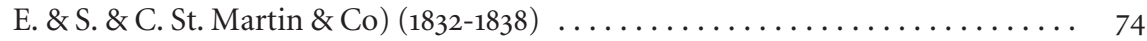

Miscellaneous private initiatives ............................. 77

Amsterdam: Nederlandsche Walvischvisscherij Maatschappij (1843) ......... 81

Amsterdam: Reederij voor de Zuidzee Walvischvangst (Reelfs Brothers) (1843-1849) 84

The aftermath of Dutch South Seas whaling $\ldots \ldots \ldots \ldots \ldots \ldots \ldots \ldots \ldots$

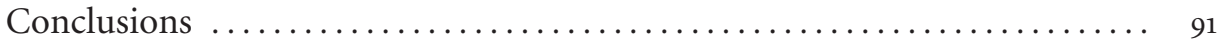

\section{Chapter 4:}

Nineteenth-Century Dutch Whaling and Sealing in the Arctic (1815-1885)

Introduction 93

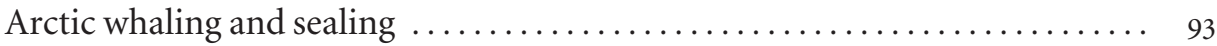

Amsterdam: Barend van Spreekens $(1815-1819) \ldots \ldots \ldots \ldots \ldots \ldots \ldots \ldots \ldots \ldots$

Wormerveer: Jan Vas \& Company $(1820-1825) \ldots \ldots \ldots \ldots \ldots \ldots \ldots \ldots \ldots$

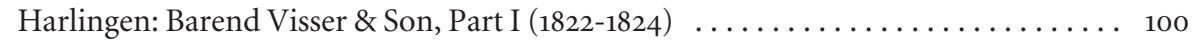

Harlingen: The Groenlandse en Straatdavidse Visscherij Sociëteit (1825-1834） … 103

Rotterdam: Nederlandsche Maatschappij voor Walvischvangst $(1825-1827) \ldots \ldots \ldots 121$

Harlingen: Barend Visser \& Son, Part II $(1835-1864) \quad \ldots \ldots \ldots \ldots \ldots \ldots \ldots \ldots \ldots$

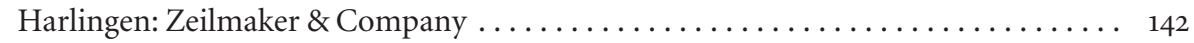

Purmerend: Nicolaas Brantjes \& Smit $(1851-1885) \ldots \ldots \ldots \ldots \ldots \ldots \ldots \ldots \ldots \ldots$

Rotterdam: Nederlandsche Walvischvaart N.V. $(1870-1872) \ldots \ldots \ldots \ldots \ldots \ldots$

Enkhuizen: Nieuwe Noordsche Compagnie $(1877) \ldots \ldots \ldots \ldots \ldots \ldots \ldots$

Conclusions ................................... 155

\section{Chapter 5:}

Ships and men. Driving and Floating Forces ................... 157

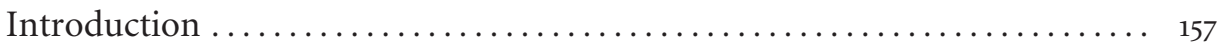

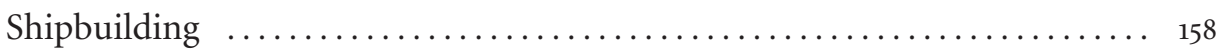

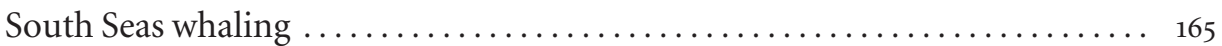

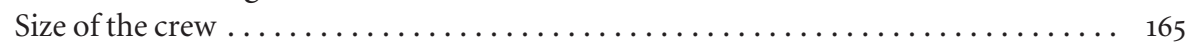

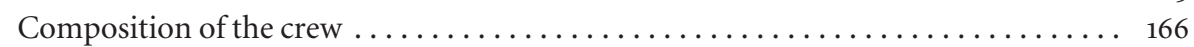

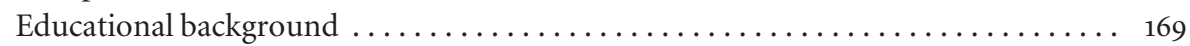

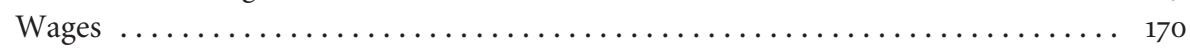

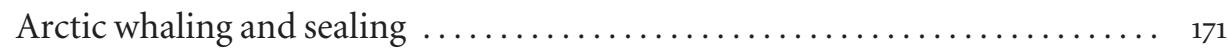

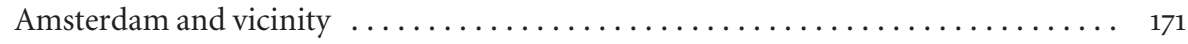

Jan Vas \& Company ................................ 173 


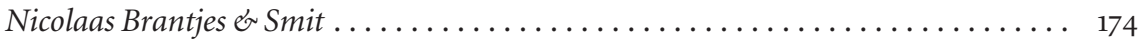

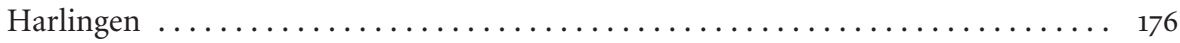

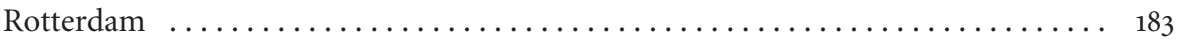

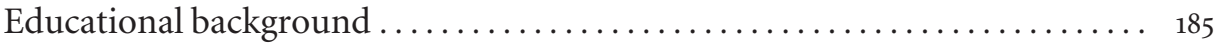

The Nautical College in Amsterdam $\ldots \ldots \ldots \ldots \ldots \ldots \ldots \ldots \ldots \ldots \ldots$

The Nautical College in Harlingen . . . . . . . . . . . . . . . . . . . . . . 190

Dogwatch .................................. 197

Wages ......................................... 199

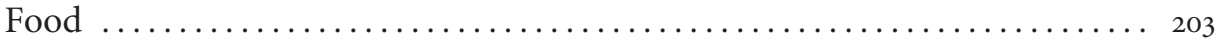

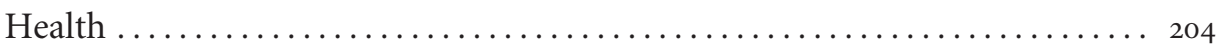

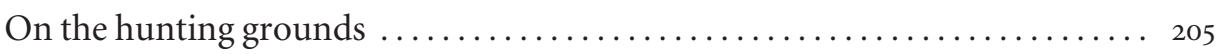

Liberty days . . . . . . . . . . . . . . . . . . . . . . . . . 213

Conclusions $\ldots \ldots \ldots \ldots \ldots \ldots \ldots \ldots \ldots \ldots \ldots \ldots \ldots \ldots \ldots \ldots \ldots \ldots$

\section{Chapter 6:}

Clients, Commodities, and Distribution $\ldots \ldots \ldots \ldots \ldots \ldots \ldots \ldots \ldots \ldots$

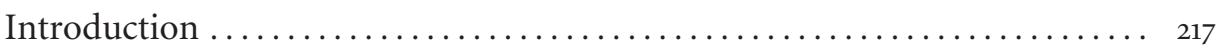

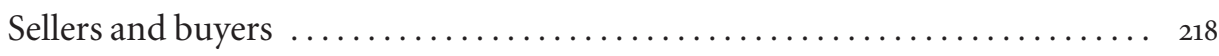

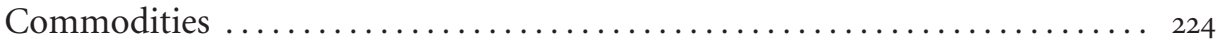

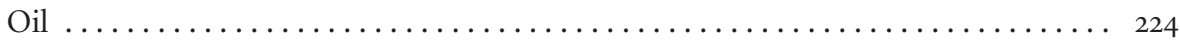

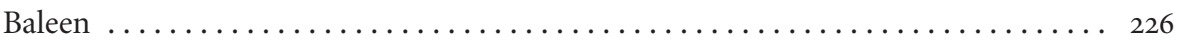

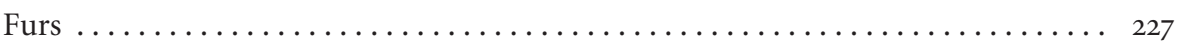

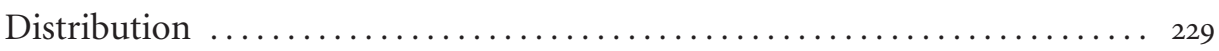

Conclusions $\ldots \ldots \ldots \ldots \ldots \ldots \ldots \ldots \ldots \ldots \ldots \ldots \ldots \ldots \ldots \ldots \ldots \ldots \ldots \ldots$

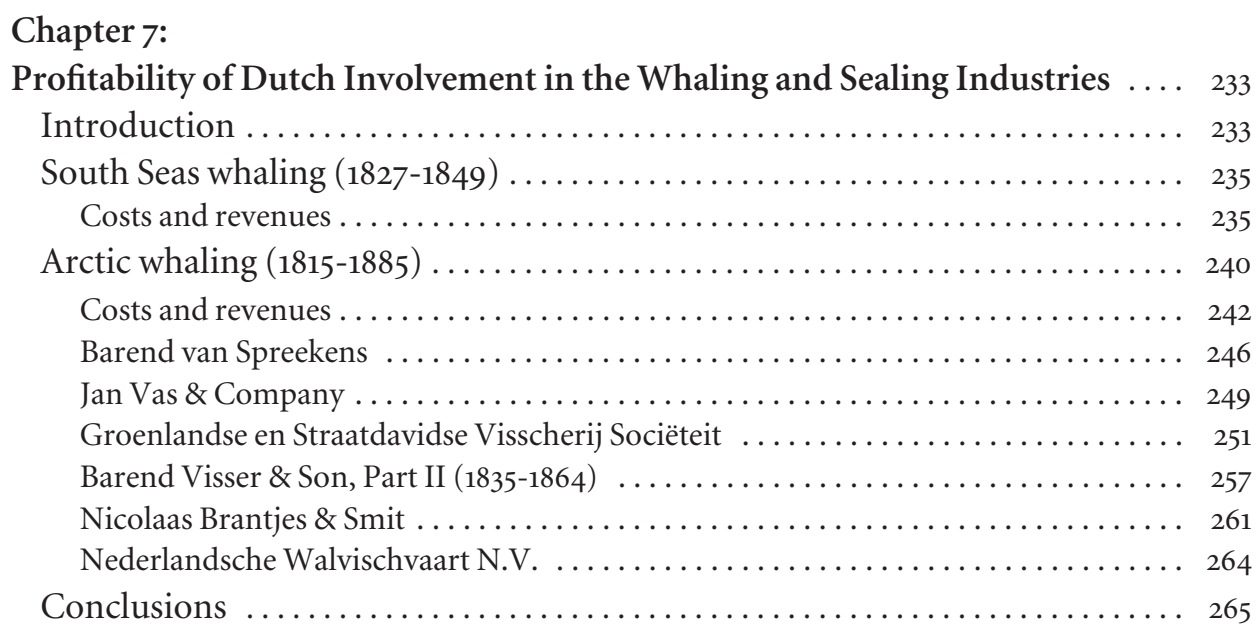




\section{Summaries}

(English, Dutch and German)

\section{Appendices}

Appendix 1: Overview of nineteenth-century Arctic whaling and sealing expeditions under Dutch ownership, $1802-1884$........................ 293

Appendix 2: Numerical overview of Dutch Arctic whaling and sealing expeditions

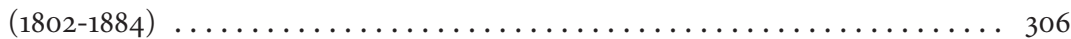

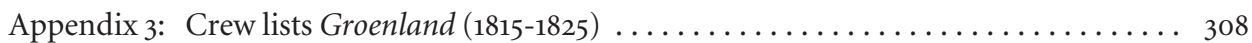

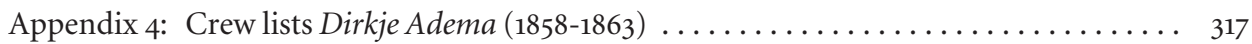

Appendix 5: Overview of pupils of the Nautical College in Harlingen (1842-1864) … ․ 323

Appendix 6: Careers of whalemen educated at the Nautical College Harlingen (1842-1864) • 330

Appendix 7: Results of auctions of whale and seal products $(1831-1838) \ldots \ldots \ldots \ldots \ldots 335$

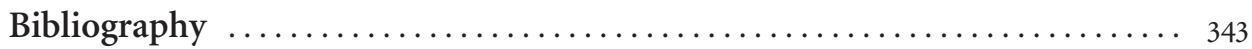

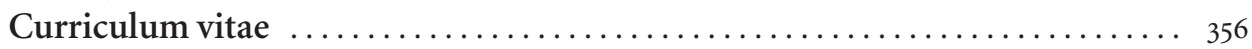

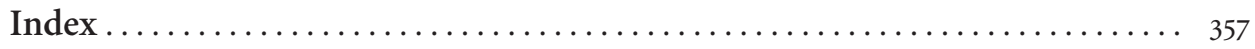




\section{Preface}

During the spring of 2004 I started research for a book on the history of naval architectural developments in the Netherlands and their impact on Dutch whaleships. In my quest for information I was confirmed in my opinion that a fair amount was written about Dutch whaling during the seventeenth and eighteenth centuries. Likewise, an impressive number of articles and books dwelling on modern, twentieth-century whaling had been published in more recent years. Amid these two fields of study the gap in maritime historiography regarding the nineteenth century could hardly be overlooked. As I will demonstrate in the following pages, this gap could not be caused by sheer lack of sources. Granted, no archival records seem to have survived directly related to the organisation and finances of the companies and individuals discussed in this thesis. However, thanks to an abundance of other types of sources I have been able to present - figuratively speaking - a dissection, an anatomy rather, of the body of people involved in conducting whaling and sealing activities to the Arctic region and the South Seas during the period 1815 to 1885 . These people were of royal descent, had governmental responsibilities, or had entrepreneurial and navigational skills. All in all, the following pages will show a wide array of characters and nationalities.

Despite the existence of three handfuls of logbooks and journals, sealers and whalers apparently seldom wrote about their greasy business. Thus, I had to rely on memoirs of whalemen and sealers, conveyed to third parties many years after the actual voyages had occurred. Also, I did not come across a large number of contemporary man-made artefacts related to the two industries. When appropriate I used the few objects I did find as historical sources, or as tangible manifestations of man's awareness of the relative importance of the whale and seal hunt.

It was by no means difficult to conceive the idea for this thesis. In contrast, to find and, consequently, analyse the data retrieved from the many archives was much harder and could not have been done without the assistance of many old and new friends and colleagues in this country and abroad. Many employees of museums, archives, and libraries frequently went out of their way to smooth the path to discoveries of data. The flexibility and interest of staff at the Nederlands Scheepvaartmuseum Amsterdam, my current employer, was unsurpassed. 
First and foremost, thanks are due to Willem Bijleveld and Henk Dessens, director and deputy director, respectively, of the Nederlands Scheepvaartmuseum Amsterdam. Both men were instrumental in supporting my research from the outset. Throughout the many months of research and writing, Willem continuously demonstrated keen interest in my findings. I also vividly remember the various enlightening discussions with Henk. Secondly, I wish to express my gratitude to the Board of Trustees of this museum for facilitating means for my research. Thirdly, my colleagues Elisabeth Spits, Diederick Wildeman each in their own way, frequently showed interest in my intellectual pursuit. Elzelien Streef and Anton Oortwijn, together with Ok Uhlenbeck and Louis Horneman, two volunteers of the museum's library, were tireless in providing books and articles. A special word of gratitude is directed to Evelien Ros, who went through the pain-staking job of compiling the index.

Thanks are also due to a number of museum colleagues outside the Nederlands Scheepvaartmuseum. I am very grateful to Hugo ter Avest of the municipal museum Het Hannemahuis in Harlingen, for putting me up and putting up with me; to curator Hester Wandel of the Zaans Museum, for retrieving data concerning artefacts in that museum's collection; to René Dekker, Kees van de Blom, and Nicole Voogd, affiliated with Naturalis, Leiden, for facilitating research and photography; to Luuk Eekhout of Het Nationaal Rijtuigenmuseum in Leek; and to Jan Piet Puype, Mark van Hattum, and Harm Steevens of the Legermuseum in Delft. Also, thanks are due to Ron Brand, librarian at the Maritiem Museum Rotterdam, and Ben Schoenmaker of the Nederlands Instituut voor Militaire Historie, The Hague. I also would like to express my gratitude to mrs. Ineke Vonk who very kindly shared the results of her research on whalemen from the island of Texel with me, and to Kees Paul who sent me copies of his documents regarding the Logan.

Abroad, director Ann Brengle and her staff, in particular, at the New Bedford Whaling Museum (NBWM) in New Bedford, Massachusetts, were extremely stimulating and helpful. Furthermore, I received much-appreciated assistance from Mike Dyer and Laura Perreira of the Research Library of the NBWM.

My trip to the German island of Föhr in September of 2006 was extremely rewarding, not in the least because of the kind and hospitable manner in which Jutta Kollbaum-Weber, director of the local Dr. Carl Häberlin-Friesenmuseum in Wyk auf Föhr, and her staff welcomed me. Later, in the summer of 2007, the Ferring-Stiftung kindly invited me to share the results of my research with the islanders.

Over the years I have blatantly abused employees affiliated with a number of archives with my perpetual questions and requests. In Leeuwarden, the provincial archives at Tresoar were of utmost importance. I cordially thank Martin Kwast, Otto Weijsenfeld, Evelien Knop and Marjan Leeuwerke, Civil servants employed by the City of Harlingen. They wholeheartedly welcomed me every time I came to work with 
their rich municipal archival records. No less committed to my cause were the employees of the municipal archives in Amsterdam. I would specifically like to thank Pieter Flinkenflögel for being such a fine intermediary between me and the sources. In the municipal archives at Koog aan de Zaan, Bob Kernkamp was of invaluable help regarding the deployment of sources. The municipal archives in Rotterdam, though less widely explored, were a treasure chest thanks to Marcia Zaaijer and her helpful colleagues. In archives abroad I benefited from the good services provided by colleagues in New Bedford and Mystic Seaport Museum, Mystic, Connecticut. In Scotland, the electronic highway enabled me to link up with Angus Johnson (Archival Services, Lerwick, Shetland Islands). Angus very kindly checked contemporary sources for data on Bottemanne's activities in and around Lerwick in the 1870 s, although in vain.

On the other side of the Atlantic, I am much indebted to John Curtis Perry (Fletcher School of Law \& Diplomacy, Tufts University, Medford, Massachusetts) and Felipe Fernandez-Armesto (History Department, Tufts University) for their hospitality, friendship, and willingness to share their wisdom. I am equally grateful to Jelle van Lottum for making a map of the Arctic whaling grounds and to Eric Stannard, who copyedited my English and remained cheerful throughout the process.

Furthermore, I am most grateful to that group of fine individuals who, while representing themselves and not so much their institutions, have shared their talents, knowledge, and ideas through correspondence or via conversation. I express my gratitude to my friends Marc van Berkel and Peter Diebels, my mother Anke Schokkenbroek-Moné, my in-laws David Smit and Jeanne Smit-Kwint, and to my American colleagues and friends Judith N. Lund, Gare B. Reid, Lisa Davidson, Jeff Davis, Bill Peterson (senior curator, Mystic Seaport Museum), James Carlton, Glenn Gordinier (both involved in the Mystic Williams College Program in Mystic, Connecticut), Dan Finamore, Sam Scott, and George Schwartz (the "three graces" at the Maritime History Department, Peabody Essex Museum, Salem, Massachusetts) and Klaus Barthelmess (Cologne). I also thank my publisher Marti Huetink, for providing ideas and paper. Finally, I wish to thank Remmelt Daalder and Piet Middelkoop, who, as two of very few, dared to read the manuscript front to back - and survived.

Jeanine, Janneke, Josefien, and Justus; as your father I could not be more proud on how the four of you managed to cope with the hectic frenzy I frequently - through my time consuming and energy consuming activities - have imposed upon you. I am indebted to all four of you for the patience you so eminently displayed. I wish to conclude by expressing my heartfelt thanks to Josje, my 'best three quarters'. She was there for me on the many moments I could not be there for her. It is to her - of course - that I dedicate this thesis. 


\section{List of Tables}

Table 1.1: Number of Dutch whaleships lost in the ice $(1664-1685) \ldots \ldots \ldots \ldots \ldots 2$

Table 1.2: Whaling expeditions destined for Greenland and fitted out around the years

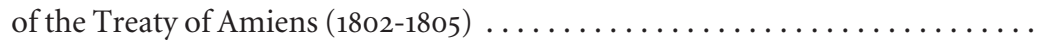

Table 2.1: Calculation of total of governmental subsidies to Dutch whaling and sealing expeditions conducted from Harlingen $(1822-1855) \ldots \ldots \ldots \ldots \ldots \ldots \ldots \ldots \ldots \ldots \ldots \ldots$

Table 3.1: Catches of the ship Logan, sailing for the NHM $(1827-1830) \ldots \ldots \ldots \ldots \ldots$

Table 3.2: Overview of whaling expeditions fitted out by the Rotterdam merchant house E. \& S. \& C. St. Martin \& Co. $(1832-1838) \ldots \ldots \ldots \ldots \ldots \ldots \ldots \ldots \ldots \ldots$. . . . . . . . 77

Table 3.3: Overview of whaling expeditions fitted out by the Amsterdam Reederij voor de Zuidzee Walvischvangst (Reelfs Brothers) $(1844-1849) \ldots \ldots \ldots \ldots \ldots . \ldots 8$

Table 3.4: Whaling expeditions to the South Seas $(1827-1849) \ldots \ldots \ldots \ldots \ldots \ldots$

Table 3.5: Overview of number of ships, number of expeditions, and catch results in Dutch South Sea expeditions $(1827-1849) \ldots \ldots \ldots \ldots \ldots \ldots \ldots \ldots \ldots \ldots \ldots \ldots \ldots$

Table 4.1: Whaling expeditions to Spitsbergen fitted out by Barend van Spreekens (1815-1819) 96

Table 4.2: Whaling expeditions to Spitsbergen and the Davis Strait fitted out by Jan Vas \&

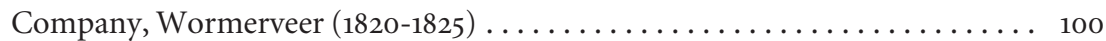

Table 4.3: Whaling and sealing expeditions to the Davis Strait fitted out by Barend Visser \&

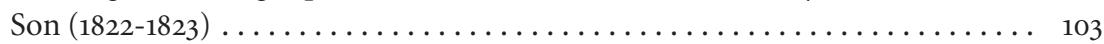

Table 4.4: Whaling and sealing expeditions to Spitsbergen and the Davis Strait fitted out by the Groenlandse en Straatdavidse Visscherij Sociëteit in Harlingen (1825-1834) . . 118

Table 4.5: Whaling and sealing expeditions to the Davis Strait fitted out by the Nederlandsche Maatschappij voor Walvischvangst $(1825-1827) \ldots \ldots \ldots \ldots \ldots \ldots$

Table 4.6: Whaling and sealing expeditions to Jan Mayen Island and Spitsbergen fitted out

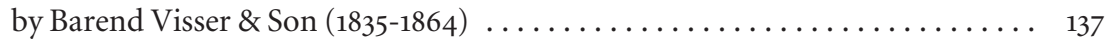

Table 4.7: Whaling and sealing expeditions to Jan Mayen Island and Spitsbergen fitted out

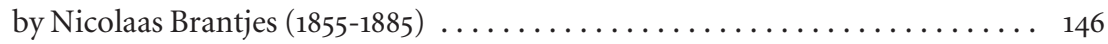

Table 4.8: Whaling expeditions to Iceland fitted out by the Nederlandsche Walvisch-

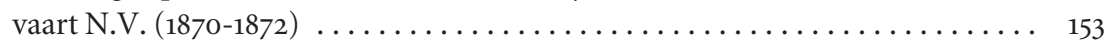

Table 5.1: Composition of the Scottish whaling and sealing fleet $(1868) \ldots \ldots \ldots \ldots$

Table 5.2: Origin of crew recruited by Barend van Spreekens $(1815-1819) \ldots \ldots \ldots \ldots$

Table 5.3: Origin of crew recruited by Jan Vas \& Company $(1820-1825) \ldots \ldots \ldots \ldots \ldots$

Table 5.4: Number of crew on board whaleships fitted out in the Amsterdam region and destined for the Arctic region $(1815-1866) \ldots \ldots \ldots \ldots \ldots \ldots \ldots \ldots \ldots \ldots \ldots \ldots \ldots \ldots \ldots$ 
Table 5.5: Number of crew on board whaleships fitted out in Harlingen and destined for

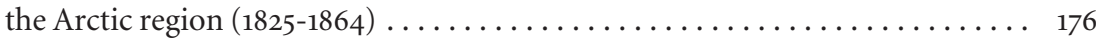

Table 5.6: Origin of the crew members of the galliot Harlingen under Captain Klaas

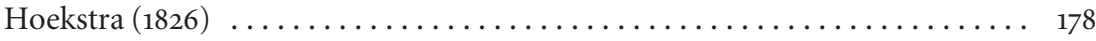

Table 5.7: Crew list of the Spitsbergen (II) under Captain Johan Both (ca. 1845) . . . . . 180

Table 5.8: Origin of crew members of Dirkje Adema (1858-1863) . . . . . . . . . . 181

Table 5.9: Origin of crew members on Arctic voyages, divided into Dutchmen and

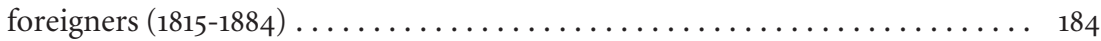

Table 5.10: Pupils from the Amsterdam Nautical College employed by the Nederlandsche Maatschappij voor Walvischvangst $(1825-1827) \ldots \ldots \ldots \ldots \ldots \ldots \ldots \ldots$

Table 5.11: Pupils from the Nautical College in Amsterdam employed by the Groenlandse en Straatdavidse Visscherij Sociëteit $(1827-1830) \ldots \ldots \ldots \ldots \ldots \ldots \ldots \ldots$

Table 5.12: Number of pupils annually employed in whaling and sealing off Greenland and the total number of pupils at the Nautical College in Harlingen (1844-1864) . . 194

Table 5.13: Practical experience of students at the Nautical College in Harlingen who pursued careers in whaling $(1844-1864) \ldots \ldots \ldots \ldots \ldots \ldots \ldots \ldots \ldots$

Table 6.1: Auction expenditures on whale and seal products by main customers

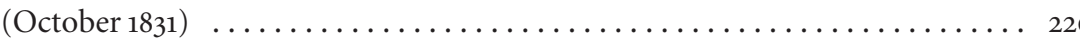

Table 6.2: Auction expenditures on whale and seal products by main customers

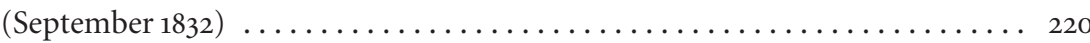

Table 6.3: Auction expenditures on whale and seal products by main customers

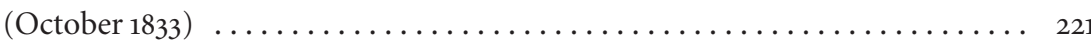

Table 6.4: Auction expenditures on whale and seal products by main customers

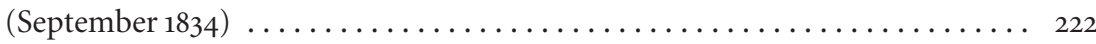

Table 6.5: Auction expenditures on whale and seal products by main customers

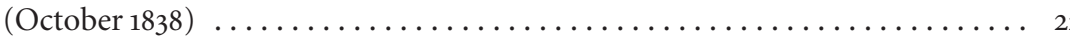

Table 6.6: Occupations of some of the Harlingen-based clients present at auctions

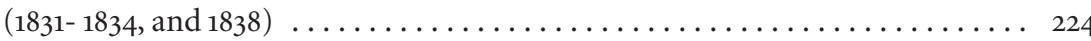

Tabel 7.1: Costs and revenues of whaling expeditions with Logan, Captain Reuben F. Coffin, to the South Seas $(1827-1830) \ldots \ldots \ldots \ldots \ldots \ldots \ldots \ldots \ldots \ldots \ldots \ldots \ldots$

Tabel 7.2: Costs and revenues of whaling expeditions to the South Seas fitted out by

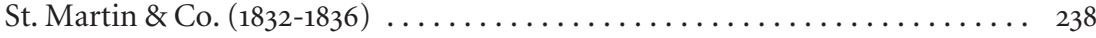

Tabel 7.3: Costs and revenues of whaling expeditions to the South Seas fitted out by Reederij voor de Zuidzee Walvischvangst $(1844-1849) \ldots \ldots \ldots \ldots \ldots \ldots \ldots . \ldots 239$

Table 7.4: Prices of whale oil ('Spektraan') (1818-1851) . . . . . . . . . . . . . 244

Table 7.5: Average prices for whale and seal products purchased at auctions in Harlingen during the years 1831-1834, and 1838 , compared with average prices quoted by

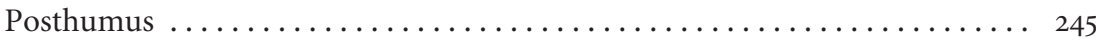

Table 7.6: Costs and revenues of whaling expeditions fitted out by Barend van Spreekens

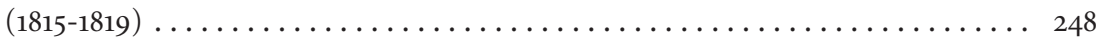

Table 7.7: Costs and revenues of whaling expeditions fitted out by Jan Vas \& Company

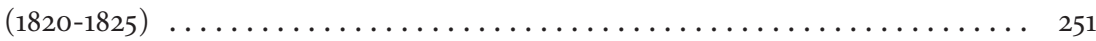

Table 7.8: Governmental subsidies issued for whaling expeditions fitted out by the Groenlandse en Straatdavidse Visscherij Sociëteit in Harlingen (1825-1834) . . . 
Table 7.9: Revenues of whaling and sealing expeditions to Spitsbergen and the Davis Strait fitted out by the Groenlandse en Straatdavidse Visscherij Sociëteit in Harlingen (1826-1834)

Table 7.10: Overview of total revenues of whaling and sealing expeditions fitted out by Barend Visser and Son $(1838 ; 1858-1863)$

Table 7.11: Overview of costs and revenues of whaling and sealing expeditions fitted out by

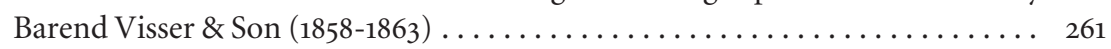

Table 7.12: Overview of catches and revenues of whaling and sealing expeditions fitted out

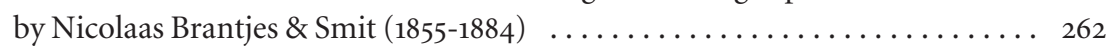

Table 7.13: Overview of costs and revenues of whaling expeditions to Iceland fitted out by the Nederlandsche Walvischvaart N.V. (1870-1872) ............... 264

Table 7.14: Overview of costs and revenues of Dutch whaling in the Arctic (1815-1884) . . . 265 


\section{List of Illustrations}

1. Dutch bay-whaling in the Arctic, ca. 1621. The whaleship is moored in the bay. In the foreground whaleboats with crew are hunting whales. Dead whales are towed to the shore, where processing takes place. The exact location of this scene is still debated. Painting on canvas by Cornelis Claesz. van Wieringen (ca. 1580-1633). Courtesy of the New Bedford Whaling Museum (Kendall Collection) $\ldots \ldots \ldots \ldots \ldots \ldots \ldots \ldots$

1a. Detail of painting by Cornelis Claesz. van Wieringen. During the first decades of the seventeenth century Dutch whaling entrepreneurs deployed Basque whalemen as harpooners and instructors. The artist depicts a number of Basques taking some rest. Courtesy of the New Bedford Whaling Museum (Kendall Collection) . . . . . . . .

2. Dutch whaling near the ice floes, circa 1700. As of the last quarter of the seventeenth century Dutch whalemen processed the whales along side their ships. Blubber was stored away aboard, in casks. Painting on canvas, attributed to Abraham Storck. Nederlands Scheepvaartmuseum Amsterdam. Inventory number A.0014 . . . . . . .

3. Oil cookery in the Netherlands, ca. 1765. This delftware plate, number 12 in a series of 12 plates produced by the factory Porceleyne Bijl after engravings by A. van der Laan and S. van der Meulen, shows how blubber transported from the Arctic whaling grounds, was processed in large ovens in the Netherlands. These cookeries were located mainly in Zaandam, Oostzaan, Jisp and other places north of Amsterdam. Nederlands Scheepvaartmuseum Amsterdam. Inventory number A.5130 (12) . . . .

4. Portrait of King I, ca 1820. The King has played a crucial part in supporting and sustaining different types of industries. Engraving by Willem van Senus (1773-1851). Zuiderzeemuseum. Inventory number 013110

4a. Detail of the engraving by Willem van Senus. Next to the herring fishery, whaling is included in the engraving - a clear indication that the artist must have been familiar with the King's support of these two maritime industries $\ldots \ldots \ldots \ldots \ldots \ldots \ldots$

5. Map of voyages of Dutch whaleships to the South Seas, 1827-1849. This map shows the various courses set by the Dutch whaling expeditions to Dutch East Indian waters and the Pacific Ocean.

Derived from F.J.A. Broeze, 'Whaling in the Southern oceans. The Dutch quest for Southern whaling in the nineteenth century', Economisch-en sociaal-historisch Jaar-

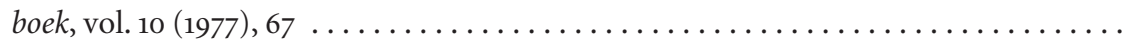

6. Mansion of the Vas family, Wormerveer, ca. 1800. Watercolour by an anonymous artist. Archief Koog aan de Zaan . . . . . . . . . . . . . . . . . . . . . . 
7. The whaleship Harlingen stuck in the ice of Melville Bay (Baffin Bay) in August 1826. This ship, built in 1826 on Johan Alta's shipyard in Harlingen, was lost on its maiden voyage. After abandoning his ship captain Klaas Hoekstra and his crew first found shelter on board the Dundee, master Robert Duncan. This vessel is depicted in the background. Hoekstra eventually returned home in August 1827. Painting on canvas by Herman Siderius (1819-1892), ca. 1850.

Nederlands Scheepvaartmuseum Amsterdam. Inventory number 2005.1543 . . . . 107

8. Portrait of whaling Captain Klaas Hoekstra, ca. 1810. Painting on panel by an anony-

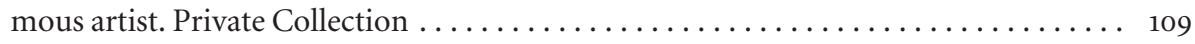

9. Woollen hat of Captain Klaas Hoekstra, ca. 1826. After abandoning his ship Harlingen, Hoekstra and his crew were forced to travel through parts of Greenland. The captain wore this hat while traversing this barren country. Hannemahuis Harlingen. Inventory number $000267 \ldots \ldots \ldots \ldots \ldots \ldots \ldots$

10. Portrait of master C.J. Bottemanne (1829-1906), ca. 1885. Caspar Josephus Bottemanne was the first Dutch whaleman to actually introduce new technology in whaling and sealing. Photograph.

Nederlands Scheepvaartmuseum Amsterdam

11. Depiction of the Nautical College in Amsterdam, ca. 1790. During the nineteenth century several whaling companies requested pupils from the Nautical College in Amsterdam. Painting on panel. Anonymous artist. Loan from private collection. Nederlands Scheepvaartmuseum Amsterdam. Inventory number RB.0452 . . . . . . .

12. Portrait of a pupil from the Nautical College in Amsterdam, ca. 1830. Pupils involved in the whaling and sealing industries must have been dressed the way this anonymous pupil is portrayed. Lithograph by Jean Baptiste Madou (1796-1877).

Nederlands Scheepvaartmuseum Amsterdam. Inventory number A.1080 (o1) ......

13. Page from journal kept by master Hendrik Rickmers on board the whaleship Spitsbergen (II), 1832. Between 1830 and 1841, Rickmers served the Groenlandse en Straatdavidse Visscherij Sociëteit en Barend Visser \& Son. He kept journals of all his whaling voyages.

Dr. Carl Häberlin Friesenmuseum, Wyk auf Föhr, Föhr (Germany)

14. Map of the whaling and sealing grounds in the Arctic. This map, compiled by Jelle van Lottum, is based on data derived from the journals kept by Hendrik Rickmers between 1830 and 1840 . Rickmers only mentions latitudes, no longitudes. Therefore, the locations indicated on this map are estimates 


\section{Glossary}

Duim $=$ inch $=2.54$ centimeters

$\mathrm{El}=68.8$ centimeters (Amsterdam el)

Fust $=$ vat, or barrel.

Kwarteel $=232.8$ litres

N.V. (Naamloze Vennootschap) = stockholding company

Partenrederij = company with fractional ownership

Resident $=$ high ranking European civil servant in the Dutch East Indies

Steekan $=1 / 12$ of a kwarteel

Wanvangst $=$ the return of a whaleship empty 


\section{Abbreviations}

FM

SAA

GAH

GAR

GS

$\mathrm{HH}$

$\mathrm{KB}$

LC

NA

NBMW

NHM

TL

WS

Dr. Carl Häberlin Friesenmuseum, Wyk auf Föhr, Föhr (Germany) Stadsarchief Amsterdam (municipal archives Amsterdam)

Gemeentearchief Harlingen (municipal archives Harlingen)

Gemeentearchief Rotterdam (municipal archives Rotterdam)

Gedeputeerde Staten van Friesland (Representatives of the Province of Friesland)

Gemeentemuseum Het Hannemahuis, Harlingen (Municipal Museum)

Koninklijk Besluit (Royal Decree)

Leeuwarder Courant

Nationaal Archief (National Archives, The Hague)

New Bedford Whaling Museum, New Bedford, Massachussetts (USA)

Nederlandsche Handel-Maatschappij

Tresoar Leeuwarden

Waterschout (Harbour master) 


\section{Introduction}

In Dutch historiography, whaling and sealing seem to have drawn less attention than the respective trading companies, the admiralties, and subsequent activities of the Royal Netherlands Navy, or the endeavours of the merchant fleet setting sail for the Mediterranean or Baltic regions. Dutch whaling and sealing activities during the nineteenth century in particular have been almost completely neglected so far. ${ }^{1}$

This situation not only relates to historiography in general, but one may also discern this neglect (or modest attention at best) in a rather unexpected field: the realm of Dutch maritime historiography. Nearly all studies about whaling and sealing that have seen the light during the last 30 years or so concentrate either on the heyday of the 'old' seventeenth- and eighteenth-century whaling expeditions to the Arctic, or on the brief, albeit intensive involvement of the Netherlands in modern, post-war whaling in the Antarctic waters during the period 1946-1964. This statement is corroborated by a number of fairly recently published overviews regarding Dutch maritime historiography. In 1994 Louwrens Hacquebord presented the harvest of one hundred years of historical research concerning Dutch whaling. ${ }^{2}$ In this overview - a lengthy article with a close to conclusive listing of publications hidden in the annotations - Hacquebord mentioned Cornelis de Jong and Frank Broeze and their works on nineteenth century whaling. ${ }^{3}$ His remarks about the writings of the two authors, however, were rather flat. Hacquebord stated:

1. In the index of his widely acclaimed book about the socio-economic history of the Netherlands between 1795 and 1940, I.J. Brugmans adopted no more than two entries on whaling. These entries briefly mention the interest of the Nederlandsche Handel-Maatschappij (NHM) in South Sea whaling, and King Willem I's financial participation in the whaling company of Harlingen, respectively. See I.J. Brugmans, Paardenkrachten mensenmacht. Sociaal-economische geschiedenis van Nederland, 1795-1940 ('s-Gravenhage 1976; reprint of 1960 edition), 110, 154. More recently, J.L. van Zanden and A. van Riel published their important work entitled Nederland 1780-1914. Staat, instituties en economische ontwikkeling (Amsterdam 2000). While discussing at length the financial involvement of the national government and king in numerous industries, the authors do not discuss whaling at all.

2. L. Hacquebord, 'Van Noordse Compagnie tot Maatschappij voor de Walvisvaart. Honderd jaar onderzoek naar de geschiedenis van de Nederlandse walvisvaart', Tijdschrift voor Zeegeschiedenis 13 (1994), no. 1, 19-40.

3. C. de Jong, Geschiedenis van de oude Nederlandse walvisvaart. Three volumes (Pretoria/Johannesburg 
"De Jong beschreef de achteruitgang en de uiteindelijke teloorgang van de Nederlandse walvisvaart in de negentiende eeuw in zijn tweede deel van de Geschiedenis van de oude Nederlandse walvisvaart [...]. F.J.A. Broeze schreef een boeiend artikel over de pogingen die in de negentiende eeuw werden ondernomen, om Nederland aan de Zuidelijke walvisvaart te laten deelnemen"

("De Jong described the recession and eventual decline of Dutch whaling in the nineteenth century $[\ldots]$. Broeze wrote an intriguing article about the attempts, made in the nineteenth century, of the Netherlands participation in Southern whaling"). ${ }^{4}$

He concluded his article with a short chapter on the future of historical whaling research. Albeit the great number of suggestions, ideas, and research projects mentioned there, nothing was devoted to the fact that the nineteenth century deserved more attention than it had received.

Coincidentally, that same year (1994), J.R. Bruijn in his 17-page contribution about the state of naval and maritime history in the Netherlands devoted just one paragraph to whaling historiography. ${ }^{5}$ He mentioned, among others, Cornelis de Jong's magnum opus on the history of 'old' Dutch whaling, Louwrens Hacquebord's multi-disciplinary study of Spitsbergen, Piet Dekker's manifold articles visà-vis whaling masters and their backgrounds, and Ad van der Woude's work on the social and economic history of the Noorderkwartier (the present-day province of North Holland) in which whaling study has been imbedded. Most of these works date from the $1970{ }^{6}{ }^{6}$ Furthermore, recent studies with regard to modern whaling were mentioned by Bruijn as well. ${ }^{7}$ Their numbers have increased over the last de-

1972; 1976-1978). For this study volume II, 449-494 has been very useful; F.J.A. Broeze, 'Whaling in the Southern oceans. The Dutch quest for Southern whaling in the nineteenth century', Economisch-en Sociaal-Historisch Jaarboek (ESHJ), volume 40 (1977), 66-112. It should be noted that no mention was made of Piet Dekker's lengthy, yet fuzzy article on Dutch whaling in the Arctic during the last decade of the eighteenth and first decade of the nineteenth centuries. See P. Dekker, 'De Nederlandse arctische walvisvaart tijdens de Bataafse Republiek', Mededelingen van de Nederlandse Vereniging voor Zeegeschiedenis, no. 38 (August 1979), 40-70.

4. Hacquebord, 'Noordse Compagnie', 22-23.

5. Jaap R. Bruijn, 'The Netherlands', John B. Hattendorf (ed.), Ubi Sumus? The State of Naval and Maritime History (Newport 1994), 227-243; esp. 238.

6. The most important works regarding this period are: S. Hart, 'De eerste Nederlandse tochten ter walvisvaart', Jaarboek Genootschap Amstelodamum, vol. 49 (1957), 27-64 (also in S. Hart, Geschrift en getal. Een keuze uit de demografisch-, economisch-en sociaal-historische studiën op grond van Amsterdamse en Zaanse archivalia, 1600-180o (Dordrecht 1976), 209-246); C. De Jong, Geschiedenis van de oude Nederlandse walvisvaart.; C. de Jong, 'Walvisvaart' in: J.R. Bruijn e.a. (eds.), De Maritieme Geschiedenis van Nederland. Volume 3 (Bussum 1977), 335-352; A.M. van der Woude, Het Noorderkwartier (Wageningen 1972); J.R. Leinenga, Arctische walvisvangst in de achttiende eeuw: de betekenis van Straat Davis als vangstgebied (Amsterdam 1995); J.R. Bruijn, 'De walvisvaart: de ontplooiing van een nieuwe bedrijfstak', in: W. Vroom \& L. Hacquebord (eds.), Walvisvaart in de Gouden Eeuw (Amsterdam, 1988), 16-24; L. Hacquebord, Smeerenburg: het verblijf van Nederlandse walvisvaarders op de westkust van Spitsbergen in de zeventiende eeuw (Amsterdam/Groningen 1984).

7. Bruijn mentioned W.J.J. Boot, De Nederlandsche Maatschappij voor de Walvischvaart (Amsterdam 1987); 
cade. ${ }^{8}$ In this same paragraph on Dutch whaling historiography, one sentence was devoted to nineteenth-century whaling. Bruijn wrote:

"F.J.A. Broeze has demonstrated why the Dutch failed to participate in nineteenthcentury whaling in the Southern Hemisphere".

And, in 1994, Bruijn was right. Except for Frank Broeze's article, based on a wide variety of primary sources, hardly anything else had been published on this era. This will be discussed later. Bruijn then concluded his overview of whaling historiography by stating:

"Further whaling research will probably serve only to refine the available knowledge [my italics]".

This statement is odd as well as challenging. Odd, as Bruijn seemed satisfied with the body of knowledge concerning Dutch whaling and sealing. Moreover, his remark disregards the possibility that new sources about these two intertwined maritime industries may be found and may lead to new interpretations of old facts or even to 'new knowledge' based on hitherto unreleased data.

Seen in a more positive context, Bruijn's remarks are provocative and challenging. As such, his claims about the failure of Dutch whaling in the nineteenth century and the presumed relative unimportance of new whaling research form the basis for the present study of relatively unchartered grounds in Dutch maritime historiography: Dutch involvement in nineteenth-century whaling and sealing both in the Southern Hemisphere and in Arctic waters.

As stated earlier, seventeenth- and eighteenth-century Dutch whale fishery is well-documented and broadly studied. Cornelis de Jong not only followed in the wake of S. Muller Fzn., ${ }^{9}$ but went far beyond the point of presenting 'just an overview' when he wrote down the results of his groundbreaking research on this period. With respect

J.R. Bruijn, 'De Nederlandsche Maatschappij voor de Walvischvaart, 1946-1967', ESHJ 48 (1985), 233-257. He left out an important study with regard to the composition of the crew on board the Dutch factoryships and catcher boats: A.M.C. van Dissel and J.E. Oosterling, 'Aan boord van de 'Willem Barendsz.' Enkele sociale aspecten van de Nederlandse walvisvaart, 1946-1964', Tijdschrift voor Zeegeschiedenis, vol. 5, nr. 2 (oktober 1986), 146-164.

8. Many of these recent publications were written by historians focusing on specific events, persons, or political and economic developments, or by men who were employed in modern whaling, be it on board the factory ships or catcher boats. See for instance W. van der Plas, Katwijkers op de walvisvaart (Katwijk/Krommenie 2002) and A. Schols, Ter walvisvaart. Dagboek van een jonge walvisvaarder op de Willem Barendsz (Leeuwarden 2002). Louwrens Hacqebord remains one of the leading scholars when it comes to old Dutch whaling. Jurjen Leinenga has published his book on Dutch whaling in Davis Strait, while Piet Dekker and the author of this dissertation have written about whaling from an art-historical perspective. These publications are mentioned in the Bibliography.

9. S. Muller FZn, Geschiedenis der Noordsche Compagnie (Utrecht 1874). 
to nineteenth-century whaling, however, much less study has been conducted. In their standard work on modern whaling, J.N. Tønnessen and A.O. Johnson were shortsighted and erroneous when it came to the presence of Dutch whaleships in Northern waters:

"In 1869 and 1875 the Dutch had attempted to resume their whaling activities in these waters [off Iceland] where they had a centuries-old tradition of whaling. These enterprises might have been expected to discourage others to try their hand: company after company went bankrupt, and was forced to go into liquidation. The reason was not a lack of whales, but a lack of technical know-how". ${ }^{10}$

Cornelis de Jong's and Frank Broeze's studies of Dutch nineteenth-century whaling in the Arctic and in the South Seas were heavily focused on catch results (De Jong) or frustrated attempts (Broeze), but have high academic merit. A handful of nineteenthcentury publicists like C. Brandligt, A.J. ten Brink, S.C.J.W. Van Musschenbroek, and A. Beaujon wrote about certain aspects of Dutch whaling in remote areas. Here, authors like S. Haagsma and H. Halbertsma, publishing their articles about Frisian involvement in nineteenth-century whaling, should also be mentioned. ${ }^{11}$ They rarely provide an overview, however, in which the dynamics playing such an important role in the whale fishery - people, ships, finances, know-how - were integrated or analysed in full.

In his three-volume work on 'old' Dutch whaling C. de Jong devoted one chapter of about 50 pages to developments in the Dutch whale fishery after 1813 . He introduced a number of participants, named some of the ships, and (probably the best part of his brief overview) discussed the political, financial, and economic context within which whaling and sealing emerged. In the tables related to this era (in volume III), most numerical data referred to whaling activities taking place during the first few

10. J.N. Tønnessen and A.O. Johnson, The History of Modern Whaling (Berkeley and Los Angeles 1982), 75. Although this translation is a much shortened version of the original, published in Norwegian in four volumes under the title Den Moderne Hvalfangst Historie: Opprinnelse og Utvikling (Oslo/Sandefjord 1959-1970), both authors suggest that the Dutch have tried to resume whaling only in these two years. Not only did the Dutch resume whaling earlier, but the authors also seem to neglect Dutch whaling and sealing off Greenland and Spitsbergen.

11. C. Brandligt, Geschiedkundige beschouwing van de Walvisch-visschery (Amsterdam 1843); A.J. ten Brink, Blik op den hedendaagschen toestand der Europeesche Noordpool-visscherij (Enkhuizen 1876); S.C.J.W. Musschenbroek, 'Cachelot-Visscherij in den Nederlandsch Indischen Archipel', Tijdschrift ter bevordering van Nijverheid, vol. XVIII, part 11 (Haarlem 1877); S. Haagsma, 'Friesland's Groenlandvaart', Ons Zeewezen 1904, 310314; republished in Jaarboek Fries Scheepvaartmuseum en Oudheidkamer (1964/1965), 41-53; H. Halbertsma, 'Uit het zeemansleven van Geert Oenes Dolstra (1792-1886)', Jaarboek Fries Scheepvaatmuseum en Oudheidkamer (1964/1965), 59-61; Anne J. Dijkstra, 'De Groenlands- en Straat Davids-Visserij Sociëteit te Harlingen', Jaarboek Fries Scheepvaartmuseum (1964/1965), 54-58; J. v.d. Weide, 'Het leven aan boord van de Dirkje Adema', Ons Zeewezen 1921. 
years after the Peace of Amiens (1802-1803), or up to 1826 at best. Here again, nineteenth-century Arctic whaling received the most attention, while whaling in the South Seas was only briefly mentioned. ${ }^{12}$

Brandligt, Ten Brink, and Van Musschenbroek were some of the very few contemporaries who wrote about the necessity of Dutch whaling entrepreneurs to explore new whaling grounds in the East Indies. Written about one century later, Frank Broeze's lengthy article on Dutch involvement in the South Seas whale fishery was a brilliant, encompassing (although incomplete) overview of Dutch exploration and exploitation of this specific type of whaling. In my treatise on Dutch whaling activities in Southern waters, his work will be quoted frequently. Some two decades after Broeze's important article - and one year after Bruijn wrote his overview of maritime historiography - C. de Jong contributed to the historiography of Dutch Southern whaling with his publication on Western whaling in the East Indies in the nineteenth century. ${ }^{13}$

The present study intends to push ahead research on Dutch whaling and sealing in the nineteenth century, focusing attention on the very nature of the expeditions. The scope, quality, and profitability of these industries will be discussed, and, where applicable and suitable, compared with those industries in other countries. Much attention will be paid to the people involved in whaling and sealing in this era. In other words, what companies and individuals contributed to nineteenth-century whaling and sealing under the Dutch flag?

To write a new history of Dutch whaling and sealing in the nineteenth century requires developing an innovative approach to the exploration and interpretation of national, municipal and local archives. Moreover, this study goes beyond the exclusive use of written sources: three-dimensional objects - stowed away in private or museum collections - were also occasionally the basis of analysis.

Next to secondary sources, many unknown, or at least hitherto unused or unquoted primary sources were studied and analysed. Crew lists in the archives of the local waterschouten (harbourmasters), notary records, minutes of meetings of town councils, archives related to orphanages, documents regarding nautical colleges and the training, and, consequently, the quality of their pupils during this era, ship's journals and business archives in libraries and museums in the Netherlands and abroad, and a wide array of local and national newspapers, all contained an overwhelming

12. The figures De Jong presented regarding the seal hunting industry after 1830 were murky and lack transparency. See for example his Oude Nederlandse walvisvaart, vol. II, 283.

13. See citations in note 3 . See also C. de Jong, Westerse walvisvangst in Oost-Indië in de $19^{e}$ eeuw (Amsterdam 1995), and S.J. de Groot, 'Het voorkomen en de vangst van walvissen en walvisachtigen in de Indo-Australische archipel, en de zaak van de walvisvaarder "Costa Rica Packet” (1891-1897)', Mededelingen van de Nederlandse Vereniging voor Zeegeschiedenis, vol. 30 (1975), 20-29. 
body of new data. Contrary to what Bruijn assumed, these primary sources provided not only a refinement of available knowledge, they enabled a filling of the gap between two well-documented eras - the seventeenth-eighteenth centuries and the twentieth century.

Chapter 1 briefly discusses the nature of Dutch whaling and sealing as conducted in the seventeenth, eighteenth and very early nineteenth centuries. Attention is paid to the composition of crews, shipbuilding technology, governmental involvement, and profitability of the industries. In early 1802, the Treaty of Amiens enabled Dutch entrepreneurs to undertake a number of whaling expeditions. Their initiatives are also discussed. Modest in scope, and non-transparent in organisation, these early nineteenth-century whaling voyages can nevertheless be considered the overture to later developments under Dutch management.

Whaling under the Dutch flag took place both in the South Seas as well as in the Arctic. A fairly generous system of subsidies - issued by the King and his ministers as of 1815 and continued until 1855 - supported Dutch entrepreneurs in their endeavours in the respective 'theatres of whaling and sealing'. In Chapter 2 the nature and scope of the financial involvement of the King and his government in whaling and sealing after 1815 are discussed and placed within a broader international context. Therefore, international developments, in the fields of whaling and seal hunting are also briefly described as well as the financial involvement of the respective national governments.

In the wake of the British and Americans the Dutch also made attempts, from the 1820 s onward, to organise whaling in the South Seas. Chapter 3 introduces the companies and individuals behind these whaling expeditions to southern latitudes and contains analyses of their activities.

Similarly, the actors who had chosen northern latitudes as their theatre of hunt are presented in Chapter 4. Companies and individuals with their personnel and ships are put to the fore, while overviews of their activities in the cold coastal waters off Greenland and in Davis Strait are provided.

Chapter 5 elaborately dwells on two crucial factors in whaling and sealing, or actually in any maritime enterprise: ships and crews. As the lack of quality in both fields has frequently been regarded as very important factors for the failure in the Dutch whaling industry, an assessment of the actual state of the art concerning shipbuilding and training of the seamen is made. Crews of Dutch whaleships are scrutinized and analysed. Where did these sailors come from? What wages did they earn? What background and level of education did they have when they signed up for their expeditions? Under what circumstances did they live their lives and perform their duties?

In Chapter 6 data concerning the commodities (whale and seal products) and the business customers are presented. Sources are such that these results only account for Arctic whaling. Who were involved in the selling and buying of these products? How 
was the sale and subsequent distribution organised? And, of course, for what purposes did people use the whale oil and seal oil, the baleen, and seal furs?

The seventh chapter seeks to present calculations regarding the profitability (or lack of profitability) of nineteenth-century Dutch whaling and sealing expeditions. Investments in ships, gear, and men are compared with revenues from their catches. Many questions are addressed such as who paid for the expeditions? And how profitable was participation in whaling and sealing to nineteenth-century investors?

The final chapter has a more summary character as all conclusions presented separately in the preceding chapters will be brought together. This chapter also provides recommendations for further study. The appendices at the end present numerical as well as socio-economic data to back up statements and interpretations of facts, and may also serve to stimulate others to pursue research on various aspects of Dutch whaling and sealing. 
Chapter 1

\title{
Dutch Whaling and Sealing in the Seventeenth and Eighteenth Centuries
}

\begin{abstract}
Introduction
Around 1600, while still at war with powerful Spain, an astounding rise in maritime enterprise took place in the young Dutch Republic. In 1602, the Dutch East India Company was established. A few years earlier Dutch mariner Willem Barentsz. tried to find a northeast passage to Asia. During his third attempt in 1596, he and his fellow sailors were forced to winter over on the desolate island of Novaya Zemlya, where he died after having suffered many ordeals. In his earlier voyages to the north, Barentsz. had not only discovered the Spitsbergen archipelago and Bear Island. In his reports on the Arctic, he also mentioned the abundance of seals, polar bears and walruses.

Whaling was a maritime enterprise known throughout Europe. Norsemen in the Viking Era hunted whales along shore, developing methods that paved the way for the Basques to carry them out to sea. As early as the twelfth century seafarers from the Basque provinces of southern France and northern Spain had hunted whales. At first these Basque whalemen stayed close to their coast. Later they turned to more remote places, hunting and killing whales off the coast of Newfoundland and Labrador, providing the European markets with valuable products like whale oil and baleen. Arabs of the Caliphate showed keen interest in obtaining narwhal tusks, considered to be an aphrodisiac when grinded and mixed with other foodstuffs.

Population rose rapidly around 1600 . As a result of these demographic developments, prices of whale products increased dramatically. The number of inhabitants of the coastal province of Holland, for example, rose to 675,000 from 275,000 in $1525 .{ }^{14}$ Although natural fats from plants were still available, the demand for substitutes exceeded availability. Changes in agriculture were introduced to the effect that more expensive grains were cultivated, providing more expensive oil. Captains of industries such as rope manufacturing and shipbuilding turned their attention to the oils derived

14. A.M. van der Woude, 'Enkele kanttekeningen bij de economische ontwikkelingen in de Republiek', L. Hacquebord and W. Vroom (eds.), Walvisvaart in de Gouden Eeuw (Amsterdam 1988), 9-15; especially 14-15.
\end{abstract}


from sea mammals. The first decade of the seventeenth century was an opportune moment for the Dutch to undermine the Spanish whaling activities and undertake means to start whaling themselves.

\section{Organisation}

In 1612, a small fleet of two ships under the command of Willem van Muyden left Amsterdam harbour, heading for the Arctic region. Upon arrival in Spitsbergen's coastal waters, the Dutch, who wisely had hired several expert Basque whalers as harpooners and instructors, met with tough, aggressive competition from the English Muscovy Company. This company, established by Queen Elizabeth I in 1577, had been active around Spitsbergen for about one year. Claiming to have discovered these islands and whaling grounds before the Dutch, the Muscovy Company forced the Dutch to hand over their cargoes and expelled the Dutch whaleships from the area. The following year (1613), again two Dutch ships set sail for Spitsbergen and again they met violent opposition from the English. They managed, however, to catch their whales and bring home the first actual cargoes of whale oil and baleen.

The Dutch whaling entrepreneurs, fed up with the English presence in what they considered to be whaling grounds discovered by the Dutch - and therefore meant to be harvested by ships under Dutch flags - turned to the States General. They requested permission to establish a stockholding whaling company, with offices (chambers or kamers) and shareholders in several Dutch cities, most notably in Amsterdam and Delft. These shareholders invested money in each whaling expedition, equipped by their own local chamber, as opposed to the English method of a joint stockholding company where money-flow was guided on a much more centralised level. ${ }^{15}$ In 1614, the States General granted the merchants a monopoly, to be renewed every three years, that stipulated the Noordsche or Groenlandsche Compagnie was allowed to hunt and process whales in the coastal waters between Novaya Zemlya and Davis Strait. Use of the open waters was not included in this monopoly. ${ }^{16}$

15. See S. Muller Fzn, Geschiedenis der Noordsche Compagnie (Utrecht 1874) for an outstanding and still very useful treatise on the differences in organisational and economic structure between the English and the Dutch companies.

16. Literature concerning the establishment of and activities undertaken by the Noordsche Compagnie is abundant. Most useful overviews can be found in: S. Muller Fzn., Op. Cit.; C. de Jonge, Geschiedenis van de oude Nederlandse walvisvaart. Three volumes (Pretoria/Johannesburg 1972; 1976-1978); C. de Jong, 'Walvisvaart' in: J.R. Bruijn and others (eds.), De Maritieme Geschiedenis van Nederland. Vol. 3 (Bussum 1978), 335352; J.R. Leinenga, Arctische walvisvangst in de achttiende eeuw: de betekenis van Straat Davis als vangstgebied (Amsterdam 1995); J.R. Bruijn, 'De walvisvaart: de ontplooiing van een nieuwe bedrijfstak', in: W. Vroom en L. Hacquebord (eds.), Walvisvaart in de Gouden Eeuw (Amsterdam 1988), 16-24; L. Hacquebord, Smeeren- 
A few months later, Dutch whaleships protected by several warships explored the coastal waters of northwestern Spitsbergen. Around the same time, new whaling grounds were discovered by Jan Jakobsz. May. His name was given to Jan Mayen Island, about 1,00o kilometres northeast of Iceland.

These expeditions proved to be quite successful. In 1619, the English finally realised they could no longer prevent the Dutch from participating in whaling. As Gordon Jackson stated in his history of British whaling:

"A tacit agreement then gave the Dutch the North of Spitsbergen, while the British, by right of discovery, kept their original 'best' bays in the south - which soon proved to be the worst". ${ }^{17}$

The number of ports involved in whaling rose steadily and in 1624 merchants in ten cities had invested large sums of money in whaling enterprises. As of 1614, about fifteen ships were involved annually in whaling with an average crew of forty-two. Ships left Dutch harbours around April, and returned in August. As a result of the method of how the whale hunt was organised, and because of the equipment of the fluitschepen used, Dutch whaling was a seasonal business, unlike, for instance, American whaling during the nineteenth century.

During the first decades of this new enterprise, the Dutch excelled in bay-whaling. The whaleships dropped their anchors along the shore and boats were lowered in the event of whale sightings. The Dutch whalemen hunted the Greenland right whale (Balaena mysticetus, Linneaus 1758), the fattest and slowest of all baleen whales. This species remain afloat when killed, which provided an obvious advantage to hunting them as the crew attached their boats to the whale. After hunting and harpooning the animal, the crew dragged the carcass to the shore, where specialists undertook processing the harvest. Traankokerijen (oil-cookeries) were erected on Amsterdam Island and other coastal strips along northern Spitsbergen, where every city (chamber) had its own cookery, the largest one being Smeerenburg with a few hundred sailors employed in the processing of the whales. ${ }^{18}$ Long pieces of baleen and casks filled with oil would be transported to the ship, which could then set sail for home. Highly skilled

burg: het verblijf van Nederlandse walvisvaarders op de westkust van Spitsbergen in de zeventiende eeuw (Amsterdam/Groningen 1984).

17. G. Jackson, The British whaling trade (London 1978; second edition St. John's, Newfoundland 2005), 47. 18. In the past, the number of whalemen, using Smeerenburg as a more or less permanent residence for their whaling business has been highly overestimated. See whaling master C. G. Zorgdrager, in his Bloeijende opkomst der Aloude en hedendaagsche Groenlandse visscherij en walvischvaart ('s-Gravenhage 1727), and the British master W. Scoresby Jr., in the second volume of his An account of the arctic regions, with a history and description of the Northern whale-fishery. Two volumes (Edinburgh 1820). They both refer to thousands of whalemen. Hacquebord has convincingly argued that this number must have been much lower, around 200 - still, however, a considerable large labour force. L. Hacquebord, Smeerenburg, 232 passim. 
and well-paid Basque whaling experts were hired both to ascertain the catch and to instruct the inexperienced Dutch mariners in this hazardous and technically complex process. These experts from Spain and France often served as harpooners and oversaw the trying-out that took place in ovens on the beach.

Competition was intense, not only from foreign whalemen, but a rivalry also escalated among directors within the Company as well. Many of them seized every opportunity to send their ships to whaling grounds that were not subject to the monopoly: the open sea between Novaya Zemlya and the Davis Strait. Eventually, the States General realised there was no point in prolonging the Greenland Company monopoly and in 1642 it was discontinued. Now there was free whaling for all and the number of whaleships showed a dramatic increase to about 70 in 1654 from about 35 in 1642 , and by 1670 had grown to no fewer than 148 . Dutch whaling reached its zenith in 1721 with 258 ships setting sail for Spitsbergen and the Davis Strait, employing approximately 11,000 whalemen. ${ }^{19}$

Around the same time, natural developments had an immense impact on the technology and logistics of whaling. As a result of climatological changes, the icepack congested the bays and inlets of Spitsbergen, making it virtually impossible for the whales to roam the coastal waters. ${ }^{20}$ During the summer they had to seek their food along the outer rims of the icepack. The whalemen, of course, had to follow their prey. Subsequently, around 1640 bay-whaling was replaced by the more hazardous icewhaling and pelagic-whaling. These two developments - a huge rise in demand for seamen and the transition from bay-whaling to ice-whaling - had serious consequences in the way the Dutch went about their whaling business.

\section{Whaleships}

The scope and impact of shipbuilding activities in the Dutch Republic during the seventeenth and eighteenth centuries was impressive. The wharves were busy in the cities where the chambers of the Dutch East India Company were located (Amsterdam, Rotterdam, Delft, Hoorn, Enkhuizen, and Middelburg) and together they managed to launch about ten to twelve ships per year. In fact, statistics about economic activities in the epicentre of shipbuilding in the Netherlands (the Zaanstreek, a vast area just

19. J.R. Bruijn and C.A. Davids, 'Jonas vrij: de Nederlandse walvisvaart, in het bijzonder de Amsterdamse, in de jaren 1640-1664’, ESHJ, 38 (Den Haag 1975), 141-178. Furthermore, De Jong presents massive statistical material in Oude Nederlandse walvisvaart, vol. III.

20. L. Hacquebord and J.R. Leinenga, 'De ecologie van de Groenlandse walvis in relatie tot walvisvaart en klimaatsveranderingen in de zeventiende en achttiende eeuw', Tijdschrift voor Geschiedenis (TvG), 107 (1994), 415-438. 
north of Amsterdam), are vague concerning the number of wharves and number of ships built. Economic historian Jan de Vries, in his book about the Dutch rural economy in the Golden Age, quoting V. Barbour, says of shipbuilding:

"In the industry's principal location, the Zaanstreek, dozens of wharves produced hundreds of ocean going vessels each year". ${ }^{21}$

The number of ships produced annually by these wharves is also merely an estimate. S. Hart calculated about 100 ships around 1731, and between 20 and 25 seagoing vessels around 1770 . A. van Braam, however, presents different figures based on the average estimates per wharf. He also presents figures for ships - both seagoing and those destined to sail on inland waters - of those having been sold at auctions in Zaandam between 1640 and 1794; and in his article on shipbuilding in the Zaanstreek in the seventeenth and eighteenth centuries, Van Braam pointed out the intertwined character of the relationship between shipbuilding and whaling.

In the whale fishery shipbuilders from the Zaanstreek regularly also acted as whaleship owners, while at the same time renting out their ships for other kinds of expeditions. These shipwrights could make temporary investments in whaling by supplying the vessels. ${ }^{22}$ At the end of the season they could sell off the ship at a handsome price. Van Braam calls this way of going about investing in one's ship and its subsequent sale a kind of 'trade in second-hand ships' ${ }^{23}$ This statement cries out for additional research both on ships as well as on the assumed intermingled positions of shipwright and whaleship owner in the Zaanstreek. Van Braam estimates that around 1640 some 40 ships were produced annually on the wharves of the Zaanstreek, as opposed to some 120 -150 during the years between 1650 and $1700 .{ }^{24}$ The explanation for this overall uncertainty may lie in this abundance: these are large numbers of vessels and huge numbers of voyages to the cold whaling grounds in the North. ${ }^{25}$

21. J. de Vries, The Dutch rural economy in the Golden Age, 1500-1700 (New Haven/London 1974), 241. De Vries refers to V. Barbour, 'Dutch and English merchant shipping in the seventeenth century', The Economic History Review (1929/1930), esp. 275-278. See for a short but in-depth analysis of the number of wharves in the Zaanstreek between ca. 1630 and 1741 A. van Braam, 'Over de omvang van de Zaandamse scheepsbouw in de 17e en 18e eeuw', Holland, vol. 24 (1992), 37-39.

22. A similar process (owning ships, renting these out while supplying them for the benefit of one's vested interests in whaling) can be discerned in the herringfishery. See A.P. van Vliet, 'The sea fishery as an opportunity for investment in the Dutch Republic or the relation between the sea fishery and the money-box', Leo M. Akveld, Frits R. Loomeijer and Morten Hahn-Pedersen (eds.), Financing the Maritime Sector. Proceedings from the Fifth North Sea History Conference. Fiskeri- og Søfartsmuseets studieserie, nr. 13 (Esbjerg 2002), 131-145.

23. Van Braam, 'Zaandamse scheepsbouw', 35.

24. Van Braam, Idem, 42-43.

25. May Van Braam's data concerning the number of voyages in the early years of the eighteenth century serve as an indication of the size of this maritime industry. He estimates that between 1700 and 1705 about 
So far, no systematic in-depth research has been published regarding the construction of seventeenth- and eighteenth-century whaleships. Those historians who have devoted a few lines or a few paragraphs to shipbuilding for the whaling industry invariably state that the whaleship was similar to the fluitschip with a few minor adaptations for the suspension of the boats. Also, the hull was occasionally double-plated with oak in order to meet the conditions of the harsh environment in which they were to be employed and utilised. Around 1700 the fluitschip was replaced by the stronger but less manoeuvrable bootschip, which had wider decks and double plating. This is about all one can find in the literature. ${ }^{26}$

There is, of course, more to say about naval architecture and its ability to adapt to new circumstances: in this case the transition from bay-whaling to ice-whaling. First, the notary records - though scattered throughout the different archives, and often lacking inventories due to the sizes of the archival corpi-provide information concerning the size and value of the vessel. Documents regarding the auctioning off of whaleships provide data about repairs, the market value of the ship, and occasionally the contents and inventory. ${ }^{27}$ Van Braam estimates that several dozen of whaleships left the twenty or so wharves in the Zaanstreek annually. As documentation about these vessels is available in abundance, one can only wonder why no one has assembled the data in order to extrapolate naval architectural standards with regard to whale fishery. Here one could focus on the longevity, dimensions of the ships, as well as on profitability, comparing the costs and revenues.

The transition from bay-whaling to ice-whaling had major consequences on catching techniques and ship design and materials used. As the whales moved away from the coast, whalemen had to follow in their wake. No longer could they tow a dead whale to the now far remote shore and obtain oil by the use of the try-works (large ovens) at the land stations. The whale had to be tied along the portside of the ship, where processing took place in a fashion fairly similar to American whaling in the nineteenth century, but with the absence of a wooden cutting-in stage, a feature so characteristic to Yankee whaleships after $1850 .{ }^{28}$ The whale was "peeled like an orange." Large strips of blubber were cut into smaller pieces and stowed away in casks. Simi-

1,000 voyages have been made to the Arctic waters. Some 400 were fitted out in Zaandam. See A. van Braam, Bloei en verval van het economisch leven aan de Zaan (Wormerveer 1944), 10-14.

26. J.C.A. Schokkenbroek, 'Walvisvaarder', in: R. Daalder (ed.), Schepen van de Gouden Eeuw (Zutphen 2005), 67-74.

27. See for example J.C.A. Schokkenbroek, 'Cartografie op hout. De scheepskist van walvisvaartcommandeur Jan Cornelisz. Buijs (ca. 1697-1765)', in: R. Daalder a.o. (eds.), Koersvast. Vijf eeuwen navigatie op zee (Zaltbommel 2005), 247 passim.

28. Looking at pictorial sources concerning Dutch ice-whaling it seems fair to state that cutting-in took place on the portside of the ship, whereas American whalemen were positioned on the starboardside of the whaleship. So far, no acceptable explanation for these phenomena has been found. 
larly, baleen was cut from the mouth and hoisted on board. All this work was done on the main deck of the ship with dozens of whalemen going about their dirty, slippery work using sharp, lethal tools. When full, the ship set sail to the Netherlands, where cookeries in villages close to Amsterdam and other ports would boil down the pieces of blubber and yield oil. As of 1670, auctioneers selling whale products no longer refer to Greenland oil but to Holland oil, thereby indicating that around that time the cookeries on Spitsbergen were no longer in use. ${ }^{29}$

As large numbers of whaleships were facing the dangers of being broken up by the ice, or their hulls being pierced by the strong and sharp icy edges, whaling vessels were supplied with doubled hulls of extra planking by oak or Swedish pine. Much later, copper was used for plating. Moreover, around 1700 the traditionally employed "multipurpose" fluitschip was replaced by the so-called bootschip. As many more men did their work on deck instead of on shore, this newly designed vessel can best be characterized by its bulky, very solid yet inelegant appearance with its stern, decks, and hull so much wider than those of a fluitschip.

Whaling had also become much more dangerous. Often a whaleboat with its crew was dragged along by the harpooned whale, and broken up or taken down. Also, many ships were crushed by the ice and crewmen had to leave their ship and be redistributed over remaining ships. Ice floes continued to cause problems for the whaling fleets during the seventeenth as well as the eighteenth century. Statistics relating the loss of Dutch whaleships in the second-half of the seventeenth century are given below from C. de Jong.

Table 1.1: Number of Dutch whaleships lost in the ice (1664-1685).30

\begin{tabular}{cccl} 
Year & Number of ships & Number of ships lost & Percentage \\
\hline 1664 & 193 & 8 & About $4 \%$ \\
1668 & 155 & 11 & About $7 \%$ \\
1675 & 149 & 14 & About 10\% \\
1678 & 110 & 18 & About $16.5 \%$ \\
1685 & 212 & 23 & About 10.1\% \\
\hline
\end{tabular}

29. C. de Jong, Oude Nederlandse walvisvaart, vol. II, 144-162. During his expedition, in 1671, to Spitsbergen Friedrich Martens noticed that the Dutch had left their cookeries. See F. Martens, Spitzbergische oder Grönlandische Reise-Beschreibung gethan im Jahre 1671 etc. (Hamburg 1675); S. Hart, 'De Zaanstreek en Oost-Zaandam in het bizonder, in het jaar 1731', De Zaende, 2 (1947), 65-76, 97-104, 129-141. Reprinted in H.A. Diederiks a.o. (eds.), Geschrift en getal; een keuze uit de demografisch-, economisch-en sociaal-historische studiën op grond van Amsterdamse en Zaanse archieven, 1600-1800. Hollandse studiën 9 (Dordrecht, 1976), 12; L. Hacquebord, Smeerenburg, 232 passim.

30. De Jong, Oude Nederlandse walvisvaart, vol. III, 145. 


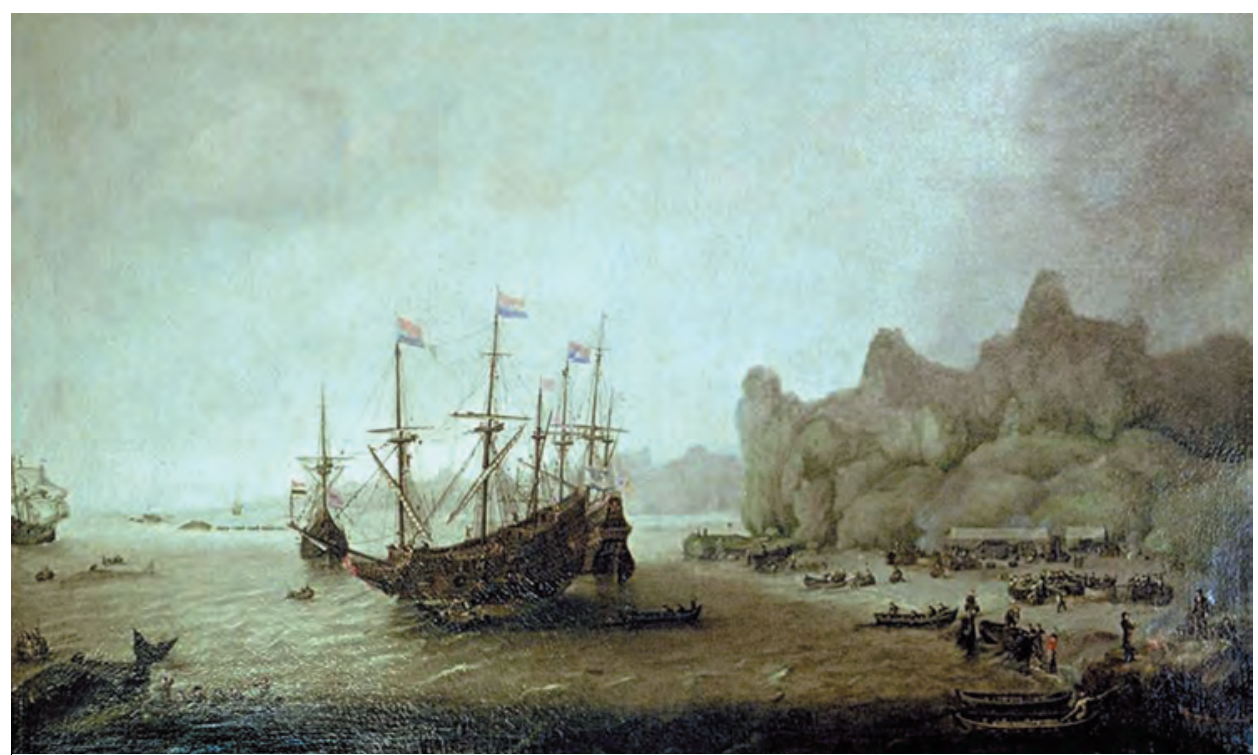

1. Dutch bay-whaling in the Arctic, ca. 1621. The whaleship is moored in the bay. In the foreground whaleboats with crew are hunting whales. Dead whales are towed to the shore, where processing takes place. The exact location of this scene is still debated. Painting on canvas by Cornelis Claesz. van Wieringen (ca. 1580-1633). Courtesy of the New Bedford Whaling Museum (Kendall Collection).

Captain Cornelis Zorgdrager, in his Bloeijende opkomst der aloude en hedendaagsche Groenlandsche visschery, provides quantitative data concerning Dutch whaleships lost in the ice. Between 1669 and 1725, 318 ships out of a total of 8,027 were crushed by the ice $(3.96 \%) .{ }^{31}$ In such cases the States General issued instructions regarding the recollection of these whaleships. Customarily the owners of these vessels were advised to fetch their ships and goods before the beginning of the new whaling season. ${ }^{32}$

\section{Men}

The majority of the whaling crews had their roots in the coastal province of Holland. ${ }^{33}$ Despite its global outlook, Dutch whaling in the seventeenth century was fairly regional

31. C.G. Zorgdrager, Bloeijende opkomst der aloude en hedendaagsche Groenlandsche visschery ('s-Gravenhage 1727 , second edition), 302-305.

32. See for example the instructions issued on 9 April 1685, and 24 November 1741. Both documents are in the collection of the Nederlands Scheepvaartmuseum in Amsterdam.

33. In particular P. Dekker and more recently P. Boon have published on the involvement of local communities in whaling, and its social and economic importance. See Dekker's, Willem 't Hart, 1750-1830. Een Zij- 


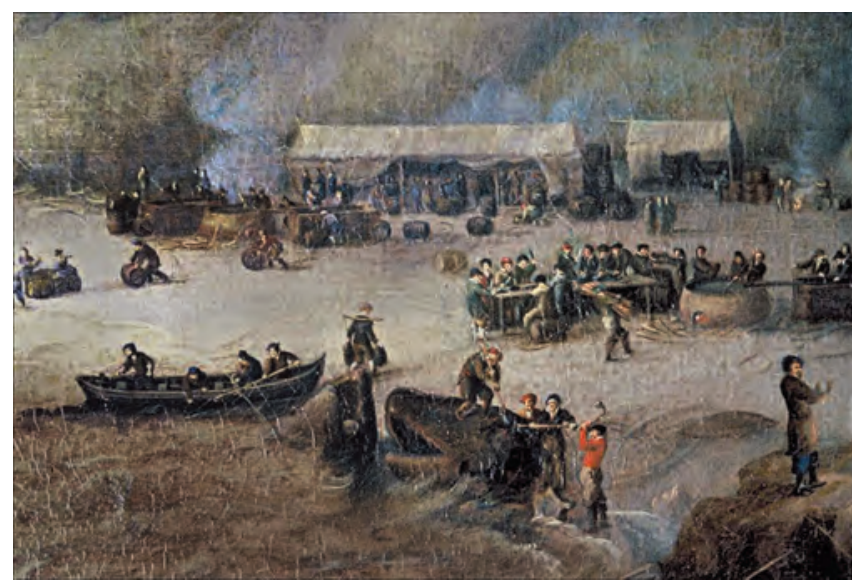

1a. Detail of painting by Cornelis Claesz. van Wieringen. During the first decades of the seventeenth century Dutch whaling entrepreneurs deployed Basque whalemen as harpooners and instructors. The artist depicts a number of Basques taking some rest. Courtesy of the New Bedford Whaling Museum (Kendall Collection).

in character. Often, the captain ('commandeur' in Dutch ${ }^{34}$ ) of the ship recruited family members, or able-bodied seamen living in the same village or town where they lived. Cooperation and trust were based on ties, be it via blood or via social life in rather small communities along the coasts. The enormous increase in whaling activities after 1642 also caused social problems. Men-of-war, as well as ships from the Dutch East India and Dutch West India Companies, the huge herring fleet, and ships sailing to the Baltic and Mediterranean, all lay claim on the limited supply of sailors. No longer could all of the whaleships be manned by locals selected by their own officers. Beginning around 1700, the number of foreign sailors aboard Dutch whaleships rose steadily, a development equalled and eventually surpassed by the Dutch East India Company. These "new" whalemen came from the East Frisian Islands, northern Germany, and Scandinavia.

per zeevaarder in de nadagen der Republiek (Zaltbommel, 1966). On pages 13, and 91-92, the author states that during the last decade of the eighteenth century whaling masters residing in the coastal area between Den Helder and recruited some $15-20 \%$ of their crew from their own local network ("Betreffende het aantal inwoners van de Zijpe dat in de laatste decennia van de $18^{\mathrm{e}}$ eeuw met de fluiten meeging naar Groenland en Straat Davis kunnen we zeggen dat de commandeurs die uit onze streken [De Zijpe] afkomstig waren minstens 15-20\% van de bemanning uit de naaste omgeving recruteerden"). See also Dekker, 'De walvisvaarders uit noordelijk Noord-Holland van 1770-1803', West-Frieslands Oud en Nieuw (WFON), vol. 40 (1973), 29-90; 'De Helderse en Huisduiner bevelhebbers ter walvisvaart in de $18^{e}$ eeuw. Het grootste commandeurs-domicilie', WFON, vol. 41 (1974), 129-165; 'Van kooikers en commandeurs. De families Colterman en Hopman actief bij de vogel- en walvisvangst', WFON, vol. 45 (1978), 41-58; vooral 48-49; 57. Piet Boon in his dissertation Bouwers van de zee: zeevarenden van het Westfriese platteland, c. 1680-1720. Hollandse Historische Reek 26 (Den Haag 1996) focuses on the relation between seafaring and farming. Here, he also dwells on additional sources of income for whalemen. See especially 158 passim.

34. Over the years the terminology referring to the Captain of a whaleship has undergone some changes. During the first decades of the seventeenth century the Captain had full responsibility over safety of ship and crew, while the commandeur was in charge of the actual hunt once the ship had reached the whaling ground. Later, at the end of the seventeenth century, this division in tasks and subsequent responsibilities was abandoned. The commandeur received full responsibility and control over ship, crew and catch. 
Cornelis de Jong calculated that between 1700 and 1825 about two-thirds of all crew members aboard Dutch whaleships were foreign nationals. ${ }^{35}$

As stated above, Dutch whaling was seasonal. No whaling activities were undertaken between October and March. Sea captains either had made enough money to be able to bridge the time between voyages or were employed in other maritime trades. Many ordinary seamen, however, encountered problems in finding employment. The important Baltic trade, encompassing many hundreds of ships making several thousands of voyages to Danzig, Koningsberg, Riga, or other destinations, would also come to a grinding halt during the winter months. Ice in the Baltic Sea would keep Dutch merchantmen away from these important harbours. Voyages to the Mediterranean would still be made; however, these journeys often took too long for a whaleman to return in time for a whaling expedition.

\section{Search for new whaling grounds}

For several decades the northwestern area of the Spitsbergen archipelago and Jan Mayen Island had been the traditional whaling grounds. Forced, among other factors, by changing migratory patterns of the whales occasioned by climatological developments discussed above, and by the huge increase of whaling activities after 1640, Dutch whalers sought new whaling grounds. ${ }^{36}$ Beginning in the 1670 , the Dutch had established contact with Inuit, the indigenous people along the shores of the Davis Strait, and regular barter trade was established. Around February or March, small vessels of about 50 to 100 tons with crews of 10-15 hands sailed to the west coast of Greenland. European luxury commodities were traded for blubber from whales and seals, baleen, tusks from walruses and narwhals, and furs. In 1721, the Kingdom of Denmark took possession of Greenland. They took over the contacts initiated by the Dutch and forbade them to continue their trade. From about 1714 onward, Dutch whaleships hunt-

35. C. de Jong, Oude Nederlandse walvisvaart, vol. I, 81. See for further reading Harald Voigt, 'Auf den Spuren nordfriesischer Seeleute in der europäischen Handelsfahrt von 1740-1830', in: Robert Bohn (eds.), Nordfriesische Seefahrer in der frühen Neuzeit (Amsterdam 1999), 11-23. In the same work Louwrens Hacquebord provides an overview concerning the composition and origin of the crews on Dutch whaleships: 'Niederländischer und Deutscher Walfang im 17. Jahrhundert', in: idem, 91-104; especially 99 passim. Furthermore, Jaap Bruijn provides information about the deployment of islanders from Föhr during the second half of the eighteenth century in his article 'A small North Frisian Island and the decline of the Dutch whaling trade c. 1780', S. Marzagalli and H. Bonin (eds.), Négoce, Ports et Océans, XVIe-XXe siècles. Mélanges offerts à Paul Butel (Bordeaux 2000), 175 passim.

36. See Zorgdrager, op. cit., 74 passim for information about the first contacts between Dutch whalemen and Inuit. De Jong in his Oude Nederlandse walvisvaart provides overviews vis-à-vis the search and exploitation of new whaling grounds off Norway, Iceland and Cape of Good Hope. 
ed whales in the Davis Strait. Although originally performed on an irregular basis, whaling expanded rapidly after 1719. The figures for 1719 and 1722, respectively, serve as examples of the keen interest in the Davis Strait for whaling and sealing. In 1719, 27 vessels marked the Davis Strait as their destination and, only three years later, at least 137 ships headed for the mammals gathered in those waters. ${ }^{37}$

\section{Decline}

Dutch supremacy in whaling over other European nations such as France, Germany, and Britain continued until the mid-1700s..$^{38}$ After about 1750, and especially after 1770, the general decline in the number of whales caught, and a subsequent decline in the number of ships whaling under Dutch flag, is easily discerned. In 1770, the English government proclaimed a raise in subsidies for British whaleships flying the Union Jack equipped by British crews, leaving British ports and returning with whale products for the British markets to British ports. In this manner, foreign whaling nations were excluded from participating in Great Britain's domestic economy.

Great Britain was not the only nation to introduce import tariffs and other economic restrictions. The French government was equally keen to stimulating their own whaling industry by providing high subsidies. Mercantilism - protection of one's own markets and one's own economy, as opposed to the use of more liberal principles of free economy as advocated by the Dutch - was the key principle of those economies. Subsidies were doubled. This financial impetus turned out to be an extremely successful incentive: within a few years, the British whaling fleet showed a tenfold increase. Dutch whaling, however, suffered severe losses. Traditionally, Dutch whaleships distributed many whale products to many parts of Europe, including France and England. These whaling entrepreneurs consequently fell victim to the new set of regulations developed by the British.

Again and again the Gecommiteerde Raden voor de walvisvaart (representatives of the owners of whaleships) turned to the States of Holland and the States General, requesting financial support in their competition with the British. Finally, on 18 January 1777 , the States of Holland for a period of two years (1777 and 1778) granted a premium of $f_{30}$ per crew member regardless of whether or not the ship returned full, half-full, or empty. With an average crew of about 42 hands, this sum would amount to $f 1,260$.

37. A more recent treatise on Dutch whaling in Davis Strait is J.R. Leinenga, Arctische walvisvangst in de achttiende eeuw: de betekenis van Straat Davis als vangstgebied (Amsterdam 1995).

38. See for more information about the decline, but also about areas of recruitment and the introduction of bounties in 1777 J.R. Bruijn, 'A small North Frisian Island', 171-18o. 


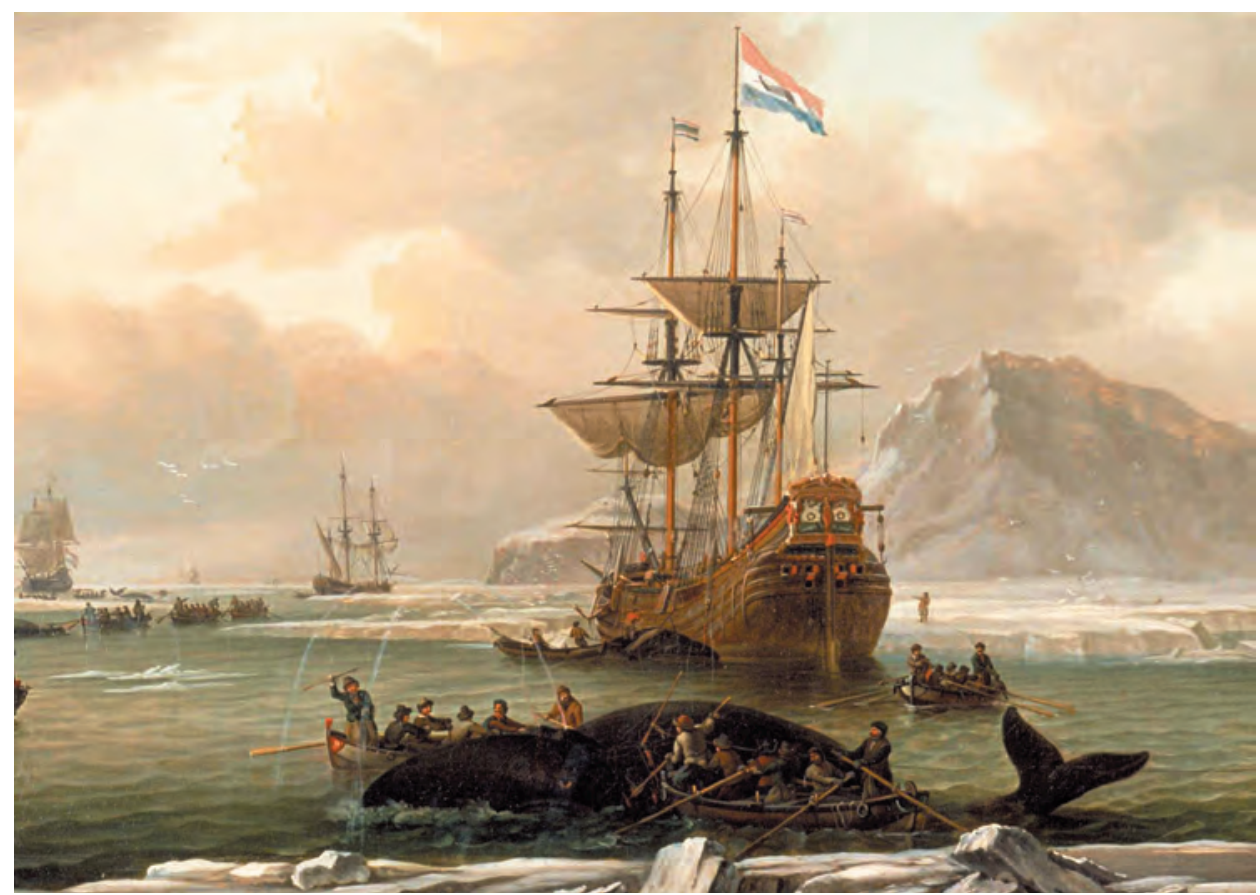

2. Dutch whaling near the ice floes, circa 1700. As of the last quarter of the seventeenth century Dutch whalemen processed the whales along side their ships. Blubber was stored away aboard, in casks. Painting on canvas, attributed to Abraham Storck. Nederlands Scheepvaartmuseum Amsterdam. Inventory number A.0014.

However, the States of Holland, contrary to the request of the above-mentioned Gecommiteerde Raden, declared itself adamantly in favour of continuation of the levying of export duties on Dutch whale products. In other words, the provincial administrative body gave with one hand but took with the other. Regardless, the premium system that was familiar to British, French, and German whalers for such a long time, was finally introduced in the Netherlands as well. ${ }^{39}$ In 1778 , the Gecommiteerde Raden requested the continuation of the premiums for the years 1779 and 1780 as well. It became increasingly obvious to the States of Holland that what had started as a temporary measure was rapidly becoming standard procedure. The States of Holland, though not whole-heartedly, gave in and acted in accordance with the request. ${ }^{40}$

Next to protectionism conducted by foreign trading partners, Dutch whaling entrepreneurs were also confronted with other circumstances and developments detrimental to the continuation of their businesses. Between 1760 and 1780, prices of raw

39. See for a lengthy discussion about the introduction of this premium system De Jonge, idem, vol. II, $432-444$.

40. De Jonge, idem, vol. II, 444-445. 


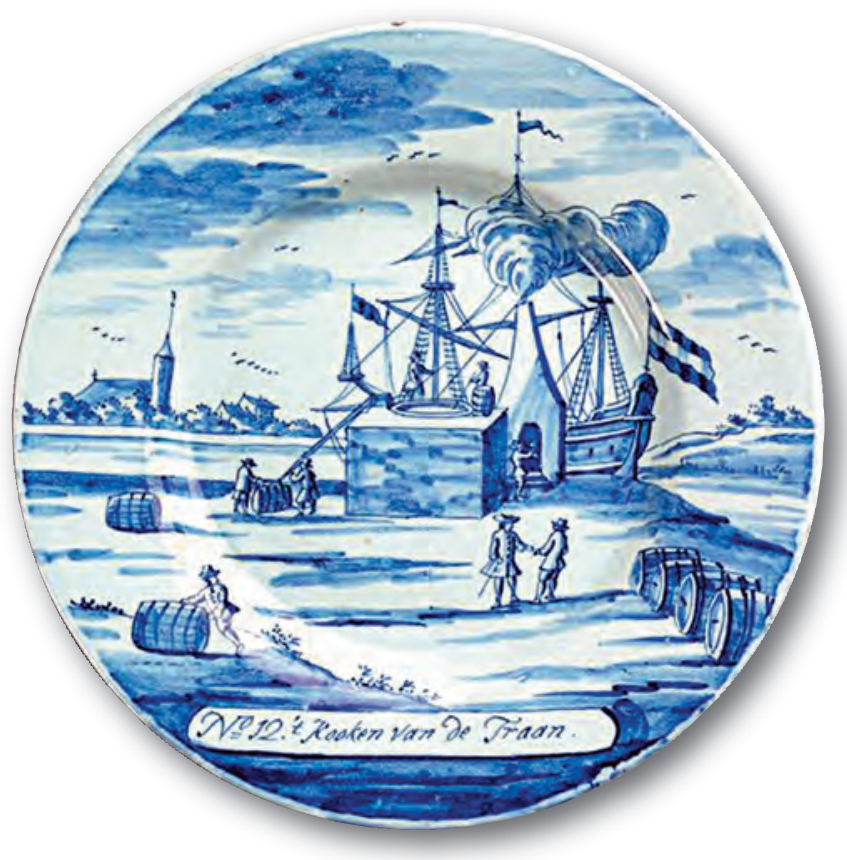

3. Oil cookery in the Netherlands, ca. 1765. This delftware plate, number 12 in a series of 12 plates produced by the factory Porceleyne Bijl after engravings by A. van der Laan and S. van der Meulen, shows how blubber transported from the Arctic whaling grounds, was processed in large ovens in the Netherlands. These cookeries were located mainly in Zaandam, Oostzaan, Jisp and other places north of Amsterdam. Nederlands Scheepvaartmuseum Amsterdam. Inventory number A.5130 (12).

materials for shipbuilding rose to an all time high. The Netherlands, and especially the province of Holland where shipbuilding for centuries has been an important industry and source of income for tens of thousands of people, suffered severely. Also, war manifested itself as a negative influence on the whaling industry in a multitude of ways. During the American War of Independence (1776-1783), many whalemen, captains, and ordinary seamen left their whaleships and signed up for voyages to the New World. Within a short period of time, this trade proved to be much more lucrative than the whale fishery. Salaries were higher and offered more opportunities to make money on the side through private trade..$^{41}$

Moreover, war for centuries had had an impact on the mariners, not only for those employed by the admiralties but also for sailors involved in other maritime industries. A certain percentage of sailors was pressed to join the Dutch men-of-war in their battles with the Spanish, English, Danish, Swedish, or French. Masters and owners of whaleships encountered increasing difficulty in manning their ships for Arctic expeditions. Whaling, therefore, occasionally came to a halt in times of war, or whaleships and crews on their way to or from those grounds ran the risk of being stopped and their goods confiscated by the enemy. The Fourth Anglo-Dutch War (1781-1784) and the

41. An example of a Dutch whaling master seeking fortune in shipping to and from North America is given by P. Dekker, Willem 't Hart, 1750-1830. Een Zijper zeevaarder in de nadagen der Republiek (Zaltbommel 1966). 
Napoleonic Wars (1795-1802; 1803-1813) had a disastrous effect on the economy of the country in general and on the number of ships setting sail for the Arctic in particular.

Research into the profitability of the business was conducted by Cornelis de Jong, especially relating to the seventeenth and eighteenth centuries. De Jong explained the supremacy of the Dutch in the Arctic waters off Greenland, Spitsbergen, Jan Mayen Island, and in the Davis Strait by focusing on the unique form by which investments were organised. The ship owners ran small companies - partenrederijen (companies with fractional ownership) - where money from the owners themselves, but also from crew, private investors, and companies involved in the outfitting of the ships (rope and sail manufacturers, for example), collaborated in their investment. Investors did not demand high dividends but covering of their costs and a gain of a marginal profit kept them satisfied. In retrospect, their profitability is difficult to analyse as the prices of whale products were far from stable during the two centuries discussed by De Jong. Moreover, there are not many sources at hand (such as accounting books or statistics concerning the depreciation of a ship) to establish a clear picture of profitability. Reports from contemporaries, however, do show a marginally profitable whaling industry with high risks, fairly large investments, and modest returns. ${ }^{42}$

A few years after De Jong had attempted to calculate profitability of seventeenthand eighteenth-century whaling (but failed due to the lack of source material), Louwrens Hacquebord defended his thesis on archaeological activities on the island of Spitsbergen. In this thesis, Hacquebord presented many new insights into the history of the Noordsche Compagnie and his findings represent a true watershed as to the symbiotic nature of the material culture related to whaling and whalemen. The book contains a reconstruction of daily life of whalemen employed in Smeerenburg on Spitsbergen, as clothing, remains of buildings, and foodstuffs are scrutinized. Moreover, Hacquebord presents calculations on the profitability of Dutch whaling enterprise for at least the major part of the seventeenth century (circa 1614-1670). These calculations were based on figures concerning costs of equipping ships, transport, salaries, and, on the other side of the ledger, revenues from oil sold. ${ }^{43}$

Few account books from the second half of the eighteenth century survive. In one particular instance, the accounts of a company owned by the Honig family in Zaandam cover the period between 1740 and 1802. These accounts show either deficits, or at best a very small margin of profit. In his ground-breaking work A. Beaujon claimed that most authors writing about Dutch whaling in this era do agree that the whale fish-

42. C. de Jong, 'Walvisvaart' in: Maritieme Geschiedenis der Nederlanden (MGN), volume III (Bussum 1976$1978), 335-352$.

43. L. Hacquebord, Smeerenburg. Het verblijf van Nederlandse walvisvaarders op de westkust van Spitsbergen in de $17^{e}$ eeuw (Amsterdam/Groningen 1984). 
ery managed to keep afloat not so much because of the profitability of the fishery itself (as it eventually proved unprofitable at all), but because trade or barter with Inuit in the Davis Strait turned out to be more lucrative. Moreover, as of 1750, the States General bestowed advantageous taxes upon the whaling industry. This way, the export of European (in casu: Dutch) commodities was exempted from levies and could consequently be used for barter in the Davis Strait. ${ }^{44}$

In 1788, a few years after the conclusion of the Fourth Anglo-Dutch War, the States of Holland decided to prolong their premium of $f_{3}$ o per crew member of whaleships equipped in the Netherlands and sailing under the Dutch flag. Previously limited to two or three years, it was decided to grant these premiums for a period of no less than twelve consecutive years. ${ }^{45}$ Only a few months later, the States of Holland decided to bring a halt on subsidies to crew members. Instead, they would financially support every ship carrying forty hands and six whaleboats that sailed before 20 July beyond $72^{\circ}$ Northern Latitude in waters east of Greenland, or before 10 July beyond $65^{\circ}$ Northern Latitude in the Davis Strait. Also, it was decided to compensate them for poor catches (the so-called wanvangst). ${ }^{46}$

In 1794, a meagre fifty-eight Dutch ships sailed the cold waters of the Davis Strait and Spitsbergen. A few years later, no ship under the Dutch flag, and just a handful of whaleships under neutral Hamburg or Bremen flags (but financially supported by Dutch entrepreneurs) were sighted there. In 1798, no fewer than twenty-nine Dutch whaleships had been seized by English privateers. Just like the Dutch East India Company and its global empire, the once thriving Dutch whaling industry had been reduced to almost nothing by around 1800 .

\section{Whaling again}

On 27 March 1802, the belligerent parties in Europe signed the Treaty of Amiens. This treaty between England and France and the areas under their control (including the Netherlands) gave room to Dutch entrepreneurs to resume whaling. Apart from this important change in political and military circumstances, developments of a more economic nature worked in favour of these entrepreneurs as well.

A few weeks prior to the Treaty, on 8 February 1802, the Gecommitteerde Raden voor de walvisvaart approached the government with a request to subsidize every

44. A. Beaujon, Overzicht der geschiedenis van de Nederlandsche zeevisscherijen (Leiden 1885); A.M. van der Woude, Noorderkwartier, II, 425-426.

45. De Jonge, Oude Nederlandse walvisvaart, II, 446.

46. De Jonge, ibidem. 
whaleship that carried at least seven boats and a crew of forty hands for a period of ten years with a financial injection of no less than $f_{3}, 000$. Moreover, they asked for a continuation of the premium on wanvangst of $f_{50}$ per kwarteel. ${ }^{47}$ They requested that this should be effective for a period of ten to twelve years. In their response the government granted a standard subsidy of $f 2,000$ per ship to be issued as of 1802 . The premium per kwarteel of oil was also continued. The introduction of the standard subsidy was a major expansion of governmental support to the Dutch whaling industry. ${ }^{48}$ That same year, a fleet of sixteen whaleships with Dutch home ports caught 63 whales, amounting to 1,031 barrels of blubber. This average of about 16 barrels per whale leads to the assumption that the whales must have been fairly small ones. None of these ships had gone to the Davis Strait. ${ }^{49}$

\section{The Afrikaanse Visscherij Sociëteit (1802-1806)}

One of the immediate political and economic consequences of the Treaty of Amiens had been the return by the British of the Cape of Good Hope to the Netherlands. This restitution also restored the hope of whaling entrepreneurs focusing on South Sea whaling adventures. Some of these men came together in Amsterdam to discuss the establishment of the so-called Afrikaanse Visscherij Sociëteit (African Fishery Society)..$^{50}$ On 2 August 1802, Johan Lumbert Umbgrove, Adriaan Teyler van Hall and Jan van Ouwerkerk de Vries petitioned for the establishment of this company at the ministry of the Interior in The Hague. This company, with Jan van Ouwerkerk de Vries and Jan Reinhart Scholten as directors, would be based in the Cape Colony, issued shares at $f_{1,000}$ a piece, and was to be established for the sole purpose of whaling and sealing in southern Pacific waters.

Following a long-standing tradition, the government granted the company a monopoly in southern whaling and sealing on 18 August 1802 for a period of twenty years; however, one of the conditions stipulated that this South Sea fishery company should also take a share in each whaling expedition leaving for Arctic waters. Between 1803 and 1806, whaling operations were conducted from a land station near Cape Town and right whales

47. One kwarteel is the equivalent of 232.8 litres. The very nature of the premium system is discussed in the next chapter.

48. De Jong, Oude Nederlandse walvisvaart, II, 447.

49. P. Dekker, 'De Nederlandse arctische walvisvaart tijdens de Bataafse Republiek', Mededelingen van de Nederlandse Vereniging voor Zeegeschiedenis, no. 38 (August 1979), 65 passim.

50. The library collection of the Nederlands Scheepvaartmuseum in Amsterdam contains a copy of the charter of the Afrikaanse Visscherij Sociëteit. The charter is titled Octroy, Bericht en Plan van de geoctrooyeerde Africaansche Visschery Sociëteit (K II 34). 
were hunted. Before the Afrikaanse Visscherij Sociëteit could even begin to blossom, war between England and Napoleonic France was resumed in May 1803, and in 1806, the Dutch whaling company was abandoned when British forces took over Cape Town. ${ }^{51}$

\section{Arctic whaling and sealing (1802-1805)}

The Treaty of Amiens gave room to entrepreneurial whaleship owners to test their luck on more familiar whaling grounds as well. We do have evidence that during these early years of the nineteenth century, whaling expeditions to Greenland were organised. Data related to these voyages stem from the office of the Waterschout (harbourmaster) in Amsterdam. Archival records state that in 1802 nine ships embarked for Greenland from this port. The names of the vessels are given in Table 1.2 below, as are the names of the masters.

When war was resumed in May 1803, ten Dutch whaleships were out hunting. British privateers captured a Dutch whaleship on $70^{\circ}$ Northern Latitude, a second ship was seized on $78^{\circ}$ Northern Latitude, and yet two more in Arctic waters. The six remaining ships fled to Norwegian harbours (three to Trondheim, two to Bergen, one to Stavanger), where masters and crew stayed for several years. In 1807 and 1808 these six Dutch whaleships were sold..$^{2}$ So far, no evidence has been found to substantiate that these ships sailed for a specific company. They may have sailed under the aegis of the master, or of one private owner. Between 1802 and 1805, at least twenty whaling voyages were made.

\section{Conclusions}

During the seventeenth and eighteenth centuries Dutch whaling had developed into a substantial maritime industry. Annually, several hundred ships participated in whaling and sealing, providing employment for thousands of sailors. Climatological and biological circumstances necessitated a search for new whaling grounds around 1700. Despite their relative success near Spitsbergen and in the Davis Strait, Dutch whale-

51. De Jong, Oude Nederlandse walvisvaart, II, 428.

52. De Jong, ibidem. In 1803, eleven-year old Geert Oenes Dolstra (1792-1886) accompanied his uncle, who had signed up as first mate on board a Dutch whaleship bound for Greenland. In his account of his life, Dolstra did not refer to the problems that arose that same year. He is either mistaken in the year of the voyage (possibly 1802 instead of 1803), or he had returned to the Netherlands before war had broken out. H. Halbertsma, 'Uit het zeemansleven van Geert Oenes Dolstra (1792-1886)', Jaarboek Fries Scheepvaartmuseum en Oudheidkamer (1964/1965), 60. 
men and whaling entrepreneurs lacked the financial and political means to withstand the rapidly increasing competition from the British, who were supported by their own government through subsidies.

During the last quarter of the eighteenth century, the Fourth Anglo-Dutch War (1780-1784) and the French Napoleonic Wars (1795-1802) had a disastrous effect on Dutch whaling activities and Dutch maritime endeavours in general. The new dawning of Dutch whaling was postponed until after the end of Napoleon's reign in 1813.

Table 1.2: Whaling expeditions destined for Greenland and fitted out around the years of the Treaty of Amiens (1802-1805).53

\begin{tabular}{|c|c|c|c|c|c|c|}
\hline Year & Ship's name & Master & Catch results & Remarks & Owner/bookkeeper & Source \\
\hline 1802 & Eendracht & $\begin{array}{l}\text { Broertjes, } \\
\text { Jacob }\end{array}$ & $?$ & $\begin{array}{l}\text { Fluitschip, } 114 \mathrm{ft}, 30 \mathrm{ft} 4 \\
\text { duim, } 12 \mathrm{ft} 10 \text { duim. Sold at } \\
\text { auction in Amsterdam on } 9 \\
\text { April } 1810 \text { - at that time } \\
\text { under command of Claas } \\
\text { Broertjes }\end{array}$ & $?$ & $\begin{array}{l}\text { SAA, Archief v.d. Water- } \\
\text { schout 38, inv.nr.61, } 25 \\
\text { March 1802; Amsterdam- } \\
\text { sche Courant, } 27 \text { February } \\
\text { 1810; Van Sluijs, Neder- } \\
\text { landse koopvaardij- } \\
\text { schepen, } 4\end{array}$ \\
\hline 1802 & Alida & $\begin{array}{l}\text { Clorn, } \\
\text { Cornelis }\end{array}$ & $?$ & $?$ & $?$ & $\begin{array}{l}\text { SAA, Archief v.d. Water- } \\
\text { schout } 38 \text {, inv.nr. } 61,31 \\
\text { March } 1802\end{array}$ \\
\hline 1802 & Vriendschap & $\begin{array}{l}\text { Boekjes, } \\
\text { Cornelis }\end{array}$ & $\begin{array}{l}1 \text { whale, } 10 \\
\text { barrels of } \\
\text { blubber }\end{array}$ & $\begin{array}{l}\text { Fluitschip, } 113 \mathrm{ft}, 29 \mathrm{ft} 1 \\
\text { duim, } 12 \mathrm{ft} \text {, verdek } 6 \mathrm{ft} 8 \\
\text { duim. Sold at auction in } \\
\text { Amsterdam on } 21 \text { April } \\
1800 \text {, for } f_{11,400 \text {, whaling }} \\
\text { equipment for } f_{3,350} \text {. }\end{array}$ & $\begin{array}{l}\text { Vas \& Dekker, } \\
\text { Wormerveer }\end{array}$ & $\begin{array}{l}\text { SAA, Archief v.d. Water- } \\
\text { schout } 38 \text {, inv. nr. 61, } 31 \\
\text { March 1802; Van Sluijs, } \\
\text { Nederlandse koopvaardij- } \\
\text { schepen, } 108,114\end{array}$ \\
\hline 1802 & $\begin{array}{l}\text { Landswel- } \\
\text { varen }\end{array}$ & $\begin{array}{l}\text { Tromp, } \\
\text { Tjelling }\end{array}$ & $?$ & Fluitschip & $\begin{array}{l}\text { Simon Jongewaard } \\
\text { Jr., Westzaan }\end{array}$ & $\begin{array}{l}\text { SAA, Archief v.d. Water- } \\
\text { schout } 38 \text {, inv.nr.62, } 3 \\
\text { April 1802; Van Sluijs, Ne- } \\
\text { derlandse walvisvaarders, } \\
373\end{array}$ \\
\hline 1802 & Onderneming & $\begin{array}{l}\text { Castricum, } \\
\text { Jan Claasz. }\end{array}$ & $?$ & $?$ & $?$ & $\begin{array}{l}\text { MAA, Archief v.d. Water- } \\
\text { schout } 38 \text {, inv. nr. } 62,4 \\
\text { April } 1802\end{array}$ \\
\hline 1802 & Groenlandia & $\begin{array}{l}\text { Hogerzijl, } \\
\text { Johannes }\end{array}$ & $?$ & $?$ & $\begin{array}{l}\text { Frank van den } \\
\text { Schoor \& Zonen, } \\
\text { Dordrecht }\end{array}$ & $\begin{array}{l}\text { SAA, Archief v.d. Water- } \\
\text { schout } 38 \text {, inv. nr. 62, } 5 \\
\text { April 1802; Van Sluijs, Ne- } \\
\text { derlandse walvisvaarders, } \\
169\end{array}$ \\
\hline 1802 & Zaandam & $\begin{array}{l}\text { Broertjes, } \\
\text { Jacob }\end{array}$ & $\begin{array}{l}4^{1 / 2} \text { whales, } \\
8 \text { o barrels of } \\
\text { blubber }\end{array}$ & $?$ & $?$ & $\begin{array}{l}\text { SAA, Archief v.d. Water- } \\
\text { schout } 38 \text {, inv. nr. 62, } 5 \\
\text { April } 1802 \text {; Van Sluijs, Ne- } \\
\text { derlandse walvisvaarders, } \\
677\end{array}$ \\
\hline 1802 & Avontuur & $\begin{array}{l}\text { Ruig, Pieter } \\
\text { Cornelisz. }\end{array}$ & $\begin{array}{l}1 \text { whale, } \\
17 \text { barrels of } \\
\text { blubber }\end{array}$ & $?$ & $\begin{array}{l}\text { Cornelis Cardinaal, } \\
\text { Zaandam }\end{array}$ & $\begin{array}{l}\text { SAA, Archief v.d. Water- } \\
\text { schout } 38 \text {, inv. nr. } 62,5 \\
\text { April } 1802 \text {; Van Sluijs, Ne- } \\
\text { derlandse walvisvaarders, } \\
33\end{array}$ \\
\hline
\end{tabular}

53. SAA stands for Stadsarchief Amsterdam (municipal archives Amsterdam). I am indebted to Mrs. Ineke Vonk from the Isle of Texel, who generously provided this data via e-mail, 12 May 2005. 


\begin{tabular}{|c|c|c|c|c|c|c|}
\hline Year & Ship's name & Master & Catch results & Remarks & Owner/bookkeeper & Source \\
\hline 1802 & Frankenda $(a) l$ & $\begin{array}{l}\text { Mooij, } \\
\text { Marten }\end{array}$ & $?$ & Fluitschip & $\begin{array}{l}\text { Jan de Cherro, Am- } \\
\text { sterdam }\end{array}$ & $\begin{array}{l}\text { SAA, Archief v.d. Water- } \\
\text { schout } 38 \text {, inv. nr. } 62,6 \\
\text { April } 1802 \text {; Van Sluijs, Ne- } \\
\text { derlandse walvisvaarders, } \\
128\end{array}$ \\
\hline 1802 & $\begin{array}{l}\text { Hoop op de } \\
\text { Walvisvangst }\end{array}$ & $\begin{array}{l}\text { Cornelisz., } \\
\text { Hendrik }\end{array}$ & $\begin{array}{l}5 \text { whales, } \\
100 \text { barrels of } \\
\text { blubber }\end{array}$ & $\begin{array}{l}\text { Fluitschip, } 113 \mathrm{ft}, 29 \text { el } 7 \\
\text { duim, } 12 \text { el, } 7^{1 / 2} \text { duim, } \\
\text { 'nieuw uitgehaald' } 1764 \text {. } \\
\text { Sold at auction in Amster- } \\
\text { dam on } 15 \text { April } 1802 \text { for } \\
\text { f8,865 }\end{array}$ & $\begin{array}{l}\text { Pieter de Jong \& } \\
\text { Zn., Nieuwendam }\end{array}$ & $\begin{array}{l}\text { Van Sluijs, Nederlandse } \\
\text { walvisvaarders, } 206\end{array}$ \\
\hline 1802 & Visserschhoop & $\begin{array}{l}\text { Gaauw, } \\
\text { Jacob }\end{array}$ & $\begin{array}{l}4 \text { whales, } \\
80 \text { barrels }\end{array}$ & $?$ & $\begin{array}{l}\text { Nicolaas Gefken \& } \\
\text { Zn., Amsterdam }\end{array}$ & $\begin{array}{l}\text { Van Sluijs, Nederlandse } \\
\text { walvisvaarders, } 5616\end{array}$ \\
\hline 1803 & $\begin{array}{l}\text { sLands Wel- } \\
\text { varen }\end{array}$ & $\begin{array}{l}\text { Clorn, } \\
\text { Pieter }\end{array}$ & $?$ & $?$ & $?$ & $\begin{array}{l}\text { SAA, Archief v.d. Water- } \\
\text { schout } 38 \text {, inv.nr. } 68,16 \\
\text { April } 1803\end{array}$ \\
\hline 1803 & Alida & $\begin{array}{l}\text { Clorn, } \\
\text { Cornelis }\end{array}$ & $?$ & $?$ & $?$ & $\begin{array}{l}\text { SAA, Archief v.d. Water- } \\
\text { schout } 38 \text {, inv.nr. } 68 \text {, } \\
16 \text { April } 1803\end{array}$ \\
\hline 1803 & Onderneming & $\begin{array}{l}\text { Castricum, } \\
\text { Jan } \\
{[\text { Claasz. }]}\end{array}$ & $?$ & $?$ & $?$ & $\begin{array}{l}\text { SAA, Archief v.d. Water- } \\
\text { schout } 38 \text {, inv.nr. } 68, \\
16 \text { April } 1803\end{array}$ \\
\hline 1803 & $\begin{array}{l}\text { Hoop op de } \\
\text { Walvisvangst }\end{array}$ & $\begin{array}{l}\text { Cornelisz., } \\
\text { Hendrik }\end{array}$ & $?$ & $?$ & $?$ & $\begin{array}{l}\text { SAA, Archief v.d. Water- } \\
\text { schout } 38 \text {, inv.nr. } 68, \\
16 \text { April } 1803\end{array}$ \\
\hline 1803 & Avontuur & $\begin{array}{l}\text { Ruig, Pieter } \\
\text { Cornelisz. }\end{array}$ & $?$ & $?$ & $?$ & $\begin{array}{l}\text { SAA, Archief v.d. Water- } \\
\text { schout } 38 \text {, inv.nr. } 68 \\
18 \text { April } 1803\end{array}$ \\
\hline 1803 & Visschershoop & $\begin{array}{l}\text { Gaauw, } \\
\text { Jacob }\end{array}$ & $?$ & $\begin{array}{l}\text { Returning from Green- } \\
\text { land, confiscated and de- } \\
\text { ported to Liverpool }\end{array}$ & $?$ & $\begin{array}{l}\text { SAA, Archief v.d. Water- } \\
\text { schout 38, inv.nr. 68, } \\
20 \text { April } 1803 \text {; Amster- } \\
\text { damsche Courant, } 8 \text { Sep- } \\
\text { tember } 1803 \text {; Van Sluijs, } \\
\text { Nederlandse walvis- } \\
\text { vaarders, } 561 \text {; Van Sluijs, } \\
\text { Nederlandse koopvaardij- } \\
\text { schepen, } 40\end{array}$ \\
\hline 1803 & Vriendschap & $\begin{array}{l}\text { Boekjes, } \\
\text { Cornelis }\end{array}$ & $\begin{array}{l}\text { Returned } \\
\text { empty from } \\
\text { Greenland; } \\
\text { sent to Green- } \\
\text { land again }\end{array}$ & Fluitschip & $\begin{array}{l}\text { Vas \& Dekker, } \\
\text { Wormerveer }\end{array}$ & $\begin{array}{l}\text { Van Sluijs, Nederlandse } \\
\text { koopvaardijschepen, } 114\end{array}$ \\
\hline 1804 & $?$ & $\begin{array}{l}\text { Broertjes, } \\
\text { Jacob }\end{array}$ & $?$ & $?$ & $?$ & $\begin{array}{l}\text { SAA, Archief v.d. Water- } \\
\text { schout } 38 \text {, inv.nr.73, } \\
12 \text { April } 1804\end{array}$ \\
\hline 1804 & Frankenda $(a) l$ & $\begin{array}{l}\text { Mooij, } \\
\text { Marten }\end{array}$ & $?$ & $\begin{array}{l}\text { Fluitschip. 'Nieuw uitge- } \\
\text { haald' in } 1760,113 \mathrm{ft}, 30 \mathrm{ft} \text {, } \\
13 \mathrm{ft} \text {. Sold at auction in } \\
\text { Amsterdam on } 9 \text { April } 1810\end{array}$ & $\begin{array}{l}\text { Jan de Cherro, Am- } \\
\text { sterdam }\end{array}$ & $\begin{array}{l}\text { Amsterdamsche Courant, } \\
31 \text { March 1810; Van Sluijs, } \\
\text { Nederlandse walvisvaar- } \\
\text { ders, } 128\end{array}$ \\
\hline 1805 & Groenlandia & $\begin{array}{l}\text { Hogerzijl, } \\
\text { Johannes }\end{array}$ & $?$ & $\begin{array}{l}\text { Fluitschip. 'Nieuw uitge- } \\
\text { haald' in } 1764,115 \mathrm{ft}, 29 \mathrm{ft} 6 \\
\text { duim, } 12 \mathrm{ft} 7 \text { duim. Sold at } \\
\text { auction in Dordrecht on } 29 \\
\text { April } 1805\end{array}$ & $\begin{array}{l}\text { Frank van den } \\
\text { Schoor \& Zonen, } \\
\text { Dordrecht }\end{array}$ & $\begin{array}{l}\text { Amsterdamsche Courant, } \\
20 \text { April } 1805 ; \text { Van Sluijs, } \\
\text { Nederlandse walvis- } \\
\text { vaarders, } 169 ; \text { Van Sluijs, } \\
\text { Nederlandse koopvaardij- } \\
\text { schepen, } 205\end{array}$ \\
\hline \multicolumn{2}{|c|}{ Totals } & & $\begin{array}{l}15^{1 / 2} \text { whales; } \\
287 \text { barrels of } \\
\text { blubber }\end{array}$ & & & \\
\hline
\end{tabular}




\title{
King Willem I and the Premium System (1815-1855)
}

\begin{abstract}
Introduction
Developments in the success and failure of Dutch whaling activities in the early years of the nineteenth century were discussed in the previous chapter. Here, the international context of Dutch whaling and sealing initiatives will be described. The activities on Southern and Arctic whaling grounds, undertaken by a fair number of whaling companies, were financially supported by the government. The nature of the premium system developed and introduced under the aegis of King Willem I will be discussed. To this effect, the municipal archives of Harlingen provide a wealth of data on the day-today operational nature of the premium system..$^{54}$ Though referring to the local situation in Harlingen during the 1820 s through the 1850 s (more specifically in the years 1826-1855), these sources relate more general developments nationwide and, therefore, may be taken to exemplify the premium system. For instance, the municipal records reflect the procedures whaling companies had to undergo in order to be eligible for subsidies and reveal which parties were involved in granting these subsidies.
\end{abstract}

\section{International developments in the nineteenth century}

\section{Britain}

Dutch whaling activities faced a dramatic decline during the last two decades of the eighteenth century. During this time, Dutch whalers had lost their competitive edge with their main rivals, the British. This, among other reasons, was caused by an inadequate, even redundant system of subsidies. It took the States General many years to

54. The municipal archives in Harlingen $(\mathrm{GAH})$ contain numerous entries to letters that were sent to the City Council, be it by private individuals, local companies and institutions, or provincial or even national representatives ranging from the States of Friesland to judges from towns located in other Dutch provinces. 
realise that whaling had to be financially supported, if it were to remain an important source for labour and revenues. It was not until 1778 that a premium system was introduced. By then, however, British whalemen were omnipresent in the Arctic. During the 1730 and 1740 s, London sent out a mere four ships per annum. After 1750, when the government granted bounties of 40 shillings per ton, a truly remarkable growth in the number of ships equipped for whaling started. 55 In the 1750 s, the port of London annually fitted out about 50 ships on average. In 1785 , no fewer that 78 ships left the capital's port and set sail for Spitsbergen.

In 1789, the English whaleship Emilia, owned by Samuel Enderby, one of the most important merchant-entrepreneurs of his time, was the first whaler to round Cape Horn and enter the Pacific Ocean..$^{56}$ Though under English ownership the vessel was commanded, and for the major part manned, by men from the island of Nantucket. The voyage lasted for two years. New whaling grounds and subsequent challenges for whaling entrepreneurs arose. For Britain, the South Sea whale fishery was quite profitable during these three decades. As a result of the fast growing competition from other nations, alternative grounds were eagerly sought and found in the North Pacific.

Initially, all seemed to be going quite well with regard to the British whale fishery in the Arctic. The statistics of the volume of whaling activities provided by German sources are impressive: between 1810 and 1818 no fewer than 824 English whaleships and 361 Scottish vessels left for the Arctic fisheries east of Greenland and in Davis Strait. Their catch results are equally impressive: between 1814 and 1817, 392 English ships alone caught 3,348 whales and an unspecified but very large number of seals, walruses, and polar bears. These harvests yielded 35,824 tons of oil and 1,806 tons of baleen. ${ }^{57}$ Scottish whalemen and seal hunters performed equally modest results. During these four years, 194 ships set sail from Scottish ports and caught 1,682 whales yielding 18,624 tons of oil and 776 tons of baleen. The highest catch was made in 1814 , when the average Scottish whaleship brought home 19 whales. These mammals, however, yielded a modest 159 tons of oil in total..$^{8}$

These figures are supported by research conducted by Gordon Jackson. In 1816, an impressive 146 English whaleships still roamed the coastal waters of the Arctic. Af-

55. In the 1700 s, 40 shillings were equal to $\mathfrak{E}_{2}$; this sum was equal to $f_{23}$. See H. Enno van Gelder, De Nederlandse munt (Utrecht/Antwerpen 1972), 253.

56. Broeze, 'Whaling in the Southern Oceans', 68; De Jong, Westerse walvisvangst, 4.

57. One ton $(\mathrm{UK})=1,016$ kilograms.

58. M. Lindeman, 'Die Arktische Fischerei der Deutschen Seestädte 1620-1868. In vergleichender Darstellung', in: A. Petermann, Mitteilungen aus Justus Perthes' Geographischer Ausstalt über wichtige neue Erforschungen auf dem Gesamtgebiet der Geographie. Ergänzungsband VI, 1869-1871 (Gotha 1871), 65 passim. Lindeman mentions the achievements by master Souter of the ship Resolution of Peterhead, who returned in 1814 with 44 whales, eventually fetching a gross profit of $\mathfrak{E} 11,000$. 
ter 1821 however, a rapid decline can be discerned (159 ships), with numbers dwindling to between 91 and 39 ships per annum in the 1830 . .9 This decline can be attributed to several factors. In 1824, the British government refused to renew the bounties for a further term. More importantly for the short term, however, oil prices declined drastically in the early $1820 s .{ }^{60}$ Moreover, in the 1820 s the British government reduced duties on foreign rape seed, stimulating an impressive increase in imports. Also, the spread of gas lighting had a devastating effect on the price and distribution of whale oil. Another blow to British whaling came two decades later, when in the 1840 s the British government decided not to continue the high level of protection against whale oil produced by Americans. In the words of Gordon Jackson,

“...whaler-owners were as adamant as they had ever been that their valuable and strategic trade could not exist in a context of unsubsidised open competition, and argued that the government was sacrificing ship owners to its Free Trade principles." ${ }^{61}$

Between 1815 and 1822 the number of ships leaving for Spitsbergen exceeded those heading for the Davis Strait. After 1822, Davis Strait whalers outnumbered those heading for Spitsbergen. After 1837, however, the pendulum swung to the other side, with more ships setting sail for Spitsbergen than for the Davis Strait. ${ }^{62}$ At first, London superseded by far the other English and Scottish ports in terms of numbers of ships equipped for whaling, both to the Arctic as well as to the South Seas. Its supremacy continued until the early years of the nineteenth century, when Hull took over the lead from the capital.

After about 1850, Hull had intense competition from two Scottish ports: firstly Peterhead and later, after about 1870 , Dundee. ${ }^{63}$ In short, during the last decades of the nineteenth century whaleships from Scottish ports controlled Arctic right whaling and sealing. In 1881, the Scottish sealing and whaling fleet consisted of fourteen screw

59. G. Jackson, The British Whaling Trade (London 1978; second edition St. John's, Newfoundland 2005), 106. See in his work also page 253 (Appendix 9); B. Lubbock, The Arctic Whalers (Glasgow 1937). Quite different figures are presented by Howard A. Clark and James Templeman Brown, 'Part XV: the Whale-Fishery', in: George Brown Goode, The Fisheries and Fishery Industries of the United States. Section V: History and Methods of the Fisheries (Washington 1887), 197-198.Clark and Brown claim that in 1750 nineteen vessels were involved. In 1756, this number had risen to 67 . Around 1815, the British whaling fleet contained 164 whaleships, with over 100 ships in the South Sea fishery (chiefly the Brazil banks) and 50 vessels were employed around Greenland and the Davis Strait. This figure dwindled to 35 in 1865.

60. Jackson, British Whaling Trade, 107 passim.

61. Jackson, Op. cit., 109.

62. Jackson, Op. cit, Appendix 9, 243. Jackson lists ships destined for Greenland, meaning Spitsbergen. The numbers are also quoted by R. Vaughan, 'Historical survey of the European whaling industry', H.K. 's Jacob, K. Snoeijing and R. Vaughan (eds.), Arctic whaling: proceedings of the international symposium Arctic whaling: February 1983 (Groningen 1983), 131.

63. R. Vaughan, 'Historical survey', 128-129. 
steamers with a total tonnage of 6,999 tons and 1,008 nominal horsepower (HP). This amounted to an average of 500 tons and $72 \mathrm{HP}$ per steamer.

\section{France}

From the very beginning, French whaling was strongly supported by the King and his closest circle of advisers. In the first half of the seventeenth century, Cardinal Richelieu initiated and supported French whaling from the port of Le Havre (Normandy). Richelieu found the right man to serve his purposes in Jean Vrolicq, who may have been of Flemish origin. Vrolicq may have lived in Saint-Jean-de-Luz, the whaling capital of the French Basques, before he moved to Le Havre, where he organised French whaling activities. He had served the Dutch Noordsche Compagnie as a harpooner before the Red Cardinal gave him a four-year charter to catch whales north of $60^{\circ}$ Northern Latitude. Vrolicq seemed adamant in his efforts to obstruct Dutch whalers as much as possible and denied Dutch claims to the discovery of Jan Mayen Island in the North Atlantic in 1614. He usurped this right for himself and shrewdly renamed the island after his most influential protagonist as the Isle de Richelieu. In 1644 Mazarin followed in Richelieu's footsteps and continued to support French whaling in the Arctic. ${ }^{64}$ In some years, more than ten ships under the French flag were involved in whaling off Spitsbergen. In the 1670 , however, the industry collapsed.

New initiatives came about a century later as a result of King Louis XVI's strong financial support in 1784 . Though rather short-lived (the whaling company was abandoned in 1787), a system based on mercantilism and heavy subsidies was developed and remained in place throughout the history of French whaling during the nineteenth century. In 1816, after the Napoleonic Wars, the French resumed whaling with great vigour. The government issued a subsidy of 50 francs per ton. A shortage of ablebodied seamen with French nationality caused the government to allow ship owners to recruit foreigners up to a maximum of two-thirds of the crew. ${ }^{65}$ Until the middle of the nineteenth century a very complex system of subsidies was developed. The results, however, were not impressive. In 1830, only three French ships were hunting in Spitsbergen waters, one of which was the three-masted ship Ville de Dieppe. A little later this ship was crushed by the ice in Davis Strait. That same year no fewer than 91 British whalers went to the Davis Strait. None, however, sailed for Spitsbergen. ${ }^{66}$ In 1831, again three ships set sail under the French flag for the Greenland whale fishery

64. See S. Dalgård, Dansk-Norsk hvalfangst, 1615-1660 (Copenhagen 1962), 156-160, 183-184. Jan Jacobszoon May, first mate on a Dutch whaleship came from the West-Frisian village of Schellinkhout.

65. Th. Du Pasquier, Les Baleiniers français au XIXe siècle (1814-1868) (Grenoble 1982), 81. Around this time 50 French francs equalled about $\mathfrak{E}_{2}-$ similar to the subsidy the English government issued per ton.

66. Jackson, The British whaling trade, 270. 
and thirteen headed for the South Seas. In all, these sixteen ships amounted to 6,412 tons and 551 crew members. Around 1830, the average French whaleship measured about 400 tons with a crew of 35 seamen. The size of the fleet remained fairly steady, with no fewer than seventeen ships being employed in 1849. The number was reduced to five vessels in 1853, with 127 whalemen on the payroll. Within 23 years the average size of the crew had been reduced drastically, from 35 to 25 hands and all vessels were moored in the port of Le Havre (Normandy). Also, bounties and allowances for whalemen (amounting to about six times that of mariners on men-of-war), were reduced under King Louis-Philippe's reign from 1830 to $1848 .{ }^{67}$

\section{Germany}

Germany had been involved in whaling and sealing from as early as the seventeenth century. After the Napoleonic Era, whaling was enthusiastically resumed. After 1818, several ports in present day Germany (Hamburg, Glückstadt, Elmshorn, and Bremen) had been involved in maritime activities in Arctic waters. These early nineteenthcentury activities mainly concentrated on sealing, but also to a lesser extent on whaling. Around the middle of the century, local merchants equipped small numbers of vessels for whaling expeditions in Arctic waters. Thus, stockholding whaling companies were established in Elsfleth and Stedinge (as of 1843). After issuing shares, the Stedinger Company accumulated a starting capital of 9,00o Thaler. ${ }^{68}$ The company had its own cookery and one ship, the August. Around 1846, many more shares were issued at 100 Thalers a piece. In this way the shareholding capital increased tremendously, amounting to 27,500 Thalers and a second vessel was bought. In 1847, the August and the newly acquired Pauline together brought home 10,261 seals, yielding 1,437 barrels of oil. Through the years extremely satisfied shareholders received dividends ranging from $30 \%$ in 1847 to an all time low of about $2 \%$ in the $1848-1849$ season. A few years later (1853), a spectacular all time high of $65 \%$ was issued by the whaling company and the Germans also remained successful in the seal hunt throughout these years. In 1850, 12 vessels from the Weser region in northern Germany carried home an impressive 48,800 seals. ${ }^{69}$

Inspired by the successes of the Scottish whaling industry, where ships with steam engines were used on a fairly large scale, German whaling experienced major changes

67. Clark and Brown, 'The Whale-Fishery', 207-208. On the collapse of French whaling and its resumption during the first half of the nineteenth century, see Ch. de la Roncière, Histoire de la marine française, 6 vols (Paris 1900-1924). Vol. 5, 675-680; L. Lacroix, Les derniers baleiniers français (Nantes 1938), 34-36.

68. Around 1800, one Thaler equalled f1.80. See Van Gelder, De Nederlandse munt, 253.

69. Lindeman, 'Arktische Fischerei der Deutschen Seestädte', 75-78. 
during the 1860 s. Sailing ships were rapidly replaced by steam ships. In 1864, five vessels were deployed. In 1865 this number was reduced to three (Comet, Oregon, and Julian), with a small growth to four vessels in $1866 .^{70}$

M. Lindeman provides more detailed information concerning the size of the whaling fleet - id est: of the ships equipped in the Weser region - in or around $1868 . .^{71}$ This fleet consisted of four vessels: Hannover (237 lasts, approximately 500 tons), captain W. Lübbers; Albert (a screw steamship of 328 lasts, built in 1865), captain H. Hashagen; and Bienenkorb (a screw steamship of 186 lasts), captain Hagens; all of which flew the Prussian flag; and the fourth ship, Hudson (229 lasts, 50 crew), captain J.H. Westermeijer, sailed under the flag of the city of Bremen.

Meanwhile dark financial clouds formed over the heads of owners and crew as interest and investments dwindled. Hamburg, traditionally one of the main centres of German whaling, left the industry by 1861 . Finally, whaling and the once very successful sealing activities came to a complete halt when war broke out with France in 1870. It would be decades before Germany resumed whaling.

\section{United States}

The situation regarding whaling in the United States after the War of 1812 can, in a sense, be compared with the situation in the Netherlands after the installation of the monarchy in 1815 . Both nations were almost simultaneously licking wounds inflicted by bloody wars that had drained entrepreneurial esprit and destroyed their respective whaling fleets. Between 1794 and 1799, the American whaling fleet contained an annual average volume of around 3,00o tons. By 1803 this figure had quadrupled. In 1814, however, the size of the American whaling fleet was a mere shadow of what it had been a decade earlier, totalling only 562 tons, as it had been reduced to "[s] everal small vessels from Nantucket [...] whaling on the shoals". ${ }^{72}$ Only one vessel was registered in New Bedford.

For the American whaling ports, peace brought a drastic change. The 35 years after the end of the Napoleonic Wars is considered the golden age of American whaling. In 1815, 68 vessels left American ports. Ten vessels sailed from New Bedford, compared to only one registered in this city during the previous year. Between 1816 and

\footnotetext{
70. Clark and Brown, 'The Whale Fishery', 218.

71. Lindeman, 'Arktische Seefischerei der Deutschen Seestädte', 78.

72. Walter S. Tower, A History of the American Whale Fishery. Series in Political Economy and Public Law, no. 20 (Philadelphia 1907), 121; quote from Alexander Starbuck, History of the American Whale Fishery from its Earliest Inception to the Year 1876 (Waltham 1878), 216; Lance E. Davis, Robert E. Gallman and Karin Gleiter, In Pursuit of Leviathan. Technology, Institutions, Productivity and Profits in American Whaling, 1816-1906 (Chicago/London 1997), 37.
} 
1820, an average of over 31 vessels annually left New Bedford for the whaling grounds. This of course meant that the fleet tripled in size compared with only a few years before. The acme was 1856-1859 when, on average, more than 320 vessels annually set sail from the famous whaling port on Buzzard's Bay in Massachusetts - ten times as many as four decades earlier. ${ }^{73}$

Demographic developments both in the United States and in Europe led to an increase in the demand for whale products. This rising demand was met by a new generation of adventurous and enterprising American whalemen, ${ }^{74}$ opening up new whaling grounds to ensure huge increases in supplies of the commodities needed. They subsequently explored uncharted whaling grounds, where whale populations were found in abundance. American whaleships set their course to the grounds off Peru (in 1818), the grounds off Japan (1820), the Northwest grounds off Alaska and Siberia (in 1835), the Sea of Okhotsk (1843) and, finally, to Bering Sea (in 1848).

The relevant statistics for 1815 to 1859 are quite impressive. During this period,

“... American output of sperm whale oil increased almost fivefold, of whale oil more than eleven fold, and of whalebone more than forty fold. Over a similar period, the real value of the industry's output rose by more than a factor of eleven." 75

Not only did the number of ships increase, but this tremendous growth of the industry had significant consequences to the size of whaling vessels as well. During the previous century, American whalemen had relied primarily on smaller types of vessels like sloops, schooners, and brigs. As these seamen moved further away from their own shores, larger vessels were needed. Ships and barks replaced the smaller vessels. The differences in vessel types used for their hazardous task could be rather extreme. In 1849, for example, the largest American whaler on the high seas was the ship South America from Providence, Rhode Island, measuring 616 tons. The smallest at hand was the schooner Atlas of New London, Connecticut, measuring a modest 81 tons. Thus, despite the losses during the War of 1812, the American whaling fleet was, if not modernised, definitively rebuilt and expanded within a remarkably short period of time.

In later years, however, contraction of the American whaling industry can be discerned, especially during the quarter century after 1850. After gold was discovered in California in 1848, numerous whaleships with their home ports in New England adjusted their courses to exchange the fields of oil, baleen, and ivory for the fields of gold.

73. Idem, 243.

74. Crew lists of American whaleships are unambiguously indicative of the melting pot of America. M. Malloy, African Americans in the maritime trades: a guide to resources in New England. Kendall Whaling Museum Monograph Series no. 6 (Sharon 1990), discusses the presence of black sailors from the Azores and Cape Verdian Islands on board American whaleships.

75. Davis, Gallman and Gleiter, In Pursuit of Leviathan, 38. 
Crews jumped ships. In this way, ship owners lost experienced labour force, and occasionally their largest capital investment - the vessel - as well. Cities and smaller communities lost their sons, who often spent a considerable length of time in the often imaginary goldfields.

From about the middle of the nineteenth century, whale oil became exposed to strong competition from other raw materials. The use of whale oil was threefold: the product served as a lubricant, as an illuminator, and for the tanning and textile industries. In 1859, petroleum was discovered in Pennsylvania. As a lubricant, whale oil was steadily replaced by petroleum and paraffin, while its use for illumination declined in favour of petroleum, coal, gas, and electricity. ${ }^{76}$ The use of whale oil in the textile industries continued until the late nineteenth century.

The American Civil War (1861-1865) had a major influence on the whaling industry in lost lives, political repercussions and the relationship between the Southern and Northern states, as well as an opening new industries that attracted capital away from the fishery. Nature also had an impact on the whaling industry as in 1871, over 30 American whaleships were trapped in the ice off Point Belcher and had to be abandoned. This catastrophe, causing a financial loss of over $\$ 1,000,000^{77}$, contributed to the rapid decline of American Arctic whaling near the Polar Circle.

In Hudson Bay and along the shore of Alaska, however, Americans remained very active and successful in their quest for animal fats and other whale products. Here, American whalers found bowhead whales. In economic terms (i.e., in size and volume of baleen and blubber) these slow-moving mammals were the most valuable representatives of all whale species. The Americans developed a flourishing whale fishery, based both on whale hibernation and intense interaction with the Inuit. Between 1860 and 1915, American participation amounted to 117 voyages to the area against a meagre 29 European trips that were mostly executed by English and Scottish whalemen. ${ }^{8}$

The Arctic was not the only destination for many hundreds of American whaleships. After the late eighteenth century, Yankee whalers set course to the Pacific and Indian Oceans, pursuing sperm whales with their valuable spermaceti, ambergris, and,

76. This development had a global effect. Because petroleum was discovered in the United States, the consequences of this development were most greatly felt in the American whaling industry.

77. The same situation occurred on a smaller but financially more damaging scale in 1876 and 1893 . Assessing the damage at approximately $\$ 1,000,000$, which means, of course, that in the early 1870 s the average value of one American whaleship, including its cargo, can be roughly estimated to be about $\$ 30,000$ to $\$ 35,000$. See Broeze, 'Whaling in the Southern Oceans', 109-110, note 161. Broeze gives numerical data concerning the value and price of purchase for American whaleships. He quotes figures of \$20,000 to \$25,00o per vessel. It is important to compare this figure with Dutch expenditures around the same time. I am indebted to Dr. Stuart M. Frank for bringing this to my attention.

78. R.A. Stackpole, American Whaling in Hudson Bay, 1861-1919 (Mystic, Connecticut 1969); W.G. Ross, Whaling and Eskimos: Hudson Bay, 1860-1915 (Ottawa 1975). 
especially, sperm oil. On average the whalemen spent two or three years while following the wake of the whales. Over the years the American South Sea whaling industry developed an intricate and complex system whereby ships could discharge their cargoes in Honolulu or San Francisco for shipment home.

\section{Premiums and procedures (1815-1855)}

As noted earlier, in the first few years after the Napoleonic Wars, the national governments of England and France were adamant in their support of the revival of industries, including whaling and premiums were granted. In both countries, however, these premiums were reduced and subsequently abandoned around 1850. In Germany and the United States, whaling activities, undertaken and fully financed by entrepreneurs, increased. In the Netherlands, the situation differed from neighbouring countries in that renewed interest in whaling and sealing was stimulated by one man: the King. During the early years of the nineteenth century this country witnessed haphazard initiatives to resume whaling. Change came in 1815 when Willem I was throned as King of the Netherlands. He was adamant in his attempts to boost Dutch industry.

One of his main fields of interest was shipping and the King invested heavily in maritime enterprises, which led to his nickname of the Merchant King. In their ground-breaking study of the Dutch economy between 1780 and 1914, Jan Luiten van Zanden and Arthur van Riel presented an estimated general total of 235.8 million guilders in governmental subsidies granted to the following categories between 1820 and $1870:^{79}$

1. industry (81.8 million guilders on textiles, shipbuilding, Fonds ter aanmoediging van de Nationale Nijverheid (Fund to stimulate National Industry, see below), sugar, and an unspecified category: miscellaneous);

2. trade and shipping (152 million guilders on cargo tariffs, commission of the Nederlandsche Handel-Maatschappij, and miscellaneous - including any insurance); and

3. herring fisheries (2 million guilders over the years 1821-1860).

By Koninklijk Besluit (KB: Royal Decree), dated 19 March 1815, premiums for the outfitting of whaleships - modestly issued in the 1770 - were increased. This KB, the very

79. J.L. van Zanden and A. van Riel, Nederland 1780-1914. Staat, instituties en economische ontwikkeling (Amsterdam 2000), 147, table 3.6. An English edition of this book was published in 2000 by Princeton University Press under the title The Strictures of Inheritance: The Dutch Economy in the Nineteenth Century. See page 119 for the table regarding premiums and subsidies. 


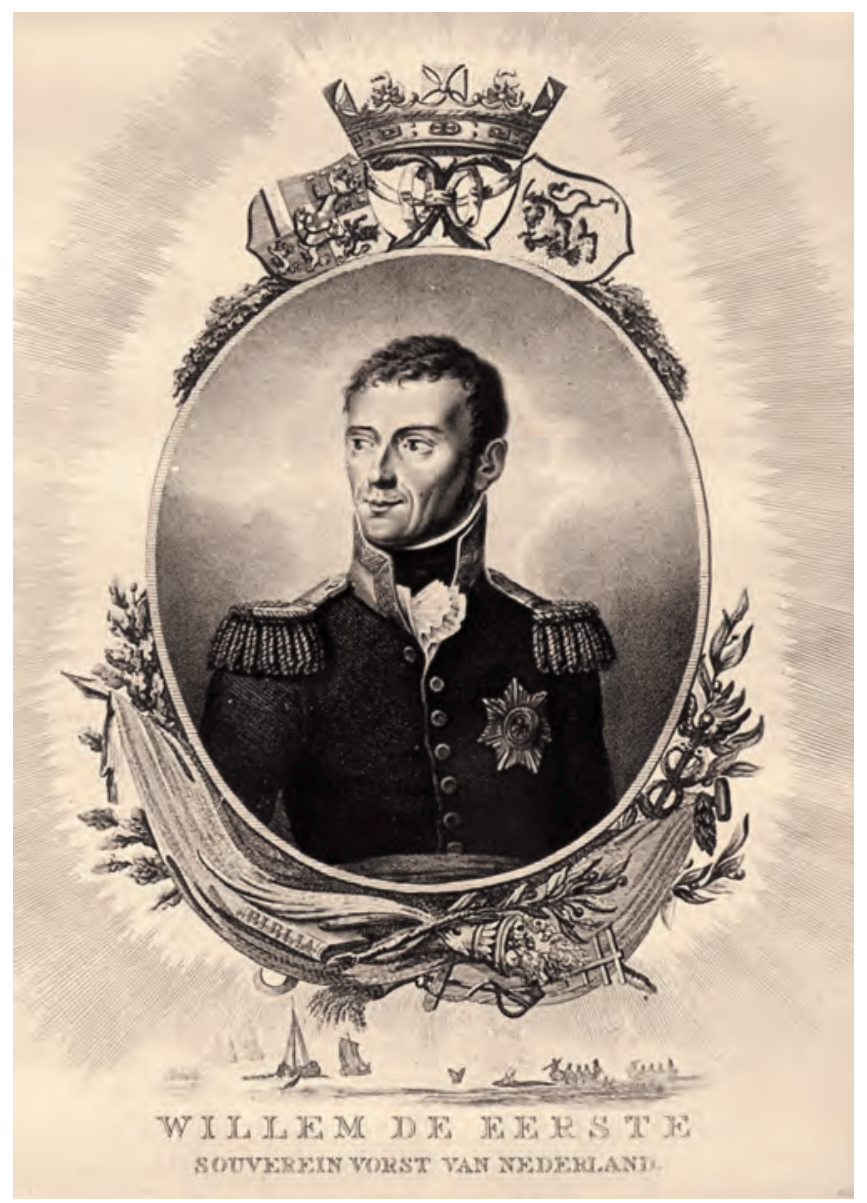

4. Portrait of King Willem I, ca. 1820 . The King has played a crucial part in supporting and sustaining different types of industries. Engraving by Willem van Senus (1773-1851).

Zuiderzeemuseum. Inventory number 013110.

first indication of the King's willingness to stimulate whaling financially, became law on 12 January 1816. Subsequent premiums were prolonged for the years 1819, 1820, and 1821. ${ }^{80}$ As noted earlier, these initiatives coincided with plans to financially stimulate the whaling industries in the United Kingdom and France, where bounties were issued per ton (Britain) or per crew member (France). In the Netherlands, premiums were paid per expedition.

Whaling and sealing were not only supported by premiums, but also during the early 1830 s, the Dutch government issued a number of laws geared to regulate and stipulate taxes on fuel used for industrial purposes. Two laws were introduced in the years 1831 and 1832. They proved fruitless. Later, during the political 'season' of 1833/1834, government achieved more success. Two proposals regulating taxes on pit and coals

80. De Jong, Oude Nederlandse walvisvaart, vol. II, 450. 


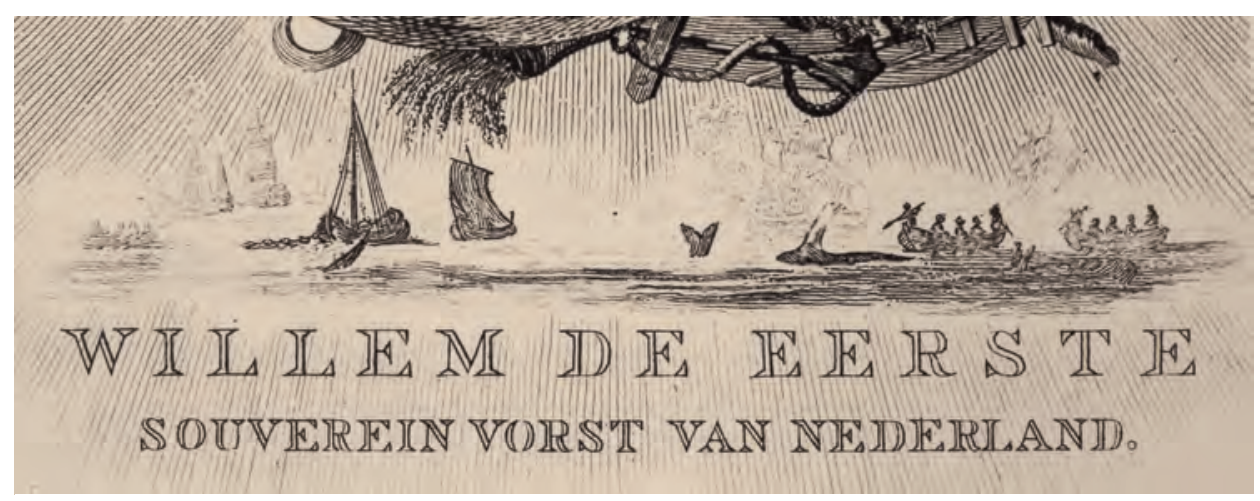

4a. Detail of the engraving by Willem van Senus. Next to the herring fishery, whaling is included in the engraving - a clear indication that the artist must have been familiar with the King's support of these two maritime industries.

were accepted by Parliament and became effective as of 1 January 1834 . These laws provided substantial reductions of taxes on fuel to a great number of industries. After 1834, cookeries deployed for the harvesting of whale blubber and seal blubber received a reduction of no less than $80 \%$ on taxes to be paid for the use of coal. Later, as of $12 \mathrm{Au}-$ gust 1857 , this reduction was increased to $95 \%$. These governmental measures were part of a large domestic political program to stimulate the use of steam power in industries. $^{82}$

Civil servants were appointed to stimulate industry. ${ }^{83}$ The first to be appointed the so-called Administrateur van de Nationale Nijverheid (literally, Administrator of the National Industry) was A.A. Stratenus (1779-1836). His more-talented successor was Johannes Theodorus Netscher (1786-1864). From as early as 1819, Netscher was involved in matters regarding the support of industries and he occupied the highest position, as Administrator, between 1828 and 1840. Until 1840, the term "industry" was applied to all economic activities, excluding trade. In other words, both agriculture as well as fisheries fell under Netscher's responsibility.

82. Verslag der Handelingen van de Staten Generaal (Minutes of the meetings of the States General), zittingsjaar 1831/32, beraadslagingen, 302/350, bijblad, $177 / 214$ and 552/595; Idem, zittingsjaar 1832/33, beraadslagingen, 168/181, bijblad, 187/243; Idem, zittingsjaar 1833/34, beraadslagingen en bijblad. Quoted in J. Teijl, 'Brandstofaccijns en nijverheid in Nederland gedurende de periode 1834-1864', J. van Herwaarden (ed.), Lof der historie. Opstellen over geschiedenis en maatschappij (Rotterdam 1973), 155-183; especially 156 and 175-177. 83. For the establishment and activities of the Fund for National Industry, see W.M. Zappey, 'Het Fonds voor de Nationale Nijverheid 1821-1846', P. Boomgaard, L. Noordegraaf a.o. (eds.), Excercities in ons verleden. Twaalf opstellen over de economische en sociale geschiedenis van Nederland en koloniën 1800-1950 (Assen 1981), 27-42; J.M.M. de Meere, Economische ontwikkeling en levensstandaard in Nederland gedurende de eerste helft van de negentiende eeuw. Aspecten en trends. Cahiers Sociale Geschiedenis I ('s-Gravenhage 1982), especially 21-23. 
By secret KB of 30 June 1825 (no. 96), the King had established the Fonds ter aanmoediging van de Nationale Nijverheid (Fund to stimulate National Industry). Netscher was head of this fund. It has been calculated that until its discontinuation in 1846 , the Fund spent about $f_{30,000,000 .}{ }^{84}$ Major investments, but also relatively smaller ones were also made. Loans ranged from $f_{380,000}$ to the firm of Nederlandsche Stoomboot Maatschappij in Rotterdam, granted between 1825 and 1833 , to smaller amounts invested in, for example, herring fisheries. In 1828, the Amsterdamsche Haringreederij received a loan of $f 40,000$ against $3 \%$ interest. In 1829, the herring firm De Hoop in Vlaardingen received a loan of $f 25,000$, while a herring firm in Maassluis received payments in the amount of $f_{24}, 800$. In his article on the Fonds ter aanmoediging van de Nationale Nijverheid, W.M. Zappey concluded his short paragraph on financial support for the fisheries with the dry remark,

"Ook de walvisvaart vanuit Harlingen genoot subsidie"

("The whale fishery conducted from Harlingen received subsidy as well"). ${ }^{85}$

Later in this chapter, the scope of these subsidies will be assessed.

In 1815, sparked by the rise of premiums, merchants and ship owners began new initiatives to stimulate whaling again. Whaling entrepreneurs focused their attention and energy on two hunting grounds: the Arctic and the South Seas. The Arctic grounds encompassed the waters between Jan Mayen Island and Spitsbergen, the waters between northern Spitsbergen and the Davis Strait, the sea lane between western Greenland, and off the mainland of present day Canada. These Arctic grounds were familiar to several generations of Dutch whalemen. More adventurous Dutch whalemen also set sail for the unfamiliar hunting grounds in the South Seas. In his subsidiary system, the King differentiated between the two areas where whales were chased. Interestingly, compared to Arctic whaling voyages under the Dutch flag, South Seas whaling received considerably less in subsidies with the difference between the two maximum figures being $33 \%$ ( $f 9,000$ against $f 6,000)$ per expedition. ${ }^{86}$

The premium issued by the government consisted of three elements: the so-called eerste helft (first half); tweede helft or wederhelft (second half) for fitting out; and the premium for wanvangst in case the ship(s) returned empty ('clean'). The first half amounted to $f 2,000$ per vessel. The second premium was granted the moment the company had filed the required paperwork regarding the return of the vessel(s). Another $f 2,000$ was then paid by the Exchequer of the States of Friesland (provincial del-

84. See Van Zanden and Van Riel, Nederland 1780-1914, 147 (table 3.6). They present an estimate of 28.7 million guilders.

85. Zappey, op. cit., 39. Author's translation.

86. De Jong, Oude Nederlandse Walvisvaart, vol. II, 450. To date, no explanation has been found for this substantial difference in subsidies. 
egates). Whaling companies were to receive a maximum of $f_{5}, 000$ for wanvangst. Depending on the catch results, smaller derivations of this amount were paid. The premium for wanvangst, which was a result of article 4 of the KB of January 1816, was determined by the number of kwartelen of oil. In his Besluit, the King had stipulated that whaling companies would receive a premium of $f_{5}$ o per kwarteel below the standard of 100 kwartelen. For example, a catch of whale blubber yielding 65 kwartelen of oil, the company would fall 35 kwartelen short and, in such a case, the government would grant a premium of $35 \times f_{50}=f_{1,750}$. Thus, in the case of 28 kwartelen, this would amount to $f_{1,400}\left(28 \times f_{50}\right)$, and so on.

The sources in the municipal archive in Harlingen reveal at least some of the stages of the application procedure. Moreover the archival records provide data concerning the settling of payments and the actual transfer of money from provincial authorities to the whaling companies; in casu, for Harlingen the Groenlandse en Straatdavidse Visscherij Sociëteit (hereafter referred to as Sociëteit), which was operational between 1824 and 1834, and the firm of Barend Visser \& Son, which was active between 1835 and 1864 .

The system involving three premiums was maintained between 1815 and 1855 . With increasing costs and decreasing success in the whaling and sealing industries, the Dutch premium system was doomed to be abandoned and in 1851 the first signs of its inevitable abolishment became apparent. Reduction of premiums was announced by the KB of 27 February (no. 77). In later years these reductions were reiterated. On 10 January 1852, King Willem II decided to re-enforce the reduction (no. 16). Finally, in the KB dated 5 January 1853 (no. 51), and published in the Staatscourant two days later, the requirements for the receipt of premiums were clearly stipulated. Those fisheries that had received guarantees for premiums applicable up to and including 1850 were still to receive subsidies but in 1851 , however, they would receive $10 \%$ less. As a consequence, a company would receive $f_{1}, 800$ per ship for premium 1 or 2 . In the case of premium 3 , the whaling company would receive a compensation of $f 45$ per kwarteel.

In the years 1853,1854 , and 1855 , these premiums were reduced to $25 \%, 50 \%$ and $75 \%$, respectively, in comparison with the levels in $1851 .{ }^{87}$ In other words, the Dutch liberal government under Prime Minister Jan Rudolph Thorbecke (1798-1872) decided to grant only $25 \%$ ( $f_{500}$ per ship in the case of premiums 1 and 2 , and $f_{12,50}$ per kwarteel in the case of premium 3) in 1855.

After 1856, the risks of whaling and sealing resided even more prominently with the whaling ship owner as opposed to the provincial or national governments. Economic change continued steadily. The situation in the Netherlands regarding the re-

87. J. Swart (ed.), Verhandelingen en berigten betrekkelijk het Zeewezen en de Zeevaartkunde, vol. 6 (1853), 191-192. 
lationship between the liberal ideas of the national government and expectations among entrepreneurs bears strong similarities with the developments in Great Britain. Almost simultaneously both England and the Netherlands witnessed the abolishment of tariff laws, which had resulted in protectionism. Such tariff laws beneficial to ships flying the Dutch flag importing commodities and paying reduced import taxes - had been in place in the Netherlands between 1822 and 1845. In Britain, import tariffs on numerous commodities had been steadily reduced since the early 1820s, culminating in the repeal of the Corn Laws in 1845, 30 years after their re-introduction. This meant a complete liberalisation of the import of agricultural products from abroad. In 1848 the infamous Navigation Acts were repealed. The Netherlands followed this British example with a repeal, in 1850, of its own version of the Laws of Navigation. ${ }^{88}$

Interestingly, similar political developments can be discerned for the Dutch herring fishery. ${ }^{89}$ In 1825 premiums for the fishing vessels (buizen) were increased by $50 \%$ (from $f_{500}$ to $f_{750}$ ). In England, the premium system for the herring fishery was abandoned as early as 1830, resulting in an important increase in activities and gains. As was the case for the whaling trade, the Dutch liberal government decided upon a gradual annulment of premiums after 1850 .

For the sake of chronology, an elaboration of the different stages of the bureaucratic procedure follows. The application of the first premium will be discussed first. Most whaleships left Harlingen harbour sometime in February or March. In order to receive what in the sources is referred to as the eerste helft of the premium, the applicants had to file paperwork. Prior to their departure the directors of the whaling company were obliged to send all information pertaining to the outfitting of their ship(s) to the City Council. Their application was occasionally initiated by requests from the Governor of the Province of Friesland. The City Council in its turn forwarded the company's paperwork to the Gedeputeerde Staten (GS, the representatives at the States of Friesland) who met in Leeuwarden. Upon receipt of the directors' application, GS would discuss matters and decide accordingly. GS or the Governor would then write to the City Council that a mandate for issuing the premium had been given during the meeting. A few days to a week later the money would actually be transferred to the whaling company by the Rijkskassier (State Exchequer). A subsequent letter from the directors of this company to the City Council would finally acknowledge the payment of the premium(s).

88. Brugmans, Paardenkracht en mensenmacht. Sociaal-economische geschiedenis van Nederland 1795-1940 ('s-Gravenhage, reprint 1976), 138-145; Van Zanden and Van Riel, Nederland 1780-1914, 233-234.

89. L.M. Akveld, 'Noordzeevisserij', F.J.A. Broeze, J.R.Bruijn and F.S. Gaastra (eds.), Maritieme Geschiedenis der Nederlanden (MGN)Vol. 3 (Bussum 1977), 323. See also especially Van Zanden and Van Riel, Nederland 1780-1914, 162-166. 
At one time these directors displayed a great sense of vigilance when it came to the manner in which GS elaborated on its decision to grant a premium. On 27 June 1826 the delegates in the Staten van Friesland informed the directors of their decision to grant premiums for four whaleships ad $f 2,000$. In their letter they referred to the premium as being the wederhelft. The whaling company was quick to correct the GS. In their letter of 6 July, they politely but firmly wrote to the City Council - as always, acting as an intermediate between the province and the whaling company - that the delegates had been erroneous in their phrasing. The payment concerned the first half of the premium for outfitting and not the second half. The fear of missing out on thousands of guilders was apparently a strong incentive for the directors to act promptly..$^{90}$ Occasionally the archival sources show a fifth party: in at least one case the clerk of the GS requested the City Council to fulfil its obligations and pay taxes over the amounts of money granted as premium..$^{11}$

Despite the many parties involved, relatively little time was wasted in the procedure. Customarily the whaling company would apply for the grant some time between mid- and late-March. The City Council would then forward the application. Judging from the fairly swift responses on the part of the GS, the City Council may have forwarded requests immediately and GS or the Governor replied within a few weeks. The subsequent order of responses would take about one month to six weeks. Between the very first letter of application (sometime in March) to the acknowledgment of the receipt of payment (often confirmed in letters dating from the second half of May) some two months would elapse. Rarely did GS decide to acknowledge payment at a later date..$^{92}$ In other words, the directors of the whaling company customarily must meet the costs involved in fitting out their fleet in advance. Although they must have assumed the delegates in the States of Friesland would abide by the execution of the King's decision to issue premiums, the company's directors were never absolutely certain whether or not they would receive the requested money.

The company received payments while the ships were out on the whaling grounds. These ships customarily returned to their home ports between mid-July and

\footnotetext{
90. GAH,\#1644 Register Missiven Ingekomen stukken; nr. 218, 27 June 1826; GAH, \#1644, nr. 228, 7 July 1826. 91. GAH, $\# 1644$, nr. 105. This concerns a request from clerk of GS to City Council of Harlingen dated 17 March 1827 , to pay $f_{74.30}$ in taxes over the received premiums, which amounted an all-time high of $f_{10}, 850$. The clerk repeated his demand nine days later. See \#1644, nr. 131, 26 March 1827. See also GAH, \#1644; nr. 48, 7 February 1827. In this letter the directors of the whaling company confirm the receipt of this amount in 'first half premiums for the two ships Spitsbergen and Willem de Eerste.

92. To date, there is only one such late reference, in which GS indicate they agreed to subsidize the first half of the premiums for the four ships fitted out in 1826. See GAH, \#1644, nr. 218, 27 June 1826. According to GAH, $\# 1644$, nr. 258 , the directors of the company acknowledge the receipt of $(4 \mathrm{x} f 2,000=) f 8,000$, more than one month later on 1 August 1826.
} 
mid-August. Then the application procedure for the second and third factors (the tweede helft of the premium for outfitting in combination with the one issued in case of wanvangst) would commence. Some time between mid-August and late-September the whaling company would send the appropriate paperwork relating to the whaling and sealing expedition - the names of ships employed and catch results - to the Harlingen City Council. In at least one case the Governor of Friesland had to ask for the required information. ${ }^{93}$ The Governor and GS would then discuss granting the premiums and inform the City Council. In most cases the whaling company acknowledged the receipt of the payments by directors' letter between mid- and late-November. Usually the company had to wait about three months, from mid-August to the second half of November, before this last phase in the application procedure was completed.

The archives have been modest in providing information about the granting of premiums for wanvangst. Therefore, some confusion has arisen in secondary literature about the amounts of money involved in this type of subsidy. ${ }^{94}$ There is one dramatic instance that unequivocally demonstrated what GS would decide in the case of wanvangst. In 1827, the Harlingen whaling company experienced the loss of one of its ships, Willem de Eerste. On 7 November, the City Council in Harlingen received word from GS and in their letter the delegates informed the city about the upcoming premium for wanvangst because of the disaster involving the company's ship. The anticipated amount was not mentioned. On 24 November, however, the Governor wrote the City Council that a mandate amounting to $f_{5,000}$ would be sent to the whaling company shortly. Apparently, money was transferred soon afterward, as the directors informed the City Council about the receipt of payment in their letter dated 1 December. ${ }^{95}$

93. GAH, \#1644, nr. 306, 19 September 1826. This request from the Governor [also on behalf of the Staatsraad administrateur of the Ministry of National Industry (Ministerie van Nationale Nijverheid)] was to the City Council. The Governor asks “....om zo spoedig mogelijk berigt te zenden nopens de uitslag der visscherij van de Schepen Willem de Eerste en Harlingen”. This request was reiterated a few weeks later. See GAH, \#1644, nr. 346, 9 October 1826, in which the Governor demanded the appropriate papers in order to fulfil the obligation and pay the second half of the premiums ad $f_{2}, 000$.

94. In his study of socio-economic developments in the Netherlands between 1795 and 1940, I.J. Brugmans devoted ten lines to the nineteenth-century whaling industry. He erroneously mentioned the premium as $f_{9}, 000$ per ship, while referring to a raise in premium for herring buizen from $f_{500}$ to $f_{750}$ in 1825 on the preceding page. See Brugmans, Paardenkracht en mensenmacht, 153-154. In order to get a sense of the size of this financial impetus, one may wish to compare this sum with the annual salary of the presiding judge of the court of Amsterdam in 1835 . In that year, this top-ranking official earned $f 3,500$. Despite the fairly circumstantial nature of this comparison - there are eleven years in between 1824 and 1834 - it clearly shows that the premium, set by the King and issued for a whaleship returning empty, can be considered quite generous. Salaries ranging from that of the presiding judge in Amsterdam down to those of the clerks of much smaller courts, suggested to be introduced in 1835, are mentioned in Leeuwarder Courant, 2 December 1834.

95. GAH, \#1644, nr. 416, 7 November 1827; nr. 440, 24 November 1827; and nr. 447, 1 December 1827. 
Table 2.1 contains an overview of governmental investments in Dutch nineteenth-century whaling and sealing, conducted from Harlingen. The overview runs from 1822 up to the abandonment of the premium system in 1855. In total, between $f 200,000$ to $f 250,000$ was spent on premiums. Several flaws were encountered in compiling this table. The data is not always complete. Also, it was difficult to obtain unambiguous information about the way all figures presented in this table came to being. Some figures concerning year Y may actually contain (partial) payments relating to the preceding year X. In 1826 , GS first granted a subsidy of $f 6,850$, to be paid to the whaling company. Later, the same company received another payment of $f 8,000$, in which the payment of premiums 1 and 2 were included. These figures present problems when it comes to their interpretation. In 1826, for instance, the whaling company fitted out no fewer than four vessels. Their applications for premiums

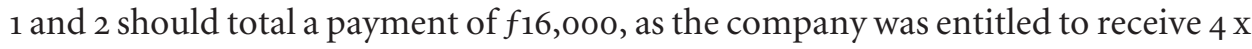
$f_{2,000}+4 \times f 2,000$. The sources at hand do not indicate why this amount was not transferred to the company's account.

Moreover, the correspondence files do not confirm whether the two amounts mentioned above $(f 6,850$ and $f 8,000)$ should have been added, or interpret that the last figure was the final payment. In other cases, only circumstantial evidence allowed the conclusion that payment of premiums had taken place. Finally, it should be noted that some numerical data is difficult to ascertain. Governmental subsidies are, in principle, given in round figures (in units of $f 2,000$ or $f 5,000$ ). But in the overview odd amounts are mentioned. We did come across several examples: $f 6,850$ in 1826; $f_{10,850}$ in 1827 ; $f_{2}, 850$ in 1828 ; $f_{3,750}$ in 1830 ; and $f_{3,900}$ and $f 6,700$ in $1831 .{ }^{96}$ Here, they are interpreted as being indicative of the catch results.

In an attempt to present a valid, well-balanced total the figures were interpreted in two ways, listing both a minimum and a maximum calculation. The first column relates to the amounts of subsidies provided in the letters. The second column gives the levels of taxes levied on the subsidies. Thus, the total amount was subtracted from the totals of the subsidies. The third column contains the figures as given in archival sources. In several instances the figures placed between brackets indicate the amounts

96. These two figures refer to the ones mentioned in the archival records at the GAH regarding the tryingout of blubber at the Cookery De Herstelder in Harlingen in the preceding year (1830). While the blubber

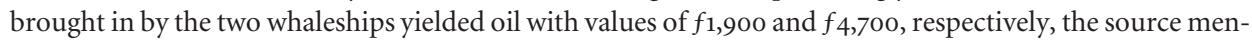
tions that the premium of $f 2,000$ had been issued in both cases. Here, the archival sources reveal that the directors of the whaling company received mandates regarding the sale of the cargo of blubber delivered by their two ships Spitsbergen and Nederland. In table 3.1 we concentrate on three figures: the amounts involving premiums 1 and $2\left(f_{3}, 750\right.$ and $\left.f_{4}, 000\right)$ and the revenues of the rendering of oil ( $f 6,600$ in total); hence the fig-

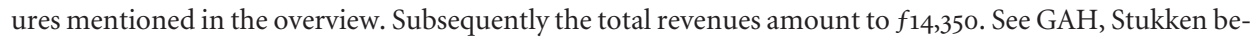
treffende het stadsbestuur van Harlingen, 1816-1924, nr. 3399: Archiefstuk betreffende de Groenland- en Straat-Davids-visserij (1830). 
were given in the indices but not confirmed by an original letter. In these instances, as the figures were unconfirmed, they were included in the maximum calculations only.

Finally, the numbers given in the column Sources refer to both the archive of incoming letter to the City Council of Harlingen (the 1400 series), as well as to the indices to these letters (1600 numbers). The 1600 numbers provide an abbreviated form of the letters' contents. The 1400 numbers, in contrast, give more detailed information. Also, the indices of outgoing letters sent by the City Council of Harlingen have been used (high 1700 numbers). The fourth source of information was the extracts from the resolutions of the Deputies in the States of Friesland (1300 numbers). In Harlingen, these resolutions run from 1815 to 1867 . The premium system, introduced and refined by King Willem I and continued by King Willem II through 1848, however, was in effect between 1816 and $1855 .{ }^{97}$ This table serves as one of the foundations of our calculations with regard to the profitability of whaling and sealing in the cases of Barend Visser \& Son's privately run expeditions (1822-1824), the Groenlandse en Straatdavidse Visscherij Sociëteit (1825-1834), and of Barend Visser \& Son during the ensuing period (1835-1864). Chapter 7 will deal with this topic in more detail.

Table 2.1: Calculation of total of governmental subsidies to Dutch whaling and sealing expeditions conducted from Harlingen (1822-1855). (Amounts are in $f$; GAH stands for Gemeentearchief Harlingen [municipal archive, Harlingen]).

\begin{tabular}{|c|c|c|c|c|c|c|}
\hline Year & $\begin{array}{l}\text { Amount given } \\
\text { in sources }\end{array}$ & Taxes levied & Sources & Remarks & Minimum & Maximum \\
\hline 1822 & & & $\begin{array}{l}\text { GAH, } 1375 ; \text { nr. } 1 \\
\text { (14 November) }\end{array}$ & $\begin{array}{l}\text { Premiums not acknowl- } \\
\text { edged due to procedural } \\
\text { flaws }\end{array}$ & & \\
\hline \multirow[t]{2}{*}{1823} & 2,000 & & $\begin{array}{l}\text { GAH, 1643: nr. } 111 \text { (28 May); } \\
\text { GAH, 1375: nr. } 1 \text { (28 May) }\end{array}$ & Premium 1 for Spitsbergen & 2,000 & 4,000 \\
\hline & {$[2,000+?]$} & & $\begin{array}{l}\text { GAH, 1375: nr. } 3 \\
\text { (13 November) }\end{array}$ & $\begin{array}{l}\text { Premiums } 2+3 \text { not ac- } \\
\text { knowledged due to proce- } \\
\text { dural flaws }\end{array}$ & & \\
\hline 1824 & No data & No data & No data & No data & No data & No data \\
\hline \multirow[t]{2}{*}{1825} & 2,000 & & $\begin{array}{l}\text { GAH, 1375: nr. } 14 \text { (14 De- } \\
\text { cember) }\end{array}$ & Premium 2 for Spitsbergen & 4,050 & \\
\hline & 2,050 & & $\begin{array}{l}\text { GAH, 1375: nr. } 14 \text { (14 De- } \\
\text { cember); GAH, 1376: nr. } 13 \\
\text { (14 February 1826) }\end{array}$ & Premium 3 for Spitsbergen & & \\
\hline 1826 & 6,850 & & $\begin{array}{l}\text { GAH, 1644; nrs. 127, 135; } \\
\text { GAH, 1414: nr. 5, 28 March; } \\
\text { GAH, 1376: nr. } 27 \text { (10 Feb- } \\
\text { ruary), nr. } 5 \text { (21 February) } \\
\text { and nr. } 4 \text { (27 June) }\end{array}$ & $\begin{array}{l}\text { Premiums } 1 \text { (GAH } 1376 \\
\text { refers to premium 2) and } 3 \\
\text { for Willem de Eerste }\end{array}$ & 14,500 & 14,850 \\
\hline
\end{tabular}

97. It should be noted that the indices seem to be applicable and subsequently useful until 1850 (GAH, \#1649). In the case of the indices only the reference numbers of the letters are mentioned. In the case of the incoming letters, both the reference numbers as well as the date of posting is given. For several years during the 1830s, the original letters referred to in the indices have not been located. Moreover, most letters were placed in chronological order, but not all. Due to misplacement of letters for some years (for example 1829 and 1848), the required data was not retrieved. 
King Willem I And the Premium System (1815-1855)

\begin{tabular}{|c|c|c|c|c|c|c|}
\hline Year & $\begin{array}{l}\text { Amount given } \\
\text { in sources }\end{array}$ & Taxes levied & Sources & Remarks & Minimum & Maximum \\
\hline & 8,000 & & $\begin{array}{l}\text { GAH, 1644: nrs. 218, 228, } \\
\text { 258; GAH, 1414: } 6 \text { July, } 1 \text { Au- } \\
\text { gust; GAH, 1376: nr. } 2 \text { ( } 27 \\
\text { July) }\end{array}$ & $\begin{array}{l}\text { Premium } 2 \text { (GAH refers to } \\
\text { premium 1) for Spitsbergen, } \\
\text { Nederland, Harlingen and } \\
\text { Willem de Eerste }\end{array}$ & & \\
\hline \multirow[t]{2}{*}{1827} & 10,850 & & $\begin{array}{l}\text { GAH, 1644: nr. 48: GAH, } \\
\text { 1416: } 7 \text { February }\end{array}$ & & 15,850 & 15,850 \\
\hline & 5,000 & $-/-12,50$ & $\begin{array}{l}\text { GAH, 1644: nrs. 416, 440, } \\
\text { 447; GAH, 1417: } 24 \text { Novem- } \\
\text { ber, } 1 \text { December }\end{array}$ & $\begin{array}{l}\text { Premium } 3 \text { due to loss of } \\
\text { Willem de Eerste }\end{array}$ & & \\
\hline \multirow[t]{2}{*}{1828} & 2,000 & & $\begin{array}{l}\text { GAH, 1644: nr. 192; GAH, } \\
\text { 1418: } 21 \text { May }\end{array}$ & Premium 1 for Nederland & 4,000 & 4,850 \\
\hline & 2,850 & $-/-15,00$ & $\begin{array}{l}\text { GAH, 1644: nr. 408; GAH, } \\
\text { 1419: } 5 \text { November }\end{array}$ & $\begin{array}{l}\text { Premium } 2+\text { part of pre- } \\
\text { mium } 3\end{array}$ & & \\
\hline \multirow[t]{3}{*}{1829} & 4,000 & & $\begin{array}{l}\text { GAH, 1645: nr. 277; GAH, } \\
\text { 1420, } 25 \text { May }\end{array}$ & Premium 1 for two vessels & 9,750 & 9,750 \\
\hline & 2,000 & $-/-5,00$ & $\begin{array}{l}\text { GAH, 1645: nrs. } 596,599 ; \\
\text { GAH, } 1421,20 \text { November, } \\
24 \text { November }\end{array}$ & $\begin{array}{l}\text { Premium } 2 \text { for Spitsbergen } \\
\text { (II) }\end{array}$ & & \\
\hline & $2,000+1,750$ & & $\begin{array}{l}\text { GAH, 1645: nr. 629; GAH, } \\
\text { 1421: } 12 \text { December }\end{array}$ & $\begin{array}{l}\text { Premium } 2 \text { for other vessel } \\
(\text { Nederland })+\text { premium } 3\end{array}$ & & \\
\hline \multirow[t]{2}{*}{1830} & 3,750 & & $\begin{array}{l}\text { GAH, 1645: nrs. 31, 64; } \\
\text { GAH, 1422: 23 January, } \\
\text { 30 January }\end{array}$ & $\begin{array}{l}\text { Premium } 2[\text { sic }]+\text { part of } \\
\text { premium } 3 \text { for Nederland }\end{array}$ & 7,750 & 7,750 \\
\hline & 4,000 & $-1-9,50$ & $\begin{array}{l}\text { GAH, 1645: nr. 339; GAH, } \\
\text { 1422: } 1 \text { June }\end{array}$ & $\begin{array}{l}\text { Premium } 1 \text { for Spitsbergen } \\
\text { (II) and Nederland }\end{array}$ & & \\
\hline \multirow[t]{6}{*}{1831} & 3,900 & & $\begin{array}{l}\text { GAH, 1645: nr. 136; GAH, } \\
\text { 1423: } 16 \text { March, 17 March }\end{array}$ & $\begin{array}{l}\text { Premium } 1+\text { part of pre- } \\
\text { mium } 3 \text { (N.B.: in their let- } \\
\text { ter, the directors of the } \\
\text { company refer to request } \\
\text { for premium } 2 \text { for Spitsber- } \\
\text { gen (II), not premium } 1 \text { ) }\end{array}$ & 18,600 & 18,600 \\
\hline & 6,700 & $-/-26,50$ & $\begin{array}{l}\text { GAH, 1645: nr. 136; GAH, } \\
\text { 1423: } 16 \text { March }\end{array}$ & $\begin{array}{l}\text { Premium } 2 \text { (for two ships) } \\
+ \text { part of premium } 3\end{array}$ & & \\
\hline & 4,000 & & $\begin{array}{l}\text { GAH, 1645: nr. 235; GAH, } \\
\text { 1423: } 18 \text { March: GAH, 1787: } \\
\text { Folio 62, nr. } 310 \text { (19 May) }\end{array}$ & Premium 1 for two ships & & \\
\hline & 4,000 & $-/-10,00$ & $\begin{array}{l}\text { GAH, 1645: nr. 451; GAH, } \\
\text { 1423: } 8 \text { November; GAH, } \\
\text { 1787: Folio 62, nr. } 633(8 \\
\text { November) }\end{array}$ & $\begin{array}{l}\text { Premium } 2 \\
1832\end{array}$ & & \\
\hline & 4,000 & & $\begin{array}{l}\text { GAH, 1645: nr. 299; GAH, } \\
\text { 1424: } 28 \text { May; GAH, 1788: } \\
\text { Folio 62, nr. } 307 \text { (28 May) }\end{array}$ & Premium 1 (for two ships) & 8,000 & 8,000 \\
\hline & 4,000 & & $\begin{array}{l}\text { GAH, 1645: nr. 481; GAH, } \\
\text { 1788: Folio 62, nr. } 539 \text { (1 Oc- } \\
\text { tober) }\end{array}$ & $\begin{array}{l}\text { Premium } 2 \text { (for two ships; } \\
\text { no premium } 3 \text { ?) }\end{array}$ & & \\
\hline \multirow[t]{4}{*}{1833} & {$[3,750]$} & & $\begin{array}{l}\text { GAH, 1645: nr. 132; GAH, } \\
\text { 1425: } 21 \text { February; GAH, } \\
\text { 1788: Folio 62, nr. } 176(22 \\
\text { February) }\end{array}$ & $\begin{array}{l}\text { [Part of premium } 3 \text { for } \mathrm{Ne} \text { - } \\
\text { derland] relates to } 1832 \text { ?] }\end{array}$ & 11,450 & 15,200 \\
\hline & 4,000 & & $\begin{array}{l}\text { GAH, 1788: Folio 62, nr. } 381 \\
\text { (25 May) }\end{array}$ & Premium 1 for two ships & & \\
\hline & 4,000 & & $\begin{array}{l}\text { GAH, 1788: Folio 62, nr. } 463 \\
\text { (24 June) }\end{array}$ & Premium 2 for two ships & & \\
\hline & 3,450 & $-1-19,69$ & $\begin{array}{l}\text { GAH, } 1645: \text { nr. } 775 ; \text { GAH, } \\
\text { 1425: } 7 \text { November; GAH, } \\
\text { 1788: Folio 62, nr. } 776 \text { (11 } \\
\text { November) }\end{array}$ & $\begin{array}{l}\text { Part of premium } 3 \text { for } \mathrm{Ne} \text { - } \\
\text { derland }\end{array}$ & & \\
\hline
\end{tabular}




\begin{tabular}{|c|c|c|c|c|c|c|}
\hline Year & $\begin{array}{l}\text { Amount given } \\
\text { in sources }\end{array}$ & Taxes levied & Sources & Remarks & Minimum & Maximum \\
\hline \multirow[t]{3}{*}{1834} & 4,000 & $-/-10,62$ & $\begin{array}{l}\text { GAH, 1645: nr. 376; GAH, } \\
\text { 1426: } 14 \text { May; GAH, 1788: } \\
\text { Folio 62, nr. } 346 \text { (20 May) }\end{array}$ & Premium 1 for two ships & 15,150 & 15,150 \\
\hline & 4,000 & & $\begin{array}{l}\text { GAH, 1645: nr. 776; GAH, } \\
\text { 1426: } 12 \text { November }\end{array}$ & Premium 2 for two ships & & \\
\hline & 7,150 & $-/-28,94$ & $\begin{array}{l}\text { GAH, } 1645: \text { nr. 776; GAH, } \\
\text { 1426: } 12 \text { November; GAH, } \\
\text { 1788: Folio 62, nr. } 726 \\
\text { (13 November) }\end{array}$ & $\begin{array}{l}\text { Premium } 3 \text { for Nederland } \\
\text { and Spitsbergen (II) }\end{array}$ & & \\
\hline \multirow[t]{2}{*}{1835} & 2,000 & & $\begin{array}{l}\text { GAH, 1645: nr. 266; GAH, } \\
\text { 1789: Folio 157, nr. } 268 \\
\text { (30 March) }\end{array}$ & $\begin{array}{l}\text { Premium } 1 \text { for Spitsbergen } \\
\text { (II) }\end{array}$ & 4,000 & 4,000 \\
\hline & 2,000 & & $\begin{array}{l}\text { GAH, 1645; nr. 586; GAH, } \\
\text { 1789: Folio 157, nr. } 598 \text { (10 } \\
\text { September), and nr. } 631 \\
\text { (28 September) }\end{array}$ & $\begin{array}{l}\text { Premium } 2 \text { for Spitsbergen } \\
\text { (II) }\end{array}$ & & \\
\hline \multirow[t]{2}{*}{1836} & 2,000 & $-/-5,62$ & $\begin{array}{l}\text { GAH, 1645: nr. 366; GAH, } \\
\text { 1428: 13 May; GAH, 1789: } \\
\text { Folio 157, nr. } 493 \text { (16 May) }\end{array}$ & $\begin{array}{l}\text { Premium } 1 \text { for Spitsbergen } \\
\text { (II) }\end{array}$ & 4,000 & 4,000 \\
\hline & 2,000 & & $\begin{array}{l}\text { GAH, 1645: nr. 679; GAH, } \\
\text { 1789: Folio 157, nr. } 922 \\
\text { (14 October) }\end{array}$ & $\begin{array}{l}\text { Premium } 2 \text { for Spitsbergen } \\
\text { (II) }\end{array}$ & & \\
\hline \multirow[t]{2}{*}{1837} & 2,000 & $\begin{array}{l}-/-5,62- \\
-/-10,15\end{array}$ & $\begin{array}{l}\text { GAH, 1378: nr. 28/98 (6 } \\
\text { April); GAH, 1645/1646; } \\
\text { nrs. 273, 350, 595, 637; GAH, } \\
\text { 1429: 6 May; GAH, 1789: } \\
\text { Folio 157, nr. } 474 \text { (11 May) }\end{array}$ & $\begin{array}{l}\text { GAH } 1378 \text { mentions pre- } \\
\text { mium } 1 \text {. GAH } 1645 / 1646 \text { con- } \\
\text { cerns mandates; amount is } \\
\text { not substantiated. GAH } 1789 \\
\text { mentions sending receipt }\end{array}$ & 5,550 & 5,550 \\
\hline & $2,000+1,550$ & & $\begin{array}{l}\text { GAH, 1378: nr. C/98 (5 Oc- } \\
\text { tober) GAH, 1789: Folio 157, } \\
\text { nr. } 882 \text { (27 October) }\end{array}$ & $\begin{array}{l}\text { GAH } 1378 \text { mentions pre- } \\
\text { mium } 2 \text { and premium } 3 \text {. } \\
\text { GAH } 1789 \text { mentions send- } \\
\text { ing receipt }\end{array}$ & & \\
\hline \multirow[t]{2}{*}{1838} & 4,000 & & $\begin{array}{l}\text { GAH, } 1646 \text {; nrs. } 305,355 ; \\
\text { GAH, } 1789 \text { : Folio 157, nr. } \\
539 \text { (13 June) }\end{array}$ & Premium 1 for two ships & 8,000 & 8,000 \\
\hline & 4,000 & & $\begin{array}{l}\text { GAH, 1646: nrs. 538, 586; } \\
\text { GAH, 1789: Folio 157, nr. } 831 \\
\text { (24 September) }\end{array}$ & $\begin{array}{l}\text { Premium } 2 \text { for two ships. } \\
\text { GAH } 1789 \text { mentions pay- } \\
\text { ment of taxes over pre- } \\
\text { miums }\end{array}$ & & \\
\hline \multirow[t]{3}{*}{1839} & 4,000 & $-/-10,62$ & $\begin{array}{l}\text { GAH, 1646; nr. } 354 \text {; GAH, } \\
\text { 1789: Folio 158, nr. } 877 \\
\text { (24 September) }\end{array}$ & Premium 1 for two ships & 11,300 & 15,300 \\
\hline & {$[4,000]$} & & GAH, 1646: nr. 636 & $\begin{array}{l}\text { Mandate premium } 2 \text { for } \\
\text { two ships (?); amount is not } \\
\text { substantiated }\end{array}$ & & \\
\hline & 7,300 & $-/-18,87$ & $\begin{array}{l}\text { GAH, 1646: nrs. } 619,687 ; \\
\text { GAH, 1431: } 24 \text { October; } \\
\text { GAH, 1789: Folio 158, nr. } \\
978 \text { (28 October) }\end{array}$ & $\begin{array}{l}\text { Premiums } 2+3(?) \text { for two } \\
\text { ships }\end{array}$ & & \\
\hline \multirow[t]{3}{*}{1840} & 4,000 & & $\begin{array}{l}\text { GAH, 1646: nr. 275; GAH, } \\
\text { 1789: Folio 158, nr. } 505 \\
\text { (13 May) }\end{array}$ & Premium 1 for two ships & 13,950 & 13,950 \\
\hline & 4,000 & & $\begin{array}{l}\text { GAH, 1646: nr. 593a; GAH, } \\
\text { 1789: Folio 158, nr. } 1079 \\
\text { (11 November) }\end{array}$ & Premium 2 & & \\
\hline & 5,950 & & $\begin{array}{l}\text { GAH, 1789: Folio 158, nr. } \\
1093 \text { (12 November) }\end{array}$ & $\begin{array}{l}\text { Premium } 3 \text { for two ships } \\
\text { (?). GAH } 1789 \text { mentions } \\
\text { sending receipt and pay- } \\
\text { ment of taxes for mandate } \\
\text { amounting } f_{5,950}\end{array}$ & & \\
\hline
\end{tabular}


King Willem I And the Premium System (1815-1855)

\begin{tabular}{|c|c|c|c|c|c|c|}
\hline Year & $\begin{array}{l}\text { Amount given } \\
\text { in sources }\end{array}$ & Taxes levied & Sources & Remarks & Minimum & Maximum \\
\hline \multirow[t]{3}{*}{1841} & 4,000 & 10,62 & $\begin{array}{l}\text { GAH, 1646: nr. 632; GAH, } \\
\text { 1789: Folio 158, nr. } 433 \text { ( } 24 \\
\text { May), and nr. } 434 \text { ( } 24 \text { May) }\end{array}$ & Premium 1 for two ships & 8,000 & 14,650 \\
\hline & 4,000 & & $\begin{array}{l}\text { GAH, 1789: Folio 158, nr. } \\
837 \text { (1 October) }\end{array}$ & Premium 2 for two ships & & \\
\hline & 6,500 & & $\begin{array}{l}\text { GAH, 1646; nr. 667; GAH, } \\
\text { 1789: Folio 158, nr. 850a (14 } \\
\text { October) }\end{array}$ & $\begin{array}{l}\text { Premium } 3 \text { for two ships. } \\
\text { Amount is not substantiat- } \\
\text { ed. GAH } 1789 \text { mentions } \\
\text { sending of receipt and pay- } \\
\text { ment of taxes for mandate }\end{array}$ & & \\
\hline 1842 & & & & $\begin{array}{l}\text { Only requests; no concrete } \\
\text { results }\end{array}$ & & \\
\hline \multirow[t]{2}{*}{1843} & {$[4, \mathrm{OOO}]$} & & $\begin{array}{l}\text { GAH, 1647: nrs. } 26,73 \\
\text { GAH, 1435, } 8 \text { March }\end{array}$ & $\begin{array}{l}\text { Premium } 1 \text { for two ships; } \\
\text { amount is not substantiated }\end{array}$ & & 8,000 \\
\hline & {$[4,000]$} & & $\begin{array}{l}\text { GAH, 1647; nr. 55; GAH, } \\
\text { 1790: Folio 322, nr. } 732 \\
\text { (8 September) }\end{array}$ & $\begin{array}{l}\text { Premium } 2 \text { for two ships; } \\
\text { amount is not substantiated }\end{array}$ & & \\
\hline \multirow[t]{2}{*}{1844} & {$[4,000]$} & & $\begin{array}{l}\text { GAH, 1647; nrs. 6, 87; GAH, } \\
\text { 1790: Folio 322, nr. } 828 \text { ( } 24 \\
\text { June), and nr. } 829 \text { (24 June) }\end{array}$ & $\begin{array}{l}\text { Premium [1 or } 2] \text { for two } \\
\text { ships; amount is not sub- } \\
\text { stantiated }\end{array}$ & 4,000 & 8,000 \\
\hline & {$[4,000]$} & & $\begin{array}{l}\text { GAH, } 1647 ; \text { nr. } 33 ; \text { GAH, } \\
1790: \text { Folio } 322, \text { nr. } 1187 \\
\text { (23 September), nr. } 1221 \\
\text { (1 October), and nr. } 1274 \\
\text { (10 October) }\end{array}$ & $\begin{array}{l}\text { Premium [ } 2 \text { or } 1] \text { for two } \\
\text { ships; amount is not sub- } \\
\text { stantiated. GAH } 1790, \text { nr. } \\
1187 \text { refers to receipt of man- } \\
\text { dates, nrs. } 1221 \text { and } 1274 \text { both } \\
\text { refer to payment of taxes }\end{array}$ & & \\
\hline \multirow[t]{2}{*}{1845} & 4,000 & & $\begin{array}{l}\text { GAH, 1647; nr. 6, } 2 \text { June; } \\
\text { GAH, 1790: Folio 322, nr. } \\
\text { 590 (13 May), and nr. } 685 \text { ( } 5 \\
\text { June) }\end{array}$ & $\begin{array}{l}\text { Premium } 1 \text { for two ships. } \\
\text { GAH } 1790, \text { nr. } 685 \text { refers to } \\
\text { receipt of payment }\end{array}$ & & 8,000 \\
\hline & {$[2,000]$} & & $\begin{array}{l}\text { GAH, 1647: nr. 46, } 16 \text { Sep- } \\
\text { tember, and nr. 59, } 16 \text { Octo- } \\
\text { ber; GAH, 1790: nr. } 1046(25 \\
\text { September) }\end{array}$ & $\begin{array}{l}\text { Premium 2; amount is not } \\
\text { substantiated. GAH } 1790 \\
\text { refers to an announcement } \\
\text { of 'assignatien' in letter to } \\
\text { Barend Visser \& Son }\end{array}$ & & \\
\hline \multirow[t]{3}{*}{1846} & 4,000 & & $\begin{array}{l}\text { GAH, 1790: Folio 322, nr. } \\
483 \text { (6 April) }\end{array}$ & $\begin{array}{l}\text { Notification of premium } 1 \\
\text { (for two ships) in letter to } \\
\text { Barend Visser \& Son }\end{array}$ & 4,000 & 4,000 \\
\hline & & & $\begin{array}{l}\text { GAH, 1790: Folio 322, nr. } \\
951 \text { (30 July) }\end{array}$ & $\begin{array}{l}\text { Request for premium } 2 \text { for } \\
\text { Dirkje Adema }\end{array}$ & & \\
\hline & & & $\begin{array}{l}\text { GAH, 1790: Folio 322, nr. } \\
987 \text { (6 August), nr. } 1062 \text { ( } 24 \\
\text { August), and nr. } 1063 \text { ( } 24 \\
\text { August) }\end{array}$ & $\begin{array}{l}\text { All letters are requests for } \\
\text { premium } 3 \text { for one/two } \\
\text { ships }\end{array}$ & & \\
\hline \multirow[t]{4}{*}{1847} & {$[4,000]$} & & GAH, 1648: nr. 986 & $\begin{array}{l}\text { Announcement of pay- } \\
\text { ment; amount not substan- } \\
\text { tiated }\end{array}$ & 8,425 & 12,425 \\
\hline & 2,000 & & GAH, 1648: nr. 2046, 1915 & $\begin{array}{l}\text { Premium } 2 \text { for Dirkje } \\
\text { Adema }\end{array}$ & & \\
\hline & 2,000 & & GAH, 1648: nr. 1988 & $\begin{array}{l}\text { Premium } 2 \text { for Spitsbergen } \\
\text { (II) }\end{array}$ & & \\
\hline & 4,425 & & GAH, 1648: nr. 2109 & $\begin{array}{l}\text { Premium } 3 \text { for Dirkje } \\
\text { Adema }\end{array}$ & & \\
\hline \multirow[t]{2}{*}{1848} & {$[4, \mathrm{OOo}]$} & & GAH, 1648: nrs. 993, 1100 & $\begin{array}{l}\text { Announcement; amount is } \\
\text { not substantiated }\end{array}$ & & 8,950 \\
\hline & {$[4,950]$} & & GAH, 1648: nr. 2443 & $\begin{array}{l}\text { Assigned premium } 3 \text { for } \\
\text { Spitsbergen (II); amount is } \\
\text { not substantiated }\end{array}$ & & \\
\hline
\end{tabular}




\begin{tabular}{|c|c|c|c|c|c|c|}
\hline Year & $\begin{array}{l}\text { Amount given } \\
\text { in sources }\end{array}$ & Taxes levied & Sources & Remarks & Minimum & Maximum \\
\hline \multirow[t]{2}{*}{1849} & & & GAH, 1442: 20 March & Request for premium (1 or 2 ) & & \\
\hline & & & GAH, 1442: 18 August & Request for premium 3 & & \\
\hline \multirow[t]{2}{*}{1850} & & & GAH, 1443: 30 March & $\begin{array}{l}\text { Request for premium } 1 \text { for } \\
\text { two ships }\end{array}$ & & \\
\hline & & & GAH, 1443: 20 August & $\begin{array}{l}\text { Request for premium } 2 \text { for } \\
\text { two ships }\end{array}$ & & \\
\hline 1851 & & & & Reduction in premiums & & \\
\hline \multirow[t]{2}{*}{1852} & 3,000 & & $\begin{array}{l}\text { GAH, 1387: nr. } 27 \\
\text { (29 March) }\end{array}$ & $\begin{array}{l}\text { Premium } 1 \text { for Dirkje } \\
\text { Adema and Spitsbergen (II) } \\
\text { (= } 75 \% \text { of pre-1851 level) }\end{array}$ & 10,369 & 10,369 \\
\hline & $7,369[7,368,75]$ & & $\begin{array}{l}\text { GAH, 1387: nr. } 26 \\
\text { (16 September) }\end{array}$ & $\begin{array}{l}\text { Premiums } 2 \text { and } 3 \text { for two } \\
\text { ships }\end{array}$ & & \\
\hline \multirow[t]{2}{*}{1853} & 2,000 & & $\begin{array}{l}\text { GAH, 1388: nr. } 43 \\
\text { (21 March) }\end{array}$ & $\begin{array}{l}\text { Premium } 1 \text { for two ships } \\
\text { (= 50\% of pre-1851 level) }\end{array}$ & 4,000 & 4,000 \\
\hline & 2,000 & & GAH, 1388: nr. 65 (28 June) & $\begin{array}{l}\text { Premium } 2 \text { for two ships } \\
\text { (= } 50 \% \text { of pre-1851 level) }\end{array}$ & & \\
\hline \multirow[t]{2}{*}{1854} & 1,000 & & $\begin{array}{l}\text { GAH, 1389: nr. } 14 \\
\text { (27 March) }\end{array}$ & $\begin{array}{l}\text { Premium } 1 \text { for Dirkje } \\
\text { Adema } \\
(=50 \% \text { of pre-1851 level) }\end{array}$ & 4,075 & 4,075 \\
\hline & 3,075 & & $\begin{array}{l}\text { GAH, 1389: nr. } 22 \\
\text { (4 September) }\end{array}$ & $\begin{array}{l}\text { Premium } 2(=50 \% \text { of pre- } \\
1851 \text { level })+ \text { premium } 3\end{array}$ & & \\
\hline \multirow[t]{2}{*}{1855} & 500 & & $\begin{array}{l}\text { GAH, 1390: nr. } 20 \\
\text { (23 April) }\end{array}$ & $\begin{array}{l}\text { Premium } 1 \text { for Dirkje } \\
\text { Adema } \\
\text { (= } 25 \% \text { of pre-1851 level) }\end{array}$ & 2,150 & 2,150 \\
\hline & 1,650 & & $\begin{array}{l}\text { GAH, 1390: nr. } 20 \\
\text { (18 September) }\end{array}$ & $\begin{array}{l}\text { Premium } 2 \text { (= } 25 \% \text { of pre- } \\
1851 \text { level })+ \text { premium } 3\end{array}$ & & \\
\hline 1856 & & & $\begin{array}{l}\text { GAH, 1390: nr. } 29 \\
\text { (15 January) }\end{array}$ & $\begin{array}{l}\text { In the national budget for } \\
1856, \text { the government did } \\
\text { not include money for pre- } \\
\text { miums beneficiary to whal- } \\
\text { ing. }\end{array}$ & & \\
\hline Total & & & & & 198,949 & 251,419 \\
\hline
\end{tabular}

Once again it should be stressed that figures pertaining to governmental subsidies for whaling and sealing were only found in Harlingen. It is safely assumed that the figures quoted in the table as minimum and maximum sums are lower than the actual scope of national investments. Now that data concerning the premium system has been given, the two theatres of whaling will be discussed next in Chapter 3 .

\section{Conclusions}

After the installation of Willem I as King of the Netherlands, many areas of the Dutch economy underwent major changes. The King invested freely and heavily in maritime enterprises. Subsidies were established or raised. Whaling and sealing industries benefitted equally from the benevolent attitude displayed by His Majesty. By Koninklijk Besluit dated 19 March 1815, premiums for the outfitting of whaleships were increased. This KB, the very first indication of the King's willingness to stimulate whaling fi- 
nancially, became law on 12 January 1816. These initiatives competed with plans of the respective national governments to financially stimulate whaling industries in the United Kingdom and France.

The Dutch premium system consisted of three elements: the first half (eerste helft), second half ( $t$ weede helft or wederhelft), and compensation for empty returns (wanvangst). At a maximum, the premium could amount to $f_{9}, 000$ per expedition. In 1855 , as a result of a complex set of national and international developments, the Liberal government in the Netherlands, headed by Prime-Minister J.R. Thorbecke, decided to discontinue granting premiums. Calculations related to the financial support of Harlingen-based whaling companies heading for the Arctic for the period 1822-1855 amounted to between $f 200,000$ and $f 250,000$. In order to complete the picture of the total State investment, subsidies for companies based in Amsterdam and Rotterdam should be added. Though relatively small, governmental support for whaling were very important to the fairly small-scale whaling companies. 
Chapter 3

\title{
Nineteenth-Century Dutch Whaling in the South Seas (1827-1849)
}

\begin{abstract}
Introduction
As stated earlier, Dutch whaling during the nineteenth century was conducted both in the Arctic as well as the South Pacific. In the Netherlands, initiatives to invest time and energy in whaling - a trade so popular among foreign entrepreneurs - in the South Seas came fairly late. After the failure of the Afrikaanse Visscherij Sociëteit (see Chapter 1), initiatives for whaling in the South Seas were postponed until the mid-1820s. In this chapter, the leading characters in this drama will be introduced. Attention will be paid to the manner in which they conducted their business. In this way, Dutch involvement in South Seas whaling and its results will be assessed.
\end{abstract}

\section{Gerrit Boon (1825)}

In 1825, Rotterdam merchant Gerrit Boon wrote a petition to King Willem I revealing his plans to establish a whaling and sealing company. This petition carried the title Memorie en Concept-Plan tot oprichting van een Walvisch en Robben Visscherij in de Zuid-Stille en Indische Zeeën (Memorandum and Preliminary Plan for the founding of a Whaling and Sealing Industry in the South Pacific and Indian Seas). Unlike the other Rotterdam-based company, Boon's firm intended to focus its activities on whaling and sealing in the South Pacific and Indian Oceans. Boon thought it necessary to raise the huge sum of $f 2,000,000$ for fitting out a fleet of no fewer than ten rather large ships, measuring between 400 and 600 tons, carrying six to eight whaleboats, and each manned with 70 to 80 crewmen.

This company would have its seat in Rotterdam. It should not come as a surprise that Gerrit Boon envisioned himself as acting director. In an attempt to attract their attention for his whaling project, Boon approached some of the finest Rotterdam merchants as well as banking and manufacturing communities: C.J. Blankenheym, Anthony van Hoboken, M.A.F.H. Hoffman, A. Mees, P. Osy, Frans Smeer, and J. van der 
Wallen van Vollenhoven..$^{98}$ None of them, however, desired to become financially involved. ${ }^{99}$

From the onset it was clear that the Dutch government would never supply that kind of money. In fact, Boon applied again, repeating his request in February, 1826. The official response from the Dutch government was striking. The government was not willing to resume whaling on such a scale. Boon was kindly advised to seek financial support and solicit capital from private sources. ${ }^{100}$

\section{Nederlandsche Handel-Maatschappij \\ (Dutch Trading Company: NHM) (1827-1830)}

While the government turned down Boon's initiative, the King himself acted differently. He approached the NHM and asked this company to commence southern whaling. The board of directors of the NHM faced a dilemma, as, according to Frank Broeze,

"...it became soon obvious to the directors that no suitable ships were available in the

Netherlands or could be built within a short time". ${ }^{101}$

In order to fill this gap (id est: the lack of suitable ships for whaling purposes), the NHM agent in the United States, captain P. Landberg, managed to arrange for a new ship to be built in accordance with the latest technological, naval architectural knowhow: the Dartmouth, Massachusetts-built Logan, 302 tons, with Reuben F. Coffin of Nantucket as master. ${ }^{102}$ Coffin was no green hand when it came to whaling. He had

98. These people were mentioned by Broeze, Whaling in the Southern Oceans, 74. Blankenheym \& Nolet were involved in the production of Dutch gin, Van Hoboken had his own fleet of ships, a private wharf and vested interests in many different industries whereas the firm of Joan Osy \& Son was involved in banking activities. See Joost Jonker \& Keetie Sluyterman, Thuis op de wereldmarkt. Nederlandse handelshuizen door de eeuwen heen (Den Haag 2000), 101, 123, 196, 201, 203. See also H. Hardenberg, 'Het handelshuis Osy', Rotterdams jaarboekje (1954), 154-176. 99. Hoffman and Smeer were directors, and Van Vollenhoven was a member of the board of the Rotterdam-based Arctic whaling company (Nederlandsche Maatschappij voor Walvischvangst), established in 1825. See Broeze, idem, 75. Conflict of interest may have forced them to refrain from participation.

100. See for Gerrit Boon's involvement: Broeze, idem, 73-75.

101. Broeze, idem, 76-78.

102. The concept of hiring American crew and/or using American-built ships was not entirely new. In his attempt to revitalize French whaling with the port of Dunkirk as its main base, King Louis XVI was forced to recruit American whalemen from Nantucket and Martha's Vineyard. Apparently, no experienced whalemen or suitable whaleships could be found in France. See S.J.C.W. van Musschenbroek, 'Cachelot-Visscherij in den Nederlandsch Indischen archipel', Tijdschrift ter bevordering van Nijverheid, vol. XVIII, part 11 (Haarlem 1877), 3. In their turn, whaling entrepreneurs from Bremen during the 1840 os bought American whaleships. Of a fleet of eight vessels, seven were built in New England. See Broeze, 'Whaling in the Southern Oceans', 110 (see also note 162: O. Höver, Von der Galliot zum Fünfmaster. Unsere Segelschiffe in der Weltschiffahrt 1780-1930 (Bremen 1934; reprinted at Norderstedt 1974), 198-199. Finally see De Jong, Oude Nederlandse walvisvaart, vol. II, 463-465 for more information on NHM's involvement, and the obscure story about the Logan. 
made four previous whaling voyages. The year preceding his command over the Logan, Coffin had lost his ship Hycso of Nantucket. ${ }^{103}$

Charter contracts concerning ship and crew were signed between representatives of the NHM and the whaling firm of John Howland \& Co., based in New York and New Bedford. The NHM did not buy the Logan, but hired this ship. The Logan's first voyage was a charter from America to the Far East via Rotterdam. Batavia in the Dutch East Indies and, above all, the Japanese Sea were to be visited and explored. Vessel and cargo were eventually to return to Rotterdam. ${ }^{104}$

This American-Dutch chapter in nineteenth-century whaling history is most bewildering, characterized by misconceptions, misunderstandings, mistakes and mischief. Logan crossed the rough Atlantic during the winter of 1826 and on 11 January 1827 , Coffin, with his skeleton crew, made their appearance at Hellevoetsluis, southwest of Rotterdam.

The NHM, and especially agent P. Landberg, had high hopes of success for this South Seas whaling venture. Some correspondence between Landberg and the directors of the NHM has survived. An appendix to a letter in English, dated 17 March 1827, written by Landberg while in Rotterdam and addressed to his employers in The Hague, contains a 'Sketch of Instruction for capt. Coffin'. In it, Landberg stated,

"The very favourable accounts we have of you, from Mr. Landberg is such that we gives [sic] you our entire confidence knowing you will do all you can for our Interest [sic]. You are no stranger to the charter of the ship. If not every thing is managed to advantage we shall lose money by the voyage. When you returns [sic] of this voyage we are in hopes to be able to give you the command of a ship belonging to our selfs [sic] and be more agreeable to you and us also". ${ }^{105}$

In Rotterdam the vessel was fitted out by the NHM with extra gear and extra crew. Their attempts to muster crew in Amsterdam turned out to be fruitless. ${ }^{106}$ At an earlier occasion, Landberg had hinted on the scarcity of good men to pull the lines and set the sails. While in New Bedford and on the brink of leaving for Rotterdam, Landberg wrote to the NHM,

103. Reuben F. Coffin had been master on board the brig Diana (1817; 1819-1820), registered in Nantucket, and the ships Trident (1820-1823) registered in New York, and Hycso (1824-1825). Judith Navas Lund, Whaling Masters and Whaling Voyages sailing from American Ports (New Bedford/Sharon/Gloucester 2001), 79. See also Louis Coffin, The Coffin Family (Nantucket 1962).

104. Broeze, idem, 79.

105. Nationaal Archief (NA), The Hague. NHM archives, inv. nr. 922, letter Landberg to NHM, 17 March 1827. Thanks are due to C.F.L. Paul who generously agreed to share his notes concerning correspondence between Landberg and NHM.

106. See Chapter 5 on the involvement of the Nautical College in Amsterdam. 
"I have not been able to get a full crew of sailors but all the officers are on board and four more for the other ship, all first rate whalemen ...". ${ }^{107}$

A few weeks later, Logan with its crew set sail for the East Indies and Japan. As far as can be judged from the information at hand, Logan set out solely for whaling purposes, and not - as often happened with ships destined for the Dutch Colonies - for the transport of armed forces. As Broeze phrased it,

"There was no mention of the ship taking any troops on the voyage out, as that would only tend to eliminate all chances of commencing whaling before the Sunda Strait were reached. Coffin apparently had refused to lead a double expedition [author's italics], and the N.H.M. did not search for a second vessel ...". ${ }^{108}$

Broeze's remark about Coffin's refusal to lead a double expedition is an interesting one. It suggests that the NHM may have asked Coffin to transport troops to the Colonies. At one time Coffin refers to this supposed request in one of his letters to the NHM. While on Owhyhee (Sandwich Islands, present day Hawai'i), in a letter dated 6 November 1828 , Coffin wrote that

"The idea of taking troops to Batava [sic] when I gain the ship in America has bin [sic] a disadvantage to the voyage Myself particularly [sic]". ${ }^{109}$

During the ensuing months the NHM suffered from a lack of information regarding the activities of Coffin and his crew. Except for one journal and a couple of letters written by Coffin, no other sources can inform us about the successes or failures of his whaling expedition in service of the NHM. The journal, formerly property of a Lyman B. Cook, who in all likelihood also kept this journal, relate events and activities experienced between March and September of $1828 .{ }^{110}$ For one thing, Cook frequently reported very large shoals of sperm whales. On 27 March, while near Pleasant Island (present day Nauru in Micronesian South Pacific), Cook's entry reads:

"Day before yesterday we saw a very large school of whale of some hundreds. We lowered our boats but it was almost sunset and they were very wild. So we only got one makes 25 bls. [barrels, JS]. We had ought to have 3 but lines parted and irons [harpoons, JS] drowd [drawn, JS] so we lost them".

107. NA, NHM archives, inv. nr. 922, letter Landberg to NHM, 8 December 1826. The letter was received by the NHM on 12 January 1827.

108. Broeze, 'Whaling in the Southern Oceans', 78.

109. NA, NHM archives, inv. nr. 922, letter Coffin to NHM, 6 November 1828.

110. New Bedford Whaling Museum, New Bedford, Massachusetts. Kendall Collection, nr. 680. Journal of the Logan, formerly property of Lyman B. Cook. The journal runs from 12 March to 8 September 1828. This important source is not mentioned by Broeze. 
A few days later, on 2 April, Logan set sail for Japan (again, as Cook adds in his journal). At that time, the ship held 750 barrels, probably of sperm oil. Their course was plotted via Woohoo and Guam and the crew arrived in late April. Cook makes an interesting statement about what he thinks of Reuben Coffin, and of the expedition as a whole, when he wrote (on 21 May),

"I believe the old man don't calculate to get anymore whale for we don't doo [sic] any thing but look for Islands and have done not much else this voyage".

Finally, on 11 June, Logan arrived in Japanese coastal waters. While on these hunting grounds, luck seems to have smiled on the crew. On 5 July, they managed to capture a whale (presumably sperm). Cook's description of the killing was jubilant:

“Quite a busy Day to Day. We raised a whale this forenoon. At ten oc [o'clock, JS] we lowered our boats and at one we had an old soghead along side and at six oc we had him in the Blubber Room the which I call pretty smart work. We had our falls to get up and reeve in the Bargain. It's the largest we have caught the voyage. I should say he would make ninety bls. by the looks of him. We struck him with our boat and the boatsteerer kild [sic] him with his iron".

That next day (6 July),

"The decks were full of cask some full of oil and some full of Blubber".

With his brief comments on the celebration of the Fourth of July, Cook presented a look behind the scenes:

"We kept the $4^{\text {th }}$ of July pretty slim. We only had two drinks of grog, one at $12 \mathrm{oc}$ and another in the evening. We danced considerably and fired some Cannon and kild [sic] a hog".

In the subsequent weeks, Cook shared his frolics and frustrations. On 12 July, the crew stowed away about 150 barrels of oil, with two more large whales alongside. On 2 August, the keeper of the journal calculated that in one month's time on the Japan grounds, about 400 barrels were filled. A few days later, on 8 August, Logan gammed with Corsair of London. This ship had been out for 21 months and carried 1,80o barrels of oil. Its crew informed Coffin of the fact that they had not seen whales for three or four days. Later that day, this information was backed up by statements from the crew of Cyrus of Nantucket. ${ }^{111}$ About seven weeks later, on 22 August while cruising around

111. In all likelihood, Cook is erroneous regarding the name of the ship. According to Alexander Starbuck, The History of the American Whale Fishery (reprint; Secaucus 1989), 254 and 264, there was no Cyrus of Nantucket out in the Pacific Ocean around this time. One Cyrus (ship, 328 tons) under master David Harris was 
$31^{\circ} 30^{\prime}$ Latitude, $142^{\circ} 20^{\prime}$ Longitude, Cook related the unsuccessful hunting of that day due to the very wild nature of the prey. He seemed to overstate the enormous number of whales when writing:

"Best Prospect today of getting whale. About 10 oc there was ten thousand whale all around us".

The journal contains one last exclamation of frustration in the entry for 31 August:

"We shall be edging off for the Islands [Sandwich Islands] now pretty shortly with a damd [sic] bad seasons work or I may say two of them if we don't get some more pretty soon".

The remaining eight days in the journal do not state any more killing of whales.

Interestingly, Coffin's letters to the NHM contain a similar touch of frustration, partly masked by expressions of hope. One of his letters, referring to the transport of troops, is partly quoted above. Another is dated 26 April 1829 . Both letters were written when Coffin was just off the Sandwich Islands. In this later letter, Coffin informed the directors of the NHM about the presence of 1,00o barrels of sperm whale oil. He acknowledged that this was 'rather unsucksesful', but he happily continued that he had fresh vegetables on board and a healthy crew, and was due to leave for the Japan whaling grounds again the following day. Obviously his spirit was high as he wrote:

“... I have my ship now well recruited with vegatbles [sic] my crew in good health and shall leave to day [sic] for the Coast of Japan where I am in hopes to fill my ship be that as it will I shall make the best of my way to Holland after this Season is done if nothing happens to me I shall be there in 12 months from this date ...”.

He also remarked of the increased level of experience among the crew. After leaving Japan he probably needed to stop again at the Sandwich Islands for vegetables and, after rounding Cape Horn, he planned to set course for the Netherlands. Coffin concluded:

"So noting [sic] more to communicate at this time for I expect in a few months after you receive this letter I shall have the pleasure of Arriving with A full ship. This from your most obedient Servent [sic] Reuben F. Coffin of Ship Logan".

His letter was in all likelihood transported by Captain H.I. Hetscher of the ship Hortense, having departed from Manila on 14 August 1829. The directors of the NHM received Coffin's letter on 11 March 1830. However, Coffin and Logan would not show 
up in Hellevoetsluis, but in New York about four months later. Though it was an experimental whaling voyage (both for the Americans under Dutch management as well as for the inexperienced NHM), the Dutch company thought it wise to deviate from the original plan to sell off the whale oil in the Netherlands, both the 'black oil' (id est: regular whale oil) as well as sperm oil. In 1827 and 1828, prices for sperm oil were much higher in New York than in the Netherlands. Therefore it is understandable that they had Coffin sail Logan to the United States, sell off the cargo, and return the money to the NHM. By resolution of 2 June 1828, the directors had decided as such. ${ }^{112}$

Because of their naive behaviour, the directors of the NHM not only missed out on revenues, but, and possibly more importantly, the Dutch whaling community missed out on an opportunity to learn the tricks of the trade annually performed by thousands of Americans. Also, the NHM "squandered her chance" to acquire a model of an American whaleship built in accordance with the latest state-of-the-art methods in shipbuilding. Dutch master shipwrights may have benefited enormously from the information they could have (and should have) obtained. As Broeze stated,

"The Logan showed in her later career that she indeed was an excellent example of American marine architecture" ${ }^{113}$

Table 3.1: Catches of the ship Logan, sailing for the NHM (1827-1830). ${ }^{114}$

\begin{tabular}{|l|l|l|l|l|l|}
\hline Year & Master & Type & Destination & Remarks & Results \\
\hline $1827-1830$ & Coffin, Reuben F. & $\begin{array}{l}\text { Ship (built in Dart- } \\
\text { mouth in 1826;302 tons) }\end{array}$ & $\begin{array}{l}\text { Pacific Ocean } \\
\text { (dep. April 1827) }\end{array}$ & $\begin{array}{l}\text { Three-year voyage } \\
\text { (April 1827 to July 1830) }\end{array}$ & $\begin{array}{l}32,569^{1 / 2} \text { gallons of sperm oil; } \\
3,222 \text { gallons of black oil }{ }^{115}\end{array}$ \\
\hline
\end{tabular}

\section{Rotterdam: De Vereeniging tot Walvischvangst om de Zuid} (Merchant House E. \& S. \& C. St. Martin \& Co) (1832-1838)

A new and fascinating chapter of Dutch whaling was written in 1832. In December of that year, the Dutch government received an application from the Rotterdam merchant house of E. \& S. \& C. St. Martin \& Co. In their request, compiled on behalf of

112. NA, NHM archives, inv. nr. 922, Resolutie 2 June 1828.

113. Broeze, idem, 79. This whaleship made eight more voyages. During its ninth voyage under master Moses L. Wells the ship was lost on Sandy Island Reef on 26 January 1855 and four men were lost. The survivors landed on Feejee Islands after much suffering. See A. Starbuck, History of the American Whale Fishery (reprint of the 1878 edition; Secaucus 1989), 258, 276, 306, 344, 388, 410, 444, 480, 514. For more detail concerning the ship's achievements under the American flag, see also Robert Lloyd Webb, On the Northwest. Commercial Whaling in the Pacific Northwest, 1790-1967 (Vancouver 1988), 47; 310, note 53. Finally, for a listing of the voyages between 1830 and 1855 and the respective masters, see Judith Navas Lund, Whaling Masters and Whaling Voyages, 556.

114. Broeze, 'Whaling in the Southern Oceans', 81.

115. The term black oil stands for oil obtained from whale species other than sperm whales. 
themselves and the merchant houses of N.J. de Cock \& Frère (former employer of Jacobus Boelen), still based in Gent in present day Belgium, and C. \& A. Vlierboom, these gentlemen introduced themselves as directors of De Vereeniging tot Walvischvangst om de Zuid ('Society for Southern Whaling'). ${ }^{116}$ Established only a few months earlier, the whaling company had managed to issue 55 stocks with a nominal value of $f_{900}$ each, thus providing a working capital of $f_{49,500 .}{ }^{117}$

Apparently, there was no lack of confidence among commercial circles in the city. Some 30 merchants and ship-owners participated financially in this first South Seas whaling expedition. Their whaleship, the bark Eersteling, 289 tons, under the command of the merchant navy Captain H.F. Horneman from Groningen, left Rotterdam in November of 1832, and made its appearance on Batavia roadstead on 6 September 1833. ${ }^{118}$ In consequence of a combined British and French embargo, resulting from the Ten Days' War between the Netherlands and Belgium, Eersteling spent only a very brief period of time on the whaling grounds. On 22 October, the vessel left Batavia for Rotterdam. The bark arrived at Hellevoetsluis on 12 February 1834, after an absence of about 15 months. Some 20,00o litres of black oil and another 7,00o litres of sperm oil were auctioned off. St. Martin \& Co. estimated the total loss of their first whaling expedition to be no less than $f 27,000$. They were quick to blame the inexperienced Dutch crew, their own ignorance concerning the working and living conditions on the whaling grounds, and finally the British and French embargo that had forced them to leave these grounds prematurely.

Whatever the size and impact of this loss may have been, their resilience to make their fortune in South Seas whaling remained unbroken. Their entrepreneurial spirit met with success. The merchant house organized a second expedition; again with Eersteling and H.F. Horneman master. Prior to this second expedition, Horneman had visited the United States and had recruited highly skilled and - as it turned out - highly opinionated officers. ${ }^{119}$ The bark departed from Hellevoetsluis on 17 August 1834 . After its return some 20 months later (20 April 1836), and after the sale of its cargo of 150,00o litres of whale oil and an unspecified quantity of baleen, the account books of the Rotterdam-based firm showed a substantial positive result of $f_{34,000}$.

116. Nicolaes de Cock and Etienne St. Martin had been co-owners of the Louisa Augusta from Antwerp. This vessel had preceded Jacob Boelen by about one year with its visit, in 1827 , to Hawai'i. F.J.A. Broeze, A merchant's perspective, $\mathrm{xxi} ; 103$, note 1.

117. Broeze, 'Whaling in the Southern Oceans', 88.

118. Interestingly, the vessel had left Rotterdam harbour before the directors of the company had sent their request for subsidies to the national government. There is disagreement over the exact tonnage of the Eersteling, as Van Sluijs, Nederlandse Koopvaardijschepen 1800-1860 (n.p.n.d.), 57, mentions a tonnage of 291. 119. The presence of American crew is stated by Broeze, idem, 92, as well as by De Jong, Oude Nederlandse walvisvaart, vol. II, 466. 
Around that time, whale oil and especially sperm oil were sold at very high prices. ${ }^{120}$ These results could have been even more impressive if it were not for the fact that Horneman had experienced the loss of one whaleboat with crew. Consequently, in February 1835 he had to go into Cape Town to recruit new whalemen to make up for those lost. Also, the crew had lost eight out of 24 whales caught. After this second expedition the bark Eersteling was sold in its hometown Rotterdam. ${ }^{121}$

With financial assistance from the NHM, the whaling company merchant house E. \& S. \& C. St. Martin \& Co bought the 15-year-old bombardeerkorvet (bomb-ketch) Proserpina (184 lasts) from the Royal Netherlands Navy and had her fitted out for the company's third expedition to the South Seas. ${ }^{122}$ Anticipating good profits, the NHM (metaphorically speaking) set sail for another financially daring whaling adventure. Again, this adventure, like the first one with the Logan under Reuben Coffin as the leading character, turned into a drama. In July 1836, the two-decked frigate Proserpina under the command of J.P. Smith left from Hellevoetsluis with a crew consisting of American, British, and Dutch sailors. The vessel returned on 24 May 1838. They had caught nineteen whales in total, amounting to 140,00o litres of black oil, 10,00o litres of sperm oil, and 5,00o kilograms of baleen. Inexperience among the Dutch crew members and the lack of co-operation between the Dutch and the foreigners (Americans and British) had negative consequences on the results of this voyage. ${ }^{123}$ Due to the disappointing results and subsequent heavy losses at auction, the liquidation of the Rotterdam whaling company in the late fall of 1838 was inevitable. That year, Proserpina and its gear were sold. ${ }^{124}$

120. See N.W. Posthumus, Nederlandsche prijsgeschiedenis. Deel I: goederenprijzen op de beurs van Amsterdam, 1585-1914. Wisselkoersen te Amsterdam, 1609-1914. Internationale wetenschappelijke commssie voor prijsgeschiedenis (Leiden 1943), 84-85, table 43. In his overview of prices of whale oil, 1818-1851, Posthumus quoted no less than $f 45.75$ per barrel for the year 1836 . This figure was an all time high for the period 1832-1851! This high figure was substantiated by Broeze, 'Whaling in the Southern Oceans', 108, Graph I and note 160 .

121. Broeze, idem, 91-93. See also Algemeen Handelsblad, 15 May 1836, and Algemeen Handelsblad, 31 May 1836. De Jong (Oude Nederlandse walvisvaart, II, 466) suggested that the Eersteling was sold after complaints filed by American officers, who regarded the ship a slow one, not suitable for whaling purposes. In later years, H.F. Horneman commanded the ships Doggersbank, Johanna Cornelia, and Diligentia on non-whaling voyages. J. van Sluijs, Nederlandse kapiteins ter koopvaardij (n.p. n.d.), 108.

122. Proserpina was built between 1818 and 1821 in the naval dockyard of Rotterdam. The NHM invested $f 12,000$ in the outfitting of Proserpina. Broeze, 'Whaling in the Southern Oceans', 93.

123. De Jong, idem, 466, hinted at these two detrimental factors.

124. Broeze, idem, 93-94. The frigate Proserpina was sold at auction in Rotterdam on 23 October 1838 . See Algemeen Handelsblad, 12 October 1838. 
Table 3.2: Overview of whaling expeditions fitted out by the Rotterdam merchant house E. \& S. \& C. St. Martin \& Co. $(1832-1838) .{ }^{125}$

\begin{tabular}{|l|l|l|l|l|l|l|}
\hline Year & Master & Ship & Type & Destination & Remarks & Results \\
\hline 1832 & Horneman, H.F. & Eersteling & $\begin{array}{l}\text { Bark } \\
(291 \text { tons })\end{array}$ & $\begin{array}{l}\text { S.Atlantic/ } \\
\text { Indian Ocean(?) }\end{array}$ & $\begin{array}{l}\text { 15-months voyage } \\
\text { (Nov. 1832 to Feb. 1834) }\end{array}$ & $\begin{array}{l}\text { 7,00o litres of sperm } \\
\text { oil; 20,000 litres of } \\
\text { black oil }\end{array}$ \\
\hline 1834 & Horneman, H.F. & Eersteling & $\begin{array}{l}\text { Bark } \\
(291 \text { tons) }\end{array}$ & $\begin{array}{l}\text { S.Atlantic/ } \\
\text { Indian Ocean(?) }\end{array}$ & $\begin{array}{l}\text { 20-months voyage } \\
\text { (Aug 1834-April 1836) }\end{array}$ & $\begin{array}{l}\text { 150,0oo litres of oil; } \\
\text { 100 bundles of baleen }\end{array}$ \\
\hline 1836 & Smith, J.P. & Proserpina & $\begin{array}{l}\text { Bomb-ketch (Bom- } \\
\text { bardeerkorvet) (184 } \\
\text { lasts; built 1818-1821) }\end{array}$ & 'South Seas' & $\begin{array}{l}\text { 22-months voyage } \\
\text { (July 1836 to May 1838) }\end{array}$ & $\begin{array}{l}\text { 10,00o litres of sperm } \\
\text { oil, 140,00o litres of } \\
\text { black oil; 5,00o kilo- } \\
\text { grams of baleen }\end{array}$ \\
\hline
\end{tabular}

\section{Miscellaneous private initiatives}

Sparked by the enterprising merchants involved in South Seas whaling, others followed, introducing plans with characterizations ranging from absolutely brilliant to plain stupid. ${ }^{126}$ When Coffin visited the Southern whaling grounds with Logan, two Dutch ships of the merchant navy were in the Pacific. One of these, Wilhelmina \& Maria, was commanded by Jacobus Boelen Jhz. ${ }^{127}$ Boelen had had an eventful career in both the Batavian Navy, operating during the French occupation of the Netherlands, as well as the Royal Netherlands Navy, which had been completely reorganized after the establishment of the Kingdom of the Netherlands in 1815. Between April 1820 and December 1824, Boelen made four round-trip voyages to Java in the service of the prominent Antwerp ship owner and merchant Nicolaes de Cock. He resigned from command when De Cock refused to have the ship Delphine completely overhauled and coppered. Around this time, Boelen was promoted in the Royal Netherlands Navy from midshipsman to Lieutenant first class.

In 1825, Boelen met his old friend and distant relative Johannes Insinger. As it turned out, the two men had independently developed similar plans for commercial

125. Broeze, 'Whaling in the Southern Oceans', 91-92.

126. For more detailed information concerning initiatives and responses, see Broeze, idem, 96-97.

127. Jacobus Boelen Jhz. (Johannuszoon) was one of the first nineteenth-century Dutchmen to enter the Pacific Ocean after Jacob Roggeveen had left this region in 1722. In 1825, naval officer Captain Willinck entered this ocean with his man-of-war Lynx. Between 1824 and 1826, two men-of-war, Maria Reigersbergen and Pollux, sailed this same area, whereas Boelen cruised southern waters between 1826 and 1829 . See J. Swart, 'De Stille Zuidzee en de Nederlandse ontdekkingen daarin gedaan, benevens een blik op de toekomstige bestemming dier zee', G.A. Tindal and J. Swart (eds.), Verhandelingen en berigten betrekkelijk het Zeewezen en de Zeevaartkunde, vol. 4 (1851), 269. While dwelling on the presence and activities in these waters of American, French, and English whalemen, Swart does not devote any text to the conceivable exploitation of the natural riches of the Pacific Ocean by Dutch whalemen. Around the time Swart wrote his article, several contemporary authors explored - at least on paper - the feasibility of Dutch whale fishery in these hitherto unexploited waters. Being in the midst of maritime historical developments, Swart should have been aware of this discussion. 
expansion in the Pacific. Boelen signed his contract with the firm of Insinger \& Co., owned by Johannes and his brother Albrecht. This firm, established in 1801 in Amsterdam by German-born Herman Albrecht Insinger (1752 or 1757-1805), ${ }^{128}$ had traditionally traded with Surinam, in which country the trading firm at one time had involvement in over 40 plantations (including 'Jagtlust'), with the West Indies, and, less frequently, with the United States. During the second half of the 1810s, the firm diverted part of its interest to the Dutch East Indies and China. As of 1830, trade with Asia became their prime interest. ${ }^{129}$

The firm found the ideal captain in Jacobus Boelen for a new commercial expedition in - to them at least - uncharted waters. They now had to find a suitable ship. In March 1825 they bought the West-Indiaman Euterpe, originally built in Baltimore in 1810 . The Insinger brothers spent a small fortune having the vessel completely rebuilt, spending $f 17,000$ to acquire the ship and an additional $f 71,765$ in repairs. The wives of the two brothers were immortalized as Euterpe was renamed Wilhelmina \& Maria. Boelen received command of the 316-ton vessel and set sail for Latin America. After many ordeals in and off Brazil and Peru, Boelen touched on the Hawai'ian Islands. In late April 1828 he arrived at the Pearl River, which led to Canton (Guangzhou), China. After a brief interlude at Manila, Boelen departed from China in August, 1828. On 1 May 1829, Jacobus Boelen arrived in Dutch waters after a voyage that had lasted no less than 1,172 days. ${ }^{130}$

Six years later, while recovering from a severe illness, Boelen published an account of his travels in three volumes. ${ }^{131}$ In his Introduction to the English translation of the account of Boelen's visit to Hawai'i in 1828 , Broeze revels in the author's skilful descriptions. He first points out the neutral character of Boelen's voyage, as

“... [his] country had no political aspirations or interests whatsoever in the future of the Hawaiian Islands”.

128. There is no consensus on Insinger's year of birth. The introduction to the Insinger archives at the municipal archives in Amsterdam (SAA) lists 1757, whereas the website of the Internationaal Instituut voor Sociale Geschiedenis (International Institute for Social History, IISG) gave 1752. See www.iisg.nl/ondernemers. 129. For more information about the activities of this trading firm, see Joost Jonker, "Roeien tegen de stroom, 1813-1860. De geschiedenis van Insinger \& Co., deel 2', Amstelodamum, Jaarboek 96 (Amsterdam 2004), 135-155. Oddly, Jonker, while describing at length the hardship this firm had to endure during the 1820 s and 1830s, does not refer to Jacob Boelen's important, well-documented voyage.

130. Broeze has translated, introduced, and annotated a specific part of Boelen's book relating to his visit to Hawai' i in 1828. In A merchant's perspective: Captain Jacobus Boelen's narrative of his visit to Hawai' i in 1828 (Honolulu 1988), Broeze provided information about Boelen's character, career, and contacts with Insinger. See especially his Introduction, xv-xxiii.

131. J. Boelen Jhz., Reize naar de Oost- en Westkust van Zuid-Amerika en, van daar, naar de Sandwichs-en Philippijnsche eilanden, China enz gedaan, in de jaren 1826, 1827, 1828 en 1829. Met het koopvaardijschip Wilhelmina en Maria. Three volumes (Amsterdam 1835-1836). See also Broeze, A merchant's perspective, 72-75. 
Broeze continued:

"But in addition to his nationality, the professional and personal character and interests of the author make the account stand out among the many travelogues and descriptions of the Sandwich Islands published in those years. Most other authors were closely connected with the missionary activities, or the exploratory, whaling, or naval expeditions that figure so prominently in Hawaiian history of the 1820s. Boelen, though an officer of the Royal Netherlands Navy on special leave, was above all a commercial man and ship's master. He was fully experienced in mercantile and maritime affairs, and primarily interested in the practical aspects of his profession and in seeking out commercial opportunities." ${ }^{\prime 12}$

Boelen's skills had certainly been noticed by contemporaries, not the least of them being Jean Chrétien Baron Baud (1789-1859), who was Secretary of Colonies. As a result of their similarity in background, Baud and Boelen must have had ample opportunity to communicate and subsequently understand one another quite perfectly. ${ }^{133}$ Inspired by his experiences in Canton, Boelen first attempted to find support for his plan to revitalize trade - especially the fur trade - with China. Two years prior to his meeting with Baud he had petitioned King Willem I for His Majesty's support. The King, however, responded negatively.

In 1830, Secretary Baud, probably familiar with Boelen's reports about the contacts he had made with Americans involved in whaling in the bays of Chile and near Hawai' i, invited Jacobus Boelen to lead a pelagic whaling expedition in the Pacific. When it dawned on him that none of his requirements were met - acquisition of a new, fast whaleship, and continuation of his salary as navy officer (as the whale hunt would provide him with uncertain revenues) - Boelen declined the invitation and decided to continue his career in the Royal Netherlands Navy rather than chase whales in Southern oceans. ${ }^{134}$ That year, war with Belgium broke out. Boelen refrained from whaling, and took a commission in the Royal Navy. After many health problems during the 1830s, he returned to active service in January, 1837 and spent the rest of his professional life in the Navy. Jacobus Boelen Jhzn. died in 1876 with the rank of vice-admiral.

132. Idem, xv.

133. In his early years, Baud developed a keen interest for maritime affairs. Between 1804 and 1811 he served in the Batavian Navy - just like Boelen. After having spent a decade in the Dutch East Indies Baud, adamant advocate of the introduction of steam in Dutch shipping, became involved in the founding of the Nederlandsche Stoomboot Maatschappij in Rotterdam. For many years he served as member of the permanent Board. Around the same time Baud with others composed a list of articles by which the Nederlandsche Handel-Maatschappij (NHM) should abide. In 1841, Jean Chrétien Baron Baud was appointed Secretary of Colonies. See Nieuw Nederlandsch Biografisch Woordenboek, vol. I (Leiden 1911), 246-251. Boelen and Baud may have met in or around 1830 .

134. Broeze, 'Whaling in the Southern Oceans', 87; De Jong, Oude Nederlandse walvisvaart, vol. II, 465; Broeze, A merchant's perspective, xxiv-xxv. 
Around the time Proserpina was cruising southern waters (1832-1838), others were contemplating possibilities with regard to Dutch participation in South Seas whaling. Captain P. Arriëns, officer in the Royal Netherlands Navy, commander of HMS Bellona and tutor of Prince Hendrik during his three-year voyage through the East Indies (1836-1838), conceived the idea to make this very region and its inhabitants work for the success of the South Seas whaling industry. In April, 1837, when moored near the island of Ternate, Arriëns put his ideas on paper. The manuscript contained a fairly detailed description of what should be done and is in the collections of the Nederlands Scheepvaartmuseum in Amsterdam. ${ }^{135}$

But Arriëns' plan was not conceived in April, 1837. In his manuscript he stresses that he had considered opportunities for whaling ventures for several years prior. During the eleven years he had cruised between Java and the Moluccas, Arriëns witnessed the whale fishery being conducted by the British. Also, hardly a day had passed without sighting sperm whales. His plan basically entailed the establishment of a large entrepôt for one or more whaling companies on the island of Ternate. This island was ideally located: often, whales were caught just off the coast, and Ternate was very close to two major whaling grounds between Java and the Moluccan islands. Oil and baleen could be collected on Ternate and transferred into ordinary Dutch merchant ships, while the whaleships could then remain close to the hunting grounds. Though willing to start this venture with the use of a modest fleet of two ships, Arriëns, in the long run, anticipated an investment of no less than $f 600,000$ for the acquisition of five vessels. Some of these ships could be built and others bought, according to Arriëns, preferably in London harbour. ${ }^{136}$

This concept, albeit developed and improved to its utmost by the American whalemen and whaling entrepreneurs from the late-eighteenth century onward, was considered close to revolutionary by the Dutch government and commercial interests in the Netherlands. ${ }^{137}$ Minister of Colonies J.C. Baud was very much in favour of Arriëns' plans, as was J.Th. Netscher, Administrateur van Nationale Nijverheid (Director of National Industry). ${ }^{138}$ They considered his ideas as an incentive to develop a con-

135. P. Arriëns, Journaal, aantekeningen en aanmerkingen van mijne reize in Celebes, Ternate, Ambon en Banda. Library Nederlands Scheepvaartmuseum Amsterdam, manuscript collections AIV2-117II, 93-101. For Arriëns and his responsibilities as tutor of the Prince, see Katrientje Huyssen van Kattendijke-Frank (ed.), Met Prins Hendrik naar de Oost. De reis van W.J.C. Huyssen van Kattendijke naar Nederlands-Indië, 1836-1838. Werken uitgegeven door de Linschoten-Vereeniging, Vol. CII (Zutphen 2004). I thank Henk Dessens of the Nederlands Scheepvaartmuseum in Amsterdam for bringing this citation to my attention.

136. Idem, 97 .

137. It took Arriëns several years to find compagnons for his plans in the persons of M.D. van Duivenbode of Ternate and Ter Boven from Menado. Idem, 96.

138. Johannes Theodorus Netscher (1786-1864) started his career with the Ministry of Koophandel en Koloniën (Commerce and Colonies) in 1817. In 1826 he was appointed Inspector-General of Nationale Nijver- 
sistent governmental policy regarding South Seas whaling. A plan, however, never materialized. Interestingly, on 12 September 1839, the Amsterdam Chamber of Commerce was informed of a similar plan, whereby ships stationed in the East Indies would hunt whales and try-out their blubber while other vessels were deployed in transporting the oil to the home country. ${ }^{139}$

Another initiative not only to start whaling but also to improve whaling activities in the Southern Hemisphere came from retired army General H.G. Baron Nahuys van Burgst. He was the resident (chief government official) of Jogyakarta between 1816 and 1822, and later, between 1827 and 1830, resident of Surakarta and Solo, and was appointed a member of the Council of the East Indies. ${ }^{140}$ According to at least one eminent Dutch historian, he was considered an intriguer. ${ }^{141}$ Nahuys van Burgst's plans were frustrated by an unwilling, uncooperative, but highly influential NHM. All in all, his initiatives did not go beyond the phase of conception and discussion. ${ }^{142}$

\section{Amsterdam: Nederlandsche Walvischvisscherij Maatschappij (1843)}

In 1843, Coenraad Brandligt published an historical overview of the Dutch whale fishery. In the introduction to his booklet, the author as brilliantly as bluntly stated why he had written this short overview:

“..., heb ik vermeend, aan het lezend publiek geene ondienst te doen om bij wijze van uittreksel uit de geschiedenis der Visscherijen, en door mijne beschouwingen deswege, hen, die een verkeerd en nadeelig denkbeeld omtrent de Walvisch-visscherij koesteren, of hen, die met den aard ende belangrijkheid der zaak geheel onbekend zijn, in weinige regelen druks in staat te stellen, zelve te oordeelen, en zich niet door vooringenomene redeneringen of wanbegrippen te doen meeslepen, ten nadeele eener zaak, waaraan ons Land, althans in den tegenwoordigen tijd, groote behoefte gevoelt"

(“... I have judged not to do injustice to the reading audience by enabling, via a synopsis of the history of fisheries, and by means of my opinions thereof, those who entertain an erroneous and detrimental conception regarding the whale fishery, or those who are unaware of the nature and importance of the matter, through the writing of a few lines to

heid (National Industry). Two years later he climbed to the rank of Administrateur (with the rank of Director) with the same department. For more information concerning Netscher, see P.C. Molhuysen and P.J. Blok (eds.), Nieuw Biographisch Woordenboek. Ten volumes (Leiden 1911-1937). Vol. V, 363.

139. Zwart, Kamervan Koophandel, 182-183.

140. Resident is a high-ranking Dutch civil servant, charged with the administration of territories in the Dutch East Indies.

141. C. Fasseur, Indischgasten (Amsterdam 1997), 240. See also Katrientje Huyssen van Kattendijke-Frank (ed.), Met Prins Hendrik naar de Oost, 109, note 59.

142. These two interludes with navy-officer Arriëns and Army General Nahuijs van Burgst were not mentioned by De Jong. 
judge for themselves, and not be overwhelmed by preconceived notions or misunderstandings, detrimental to a cause, at least currently much needed by our country"). ${ }^{143}$

In other words, Brandligt acknowledged that his brochure was for promotional purposes, not to present a neutral overview. During his long and active career - he had been a captain of Dutch merchantmen bound for the East Indies between 1815 and 1850 - Brandligt often witnessed foreign whaling activities near South America, the Dutch East Indies, and Cape of Good Hope. According to his observations, whales were roaming about in abundance. This biological phenomenon, combined with the more economical and financial backing of whaling expeditions by King and government, made Brandligt wonder why the courage to resume whaling on a large scale was lacking among whalemen and entrepreneurs in the Netherlands. Brandligt was one of very few contemporaries who wrote more than one line about the state of the whaleships when they left Dutch ports. He claimed to know that they were old ships and inadequately suited to their tasks. Contrary to what he called "the present situation" [1843], during the first decades of the nineteenth century there had been very few new shipbuilding programs geared to the resumption of whaling. ${ }^{144}$

Blaming former generations for their lack of entrepreneurial courage and for their abundance of unsuitable crew, Brandligt advised newly established companies to seize the rudder, raise the sails and set course; no longer to Greenland or the Davis Strait, but to whaling grounds hitherto hardly exploited by the Dutch. In his book he mentioned many destinations: the coastal waters of South Africa, Mozambique, Seychelles Islands, Madagascar, Tristan da Cunha, the Crozets, the whole of the Indian Ocean, the northeastern coast of Australia, New Zealand, New Guinea, the Moluccas, the Solo and Java Seas, the Brazilian coast, and the Falklands.

At the end of this long list, Brandligt recommended that Dutch whalemen round Cape Horn and head for the Northwest Coast of North America. Brandligt optimistically continued that in 1843 the time had come to benefit from the abundance of ships that were cheap to acquire, from the financial support of the government, and from the logistical support of the Nederlandsche Handel-Maatschappij. ${ }^{145}$ In his appeal to sailors and merchants, the author stressed the importance of the whaling industry, not only as a nursery for mariners, but also for closely-related industries involved either in delivering the necessary commodities or in utilising the products derived from whaling. Moreover, Brandligt pointed out that the timing to resume whaling, at least in the Dutch East Indies and especially in the coastal waters of Japan,

143. C. Brandligt, Geschiedkundige beschouwing van de Walvisch-visschery (Amsterdam 1843), iii-iv. Translation by the author.

144. Brandligt, idem, 9.

145. Brandligt, idem, 21-23. 
could not have been better for the Dutch, as the Dutch and the Japanese were longtime friends. ${ }^{146}$

Although not the first protagonist of the resumption of whaling, Brandligt was one of the first and probably the most outspoken Dutchman to acknowledge the importance for the whaling industry to seek new, relatively unexploited whaling grounds as alternatives to the crowded Arctic waters. The grounds off Japan, for example, were not uncharted, as many American whalers had cruised these waters and had harvested them richly. ${ }^{147}$ The hunting grounds in the Dutch East Indian archipelago were equally well known to the peripatetic Americans. Between 1830 and 1880 many harbours on the islands, like Anjer on West-Java or Kupang on the isle of Timor, served the American whalemen as place of rendezvous or as station for refreshments. ${ }^{148}$

We should keep in mind, however, that old seadog Brandligt made his remarks about exploring and exploiting new whaling grounds first and foremost to serve his own cause: the establishment of a South Seas whaling company. In this respect, his notion that the Dutch government was in full support of entrepreneurial whalemen and investors deserves further attention. In his book he claimed:

“..., en Zijne Excellentie de Minister van Koloniën is genegen om van regeringswege te beproeven bij het Japansche Bestuur zoo mogelijk verlof te bekomen, om in de Baaijen van het Japansche Rijk te mogen visschen"

(“... the Minister of Colonies [Jean Chrétien Baud] is willing on behalf of the government to request permission from the Japanese government to fish in coastal waters"). ${ }^{149}$

146. Only one year after Brandligt's remarks about the friendship between the two nations, the relationship experienced rough weather due to undiplomatic action from the side of the Dutch. In 1844 the Dutch government, by means of a letter signed by King Willem II, suggested to the Japanese shogun to open his empire, which by then had been secluded for over 200 years to all foreign trade and contacts except for the Dutch and the Chinese and embrace Western commodities and the presence of western powers. See E.M. Jacobs, 'Met alleen woorden als wapen. De Nederlandse poging tot openstelling van Japanse havens voor de internationale handel (1844)', Bijdragen en mededelingen betreffende de geschiedenis der Nederlanden (BMGN), vol. 105 (1990), nr. 1, 54-77; see also J.C.A. Schokkenbroek, 'Koning Willem II schrijft een brief aan de Japanse shogun', R. Daalder (ed.), Maritieme geschiedenis van Nederland in 70 hoogtepunten, 1500-2000 (Amsterdam/ Zutphen 2004), 116-118.

147. Decades before Commodore Perry practised his gunboat diplomacy to open up an initial limited number of Japanese ports for Western commodities, American whalers showed their presence in the coastal waters of the archipelago. For a description of their presence and their interaction with local communities, for example, see Hyoson Kiryaku, Drifting toward the Southeast. The story of five Japanese castaways. Translation by Junya Nagakuni \& Junji Katadai (New Bedford, Mass. 2003).

148. J.G.V.Smit, Whales, wood and water. American whalers in the Dutch East Indies, 1830-1880 (unpublished thesis. Leiden 1989) presents a transparent overview of American presence and activities in these waters; see also C. de Jong, Westerse walvisvaart in Oost-Indië in de 19e eeuw (n.p. 1995).

149. Brandligt, Beschouwing, 21. Translation by the author. 
In his attempts either to convince the Dutch government that whaling in the South Seas could be and should be successful, or to strengthen the communis opinion, Brandligt joined forces with the merchant house of J. \& Th. van Marselis. One may wonder why Brandligt decided to seek contact with this firm, as Van Marselis had strong commercial ties with Surinam and much less so with the Dutch East Indies. Brandligt's plans to incorporate the Royal Netherlands Navy in their commercial endeavours did not materialize. The disgruntled NHM, however, granted some support.

In June, 1843 it was decided by the government that two prospective Amsterdambased whaling companies would receive small subsidies. These premiums were to be used for a promotional campaign and to cover initial costs. In their prospectus, Brandligt and Van Marselis tried to evoke interest among potential shareholders. It was estimated that their company, operating under the name Nederlandsche Walvischvisscherij Maatschappij (Dutch Whale fishery Company), needed capital of not less than $f 600,000$ for the construction and fitting out of five ships. Interestingly, this figure is commensurate with the one mentioned by Arriëns a few years earlier. He estimated needing such an amount for the construction of five vessels as well. Brandligt did not receive governmental support, nor privately owned capital, as others had proposed a more sound, and above all a cheaper, plan..$^{150}$

\section{Amsterdam: Reederij voor de Zuidzee Walvischvangst (Reelfs Brothers) (1843-1849)}

Local competition had been fatally tough for Brandligt and Van Marselis. The masterminds behind this rivalry were the two brothers Johann Anton and Johann Hayen Reelfs. Both born at Heppens, near Oldenburg (North-West Germany), the brothers had only arrived in Amsterdam after 1815. They had initially concentrated their trade on Surinam and the island of Madeira. Within a short period of time they had managed not only to become well-established in the Dutch capital but also to start a blossoming trading company. ${ }^{151}$ As was the case with Brandligt, the brothers initially assumed that a fleet of five ships would suffice. They estimated a required capital of $f_{566,000}$ and anticipated two whaling expeditions: one in 1843, involving two vessels, and one in 1844 with three ships heading for the South Seas. As a result of the Koninklijk Besluit, dated 23 June 1843 and stipulating a subsidy of $f_{5}$,000 per ship (half

150. According to the minutes of a meeting of the members of the Amsterdam Chamber of Commerce dated 3 August 1843, Brandligt and Van Marselis would have received premiums amounting $f 25,000$ for five ships if they had been successful in organising whaling expeditions in 1844 and 1845 . B.C.E. Zwart, De Kamervan Koophandel en Fabrieken te Amsterdam. Overzicht van hare handelingen gedurende het tijdvak 1811-1911 (Amsterdam n.d. [1911]), 188.

151. Broeze, 'Whaling in the Southern Oceans', 98 , note 115. 
of the premium to be paid upon departure, the other half upon arrival of the vessel), Reelfs Brothers received a total of $f 25$, 000 in subsidies for their five vessels. The Chamber of Commerce in Amsterdam received news about this subsidy on 3 August. ${ }^{152}$

They at least had some starting capital for the establishment of their Reederij voor de Zuidzee Walvischvangst (Company for the South Seas Whale Fishery). Despite their strong ambition, sound plans, and solid commercial experience, Reelfs Brothers were confronted with problems from the beginning. In the autumn of 1843 they purchased the 17-year-old two-decked frigate Anna \& Louisa (320 tons). This ship was built in 1826 on the shipyard 'Het Roopaard' at the Kadijk in Amsterdam by shipwright C.E. Duyts for the Heemskerk brothers. Having bought the ship in previous years, the Amsterdam merchant J.H. Luden sold Anna \& Louisa to Reelfs Brothers for f19,200. ${ }^{153}$

After repairs and re-rigging as a bark - adding another $f_{34,500}$ to the debit side of the account books - Anna \& Louisa left Amsterdam on 3 April $1844 .{ }^{154}$ In the Nieuwediep the Scotsman George Gray was appointed Captain of the ship. An experienced Peterhead whaleman himself, Gray worked with English officers and harpooners. The rest of the crew were Dutch. Finally, the whaling bark left Texel roadstead on 21 April.

Initially all went well. After an uneventful voyage Anna \& Louisa arrived in Kupang on the island of Timor in October 1844. In July 1845 a sperm whale was caught. Around this time, however, the relationship between the English officers and Dutch crew had been disturbed to such an extent that fighting broke out on board. After the death of

152. Zwart, Kamer van Koophandel, 188. De Jong, Oude Nederlandse walvisvaart, vol. II, 467.

153. Broeze pointed out that Luden either worked for himself or for the consortium of Nolthenius, Luden \& Van Geuns. Broeze, 'Whaling in the Southern Oceans', 100-101. From Zwart's book on the Amsterdam Chamber of Commerce, Luden was a member of this Chamber during the 1830 . As such he must have been well-informed about all matters in the capital, and beyond, related to whaling initiatives. See Zwart, Kamer van Koophandel, 182-183. Here, the author refers to a meeting of 12 September 1839, during which a letter revealing plans to conduct whaling in East Indian waters was discussed. About one week later, on 20 September, the gentlemen Borski (of the banking firm) and Luden represented the Chamber at the occasion of the opening of the very first railway in the Netherlands between Amsterdam and Haarlem. In their overview of Dutch merchant houses through the ages, Jonker and Sluyterman devote five lines to Luden \& Van Geuns (Nolthenius is not mentioned), merely to state that nothing was known about this firm and that rumour had it that they were involved in business (“... naar verluidt actief in zaken”). Luden \& Van Geuns did exist until the late 1860 s or early 1870 s. Despite the fact that the two authors referenced four publications written by Broeze, they must not have checked the data given in his article on Dutch involvement in South Seas whaling. See Joost Jonker \& Keetie Sluyterman, Thuis op de wereldmarkt. Nederlandse handelshuizen door de eeuwen heen (Den Haag 2000), 168-169. Jacob Hendrik Luden (1765-1834) was born one of five children, conceived through the marriage of Johannes Luden Hendricksz. and Catharina Speciaal. His mother was from an old family involved in whaling activities for many decades. The firm of Jb.H. Luden \& Sons was active in businesses in the West-Indian Colonies. See G.J. Honig, Uit den gulden Bijkorf. Genealogisch-historischeconomische studiën over Zaansche families. Uitgegeven als vervolgdeel op het stamboek Smit (Koog aan de Zaan 1952), 204-210.

154. Total costs of purchase, repairs, and fitting out amounted to $f 113.200$. Mentioned in Honig, Idem, 101 
Captain Gray - he died at Kema on North Celebes - and several officers and crew, the Dutch resident of Menado appointed second mate S. Ward Captain of the vessel. This must have happened after April 1846. While on its way to this island, the vessel ran aground off Ternate. After inspection in Batavia the bark was condemned and requests by Ward to receive $f 45,000$ for bottomry were denied. Anna \& Louisa, with its small cargo of spermaceti, was auctioned off before 28 November 1846.155

Reelfs Brothers found themselves in difficult circumstances. When briefed about the dramatic events concerning Anna \& Louisa, the two entrepreneurs had to act swiftly. They desperately needed a second ship to attempt to make up for valuable time lost and to please the investors waiting for their dividends. King Willem II came to their rescue, as he provided them with a premium for the purchase of a new ship. The 27-year-old Rotterdam whaleship Proserpina, previously owned and used by De Vereeniging tot Walvischvangst om de Zuid (until 1838), was thus added to the fleet and the ship's name was changed to Zuidpool. Not only its name, but actually the complete ship underwent an elaborate and costly transformation. Spending f87,00o Reelfs Brothers had the frigate/bark-rigged Zuidpool enlarged to a staggering 536 tons ${ }^{156}$, making it by far the largest vessel employed in both the Dutch Arctic as well as South Seas whaling industries. In its new capacity Zuidpool could hold 500,000 litres of whale oil (roughly 2,00o barrels) and 40,000 kilograms of baleen or the equivalent of about 50 whales. ${ }^{157}$

With the acquisition of this unusually large whaleship, Reelfs Brothers entered the last phase of active Dutch involvement in South Seas whaling. Zuidpool, commanded by T.A. Brunn with a crew of only 36 , left the Netherlands on 16 April $1845 .{ }^{1.8}$ The vessel set its course for the town of Hobart on the island of Tasmania. With a crew of 32, Zuidpool arrived at Hobart on 21 December. Here, another five men signed up as crew. While on their way to Tasmania, Brunn had lost one whaleboat with four men, possibly during a chase.

Zuidpool left Hobart for whaling grounds in the Pacific Ocean and the vessel was hailed by the crew of the American whaleship William Hamilton on 17 May 1846 in $52^{\circ} 45^{\prime}$ North, $156^{\circ} 60^{\prime}$ West. On that occasion Brunn told his American colleagues he had been out for eight months and yet still was without any oil. In his journal Abraham Wilcox Pierce noted:

"Spoke the Zuid Pool of Amsterdam 8 Mos [Months] out Clean". 159

155. De Jong, Oude Nederlandse walvisvaart, vol. II, 468.

156. Sluijs cites 509 tons.

157. Broeze, 'Whaling in the Southern Oceans', 103-104.

158. The master's name may also have been A.F. Brunn.

159. Abraham Wilcox Pierce, manuscript journal aboard the ship William Hamilton of New Bedford, Mas- 
On 10 December 1846, after about 15 months of cruising, the vessel dropped anchor in Sydney harbour. Up until then, the catch results can be considered mediocre at best: the ship carried 370 barrels of black oil, 130 barrels of sperm, and a meagre 1,00o kilograms of baleen. Meanwhile, the ship had not only lost another whaleboat but also its Captain, Brunn, and A.J. Meyer was newly appointed. While in Sydney, Meyer tried to recruit new crew.

From Sydney the Dutch whaleship set sail for the Samoa Islands, catching two sperm whales during this trip. On 20 March 1847, Zuidpool arrived at Honolulu from Magdalena Bay with 360 barrels of sperm whale oil and 1,200 barrels of oil. The vessel left again on 6 April, heading for the Northwest Coast. ${ }^{160}$ Zuidpool cruised the Bay of Kamchatka in the ensuing months. On 30 August 1847, Meyer and his crew arrived at Honolulu with 900 barrels of black oil and 300 barrels of sperm oil. Another 2,000 barrels of oil were registered in early $1849 .{ }^{161}$ Zuidpool discharged its cargo of oil on 4 April 1849, at Valparaiso. From there, the vessel set sail for San Francisco where its arrival was recorded on 6 July 1849. A little later the ship was sold. ${ }^{162}$

Both Anna \& Louisa and Zuidpool must have felt like millstones around the white-collared necks of the Reelfs Brothers. Costs had been sky-high and revenues were very low. Broeze pointed out that the brothers had benefited from the setbacks they had endured, if only to realise that the organisation of their enterprise should be changed drastically:

\begin{abstract}
"After the Zuidpool had left Holland, they [Reelfs Brothers] had finally arrived at the correct conclusion that it would be cheaper in the long run to buy new ships in the United States than to try and patch up old Dutch ones. The government fully agreed with them on this point, and undertook to grant them Dutch registration for any foreign whalers they choose to import. The only conditions they imposed were that the ships were fitted out in Holland and only used for whaling purposes". ${ }^{163}$
\end{abstract}

In this way, the Dutch could have followed the example given by Bremen whalemen and entrepreneurs, as they acquired the majority of their whaling fleet in the United

sachusetts, Captain Lorenzo Fisher, 1845-1848; entry of 17 May 1846. Kendall Collection, journal \#548, New Bedford Whaling Museum, New Bedford, Massachusetts, USA. See also Robert Lloyd Webb, On the Northwest. Commercial Whaling in the Pacific Northwest, 1790-1967 (Vancouver 1988), 63. Here, the name of the master of Zuidpool was misspelled as Braun.

160. Honolulu Archival Records (HAR), Harbourmaster, whaleships 1847. The author would like to express his gratitude to Susan Lebo, Honolulu, Hawai'i, for drawing attention to these sources and for providing the related information.

161. Sources do not reveal if these barrels were filled with black oil (regular whale oil) or sperm oil (oil harvested from sperm whales).

162. Broeze, 'Whaling in the Southern Oceans', 104-105.

163. Broeze, idem, 106. 
States. ${ }^{164}$ Dutch entrepreneurs, however, seem to have refrained from investing any more capital in South Seas whaling expeditions. Only two decades prior to the abandonment of Zuidpool, the NHM had endured the eventful experiment with a brand new American whaleship (Logan), an experienced American master (Reuben F. Coffin of Nantucket), and loads of inexperienced managers and crew members from the Netherlands. We may safely assume that Reelfs Brothers must have had intelligence about its failure, as news must have been brought to them via newspapers or during board meetings.

Table 3.3: Overview of whaling expeditions fitted out by the Amsterdam Reederij voor de Zuidzee Walvischvangst (Reelfs Brothers) (1844-1849). ${ }^{165}$

\begin{tabular}{|l|l|l|l|l|l|l|}
\hline Year & Master & Ship & Type & Destination & Remarks & Results \\
\hline 1844 & $\begin{array}{l}\text { Mey, J. van der } \\
\text { (1st mate)/Gray, } \\
\text { George (master)/ } \\
\text { Ward, S. }\end{array}$ & $\begin{array}{l}\text { Anna \& } \\
\text { Louisa }\end{array}$ & $\begin{array}{l}\text { Two-decked ship } \\
\text { (built 1827; 319 tons) }\end{array}$ & 'South Seas' & $\begin{array}{l}\text { April 1844-Nov. 1846; } \\
\text { condemned due to } \\
\text { poor condition }\end{array}$ & $\begin{array}{l}\text { 160 barrels of oil on } \\
\text { board }\end{array}$ \\
\hline 1845 & $\begin{array}{l}\text { Brunn, T.A/A.F. } \\
\text { Replaced by A.J. } \\
\text { Meyer as of late } \\
1846\end{array}$ & $\begin{array}{l}\text { Zuidpool } \\
\text { (ex-Proser- } \\
\text { pina) }\end{array}$ & $\begin{array}{l}\text { Bark } \\
\text { (536 tons, Broeze; } \\
509 \text { tons, V. Sluijs) }\end{array}$ & Pacific Ocean & $\begin{array}{l}\text { Aug. 1845; sold at San } \\
\text { Francisco? Aug. 1849? }\end{array}$ & \\
\hline
\end{tabular}

\section{The aftermath of Dutch South Seas whaling}

In 1877, S.C.J.W. van Musschenbroek published an article on the American sperm whale fishery in the Dutch East Indian waters. Through this publication the former resident of Menado eloquently shared his innovative ideas with the rest of the world vis-à-vis Dutch involvement in whaling in Dutch East Indian waters. Until then, Dutch entrepreneurs had tried to have their whaleships built in the Netherlands, sail these vessels to remote areas in the world, and have them return home to sell off their cargo of baleen and whale oil. As in the case of Logan, one or two original minds developed the idea to hire both a vessel and experienced crew from abroad and have them work for the company based in the Netherlands - with disappointing results. Van Musschenbroek cleverly came up with a third variation to the theme.

Around the time Van Musschenbroek put his ideas on paper, the Dutch government had developed a firm grip over most coastal regions in the Dutch East Indies. Van Musschenbroek's solution was as simple as it was ingenious. He advocated Dutch

164. Broeze, idem, 110. See also O. Höver, Von der Galliot zum Fünfmaster.Unsere Segelschiffe in der Weltschiffahrt 1780-1930 (Bremen 1934; reprinted at Norderstedt 1974), 198-199.

165. Broeze, 'Whaling in the Southern Oceans', 100-106. 


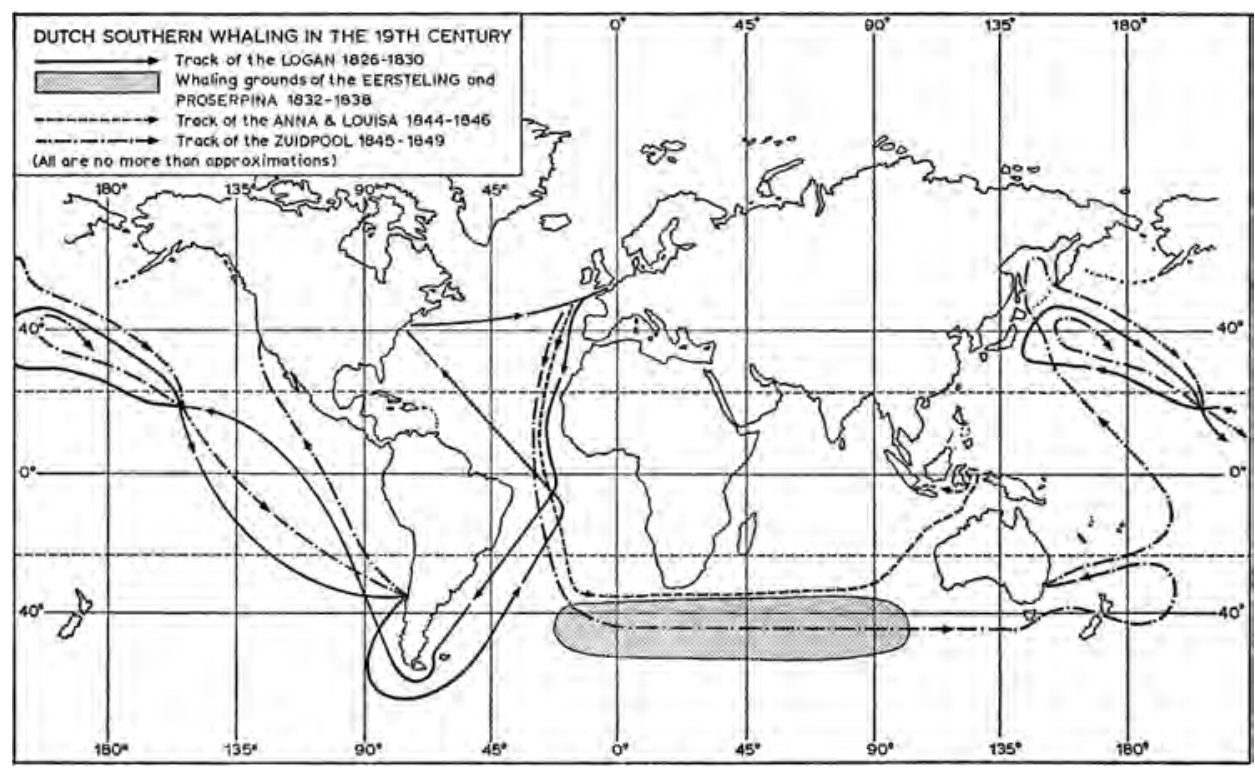

5. Map of voyages of Dutch whaleships to the South Seas, 1827-1849. This map shows the various courses set by the Dutch whaling expeditions to Dutch East Indian waters and the Pacific Ocean. Derived from F.J.A. Broeze, 'Whaling in the Southern oceans. The Dutch quest for Southern whaling in the nineteenth century', Economisch-en sociaal-historisch Jaarboek, vol. 10 (1977), 67.

sperm whaling in Dutch East Indian waters. This specific type of whaling, he claimed, would be much cheaper than the Arctic whaling with regard to crew, shipbuilding, and outfitting costs. To this extent he suggested commencing with building ships in or close to the East Indian archipelago. Singapore and Java were mentioned as excellent locations. ${ }^{166}$ These newly-built vessels, preferably schooners of about 80 to 100 tons, according to Van Musschenbroek, could be manned by a cheap, experienced, indigenous crew of between 30 to 40 hands. The ships could be fairly small as whaling masters could easily discharge their cargoes of whale products in many harbours near the hunting grounds. In his view, the shipbuilding program should initially bear a modest character with the construction of six to ten vessels, including four or five whaleboats each. ${ }^{167}$

Moreover, the former resident presented himself as a strong advocate for fol-

166. S.J.W.C.van Musschenbroek, 'Cachelot-Visscherij in den Nederlandsch Indischen archipel', Tijdschrift ter bevordering van Nijverheid, vol. XVIII, part 11 (Haarlem 1877), 22 passim.

167. De Jong, Westerse walvisvangst, 18-19. If this plan had been executed, the Dutch would have met tough competition. Around 1877, the British had almost completely abandoned the East Indian whaling grounds. Since about 1840, however, the numbers of American and Australian whaleships cruising these waters had increased. 
lowing in the wake of the highly successful Americans and start hunting sperm whales instead. To Van Musschenbroek it was inconceivable that the Dutch would leave the profitable sperm whale fishery to foreigners. In his opinion the Dutch should participate in this industry, which took place in an archipelago brought under their control with subsequent political, military, and, above all, economic advantages. ${ }^{168} \mathrm{His}$ plans, however, were never met by the crucial combination of enthusiasm and finances.

In order to obtain a firm and unambiguous perception of the size and intensity of the whaling expeditions to the South Seas, the above-mentioned activities, and the tables, presented earlier, are combined in table 3.4.

Table 3.4: Whaling expeditions to the South Seas (1827-1849). ${ }^{169}$

\begin{tabular}{|c|c|c|c|c|c|c|c|}
\hline Year & $\mathrm{O} / \mathrm{C}$ & Master & Ship & Type & Destination & Remarks & Results \\
\hline 1827 & NHM & $\begin{array}{l}\text { Coffin, } \\
\text { Reuben F. }\end{array}$ & Logan & $\begin{array}{l}\text { Ship(built. in } \\
\text { Dartmouth in } \\
1826 ; 302 \text { tons) }\end{array}$ & $\begin{array}{l}\text { Pacific Ocean } \\
\text { (dep. April, } \\
1827 \text { ) }\end{array}$ & $\begin{array}{l}\text { Three-year voy- } \\
\text { age (April 1827- } \\
\text { July 1830) }\end{array}$ & $\begin{array}{l}32,569^{1 / 2} \text { gallons of } \\
\text { sperm; } 3,222 \text { gallons of } \\
\text { black oil (South Seas } \\
\text { oil) }\end{array}$ \\
\hline 1832 & $\begin{array}{l}\text { St. Martin \& } \\
\text { Co., Rotter- } \\
\text { dam }\end{array}$ & $\begin{array}{l}\text { Horneman, } \\
\text { H.F. }\end{array}$ & Eersteling & $\begin{array}{l}\text { Bark } \\
\text { (291 tons) }\end{array}$ & $\begin{array}{l}\text { S. Atlantic / } \\
\text { Indian Ocean } \\
(?)\end{array}$ & $\begin{array}{l}\text { 15-month voyage } \\
\text { (Nov. 1832-Feb. } \\
1834) ;\end{array}$ & $\begin{array}{l}\text { 7,00o litres of sperm; } \\
20,000 \text { litres of black oil } \\
\text { (South Seas oil) }\end{array}$ \\
\hline 1834 & $\begin{array}{l}\text { St. Martin \& } \\
\text { Co., Rotter- } \\
\text { dam }\end{array}$ & $\begin{array}{l}\text { Horneman, } \\
\text { H.F. }\end{array}$ & Eersteling & Bark & (291 tons) & $\begin{array}{l}\text { S. Atlantic / } \\
\text { Indian Ocean (?) }\end{array}$ & $\begin{array}{l}\text { 20-months voyage } \\
\text { (Aug 1834-April 1836); } \\
\text { 150,00o litres of oil; } 100 \\
\text { bundles of baleen }\end{array}$ \\
\hline 1836 & $\begin{array}{l}\text { St. Martin \& } \\
\text { Co., Rotter- } \\
\text { dam }\end{array}$ & Smith, J.P. & Proserpina & $\begin{array}{l}\text { Bombardeer- } \\
\text { korvet (184 } \\
\text { lasts; built. } \\
1818-1821)\end{array}$ & 'South Seas' & $\begin{array}{l}\text { 22-month voyage } \\
\text { (July 1836-May } \\
\text { 1838); }\end{array}$ & $\begin{array}{l}\text { 10,00o litres of sperm, } \\
\text { 140,00o litres of black } \\
\text { oil; 5,00o kilograms of } \\
\text { baleen }\end{array}$ \\
\hline 1844 & $\begin{array}{l}\text { Reederij voor } \\
\text { de Zuidzee } \\
\text { Walvisch- } \\
\text { vangst (Reelfs } \\
\text { Brothers), } \\
\text { Amsterdam }\end{array}$ & $\begin{array}{l}\text { Mey, J. van der } \\
\text { (1st } \\
\text { mate)/Gray, } \\
\text { George (mas- } \\
\text { ter)/ Ward, S. }\end{array}$ & $\begin{array}{l}\text { Anna \& } \\
\text { Louisa }\end{array}$ & $\begin{array}{l}\text { Two-decked } \\
\text { ship (built } \\
\text { 1827; } 319 \text { tons) }\end{array}$ & 'South Seas' & $\begin{array}{l}\text { April 1844-Nov. } \\
1846 ; \text { condemned } \\
\text { because of poor } \\
\text { condition }\end{array}$ & $\begin{array}{l}\text { 16o barrels of oil on } \\
\text { board }\end{array}$ \\
\hline 1845 & $\begin{array}{l}\text { Reederij voor } \\
\text { de Zuidzee } \\
\text { Walvisch- } \\
\text { vangst (Reelfs } \\
\text { Brothers), } \\
\text { Amsterdam }\end{array}$ & $\begin{array}{l}\text { Brunn, } \\
\text { T.A/A.F. / } \\
\text { Replaced by } \\
\text { Meyer, A.J. as } \\
\text { of late } 1846\end{array}$ & $\begin{array}{l}\text { Zuidpool } \\
\text { (ex-Proser- } \\
\text { pina) }\end{array}$ & $\begin{array}{l}\text { Bark (536 tons } \\
\text { - Broeze/509 } \\
\text { tons, V. Sluijs) }\end{array}$ & Pacific Ocean & $\begin{array}{l}\text { Aug. 1845-sold at } \\
\text { San Francisco? } \\
\text { Aug. 1849? }\end{array}$ & \\
\hline
\end{tabular}

Table 3.5 presents a numerical overview of all South Seas whaling voyages under the Dutch flag.

168. Van Musschenbroek, 'Cachelot-Visscherij', 21.

169. Broeze, 'Whaling in the Southern Oceans', 66-112. 
Table 3.5: Overview of number of ships, number of expeditions, and catch results in Dutch South Seas expeditions (1827-1849).

\begin{tabular}{|c|c|c|c|c|c|c|c|c|c|}
\hline Year & A & B & $\mathrm{C}$ & D & $\mathrm{E}$ & $\mathrm{F}$ & G & $\mathrm{H}$ & I \\
\hline 1827 & 1 & o & 1 & o & $?$ & $\begin{array}{l}\left(32,569^{1 / 2} \text { gallons }\right) \\
123,764 \text { litres }\end{array}$ & $\begin{array}{l}\text { (3,222 gallons) } \\
12,244 \text { litres }\end{array}$ & $?$ & $?$ \\
\hline 1832 & 1 & 2 & 1 & 2 & $?$ & 7,0oo litres & 20,00o litres & $?$ & $?$ \\
\hline 1834 & 1 & 3 & 1 & 3 & $?$ & $?$ & $?$ & $\begin{array}{l}\text { 150,ooo litres } \\
\text { (black oil?) }\end{array}$ & $\begin{array}{l}\text { 10o bundles (num- } \\
\text { ber of kilograms } \\
\text { unknown) }\end{array}$ \\
\hline 1836 & 1 & 4 & 1 & 4 & $?$ & 10,000 litres & 140,0oo litres & $?$ & 5,00o kilograms \\
\hline 1844 & 1 & 5 & 1 & 5 & $?$ & $?$ & $?$ & $\begin{array}{l}\text { 16o barrels of oil on } \\
\text { board }\end{array}$ & $?$ \\
\hline 1845 & 1 & 6 & 1 & 6 & ? & ? & ? & $?$ & ? \\
\hline Totals & & 6 & & 6 & ? & 140,764 litres & 172,244 litres & $\begin{array}{l}\text { 150,00o litres }+ \\
160 \text { barrels }\end{array}$ & $\begin{array}{l}5,000 \mathrm{~kg}+ \\
100 \text { bundles }\end{array}$ \\
\hline
\end{tabular}

\section{Conclusions}

The history of Dutch involvement in the South Seas whale fishery is intriguing and bewildering. The NHM played an uncooperative role by not showing any inclination to support initiatives. Moreover, after the death of King Willem I in 1840, his son refrained from any involvement in the resumption of whaling, be it in the Northern or Southern Hemispheres. Whaling entrepreneurs were supported by members of the government - in words, but much less in subsidies. Despite the sense of entrepreneurship among wealthy and influential individuals, the government did not develop a policy commensurate with the wishes and ambitions of these adventurous men. The resilience of a handful of merchants and masters from the two largest urban communities in the Netherlands, Amsterdam and Rotterdam, was thus put to the test. The South Seas whaling adventure - if one may apply such a term to these scattered, overly expensive and meagrely supported initiatives - lasted for only about two decades (1827-1849), although initiated on paper by the Afrikaansche Visscherij Sociëteit in 1802.

A fair number of individuals and companies conducted whaling activities in the waters of the South Pacific and the Dutch East Indies. The number of expeditions six in total - is unimpressive. Similarly, catches were modest. While interpreting these figures, we should bear in mind that the nature of this type of whaling differed enormously from the methods employed in Arctic waters. Contrary to the whaling voyages to East and West Greenland, expeditions to the Southern Hemisphere took many months and occasionally lasted several years. Ships cruised the whaling grounds and 
touched upon harbours in those areas for recruitment, relaxation, or for food and water. Dutch whalemen had no expertise whatsoever in whaling voyages of such long duration, and little expertise in sperm whaling. In several instances, directors of companies showed keen interest in hiring expertise from abroad. Americans, but also British whalemen were hired to teach Dutch sailors the ropes - without success.

During the 23-year period of 1827-1849, there were six years during which no South Seas whaling expeditions sailed from Dutch harbours. As such, Dutch participation in South Seas whaling can be considered to have been a small-scale, yet financially intensive activity. ${ }^{170}$ Data is lacking regarding the numbers of whales caught. In this respect, analysis and comparison to its northern counterpart - the Greenland whale fishery - evokes an image of a more dynamic and fairly well-managed industry. This will be the focus of Chapter 4 .

170. The total number of barrels of sperm oil and black oil, acquired in four long, money-consuming whaling voyages equalled the results of one typical, but successful American whaleship. 


\section{Nineteenth-Century Dutch Whaling and Sealing in the Arctic (1815-1885)}

\section{Introduction}

Dutch whaling masters had steered their ships toward the "old," familiar whaling grounds east and west of Greenland in the early years of the nineteenth century. The resumption of war in 1803 hindered these captains in their attempts to resume whaling in the Arctic region. As had been the case with South Seas whaling, Dutch whaling entrepreneurs had to wait for peace and for the incentives from King Willem I before they could devote their time and finances to whaling expeditions to the North. In this chapter, companies and individuals working in the Arctic will be discussed. Their activities and catches will be scrutinized and analysed in order to present an idea of scope and intensity of Dutch whaling and sealing in the coastal waters of Jan Mayen Island, Spitsbergen, and Greenland.

\section{Arctic whaling and sealing}

Amsterdam: Barend van Spreekens (1815-1819)

Immediately after King Willem I published his KB of 19 March 1815, which eventually resulted in an increase of premiums, Amsterdam merchant Barend van Spreekens was one of the first to realise the importance of a revitalisation of the whaling industry.

On 24 April 1815, at an auction in Dordrecht, Van Spreekens paid $f 16,700$ for a fluitschip of 200 lasts (about 400 tons). It is likely that this sale concerned Groenlandia, formerly owned by the firm of Frank van den Schoor \& Sons in Dordrecht. ${ }^{171}$ This ship must have been at least fifty years old at the time, as the announcement in the

171. Sources do not agree on the rig of Groenlandia, as both fluitschip and pink are mentioned. The ship may have been re-rigged prior to the sale. See De Jong, Oude Nederlandse walvisvaart, vol. II, 451; vol. III, 155; Van Sluis, Nederlandse koopvaardijschepen, 205. 
newspaper mentioned that the ship had been completely refurnished ('uitgehaald') in 1764, and again in $1788 .{ }^{172}$

In 1815, well experienced Captain Jacob Broertjes from Amsterdam took the vessel, appropriately named Groenland, to the coastal waters of the vast territory bearing this name. As stated earlier in Chapter 1, Broertjes had been involved in several whaling expeditions during the period between 1802 and 1805 . This ship carried seven boats and a crew of 43. Its crew list was compiled on 5 April. ${ }^{173}$

One year later, on 7 April 1816, the vessel with a crew of 50 left again from Texel for Greenland, again under Jacob Broertjes. The ship returned on 15 August, having caught two whales that yielded 40 kwartelen of oil. Broertjes took Groenland to the whaling grounds in 1817 , and again in $1819 .{ }^{174}$

Results, however, were not encouraging. Two whales were caught in 1816, another two in 1819, and Groenland returned empty in the years in between. Broertjes blamed the lack of success to natural causes. He mentioned the unfavourable ice conditions east of Greenland, where during the years 1816 to 1818 the icepack had opened quite early in the year. Because of this, whales could move among the ice fields at a much earlier stage than the whale hunters. Broertjes was backed in his conclusion by statements articulated by the notorious English whale hunter William Scoresby, Jr. ${ }^{175}$

Not much is known about Barend van Spreekens. This intriguing entrepreneur must have been a strong and influential advocate of new mercantile and maritime initiatives, and showed great determination in his endeavours to resume whaling activities. Born around 1780 as the second son of Schelte van Spreekens and Cornelia Witveld, Van Spreekens married Anna Maria Louisa Elisabeth Gillieron in 1801. At that time, he lived at Singel 209 in Amsterdam. ${ }^{176}$ In the early archival records, no profession is given. He was granted permission to receive premiums in 1815. Two years later, in 1817 , he applied for prolongation of these premiums, which were scheduled to ex-

172. Amsterdamsche Courant, 20 April 1805.

173. SAA, Archief van de Waterschout, inventory nr. 38; nr. 95 (1815). In a later chapter (chapter 5) we will analyse size and composition of the crew.

174. SAA, Archief van de Waterschout, inventory nr. 38; nrs. 99 (1816), and 110 (1819). In this specific archive, no information was given about the 1817 voyage.

175. De Jong, Oude Nederlandse walvisvaart, vol. II, 451-452. Jacob Broertjes must have been an experienced officer. In 1810, the fluitschip Zaandam (in former years most probably a whaling ship, 1796), Captain [sic] J. Broertjes, was sold at auction. See Amsterdamsche Courant, 27 February 1810.

176. The municipal archives in Amsterdam (SAA) mention 20 February 1780 as date on which he was baptized. Websites specialising in genealogical data list 1778 as Van Spreekens' year of birth. The marital relationship produced 3 (website) or 4 (archival records) children. So far, the names of two daughters (Cornelia and Aleida Maria) and one son (Schelte, 1803-1829) have been retrieved. See http://home.hetnet.nl/ $\sim$ windgenealogie/RE/re_oo108.htm. See also SAA, Akte van ondertrouw (act of undermarriage), 9 January 1801. I am grateful to Pieter Flinkenflögel of the Municipal Archive in Amsterdam for providing this information. 
pire on 1 January 1818 . His request was initially declined, as a sufficiently large crowd of whaling entrepreneurs had to announce themselves in order to be eligible for financial support. During these years, continuation of the premium system was threatened. Van Spreekens' initiatives were subjected to discussion in the meeting of the Amsterdam Chamber of Commerce on 20 January. In a letter to King Willem I, the Chamber indicated that as a sole whaling entrepreneur, Van Spreekens considered bringing an end to his activities as he felt threatened by a pending discontinuation of the premium. King Willem I personally interceded. Not only did he make an appeal to the merchants in the capital, but the King also indicated that he was willing to invest part of his private capital for the good of the whaling cause. In 1818 it was decided that half of the premium of $f$, 000 was to be paid before the whaleship departed. ${ }^{177}$

In his professional life, Van Spreekens was not only involved in re-establishing a Dutch whale fishery but also in organizing the first lifesaving company in the Netherlands. On 14 October 1824, a storm ruined part of the Dutch merchant marine. Traces of wrecked ships could be seen all along the Dutch coast and volunteers were involved in rescue operations. Sparked by the news clippings regarding these rescue operations, Van Spreekens decided to take action with influential countrymen. In late October, Van Spreekens and Amsterdam attorney Adriaan de Bruine, turned for support to H.J. Ortt, naval Captain and inspector for the pilotage north of the river Maas; to colonel Joan Hodhon, commander of the local militia; and, finally, to insurer Abraham Fock. Their common goal was to establish a national Association for the Rescue of Seamen. By doing this, Barend van Spreekens became one of the founding fathers of the Noorden Zuid-Hollandsche Redding Maatschappij, the first professionally run and government-supported lifesaving company in the Netherlands, which was established on 11 November $1824 \cdot{ }^{178}$

Also, Barend van Spreekens was one of seven gentlemen certified to set the prices of certain commodities imported from (among other regions) the Dutch East Indies, Persia, Italy, and the North and South polar seas. Prices for these products were set in accordance with instructions stipulated in article 123 of the law on the levy of duties and taxes on incoming and outgoing commodities (proclaimed on 26 August 1822). In this manner, Van Spreekens, while executing his responsibility had a voice in the fluctuation of price levels vis-à-vis the very whale products he wanted to import in the Netherlands: baleen. ${ }^{179}$ After 1828, no record of Barend van Spreeken has been found

177. Zwart, Kamer van Koophandel, 92. See also De Jong, idem, vol. II, 454.

178. See for an account on Van Spreekens' involvement in the establishment of the company H.Th. de Booy, Strandrovers, jutters en redders. Voorgeschiedenis en geboorte van het reddingwezen (Den Haag 1959), 75-105; especially 77-93. Between 1933 and 1990, one of the lifesaving boats in use along the Dutch coastline bore his name in commemoration. This fact is mentioned on website www.dorusrijkers.nl/reddingboten.

179. Van Spreekens' involvement is mentioned in the Drie Maandelijksche Prijs-Courant, included in the 
providing information about his whereabouts, or commercial or personal activities. He died in $1833 .{ }^{180}$

Table 4.1: Whaling expeditions to Spitsbergen fitted out by Barend van Spreekens (1815-1819). ${ }^{181}$

\begin{tabular}{|l|l|l|l|l|l|}
\hline Year & Master & Ship's name & Type & Destination & Results/remarks \\
\hline 1815 & Broertjes, Jacob & $\begin{array}{l}\text { Groenland } \\
\text { Built prior to 1764 }\end{array}$ & Fluitschip & Spitsbergen & \\
\hline 1816 & $\begin{array}{l}\text { Broertjes, Jacob } \\
\text { 7 Apr. -15 Aug. }\end{array}$ & Groenland & Pink & Spitsbergen & 2 whales/40 kwartelen of oil/57 barrels of oil \\
\hline 1817 & Broertjes, Jacob & Groenland & Pink & Spitsbergen & \\
\hline 1818 & Broertjes, Jacob & Groenland & Pink & Spitsbergen & \\
\hline 1819 & Broertjes, Jacob & Groenland & Pink & Spitsbergen & 2 whales/70 barrels \\
\hline Total catch & & & & & 4 whales + 127 barrels of oil \\
\hline
\end{tabular}

Wormerveer: Jan Vas \& Company (1820-1825)

In February, 1820, Van Spreekens sold his whaleship Groenland for $f 6,000$ to merchant Jan Vas (1773-1824). ${ }^{182}$ Vas lived and worked in the village of Wormerveer, just north of Amsterdam and grew up in an affluent environment. His father, Vastert Claasz. Vas (1729-1808), owned no fewer than 16 oil mills, was the major shareholder in five large paper mills belonging to the important and large paper manufacturing firm of his father-in-law Dirk Blaauw, manufactured starch, and was involved in the export of East Indian commodities to Norway. His business, as well as his two marriages, had made Vastert Claasz. Vas a very wealthy man. The family owned a large, stately house along the canal in Wormerveer.

monthly journal De Nederlandse Hermes, tijdschrift voor de Koophandel, Zeevaart en Nijverheid, vol. III, no. 9 (1828), 88; 90; vol. III, no. 11 (1828), 78; 80. To 21st-century standards this situation of course is unheard of, as Van Spreekens by consequence of his responsibility could regulate his very own commercial gains and losses. 180. In 1850 , on the occassion of its 25 th anniversary, the directors of the Noord- en Zuid-Hollandsche Redding-Maatschappij (NZHRM) wrote a report about the conception and activities of this life-saving institute. Established 11 November 1824, Barend van Spreekens together with A. de Bruine had been the two founding fathers. With their appeal to the nation to donate money for the NZHRM, they managed to raise a phenomenal $f_{17}, 070$, just $f_{500}$ short of covering all expenses. In later years, the company did extremely well with its finances, which were partly invested in stocks. In their article the directors mention the year in which Van Spreekens passed away (1833). See A. Fock, P. Huidekoper, D.A. Portielje, A. Huidekoper and S. Dedel, 'Verslag bij gelegenheid van het vijf-en-twintig-jarig bestaan van de Noord- en Zuid-Hollandsche ReddingMaatschappij', G.A. Tindal and J. Swart (eds.), Verhandelingen en berigten betrekkelijk het Zeewezen en de Zeevaartkunde, vol. 3 (1850), 32-48.

181. See SAA, Archief van de Waterschout, inventory number 38; nrs. 95 (5 April 1815); 99 (26 March 1816); 110 (22 March 1819); De Jong, Oude Nederlandse walvisvaart, vol. II, 451; vol. III, 155; Van Sluis, Nederlandse koopvaardijschepen, 205.

182. De Jong, idem, vol. II, 451. 
6. Mansion of the Vas family, Wormerveer, ca. 1800 . Watercolour by an anonymous artist. Archief Koog aan de Zaan.

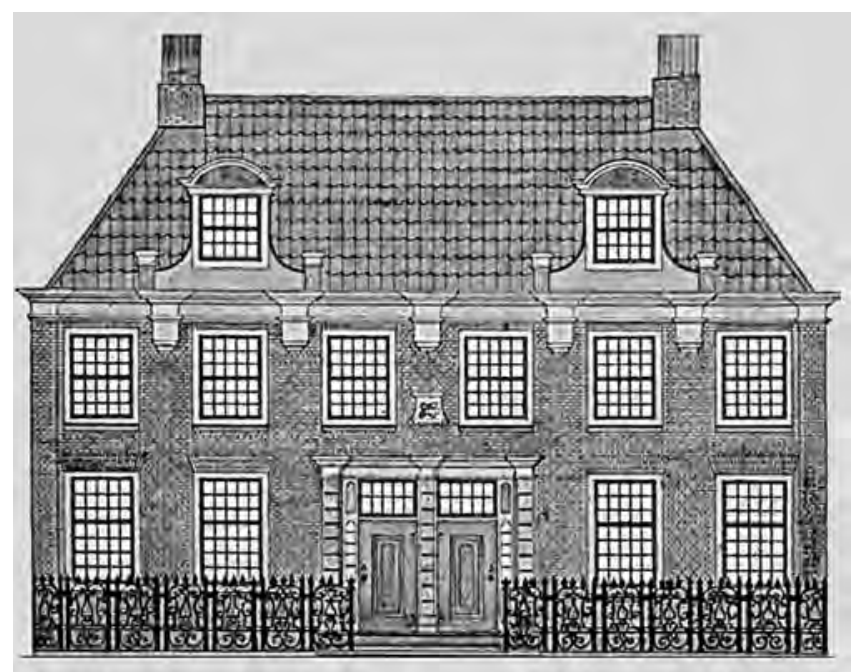

In the early 180os, Vas invested in whaling expeditions. In 1802, the whaleship Vriendschap under command of Cornelis Boekjes sailed to Greenland waters under the ownership of Vas and Dekker. Boekjes brought home a modest catch: one whale and ten barrels of blubber. The following year Vriendschap was fitted out again under the same management. This time Boekjes returned with an empty vessel and so he was sent to Greenland again. ${ }^{183}$

When the pater familias died in 1808 , he left an impressive amount of $f_{1}, 800,000$ to be divided among three children. ${ }^{184}$ Jan inherited the oil mills and he followed in his father's footsteps, displaying talents for entrepreneurial undertakings. His marriage with Lijsbeth Kuijper, daughter of Cornelis Kuijper, merchant, paint manufacturer, and burgomaster of the village of Wormer, remained childless. Jan Vas died in Amsterdam on 16 October 1824 .

In his whaling activities Jan Vas sought to establish an alliance with Cornelis Claasz. Honig (1773-1845), who was an influential local merchant, large-scale mill owner, and a very active member in the community of Mennonites in Koog aan de Zaan. In 1815 Honig became president of the local association of olieslagers (oil millers). In his elegant estate, located in the Dubbele Buurt in Zaandam, he frequently organised

183. SAA, Archief van de Waterschout, inventory number 38; inv. nr. 61 (31 March 1802); Van Sluijs, Nederlandse koopvaardijschepen, 108, 114. See chapter 1 for Boekjes' voyages.

184. His wife had died in 1799 and his second child, Cornelis, passed away in 1802. Vastert's first wife was Jacoba Pietersdochter Nanning ( $† 1759)$. For more about the Vas family, see L.A. Ankun et al. (eds.), Encyclopedie van de Zaanstreek (Wormerveer/Zaanstad 1991), vol. 2, 721; G.J. Honig, 'Sociëteit van de blauwselfabriek te Westzaan', Die Zaende: Maandblad gewijd aan de historie, folklore en genealogie van de Zaanstreek, vol. 5 (1950), 114; See also: http://www.camerama.demon.nl/vas. 
meetings of oil millers and members of the Mennonite movement. Honig was wellconnected in local affairs, with a strong network among fellow-merchants, and was the right man for Vas. ${ }^{185}$ He participated in Vas' enterprise and bought a $1 / 4$ share:

“... in het Pink Genaamt Groenland met deszelvs walvischvangersgereedschap onder Directie van Jan Vas"

("in the pink by the name of Groenland with its whaling gear under direction of Jan Vas"). ${ }^{186}$

Together, the two men established Vas \& Company Groenland had entered the service of the company in 1820 and, from the onset, Frans Oom was appointed master. Between 1820 and 1825, Oom made six voyages to Spitsbergen and the Davis Strait but was apparently rather unsuccessful. In his work about several influential families in the Zaanstreek, G.J. Honig referred to a meeting he once had with Gijsbert Krijt, ship's carpenter on Groenland. According to Krijt, every time Oom returned empty, he reported this to his Directors with tears in his eyes. ${ }^{187}$ This passionate, intimate observation was confirmed by the data about the catch results presented in the Amsterdamsche Courant. In 1820, Oom returned 'empty'. In 1821, Oom and his crew caught six whales that yielded 90 kwartelen of oil. ${ }^{188}$ In March 1822 and again in March 1823, Oom left for the Davis Strait. ${ }^{189}$ In 1822 , his expedition resulted in a catch of two whales. On 29 September 1823, however, he returned to Texel roadstead with eleven whales and 207 barrels of blubber, yielding more than 100 kwartelen of oil. ${ }^{190}$ In 1827 , an accident with Groenland brought an end to Oom's life. ${ }^{191}$

After Jan Vas' death in 1824 his widow Lijsbeth Kuijper continued at least some of the businesses. She found an enterprising partner in her sister-in-law Aaltje, wid-

185. See G.J. Honig, Uit den gulden bijkorf. Genealogisch-historisch-economische studiën over Zaansche families. Uitgegeven als vervolgdeel op het stamboek Smit (Koog aan de Zaan 1952), 38-40 for information concerning Honig's marital and business affairs, including the whaling activities undertaken by Vas and Honig. 186. Staatboek C.C. Honig. Quoted by G.J. Honig, idem, 39. Unfortunately, no price is mentioned.

187. Ibidem.

188. A passenger travelling with Captain D. Ouwehand from Hull, Scotland, referred to the fact that he, while on board an English whaleship in the Davis Strait, spoke with Frans Oom on 8 August 1821. At that time, Oom had caught five whales. Two months later, Groenland returned with a total catch of six whales. Passenger cited by Honig, Gulden bijkorf, 39. See also Haarlemsche Courant, 18 October 1821. Compared to the seventeenth century, the average number of kwartelen rendered per whale during the early 1820 s was very small. In the seventeenth century, examples of whales rendering 50 kwartelen were recorded, whereas the whales caught in 1821 ( 15 kwartelen per whale) and 1823 (9.9 kwartelen per whale) rendered much less. This may be an indication that the whales caught were much smaller than the ones harvested in the preceding centuries. 189. Until 1822, Groenland had been the only whaleship under Dutch flag. De Jong, Oude Nederlandse walvisvaart, vol. II, 451.

190. De Jong, idem, vol. II, 457.

191. J. van Sluijs, Nederlandsche koopvaardijschepen 1800-1860 (Unpublished listings; n.p. n.d.), 205-206. Sources do not agree regarding the year in which Groenland was lost (see note 194). 
ow of Dirk Visser. The two ladies henceforth operated the oil mills. ${ }^{192}$ Under the firm name of Weduwe Jan Vas (widow of Jan Vas), the last whaling expeditions to the Arctic took place in $1825 .{ }^{193}$ The ship Groenland remained in service until 1827. That year, the shipping company was dismantled after serious financial losses ${ }^{194}$ C.C. Honig, former business partner of Jan Vas, kept his $1 / 4$ share in the vessel until the very end. ${ }^{195}$ His two sons Klaas and Cornelis cleaned out some harpoons and other whaling gear in the warehouse De Visser in Wormerveer. Beginning in 1825, this building was one of the many warehouses owned by C.C. Honig. ${ }^{196}$

Lijsbeth died on 15 April 1828. Her brother Claas Kuijper, sole heir to the mills, sold the remaining ten mills to Aaltje for f16,350. Eventually, Aaltje's son Vastert Vas Visser took over all business linked to Wormerveer. Soon after, Vastert turned out to be less industrious than his grandfather Vastert Claasz. Vas, and his uncle Jan in his looking after his affairs. He left for Amsterdam and brought an end to his business. ${ }^{197}$

192. Late 1825 , Aaltje Vas paid $f_{9}$,ooo for the kofschip Vrouw Catharina (formerly known as Dorothea, 1818), thus becoming at least the fourth owner of this vessel. Documents to this order were signed on 29 December 1825, at the office of notary J. Evenblij, Zaandam, and are at present presumably in the collection of the Zaans Museum or Zaanlandsche Oudheidkundige Vereeniging (Historical Society of Zaandam). Honig, Gulden bijkorf, 377. See also Van Sluijs, Lijst van Nederlandse reders, ca. 1800-189o (n.p. 1935-1955), 173. This ship was involved in non-whaling voyages to Norway and the Baltic.

193. For a crew's list see Municipal Archives Amsterdam (SAA), Archief van de Waterschout, inventory number 38; nr. 124 (25 February 1825). In 1826 the firm fitted out Groenland for two non-whaling voyages. See crew lists SAA, inv. nr. 38: archief Waterschout, nr. 126 (15 March 1826), and 127 (18 August 1826).

194. Honig, Gulden bijkorf, 377, stated that the pink Groenland was lost in 1829. Evidence to confirm this has not been found. In his important work on families in the Zaanstreek, Honig (born in 1864) referred to a meeting he had in in his early years with Gijsbert Krijt, at the time a very old man who lived in Wormer and who, in the capacity of ship's carpenter, had joined master Frans Oom on more than one whaling expedition. During this meeting Krijt showed Honig a model of an Inuit in his kayak that he had acquired while whaling in the Davis Strait. He also showed him a drawing one of the crew had made of an Inuit with his wife. This drawing was in the collections of the Zaans Museum in Zaandam but was moved to the archives in Zaanstad. The model and a journal kept by Krijt were, in Honig's time (1852) still in possession of the Krijt-family. Today, the model of the kayak is part of the exhibit at the Zaans Museum. I thank curator Hester Wandel of the Zaans Museum for her assistance in discovering the location of documents and artefacts related to Krijt. 195. Apart from whaling, C.C. Honig apparently did not have a special interest in a wide variety of maritime industries. In his privately kept staatboek, Honig referred to a share, dated 1818 , of $f_{3} 00$ in the Sociëteit der haringreederij, directed by H.J. van Marle in Monnikendam. He also mentioned an unspecified share in the Visscherij in Wijk aan Zee, dated 1824. There were no references to financial involvement of any type in maritime enterprises in his last will. Honig, Gulden bijkorf, 40.

196. Message from M.K. Honig, dated 21 March 1905. Quoted by Honig, Gulden bijkorf, 40, note 2.

197. G.J. Honig, Stamboek familie Smit (Koog aan de Zaan 1935), vol. 1, 175. On Vastert Vas Visser: Jan Aten, Wormerveer langs weg en Zaan (Wormerveer 1967), 132. Here, I would like to express my gratitude to Bob Kernkamp, formerly of the municipal archives of Koog aan de Zaan, for making me aware of the existence of these publications. 
Table 4.2: Whaling expeditions to Spitsbergen and the Davis Strait fitted out by Jan Vas \& Company, Wormerveer (1820-1825). ${ }^{198}$

\begin{tabular}{|c|c|c|c|c|c|}
\hline Year & Master & Ship's name & Type & Destination & Results/remarks \\
\hline 1820 & $\begin{array}{l}\text { Oom, Frans } \\
\text { Dep. } 4 \text { April, Texel } \\
\text { Ret.? }\end{array}$ & $\begin{array}{l}\text { Groenland } \\
\text { Built prior to } 1764\end{array}$ & Pink & Spitsbergen & No whales \\
\hline 1821 & $\begin{array}{l}\text { Oom, Frans } \\
\text { Dep. ca. } 3 \text { March } \\
\text { Ret. 9/10 Nov., Texel }\end{array}$ & Groenland & Pink & Davis Strait & $\begin{array}{l}\text { Caught } 6 \text { whales, yielding 9o barrels of } \\
\text { blubber }\end{array}$ \\
\hline 1822 & $\begin{array}{l}\text { Oom, Frans } \\
\text { Dep. 3 March, Texel } \\
\text { Ret. 25 Sept. }\end{array}$ & Groenland & Pink & Davis Strait & $\begin{array}{l}\text { Caught } 2 \text { whales, yielding } 110 \text { barrels of } \\
\text { blubber (Honig, 39) } \\
\text { De Jong, III, 156, gives crewnumbers } \\
\text { for one (1) ship in } 1822 \text {, while next to } \\
\text { the Groenland the Spitsbergen under } \\
\text { master Ruygh cruised the Arctic waters } \\
\text { as well (see below) }\end{array}$ \\
\hline 1823 & $\begin{array}{l}\text { Oom, Frans } \\
\text { Dep. 25 March, Texel } \\
\text { Ret. 29 Sept., Texel }\end{array}$ & Groenland & Pink & $\begin{array}{l}\text { Davis Strait/ } \\
\text { Spitsbergen }\end{array}$ & $\begin{array}{l}\text { Returned with } 11 \text { whales and } 207 \text { barrels } \\
\text { of blubber/fat, yielding over } 100 \text { barrels } \\
\text { of oil; } \\
\text { Honig, } 39 \text {, does not provide data con- } \\
\text { cerning catch results }\end{array}$ \\
\hline 1824 & $\begin{array}{l}\text { Oom, Frans } \\
\text { Dep. ca. } 1 \text { March } \\
\text { Ret. 3o Sept. }\end{array}$ & Groenland & Pink & Davis Strait & $\begin{array}{l}\text { No whales (Honig, } 39 \text { ) } \\
\text { De Jong, III, } 152 \text { mentions one ship for } \\
1824 \text {, but crew numbers for two. } \\
\text { [See De Jong, II, 451] }\end{array}$ \\
\hline 1825 & $\begin{array}{l}\text { Oom, Frans } \\
\text { Dep.ca. } 3 \text { March } \\
\text { Ret. } 21 \text { Oct. }\end{array}$ & Groenland & Pink & Davis Strait & $\begin{array}{l}\text { No whales, } 50 \text { barrels of blubber. } \\
\text { De Jong, III, } 152 \text { mentions no ships for } \\
\text { this year, but gives crewnumbers for } \\
\text { one ship (III, 156). }\end{array}$ \\
\hline Total catch & & & & & $\begin{array}{l}\text { Circa } 19 \text { whales }+457 \text { barrels of blubber } \\
+>100 \text { barrels of oil }\end{array}$ \\
\hline
\end{tabular}

\section{Harlingen: Barend Visser \& Son, Part I (1822-1824)}

Around the same time, initiatives for whaling and sealing expeditions were developed in Friesland on the other side of the Zuiderzee as well. Like many other harbour towns in the Netherlands Harlingen had suffered severely from the Napoleonic wars, the French occupation (1810-1813) and subsequent administrative turmoil. Shipping to and from Harlingen around 1815 was but a mere shadow of what it had been in the years before 1795. At the same time, its population decreased fairly substantially (from 7,456 in 1796 to 6,913 in 1815 ). ${ }^{199}$ In 1798, the Admiralty of Friesland - one of the im-

198. SAA, Archief van de Waterschout, inventory number 38; nrs. 113 (22 March 1820), 116 (23 February 1821), 118 (23 February 1822), 120 (7 March 1823), 122 (20 February 1824), and 124 (25 February 1825). See also Leeuwarder Courant, 26 Oct. 1825; De Jong, Oude Nederlandse walvisvaart, vol. III, 155-156, and III, Table 5, 164; Van Sluijs, Nederlandse koopvaardijschepen, 205-206; Honig, Gulden bijkorf, 39.

199. P.M. Klaver, 'De bevolkingsontwikkeling van Harlingen 1800-1980', J.J. Huizinga, L.G. Jansma and C.H.A. Verhaar (eds.), Harlingen. Bijdragen tot de geschiedenis van de laatste twee eeuwen (Leeuwarden 1989), 41. This growth made Harlingen the most densely populated town in Friesland in 1879 (10,505 inhabitants per square kilometre). See P.M. de Klaver, 'Bouwen en wonen 1800-1980', Huizinga a.o. (eds.), Harlingen, 55. 
portant employers for the city - merged into the Department of the Navy (Departement van Marine), which was established in Amsterdam and Rotterdam. The presence of French troops, quartered in houses in the small town, combined with restrictions imposed upon trade with England - which was for many decades one of the most important markets for Dutch products shipped by vessels built and based in Harlingen certainly left their marks with the local population. Industries, traditionally involved in the manufacturing of cloth and linen dwindled. By 1813 it was obvious to everyone that markets were lost to the English. ${ }^{200}$ It is against this background that we should interpret local initiatives to resume whaling.

The first company in Harlingen to fit out ships for whaling was the firm of Barend Visser \& Son. This firm had been active in the whale fishery from as early as around 1760. In 1822 acting director Pieter Rodenhuis (1777-1826), his father and former burgomaster of the city, Ype Jetzes Rodenhuis (1751-1835), Dirk Cornelis Zijlstra (1775-1844), Jan Sikkes Yzenbeek (1779-1862) and Jarig Cornelis Mollema (1795-after 1857) ${ }^{201}$ bought the brig Spitsbergen. ${ }^{202}$

The initial plan was to buy more ships for whaling purposes. Lack of funds forced the ship owners to limit their operations to only one ship. The first two voyages to the Davis Strait - in 1822 under master Willem Rab and in 1823 under Ymke Jansz. Ruygh of the Frisian island of Terschelling - were not unsuccessful. But these expeditions were not successful enough to make the revenues cover the expenses. In the municipal archives in Harlingen, several indices on incoming letters addressed to the City Council referred to Barend Visser \& Son and their claims for premiums. On 28 October 1822, the City Council received documents from Visser \& Son to this effect. The ship Spitsbergen, fitted out under command of Willem Rab, was specifically mentioned in the index to this letter. About two weeks later, the City Council received news from the States of Friesland that Barend Visser's claim was to be granted. ${ }^{203}$ Interestingly this decision was annulled a few days later. The minutes of the

200. J.J. Huizinga, 'De geschiedenis van Harlingen', J.J. Huizinga a.o.(eds.), Harlingen, 31-32. Also P.M. de Klaver, 'Ontwikkeling van de nijverheid in Harlingen in de $19^{\text {de }}$ en $20^{\text {ste }}$ eeuw', idem, 70-71; 73.

201. Jarig Cornelis Mollema, born in Harlingen on 21 May 1795, is mentioned in local archives as merchant in 1820, and soap manufacturer (zeepzieder) from about 1839 onwards. Jarig Cornelis was son of Cornelis Mollema, proprietor of a warehouse located on E-20o. See about J.C. Mollema: Gemeentearchief Harlingen (Municipal Archives Harlingen (GAH), Burgelijke standsregisters Harlingen, 1820/1823/1825/1826/1830/1840 huwelijk (marriage); Bevolkingsregister Harlingen 1851 A-17; Volkstelling 1839.

202. Gemeentearchief Harlingen (GAH). Stukken betreffende het stadsbestuur van Harlingen, 1816-1924. Archiefstuk betreffende de Groenland- en Straat-Davids-visserij 1830 (1 omslag), nr. 3399. This document with appendices (statuten) eventually lead to the establishment of the Sociëteit. I have not been able to retrieve information concerning the former owners of the brig Spitsbergen.

203. GAH, Stukken betreffende het stadsbestuur van Harlingen. Index op ingekomen stukken, 1643 (18171823), no. 227: 28 October 1822; no. 242: 14 November 1822. 
meeting of the States of Friesland dated 14 November provide the explanation for this annulment. In his request for receipt of premiums, Visser apparently had overlooked that the company's ship Spitsbergen had been involved in both whaling and sealing activities. $^{204}$

Likewise, in the spring of 1823 Barend Visser \& Son requested a governmental premium in advance, before the whaling voyage had taken place. The King informed the City Council by way of the States of Friesland that he had granted half of the regular premium to the whaling company for the fitting out of Spitsbergen. ${ }^{205}$ Later, on 13 November, the City Council of Harlingen received a letter from the States of Friesland in order to finalise the payment of the premium for the fitting out and return of Spitsbergen, Captain 'Ruige' (sic). In their letter, the Gedeputeerde Staten (GS) again pointed out that Barend Visser \& Son had made a procedural mistake. Ymke Jansz. Ruygh and his crew had managed to catch and kill 193 seals. The blubber had yielded 6 kwartelen and 91/8 steekannen (=81/1/8 steekannen). Visser, however, had filed for 6 kwartelen and $9^{1 / 2}$ steekannen ( $=81^{1 / 2}$ steekannen). The GS clearly stated that Barend Visser should have filed for 7 kwartelen, reasoning that $9^{1 / 8}$ steekannen is $3^{1 / 8}$ steekannen more than half a kwarteel (6 steekannen). ${ }^{206}$ Over a year later, in December 1824, Barend Visser \& Son requested the payment of the premium of $f_{2,000}$ for the return in Harlingen harbour of Spitsbergen under command of master Ruygh. ${ }^{207}$

In fact, the results of these voyages sparked interest among some notable Harlingers who were involved in Barend Visser \& Son to consider the establishment of a company specifically geared towards whaling. Visser temporarily "hung his harpoons in the willow" and sold his ships to this new whaling company, as will be discussed later. ${ }^{208}$

204. GAH, Afschriften van resoluties van Gedeputeerde Staten, 1375 (1822-1825), no. $1: 14$ November 1822. 205. GAH, 1375, no. 1: 28 May 1823; GAH, 1643, no. 111: 28 May 1823.

206. One kwarteel $=12$ steekannen. As the level of premiums for wanvangst were based on the number of kwartelen not yielded, the GS - although at first made the point of a fairly marginal matter - had reason to bring this mistake to Visser's attention. GAH, 1375, no. 3: 13 November 1823; 1643, no. 234.

207. GAH, 1644, no. 284: 14 December 1824.

208. Next to the firm's involvement in the timber trade with the Baltic, Barend Visser \& Son was one of the few Friesland-based shipping companies - and probably the only one - that freighted out one of its ships to the NHM. In June of 1825, Waterloo left for Batavia. SAA, Particulier Archief 38, Waterschout, 124, 15 June 1825. Quoted by F.J.A. Broeze, De stad Schiedam. De Schiedamse Scheepsreederij en de Nederlandse vaart op OostIndië omstreeks 1840. Werken uitgegeven door de Linschoten-Vereeniging LXXX ('s-Gravenhage 1978), 62. 
Table 4.3: Whaling and sealing expeditions to the Davis Strait fitted out by Barend Visser \& Son $(1822-1823) .{ }^{209}$

\begin{tabular}{|l|l|l|l|l|l|}
\hline Year & Master & Ship's name & Type & Destination & Results/remarks \\
\hline 1822 & $\begin{array}{l}\text { Rab, Willem } \\
\text { Dep. 13 April 1822 } \\
\text { Ret. }\end{array}$ & Spitsbergen & $\begin{array}{l}\text { Brig } \\
\text { Two-decks }\end{array}$ & Davis Strait & Walruses/seals \\
\hline 1823 & $\begin{array}{l}\text { Ruygh, Ymke Janzs. } \\
\text { Dep. } \\
\text { Ret. 25 August 1823 }\end{array}$ & Spitsbergen & Brig & Davis Strait & 193 seals (yielding 63/4 wartelen of oil) \\
\hline
\end{tabular}

\section{Harlingen: The Groenlandse en Straatdavidse Visscherij Sociëteit} (1825-1834)

Support for the resumption of whaling expeditions came in a royal manner. On $4 \mathrm{Au}-$ gust 1824, King Willem I endorsed the establishment of a whaling company by Koninklijk Besluit. ${ }^{210}$ A few weeks later, on 30 September, Pieter Rodenhuis wrote (and signed) a document to stimulate potential shareholders to support the establishment of this new whaling company. The five undersigned stressed the solid foundation on which Dutch whaling enterprise could be built. King Willem I, in his KB, had promised to have his government pay premiums to whaleship owners in order to promote interest in the business. Moreover, according to the promotional brochure, Harlingen harbour was ideally located with easy access to the Frisian Islands, where many sailors could be trained for whaling, as well as to markets for whaling products. These commodities could be distributed relatively easily via the Zuiderzee. Finally, Rodenhuis stressed the importance of the presence of a cookery in Harlingen that could be expanded if necessary. In broader terms, the prospective directors stated that they considered it almost their national duty to equip whaleships under the Dutch flag.

In their promotional publication, Rodenhuis and his future co-directors were exceptionally frank about the disappointing catches to date. In the two preceding expeditions in 1822 and 1823 with Spitsbergen, under the ownership of Barend Visser \& Son, some walruses and seals were caught. The authors claimed, however, to have optimistic hope for 1824 with Spitsbergen destined for the Davis Strait. ${ }^{211}$ The company in-

209. GAH, 1644, no. 284: 14 December 1824; Amsterdamsche Courant, 14 April 1822; De Jong, Oude Nederlandse walvisvaart, vol. II, 456; vol. III, 156.

210. Koninklijk Besluit, 4 August 1824, no. 101.

211. On 11 March 1824, ordinary seaman Inne Innes Wijga (born in Sneek in 1802), while sailing on the Davis Strait grounds, fell into the sea from the top-sail yard of the main mast and drowned. See Burgerlijke standsregisters Harlingen, 1824 overlijden (deceased). I express my gratitude to Mr. J. van Wilsum, employed by the municipality of Harlingen, for sharing his database on citizens from that Frisian city via Hugo ter Avest, curator at the Municipal Museum Het Hannemahuis. 
tended to issue 800 shares at $f_{500}$ each, thus resulting in a substantial starting capital of $f 400,000$.

The company, established on 1 January 1825 for a period of ten years, operated under the name of Groenlandse en Straatdavidse Visscherij Sociëteit and Pieter Rodenhuis was appointed chief executive officer ('President Directeur'). ${ }^{212}$ The first general shareholders meeting took place on 2 February 1825 . Two months later, 433 shares at a nominal value of $f_{500}$ had been issued, for a total sum of $f_{216,500}$ to the company's account. According to Article 6 of the founding regulations (oprichtingsstatuten), a minimum of 200 shares had to be sold in order to have the company effectively established. ${ }^{213}$ The issue had been quite successful. It appears that the five affluent directors, well-imbedded in local (and possibly also regional) affairs and networks, had invested time, energy, money, and, last but not least, influence to encourage investors to buy shares. ${ }^{214}$ The City Council of Harlingen was granted permission from the King to take a group of ten shares in the company at $f_{500}$. In the promotional document, King Willem I was mentioned as one of the shareholders but the size of his investment was not specified. ${ }^{215}$

Before visiting Jacob Hanekuyk's office, one of the local notaries, the directors first awaited the results of issuing shares. On 18 June 1825 , all five directors met with notaries Hanekuyk and Sjoerd Simons Wijma, which also satisfied one of the requirements laid down in the founding regulations (Article 47, which stated that the directors must leave a copy of their founding regulations at a local notary office in the presence of two notaries). A few days later, on 21 June 1825, the document was ceremoniously signed by all present at the house of Dirk Fontein Pieterszoon, located at the Noorderhaven. At an earlier stage, the founding regulations were officially approved by L.H. Elias Schorel, clerk at the office of Secretary of State J.G. de Mey van Streefkerk. ${ }^{216}$

212. From now on the whaling company will frequently be referred to as Sociëteit. Rodenhuis did not live long enough to experience the rise and subsequent fall of the company. He died on 10 October 1826. See De Jong, Oude Nederlandse walvisvaart, II, 457.

213. De Jong, idem, 457; Anne J. Dijkstra, 'De Groenlands- en Straat davids-Visserij Sociëteit te Harlingen', Jaarboek Fries Scheepvaartmuseum en Oudheidkamer (1964/1965), 55. Dijkstra erroneously suggested that the Sociëteit had provided the money, as if the Harlingen had been the first purpose-built ship. He thus overlooked the existence of Willem de Eerste.

214. Pieter Rodenhuis was a well-established landowner with his properties amounting to many tens of thousands of square metres as well as a proprietor of several buildings and houses with servants. His father, Ype Jetzes Rodenhuis, was one of the directors of the orphanage, had been burgomaster of Harlingen, and was a very successful and wealthy merchant with five warehouses. The same accounts for Dirk Cornelis Zijlstra, Jan Sikkes IJzenbeek and, to a lesser extent, for Jarig Cornelis Mollema.

215. I.J. Brugmans was apparently very well informed about the size of the King's investments. He wrote about King Willem I as having had a major share in the whaling company that was established in Harlingen in 1824. Brugmans, Paardenkracht en mensenmacht, 154.

216. Tresoar Leeuwarden (TL). Notary archives. Notary records Harlingen. Notary Jacob Hanekuyk, minuut-akten 51014 (1825), no. 78 : 18 June 1825. 
The management of the company consisted of five directors, each owning four shares or more. The names of these five directors were, not surprisingly, identical to the names underneath the document. Five members of the Board would oversee the activities of the directors. These Board members were owners of two shares or more, or, in other words, they had invested $f 1,000$ or more, a substantial amount in those days. The directors were to be selected by the shareholders based on the principle of "one share, one vote." Both functions of Director and Board member were honorary. The company would insure its ships in Rotterdam or Amsterdam for each voyage from Harlingen to either Spitsbergen or the Davis Strait. Their goal was to hunt for both whales and seals. ${ }^{217}$

The Sociëteit had a very bad start. Early in 1825 , the first whaleship specifically built for the Sociëteit was put in service. This two-decked pink Willem de Eerste was built around 1822 or 1823 by Johan Alta in Harlingen and, for obvious reasons, was named after the King who was so supportive to the industry. ${ }^{218}$ In 1825 , the vessel left Harlingen harbour with a large crew of 46. Ymke Jansz. Ruygh, who had commanded Spitsbergen in the two previous years, was assigned as Captain. On this trip Ruygh had his three sons on board. During his stay on the hunting grounds in the Davis Strait, Ruygh filled his ship with an unimpressive 40 kwartelen (about 9,300 litres) of seal blubber and three barrels of blubber from a dead whale they had found floating. According to the Nederlandsche Staatscourant, Ruygh referred to the presence on the whaling grounds of Frans Oom, Captain of Groenland and sailing for the company of Jan Vas in Wormerveer, and stated they had 50 barrels on board. Like Ruygh, Oom received a pilot from Texel. ${ }^{219}$

For Ymke Ruygh, disaster was not limited to bad catch results. Ill fate awaited the ship and its crew on their return passage. After having spent all summer on the whaling grounds, Willem de Eerste left for the Netherlands on 21 September. On 19 October, Ruygh saw the fire beacon at Kijkduin, close to Huisduinen. The next morning the wind had changed. Coming from the north, it prevented Ruygh from sailing toward

217. Typoscript Hannemahuis, number 2330, appendices, article 2.

218. Master shipwright Johannes Dirksz. Alta was born in Makkum in 1777. He and his brother arrived in Harlingen around 1815 and he died in this city on 8 August 1834. On 9 July 1816, the Minister of Naval Affairs ('Minister van Marine') sold the navy wharf at the Zuiderhaven to the brothers. Much later, in 1910, the City Council of Harlingen purchased Alta's wharf Welgelegen and resold the premises to an independent, limited liability company in 1917. Johannes Alta married twice and had two daughters and one son, Dirk Johannes, who followed his father in that he became a ships carpenter. GAH, Burgelijke standsregisters Harlingen, 1818 huwelijken (marriages), 1826, 1834, 1850 1851, 1880 overlijden (deceased). On Dirk Johannes Alta, see Burgelijke standsregisters Harlingen, 1828 and Volkstelling Harlingen 1839. Van Sluijs, Nederlandse Koopvaardijschepen 1800-1860, 135. H.T. Obreen, 'Harlingen', Bulletin van de Koninklijke Nederlandse Oudheidkundige Bond, vol. 69 (1970), no. 2, 88 briefly referred to Alta's wharf.

219. Nederlandsche Staatscourant, 25 October 1825. See Honig, Gulden bijkorf, 40. 
Harlingen and he ordered two anchors dropped. Later that afternoon the wind gained much more strength, so much so that Ruygh found his ship in the midst of a hurricane. That night, around eight o'clock, both anchor-chains broke and the whaleship was adrift. Ruygh and his men attempted to get their ship on shore but they did not succeed. One of the whaleboats was lowered in order to search for help on the beach. A strong undercurrent lifted Willem de Eerste over the whaleboat and, out of a crew of ten, only three could be saved. A second attempt to lower a boat and reach the mainland failed as well. Meanwhile the ship had lost its rudder and the stern started to break. The crew tried to reach the stern but not all succeeded. Some managed to hold on to the main mast, although not for long, as the storm caused the main mast to snap. Three whalemen, while holding on to the floating mast, tried to reach the beach but only Jan Diedrichs Ehlers, the second carpenter on board, was able to reach the shore alive and establish contact with the locals.

Meanwhile, about half of the remaining crew had reached the stern of the ship. Moments later the stern broke off, causing the loss of many lives. The vessel next lost its fore-mast, where several whalemen had sought shelter. Around midnight, the foreward section of Willem de Eerste was completely ruined. Survivors were floating about, desperately holding onto the remains of the ship. It was not until four o'clock that night that people from shore could throw their lines and rescue the exhausted whalemen. Because of the high tide, a lifeboat, safely stored away in the dunes, could not be used.

The hurricane had cost the whaling company a very high price: of a crew of 46 , only 17 were rescued. Master Ymke Ruygh and his three sons had drowned, along with 25 others, including the first mate and the pilot. ${ }^{220}$ The directors of the company organised a fair to raise money for the survivors. The material damage - the loss of the ship - was covered by the insurance company. ${ }^{221}$ Soon after this catastrophe the directors of the Noord-en Zuid-Hollandsche Redding-Maatschappij wrote a letter to the local representative, A. Korff. The letter contained certificates and 12 golden ducats for the crew of the life-boat. ${ }^{222}$

220. Amsterdamsche Courant, 15 April 1825; Amsterdamsche Courant, 20 October 1825; Amsterdamsche Courant, 24 October 1825; De Reddingboot, no. 54 (Christmas 1942). This disaster is also mentioned by the directors of the Noord- en Zuid-Hollandsche Redding-Maatschappij in their report, written on the occasion of the $25^{\text {th }}$ anniversary of the life saving company. The report contained a listing of ships stranded and number of persons rescued between 1824 and 1849. During these years the company managed to bring 756 persons safely to the shore. In their listing, the directors mention 20 October 1825 as the date. Also, they gave a total of 16 persons rescued. See A. Fock and others, 'Verslag bij gelegenheid van het vijf-en-twintig-jarig bestaan van de Noord- en Zuid-Holandsche Redding-Maatschappij', G.A. Tindal and J. Swart (eds.), Verhandelingen en berigten betrekkelijk het Zeewezen en de Zeevaartkunde, vol. 3 (1850), 39. A fairly elaborate acount of the events during the night of 21 October can be found in H.Th. Booy, Strandrovers, jutters en redders. Voorgeschiedenis en geboorte van het reddingwezen (Den Haag 1959), 97, 101-103.

221. De Jong, Oude Nederlandse walvisvaart, II, 457.

222. Booy, Strandrovers, 97. 

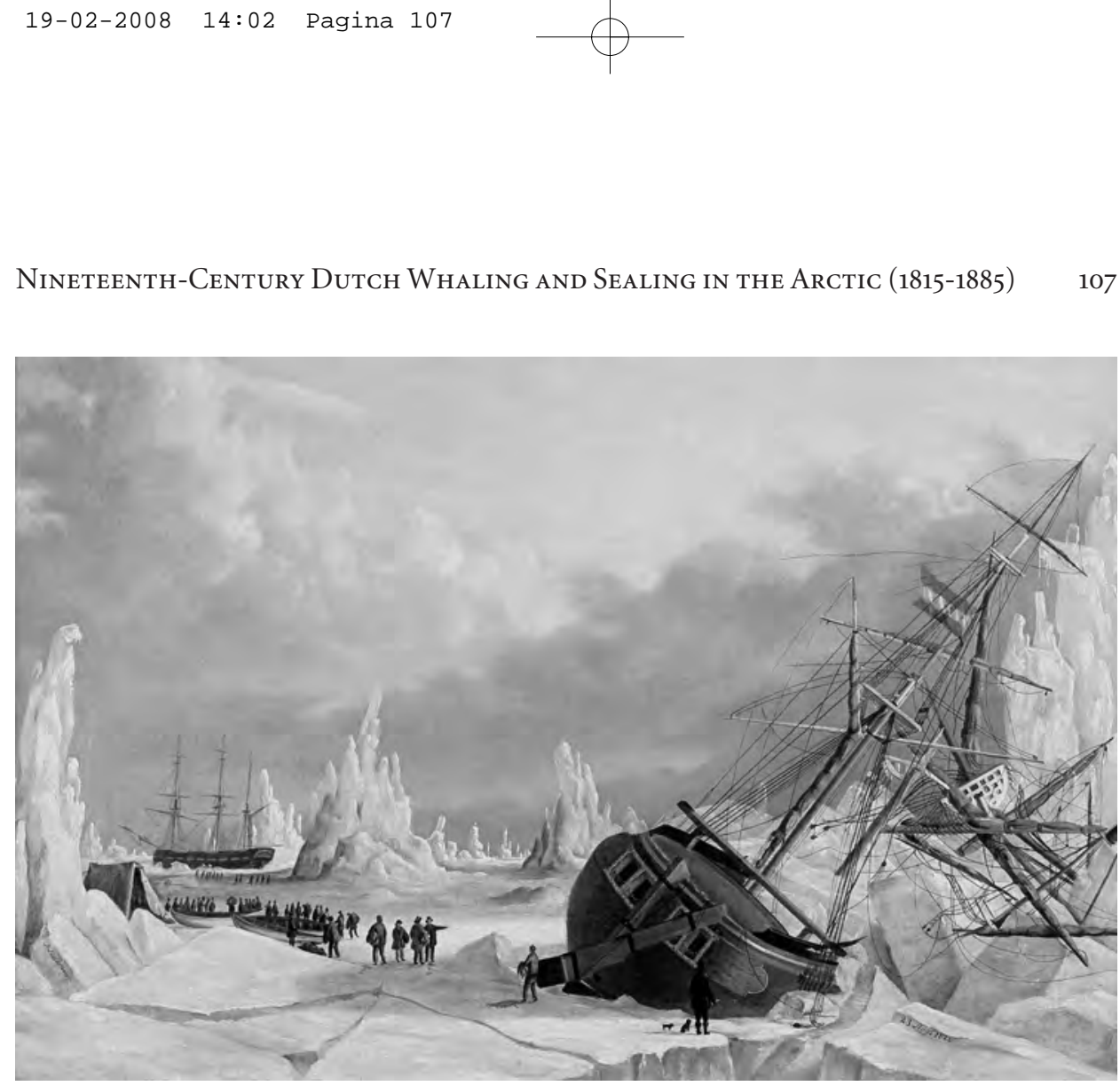

7. The whaleship Harlingen stuck in the ice of Melville Bay (Baffin Bay) in August 1826. This ship, built in 1826 on Johan Alta's shipyard in Harlingen, was lost on its maiden voyage. After abandoning his ship captain Klaas Hoekstra and his crew first found shelter on board the Dundee, master Robert Duncan. This vessel is depicted in the background. Hoekstra eventually returned home in August 1827. Painting on canvas by Herman Siderius (1819-1892), ca. 1850. Nederlands Scheepvaartmuseum Amsterdam. Inventory number 2005.1543.

Despite the loss, the Harlingen-based company fitted out no fewer than four ships in 1826. The first to return was the newly-acquired Nederland. This vessel, a three-masted, square-rigged 349-ton frigate, had been built in 1800 in the little town of Itzehoe near the mouth of the river Elbe, some 50 kilometres northwest of Hamburg. ${ }^{223}$ Nederland moored in Harlingen harbour on 3 June with 1,890 seals. Spitsbergen also had a very early and more successful return. Hendrik (originally Hinrich) Rickmers (1781-1842) had been appointed Captain of this vessel. Rickmers came from the East Frisian island of Föhr and had arrived in Harlingen only a short time prior to his first command over a Dutch whaling vessel. ${ }^{224}$ Rickmers sailed his ship into Harlingen harbour on 26 July, with a greasy cargo of 3,124 seals. The third

223. C. de Jong, 'De "Dirkje Adema", Nederlands laatste Groenlandvaarder', Jaarboek Fries Scheepvaartmuseum en Oudheidkamer, jaargang 1965, 40. The original name of the vessel was Dolphin. In 1835, its name was changed from Nederland to Dirkje Adema, the preferred spelling and used here, but also occasionally spelled Dirkje Adama. Nothing is known about the activities undertaken with this vessel between 1800 and 1826 . 224. Ibidem. 
ship was the newly-built Willem de Eerste (II). This second whaleship to bear the King's name returned "clean" from the Davis Strait to the home port on 27 October under command of Jan Cornelisz. Groendijk. In other words, no whales or seals had been caught.

In addition to Nederland, Spitsbergen and Willem de Eerste (II), the appropriately named galliot Harlingen (about 440 tons) was the fourth ship employed by the Sociëteit and Klaas Hoekstra, from the isle of Texel, was assigned as master. ${ }^{225}$ The vessel was built in Harlingen, again by shipwright Johan Alta. ${ }^{226}$ Prior to launching the vessel the City Council decided to have the whaleship decorated with a standard bearing the word "Harlingen" and a new flag depicting Neptune, god of the sea. ${ }^{227}$ They did not anticipate the disaster that Harlingen was shortly to meet, as the brand-new ship was lost in Baffin Bay on 23 August 1826. The British whaleship Dundee under command of David Duncan came to the rescue of the crew. Hoekstra's ordeals inspired many - marine artists, poets and historians alike-to serve their respective muses. ${ }^{228}$ Klaas Hoekstra, the unfortunate master, kept a journal of his voyage to the Davis Strait, the accident in Melville Bay on $74^{\circ}$ Northern Latitude, the subsequent expeditions to the mainland of Greenland, and the return passage home. It goes without saying that the loss of the brand new Harlingen must have caused severe problems for the newly-established Sociëteit. Not only did they lose a new, expensive ship, although the vessel may have been insured and financial damages compensated, but more importantly, they lost faith among shareholders as they did not receive dividends in 1825 or $1826 .{ }^{229}$

The 1827 season again brought misfortune to the company. Willem de Eerste (II) left the harbour of Harlingen on 27 March 1827 under the command of Jan Cornelisz. Groendijk. Among the crew were H.H.V.N. Schermerts and J.H. Manheim, pupils

225. Klaas Sytses Hoekstra was born in Den Helder on 25 January 1788. He married Jantje Jans Hillenius on 11 March 1809. The couple had nine children (three boys, six girls). Hoekstra died on the isle of Texel after 1831. See A.H. Stikker Velsen, Een familie van galjootpers, commandeurs op Groenland en Friese vermaners. BaskeHoekstra-Veenstra (unpublished typescript in the collection of the Nederlands Scheepvaartmuseum Amsterdam. No date [ca. 1965].

226. Within a relatively short period of time nine ships left Alta's wharf in Harlingen. Two of these ships (Arius Johannes and Vrouw Jantina) were commissioned by Barend Visser, and two (Spitsbergen and Harlingen) by the Sociëteit. The Harlingen was the biggest of all. Willem de Eerste was not mentioned. See De Nederlandse Hermes, tijdschrift voor de Koophandel, Zeevaart en Nijverheid, vol. III, no. 9 (1828), 78-79.

227. Later that year, a letter from the States of Friesland urged the City Council to take care of the payment. GAH, Stukken betreffende het stadsbestuur van Harlingen. Index op ingekomen stukken 1644 (1824-1828), no. 613: 11 October 1825 .

228. The location of at least two contemporary oil paintings that depict the Harlingen stuck in the ice are known. One is in the collection of the Municipal Museum Het Hannemahuis in Harlingen and one is in the collection of the Nederlands Scheepvaartmuseum in Amsterdam. The collection of the Hannemahuis in Harlingen contains a handwritten booklet with poetry and prose about the construction, the voyage, and the disaster of Harlingen by A. Hoekstra. Hannemahuis, documents collection E1H69a.

229. De Jong, Oude Nederlandse walvisvaart, II, 458. 
8. Portrait of whaling Captain Klaas Hoekstra, ca. 1810. Painting on panel by an anonymous artist. Private Collection.

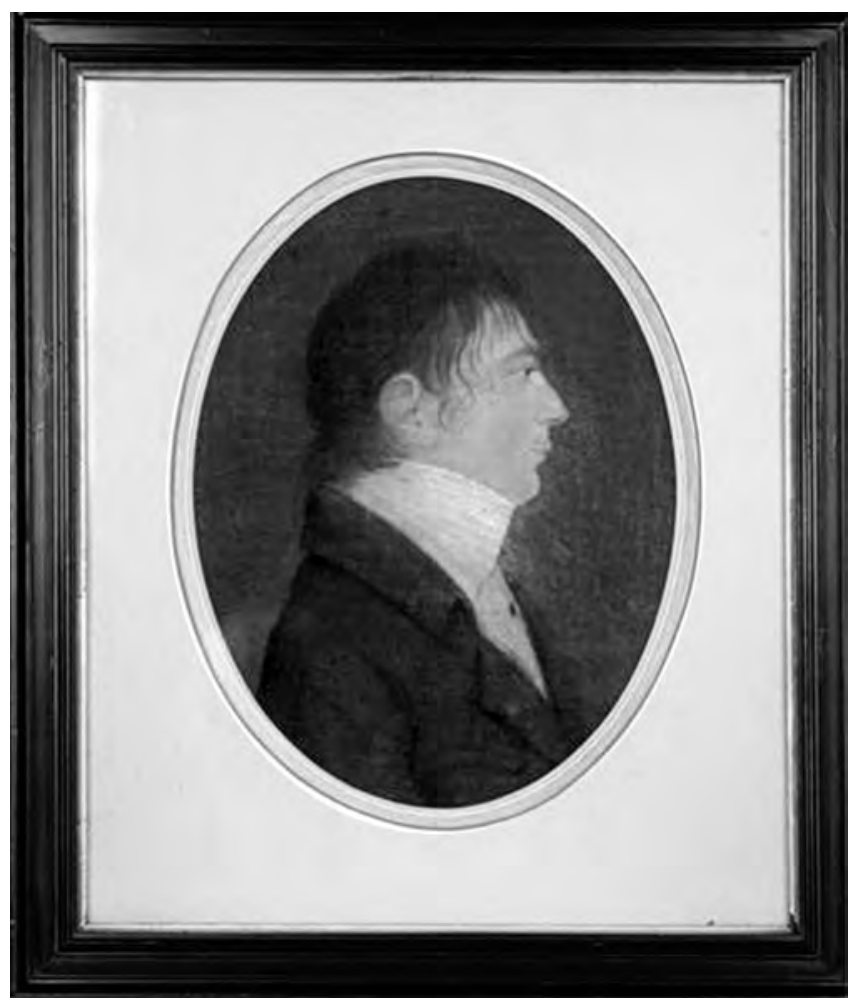

from the Nautical College in Amsterdam. ${ }^{230}$ Exactly two months later, while on the Greenland whaling grounds, the vessel was damaged and had to be abandoned. Douwe Jansz. Cupido, whaling captain from Rotterdam, came to the rescue of the crew and took them all on board his ship Maasstroom. Later, some crew were transferred to whaleships sailing under the flags of Bremen and Hamburg. J.J. Adriaan, Captain of Nederland, brought Groendijk and 14 men back to their home port. Adriaan, sailing his second of four seasons (in total) for the Sociëteit of Harlingen, had caught five whales and returned with 160 barrels of blubber. ${ }^{231}$ Like Groendijk, he also carried two pupils from the Amsterdam-based Nautical College, J.W. van Schaik and Teunis

230. SAA, inv. nr. 949 (archief Kweekschool voor de Zeevaart), nr. 27 (1827), fos. 230-231 (Directors' meeting on 14 February), and fo. 235 (idem, 7 March). This specific archive provides data concerning the employment of its pupils on board whaleships fitted out in Rotterdam (1825-1827) as well as in Harlingen (18271830). The developments regarding the Rotterdam Maatschappij voor Walvischvangst will be discussed in the next subchapter. As for the Sociëteit, further discussion of the recruitment of pupils from Amsterdam will be given in Chapter 5 .

231. SAA, inv. nr. 949 (archief Kweekschool voor de Zeevaart), nr. 27 (1827), fo. 308 (Directors' meeting on 8 August); Leeuwarder Courant, 7 August 1827. 


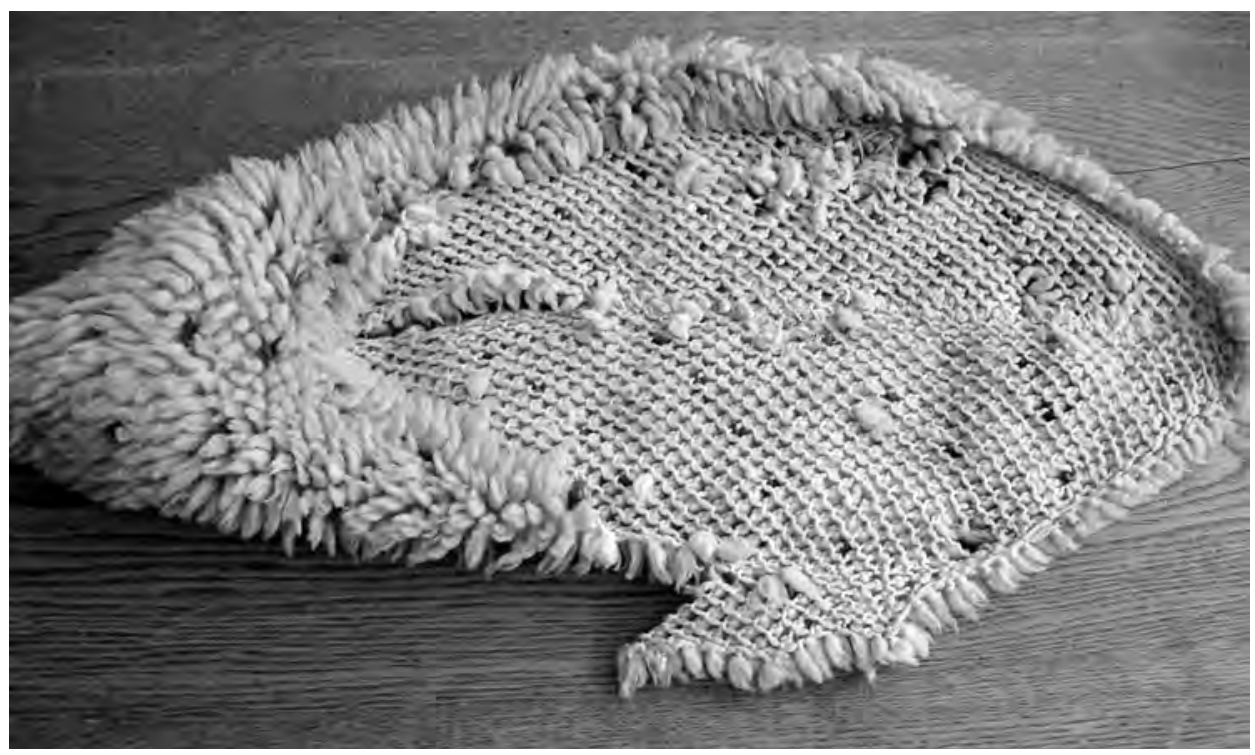

9. Woollen hat of Captain Klaas Hoekstra, ca. 1826. After abandoning his ship Harlingen, Hoekstra and his crew were forced to travel through parts of Greenland. The captain wore this hat while traversing this barren country. Hannemahuis Harlingen. Inventory number oo0267.

Hagen. On 24 September 1827 , an insurance company covered $98 \%$ of the damage inflicted on vessel and company. ${ }^{232}$

Later that year, on 31 October, Spitsbergen was sold at auction. During this public sale at the home of Hendrik Winter, proprietor of the Heeren Logement in Harlingen, several parties showed keen interest in this vessel. After two bids, one of $f 626$ from local merchant Simon Jansz. Schere and another of $f 676$ from local master shipwright Simon van der Meij, Spitsbergen was eventually purchased by merchant Tjerk Pieters Metzelaar for $f 745 .{ }^{233}$ The Directors of the Sociëteit commissioned the construction of another Spitsbergen. ${ }^{234}$

In 1828 Nederland was the only vessel sailing for the company, but brought home more than 3,000 seals, a remarkably good catch. ${ }^{235}$ That same year the brig Spitsber-

232. Van Sluijs, koopvaardijschepen, 136; Archives Vereeniging Nederlandsch Historisch Scheepvaart Museum (VNHSM), correspondence, letter from ds. W.A. Poort, agendanumber 16340. I am grateful to my colleague Elzelien Streef at the Nederlands Scheepvaartmuseum for her assistance in retrieving information from this archive.

233. Though not specifically identified as Spitsbergen, the notary records mention the sale of a brig belonging to the Sociëteit, to be sold by request of Dirk Cornelis Zijlstra. Tresoar Leeuwarden (TL), Notary records Harlingen. Notary Hanekuyk, Repertoires \#51015, 102: 31 October 1827.

234. De Jong, Oude Nederlandse walvisvaart, II, 458.

235. De Jong, Ibidem. 
gen (II) left Alta's wharf in Harlingen. ${ }^{236}$ The vessel measured 251 tons (150 last) and, according to the certificate of registry, its dimensions were $26.18 \times 8.26 \times 4.1 \mathrm{el}$ (about $18.5 \times 5.6$ x 2.8 metres). ${ }^{237}$

In 1829, both Nederland under command of Klaas Hoekstra and the newly-built Spitsbergen (II) sailed for Spitsbergen. Catches were disappointing, as the first vessel returned empty. ${ }^{238}$ Klaas Hoekstra was again assigned master of Nederland in 1830 and remained in command until the discontinuation of the Sociëteit (1834). Spitsbergen (II) made its voyage to the Arctic under the command of Captain Hendrik Rickmers, who maintained command over vessel and crew until 1841. This German whaling master from the island of Föhr kept journals of all of the voyages he made between 1830 and 1840 . These primary sources provide important information on catches and hunting grounds. As such, the data concerning crew, results and, thus, profitability, will also be used in later discussion ( see Chapters 5 and 7 ). Moreover, they give insight into the course whaling masters took from Harlingen to the Arctic Ocean. ${ }^{239}$

Rickmers' 1830 journal has 8 April as the first entry. Following their course off the Norwegian coast, he and his crew passed the island of Jan Mayen ('Jan Mijn') on 2 May. In between the two dates, Rickmers had been fairly successful in harvesting several hundred seals. In all his journals, he differentiates between white seals, grey seals, and blue seals, but unfortunately he does not specify to such an extent that the various species can be discerned. ${ }^{240}$ After Jan Mayen, Spitsbergen (II) set its course to the archipelago for which the vessel was named, again taking several hundred seals on their way. On 12 May, Rickmers wrote in his journal that he had the ship and crew prepared for whaling. They sighted the Voorland of Spitsbergen around $77^{\circ} 36^{\prime}$ N.L. on the next day, 13 May. In the ensuing weeks, Rickmers and his crew proceeded into higher latitudes, eventually reaching Kwade Hoek off Amsterdam Island ( $79^{\circ} 58^{\prime}$ N.L.) on 23 May. After one attempt to harpoon and kill a whale on 26 May, Rickmers reset his

236. De Jong, Ibidem, gives 1828 as the year of construction. All other sources refer to 1829.

237. One el equals o.688 centimetres. This is not commensurate with the dimensions given at the time Spitsbergen was offered for sale by auction in 1834. In that year its dimensions were 26 el 18 duim, 5 el 26 duim, 4 el 10 duim respectively. See Leeuwarder Courant, 12 December 1834.

238. De Jong, Oude Nederlandse walvisvaart, II, 459.

239. Rickmers wrote journals of all eleven voyages. These journals, written in Dutch, are bundled together as a package containing some 300 pages in total. Their present day repository is the Dr. Carl-HäberlinFriesenmuseum in Wyk auf Föhr, Northern Germany. Friesenmuseum, Archiv A3M 431. Furthermore, the museum collection contains three journals covering the 1846-1848 whaling expeditions of Spitsbergen. Friesenmuseum, Archiv A3M 432.

240. There are two main divisions in the Pinnipeds: the Otariidae and the Phocidae. In the Arctic, the first family is represented by the walrus. Ringed seals (Phoca hispida), bearded seals (Erignathus barbatus), harp seals (Phoca groenlandica) and hooded seals (Cystophora cristata), all belong to the second category. Most, if not all seals mentioned in the journals are greyish-white in colour, while the pup of the hooded seal is known as a 'blueback'. Tony Soper, The Arctic. A guide to coastal wildlife (Bucks; second edition 2005), 104-115. 
priorities and hunted seals instead. They shot bears, seals, and so-called 'klapmutsen' (hooded seals, or bladdernose seals; Cystophora cristata). They frequently sighted narwhals (in the sources reffered to as 'eenhoorns' - unicorns) as well. Returning to the coast of Spitsbergen on approximately $78^{\circ} 35^{\prime}$ N.L. on 22 July, Rickmers decided to set sail for the home country. With his description of the order of matters - first reaching the waters off Jan Mayen, then hunting seals for about one month prior to preparing for the whale hunt that took place further north, and then, around 20 July, starting the homeward passage - Rickmers set a pattern for the remaining ten expeditions under his command. ${ }^{241}$

The vessel returned to Harlingen on 12 August 1830 and four days later Rickmers and twelve of his men started to unload the vessel. The blubber was transported to Harlingen and tried out at the cookery De Herstelder. The oil was eventually stored with Tjeerd Jacobs Vellinga, Rijks Roeier (literally, State rower). ${ }^{242}$

Two documents in the municipal archive in Harlingen relate to the arrivals and catch results of these two ships deployed by the Sociëteit in 1830 . They also provide information about the trying-out of the blubber. ${ }^{243}$ The first of the two documents referred to Captain Hendrick Rickmers and his ship Spitsbergen (II). The statement by Rickmers and flenser Johan Kroese (in the absence of the first mate) is dated 4 Sep-

241. The route to and from the hunting grounds will be discussed more elaborately in Chapter 5 .

242. Customarily, at a cookery the roeier (rower) was responsible for measuring the oil that had been tried out. Around 1816, according to C. de Jong (Oude Nederlandse walvisvaart, vol. II, 451), the Zaanstreek did lack the presence of such an official. G.J. Honig in his Gulden bijkorf, referred to a dr. Van Marle who on 7 July 1768 had himself appointed traanroeier (oil rower) in Oostzaan for the period of three years (p. 220). The inventory of his belongings, made up after his death in October 1796 and sold publicly on 21 March 1797, mentions “... 1 roeystok (voor het traanroeien)..."; see Honig, idem, 224-225. At present, the catalogue is in the library of the Zaans Museum in Zaandam. Obviously, cookery De Herstelder in Harlingen did provide one traanroeier, personified by Tjeerd Vellinga, who was born in 1792 in Minnertsga. Vellinga died in Harlingen on 27 February 1837. He married twice and was a merchant in the timber trade (houtkoper). His work at the cookery was probably done “on the side." GAH, Burgerlijke standsregisters Harlingen, 1814/1819/182o huwelijk (marriages), 1837 overlijden (deceased). For additional information on the tasks and responsibilities of the traanroeier, see S. Lootsma, 'Over een paar belangrijke ambten in vroeger tijd (Makelaar en Traanroeier)', Zaanlandsch Jaarboek 1934, 163.

243. Gemeentearchief Harlingen (Municipal Archives Harlingen). Stukken betreffende het stadsbestuur van Harlingen, 1816-1924. Archiefstuk betreffende de Groenland- en Straat-Davids-visserij 1830 (1 omslag), nr. 3399. Despite his thorough research, De Jong obviously was not aware of the existence of this highly interesting archival source. In his Oude Nederlandse walvisvaart, vol. II, 459 De Jonge stated: "In 1829 en 1830 voeren de 'Nederland' en de nieuwe 'Spitsbergen' uit. Zij hadden een slechte vangst. Het eerste schip kwam schoon terug, vermoedelijk uit Straat Davis, waar de robbevangst niet werd uitgeoefend. In 1831, ' 32 en ' 33 zond de directie haar beide schepen naar "Groenland" (dit is de zee beoosten dat eiland) op de robbe- en walvisvangst" (In 1829 and 1830 Nederland and the newly-built Spitsbergen sailed out. They had bad catches. The first vessel returned empty, presumably from the Davis Strait, where no seal hunting was executed [author's italics]. In 1831, ' 32 and ' 33 the board of directors sent both of her ships to "Greenland" (id est the sea east of that island) for seal hunting and whaling). As is shown, revenues from seal hunting were not to be neglected. 
tember 1830. The document also bears the signature of K. Blik, burgomaster of Harlingen, who had the document compiled on 9 September. With his signature, Blik ratified master Rickmers's statement. ${ }^{244}$

According to the document, Spitsbergen (II) was involved in whaling and sealing until 23 July, working on $72^{\circ}$ N.L. The document also contains a statement by Johannes Eeuwes van der Heide, working overseer (meesterknecht) at the cookery, ${ }^{245}$ in which document he confirmed that under his supervision seal blubber had been tried out, yielding 62 kwartelen of oil. ${ }^{246}$ As per KB of 1816, $f_{50}$ was paid for each kwarteel short of 100 , thus resulting in a total of $f 1,900\left(100-62=38 \times f_{50}\right)$ for the oil. Also, the owners received $f$, 000 as the second half of the premiums issued by King Willem I and his government. Therefore, the results of Rickmers' voyage were summed up as follows:

$$
\begin{array}{ll}
\text { Premium for wanvangst amounted to } 38 \text { kwartelen at } f_{50} / \text { each } & f_{1,900} \\
\text { Second half of premium for outfitting } & f_{2,000} \\
\text { Total revenues } & f_{3,900}
\end{array}
$$

From the documents at hand, the revenues of yet another combined whaling and sealing expedition organised under the aegis of the Sociëteit can be discerned in a similar fashion.

The second document concerns Klaas Hoekstra, formerly Captain of the ill-fated Harlingen, and his ship Nederland, having arrived from the Davis Strait. Again the burgomaster of the city of Harlingen compiled and signed a financial overview. In the document, dated 7 December 1830, Hoekstra and his first mate, Jacob O. Boon, stated that their ship had passed $65^{\circ}$ N.L. “... until and after...” 10 July 1830 , while cruising the Davis Strait. All the blubber from whales and seals had been delivered at the cookery in Harlingen, with all yields of the trying-out having gone to the above-mentioned 'State rower' Tjeerd Jacobs Vellinga. Hoekstra performed very poorly compared with his colleague Rickmers, as he returned to the home port with blubber yielding no more than 6 kwartelen of oil; hence the high payment for wanvangst $\left(f_{4,700}\right)$. The results were as follows:

244. Here, we must bear in mind that the town of Harlingen, as one of the company's major shareholders, was financially involved.

245. Johannes Eeuwes van der Heijde was born in Grootegast on 5 November 1769. In GAH, book \#204,Van der Heide is mentioned as pakhuisknegt (warehouse assistant) located on lot \#E-20o, owned by C. Mollema, father of Jarig Cornelis Mollema, one of the founding fathers of the Sociëteit. See also Doopregister Grootegast 1769; Volkstelling Harlingen 1839, Wijk (district) F-144.

246. Figures of catches are given in the ship's journal. Rickmers wrote of about 1,411 seals and 734 steekannen blubber rendering $62^{1 / 2}$ kwartelen and 738 steekannen oil, respectively. As in all cases, where measurements are involved, we follow J.M. Verhoeff, De oude Nederlandse maten en gewichten. Publikaties van het P.J. Meertens-Instituut. Deel 3 (Amsterdam 1983), 5, 110, 128. Verhoeff equals one kwarteel (or kardeel) to one barrel to 12 steekannen à 19.4 litres which equals 232.8 litres. 
94 kwartelen at $f_{50} / \mathrm{kwarteel}$

$f 4,700$

Second half of premium for outfitting

$f 2,000$

Total revenues

$f 6,700$

Notwithstanding the modest results of his voyage, Klaas Hoekstra received orders from the company to sail the following year.

Hendrik Rickmers was assigned to sail out as master of Spitsbergen (II) for the 1831 season as well and left Harlingen harbour on 20 March, with 46 men as crew. On 13 July, it was decided to return home. In the last entry of the journal (16 August) of this fairly successful expedition, Rickmers summed up the catches of seals. These amounted to 4,421 units yielding 2,244 steekannen - or 187 kwartelen - of oil. Klaas Hoekstra with his Nederland had harvested about 1,0oo seals, and three whales. Combined, these two ships returned home with the blubber and baleen of three whales, while their holds were filled with 5,349 seals. Expectations about these results were high, as whale and seal oil fetched very good prices and late in 1831 the directors of the Sociëteit invited interested parties to be present at the public sale of the catch. On 6 October, the following commodities were sold in presence of the two local notaries Hanekuyk and Wijma: around 500 barrels of seal and whale oil, approximately 5,000 pieces of salted and dried seal furs, and about 2,500 Dutch pounds of baleen. Moreover, fur of polar bears, 'vinken' (or so-called horse pieces that were smaller pieces of whale blubber), whale tails, old barrels, and rope work were included in this sale. ${ }^{247}$

A later edition of the Leeuwarder Courant provides more information about the results of the 1831 season. The provincial Governor, in his annual report to the representatives of the province of Friesland (Provinciale Staten van Friesland), among other matters, also referred to the state of affairs with regard to the Sociëteit in Harlingen. ${ }^{248}$

Again, one year later, in his annual report to the Provinciale Staten, the Governor of Friesland provided data concerning their catches. In 1832, the total number of ships calling at Harlingen had increased from 240 to 262 . Two of these were whaleships under the Dutch flag. Spitsbergen (II) returned on 27 July and brought home one whale

247. The announcement of this sale was placed in Leeuwarder Courant, 6 September 1831. According to the announcement, one could receive more information about the commodities for sale at the office of the whaling company, as it stated "Nadere information, Notitien en Monsters te bekomen ten Kantore der Directie te Harlingen" (more specific information, notices and stalemates will be received at the office of the company in Harlingen). The figures given are not exactly commensurate with the quantities sold off at auction. A complete overview of this auction and four others, organised in succeeding years, with quantities, the names of the buyers, and amounts paid, is presented in Appendix 7.

248. In the Leeuwarder Courant, the Governor optimistically remarked that “... de Sociëteit is eindelijk eene gelukkiger uitkomst dan in vorige jaren te beurt mogen vallen ..." (finally, the Sociëteit should receive more satisfying results than in the past years). Verslag van de gouverneur van Friesland in de vergadering van Provinciale Staten d.d. 3 July 1832. Printed in Leeuwarder Courant, 17 July 1832 . It should be noted that the total number of ships calling at Harlingen had decreased by 17 in comparison with 1830 . 
and 3,400 seals, whereas the other whaleship, Nederland, contained one small whale and only 120 seals. The Governor provided data other than what was reported by the public media. Shortly after the return of both vessels, the Leeuwarder Courant stated that Spitsbergen (II) brought home 3,354 seals whereas Nederland, under command of Klaas Hoekstra, carried 166 seals. ${ }^{249}$ Last but not least, Rickmers himself stated the catches in the entry of 30 July in his 1832 journal. Here he related to the catch of 3,500 seals and two whales, in total representing 227 kwartelen of oil. Be this as it may, the Governor rightly remarked that this catch was a far cry from satisfactory. According to the Governor, the accounting books could only be closed with a minor deficit due to the premiums issued by the government. ${ }^{250}$

The 1832 expedition was also quite eventful. Problems arose from the very first day, when on 14 March Spitsbergen (II) became stuck in the mouth of Harlingen harbour. During the ensuing month, heavy storms rocked the vessel. Parts of the upper construction of the ship were smashed away by high waves. On 9 April, while on his way to the Arctic, Rickmers lost one boat with all its gear. On 15 April, a hurricane came suddenly from the northeast and Spitsbergen (II) almost lost its sails. Meanwhile, three of the crew were forced to stay on the ice for quite some time as Rickmers had to do his utmost to regain control over the ship. That same day, Jan Schöder died and the next day he was buried at sea. ${ }^{251}$ Between 28 May and 1 June, Spitsbergen (II) became stuck in the ice around $78^{\circ} 50^{\prime}$ N.L., together with three or four other ships. To counter-balance all these ordeals, harpooner Hinrich Schieland managed to harpoon a whale on 17 June, on $79^{\circ} 44^{\prime}$ N.L and Rickmers proudly illustrated his journal with a whale's fluke.

In 1833, both Spitsbergen (II) and Nederland returned from the whaling and sealing grounds with disappointing catches. Spitsbergen (II) had the blubber of three whales on board and Rickmers' crew had taken 150 seals. ${ }^{252}$ The cargo of Nederland consisted of blubber of only one small whale and 256 seals. This total catch yielded about 150 kwartelen of oil, about 130 of which were yielded from blubber gathered by Rickmers' crew. ${ }^{253}$ But revenues were disastrous because when auctioned, on 3 October 1833 , prices were about one-third lower than in the previous year. ${ }^{254}$

249. Leeuwarder Courant, 3 August 1832.

250. Verslag van de gouverneur van Friesland in de vergadering van Provinciale Staten d.d. 2 July 1833. Printed in Leeuwarder Courant, 16 July 1833.

251. During the preceding two centuries it was customary to bury whalers on Spitbergen. In the nineteenth century no instances of land burials have been found.

252. These whales were caught by flenser [sic] Mathijs Suft (or Sinft) on 30 May, by the anonymous first mate on June 3 , and again by this first mate on 16 June.

253. H. Rickmers, Ship's journal 1833, 13 August. Friesenmuseum, Wyk auf Föhr.

254. Leeuwarder Courant, 13 September 1833. In 1831 the average price level of whale oil per kwarteel was $f 120$. One year later, this level had dropped to $f 91$ per kwarteel. For the development of prices see: N.W. Posthumus, Nederlandsche prijsgeschiedenis. Deel I: goederenprijzen op de beurs van Amsterdam, 1585-1914. Wissel- 
In his article on Frisian involvement in Arctic whaling, S. Haagsma sought an explanation for these poor results. Due to the English embargo on Dutch ships and shipping, both ships had left the harbour of Harlingen no less than one month later than usual. He probably based this assumption on statements made by the Governor of the province of Friesland in his annual report to the Provinciale Staten. Here, the Governor pointed out the fact that both ships, Spitsbergen (II) and Nederland, left Harlingen one month later than customary. Rickmers provided additional information about the impact of the English embargo. Spitsbergen (II) departed from the hunting grounds on 13 July, but instead of heading for Harlingen, Rickmers set a course for Norway. On 25 July a pilot came on board the whaleship to direct Spitsbergen (II) to Christiansand. The next day, Rickmers met with Sören Knodsen, consul for the Netherlands, in Norway. Knodsen told Rickmers that he could "vrij varen", in other words, that it would be safe to continue his journey home.

Year after year no dividend was paid to the shareholders and the first signs of discontentment appeared in 1830-1831. Two years later, on 5 April 1833, during the general meeting at the Inn 'Roma', owned by H. Heep and located at the Both Apothekerstraat, the Board of Directors took the initiative by asking the shareholders whether or not they should fit out ships for Greenland. ${ }^{255}$ The answer must have been in the affirmative as both Spitsbergen (II) and Nederland did go whaling and sealing that year as discussed earlier. ${ }^{256}$ Only 18 months later, it was decided at the shareholders meeting of 21 October 1834 to discontinue the company, which was in line with Article 43 of the articles of association.

In 1834, catches had again been disappointing. Having left Harlingen on 12 March, Spitsbergen (II) reached the ice on 2 April. Rickmers and his crew waited for over two weeks before they killed two seals. On 16 June, flenser Mathijs Suft, who had been successful in the preceding year, hit a whale, but lost the animal. ${ }^{257} \mathrm{~A}$ second attempt later that night was more successful. On 20 June, Suft again harpooned a whale but due to the heavy ice flows the crew could not pursue it. Later, Spitsbergen (II) became stuck

koersen te Amsterdam, 1609-1914. Internationale wetenschappelijke commissie voor prijsgeschiedenis (Leiden 1943), 151. Next to about 160 oxheads of whale oil, some 2,000 pounds of baleen, over 400 seal furs, several bear furs, and other parts of the animals harvested were sold; S. Haagsma, 'Frieslands Groenlandvaart', Jaarboek Fries Scheepvaartmuseum en Oudheidkamer (1964/1965), 51. See also the annual report of the Governor d.d. 1 July 1834, printed in Leeuwarder Courant, 1 July 1834.

255. During the seventeenth, eighteenth, and nineteenth centuries an association intended for the financial support of seamen operated in Harlingen under the name of Roma. The municipal archives of this city cover the period 1634 to 1815 . It is probable that this association and the building (erected before 1640) are historically linked. See H.T. Obreen, 'Harlingen', Bulletin van de Koninklijke Nederlandse Oudheidkundige Bond, vol. 69, no. 2 (1970), 88.

256. Haagsma, 'Frieslands Groenlandvaart', 51.

257. The name of this flenser may also read Sinft. His rank of flenser is specifically stated as such in the journal. 
in the ice on 30 June, close to Magdalena Bay, and was forced to stay there for 26 days. On 23 July, Rickmers set sail for Harlingen but unfortunately the last few pages of the 1834 journal have been torn out. Thus, no final calculation of the harvest could be retrieved. Based on remarks in the journal, the total catch of seals may be estimated at about 105 units. ${ }^{258}$

By that time, the real value of shares had been reduced dramatically. The original estimate of $20 \%$ was too optimistic: in nine years' time, the value had been reduced to $14 \%$ of the initial nominal value of $f_{500}$. Instead of the anticipated $f_{100}$ only $f_{70,25}$ per share was reimbursed. ${ }^{259}$ Further, they had to wait until after 16 December and announce themselves at the desk of D. Fontein Pieterszoon, bookkeeper of the company, to receive payments.

The belongings and property of the Sociëteit were auctioned off and the public sale was announced in the Leeuwarder Courant on 30 December 1834. In addition to Spitsbergen (II) and Nederland, the company owned two idle ships moored in the Zuiderhaven in Harlingen that were also offered for sale with their rigging, anchors, casks, sails and other equipment. The advertisement indicated that strijkgeld (a premium to be paid by the highest bidder) would be levied on both ships: $f$ 10o on the pink Nederland, and $f_{150}$ on the more recently built (1829) brig Spitsbergen (II). The Sociëteit also owned a warehouse with several attics and one very large basement, a large shed located on the Zuidzijde, and 15 roeden of land (the equivalent of 1500 square metres) adjacent to the Westerkerk. ${ }^{260}$

Notary records regarding this auction have been preserved. ${ }^{261}$ These show, for one thing, that buildings and property had all been purchased from Jan Sikkes IJzenbeek, one of the company's directors, on 9 September 1825. That day, IJzenbeek solemnly declared in the presence of notary Hanekuyk that he had sold the premises, which had been under his ownership since 9 July 1816, to Pieter Rodenhuis, Dirk Cornelis Zijlstra, Ype Rodenhuis, Jan Sikkes IJzenbeek (sic!) and Jarig Cornelis Mollema, all directors of the whaling company. During this transaction, IJzenbeek received a payment 'uit de hand' (in cash) of $f_{2}, 500$. Notary Hanekuyk charged $f_{126}$ (about $1 / 2 \%$ ) for his services. ${ }^{262}$ The actual sale of the 'excellent ('uitmuntend') warehouse and barn took place in the late morning of 27 January 1835. The two local notaries Hanekuyk and Wijma presided at the session. After having informed the gathered crowd about the

258. H. Rickmers, Ship's journal 1834, Friesenmuseum, Wyk auf Föhr. See entries concerning 18 April (2 seals), and 11 July ( 82 , respectively 23 seals).

259. Haagsma, ibidem. See also C. de Jong, Oude Nederlandse walvisvaart, vol. II, 459.

260. Since 1820, one roede equals 100 square metres. See Verhoeff, Maten en gewichten, 121

261. Tresoar Leeuwarden (TL), Notary records Harlingen. Notary Wijma, Repertoires \#49028, 25: 27 January 1835. The exact cadastral registration of the company's property is: district H, no. 218.

262. TL, Notary records Harlingen. Notary Hanekuyk, Repertoires \#51014, 106: 9 September 1825. 
condition of the property, plates describing the premises went around. After an initial high bid of $f 1,520$ from the Amsterdam merchant Jan Goedkoop, the property eventually went to the Harlingen-based merchant Jean Louis Ledeboer. His final bid of $f 1,970$ was accepted by Dirk Cornelis Zijlstra, acting on behalf of the other directors of the Sociëteit. The directors obviously noted their loss of $f_{530}$ (being the difference between $f 2,500$ paid and $f 1,970$ received). The total notary costs amounted $f 116,47^{1 / 2}$. A little later, all whaling gear and other inventory from the warehouse and adjacent buildings were auctioned off. ${ }^{263}$

As a result of the discontinuation of the Sociëteit in 1834, the two ships still in service, Spitsbergen (II) and Nederland, were auctioned off in Amsterdam. The Harlingenbased firm of Barend Visser \& Son, knowledgeable and well experienced in whaling expeditions, acquired them both.

Table 4.4: Whaling and sealing expeditions to Spitsbergen and the Davis Strait, fitted out by the Groenlandse en Straatdavidse Visscherij Sociëteit in Harlingen (1825-1834).

\begin{tabular}{|c|c|c|c|c|c|c|c|}
\hline Year & Master & Ship's name & Type & Destination & Results/remarks & FM & Sources \\
\hline \multirow[t]{2}{*}{1825} & $\begin{array}{l}\text { Groendijk, } \\
\text { Jan Cornelisz. }\end{array}$ & Spitsbergen & Brig & & $\begin{array}{l}\text { Unknown quantity } \\
\text { of blubber yielding } \\
58 \text { kwartelen of oil }\end{array}$ & & $\begin{array}{l}\text { GAH 1375, nr. 14, } 14 \\
\text { December; GAH } \\
1376, \text { nr. } 13,14 \text { Febru- } \\
\text { ary, } 1826 \text { (premium } \\
\text { for wanvangst refers } \\
\text { to preceding year?) }\end{array}$ \\
\hline & $\begin{array}{l}\text { Ruygh, } \\
\text { Ymke Jansz. } \dagger\end{array}$ & $\begin{array}{l}\text { Willem de } \\
\text { Eerste } \\
\text { (built in 1822/ } \\
23 \text { by Johan } \\
\text { Alta, Harlin- } \\
\text { gen) }\end{array}$ & $\begin{array}{l}\text { Pink } \\
\text { (two- } \\
\text { decks) }\end{array}$ & & $\begin{array}{l}20 \text { Oct. } 1825 \text { : lost off } \\
\text { Texel. } 30 \text { persons } \\
\text { drowned ( } 29 \text { crew }+ \\
\text { pilot); } 3 \text { barrels of } \\
\text { blubber on board. }\end{array}$ & & $\begin{array}{l}\text { GAH } 1376, \text { nrs. } 5(21 \\
\text { February) and } 27 \\
\text { (10 February ) men- } \\
\text { tions } f 4,850(=97 \\
\text { kwartelen) as pre- } \\
\text { mium for wan- } \\
\text { vangst; Leeuwarder } \\
\text { Courant, } 25 \text { and } 28 \\
\text { October } 1825\end{array}$ \\
\hline \multirow[t]{4}{*}{1826} & Hoekstra, Klaas & Harlingen & Galliot & Davis Strait & $\begin{array}{l}\text { Lost in Davis Strait, } \\
23 \text { August } 1826\end{array}$ & & \begin{tabular}{|l} 
Leeuwarder \\
Courant, 22 June \\
1827 contains refer- \\
ence to disaster.
\end{tabular} \\
\hline & $\begin{array}{l}\text { Groendijk, } \\
\text { Jan Cornelisz. }\end{array}$ & $\begin{array}{l}\text { Willem de } \\
\text { Eerste (II) }\end{array}$ & $\begin{array}{l}\text { Frigate ca. } \\
484 \text { tons } \\
(242 \text { lasts) }\end{array}$ & Davis Strait & $\begin{array}{l}\text { Returned empty; } \\
\text { cargo yielded } 43 \\
\text { kwartelen when } \\
\text { tried out }\end{array}$ & & $\begin{array}{l}\text { GAH 1376, nr. } 11 \text { (31 } \\
\text { January } 1827) ; \\
\text { Leeuwarder } \\
\text { Courant, } 31 \text { January } \\
1826 \text { refers to Wil- } \\
\text { lem de Eerste (I) be- } \\
\text { ing replaced by a } \\
\text { frigate of } 242 \text { lasts. }\end{array}$ \\
\hline & $\begin{array}{l}\text { Rickmers, } \\
\text { Hendrik } \\
\text { Dep. } \\
\text { Ret. July } 26 \\
\end{array}$ & Spitsbergen & Brig & & $\begin{array}{l}\text { Returned with } 3,124 \\
\text { seals }\end{array}$ & & $\begin{array}{l}\text { Leeuwarder } \\
\text { Courant, } 4 \text { August } \\
1826\end{array}$ \\
\hline & Adriaan, J.J. & $\begin{array}{l}\text { Nederland } \\
\text { (built 1800) }\end{array}$ & $\begin{array}{l}\text { Pink } \\
363 \text { tons }\end{array}$ & & & & \\
\hline
\end{tabular}

263. Haagsma,'Frieslands Groenlandvaart', 51, gives 18 March 1835 as date on which the last whaling gear was sold by auction. 
Nineteenth-Century Dutch Whaling and Sealing in the Arctic (1815-1885)

\begin{tabular}{|c|c|c|c|c|c|c|c|}
\hline Year & Master & Ship's name & Type & Destination & Results/remarks & FM & Sources \\
\hline \multirow[t]{2}{*}{1827} & $\begin{array}{l}\text { Adriaan, J.J. } \\
\text { Dep. } \\
\text { Ret. } 28 \text { July } 1827 \text { at } \\
\text { Texel. } 3 \text { August in } \\
\text { Harlingen }\end{array}$ & Nederland & $\begin{array}{l}\text { Pink } \\
363 \text { tons }\end{array}$ & & $\begin{array}{l}5 \text { whales; } 160 \text { barrels } \\
\text { of fat/blubber }\end{array}$ & & $\begin{array}{l}\text { SAA, inv. nr. } 949 \\
\text { (archief Kweek- } \\
\text { school voor de Zee- } \\
\text { vaart), nr. } 27 \text { (1827), } \\
\text { fo. } 308 \text { (Directors' } \\
\text { meeting on } 8 \text { Au- } \\
\text { gust); Leeuwarder } \\
\text { Courant, } 7 \text { August } \\
1827\end{array}$ \\
\hline & $\begin{array}{l}\text { Groendijk, Jan } \\
\text { Cornelisz. } \\
\text { Dep. from 't Vlie } \\
\text { on } 27 \text { March. }\end{array}$ & $\begin{array}{l}\text { Willem de } \\
\text { Eerste (II) }\end{array}$ & $?$ & Davis Strait & $\begin{array}{l}\text { Lost by accident } 27 \\
\text { May near Spitsber- } \\
\text { gen. Crew first trans- } \\
\text { ferred to D.J. Cupi- } \\
\text { do's Maasstroom. } \\
\text { Later Groendijk + } 14 \\
\text { hands were trans- } \\
\text { ported to Texel, } \\
\text { Netherlands by J.J. } \\
\text { Adriaan, Captain of } \\
\text { Nederland }\end{array}$ & & $\begin{array}{l}\text { Mentioned by } \\
\text { Hoekstra, Dagver- } \\
\text { haal, } 5\end{array}$ \\
\hline 1828 & $\begin{array}{l}\text { Adriaan, J.J. } \\
\text { Dep.? } \\
\text { Ret.? }\end{array}$ & Nederland & $\begin{array}{l}\text { Pink } \\
363 \text { tons }\end{array}$ & & & & \\
\hline 1829 & $\begin{array}{l}\text { Adriaan, J.J. } \\
\text { (Jacob) } \\
\text { Dep.? } \\
\text { Ret.? }\end{array}$ & Nederland & $\begin{array}{l}\text { Pink } \\
363 \text { tons }\end{array}$ & & & & \\
\hline \multirow[t]{2}{*}{1830} & $\begin{array}{l}\text { Rickmers, } \\
\text { Hendrik } \\
\text { Dep. 16 April } \\
\text { Ret. 12 August. } \\
\text { Dismissal of crew } \\
\text { 14 August after } 3 \\
\text { months and } 28 \\
\text { days }\end{array}$ & $\begin{array}{l}\text { Spitsbergen } \\
\text { (II) } \\
\text { (built 1829; } \\
\text { Joh. Alta) }\end{array}$ & $\begin{array}{l}\text { Pink } \\
251 \text { tons }\end{array}$ & $\begin{array}{l}\text { Jan Mayen } \\
\text { Spitsbergen }\end{array}$ & $\begin{array}{l}\text { 1,375 seals yielding } \\
45 \text { kwartelen of oil. } \\
\text { Oil tried out at } \\
\text { cookery De Her- } \\
\text { stelder, Harlingen, } \\
\text { September } 1830 .\end{array}$ & $\begin{array}{l}1,411 \text { seals } \\
\text { yielding } 62 \\
\text { kwartelen of } \\
\text { oil. }\end{array}$ & $\begin{array}{l}\text { (Nederlandsche Her- } \\
\text { mes, III, } 78 \text { ); } \\
\text { (Leeuwarder } \\
\text { Courant, } 17 \text { August } \\
\text { 1830 refers to Spits- } \\
\text { bergen (II) as being } \\
\text { a pink); document } \\
\text { GAH; Ship's jour- } \\
\text { nal, Friesenmu- } \\
\text { seum, Wyk auf Föhr }\end{array}$ \\
\hline & $\begin{array}{l}\text { Hoekstra, Klaas } \\
\text { Dep.? } \\
\text { Ret. } 11 \text { April, with } \\
\text { leaks }\end{array}$ & Nederland & $\begin{array}{l}\text { Pink } \\
363 \text { tons }\end{array}$ & Davis Strait & $\begin{array}{l}\text { Oil tried out at } \\
\text { cookery De Her- } \\
\text { stelder, Harlingen, } \\
\text { December } 1830\end{array}$ & & $\begin{array}{l}\text { Leeuwarder } \\
\text { Courant, } 20 \text { April } \\
1830 ; \text { document } \\
\text { GAH }\end{array}$ \\
\hline \multirow[t]{2}{*}{1831} & $\begin{array}{l}\text { Rickmers, } \\
\text { Hendrik } \\
\text { Dep. 20 March } \\
\text { Ret. 7 August } \\
\text { Dismissal of crew } \\
11 \text { August after } 4 \\
\text { months and } 4 \\
\text { days }\end{array}$ & $\begin{array}{l}\text { Spitsbergen } \\
\text { (II) }\end{array}$ & $\begin{array}{l}\text { Pink } \\
251 \text { tons }\end{array}$ & $\begin{array}{l}\text { Jan Mayen } \\
\text { Spitsbergen }\end{array}$ & \begin{tabular}{|l|} 
4,ooo seals \\
Combined results of \\
these two ships: 3 \\
whales, 5,349 seals \\
yielding 500 barrels \\
of seal oil and whale \\
oil; 5, ooo seal furs; \\
2,500 pounds of \\
baleen
\end{tabular} & $\begin{array}{l}4,421 \text { seals } \\
\text { yielding } 187 \\
\text { kwartelen of } \\
\text { oil }\end{array}$ & $\begin{array}{l}\text { Leeuwarder } \\
\text { Courant, } 6 \text { Sept. } \\
\text { 1831; Leeuwarder } \\
\text { Courant, 17 July } \\
\text { 1832; Ship's journal, } \\
\text { Friesenmuseum, } \\
\text { Wyk auf Föhr }\end{array}$ \\
\hline & $\begin{array}{l}\text { Hoekstra, Klaas } \\
\text { Dep.? } \\
\text { Ret.? }\end{array}$ & Nederland & $\begin{array}{l}\text { Pink } \\
363 \text { tons }\end{array}$ & & & & \\
\hline 1832 & \begin{tabular}{|l} 
Rickmers, \\
Hendrik \\
Dep. 14 March \\
Ret. 27 July \\
Dismissal of crew \\
28 July after \\
3 months and \\
22 days
\end{tabular} & $\begin{array}{l}\text { Spitsbergen } \\
\text { (II) }\end{array}$ & $\begin{array}{l}\text { Pink } \\
251 \text { tons }\end{array}$ & $\begin{array}{l}\text { Jan Mayen } \\
\text { Spitsbergen }\end{array}$ & $\begin{array}{l}\text { One whale; } 3,354 \\
\text { seals }\end{array}$ & $\begin{array}{l}\text { One whale; } \\
3,500 \text { seals in } \\
\text { total yielding } \\
227 \text { kwartelen } \\
\text { of oil }\end{array}$ & $\begin{array}{l}\text { Leeuwarder } \\
\text { Courant, } 3 \text { August } \\
\text { 1832: Leeuwarder } \\
\text { Courant, 16 July } \\
\text { 1833; Ship's journal, } \\
\text { Friesenmuseum, } \\
\text { Wyk auf Föhr }\end{array}$ \\
\hline
\end{tabular}




\begin{tabular}{|c|c|c|c|c|c|c|c|}
\hline Year & Master & Ship's name & Type & Destination & Results/remarks & FM & Sources \\
\hline & $\begin{array}{l}\text { Hoekstra, Klaas } \\
\text { Dep.? } \\
\text { Ret.? }\end{array}$ & Nederland & \begin{tabular}{|l|} 
Pink \\
363 tons \\
$(29,55 \times 5,8 \mathrm{x}$ \\
$4,77 \mathrm{el})$
\end{tabular} & Spitsbergen & $\begin{array}{l}\text { One whale; } 166 \\
\text { seals. Blubber yield- } \\
\text { ed } 46 \text { kwartelen of } \\
\text { oil }\end{array}$ & & $\begin{array}{l}\text { Leeuwarder } \\
\text { Courant, August } 3 \text {, } \\
\text { 1832: Leeuwarder } \\
\text { Courant, } 16 \text { July } \\
1833 . \text { GAH } 1378, \text { nrs. } \\
5 \text { (15 September) } \\
\text { and } 12 / 98 \text { (25 Sep- } \\
\text { tember }) \text {. Premium } \\
\text { for wanvangst } \\
\text { amounted to } f_{2,700}\end{array}$ \\
\hline \multirow[t]{2}{*}{1833} & $\begin{array}{l}\text { Rickmers, Hen- } \\
\text { drik } \\
\text { Dep. 10 April. } \\
\text { Ret. 13 August. } \\
\text { Dismissal crew } 14 \\
\text { August after } \\
3 \text { months and } \\
8 \text { days }\end{array}$ & $\begin{array}{l}\text { Spitsbergen } \\
\text { (II) }\end{array}$ & $\begin{array}{l}\text { Pink } \\
251 \text { tons }\end{array}$ & $\begin{array}{l}\text { Jan Mayen } \\
\text { Spitsbergen }\end{array}$ & 3 whales, 150 seals & $\begin{array}{l}3 \text { whales; un- } \\
\text { specified } \\
\text { number of } \\
\text { seals in total } \\
\text { yielding } 129^{3 / 4} \\
\text { kwartelen of } \\
\text { oil }\end{array}$ & $\begin{array}{l}\text { Leeuwarder } \\
\text { Courant, } 13 \text { Septem- } \\
\text { ber } 1833\end{array}$ \\
\hline & $\begin{array}{l}\text { Hoekstra, Klaas } \\
\text { Dep. } 19 \text { April . } \\
\text { Ret. }\end{array}$ & Nederland & $\begin{array}{l}\text { Pink } \\
363 \text { tons }\end{array}$ & $\begin{array}{l}\text { Jan Mayen } \\
\text { Spitsbergen }\end{array}$ & \begin{tabular}{|l|} 
small whale, 256 \\
seals \\
Combined results of \\
these two ships: \\
4 whales, 406 seals; \\
yielding 150 kwarte- \\
len of oil, about \\
2, ooo pounds of \\
baleen, about 400 \\
seal furs (and some \\
bear furs)
\end{tabular} & & $\begin{array}{l}\text { Leeuwarder } \\
\text { Courant, } 13 \text { Septem- } \\
\text { ber } 1833 \text {; Haagsma, } \\
\text { 'Friesland's Groen- } \\
\text { landvaart', 51; } \\
\text { Leeuwarder } \\
\text { Courant, } 8 \text { October } \\
\text { 1833; Leeuwarder } \\
\text { Courant, } 1 \text { July } 1834\end{array}$ \\
\hline \multirow[t]{2}{*}{1834} & $\begin{array}{l}\text { Rickmers, Hen- } \\
\text { drik } \\
\text { Dep. 19 March. } \\
\text { Ret. } 16 \text { August. } \\
\text { Dismisal crew ap- } \\
\text { proximately } 17 \\
\text { August. }\end{array}$ & $\begin{array}{l}\text { Spitsbergen } \\
\text { (II) }\end{array}$ & $\begin{array}{l}\text { Pink } \\
251 \text { tons }\end{array}$ & $\begin{array}{l}\text { Jan Mayen } \\
\text { Spitsbergen }\end{array}$ & $\begin{array}{l}\text { Combined results } \\
\text { amount to } 57 \\
\text { kwartelen of oil }\end{array}$ & $\begin{array}{l}\text { Totals not } \\
\text { specified (ca. } \\
105 \text { seals; one } \\
\text { whale) }\end{array}$ & $\begin{array}{l}\text { GAH } 1378, \text { nrs. } 6 \text { (14 } \\
\text { October ) and D/98 } \\
\text { (20 October). Pre- } \\
\text { mium for wan- } \\
\text { vangst amounted to } \\
f 7,150\end{array}$ \\
\hline & $\begin{array}{l}\text { Hoekstra, Klaas } \\
\text { Dep. } 19 \text { March. } \\
\text { Ret. }\end{array}$ & Nederland & $\begin{array}{l}\text { Pink } \\
363 \text { tons }\end{array}$ & Spitsbergen & & & \\
\hline $\begin{array}{l}\text { Total } \\
\text { catch }\end{array}$ & & & & & $\begin{array}{l}\text { About } 4,500 \text { pounds } \\
\text { of baleen; } 813 \text { bar- } \\
\text { rels of blubber; } \\
\text { about } 12,754 \text { seals; } \\
\text { about } 12 \text { whales }\end{array}$ & $\begin{array}{l}\text { About } 605^{3 / 4} \\
\text { kwartelen of } \\
\text { oil; about } \\
9,437 \text { seals; } 5 \\
\text { whales }\end{array}$ & \\
\hline
\end{tabular}

264. Results of catches are occasionally mentioned in newspapers or archival records, for instance in those at the Gemeentearchief Harlingen (municipal archives in Harlingen - GAH). In the case of absent direct references, results were deducted from governmental bounties for wanvangst. As stated before, whaling companies would receive a premium of $f_{5}$ o for every kwarteel of whale oil less than 100 . If, for example, the blubber of seals and whales after having been tried out would render 50 kwartelen, the government would support the company with a premium of $50 \times f_{50}=f 2,500$. The figures are estimates. Also, while calculating catch results - or more precisely making calculations of the amount of oil yielded from blubber - it is still unclear when it comes to the number of seals caught or the number of furs imported from the Arctic. Next to the Results column, catches as presented by Hendrik Rickmers in his journals are listed under the heading FM (Friesenmuseum). These totals, of course, relate to the achievements of the crew of the Spitsbergen (II) only from 1830-1840. 


\section{Rotterdam: Nederlandsche Maatschappij voor Walvischvangst}

(1825-1827)

Attempts were made to spark interest in the resumption of whaling not only in the Amsterdam region or in Harlingen, but also in Rotterdam. In an anonymous article published in 1826 in the short-lived monthly magazine De Nederlandsche Hermes, the author implicitly provided a bit of information concerning whaling from Rotterdam as he referred to the mediocre success of the whaling companies established "... in Rotterdam three years ago, and in Harlingen two years ago". ${ }^{265}$

Masterminds behind the Rotterdam-based whaling and sealing expeditions were the local merchants Frans Smeer, D.H. van Damme, and M.A.F.H. Hoffman. At the very first meeting to formally establish the company, on 21 January 1825 , these three gentlemen were appointed directors of what was to be called the Nederlandsche Maatschappij voor Walvischvangst. As had been the case with the Sociëteit in Harlingen, here again King Willem I subscribed to several shares at $f_{500}$ each. The City Council of Rotterdam received permission from the Governor of South-Holland, on behalf of King Willem I, to take a substantial share as well. The matter was discussed in the City Council's meetings of 13 April and 2 May. Rotterdam invested f5,000 in the company. ${ }^{266}$ Between 1825 and 1828, two ships - Rotterdam, Jacob Keller master and the pink Maasstroom (155 lasts/294 tons) under Douwe Jansz. Cupido, who was born on Ameland - were equipped for whale and seal hunting in the Arctic. ${ }^{267}$

Because it lacked its own Nautical College, the Rotterdam whaling company like the Harlingen-based Sociëteit, had to rely on the Amsterdam-based Kweekschool voor de Zeevaart (Nautical College) for a small portion of its crew. Documents in the archives of Amsterdam reveal that students from this institution were recruited regularly by the company's directors in Rotterdam. In 1825, no fewer than four pupils - J. Elias, P.T. Walkes, Van den Berg, and De Vries ${ }^{268}$ - were sent to Rotterdam to join the crew of an unspecified whaleship heading for Greenland. They left for Rotterdam on 29 March and set sail for the whaling grounds. They finally returned to their College in Amsterdam on 17 August. ${ }^{269}$

265. De Nederlandse Hermes, tijdschrift voor de Koophandel, Zeevaart en Nijverheid, vol. I, no.3 (1826), 8.

266. Gemeentearchief Rotterdam (Municipal Archives Rotterdam-GAR), Resoluties gemeenteraad, inv. nr. 444.01, nr. 13 (1825), fos. 20 verso (13 April), and 29 verso (2 May). See also De Jong, Oude Nederlandse walvisvaart, vol. II, 460 .

267. To date, there is not much information about the composition and origin of the crew of these ships. The German bombardment of Rotterdam on 14 May 1940, destroyed the archives of the havenmeester (Harbourmaster) related to developments that had taken place before 1842 . Consequently, no crew lists regarding whaleships survived. Also, the Nautical College in Rotterdam was established in 1833, five years after the company had brought an end to its whaling activities.

268. Neither the initials nor the first names of the last two pupils are known.

269. SAA, inv. nr. 949 (archief Kweekschool voor de Zeevaart), nr. 27 (1825), fos. 223 (Directors' meeting 
In 1826, the Rotterdam whaling company asked for no fewer than six pupils out of a total of a few dozen students to man their two ships. The Directors of the Nautical College in Amsterdam again responded positively to their request. J. Blad and E. Barnevelt were mustered on board Maasstroom, commanded by Cupido, and destined for Greenland. They received monthly wages of $f 20$ each. The remaining four - J.W. Retgers, W.C. Veenstra, J. Elias (again), and D. Herderschée - were employed on board Rotterdam, commanded by Keller, and heading for the Davis Strait. The company paid them $f_{1} 6$ monthly “... with a promise for more". The pupils left Amsterdam on 8 February and Blad and Barnevelt returned to their school on 12 August after an absence of over six months. ${ }^{270}$

The following year (1827), the Rotterdam whaling company again requested the presence of pupils from Amsterdam. This time G. Kreulen and P. Veltkamp joined Captain Cupido on his ship Maasstroom destined for Greenland. That year, the pupils left around 21 February, only to return as late as 29 August, carrying in their pockets an enthusiastic affidavit from Captain Cupido - they must have performed very well. A few months later, however, the whaling company was dissolved..$^{271}$

Throughout these years catches were disappointing. Rotterdam headed for the Davis Strait twice, in 1825 and 1826. In both instances the vessel returned empty. For both years the owners received the total premium of $f_{4}, 000$ for outfitting the vessel (an extraordinary event as normally the government would provide two separate premiums), as well as the financial support for wanvangst, amounting to $f_{5}, 000$. In total, government aid amounted to $f_{18}$, 000 for two highly unsuccessful whaling voyages. Rotterdam was taken out of service in $1826 . .^{272}$

The Rotterdam-based company achieved better results with Maasstroom. After an unsuccessful first season (1825), with the government issuing another $f 4,900$ for wanvangst, the vessel returned to Rotterdam on 11 August 1826 with 2,800 seals, yielding 128 barrels of blubber. Whaling, however, had been a complete failure. There is no data on whether or not the premiums for outfitting were issued in 1826 .

Even before Maasstroom set sail again in 1827, the Dutch government granted the company a total premium for outfitting, amounting to $f_{4}, 000$. That year Cupido came to the rescue of the crew of the ill-fated Willem de Eerste (II) under command of Jan Cornelisz. Groendijk. On 22 August 1827, Cupido returned from Greenland on

on 16 March), 230 (idem, 30 March), 359 (idem, 17 August).

270. SAA, inv. nr. 949 (archief Kweekschool voor de Zeevaart), nr. 27 (1826), fos. 7 (Directors'meeting on 18 January), 16 (idem, 8 March), 159 (idem, 16 August). No information has been found concerning the remaining four students on board Rotterdam.

271. SAA, inv. nr. 949 (archief Kweekschool voor de Zeevaart), nr. 27 (1827), fos. 233 (Directors'meeting on 21 February), and 317-318 (idem, 29 August).

272. GAR, Repertorium Stadsbestuur, inv. nr. 444.01, nr. 3745 (1825), fo. 278; idem, nr. 3746 (1826), fo. 275; Koninklijk Besluit, 6 November 1826; De Jong, Oude Nederlandse walvisvaart, vol. II, 460. 
Brielle roadstead, a little north of Rotterdam. He and his crew had harvested a modest 88 seals, yielding 30 kwartelen of blubber. ${ }^{273}$ Apart from the revenues of the sale, the directors of the company received another $f_{3,250}$ as compensation for wanvangst. In short, between 1825 and 1827 , the Rotterdam whaling entrepreneurs received a total of $f_{18,150}$ for wanvangst and a considerable $f_{12,000}$ in premiums, and possibly even $f_{16,000}$ if we include outfitting premiums for 1826 . In a three-year period, the government invested no less than $f_{30,150}$ in five voyages with extremely modest results. All these financial injections could not hide the considerable losses the company had suffered. Soon after the return of Maasstroom the board of directors informed the shareholders that the company had to be liquidated:

"... ter oorzake van de importante schade en verliezen door dezelve geleden"

("caused by the considerable damage and losses, suffered by them").

The last remaining vessel, Maasstroom, was auctioned on 23 October 1827. One year later, all gear and equipment was sold. With an investment of $f_{5,000}$ the City Council of Rotterdam had been one of the main investors in the whaling company. At the time of its liquidation, the City Council received a polite letter from the directors, first thanking the city for its financial support but, furthermore, the directors dryly remarked that per share only $f 40$ ( 8 percent of its nominal value) would be paid through the service of R. Mees \& Zoonen in Rotterdam. All in all, the city lost $f 4,600$ in this whaling adventure. ${ }^{274}$

Table 4.5: Whaling and sealing expeditions to the Davis Strait fitted out by the Nederlandsche Maatschappij voor Walvischvangst (1825-1827). ${ }^{275}$

\begin{tabular}{|c|c|c|c|c|c|}
\hline Year & Master & Ship's name & Type & Destination & Results/remarks \\
\hline \multirow{2}{*}{1825} & Keller, Jacob & Rotterdam & $?$ & Davis Strait & Returned empty \\
\hline & $\begin{array}{l}\text { Cupido, } \\
\text { Douwe Jansz. }\end{array}$ & $\begin{array}{l}\text { Maasstroom } \\
\text { (294 ton) }\end{array}$ & Pink & & Bad catch \\
\hline \multirow[t]{2}{*}{1826} & Keller, Jacob & Rotterdam & $?$ & Davis Strait & Returned empty (taken out of service) \\
\hline & $\begin{array}{l}\text { Cupido, } \\
\text { Douwe Jansz. } \\
\text { Ret. } 11 \text { August to } \\
\text { Rotterdam }\end{array}$ & $\begin{array}{l}\text { Maasstroom } \\
\text { (294 ton) }\end{array}$ & Pink & $?$ & $\begin{array}{l}2,800 \text { seals, yielding } 128 \text { barrels of blub- } \\
\text { ber }\end{array}$ \\
\hline 1827 & $\begin{array}{l}\text { Cupido, } \\
\text { Douwe Jansz. } \\
\text { Ret. 10 August to } \\
\text { Brielle }\end{array}$ & $\begin{array}{l}\text { Maasstroom }(294 \\
\text { ton })\end{array}$ & Pink & Davis Strait & $\begin{array}{l}88 \text { seals, yielding } 30-35 \text { kwartelen (auc- } \\
\text { tioned on } 23 \text { October) }\end{array}$ \\
\hline Total catch & & & & & $\begin{array}{l}\text { No whales; about } 2,888 \text { seals; } 30-35 \\
\text { kwartelen of oil; } 128 \text { barrels of blubber }\end{array}$ \\
\hline
\end{tabular}

273. Amsterdamsche Courant, 22 August 1827; According to Van Sluijs, Douwe Jansz. Cupido sailed for the Groenlandse en Straatdavidse Visscherij Sociëteit in Harlingen: J. van Sluijs, Nederlandse Koopvaardijschepen 18001860 (n.p. n.d.), 18. De Jong, Oude Nederlandse walvisvaart, vol. II, 460, listed a total of 35 kwartelen blubber. 274. GAR, Resoluties gemeenteraad, inv. nr. 444.01, nr. 16 (1828), fo.66 recto et verso (10 October). De Jong, Oude Nederlandse walvisvaart, II, 460-461.

275. Amsterdamsche Courant, 22 August 1827; De Jong, Oude Nederlandse walvisvaart, vol. II, 460. 


\section{Harlingen: Barend Visser \& Son, Part II (1835-1864)}

In the province of Friesland, the Sociëteit was dissolved in 1834 and Nederland and Spitsbergen (II) were auctioned off in Amsterdam on 26 January 1835. Both ships were added to the fleet of the merchant house of Barend Visser \& Son, who paid $f 15,227$ for the five-year-old Spitsbergen (II), considerably more than the $f 6,635$ the firm paid for the much older Nederland. ${ }^{276}$ This ship was built in 1800 in Itzehoe near Hamburg, Germany. Changing ownership in 1826, the vessel was baptized Nederland and was in service for the Sociëteit until 1834. In 1835 the vessel changed ownership again. $\mathrm{Ne}$ derland was baptized Dirkje Adema, probably named after the first wife of Dirk Cornelis Zijlstra, an important local merchant and co-director of the Sociëteit. ${ }^{27}$ This ship served the firm of Barend Visser \& Son well for another 27 years: the Dirkje Adema sailed to the Arctic waters until $1864 .{ }^{278}$ Spitsbergen (II) made its last voyage to the Arctic in 1853 and later that year the ship was sold to a Harlingen-based timber merchant. All in all, Barend Visser \& Son established a 'national record' with their involvement in whaling expeditions: no other Dutch firm managed to equip its ships for whaling voyages for such a long period.

With the disappearance of the Sociëteit and the re-appearance of Barend Visser \& Son, a new dawn seemed to have emerged for Dutch Arctic whaling. In his annual report of 1834-1835 Governor Jan Adriaan baron Van Zuylen van Nyevelt (1776-1840) wrote a mixed message. Or more accurately, he must have delivered this message with mixed feelings. On the one hand the Governor dwelled on the liquidation of the Groenlandse en Straatdavidse Visscherij Sociëteit, while on the other hand he joyfully announced the establishment of a new whaling company. In his meeting with the States of Friesland the Governor phrased matters as follows:

"De Groenlands en Straat Davis Visscherij Societeit te Harlingen, werd ten gevolge van het daartoe door de Directie gezamenlijk met de Deelnemers genomen besluit ontbonden en gelijk algemeen bekend is, was zulks met schade voor de actiehouders vergezeld. Het Schip Spitsbergen is evenwel in dit jaar door de Heeren Barend Visser en Zoon

276. Handelsblad, 26 January 1835; J. van Sluijs, Nederlandse Koopvaardijschepen 180o-186o (n.p. n.d.), 43, 16. 277. Dirk Cornelis Zijlstra, member of a highly esteemed local family, married Dirkje Adema in 1803. Zijlstra owned a handful of lots that he rented out. He also owned a 30 -foot kotter and a chais, a certain type of carriage with one horse. Finally, he and his trading partner, Fontein, received fairly large payments for deliveries of butter and cheese. GAH, book number 204; Volkstelling 1839. See book numbers 1133, 1138, 1139, 1140, 1141 for foodstuffs delivered between 1801-1809. Payments were made by the estate-steward (rentmeester) of the local orphanage. So far, no explanation has been found for the fact that the vessel may have been named after Zijlstra's wife at a time when Zijlstra was apparently no longer involved in whaling activities.

278. J. van Sluijs, Nederlandse Koopvaardijschepen 1800-1860 (n.p. n.d.), 8o. For more about Dirkje Adema see: S. Haagsma, 'Friesland's Groenlandvaart', Ons Zeewezen 1904, 310-314; J. v.d. Weide, 'Het leven aan boord van de Dirkje Adema', Ons Zeewezen 1921; Handelsblad, 27 February 1857. 
te Harlingen, voor hunne bijzondere rekening [mijn cursivering, JS] ter Walvischvangst uitgerust, en daar door heeft die stad, ten minsten gedeeltelijk deze voor haar vertier belangrijke inrigting mogen behouden"

("As a result of a decision made by the Directors, together with their shareholders, the Greenland and Davis Strait Fishery Society in Harlingen has been dissolved, which, as is commonly known, has caused damage to the shareholders. This year, however, the ship Spitsbergen was equipped for whaling by the gentlemen Barend Visser \& Son on their own specific account [author's italics] - hereby enabling the town to at least partially maintain this locally important industry"). ${ }^{279}$

It was discussed at an earlier stage that the firm of Barend Visser \& Son had been among the very first entrepreneurs in the Netherlands to embark on whaling adventures. ${ }^{280}$ The company must have had money in abundance. Barend Jansen Visser at one time supplied money to the municipality of Harlingen for the construction of the local orphanage. He was also apparently involved in the timber trade, in the supply of seeds on behalf of the treasurer of the orphanage, and in the delivery of flags. ${ }^{281}$ Also, Visser was the proud proprietor of seven warehouses, one rope factory, and two mansions. ${ }^{282}$ Moreover, in the words spoken by the Governor of the province, in his speech of 1835 , it was suggested that the firm not only established a new whaling company but that this business was financed with its own money. In other words, unlike so many other contemporary whaling entrepreneurs, Visser \& Son did not rely on investments made by shareholders. This whaling company was a private one, as opposed to the Harlingen-based Sociëteit which had issued shares. ${ }^{283}$

In 1835 Barend Visser \& Son fitted out the bark Spitsbergen (II). The vessel left Harlingen harbour on 19 March, again under the command of Hendrik Rickmers. Thanks to Rickmers' journals at the Friesenmuseum in Wyk auf Föhr, which relate to his voyages between 1830 and 1840, one becomes familiarized with his routes and catches. The

279. Leeuwarder Courant, 21 July 1835.

280. Visser \& Son must have owned a considerable number of ships. Apart from the whaling fleet, the company in 1824 allegedly owned two ships sailing to the East Indies: the frigate Waterloo (240 lasts) and the pink Antoinetta Jacoba (190 lasts). Both ships were built in the Baltic. In the monthly journal De Nederlandsche Hermes, the Antoinetta Jacoba was acknowledged as a whaleship but to this effect no evidence has been found. De Nederlandse Hermes, tijdschrift voor de Koophandel, Zeevaart en Nijverheid, vol. III, no. 9 (1828), 66-67.

281. Over and over again, the firm of Barend Visser \& Son was mentioned in the Leeuwarder Courant as the prime party for information concerning the sale of timber. See for example Leeuwarder Courant, 1 June 1830; or Leeuwarder Courant, 23 November 1830; or Leeuwarder Courant, 27 November 1832. Visser was also mentioned as intermediary of sales regarding seeds. See for example Leeuwarder Courant, 21 November 1837. At that time the sale included several thousands of kilograms of cole-seed.

282. There is no data concerning Barend Jansen Visser's date of birth. It is known, however, that he must have died before 1828. GAH, Burgerlijke standsregisters 1827; book numbers 45, 204, 650, 1138, 1140 .

283. The whaling company of Barend Visser may have been organised along the principles of a so-called 'partenrederij'. So far no evidence to this extent has been found. 
master from this North Frisian island was accompanied by 48 men. Spitsbergen (II) encountered bad weather on its outward passage along the Norwegian coast but reached the ice about three weeks later on 8 April. On 16 April, Jan Mayen Island was sighted. The men were quite successful in sealing. Whaling, however, was a disaster as hardly any whales were caught. On 21 July, Rickmers set his course for the Netherlands. Upon his return to Harlingen harbour on 6 August, approximately 100 kwartelen of blubber and about 2,600 seal furs were unloaded. In total 152 kwartelen of oil were yielded. ${ }^{284}$

The vessel left Harlingen again on 6 March $1836 .{ }^{285}$ Information about catch results was retrieved from both Rickmers' journal and from later issues of the Leeuwarder Courant. On 8 April, Rickmers and his crew of 49 cast their eyes upon the Beerenberg, the volcano on Jan Mayen Island. From that day until 11 May, seals were caught on an almost daily basis. Later, in July, another 100 were added and the total catch amounted to at least 1,622 units. ${ }^{286}$ Vessel and crew returned safely, having passed the coast of Norway. Spitsbergen moored in Harlingen harbour on 25 August.

Rickmers' journal is not the only source for Barend Visser \& Son. During the Governor's annual address to the representatives of the province of Friesland the following year (1837), he referred to the successful endeavours of this firm. After discussing the miserable state of shipbuilding in Friesland during the preceding year and the first months of 1837, the Governor immediately singled out in an almost joyful way Visser's commission to construct a kofschip. ${ }^{287} \mathrm{He}$ then continued to compliment the company for its fairly good results in their sealing activities.

Master Rickmers was quite successful in sealing, but not in whaling. With his crew he had managed to catch over 3,00o seals. These seals had yielded much oil, which was sold at high prices. As a consequence, the whaling company did not use its right to request a premium for wanvangst.

This catch should be considered quite an astounding accomplishment when compared with the achievements of the well-experienced British seal hunters. Late in 1836, news about the failures of the British whaling and sealing fleet had reached the offices of the Leeuwarder Courant as well. This newspaper was informed of reports from Leith, Scotland, that as late in the season as 17 September, out of a fleet of 61 ships, no fewer than 52 were still completely empty. The remaining nine had a modest catch of twelve whales in total. ${ }^{288}$

284. H. Rickmers, Ship's journal Spitsbergen, 5 and 6 August 1835. Friesenmuseum, Wyk auf Föhr.

285. H. Rickmers, Ship's journal Spitsbergen, 6 March 1836. Friesenmuseum, Wyk auf Föhr. See also Leeuwarder Courant, 8 March 1836.

286. In his journal for 1836 , Rickmers omitted total catches. This figure of at least 1,622 was compiled by the author and was based on remarks and figures in the journal.

287. The name of this ship was not mentioned. It seems fair to assume the Governor referred to Dirkje Ade$m a$ (formerly Nederland). This vessel did not sail to the Arctic until 1838 .

288. Leeuwarder Courant, 25 October 1836 . No data concerning the number of seals caught has been found. 
The Governor concludes his remarks concerning the whaling and sealing enterprise under the flags of Friesland and the Netherlands with a political, socio-economic statement wrapped up in a wishful thought:

"Het zoude der welvaart van Harlingen zeer bevorderlijk zijn, indien deze onderneming de gewenschte gevolgen mogte hebben, en meer en meer konde worden uitgebreid" ("It would be most advantageous to the prosperity of the city of Harlingen, if this enterprise would have the desired consequences, and could be gradually expanded"). ${ }^{289}$

This, however, was neither the responsibility of the Governor, nor of his provincial authorities. It was up to the private individuals to decide whether or not expansion was needed, and up to the national government to support their activities financially.

According to the issues of the Leeuwarder Courant of 1837, Spitsbergen (II) was the only vessel employed by Barend Visser \& Son. On 11 March, Rickmers and his bark ${ }^{290}$ Spitsbergen (II) set sail for Jan Mayen Island and Spitsbergen again. ${ }^{291}$ In the Arctic, he apparently gammed with Captain H. Ponsilius. The Leeuwarder Courant quoted Ponsilius who, upon arrival in Harlingen, had stated that Hendrick Rickmers had caught one whale in May. ${ }^{292}$ This statement was substantiated by the primary source at hand. On 8 April, Spitsbergen reached the icepack around $70^{\circ}$ N.L., not far from Jan Mayen Island. The men had killed a few dozens of seals when, on 2 May, the ship was prepared for whaling. On 18 May, harpooner Jacob Schiphorst killed a whale on about $78^{\circ} 40^{\prime}$ N.L. Two days later, Schiphorst struck another one, but had to let it go.

In his journal, Rickmers kept track of which masters he had spoken with on the hunting grounds and what they stated about their catches. He spoke with Otto Moelen of Hoffnung (Hamburg), with 600 seals, Captain Erik Ketelsen of De Kleine Hendrik (from Gluckstadt, with 1,700 seals), and Captain Stokvleet commanding Flora with no fewer than 3,200 seals in its holds. All Rickmers could do was shake hands with his 'partner in failure' L. Mein. His ship De Jonge Martien from Hamburg carried only 50 seals. ${ }^{293}$ Spitsbergen (II) returned to its home port on 11 August, with 40 kwartelen of

289. 'Verslagen van de Heer Staatsraad, Gouverneur, en van Heeren Gedeputeerde Staten der Provincie Vriesland, gedaan in derzelver gewone Vergadering van den 4 Julij 1837'; printed in Leeuwarder Courant, 4 July 1837 .

290. In his eleven journals, Rickmers referred to Spitsbergen first as being a pink (1830-1834), and later as being a bark (1835-1840).

291. Leeuwarder Courant, 21 March 1837. Initially the crew consisted of 48 hands. On 11 March, Jan A. van der Wijk joined the men in his rank of ordinary seaman with $f_{2} 0$ in hand. H. Rickmers, Ship's journal Spitsbergen, 11 March 1837.

292. Leeuwarder Courant, 25 July 1837 . However, Rickmers' journal concerning the 1837 expedition does not refer to such a meeting with Ponsilius. It may be that the newspaper had misinterpreted and/or misspelled its source. In 1839, Rickmers frequently mentioned German master Bonfillios in his journal. See, for instance, the entries of 29 May and 14 June 1839.

293. H. Rickmers, Ship's journal Spitsbergen, 1837; 23 April, 14 May, 2 June, and 6 June, respectively. 
blubber. ${ }^{294}$ As a result of disappointing catches, the government granted $f 1,550$ as premium for wanvangst. ${ }^{295}$

From the 1838 season through 1853 , the company annually fitted out two vessels. Spitsbergen under master Hendrik Rickmers left Harlingen on 23 March. ${ }^{296}$ Three days later, Dirkje Adema, under command of Hendrik's second son, Hinrich Braren Rickmers (1810-1869), followed Spitsbergen (II) in its wake to the hunting grounds between Jan Mayen Island and Spitsbergen. ${ }^{297}$ Spitsbergen (II) reached the ice on 14 April, on $69^{\circ} 37^{\prime}$ N.L. For about one month (until 17 May), Rickmers and his crew focused on catching seals and killed 562 .

After a month they prepared for whaling, on $76^{\circ} 20^{\prime}$ N.L. The first whale was killed by harpooner Hermann Stellmann on 24 May and a few days later, on 31 May, a second whale was caught, thanks to flenser's mate Jacob Schiphorst. A third whale was hit on 22 June. This time harpooner Christian Poppe had been instrumental in the catch and killing it.

Rickmers and his son met several times during their stay on the hunting grounds. On these occasions Hendrik informally referred to his son as Hinrich. Also, when referring to a gamming with J. Okken's ship Hoffnung of Flensburg on 18 June, he explained he was on board 'als ok [sic] mein Zoon [sic]' ('and so was my son'). Rickmers crew also assisted in catching whales for Dirkje Adema. In his entry for 3 June, Hendrik Rickmers wrote about a whale caught on 28 May at $78^{\circ} 20^{\prime}$ N.L. by the crew of Dirkje Adema, and about the flensing of the mammal alongside the ship. He continued,

“... in welker vis onse speksneidersmaat Jacob Schiphorst de tweede harpoen had geschoten waar voor hij zal genieten 3 gulden / de geschoten harpoon aan boord bij Dkje [Dirkje Adema]"

(“... in which fish our flenser's mate Jacob Schiphorst had shot the second harpoon, for which he will enjoy 3 guilders /the harpoon shot is on board the Dkje [Dirkje Ade$m a]^{\prime \prime}{ }^{298}$

294. Idem, 11 August. Rickmers did not provide a detailed overview of his catches. Thanks to his journal, his total catch must have been one whale, 53 seals, and one narwal ('eenhoorn'). See also Leeuwarder Courant, 15 August 1837 .

295. Leeuwarder Courant, 10 July 1838. GAH, 1379 referred to only one ship (Spitsbergen (II)). These minutes of meetings of the States of Friesland for the period 1839-1840 unambiguously show that Barend Visser \& Son were granted $f_{4}, \mathrm{OoO}+f 1,550$ for outfitting and wanvangst, respectively. See GAH, 1375, nr. 28/98 (6 April 1837), and GAH, 1375, nr. C/98 (5 October 1837).

296. Leeuwarder Courant, 27 March 1838. I thank Frau Jutta Kollbaum-Weber of the Friesenmuseum, Wyk auf Föhr, and Herr Reinhard Jannen, Archivist of the Ferring-Stiftung on the island of Föhr, for their assistance in establishing the relationship between Hinrich Rickmers and Hinrich Braren Rickmers.

297. Leeuwarder Courant, 3 April 1838

298. H. Rickmers, Ship's journal Spitsbergen, 3 June 1838. 
Rickmers obviously stressed the point that the harpoon had not been lost but had remained in possession of the company. About four months later both ships returned: Dirkje Adema on 28 July and Spitsbergen (II) on 30 July. ${ }^{299}$ Data about the catches is provided by three sources: an announcement in the Leeuwarder Courant concerning a public auction, which took place in the autumn of 1838 ; the actual results of this auction; and the annual report of the Governor, printed in the newspaper in 1839 but, of course, referring to the preceding year. According to an advertisement in the Leeuwarder Courant, a public auction was scheduled to take place in the Inn 'Roma' in Harlingen on 10 October. At this auction about 100,000 steekannen oil (approximately 8,333 kwartelen of oil), approximately 5,500 pounds of baleen, and some 800 seal furs were to be sold..$^{300}$ In his annual report over 1838, Governor Van Zuylen van Nyevelt presented the results. Spitsbergen had caught three whales and 600 seals. Dirkje Adema had been more successful in catching whales (four in total), but had taken fewer seals in its hold (130 units). In total, these animals yielded about 300 kwartelen (about 7,00o litres) of oil. These results could have been better if it had not been for the fact that both ships had encountered bad weather and a late winter as the two vessels reached the grounds for seal hunting much later than usual.

The auction results present a very different picture. The listing for 1838 mentions 87 barrels of whale oil, 3,074 pounds of baleen, and no seal oil. There is a substantial discrepancy between the figures given at auction and those mentioned by the Governor. The definitive and more reliable auction results will be used henceforth. ${ }^{301}$

In 1839 Dirkje Adema and Spitsbergen (II) sailed from Harlingen. As usual they left in March - on the 8th and the 10th, respectively. ${ }^{302}$ This time, the two captains stayed away a fairly long time as they returned to Harlingen as late as 4 August. ${ }^{303}$ The voyages had lasted almost five months. In 1839 no advertisement or announcement indicating an upcoming auction have survived. Governor R.H.S.G.J. van Burmania baron Rengers' report, however, clarifies matters. It stated that due to stormy weather and the disadvantageous location of the icepack, the expeditions failed almost completely. The total catch for 1839 was very modest. It accounted for one small whale and 1,000 seals, again resulting in a governmental subsidy for wanvangst. ${ }^{304}$

299. Leeuwarder Courant, 31 July 1838 , and 7 August 1838.

30o. Leeuwarder Courant, 2 October 1838 . According to one of the broadsides in the Kendall Institute, New Bedford, Massachusetts (Library. Folder 3: oil prices at Amsterdam), 12 steekannen made up for 1 kwarteel. One steekan $=5-5^{1 / 2}$ gallon $=19-20,9$ litres. The total number of kwartelen mentioned here $(8,333)$ seems to be very high considering the small number of whales ( 7 ) and seals (730) caught.

301. Leeuwarder Courant, 2 July 1839. For auction results see Tresoar Leeuwarden, Notary archives, Wijma, repertoires 49031, \#191.

302. Leeuwarder Courant, 19 March 1839.

303. Leeuwarder Courant, 13 August 1839.

304. Leeuwarder Courant, 14 July 1840. Governor Jan Adriaan baron Van Zuylen van Nyevelt died on 29 
The following season (1840), both ships left Harlingen harbour on 11 March, again under command of Hendrick Rickmers and Hinrich Braren Rickmers. ${ }^{305}$ Again, both ships stayed on the whaling grounds for a relatively long period of time. Spitsbergen (II) returned on 8 August and Dirkje Adema was as late as 10 August. ${ }^{306}$ Again, as in 1839 , no fall auction was held in 1840 . The data concerning the results was obtained by checking the Governor's annual report for 1840 (presented in 1841). On 6 July, the newly appointed Governor Maurits Pico Diederik baron van Sytzama (1789-1848) reported, in far from enthusiastic terms, about the whaling and sealing endeavours. Similar to 1839,1840 was not a successful year. In total both ships caught 1,800 seals and the premium for wanvangst was again issued. Nevertheless, Barend Visser \& Son continued to equip its ships and send them to the Arctic waters. ${ }^{307}$

In 1841, Captain Hinrich Braren Rickmers was succeeded by Otto Mehlen, who left Harlingen harbour on 9 March on board Dirkje Adema, in company with the Spitsbergen (II), which was under the newly appointed Captain Johan Both, who in turn had succeeded Hendrick Rickmers. ${ }^{308}$ The two ships returned on the same date, 27 July. ${ }^{309}$ The Leeuwarder Courant does not provide any information about the catches. Furthermore, the newspaper does not contain the Governor's annual report for the year 1842. In short, with regard to the results of the 1841 season, there is no information available.

Data is fairly scarce for the subsequent years. In 1842, the much-quoted newspaper revealed only the date of departure and does not provide information about the date of return or about the catches. According to the Leeuwarder Courant both ships left Harlingen together on 10 March $1842 .{ }^{310}$ In his annual report for 1843 the provin-

March 1840. Regnerus Hendrik Sjuk Gerruld Jukkema van Burmania baron Rengers (1796-1873), ordinarily a member of the Provinciale Staten (States of Friesland), replaced him temporarily. In October 1839, Barend Visser \& Son had commissioned the construction of the kofschip De Gouverneur Baron van Zuylen van Nyevelt $(160$ last $=$ ca. 320 tons $)$, obviously in honour of the deceased Governor. The ship was built at the wharf of Alta in Harlingen and almost one year later, mention was made of another ship being built for Barend Visser \& Son. It concerned the kofschip Groot Lankum at the shipyard of Sjollema in Grouw, to be commanded by Captain H. de Weerdt, Jr. but was not employed in whaling or sealing activities. A vessel under this very same name had served the company in earlier years between 1817 and 1838 under command of $H$. de Weerd(t). See Leeuwarder Courant, 23 July 1840; G.N. Bouma, Sailing vessels visiting the port of Harlingen 1818-1918 [Haren 1994], 13. In his listings, of vessels, Bouma made no mention of the two whaleships Spitsbergen and Dirkje Adema. Furthermore, in the introduction of his privately printed work, Bouma stated that in 1843 the provision of information related to shipping in the Leeuwarder Courant was taken over by the Provinciale Friesche Courant. As noted in numerous annotations, however, after 1843 the Leeuwarder Courant continued to be one of the prime sources for ships' movements in and out of Harlingen harbour.

305. Leeuwarder Courant, 17 March 1840.

306. Leeuwarder Courant, 11 August 1840; Leeuwarder Courant, 18 August 1840.

307. Leeuwarder Courant, 6 July 1841.

308. Leeuwarder Courant, 16 March 1841.

309. Leeuwarder Courant, 3 August 1841.

310. Leeuwarder Courant, 22 March 1842. The ship's journal in the Friesenmuseum referred to 4 March as 
cial Governor, while presenting a new layout regarding the overview of activities in Friesland during the preceding year (1842), stated that for the year the results of the sealing expeditions were not unsatisfactory. They captured and killed 8,700 seals. Whaling, however, had been a complete failure. ${ }^{311}$

In 1843, Spitsbergen (II) commanded by Johan Both left for Spitsbergen as early as 5 March. ${ }^{312}$ The date of departure of Dirkje Adema, however, has not been retrieved, but later issues of the newspaper refer to the return of both vessels, Dirkje Adema, Captain Otto Mehlen commanding, on 30 July, and Spitsbergen (II) on 6 August. ${ }^{313}$ The Governor's annual report for 1844 is missing; moreover, no auction is recorded. Consequently, there is no information about the results of their voyages.

In 1844, the Leeuwarder Courant announced the return of both vessels (Spitsbergen and Dirkje Adema) in late July. Barend Visser \& Son welcomed their two whaleships back in town: Dirkje Adema arrived on 27 July and Spitsbergen (II) four days later, both safe and sound. ${ }^{314}$

Again, the Leeuwarder Courant proved to be the only useful source with respect to shipping intelligence for 1845 . No dates of departure of the vessels have been found. Also that year's issue of the newspaper does not contain an annual Governor's report, or auction results. Only the return dates of both ships, Dirkje Adema on 6 August and Spitsbergen (II) on 13 August, are given. Again, Mehlen and Both were mentioned as captains. ${ }^{315}$

Thanks to the annual report given by the Governor for 1845, printed in the Leeuwarder Courant the following year, the catch results of the two whaleships deployed can be found. The Governor remarked that 1845 was more successful than 1844 , despite the fact that both ships had only a short time to hunt whales and seals; successful to such an extent that no requests for a governmental premium for wanvangst had to be filed. According to the annual report, Dirkje Adema returned with 2,076 seals and the blubber of 8 whales. Spitsbergen (II) performed poorer with 1,934 seals and only one whale. ${ }^{316}$

Of interest here is that later that year, on 18 November, an advertisement in the Leeuwarder Courant must have drawn the attention of potential buyers of whale and seal oil. A few weeks prior to the return of the Harlingen whaling fleet, the kofschip

date on which the crew embarked.

311. Leeuwarder Courant, 11 July 1843, $\$ 34$ (p. 35). On this occasion the Governor referred to whaling as the 'Groote Visscherij', a term generally used for the herring fishery.

312. Leeuwarder Courant, 14 March 1843.

313. Leeuwarder Courant, 8 and 15 August 1843.

314. Leeuwarder Courant, 30 July and 6 August 1844.

315. Leeuwarder Courant, 12 August and 19 August 1845.

316. Leeuwarder Courant, 14 July 1846. Governor's annual report, 45-46. 
Berndina, registered in Oldenburg (Germany), while on its way from Bergen, Norway, to Antwerp, had run aground with a cargo of oil. ${ }^{317}$ This cargo was due to be sold at auction on 27 November in an unspecified inn at Wierum, near Dokkum. The auction was held under the auspices of clerk J.J. Heep in Holwerd. According to the advertisement, additional information could be obtained via Barend Visser \& Son ${ }^{318}$

The scarcity of data concerning catch results for 1846 is a problem. For this year, the dates on which the two ships departed from Harlingen were 3 March. ${ }^{319}$ Also, some information about Dirkje Adema was recovered from the newspaper published in Leeuwarden. This whaleship returned on 28 July with a disappointing cargo of 300 to 400 seals. ${ }^{320}$

There is slightly better information about Spitsbergen (II). Here again, ship's journals at the repository of the Friesenmuseum on Föhr proved invaluable. In addition to the journals, written in Dutch by Hendrik Rickmers and covering the years 18301840, this museum's manuscript collection contains journals covering the years 18461848. The hitherto unknown keeper, with his tiny, close-to-unreadable handwriting, referred to Captain Johan Both in German in the third person singular. ${ }^{321}$ Spitsbergen (II) apparently departed on 27 February 1846 with a crew of 43. The next day, seven more whalemen were added. On the pages covering the period 24 March to 9 May, the heading reads: "Journahl im Grönland auf der Robbenküste". During this time, Spitsbergen (II) cruised the waters around $71^{\circ}-72^{\circ}$ N.L. and Captain Otto Mehlen of Dirkje Adema was mentioned several times. After an unsuccessful trip, with $79^{\circ} 3^{\prime}$ N.L. as the highest latitude, Captain Both decided to return to Harlingen. The keeper of the journal gave 2 August as date of arrival but unfortunately no catches were mentioned.

However, an 1847 issue of the provincial newspaper contained the annual report for 1846 , confirming the bad results for the 1846 season. Moreover, the report allows the derivation of the number of seals caught by the crew on board Spitsbergen (II), as the Governor referred to a total of 700 seals caught. No whales were killed. Consequently, the premium for wanvangst was issued. The Governor concluded in a positive manner by stating that expectations for 'this year' (1847) are higher, based on good reports from the whaling grounds. ${ }^{322}$

317. The Berndina is not mentioned in Lloyd's Registers 1844-1846.

318. Leeuwarder Courant, 18 November 1845. To date, no relationship has been established between H. Heep, keeper of the Inn 'Roma' in Harlingen, and J.J. Heep in Holwerd.

319. Leeuwarder Courant, 10 March 1846.

320. Leeuwarder Courant, 4 August 1846.

321. Thanks to an undated crew list of the Spitsbergen (II) - attributed to 1845 or 1846 - in the collection of the Friesenmuseum we know that Christoffer Osenburgen served as first mate. Chances are that he kept these journals.

322. Leeuwarder Courant, 19 July 1847; Governor's annual report, 37. 
Thanks to the journals, data regarding the 1847 season is available. Both whaleships left the harbour of Harlingen quite early. Spitsbergen departed with $49 \mathrm{crew}$ members on 2 March, probably because the company aimed for a long hunting season to counter balance the very poor catches of the preceding year. Dirkje Adema, under Captain Otto Mehlen, had already left Harlingen harbour on 8 February. Later that year, this change in tactics proved to be successful. According to the newspaper, Mehlen aboard Dirkje Adema returned to the home port on 12 July 'with seals'. ${ }^{323}$ Johan Both followed much later. He arrived on 31 July with more than 5,500 seals and $1 / 2$ whale. On 3 June, his crewmember Johann Hollmann, together with Captain L. Mein, managed to harpoon and kill a whale. They divided the catch, hence Captain Both's share of $1 \frac{2}{2}$ whale. ${ }^{324}$

Again, this data can and should be checked against the information provided in the Governor's annual report. ${ }^{325}$ The report for 1847 is somewhat bewildering, as the achievements of the whaling firm were paradoxically presented. First, no whales were caught. Secondly, a bizarre rumour about the loss of a whaleship was articulated in the Governor's report. In retrospect, there is no data to confirm this rumour. Thirdly, sealing was very successful: in total 14,400 seals were harvested. Thus, Dirkje Adema carried home close to 9,000 seals. But, as a result of the extremely low prices of oil and furs, this whaling season could hardly be called profitable.

The report contained no news of the 1848 expedition. The only information retrieved from the newspaper is that Dirkje Adema returned home that year on 30 July - completely empty. ${ }^{326}$ Research in the municipal archives in Harlingen, however, has provided substantially more information. In the archives of incoming correspondence to the City Council, two letters from Barend Visser \& Son, dated 12 and 25 August, contain data regarding the catches by both ships' crew and subsequent trying-out of the blubber. Dirkje Adema delivered a modest four barrels of blubber, yielding $11^{1 / 2} \mathrm{kwarte}$ len of oil. Spitsbergen (II) performed even worse, with only one barrel of blubber, yielding about $3 / 4$ of one kwarteel. This information is corroborated by the journal of Spitsbergen (II) in the Friesenmuseum on Föhr, which stated that the vessel left Harlingen on 6 March. Three weeks later the crew arrived at Greenland, had an uneventful voyage, and returned home safely on 11 August. Not surprisingly, the whaling company requested a premium for wanvangst for both ships..$^{327}$

323. Leeuwarder Courant, 20 July 1847 . This edition mentions 4 February as the date of departure for Spitsbergen (II).

324. Leeuwarder Courant, 10 August 1847. The ship's journal in the Friesenmuseum presents a different figure of 4,763 seals killed by the Spitsbergen (II) crew.

325. Leeuwarder Courant, 11 July 1848. Governor's annual report, 37.

326. Leeuwarder Courant, 8 August 1848.

327. GAH, 1648: fol. 125, nrs. 991, and 1037. 
That year, however, an interesting phenomenon took place. Otto Mehlen's name pops up in the newspaper a few months after his return in Dirkje Adema. In between whaling voyages, he apparently tried to make some money on the side as Captain of Vriesland but without success: on 20 September he came back home from Amsterdam with an 'empty' ship. Its supposed cargo was not specified. ${ }^{328}$ Both captains must have been frustrated by the disappointing results. The Governor's annual report for 1848 was a dramatically clear indication of the very poor results achieved in Dutch whaling and sealing. The two ships combined harvested no more than 109 seals (one ship carried no more than nine). The report contained no news about the current season (1849). ${ }^{329}$ Johan Both remained employed by Visser \& Son until 1849. P. Nagel was his successor for the following three seasons (1850-1852). ${ }^{330}$

The newspapers were silent as to the results of the whaling expedition organised between 1849 and 1852. To reconstruct what activities the company undertook during these years, only scarce primary sources were used. Premiums for fitting out and wanvangst were issued. The records of the GS for 1849 reveal that Dirkje Adema and Spitsbergen had left Harlingen harbour before mid-April. By early September it was clear that a substantial wanvangst premium of $f 4,800$ (imbursement for the combined shortfall of 96 kwartelen of oil) was issued. In other words, only four kwartelen of oil were obtained. ${ }^{331}$

In official correspondence with the City Council of Harlingen dated 1850, the first signs of an upcoming dramatic change in the governmental premium system can be discerned. Though no amounts are stated, it is clear that the company has received premiums for outfitting as well as for wanvangst. As A. van der Laan, clerk at the States van Friesland, wrote to the city magistrates, while quoting the Minister for the Interior:

" [ dat er] geen zwarigheid bestaat in toekenning, onder de gewone voorwaarde, van de uitrustingspremie en schadevergoeding voor de beide schepen uit Harlingen.”

("There is no problem in assigning, under normal conditions, the premium for fitting out and for indemnation of damage [wanvangst, JS] to both ships from Harlingen”).332

At the time Van der Laan wrote his letter both ships already had left for Greenland. It is not clear whether or not he, in his statement concerning wanvangst, anticipated losses for 1850 , or if he was referring to the results of the preceding year.

328. Leeuwarder Courant, 26 September 1848.

329. Leeuwarder Courant, 13 July 1849. Governor's annual report, 44.

330. Johan Both pursued a long and successful career. He eventually returned with Barend Visser \& Son to sail their ships as Captain between 1858 and 1870. See G.N. Bouma, Lijst van Harlinger Koopvaardijkapiteins (Haren 1997), 2.

331. GAH 1384, nrs. 32 (18 April) and 45 (11 September).

332. GAH 1385, nr. 43 (9 April 1850). 
In 1851 problems arose. Reductions of premiums were fairly substantial. The company received 10\% less, both on outfitting premiums as well as on compensation for wanvangst. Dirkje Adema and Spitsbergen (II) set sail for Spitsbergen sometime before 3 April. At the end of the season GS had problems with granting premiums. Eventually the whaling company was credited with all three premiums. ${ }^{333}$ The results of this season were not satisfactory: Spitsbergen (II) brought home 27 barrels of blubber, yielding close to 59 kwartelen of oil for a rato of 1:2.16. Catches of Dirkje Adema have not been retrieved. 334

The following year did not show much improvement. In 1852 the two ships, with the Spitsbergen (II) under command of Herman Stockfleet, ${ }^{335}$ brought home a meagre 34 barrels of blubber in total. At the Harlingen cookery the blubber yielded $83^{1 / 2}$ kwartelen of oil. ${ }^{336}$

In 1853, Stockfleet with Spitsbergen (II) made one last whaling expedition under the aegis of Barend Visser \& Son. ${ }^{337}$ He roamed the whaling grounds in company with Otto Mehlen and Dirkje Adema. That season, no fewer than 13,500 seals in total were captured. Later that year, on June 29, the firm of Barend Visser sold the brig Spitsbergen (II) via auction in Amsterdam to Reindert Jans Zeilmaker, director of the firm Zeilmaker \& Company. Zeilmaker paid $f_{5,000}$ for the 25 -year old vessel. ${ }^{338}$ On that occasion the ship was re-baptized Triton..$^{339}$ From this point on Dirkje Adema was the only whaleship fitted out in Harlingen.

Sources about the whaling activities of Barend Visser \& Son between 1854 and 1859 are scarce. So far, no information has been derived from the Leeuwarder Courant. For the last few years of the 1850s, Harlinger Courant (established in 1852) is a revealing source. Occasionally, archival records in Harlingen relate to catch results. Based on these sources we cannot but conclude that the 1854 season was a downright disaster. Otto

333. GAH 1386, nr. 19 (29 September). Compensation for wanvangst for Spitsbergen (II) only amounts to $f 1,845$. This equals 41 kwartelen of oil.

334. GAH 1444, nr. 849 (21 August 1851).

335. GAH 1445, nr. 817 (18 August 1852). The master's name is also spelled Stockfleth. Next to nothing is known about the mysterious mister and master Stockfleet. According to S. Parma, Harlinger koopvaardijkapiteins en Harlinger reders uit de tweede helft van de negentiende eeuw (Hilversum 1999), 43, a Stockfleet commanded the three-masted pink Spitsbergen (II) in 1852 while being employed by Barend Visser \& Son, while Sweijs mentioned a Stockfleeth (sic) as master of the bark (sic) Spitsbergen (II) in the service of Barend Vis$\operatorname{ser}(1853 ; 29)$.

336. GAH 1445, idem. Spitsbergen (II) brought home 23 barrels of blubber (rendering 49 kwartelen of oil), while Dirkje Adema provided for the remainder (11 barrels of blubber rendering $34^{1 / 2}$ kwartelen of oil).

337. GAH 1446, nr. 211 (3 March 1853)

338. S. Zeeman, 'Harlingen en de walvisvaart', Spiegel der zeilvaart, vol. 6. no. 9 (November 1982), 19. Zeeman erroneously mentioned 1852 as the year in which Zeilmaker purchased Spitsbergen (II).

339. For information about the Spitsbergen (II): see De Nederlandsche Hermes, vol. III, 78; Handelsblad, 26 January 1853 . 
Mehlen with Dirkje Adema returned from the hunting grounds with only 6 barrels of seal blubber. ${ }^{340}$ The next season (1855) was even worse with a catch of one polar bear and 4 barrels of blubber. ${ }^{341}$

In 1856 and 1857, Mehlen had a fairly early return (on 19 and 26 July, respectively). The only information available concerns results for the latter year. In 1857, Dirkje Adema's crew killed 1,300 seals. ${ }^{342}$ The following year (1858), Mehlen had his last command. His ship departed on 10 March and upon its return, in Harlingen after an absence of about $4^{1 / 2}$ months, 100 seals were unloaded. ${ }^{343}$ Mehlen's command was taken by C. Brinkmann in 1859. Departing from Harlingen as early as 20 February, Brinkmann must have been adamant in his attempt to reach the ice as early as possible and stay on the whaling and sealing grounds as long as possible. The results, however, continued to be disappointing. Dirkje Adema returned in Harlingen harbour on 27 July, after an absence of over 5 months, with 1,000 seals caught. This relatively long season once again must have been considered a failure by the directors of the firm. ${ }^{344}$

It was not until 1860 that the vessel in service of Barend Visser \& Son sailed under Dutch command again. That year, Hendrik Wildst (1802-1877) from the little Frisian town of Sneek, took the helm. Thus, for all 24 years between 1835 and 1859 the vessel had a foreign master.

The 1860 season was a failure. Based on the information available, that year's catch amounted to two polar bears and an unspecified number of seals. ${ }^{345}$ Moreover, Hendrik Wildst lost two of his men: a German surgeon and, about eight days later, an able bodied seaman. Both men received seamen's burials. ${ }^{346}$ Slightly better results were obtained during the 1861 season, with a total catch of 560 seals yielding 100 kwartelen

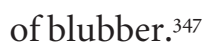

During the last two years of their whaling and sealing activities, Barend Visser \& Son were slightly more successful. In 1862, however, one of the boys died on the voyage to Greenland..$^{348}$ In total 500 adult seals and 2,300 pups were slaughtered and trans-

340. The Governor's annual report printed in Leeuwarder Courant, 6 July 1855 does not refer to any whaling activities; MAH, 1448/1449: reg. nr. 850 (14 August 1854).

341. MAH, 1450: reg. nr. 928 (25 August 1855).

342. Typescript A.J. Dijkstra.

343. Harlinger Courant, 4 March 1858; Idem, 27 July 1858; C. de Jong, 'De Dirkje Adema', 42; typescript A.J. Dijkstra; C. Nielsen, 'Uit de geschiedenis van de Harlinger walvisvaart', 25.

344. Harlinger Courant, 23 February 1859; typescript A.J. Dijkstra erroneously mentioned 27 August as the date of return.

345. Typescript A.J. Dijkstra.

346. A.B. van Deinse (introduction), Journaal der merkwaardige reizen van Jan Wever (van West-Terschelling) naar Turkije, Oost-Indië, China, Noord-en Zuid-Amerika, ter walvischvaart bij Groenland, enz. Loopende van 1847-1904 (Den Haag 1946), 24.

347. Wumkes, Tusschen Flie en Borne, 100; typescript A.J. Dijkstra.

348. Van Deinse, Journaal der merkwaardige reizen, 32. 
ported home. ${ }^{349}$ Information about the number of barrels of oil yielded has not been retrieved. Dirkje Adema made its last voyage to the Arctic in 1863. At the season's conclusion in June, the vessel returned with a modest 900 seals in its holds. ${ }^{350}$

In 1863 , the whaling activities of Barend Visser \& Son were discontinued. Hendrik Wildst spent the last years of his active and adventurous life in St. Anthony Gasthuis in Leeuwarden. ${ }^{351}$ The following year, the 64-year old Dirkje Adema was sold to Norway for $f 9,000 .{ }^{352}$ In Norway the vessel was used in the transport of timber but one year later (1865), the vessel ran aground near the German island of Rügen. After a life-long service of 65 years and hundreds of thousands of miles of sailing, the vessel found its final mooring place about 150 kilometres to the northwest of Itzehoe, where the ship had been built.

Barend Visser \& Son were involved in whaling and sealing for 29 years. The firm equipped at least one ship annually and two ships during most years between 1838 and 1854. In 1855 the governmental premium system was abandoned. Late in 1870 or early 1871 the firm of Visser \& Son temporarily disappeared, only to return in the shipping lists in 1873 . For two years, 1871 and 1872, its three vessels were placed under ownership of Rodenhuis \& Son. ${ }^{353}$ Seven years later, in 1880, the curtain fell and from 1881 onward, the shipping firm of Barend Visser \& Son does not appear in Sweijs' listings.

Table 4.6: Whaling and sealing expeditions to Jan Mayen Island and Spitsbergen fitted out by Barend Visser \& Son (1835-1864).

\begin{tabular}{|l|l|l|l|l|l|l|l|}
\hline Year & Master & Ship's name & Type & Destination & Results/remarks & FM & Sources \\
\hline 1835 & $\begin{array}{l}\text { Rickmers, Hen- } \\
\text { drik } \\
\text { Dep. 18 March; } \\
\text { Ret. 6 August }\end{array}$ & $\begin{array}{l}\text { Spitsbergen } \\
\text { (II) } \\
\text { Built 1828; Joh. } \\
\text { Alta }\end{array}$ & $\begin{array}{l}\text { Bark } \\
251 \text { tons }\end{array}$ & $\begin{array}{l}\text { Jan Mayen } \\
\text { Spitsbergen }\end{array}$ & $\begin{array}{l}\text { Visser paid f15,227, } \\
\text { for vessel at auction, } \\
\text { 26 Jan., Amsterdam. }\end{array}$ & $\begin{array}{l}\text { 2,694 seals } \\
\text { Rickmeeuwarder Courant, } \\
\text { 24 March 1835; } \\
\text { Leeuwarder Courant, } \\
\text { considerable num- } \\
\text { ber of seals" } \\
\text { Leeuwarder Courant, } \\
11 \text { August 1835; Han- } \\
\text { delsblad, 26 January } \\
1835 ; \\
\text { Leeuwarder Courant, } \\
12 \text { July 1836: Ship's } \\
\text { journal, Friesenmu- } \\
\text { seum, Wyk auf Föhr; } \\
\text { J. van Sluijs, Neder- } \\
\text { landse Koopvaardij- } \\
\text { schepen 1800-1860 } \\
\text { (n.p. n.d.), 43, 16 }\end{array}$ \\
\hline
\end{tabular}

349. C. Nielsen, 'Uit de geschiedenis van de Harlinger walvisvaart', 25. According to whaleman Jan Wever, the catch amounted to more than 3,00o. See Van Deinse, Journaal der merkwaardige reizen, 35.

350. Typescript A.J. Dijkstra.; J. van Sluis, Koopvaardijschepen, 80.

351. Haagsma, 'Frieslands Groenlandvaart', 52. In 1877, Wildst was buried in the cemetery at the Spanjaardslaan in Leeuwarden; see Dijkstra, 'De Groenlands- en Straat-Davids Visserij', 57.

352. J. van Sluijs, Koopvaardijschepen, 80.

353. The three vessels were the schooner kof Harmonie (built in 1846, 175/181 tons), Captain W.J. van der Meer; the brig Mercurius (built in 1850, 264 tons), Captain H. Helmers; and the schooner brig Willem (built in 1853, 194 tons), Captain M.J. de Weerd. Sweijs, 1871, 117; 1872, 117; 1873, 114. 


\begin{tabular}{|c|c|c|c|c|c|c|c|}
\hline Year & Master & Ship's name & Type & Destination & Results/remarks & FM & Sources \\
\hline 1836 & $\begin{array}{l}\text { Rickmers, } \\
\text { Hendrik } \\
\text { Dep. 6 March; } \\
\text { Ret. 25 August }\end{array}$ & $\begin{array}{l}\text { Spitsbergen } \\
\text { (II) }\end{array}$ & $\begin{array}{l}\text { Bark } \\
251 \text { tons }\end{array}$ & $\begin{array}{l}\text { Jan Mayen } \\
\text { Spitsbergen }\end{array}$ & $\begin{array}{l}>3,000 \text { seals, yield- } \\
\text { ing substantial } \\
\text { amount of oil }\end{array}$ & 1,522 seals & $\begin{array}{l}\text { Leeuwarder } \\
\text { Courant, } 8 \text { March } \\
\text { 1836; Leeuwarder } \\
\text { Courant, } 4 \text { July 1837; } \\
\text { Ship's journal, } \\
\text { Friesenmuseum, } \\
\text { Wyk auf Föhr }\end{array}$ \\
\hline 1837 & $\begin{array}{l}\text { Rickmers, } \\
\text { Hendrik } \\
\text { Dep. } 11 \text { March; } \\
\text { Ret. 11 August } \\
\text { (153 days) }\end{array}$ & $\begin{array}{l}\text { Spitsbergen } \\
\text { (II) }\end{array}$ & \begin{tabular}{|l} 
Bark \\
251 tons
\end{tabular} & $\begin{array}{l}\text { Jan Mayen } \\
\text { Spitsbergen }\end{array}$ & $\begin{array}{l}\text { Bad catch; premium } \\
\text { for wanvangst }\end{array}$ & $\begin{array}{l}1 \text { whale; } \\
53 \text { seals; } \\
\text { one narwal }\end{array}$ & $\begin{array}{l}\text { Leeuwarder } \\
\text { Courant, } 21 \text { March } \\
1837 ; 15 \text { August 1837; } \\
\text { Ship's journal, } \\
\text { Friesenmuseum, } \\
\text { Wyk auf Föhr } \\
\end{array}$ \\
\hline \multirow[t]{2}{*}{1838} & $\begin{array}{l}\text { Rickmers, } \\
\text { Hendrik } \\
\text { Dep. 23 March; } \\
\text { Ret. 30 July (129 } \\
\text { days) }\end{array}$ & $\begin{array}{l}\text { Spitsbergen } \\
\text { (II) }\end{array}$ & $\begin{array}{l}\text { Bark } \\
251 \text { tons }\end{array}$ & $\begin{array}{l}\text { Jan Mayen } \\
\text { Spitsbergen }\end{array}$ & 3 whales; 600 seals & $\begin{array}{l}3 \text { whales; } \\
6 \text { oo seals }\end{array}$ & \begin{tabular}{|l} 
Leeuwarder \\
Courant, 27 March \\
1838; Leeuwarder \\
Courant, 7 August \\
1838; Leeuwarder \\
Courant, 2 July 1839: \\
Ship's journal, \\
Friesenmuseum, \\
Wyk auf Föhr
\end{tabular} \\
\hline & $\begin{array}{l}\text { Rickmers, } \\
\text { Hendrik B. } \\
\text { Dep. 26 March; } \\
\text { Ret. 28 July } \\
\text { (128 days) }\end{array}$ & $\begin{array}{l}\text { Dirkje Adema } \\
\text { (built } 1800 \text { in } \\
\text { Itzehoe, N- } \\
\text { Germany, for- } \\
\text { merly Neder- } \\
\text { land) }\end{array}$ & $\begin{array}{l}\text { Frigate/ } \\
\text { pink (LC) } \\
349 \text { tons }\end{array}$ & $\begin{array}{l}\text { Jan Mayen } \\
\text { Spitsbergen }\end{array}$ & \begin{tabular}{|l} 
Visser paid $f 6,635$ \\
for vessel at auction, \\
26 Jan., Amsterdam. \\
4 whales; \\
130 seals \\
\\
Combined results: \\
100, ooo steekannen \\
of oil (about 8,333 \\
kwartelen of oil); \\
5,500 pounds of \\
baleen; 8oo seal furs
\end{tabular} & 4 whales & $\begin{array}{l}\text { Handelsblad, } 26 \text { Jan. } \\
\text { 1835; J. van Sluijs, } \\
\text { Nederlandse Koop- } \\
\text { vaardijschepen } 1800- \\
\text { 186o (n.p. n.d.), 43, } \\
\text { 16; Leeuwarder } \\
\text { Courant, } 3 \text { April } \\
\text { 1838; Leeuwarder } \\
\text { Courant, } 31 \text { July } 1838 \text {; } \\
\text { Leeuwarder Courant, } \\
\text { 2 July } 1839 ; \\
\text { Leeuwarder Courant, } \\
2 \text { October } 1838\end{array}$ \\
\hline \multirow[t]{2}{*}{1839} & $\begin{array}{l}\text { Rickmers, } \\
\text { Hendrik } \\
\text { Dep. 10 March; } \\
\text { Ret. 4 August } \\
\text { (147 days) }\end{array}$ & $\begin{array}{l}\text { Spitsbergen } \\
\text { (II) }\end{array}$ & $\begin{array}{l}\text { Bark } \\
251 \text { tons }\end{array}$ & $\begin{array}{l}\text { Jan Mayen } \\
\text { Spitsbergen }\end{array}$ & & $\begin{array}{l}252 \text { seals; } \\
2 \text { narwals }\end{array}$ & $\begin{array}{l}\text { Leeuwarder } \\
\text { Courant, } 19 \text { March } \\
1839 ; \text { Leeuwarder } \\
\text { Courant, } 13 \text { August } \\
\text { 1839; Ship's journal, } \\
\text { Friesenmuseum, } \\
\text { Wyk auf Föhr }\end{array}$ \\
\hline & $\begin{array}{l}\text { Rickmers, } \\
\text { Hendrik B. } \\
\text { Dep. } 8 \text { March; } \\
\text { Ret. } 4 \text { August. } \\
\text { (149 days) }\end{array}$ & Dirkje Adema & $\begin{array}{l}\text { Frigate/ } \\
\text { pink } \\
349 \text { tons }\end{array}$ & $\begin{array}{l}\text { Jan Mayen } \\
\text { Spitsbergen }\end{array}$ & $\begin{array}{l}\text { Combined results: } \\
1 \text { small whale; } \\
1, \text { ooo seals. } \\
\text { Bad catch; premium } \\
\text { for wanvangst }\end{array}$ & $\begin{array}{l}\text { [1 whale; } \\
450 \text { seals] }\end{array}$ & $\begin{array}{l}\text { Leeuwarder } \\
\text { Courant, } 19 \text { March } \\
1839 ; \text { Leeuwarder } \\
\text { Courant, } 13 \text { August } \\
1839 ; \text { Leeuwarder } \\
\text { Courant, 14 July } \\
\text { 1840; Ship's journal, } \\
\text { Friesenmuseum, } \\
\text { Wyk auf Föhr }\end{array}$ \\
\hline 1840 & $\begin{array}{l}\text { Rickmers, } \\
\text { Hendrik } \\
\text { Dep. 17 March; } \\
\text { Ret. 8 Aug. } \\
\text { (144 days) }\end{array}$ & $\begin{array}{l}\text { Spitsbergen } \\
\text { (II) }\end{array}$ & $\begin{array}{l}\text { Bark } \\
251 \text { tons }\end{array}$ & $\begin{array}{l}\text { Jan Mayen } \\
\text { Spitsbergen }\end{array}$ & & 1,186 seals & $\begin{array}{l}\text { Leeuwarder } \\
\text { Courant, } 17 \text { March } \\
\text { 1840; Leeuwarder } \\
\text { Courant, } 11 \text { August } \\
\text { 1840; Ship's journal, } \\
\text { Friesenmuseum, } \\
\text { Wyk auf Föhr (11 } \\
\text { March-6 August) }\end{array}$ \\
\hline
\end{tabular}


Nineteenth-Century Dutch Whaling and Sealing in the Arctic (1815-1885)

\begin{tabular}{|c|c|c|c|c|c|c|c|}
\hline Year & Master & Ship's name & Type & Destination & Results/remarks & FM & Sources \\
\hline & $\begin{array}{l}\text { Rickmers, } \\
\text { Hendrik B. } \\
\text { Dep. 11 March; } \\
\text { Ret. 10 August } \\
\text { (152 days) }\end{array}$ & Dirkje Adema & $\begin{array}{l}\text { Frigate/ } \\
\text { pink } \\
349 \text { tons }\end{array}$ & $\begin{array}{l}\text { Jan Mayen } \\
\text { Spitsbergen }\end{array}$ & $\begin{array}{l}\text { 1,80o seals. Bad } \\
\text { catch; premium for } \\
\text { wanvangst }\end{array}$ & [6oo seals] & $\begin{array}{l}\text { Leeuwarder } \\
\text { Courant, } 17 \text { March } \\
1840 ; \text { Leeuwarder } \\
\text { Courant, } 18 \text { August } \\
1840\end{array}$ \\
\hline 1841 & $\begin{array}{l}\text { Rickmers, } \\
\text { Hendrik } \\
\text { Dep. 9 March; } \\
\text { Ret. 27 July } \\
\text { (140 days) }\end{array}$ & $\begin{array}{l}\text { Spitsbergen } \\
\text { (II) }\end{array}$ & $\begin{array}{l}\text { Bark } \\
251 \text { tons }\end{array}$ & Spitsbergen & & & $\begin{array}{l}\text { Leeuwarder } \\
\text { Courant, } 16 \text { March } \\
\text { 1841; Leeuwarder } \\
\text { Courant, } 3 \text { August }\end{array}$ \\
\hline 1841 & $\begin{array}{l}\text { Mehlen, O. } \\
\text { Dep. 9 March; } \\
\text { Ret. 27 July } \\
\text { (140 days) }\end{array}$ & Dirkje Adema & $\begin{array}{l}\text { Frigate/ } \\
\text { pink } \\
349 \text { tons }\end{array}$ & Spitsbergen & & & $\begin{array}{l}\text { Leeuwarder } \\
\text { Courant, } 16 \text { March } \\
1841 ; \text { Leeuwarder } \\
\text { Courant, } 3 \text { August } \\
1841\end{array}$ \\
\hline \multirow[t]{2}{*}{1842} & $\begin{array}{l}\text { Both. J. } \\
\text { Dep. 10 March; } \\
\text { Ret. ? }\end{array}$ & $\begin{array}{l}\text { Spitsbergen } \\
\text { (II) }\end{array}$ & $\begin{array}{l}\text { Bark } \\
251 \text { tons }\end{array}$ & Spitsbergen & $\begin{array}{l}\text { No bad results; total } \\
\text { catch } 8,700 \text { seals; } \\
\text { whale fishery failed }\end{array}$ & & $\begin{array}{l}\text { Leeuwarder } \\
\text { Courant, } 22 \text { March } \\
\text { 1842; Leeuwarder } \\
\text { Courant, } 11 \text { July } 1843\end{array}$ \\
\hline & $\begin{array}{l}\text { Mehlen, O. } \\
\text { Dep. 10 March; } \\
\text { Ret. ? }\end{array}$ & Dirkje Adema & $\begin{array}{l}\text { Frigate/ } \\
\text { pink } \\
349 \text { tons }\end{array}$ & Spitsbergen & & & $\begin{array}{l}\text { Leeuwarder } \\
\text { Courant, } 22 \text { March } \\
1842\end{array}$ \\
\hline \multirow[t]{2}{*}{1843} & $\begin{array}{l}\text { Both, Johan } \\
\text { Dep. 5 March; } \\
\text { Ret. 6 August } \\
\text { (154 days) }\end{array}$ & $\begin{array}{l}\text { Spitsbergen } \\
\text { (II) }\end{array}$ & $\begin{array}{l}\text { Bark } \\
251 \text { tons }\end{array}$ & Spitsbergen & & & $\begin{array}{l}\text { Leeuwarder } \\
\text { Courant, } 14 \text { March } \\
1843 ; \text { Leeuwarder } \\
\text { Courant, } 15 \text { August } \\
1843\end{array}$ \\
\hline & $\begin{array}{l}\text { Mehlen, O. } \\
\text { Dep. ?; } \\
\text { Ret. 30 July }\end{array}$ & Dirkje Adema & $\begin{array}{l}\text { Frigate/ } \\
\text { pink } \\
349 \text { tons }\end{array}$ & Spitsbergen & & & $\begin{array}{l}\text { Leeuwarder } \\
\text { Courant, } 8 \text { August } \\
1843\end{array}$ \\
\hline \multirow[t]{2}{*}{1844} & $\begin{array}{l}\text { Both. J. } \\
\text { Dep. } 8 \text { March; } \\
\text { Ret. 31 July }\end{array}$ & $\begin{array}{l}\text { Spitsbergen } \\
\text { (II) }\end{array}$ & $\begin{array}{l}\text { Bark } \\
251 \text { tons }\end{array}$ & Spitsbergen & 450 seals & & $\begin{array}{l}\text { Leeuwarder } \\
\text { Courant, } 12 \text { April } \\
\text { 1844; Leeuwarder } \\
\text { Courant, } 6 \text { August } \\
\text { 1844; typoscript A.J. } \\
\text { Dijkstra }\end{array}$ \\
\hline & $\begin{array}{l}\text { Mehlen, O. } \\
\text { Dep. } 8 \text { March; } \\
\text { Ret. 27 July }\end{array}$ & Dirkje Adema & $\begin{array}{l}\text { Frigate/ } \\
\text { pink } \\
349 \text { tons }\end{array}$ & Spitsbergen & & & $\begin{array}{l}\text { Leeuwarder Courant, } \\
12 \text { April } 1844 \text {; } \\
\text { Leeuwarder Courant, } \\
\text { 30 July } 1844\end{array}$ \\
\hline \multirow[t]{2}{*}{1845} & $\begin{array}{l}\text { Both. J. } \\
\text { Dep. 1 April; } \\
\text { Ret. 13 August }\end{array}$ & $\begin{array}{l}\text { Spitsbergen } \\
\text { (II) }\end{array}$ & $\begin{array}{l}\text { Bark } \\
251 \text { tons }\end{array}$ & Spitsbergen & 1,934 seals/1 whale & & $\begin{array}{l}\text { Leeuwarder Courant, } \\
8 \text { April } 1845 ; \\
\text { Leeuwarder Courant, } \\
19 \text { August } 1845 ; \\
\text { Leeuwarder Courant, } \\
14 \text { July } 1846\end{array}$ \\
\hline & $\begin{array}{l}\text { Mehlen, O. } \\
\text { Dep. } 1 \text { April; } \\
\text { Ret. } 6 \text { August }\end{array}$ & Dirkje Adema & $\begin{array}{l}\text { Frigate/ } \\
\text { pink } \\
349 \text { tons }\end{array}$ & Spitsbergen & $\begin{array}{l}2,076 \text { seals/ } \\
8 \text { very small whales }\end{array}$ & & $\begin{array}{l}\text { Leeuwarder Courant, } \\
8 \text { April } 1845 \text {; } \\
\text { Leeuwarder Courant, } \\
12 \text { August } 1845 \text {; typo- } \\
\text { script A.J. Dijkstra }\end{array}$ \\
\hline 1846 & $\begin{array}{l}\text { Both. J. } \\
\text { Dep. } 3 \text { March; } \\
\text { Ret. } 2 \text { August }\end{array}$ & $\begin{array}{l}\text { Spitsbergen } \\
\text { (II) }\end{array}$ & $\begin{array}{l}\text { Bark } \\
251 \text { tons }\end{array}$ & $\begin{array}{l}\text { Jan Mayen } \\
\text { Spitsbergen }\end{array}$ & $\begin{array}{l}<100 \text { barrels of } \\
\text { blubber/ } \\
300 \text { à } 400 \text { seals }\end{array}$ & & $\begin{array}{l}\text { Leeuwarder Courant, } \\
\text { 1o March 1846; } \\
\text { Leeuwarder Courant, } \\
\text { 19 July 1847; C. } \\
\text { Nielsen, 'Uit de } \\
\text { geschiedenis van de } \\
\text { Harlinger walvis- } \\
\text { vaart', 25; Ship's } \\
\text { journal, Friesenmu- } \\
\text { seum, Wyk auf Föhr }\end{array}$ \\
\hline
\end{tabular}




\begin{tabular}{|c|c|c|c|c|c|c|c|}
\hline Year & Master & Ship's name & Type & Destination & Results/remarks & FM & Sources \\
\hline & $\begin{array}{l}\text { Mehlen, O. } \\
\text { Dep. } 3 \text { March; } \\
\text { Ret. 28 July }\end{array}$ & Dirkje Adema & $\begin{array}{l}\text { Frigate/ } \\
\text { pink } \\
349 \text { tons }\end{array}$ & $\begin{array}{l}\text { Jan Mayen } \\
\text { Spitsbergen }\end{array}$ & 300 à 400 seals & & $\begin{array}{l}\text { Leeuwarder Courant, } \\
\text { 10 March } 1846 \text {; } \\
\text { Leeuwarder Courant, } \\
4 \text { August } 1846\end{array}$ \\
\hline \multirow[t]{2}{*}{1847} & $\begin{array}{l}\text { Both. J. } \\
\text { Dep. } 2 \text { March; } \\
\text { Ret. 31 July }\end{array}$ & $\begin{array}{l}\text { Spitsbergen } \\
\text { (II) }\end{array}$ & $\begin{array}{l}\text { Bark } \\
251 \text { tons }\end{array}$ & $\begin{array}{l}\text { Jan Mayen } \\
\text { Spitsbergen }\end{array}$ & $1 / 2$ whale; 5,500 seals & $\begin{array}{l}1 / 2 \text { whale; } \\
4,938 \text { seals }\end{array}$ & $\begin{array}{l}\text { Leeuwarder Courant, } \\
9 \text { March 1847; } \\
\text { Leeuwarder Courant, } \\
\text { 10 August 1847; } \\
\text { Ship's journal, } \\
\text { Friesenmuseum, } \\
\text { Wyk auf Föhr }\end{array}$ \\
\hline & $\begin{array}{l}\text { Mehlen, O. } \\
\text { Dep. } 8 \text { February; } \\
\text { Ret. } 11 \text { August }\end{array}$ & Dirkje Adema & $\begin{array}{l}\text { Frigate } \\
349 \text { tons }\end{array}$ & $\begin{array}{l}\text { Jan Mayen } \\
\text { Spitsbergen }\end{array}$ & 8,900 seals & & $\begin{array}{l}\text { Leeuwarder Courant, } \\
9 \text { March } 1847 \text {; } \\
\text { Leeuwarder Courant, } \\
\text { 20 July } 1847 \text {; } \\
\text { Leeuwarder Courant, } \\
11 \text { July } 1848 \text { (gover- } \\
\text { nor's annual report, } \\
\text { p. } 37 \text { ) }\end{array}$ \\
\hline \multirow[t]{2}{*}{1848} & $\begin{array}{l}\text { Both. J. } \\
\text { Dep. } 6 \text { March; } \\
\text { Ret. 11 August }\end{array}$ & $\begin{array}{l}\text { Spitsbergen } \\
\text { (II) }\end{array}$ & $\begin{array}{l}\text { Bark } \\
251 \text { tons }\end{array}$ & $\begin{array}{l}\text { Jan Mayen } \\
\text { Spitsbergen }\end{array}$ & $\begin{array}{l}1 \text { barrel of blubber } \\
\text { (yielding } 73 / 100 \text { of a } \\
\text { kwarteel) }\end{array}$ & $?$ & $\begin{array}{l}\text { GAH, 1648: fol. 125, } \\
\text { reg. nr. 1037 (25 Au- } \\
\text { gust 1848); Ship's } \\
\text { journal, Friesenmu- } \\
\text { seum, Wyk auf Föhr }\end{array}$ \\
\hline & $\begin{array}{l}\text { Mehlen, O. } \\
\text { Dep.; } \\
\text { Ret. 30 July }\end{array}$ & Dirkje Adema & $\begin{array}{l}\text { Frigate } \\
349 \text { tons }\end{array}$ & $\begin{array}{l}\text { Jan Mayen } \\
\text { Spitsbergen }\end{array}$ & $\begin{array}{l}4 \text { barrels of blubber } \\
\text { (yielding } 11^{1 / 2} \\
\text { kwartelen of oil) }\end{array}$ & & $\begin{array}{l}\text { Leeuwarder Courant, } \\
8 \text { August } 1848 \\
\text { ('empty'); GAH, } \\
\text { 1648: fol. 125, reg. nr. } \\
991 \text { (12 August 1848) }\end{array}$ \\
\hline \multirow[t]{2}{*}{1849} & $\begin{array}{l}\text { Both. J. } \\
\text { Dep. ?; } \\
\text { Ret.? }\end{array}$ & $\begin{array}{l}\text { Spitsbergen } \\
\text { (II) }\end{array}$ & $\begin{array}{l}\text { Bark } \\
251 \text { tons }\end{array}$ & $\begin{array}{l}\text { Jan Mayen } \\
\text { Spitsbergen }\end{array}$ & $\begin{array}{l}\text { 70o seals; } 17 \text { barrels } \\
\text { of blubber (yielding } \\
\text { 40 kwartelen } \text { of oil) }\end{array}$ & & $\begin{array}{l}\text { typoscript A.J. Dijk- } \\
\text { stra; GAH, 1442: reg. } \\
\text { nr. } 987 \text { (18 August } \\
1849)\end{array}$ \\
\hline & $\begin{array}{l}\text { Mehlen, O. } \\
\text { Dep. ?; } \\
\text { Ret. ? }\end{array}$ & Dirkje Adema & $\begin{array}{l}\text { Frigate } \\
349 \text { tons }\end{array}$ & $\begin{array}{l}\text { Jan Mayen } \\
\text { Spitsbergen }\end{array}$ & $\begin{array}{l}\text { 1,10o seals; } 24 \text { bar- } \\
\text { rels of blubber } \\
\text { (yielding } 64 \text { kwarte- } \\
\text { len of oil) }\end{array}$ & & $\begin{array}{l}\text { typoscript A.J. Dijk- } \\
\text { stra; GAH, 1442: reg. } \\
\text { nr. } 987 \text { (18 August } \\
1849)\end{array}$ \\
\hline \multirow[t]{2}{*}{1850} & $\begin{array}{l}\text { Nagel, P. } \\
\text { Dep. ?; } \\
\text { Ret.? }\end{array}$ & Spitsbergen & $\begin{array}{l}\text { Bark } \\
251 \text { tons }\end{array}$ & $?$ & $\begin{array}{l}\text { 4,ooo seals/ } \\
1 \text { whale (?) }\end{array}$ & & $\begin{array}{l}\text { typescript A.J. Dijk- } \\
\text { stra }\end{array}$ \\
\hline & $\begin{array}{l}\text { Mehlen, O. } \\
\text { Dep. ?; } \\
\text { Ret.? }\end{array}$ & Dirkje Adema & $\begin{array}{l}\text { Frigate } \\
349 \text { tons }\end{array}$ & $?$ & 9,ooo seals & & $\begin{array}{l}\text { typoscript A.J. Dijk- } \\
\text { stra }\end{array}$ \\
\hline \multirow[t]{2}{*}{1851} & $\begin{array}{l}\text { Nagel, P. } \\
\text { Dep. ?; } \\
\text { Ret.? }\end{array}$ & $\begin{array}{l}\text { Spitsbergen } \\
\text { (II) }\end{array}$ & $\begin{array}{l}\text { Bark } \\
251 \text { tons }\end{array}$ & $?$ & $\begin{array}{l}900 \text { seals; } 27 \text { barrels } \\
\text { of blubber (yielding } \\
58^{178} / 233 \text { kwartelen of } \\
\text { oil) }\end{array}$ & & $\begin{array}{l}\text { typoscript A.J. Dijk- } \\
\text { stra; GAH, 1444; } \\
\text { reg. nr. } 849 \text { (21 Au- } \\
\text { gust 1851) }\end{array}$ \\
\hline & $\begin{array}{l}\text { Mehlen, O. } \\
\text { Dep.?; } \\
\text { Ret.? }\end{array}$ & Dirkje Adema & $\begin{array}{l}\text { Frigate } \\
349 \text { tons }\end{array}$ & $?$ & 3,500 seals/ 1 whale & & $\begin{array}{l}\text { typoscript A.J. Dijk- } \\
\text { stra }\end{array}$ \\
\hline \multirow[t]{2}{*}{1852} & $\begin{array}{l}\text { Stockfleth, H. } \\
\text { [sic] } \\
\text { Dep. ?; } \\
\text { Ret.? }\end{array}$ & $\begin{array}{l}\text { Spitsbergen } \\
\text { (II) }\end{array}$ & $\begin{array}{l}\text { Bark } \\
251 \text { tons }\end{array}$ & $?$ & $\begin{array}{l}23 \text { barrels of blubber } \\
\text { (yielding } 49 \text { kwarte- } \\
\text { len of oil) }\end{array}$ & & $\begin{array}{l}\text { GAH, 1445: reg. nr. } \\
817 \text { (18 August 1852) }\end{array}$ \\
\hline & $\begin{array}{l}\text { Mehlen, O. } \\
\text { Dep. ?; } \\
\text { Ret. ? }\end{array}$ & Dirkje Adema & $\begin{array}{l}\text { Frigate } \\
349 \text { tons }\end{array}$ & $?$ & $\begin{array}{l}11 \text { barrels of blubber } \\
\text { (yielding } 34^{1} \frac{2}{2} \text { barrel } \\
\text { of oil) }\end{array}$ & & $\begin{array}{l}\text { GAH, 1445: reg. nr. } \\
817 \text { (18 August 1852) }\end{array}$ \\
\hline
\end{tabular}


Nineteenth-Century Dutch Whaling and Sealing in the Arctic (1815-1885)

\begin{tabular}{|c|c|c|c|c|c|c|c|}
\hline Year & Master & Ship's name & Type & Destination & Results/remarks & FM & Sources \\
\hline \multirow[t]{2}{*}{1853} & $\begin{array}{l}\text { Stockfleth, H. } \\
\text { Dep.?; } \\
\text { Ret.? }\end{array}$ & $\begin{array}{l}\text { Spitsbergen } \\
\text { (II) }\end{array}$ & $\begin{array}{l}\text { Bark } \\
251 \text { tons }\end{array}$ & $?$ & $\begin{array}{l}9,000 \text { seals; } \\
29 \text { June } 1853 \text { sold for } \\
\text { f5,0oo to Reindert } \\
\text { Jans Zeilmaker \& } \\
\text { Company at auc- } \\
\text { tion in Harlingen; } \\
\text { re-named Triton }\end{array}$ & & $\begin{array}{l}\text { typescript A.J. Dijk- } \\
\text { stra; S. Zeeman, } \\
\text { 'Harlingen en de } \\
\text { walvisvaart', } 19\end{array}$ \\
\hline & $\begin{array}{l}\text { Mehlen, O. } \\
\text { Dep. ?; } \\
\text { Ret.? }\end{array}$ & Dirkje Adema & $\begin{array}{l}\text { Frigate } \\
349 \text { tons }\end{array}$ & $?$ & 4,500 seals & & $\begin{array}{l}\text { typescript A.J. Dijk- } \\
\text { stra }\end{array}$ \\
\hline 1854 & $\begin{array}{l}\text { Mehlen, O. } \\
\text { Dep.? } \\
\text { Ret.? }\end{array}$ & Dirkje Adema & $\begin{array}{l}\text { Frigate } \\
349 \text { tons }\end{array}$ & $?$ & $\begin{array}{l}6 \text { barrels of blubber } \\
\text { (yielding } 1769 / 233 \\
\text { kwartelen of oil) }\end{array}$ & & $\begin{array}{l}\text { The Governor's an- } \\
\text { nual report printed } \\
\text { in Leeuwarder } \\
\text { Courant, } 6 \text { July } 1855 \\
\text { does not refer to any } \\
\text { whaling activities; } \\
\text { GAH, 1448/1449: } \\
\text { reg. nr. } 850 \text { (14 Au- } \\
\text { gust } 1854 \text { ) }\end{array}$ \\
\hline 1855 & $\begin{array}{l}\text { Mehlen, O. } \\
\text { Dep. ?; } \\
\text { Ret. 30 July }\end{array}$ & Dirkje Adema & $\begin{array}{l}\text { Frigate } \\
349 \text { tons }\end{array}$ & $?$ & $\begin{array}{l}\text { Returned with liv- } \\
\text { ing polar bear; } 4 \\
\text { barrels of blubber } \\
\text { (yielding } 7219 / 233 \\
\text { kwartelen of oil) }\end{array}$ & & $\begin{array}{l}\text { typescript A.J. Dijk- } \\
\text { stra; GAH, 145o: reg. } \\
\text { nr. } 928 \text { (25 August } \\
\text { 1855) }\end{array}$ \\
\hline 1856 & $\begin{array}{l}\text { Mehlen, O. } \\
\text { Dep. ?; } \\
\text { Ret. 19 July } \\
\end{array}$ & Dirkje Adema & $\begin{array}{l}\text { Frigate } \\
349 \text { tons }\end{array}$ & $?$ & & & \\
\hline 1857 & $\begin{array}{l}\text { Mehlen, O. } \\
\text { Dep. ?; } \\
\text { Ret. } 26 \text { July }\end{array}$ & Dirkje Adema & $\begin{array}{l}\text { Frigate } \\
349 \text { tons }\end{array}$ & $?$ & 1,300 seals & & $\begin{array}{l}\text { typescript A.J. Dijk- } \\
\text { stra }\end{array}$ \\
\hline 1858 & $\begin{array}{l}\text { Mehlen, O. } \\
\text { Dep. 10 March; } \\
\text { Ret. 24 July }\end{array}$ & Dirkje Adema & $\begin{array}{l}\text { Frigate } \\
349 \text { tons }\end{array}$ & $?$ & 100 seals & & $\begin{array}{l}\text { Harlinger Courant, } \\
4 \text { March 1858; Idem, } \\
27 \text { July 1858; C. de } \\
\text { Jong, 'De Dirkje } \\
\text { Adema', 42; type- } \\
\text { script A.J. Dijkstra; } \\
\text { C. Nielsen, 'Uit de } \\
\text { geschiedenis van de } \\
\text { Harlinger walvis- } \\
\text { vaart', } 25\end{array}$ \\
\hline 1859 & $\begin{array}{l}\text { Brinkmann, C. } \\
\text { Dep. 20 February; } \\
\text { Ret. 27 July }\end{array}$ & Dirkje Adema & $\begin{array}{l}\text { Frigate } \\
349 \text { tons }\end{array}$ & $?$ & 1,000 seals & & $\begin{array}{l}\text { Harlinger Courant, } \\
23 \text { February } 1859 ; \\
\text { typescript A.J. Dijk- } \\
\text { stra erroneously } \\
\text { mentioned } 27 \text { Au- } \\
\text { gust as date of re- } \\
\text { turn }\end{array}$ \\
\hline 1860 & $\begin{array}{l}\text { Wildst, H. } \\
\text { Dep. ?; } \\
\text { Ret. 11 July }\end{array}$ & Dirkje Adema & $\begin{array}{l}\text { Frigate } \\
349 \text { tons }\end{array}$ & $?$ & $\begin{array}{l}\text { Seals and two polar } \\
\text { bears }\end{array}$ & & $\begin{array}{l}\text { typescript A.J. Dijk- } \\
\text { stra }\end{array}$ \\
\hline 1861 & $\begin{array}{l}\text { Wildst, H. } \\
\text { Dep. ? } \\
\text { Ret. 28 July }\end{array}$ & Dirkje Adema & $\begin{array}{l}\text { Frigate } \\
349 \text { tons }\end{array}$ & $?$ & $\begin{array}{l}560 \text { seals } / 100 \\
k \text { wartelen of seal } \\
\text { blubber }\end{array}$ & & $\begin{array}{l}\text { Wumkes, Tusschen } \\
\text { Flie en Borne, 10o; } \\
\text { typoscript A.J. Dijk- } \\
\text { stra }\end{array}$ \\
\hline 1862 & $\begin{array}{l}\text { Wildst, H. } \\
\text { Dep. ?; } \\
\text { Ret. } 8 \text { July }\end{array}$ & Dirkje Adema & $\begin{array}{l}\text { Frigate } \\
349 \text { tons }\end{array}$ & $?$ & $\begin{array}{l}>400 \text { seals; } \\
2,300 \text { young/ } \\
500 \text { adults }\end{array}$ & & $\begin{array}{l}\text { C. Nielsen, 'Uit de } \\
\text { geschiedenis van de } \\
\text { Harlinger walvis- } \\
\text { vaart', } 25\end{array}$ \\
\hline
\end{tabular}




\begin{tabular}{|l|l|l|l|l|l|l|l|}
\hline Year & Master & Ship's name & Type & Destination & Results/remarks & FM & Sources \\
\hline 1863 & $\begin{array}{l}\text { Wildst, H. } \\
\text { Dep. ?; } \\
\text { Ret. 5 July }\end{array}$ & Dirkje Adema & $\begin{array}{l}\text { Frigate } \\
349 \text { tons }\end{array}$ & $?$ & 900 seals & & $\begin{array}{l}\text { typescript A.J. Dijk- } \\
\text { stra. Last voyage. } \\
\text { Sold to Norway in } \\
\text { 1864 for f9,00o; ran } \\
\text { aground near Ger- } \\
\text { man island of Rü- } \\
\text { gen, 1865. J. van } \\
\text { Sluis, Koopvaardij- } \\
\text { schepen, 80 }\end{array}$ \\
\hline Total & & & & $\begin{array}{l}\text { About 70,400 seals; } \\
\text { circa 13 whales; cir- } \\
\text { ca. 10o barrels of } \\
\text { blubber }\end{array}$ & \\
\hline
\end{tabular}

\section{Harlingen: Zeilmaker \& Company}

Barend Visser was not the only Frisian entrepreneur involved in Arctic expeditions. From the last decades of the eighteenth century onward, Visser's whaleships left Harlingen for Greenland in the company of ships fitted out by the Harlingen-based firm of Reindert Jans Zeilmaker. During the last fifty years of the nineteenth century Visser and Zeilmaker rapidly became the two largest shipping companies in Harlingen, with Zeilmaker in the lead from 1861 onwards. Until about 1870, Zeilmaker annually operated between 11 and 13 ships on average, and continued to do so until $1886 .{ }^{354}$

In 1853, Zeilmaker \& Company purchased Barend Visser's brig Spitsbergen (II) at auction in Amsterdam. Having paid $f_{5}, 000$ for this vessel, the company hired a Norwegian crew under command of Captain Stockfleet, had the ship operate from Norway, and concentrated on sealing and not at all on whaling. In this way, Zeilmaker may have tried to counter-balance the drastic reduction (and eventual abolishment in 1855) of governmental support by way of premiums. ${ }^{355}$

Zeilmaker repeated this strategy - operating a ship under the Dutch flag but departing from Norwegian ports with Norwegian crew - with the large three-mast ship Noordpool (ex-Cameleon). Built in 1850, this large vessel (447 tons) was added to the Zeilmaker fleet around 1858. C. Koch (also spelled Kok) remained its Captain until 1864. The Zeilmaker Company appointed Captain N. Knudsen as commander of Noordpool and Knudsen made his first voyage for the Dutch company in 1865. As of 1866, the ship disappeared from the lists of ships compiled by Sweijs. ${ }^{356}$ In February and July of 1859 , however, the vessel is mentioned in two instances. In the Harlinger Courant, on 7 February 1859, Noordpool departed from Harlingen harbour and, almost $5^{\frac{1}{2}}$

354. See Sweijs, 1853-1886.

355. S. Zeeman, 'Harlingen en de walvisvaart', 19.

356. Sweijs, 1865,58 . 
months later, the newspaper mentioned the vessel as the Norwegian ship Noordpool, thus suggesting the presence of the Norwegian flag, or at least Norwegian registry. After having discharged its cargo of seals in Harlingen, Noordpool apparently continued its voyage to Tønsberg to winter over. ${ }^{357}$ There is no data concerning catches. The following week the Harlinger Courant provided another interesting bit of information concerning whaling and sealing. Earlier that week, on 24 July, the ship Eger (nationality unspecified), with Captain H. Murk arrived in Harlingen with a cargo of seal blubber. ${ }^{358}$ Could it be that as of 1859 , Norwegians had found new markets for their whale and seal products in the Netherlands?

When Dirkje Adema was taken out of service, it did not mean the close of Frisian participation in whaling and sealing in Arctic waters. The very nature of the operation, however, had changed from a relatively transparent, locally-organised business into a manifestation of fairly complex international entrepreneurship. While the catches from the Arctic were still transported to Harlingen, Zeilmakers crew and equipment came from Norway and their vessel Noordpool had its home port alternately in either Tønsberg or Sandefjord (Norway), not in Harlingen or another Dutch harbour.

\section{Purmerend: Nicolaas Brantjes \& Smit (1851-1885)}

Another firm interested in whaling and sealing in the Arctic was Nicolaas Brantjes \& Smit in Purmerend, a town located about 20 kilometres north of Amsterdam. ${ }^{359}$ Nicolaas Brantjes (1793-1862) was an important shipowner and merchant in whale oil. Brantjes also imported timber from Norway and the Baltic, and operated sawmills. ${ }^{360}$ In 1813, Brantjes married Maria Stuijt. ${ }^{361}$

During the 1850 and 1860 on only two ships were equipped for seal hunting near the island of Jan Mayen. Customarily these ships carried a crew of between 40 and 45

357. Harlinger Courant, 9 February and 20 July 1859.

358. Harlinger Courant, 27 February 1859.

359. On Brantjes \& Smit, see De Jong, Oude Nederlandse walvisvaart, II, 461-462.

360. For more information about the firm of Brantjes see J. Otsen, 'Cement in Purmerend. Van schelpzandmolen tot portlandcementfabriek (1646-189o)', Nederlandse Historiën, vol. 27, no. 6 (December 1993), 129 passim.

361. Two girls, Margaretha Johanna and Maria Anna were born. Through their respective marriages with affluent parties, the two daughters increased the influence of the Brantjes family on local trade. Their oldest daughter Margaretha Johanna married Hendricus Johannes Conijn, ship owner and timber merchant in the city of Alkmaar. Maria Anna, the second daughter, married Pieter Adrianus van de Drift, merchant, rope manufacturer, ship owner, and importer and exporter of wine. Van der Drift lived in the city of Alkmaar as well. Brantjes' wife Maria outlived all three and she died in 1873. See: home.tiscali.nl/ ti128393/conijn/647.htm - 3k. Nicolaas Brantjes and P.A. van de Drift co-operated in maritime activities. Between 1858 and 1867, with a very brief interval, they owned the clipperbark Argonaut. J. van Sluijs, Lijst van Nederlandse reders, ca. 1800 1890 (n.p. 1935-1955), 51. Idem, Koopvaardijschepen, 119. 
hands. The vessels left the Netherlands in late February to return some time in late June or early July. In 1851 the ship Martha set sail on its maiden voyage to Arctic waters. In 1857 the ship was sold to Norway. The second vessel in Brantjes' fleet, Maria, explored the waters in high northern latitudes for the first time in 1854 and its timing was bad. During the very first decades of the nineteenth century the Dutch government had provided premiums, however, these premiums were rapidly reduced and subsequently abandoned between 1851 and 1855 . As a result the costs of organizing whaling or sealing expeditions increased dramatically during the second half of the 1850 .

The 1877 issue of the Staatkundig en staathuishoudkundig jaarboekje contained an overview of catches between 1855 and 1874 (see Table 4.7). This source also provided the gross revenues and will be discussed in Chapter $7 .{ }^{362}$ The seals were transported from the Arctic waters to the cookery near Purmerend, which is located on the Nekkervaart along the Noordhollands Kanaal. This cookery was established in 1850 and continued until around $1875 \cdot{ }^{363} \mathrm{~A} . \mathrm{W}$. Stellwagen visited the cookery in 1866 and from his eyewitness account it is known that most of the oil yielded from seals found its way to Germany. The home market, however, also showed interest. ${ }^{364}$

Throughout this long period of twenty years (1855-1874), Brantjes \& Smit continuously transported large quantities of seals. In 1870, 4,700 seals were caught. ${ }^{365} \mathrm{Also}$, Brantjes' crew managed to catch one fin whale. ${ }^{366}$ Catches for 1872 were extraordinarily good, as no less than 13 fin whales were killed. ${ }^{367}$ The two succeeding seasons ( 1873 and 1874), however, were so disappointing that Brantjes decided to keep his ship in port for the 1875 season. Meanwhile, difficulties loomed ahead for seal hunters using Norwegian waters as their whaling grounds. In the Arctic waters, the seal population had been reduced drastically. Hunters had killed increasing numbers of very young seals, threatening the future of their own industry. The scale on which seals were caught reached enormous proportions, due to (among other factors) the transition from sail to steam propulsion. In order to preserve seal hunting conditions and to prevent the industry from going 'belly up', both the British and the Norwegian governments is-

362. Staatkundig en staathuishoudkundig jaarboekje (1877), 60.

363. For a description of the cookery see both G.J. Honig, 'Purmerenders togen ter walvisvaart', Nieuwe Noordhollandsche Courant, 24 February 1947, and De Jong, Oude Nederlandse walvisvaart, vol. II, 462.

364. A.W. Stellwagen, 'De Noorweegsche visscherijen in de IJszee', Onze Tijd, nieuwe serie, jaargang 7 (1872), deel 1, 71-75; De Jong, ibidem.

365. Ten Brink, Noordpool-visscherij, 9.

366. C.J. Bottemanne, 'Economische nalezingen en berigten. Walvischvangst', J.L. de Bruyn Kops (ed.), De Economist (1872). Part I, 344 .

367. Ibidem. It seems virtually impossible that these fin whales were caught with sailing ships, and not with steam ships. Likewise, however, it seems virtually impossible that our source, Bottemanne, with all his experience, was completely mistaken in his statement. 
sued laws in 1876 that impeded sealers to hunt in the waters near Jan Mayen Island. It was also decided that seal hunting in other areas should not take place before 3 April. ${ }^{368}$ As the Dutch seal hunting industry was dependent upon Norwegian labour and expertise, the Dutch government followed their British and Norwegian counterparts. A number of laws, issued in 1876 and 1877 , restricted Brantjes and others in their catch. ${ }^{369}$

In subsequent years, Maria continued to leave for the seal hunting grounds. The vessel made its last and most profitable whaling and sealing voyage in $1884 .{ }^{370}$ Upon its return, the cargo consisted of no fewer than 7,000 seals. The total revenues were calculated at $f 70,000$. By the mid-188os, however, it had dawned on the Dutch whaling and sealing company that their industry could fully prosper only if they were inclined and prepared to make the transition from sail to steam. Rival companies from abroad had done so at a much earlier stage and the advantages were manifold. In this way, they could shorten their voyages, extend the hunting season, penetrate much further into the icepack, be more flexible when it came to seeking new grounds, and bring in their catches in a much shorter period of time. Brantjes \& Smit would not or could not bring their operations in line with these new technological requirements. This modernisation of the seal hunt was a significant factor that forced the directors to dissolve the firm. ${ }^{371}$

Founder of the company Nicolaas Brantjes, however, did not live to witness the decline. He passed away on 2 November $1869 .{ }^{372}$ Shortly before his death he had been approached by another remarkable Dutch entrepreneur in the sealing and whaling industry, Captain Caspar Josephus Bottemanne. ${ }^{373}$

368. Jan Ström, Norsk fiskeri og fangst handbook (Oslo 1950), vol. I, 853-854; quoted by De Jong, Oude Nederlandse walvisvaart, vol. II, 463.

369. Wet (Law) 31 December 1876. Stated in Staatsblad 1876, no. 289; Koninklijk Besluit 5 February 1877. Stated in Staatsblad 1877, no. 19; Wet (Law) 21 June 1881. Stated in Staatsblad 1881, no. 76. See also Beaujon, Nederlandsche zeevisscherijen, 308-309; De Jong, Oude Nederlandse walvisvaart, II, 463; III, 132 (notes 66-68).

370. Brantjes \& Smit continued to deploy the Maria until 1896.

371. De Jong, idem, II, 462.

372. home.tiscali.nl/ ti128393/conijn/647.htm - 3k.

373. In 1871, around the time they were approached by the Nederlandsche Walvischvaart N.V., the firm of Nicolaas Brantjes owned a fleet of six ships (three barks, two brigs and one three-masted vessel), in total amounting 1,529 lasts (the equivalent of 2,892 tons). The oldest ship in the fleet was built in 1826 (the threemasted Vrede) The youngest ship was Maria (built in 1856), Captain C.M. Brijde. H. Sweijs, Neêrlands vloot en reederijen. Vol. 14 (Rotterdam 1871), 143. 
Table 4.7: Whaling and sealing expeditions to Jan Mayen Island and Spitsbergen fitted out by Nicolaas Brantjes \& Smit (1855-1885). ${ }^{374}$

\begin{tabular}{|c|c|c|c|c|c|}
\hline Year & Master & Ship's name & Type & Catches & Results/remarks \\
\hline 1855 & $?$ & Maria & $\begin{array}{l}\text { Brig } \\
265 \text { tons } \\
\text { Built Gothen- } \\
\text { burg, } 1856\end{array}$ & 1,217 & \\
\hline 1856 & $?$ & Maria & & 5,702 & \\
\hline 1857 & $?$ & Maria & & 4,238 & \\
\hline 1858 & $?$ & Maria & & 3,871 & \\
\hline 1859 & $?$ & Maria & & 1,959 & \\
\hline 1860 & $?$ & Maria & & 415 & \\
\hline 1861 & $?$ & & & & Did not sail \\
\hline 1862 & Andersen, N.A. & Maria & & & $\begin{array}{l}\text { Did not sail; } \\
\text { Based in Tønsberg, Norway }\end{array}$ \\
\hline 1863 & $?$ & Maria & & 3,226 & \\
\hline 1864 & $?$ & Maria & Brig & 819 & Based in Tønsberg, Norway \\
\hline 1865 & Brijder, C.M. & Maria & Brig & 3,018 & Based in Tønsberg, Norway \\
\hline 1866 & $?$ & Maria & & 4,034 & \\
\hline 1867 & $?$ & Maria & & 6,500 & \\
\hline 1868 & $?$ & Maria & & 7,600 & \\
\hline 1869 & $?$ & Maria & & 4,234 & \\
\hline 1870 & $?$ & Maria & Brig & 4,677 & Based in Tønsberg, Norway \\
\hline 1871 & $?$ & Maria & Brig & \begin{tabular}{|l}
7,524 \\
1 fin whale
\end{tabular} & \\
\hline 1872 & $?$ & Maria & Brig & $\begin{array}{l}2,683 \\
13 \text { fin whales }\end{array}$ & \\
\hline 1873 & Larsen. L.A. & Maria & Brig & 323 & Based in Tønsberg, Norway \\
\hline 1874 & $?$ & Maria & & 1,440 & \\
\hline 1884 & Larsen. L.A. & Maria & Brig & 7,000 & $\begin{array}{l}\text { Based in Tønsberg, Norway. } \\
\text { Registered in the Netherlands. } \\
\text { Whaling was discontinued. }\end{array}$ \\
\hline 1885 & Ketelaar, J. & Maria & Brig & & Based in Tønsberg, Norway \\
\hline Total catch & & & & $\begin{array}{l}\text { Ca. } 63,480 \text { seals/ } \\
14 \text { fin whales }\end{array}$ & \\
\hline
\end{tabular}

\section{Rotterdam: Nederlandsche Walvischvaart N.V. (1870-1872)375}

Born in Dordrecht in 1829, Captain Caspar Josephus Bottemanne (1829-1906) started out as a sailor in the merchant marine..$^{376}$ During his service in the East Indies, Bottemanne witnessed many American whalers chasing sperm whales. His interest in whales and whaling must have been conceived in those early years. After receiving his certificate as a mate, Bottemanne signed up as skipper of the two-masted sup-

374. Staatkundig en staathuishoudkundig Jaarboekje (1858), 83; idem (1877), 60; ; Ten Brink, Europeesche Noordpoolvisscherij, 9; De Jong, Oude Nederlandse walvisvaart, vol. II, 461-462. Sweijs, 1855-1885.

375. N.V. stands for 'Naamloze Vennootschap', an indication that this company was a stockholding company issuing shares.

376. For a short biography on Bottemanne see: C. de Jong, 'Twee scheepsjournalen van C.J. Bottemanne 
American whaling station in the Icelandic fjord as well. Thus, Bottemanne entered the service of the firm of Thomas Welcome Roys. The following year (1866), Bottemanne, who was determined to familiarize himself with the whaling practice of the Americans, sailed as a passenger from the River Clyde with Staperaider, operated and owned by Thomas Roys, with C. Fotel of Copenhagen in command. Staperaider headed for Seydisfjördur. Upon his arrival in Iceland, Bottemanne worked at the shore station. Finally, in 1867, Roys withdrew from the station and Bottemanne seized the opportunity and requested that Roys's former business partner Lilliendahl appoint him as the new manager of the station. Lilliendahl responded positively. But Bottemanne's responsibility was not limited to land activities, as Lilliendahl allowed him to hunt whales with Sileno. While serving his masters, Bottemanne trained himself in the use of the bomb harpoon gun, which was invented by Roys and Lilliendahl.

Bottemanne should rightly be considered the first Dutchman involved in modern whaling activities. During the winter of 1866-1867, he was requested to establish a whaling company in the Netherlands. He felt strongly that he was not ready to take on this adventure and had strong doubts about the bomb harpoon gun. Later, in the spring of 1868 , the pendulum had swung to the other side. The previous year Bottemanne had basically run the shore station but encouraged by the technological developments regarding the gun and supported by his increased expertise regarding the fishery, the trying-out and the fabrication of glue from waste material, he tried to establish a company in early 1868 . His attempts to link up with the successful, good-sized company of Nicolaas Brantjes \& Smit in Purmerend turned out to be fruitless. Brantjes declined Bottemanne's offer to cooperate in the establishment of a company geared to hunt the fast fin whales and kill them with the bomb harpoon gun..$^{380}$

Bottemanne single-handedly developed this new prototype of a rocket bomb harpoon gun that fired a projectile from the shoulder, supposedly to hit the whale, and exploded inside it. In their annual report for 1868, the Comité der Nederlandsche Zeevisscherijen (Committee for the Dutch sea fisheries) devoted a few lines to describe the appearance and use of Bottemanne's vuurpijlbomharpoenkanon (rocket bomb harpoon gun). After years of trial and error, the apparatus seemed to have achieved perfection. A harpoon was placed inside a 'colossal gun'. The harpoon, to which a long line was attached, was fired by a vuurpijl (rocket). A bomb was placed inside the hollow harpoon. This bomb, connected to a fuse, would be detonated when the harpoon was fired. This fuse had a specific length, calculated to ignite the bomb when the harpoon entered the whale. The consequent explosion

380. De Jong, Oude Nederlandse walvisvaart, vol. II, 462. 
was supposed to kill the animal instantly. ${ }^{381}$ A specimen of this prototype was recently discovered. ${ }^{382}$

On 16 March 1869, Bottemanne organised a meeting in Rotterdam to provide information about his plans to revive whaling and to attract investors. The meeting took place at the Royal Netherlands Yacht club and his speech was published in an issue of the journal De Economist. ${ }^{383}$ In the speech, he dwelled on the successes of British and American whalers, referred to the abundant presence of Noordkapers (known to Americans as Sulphur bottoms, Bottemanne states) in the waters off Iceland, and explained the technological advantages of the use of the rocket bomb harpoon gun. The annual report on Dutch sea fisheries for 1868 (written in 1869), referred to this meeting and its background. ${ }^{384}$ Emotional and financial support for Bottemanne's initiatives was quite impressive. He had estimated the operational costs of the firm to be around $f 80,000$ and, within a short period of time, he managed to raise $f 100,000$, part of which was designated to the construction of a steam vessel.

In 1870 the Nederlandsche Walvischvaart N.V. was established. ${ }^{385} \mathrm{~A}$ handful of investors from Rotterdam were shareholders. Hendrik Veder and H. van Vollenhove were Directors. ${ }^{386}$ In the new organisational form, shareholders were only responsible to the extent of their share in the company ${ }^{387}$ C.J. Bottemanne was appointed expedition leader.

That same year, the Nederlandsche Walvischvaart N.V. purchased a sailing ship with a steam engine at the British wharf of W.B. Hornby Wellington in Tynemouth, Northumberland. The three-masted Noordkaper carried three whaleboats with each

381. Verslag van den staat der Nederlandsche Zeevisscherij over 1868 ('s-Gravenhage 1869), 53-54.

382. In August of 2005 I visited the storage area of Naturalis, the National History Museum of the Netherlands in Leiden. Amid piles of whale bones and luxury commodities made from whale products, I noticed a bizarre piece of equipment. As it turned out, it was a prototype of Bottemanne's invention, given on loan to Dr. A.B. van Deinse by mrs. C.W. Bottemanne-Dumont. In his time, Van Deinse was a famous cetologist. Thanks are due to René Dekker, Kees van de Blom, and Dr. Nicole de Voogd (Natural History Museum Naturalis in Leiden).

383. C.J. Bottemanne, 'Beschouwingen over de kleine visscherij', J.L. de Bruyn Kops (ed.), De Economist (1870), part I, 113-128.

384. Verslag van den staat der Nederlandsche Zeevisscherijen over 1868 ('s-Gravenhage 1869), 53-54. Thanks are due to Ms. Alex Poldervaart, Curator at the Visserijmuseum in Vlaardingen, who kindly directed me to this source.

385. N.V. stands for Naamloze Vennootschap, and is indicative of a stockholding company. The establishment of stockholding companies experienced a revival during the first half of the nineteenth century. The main difference with a 'partenrederij', where shareholders bought their shares per expedition, was that in former days part-owners were fully liable. See H.J. den Heijer, De geoctrooieerde compagnie: de VOC en de WIC als voorlopers van de naamloze vennootschap (Amsterdam/Deventer 2005).

386. Around this time Veder made his move to whaling and he owned the following vessels: Toma (1852-1853), Twee Gebroeders (1853-1858), Twee Gezusters (1854-1869), Toma (1855-1872), Resident van Rijckevorsel (1856-1871), Jacoba Helena (1858-1875), Hugo Grotius (1860-1866), Sumatra (1865-1871), and, finally, Zuid-Holland. 
to be manned by seven hands. The schooner-rigged auxiliary steamer measured about 150 tons. The vessel was fitted out with a forty- or seventy-horsepower engine and a screw-type propeller. ${ }^{388}$ More importantly, from a technical point of view, the ship also carried try-works on the upper deck to boil down the fat of the catches while being afloat. In this way, Bottemanne could operate his ship in the same way Americans from dozens of ports in the New England and New York area had done for many decades. With a vessel of this kind, the Dutch could deviate from the 'direct return voyage' principle and commence with pelagic whaling. There is no evidence, however, that Bottemanne ever used the furnace for these purposes. On the contrary, he revealed that he felt a land station would be more desirable,

“... for it would enable the steamer to function more efficiently in the variable Icelandic weather". ${ }^{889}$

Noordkaper made three whaling voyages to Iceland and expectations remained higher than the actual catches. Commander Bottemanne kept journals of his expeditions of 1870 and 1871 for the directors and shareholders of the company.

On 24 April 1870, Noordkaper was ready for its first expedition. However, the vessel did not leave Newcastle upon Tyne for Iceland until 5 May. Foul weather rendered the sails useless. Steaming up north, the trip to Seydisfjördur - a distance of about 1,400 kilometres - had taken less than five days. Upon arrival on the whaling grounds, the abundance of whales must have been tantalizing to Bottemanne and his crew but fog, snow, hail, and high seas impeded them from lowering the boats to hunt.

On 1 July, the second mate killed the first whale. This whale, however, sank in 65 fathoms of water. ${ }^{390}$ The crew nevertheless managed to raise the animal and dragged it to Finnafjördur on the northeastern coast of Iceland, where they processed the whale. Due to their inexperience in the flensing and processing, they laboured until the next morning. In his report, Bottemanne was ambiguous about whether or not this trying-out took place on shore or aboard Noordkaper. He does, however, refer to 2 July as one of the days the try-works were in use. ${ }^{391}$

Bottemanne related the problems he had to overcome with the try-works. When the whale oil reached the right temperature to boil, they experienced an 'overboiling'

387. De Jong, Oude Nederlandse walvisvaart, vol. II, 481.

388. Sweijs, 1870, 304 mentioned the iron steamship Noordkaper as being equipped with a forty-horsepower engine. Schmitt et alia, Thomas Welcome Roys, 165, mentioned the much stronger seventy-horsepower engine. 389. See Schmitt et alia, ibidem.

390. It is not clear if Bottemanne referred to a Rijnlandsche fathom (=1.88 metres) or an Amsterdam fathom (= 1.698 metres).

391. For Bottemanne's report on weather conditions and inexperience of his crew see: De Jong, 'Twee scheepsjournalen', 100-110. 
of this hot fluid. At first, the experienced commander assumed the cause was the freshness of the blubber. As it turned out, the problem also occurred when boiling oil from several-days-old whale blubber. ${ }^{392}$

Almost three months after Bottemanne's return in the Netherlands-Noordkaper arrived at the Leuvehaven in Rotterdam on 3 October 1870 - he presented the results of this first voyage to the shareholders in Rotterdam. During the meeting, on 28 December 1870 , the captain displayed a great talent for combining a meticulous sense of mathematics and statistics with a fine feeling for circumstances. In his paper, Bottemanne elaborated extensively on the number of days the first expedition had consumed (150 days in total), how many watches had passed (900), how many of these watches had experienced reasonably good weather $\left(107^{1 / 2}\right)$, how often boats were lowered during these watches with sufficient visibility (during 52 watches), what had happened during the remaining watches with fair weather ( 55 watches: no sightings of whales, night time, or Noordkaper going back and forth for bunkering coal), how many shots were fired, and how successful he and his crew had not been in applying this new technology to the fullest (of 26 shots fired, 17 missed their target, 6 were hits, and 3 exploded before reaching the whales). Of the six whales hit, only one was kept. The other five sunk after being killed and could not be retrieved. Seventy feet long, the whale yielded $77^{1 / 2}$ barrels of oil and 250 kilograms of baleen. ${ }^{393}$ All in all, however, Bottemanne was optimistic in his concluding remarks. An abundance of whales had been sighted off the coast of Iceland, and the new bomb harpoon gun had met all expectations. The Dutchman clearly blamed the failure of the first expedition on two major causes: bad weather conditions and the inexperience of the Dutch crew.

The second journal, issued by Bottemanne in March 1872, related to the whaling expedition of 1871. In many ways the whaling company had adapted the organisation of its activities according to Bottemanne's recommendations, both in terms of crew and whaling technology. Noordkaper left Rotterdam on 3 April 1871 under command of Bottemanne. They first set a course for Lerwick (Shetland Islands) for the mustering of experienced Scottish hands. Three days later, Noordkaper moored on Bressay Sound, just off Lerwick, where they encountered a ferocious storm and almost lost the starboard boat. Moreover, water entered the engine room through the ventilators, causing a fire. ${ }^{394}$ Leaving for Seydisfjördur on 25 April, the ship arrived on the Iceland whaling grounds and cruised there until 27 September.

One of the main problems Bottemanne had encountered but did not manage to

392. C. de Jong, 'Twee scheepsjournalen van C.J. Bottemanne als laatste Nederlandse commandeur ter walvisvangst', Economisch-historisch Jaarboek. Bijdragen tot de economische geschiedenis van Nederland, vol. 30 (Den Haag 1965), 89; 100-101.

393. Idem, 109.

394. Idem, 111, 113 . 
overcome on his first expedition to the Iceland whaling grounds was the great loss of whales shot. Frequently, dead whales could not be fastened well enough to the lines of the harpoon to prevent them from sinking. Under normal circumstances a carcass would naturally rise after six or seven days and be collected by a ship's crew. Considering the climatological conditions in which Bottemanne had to perform, re-collection of dead whales seemed virtually impossible. On the way to the whaling grounds Bottemanne had bought a so-called klauwduiker (claw diver) near Seydisfjördur in order to overcome the problem of sinking whales. ${ }^{395}$ In his report, the Dutch captain gave a description of this technically sophisticated piece of machinery: a fairly heavy, elongated, square piece of iron that was lowered alongside the harpoon line after a whale was harpooned, and designed to get a grip on the harpoon itself. The very thick rope, fastened to a steam winch and windlass and to the klauwduiker, replaced the harpoon line and thus decreased the tension on this line.

In comparison with the 1870 expedition, Bottemanne and his more experienced crew showed important improvements in their use of the rocket bomb harpoon gun. In 1871, during about 100 watches (17 days of clear weather and good visibility), 76 shots were fired with 30 hits, however, they did not kill 30 whales as on two occasions two shots hit one whale and on one occasion five harpoons were wasted on one whale. ${ }^{396}$

In 1871 the catch amounted thirteen whales with another thirteen lost. Thanks to the annual report on the Dutch sea fisheries for 1872 , there is some data concerning the problems Bottemanne had to overcome. ${ }^{397}$ In their annual meeting, the Committee for sea fisheries had received a letter from the director of the Rotterdam whaling company. Bottemanne had endured stiff regulations from the Danish government, forbidding foreign (id est: non-Danish) fishing activities off the coast of Iceland, so the director requested assistance from the Committee in facilitating fishing facilities off the Icelandic coast. The Committee turned to the Minister of the Interior with a request to take up matters with the Ministery of Foreign Affairs. They, in their turn, advised them to contact the Danish government via the Dutch ambassador in Copenhagen. ${ }^{398}$

One of the more important secondary sources on Bottemanne's catches indicated that no data was available for 1872.399 The annual report on Dutch fisheries, however, again proved to be a valuable source. Tempests, rough weather in general, and

395. Through his employment for Thomas Welcome Roys, Bottemanne had knowledge about the existence of such an apparatus - one of many inventions by Roys. Bottemanne had seen one in use in 1870 . He referred to the apparatus as 'klaauwduiker' instead of 'klauwduiker', what seems to be the proper word in Dutch. Idem, 115-117.

396. Idem, 114 .

397. Verslag van den staat der Nederlandsche Zeevisscherijen over 1872 ('s-Gravenhage 1873), 16-18.

398. Idem, 17 .

399. Schmitt et alia, Thomas Welcome Roys, 165. 
fog had impeded Bottemanne from discovering the whales whereabouts and, consequently, from being successful with their catches. In total 26 harpoons were shot (as opposed to 76 in 1871); two were lost, thirteen missed their targets, and the remaining eleven were hits. Nine whales were caught, but the majority were lost again. Bottemanne managed to obtain some blubber from the remaining two whales. This catch was added to that of one whale, caught at an earlier stage. ${ }^{400}$ In December 1872 , the company was dissolved and the ship was sold.

Of all the whalemen and entrepreneurs mentioned in this work, C.J. Bottemanne was the only one to see the value of the introduction and application of new whaling methods and technology. More than anyone else, Bottemanne was aware of the necessity to modernize in whaling and sealing. Though unsuccessful, his role in trying to bring Dutch whaling to a higher, more modernised level by the use of shore stations and newly developed types of bomb harpoons has generally been underestimated. ${ }^{401}$

Table 4.8: Whaling expeditions to Iceland fitted out by the Nederlandsche Walvischvaart N.V. (1870-1872).

\begin{tabular}{|l|l|l|l|l|l|l|}
\hline Year & Master & Ship's name & Type & Destination & Results/remarks & Sources \\
\hline 1870 & Bottemanne, C.J. & $\begin{array}{l}\text { Noordkaper } \\
\text { Built 1869/7o by } \\
\text { W.B. Hornby } \\
\text { Wellington, } \\
\text { Tynemouth } \\
\text { (Northumberland) }\end{array}$ & $\begin{array}{l}\text { Three-mast } \\
\text { auxiliary } \\
\text { steamship, } \\
\pm 150 \text { tons; } \\
\text { carried three } \\
\text { whaleboats }\end{array}$ & Iceland & $\begin{array}{l}\text { one small fin whale, } \\
\text { yielding } 77^{1 / 2} \text { barrels of oil, } \\
\text { 250 kilograms of baleen }\end{array}$ & De Jong, II, 484 \\
\hline 1871 & Bottemanne, C.J. & Noordkaper & Idem & Iceland & $\begin{array}{l}\text { Thirteen whales } \\
\text { (species unspecified) }\end{array}$ & De Jong, II, 485 \\
\hline 1872 & Bottemanne, C.J. & Noordkaper & Idem & Iceland & 'Some' whales (3) & De Jong, II, 486 \\
\hline $\begin{array}{l}\text { Total } \\
\text { catches }\end{array}$ & & & & $\begin{array}{l}\mathbf{1 7} \text { whales; 77² barrels of oil; } \\
\mathbf{5 0 0} \text { pounds of baleen }\end{array}$ & \\
\hline
\end{tabular}

\section{Enkhuizen: Nieuwe Noordsche Compagnie (1877)}

Once steam engines were used, A.J. ten Brink, director of the Hogere Burgerschool in Enkhuizen, saw the new challenges for Dutch whaling expeditions. ${ }^{402}$ An influential local member of the Nederlandsch Aardrijkskundig Genootschap (Dutch Geographical Society), Ten Brink wrote several pamphlets that stimulated interest in the 'glorious

400. Nederlandsche Zeevisscherijen 1872, 17-18.

401. Cornelis de Jong is one of few to recognise Bottemanne's importance. Louwrens Hacquebord, in his overview of Dutch whaling through the ages, referred to Dirkje Adema as being the last Dutch ship on the whaling grounds but does not mention Bottemanne. L. Hacquebord, 'De walvisvaart: geschiedenis van een bedrijfstak', in: E. Naayer (ed.), Smeerenburg: Holland op z'n koudst. Mededelingen van het Arctisch Centrum nr. 7 (n.p. n.d.) [Groningen 1983], 26.

402. No substantial information about A.J. ten Brink has been found. In the indices of the Tijdschrift van 
history' of the Dutch presence in the Arctic in the seventeenth and eighteenth centuries. Ten Brink, however, went beyond the evocation of interest as he focused on the successes of Dutch whaling for the sake of invigorating support for the renewal of this old maritime industry.

Together with M.C. Teves from Harlingen ${ }^{403}$ and ex-naval officer L.H.F. Tuckermann, Ten Brink developed a plan to establish the Nieuwe Noordsche Compagnie ter uitoefening van de Robben-en Walvischvangst in the Noordelijke IJszee (New Greenland Company for Sealing and Whaling in the Arctic Ocean). Their initiative was sparked by M.H. Jansen, Staatsraad (Privy Councillor), who in 1875, during the $8^{\text {th }}$ General Meeting of the Dutch Geographical Society, called for the resumption of whaling and the re-establishment of whaling companies. ${ }^{404}$

Moreover, in 1877 the Directors of the Nederlandsche Maatschappij ter Bevordering van Nijverheid (Netherlands Association of the Promotion of Industry) wrote a request to King Willem III to stimulate interest in new whaling enterprises under the Dutch flag. Contrary to Ten Brink, these directors asked for the establishment of a Dutch whaling and sealing company that would not only operate in Arctic waters, but also in the Antarctic Ocean. In their request, the directors referred to several inhabitants of Enkhuizen, who desired to establish a company for whaling. Finally, they suggested to King Willem III that he instruct naval officers to execute research in the Polar Regions in order to expand the knowledge of the local natural history and physics. ${ }^{405}$

The three men - Teves, Tuckerman, and Ten Brink - calculated that they needed the enormous sum of $f 250,000$ for one steamship and crew. In comparison, less than a decade earlier, C.J. Bottemanne purchased Noordkaper for $f 80,000$. According to the three gentlemen, a stockholding company should be established and in 1877 they launched their plans. The money, however, was never raised, and their plan to establish the New Greenland Company never left paper.

het Aardrijkskundig Genootschap, covering many decades during the nineteenth and twentieth centuries, Ten Brink was mentioned once (in a paraphrased manner) as having been the author of an article on the Banda islands in the Dutch East Indies. See A.J. ten Brink, 'Over het verleden en de toekomst der Banda-groep', Tijdschrift van het Aardrijkskundig Genootschap, vol. 1 (1876), 71.

403. M.C. Teves was mentioned in Sweijs, 1880, 101, as being the owner of the Anna (ex-XIII Oct). The next year, this vessel was added to Zeilmaker's fleet.

404. Dijkstra, 'De Groenlands- en Straat-Davids Visserij', 58, note 10. See also J.C.A. Schokkenbroek, 'Cartografie op hout. De scheepskist van walvisvaartcommandeur Jan Cornelisz. Buijs (ca. 1697-1765)', R. Daalder a.o. (eds.), Koersvast. Vijf eeuwen navigatie op zee (Zaltbommel 2005), 241.

405. C.M. Kan and N.W. Posthumus (eds.), Tijdschrift van het Aardrijkskundig Genootschap, vol. 2 (1877), 65-66. 


\section{Conclusions}

One may draw several conclusions from the data gathered in this chapter, as well as from the many statistical tables of Dutch Arctic whaling and sealing (see Tables 4.1 through 4.8, and Appendices 1 and 2). First, Dutch whaling in the nineteenth century - that is, between the Treaty of Amiens in 1802 and 1885 - was controlled and conducted by a small number of individuals, or by stockholding companies. In large urban communities like Amsterdam and Rotterdam, ambitious private enterprise seemed to overrule the establishment of stockholding companies. In some cases cooperation, even to the extent of intermarriage among several commercial families (as in the case of the daughters of Jan Vas, marrying into well established, wealthy entrepreneurial families in the city of Alkmaar), led to combined commercial activities, be it in the industries of wine, timber, or whale products. In smaller communities, however, such as the town of Harlingen in Friesland, entrepreneurs joined forces and talents in order to establish relatively strong, although (as it turned out) short-lived whaling companies. Together, the small number of individuals and companies organised 113 whaling and sealing expeditions to Jan Mayen Island, the Davis Strait, and Spitsbergen.

Secondly, based on information derived especially from Hendrik Rickmers' journals, kept on board Spitsbergen (II) between 1830 and 1840, it may safely be stated that on the hunting grounds near Jan Mayen Island the crew were first deployed in sealing. After about four to five weeks, the commander would set a northwesterly course for Spitsbergen. The barrel for the look-out would be placed on the mainmast and the crew commenced its whaling activities. Sealing, however, turned out to be of much greater importance than whaling - both in terms of volume and of value. Dutch whalemen continued their search for whales, while whale stocks on the old, familiar grounds seemed to have been depleted as of the 1840 .

Thirdly, Dutch whaling entrepreneurs had most of their ships built in the Netherlands. In only a few instances did shipbuilding expertise from abroad enter into the fairly secluded, conservative realm of Dutch entrepreneurs, mastermariners, and shipwrights. Dirkje Adema was built in Itzehoe, Germany, in 180o. Noordkaper left the wharf of Hornby Wellington in Tynemouth in 1869. Most of the other ships employed had been constructed in Dutch shipyards.

Fourth, a few remarks about the size of the ships owned and used by Dutch whalemen may be made. Compared with the average French whaleship of the 1830 ( 400 tons) or with figures given with respect to the smallest and largest vessels of the American whaling fleet in 1849 ( 81 tons and 616 tons, respectively), the Dutch vessels were fairly small, measuring 250 to 350 tons. The Dutch started out with fluitschepen, later to be complemented with or replaced by pinken, brigs (251 to 256 tons), an occasion- 
al galliot, a frigate (349 tons) and one iron auxiliary steamship (150 tons). With the exception of Noordkaper, they all used sails as means of propulsion.

Fifth, numerically speaking, Dutch whaling during the nineteenth century was but a mere shadow of former Dutch whaling activities. A total of 113 expeditions during a timeframe of about 70 years is not impressive: neither when compared with Dutch whaling during the seventeenth and eighteenth centuries, nor when compared with the number of whaling (and sealing) expeditions organised by other European countries such as Great Britain, ${ }^{406}$ France, ${ }^{407}$ and Germany, ${ }^{408}$ not to mention the United States with hundreds of ships annually leaving the many harbour towns along the East coast.

Sixth and finally, ships were used for a relatively longer period of time. The longevity of the Dutch whaleships is a rather remarkable feature. Should it be judged as a clear indication of the quality of Dutch shipbuilding or, in an attempt to explain this phenomenon, should more focus be placed on the thriftiness of the owners? In other words, were the ship owners unwilling to invest in new ships and, subsequently, in new technology? These questions will be addressed in two later chapters: Chapter 5 on shipbuilding and crew and Chapter 7 on investments and revenues.

406. In 1868 , for example, the Scottish whaling and sealing fleet amounted up to 29 vessels, both steamships and sailing vessels. Being involved in both 'hunting industries', the number of expeditions may be even much higher than the number of ships in the fleet! See: A.J. ten Brink, Blik op den hedendaagschen toestand der Europeesche Noordpool-Visscherij (Enkhuizen 1876), 3-5; 10-12.

407. At one time, in 1849, the French whaling fleet, sailing out to the Arctic as well as the South Seas, consisted of 17 vessels. An all time low was reached in 1853, when five whaleships operated from Le Havre. For a treatise on French whaling during the nineteenth century, see Chapter 2; see also Clark and Brown, 'The Whale-Fishery', 207-208; Ch. de la Roncière, Histoire de la marine française. Six volumes (Paris 1899-1920). Vol. 5, 675-680; L. Lacroix, Les derniers baleiniers français (Nantes 1938), 34; 36.

408. Between 1864 and 1866, for instance, twelve sealing and whaling expeditions left the northern German ports. Clark and Brown, 'The Whale-Fishery', 218. In comparison, in 1864 Dutch companies equipped two vessels (the frigate Dirkje Adema and the brig Maria) for whaling expeditions. 
Chapter 5

\section{Ships and Men. Driving and Floating Forces}

\section{Introduction}

Ships and men - and the interaction between these two components in working and living conditions on board - are the two most important elements in any maritime endeavour. In 1817, the Dutch government through the Minister of Foreign Affairs commented on the possibilities and difficulties of the resumption of whaling by stating,

"Het ontbreekt ... aan die vaart aan geschikte commandeurs en zeelieden en aan kundige bouwlieden van sloepen, welke laatste geheel nieuw moeten worden aangeschaft en groote kosten vereischen"

("In this maritime industry [whaling] there is a lack of suitable masters and sailors and knowledgeable craftsmen of sloops, which need to be newly acquired and, hence, ask for considerable investments"). ${ }^{409}$

Twenty-six years later, in his essay on the history of whaling (1843), Captain C. Brandligt reiterated the critical perception of the Dutch government regarding Dutch whaleships and whalemen. He mentioned two elements that are worth scrutiny. First, he referred to the lack of shipbuilding programs in the Netherlands during the first decades of the nineteenth century. Secondly, he questioned the level of sophistication among Dutch whalemen.

In this chapter, the focus will be on the state of the art regarding ships and crews. As was done in previous chapters, a division will be made between South Seas whaling and Arctic whaling. Subsections will deal with the crews of whaleships under the Dutch flag but nineteenth-century data concerning the numbers of crew on board Dutch whaleships - or the compositions of whaleship crews - are scarce. Similarly, figures concerning the wages of whalemen involved in South Seas or Arctic enterprises

409. NA, Archief Waterstaat na 1813, Koninklijk Besluit 20 December 1817, no. 75, Bijlage: Brief van de Minister van Binnenlandse Zaken, 18 December 1817. Quoted by De Jong, Oude Nederlandse walvisvaart, II, 452 (author's translation). 
are scarce. In his many tables regarding Dutch whaling in the seventeenth and eighteenth centuries, De Jong used 42 hands as a standard size for crews, based on data for the year 1748. De Jong frankly stated that one must be careful in using this figure, as the size of the crew was often determined by the size of the vessel. De Jong's figure may account for the first half of the eighteenth century. In the seventeenth century and also during the first half of the eighteenth century, the 'standard figure' may have been quite different than 42 , as seventeenth-century whaleships were generally smaller and ships sailing for the Arctic under the Dutch flag after about 1750 were generally larger than the ones used during the first half of the eighteenth century. De Jong justified his standard figure by stating that sizes of crews could vary between 6 and 45 and that concrete, more exact averages about crews were lacking. ${ }^{410}$

De Jong does not deviate from the standard 42 hands in his analysis of results for the early decades of the nineteenth century. In the municipal archives of the towns in Friesland and Holland that were involved in whaling and sealing, however, ample data is available for at least some of the nineteenth-century voyages. Moreover, in De Jong's magnum opus no information was provided concerning the demographic and socio-economic background of the crews manning whaleships operating under the Dutch flag.

As for the labour force on nineteenth-century Dutch whaleships, questions related to origin and quality of the seamen making their modest living under harsh circumstances will be examined. Where did these men come from? Are there any demographic and geographical links between whalemen, or between whalemen and ship owners? What education did they have, and how experienced were they? The reasons for the attractiveness of the whaling industry for these officers and ordinary seamen will also be analysed. How were they paid and how well were they paid? Finally, what other sources of income did they enjoy once the whaling season came to an end?

\section{Shipbuilding}

During the years 1795 to 1815 shipbuilding in the Netherlands had been reduced to next to nothing, with an ultimate standstill between 1809 and 1814. In the years following the return of King Willem I, the domestic demand for merchantmen increased. However, problems on Dutch wharves - in terms of quantity and quality of the labour force - resulted in the construction of expensive, less manoeuvrable ships. As a consequence, during the 1820 s most merchantmen deployed under Dutch flag were aboard

410. See De Jong, Oude Nederlandse walvisvaart, III, 148-149, 155-156; and 201, 206. 
ships that had been built abroad..$^{41}$ In 1824 , a total of no more than three ships measuring more than 100 tons were built on yards in the Netherlands. ${ }^{412}$

Here again King Willem I turned out to be a strong supporter of the whaling industry with regard to the construction of ships. A number of Koninklijk Besluiten (KB) was specifically geared toward stimulating shipbuilding. Zeebrieven (certificates of registry) were only issued to ships built in the Netherlands. By KB of 3 October 1823 no. 146 , premiums were paid for all newly-constructed ships measuring more than 300 tons. These premiums amounted to $f 8$ per ton per ship. Michael Jansen calculated that this premium meant a reduction of $10 \%$ of the total costs for construction. Two years later, in 1825, the premium system was expanded to smaller vessels as well. The construction of these smaller vessels was supported by a premium of $f 12$ per ton. ${ }^{413}$ But the premium system was in effect for only a brief period. In 1829 the financial support of shipbuilding in the Netherlands was discontinued. Mansvelt calculated that between 1824-1830 the Dutch government must have invested no less than $f 1,700$,000 in premiums for shipbuilding. ${ }^{414}$ It has been stated that the combination of the abolishment of the premium system and the increasing involvement of the Nederlandsche HandelMaatschappij in freighting Dutch ships forced Dutch wharves to modernise and withstand foreign competition. ${ }^{415}$ Because of the lack of archival documents, however, no research could be conducted on the consequences this abolishment may have had related to the construction of whaleships. ${ }^{416}$

Likewise, the King played an important role in the introduction and deployment of steamships - both for the Royal Netherlands Navy as well as for the merchant marine. One of his most important advisers was Gerhard Moritz Roentgen (1795-1852). In 1828, he introduced his multiple expansion machine at the shipyard of Feijenoord, which was established in Rotterdam in 1825 . This type of propulsion inevitably led to reductions in the consumption and cost of fuel. Also, it contributed to reductions in the weight and dimensions of engines. The influence of British technology on Dutch shipbuilding during the 1820 s cannot be underestimated. On the contrary, steam-

411. Mansvelt, De Nederlandsche Handel-Maatschappij, I, 146. M. Jansen, De industriële ontwikkeling in Nederland 1800-1850 (Amsterdam 1999), 81.

412. Jansen, Industriële ontwikkeling, 80-81.

413. KB 29 July 1825. See also Jansen, op.cit., 82.

414. Mansvelt, De Nederlandsche Handel-Maatschappij, II, 332.

415. Jansen, op. cit., 82.

416. I.J. Brugmans, Paardenkracht en Mensenmacht. Sociaal-economische geschiedenis van Nederland, 17951940 (Den Haag; reprint 1976), 140. See also F.J.A. Broeze, De Stad Schiedam. De Schiedamsche Scheepsrederij en de Nederlandse vaart op Oost-Indië omstreeks 1840 (Den Haag 1978), 3-4. Broeze referred to the disappearance of the related documents on page 4, note 9. Finally, premiums for shipbuilding were briefly mentioned in F.S. Gaastra, Vragen over de koopvaardij. De 'Enquête omtrent den toestand van de Nederlandsche koopvaardijvloot' uit 1874 en de achteruitgang van de handelsvloot (Leiden 2004), 5. 
powered engines from Britain were applied to Dutch naval vessels. During this decade the Dutch imported technological expertise mainly from Britain. From about 1830 onward, however, they turned to the United States. ${ }^{417}$ Around that time steam propulsion was gradually introduced in the Royal Netherlands Navy. In commercial shipping (whaling included), the introduction of steam technology occurred a few decades later. ${ }^{418}$

As stated above, the longevity of whaleships built for and deployed by Dutch whaling entrepreneurs was extraordinary and impressive. The Groenlandse en Straatdavidse Visscherij Sociëteit in Harlingen, for example, lasted for only one decade but its ships were purchased by Barend Visser \& Son and continued to serve this company for several decades. Some ships were lost at a very young age. Willem de Eerste, built in $1822 / 1823$, was lost two years later. Harlingen, built in 1826 , became stuck in the ice that very same year. These losses, however, are exceptions rather than the rule. Spitsbergen (II) served its owners for 24 years non-stop - between 1828 and 1852. Built in Sweden in 1856, Maria, under ownership of the firm Nicolaas Brantjes \& Smit in Purmerend, was mentioned in Sweijs' lists and Lloyd's registers as late as 1895 . Phenomenal records were set by Groenland (built before 1764, in service until at least 1827) and Dirkje Adema (1800-1865). In this respect whaleships stand out in comparison with other merchantmen flying the Dutch flag. In his important study on industrialisation in the Netherlands during the first half of the nineteenth century, Jansen claimed that frigates, barks, and brigs not deployed by the NHM had an average life of about ten years. ${ }^{419}$

It should be noted that there are at least three different categories of ships deployed in the whaling and sealing industries. The first category comprises whaleships built abroad. Dirkje Adema, the 'grandmother' of the whaling fleet, was built in Itzehoe near Hamburg in northern Germany. Logan, the ship involved in whaling in the Southern Seas during the 1820s, was built in Dartmouth, Massachusetts, whereas Noordkaper was constructed close to Newcastle-upon-Tyne, England, in 1869.

The second category entails ships that were not originally built for whaling and sealing. Proserpina (later renamed Zuidpool) was built on Dutch wharves; not to serve as a whaleship, but as a man-of-war. In later years the Royal Netherlands Navy had the ship taken out of service, whereupon Proserpina was purchased for a second career in whaling and sealing.

Finally, the last category of ships comprises those specifically built to serve entrepreneurs in whaling and sealing. Data about the construction of whaleships on

417. Davids, 'Transfer of technology', 16-17.

418. Lintsen, 'Dutch shipbuilding industry in historical perspective', 118-119. For information about Roentgen, see M.G. de Boer, Leven en bedrijfvan Gerhard Moritz Roentgen. Grondvester van de Nederlandsche Stoomboot-Maatschappij thans Maatschappij voor scheeps- en werktuigbouw 'Fijenoord' 1823 -1923 (Rotterdam 1923). 419. NA, NHM archief inv.nr. 9478. See also Jansen, op. cit., 79, note 174. 
Dutch shipyards are very scarce. Johannes Alta in Harlingen received orders from Barend Visser \& Son and from the Groenlandse en Straatdavidsche Visscherij Sociëteit. Several vessels specifically designed as whaleships left Alta's wharf during the 1820 . Willem de Eerste and, above all, the Harlingen serve as examples. No official primary records of Alta's wharf and his shipbuilding activities have survived. There are, however, sources available. In the early months of 2005, the municipal museum Het Hannemahuis in Harlingen acquired a small bundle of notebooks. ${ }^{420}$ These books were kept by Klaas Hoekstra, master of the unfortunate, brand new galliot Harlingen, which on its maiden voyage became stuck in the ice in Baffin Bay in 1826 and consequently was abandoned. Among these important personal documents, a notebook with data regarding the rigging and provisioning of that ship was found. These contain the smallest details about the advanced payments made to certain persons, the daily wages of those involved in carrying and heaving the masts, and the sizes of the many sails the Harlingen carried. Moreover, at the end this booklet contains notes about deliveries of specific commodities Klaas Hoekstra was to handle the next time he was in the area (“op een ander Jaar mede te brengen”). The products concerned were 200 pounds of white bread, a hunting rifle, and twenty baskets ('korven') of potatoes. It is tempting to suggest that Hoekstra wanted to give these items to the people who had helped him and his crew who had survived their ordeals. ${ }^{421}$

More important to this chapter, however, are the notes within this booklet that concern the rigging of the ship. Harlingen measured 115 feet in length, $27^{1 / 2}$ feet in width, and had a height of $47^{1 / 2}$ feet. The sizes of the many masts and sails were also described. The mainmast measured 69 feet with a diameter of 19 thumbs, the foremast 66 feet, and the mizzen 59 feet. The booklet contained instructions for the sailmaker as well. The sizes of all sails are given in Amsterdam feet. Prices and other financial information about sails and woodwork, however, are absent. Financial data can be found in the section that deals with the wages of the riggers, the craftsmen who had had the important task of rigging the ship. The information related to the period 5 December 1825 to 11 February 1826 and the number of riggers and their wages varied. During the second half of December, 21 men were working on the rigging, compared to four during the second week of February. In total $f 457.20$ was spent on rigging alone. When the money spent on the placing of the masts $(f 8)$ is added, the costs involved in the rigging of Harlingen amounted to $f_{465.20}$.

420. Upon receipt of these documents, the ever vigilant curator of the Hannemahuis, Hugo P. ter Avest, immediately informed me of their existence. I am greatly indebted for his kindness in doing so.

421. This remark was written on a page in the notebook where the names of Carl Peter Holbou and Peter Julius Kall were mentioned. The notes in the booklet reveal that Hoekstra had met Holbou - at the time Royal Inspector with the rank of Captain Lieutenant - on 20 June 1826, in Lively near Goedhaven on Greenland. Kall was introduced as a merchant in Holsteinburg. Hoekstra apparently met him in the Weide Fjord on 1 July 1827. 
Dutch whalemen had cruised the waves near Jan Mayen Island, Spitsbergen, and Greenland for many decades prior to the nineteenth century. The times and techniques, however, had changed. While many other nations (Germany, for instance) kept a close eye on developments in neighbouring countries - especially Scotland, Norway, and the United States of America - but Dutch shipwrights and whaling entrepreneurs seem to have turned away from foreign expertise. The experiment with the American whaleship Logan between 1827 and 1830 showed in unambiguous ways that these men lacked the intelligence and willingness to learn from American shipbuilders. No drawings had been made, nor did anyone build a ship model based on the actual vessel.

Likewise, no data has been found indicating an eagerness to travel to these countries (Norway, the United States, or the United Kingdom) to absorb information, learn from experienced whaleship builders and, consequently, benefit from other people's knowledge. Even Captain H.F. Horneman of the bark Eersteling, while in the United States during the summer of 1834 to select the most suitable crew for the whaling expedition under the aegis of the Rotterdam-based Vereeniging tot Walvischvangst om de Zuid (Society for Southern Whaling), did not compile (or at least did not leave tangible evidence of) a report about the state of the art in building whaleships there. So far, no evidence of meetings with American shipwrights or whaling entrepreneurs has been found.

Abroad, developments in shipbuilding were impressive, especially by English and Scottish builders. While the Dutch deployed relatively small sailing ships to explore well-known whaling grounds, the British sent rapidly increasing numbers of steampropelled vessels to the Davis Strait. In 1857, the first steam whaleship was launched in Hull. A little later, Dutch whaling entrepreneurs and ship owners were informed about this novelty. A leading Dutch maritime magazine of that era contained a brief announcement of the construction of an iron whaleship on one of the wharves near the river Tyne in Northumberland. The ship had an overall length of 170 feet, a width of 25 feet and a depth of $16^{1 / 2}$ feet, with a $60 \mathrm{HP}$ (horsepower) auxiliary steam engine. Therefore, it is inconceivable that Dutch shipwrights and whale ship owners had not learned of technological developments abroad. ${ }^{422}$

Whaling entrepreneurs from Dundee were quick to follow this example and launched their first steam whaleship in 1858. The next year, two more steamships were built at the shipyard of Stephens \& Son in Dundee. In 1867, two years after Dirkje Adema had run aground near Rügen (northern Germany) and two years before C.J. Bottemanne made headway with his initiatives to sail with ships with furnaces and whale-

422. J. Swart (ed.), Verhandelingen en berigten betrekkelijk het Zeewezen en de Zeevaartkunde, vol. 10 (1857), message no. 83,455 . 
boats, and to fit out shore stations and so forth, the Scots had a fleet of no fewer than eleven steamships for whaling and sealing purposes. This is an astounding total, making the Dutch attempts to hunt whales and seals look amateurish. In 1868, the figures for the Scottish whaling and sealing fleet were as given in Table 5.1:423

Table 5.1: Composition of the Scottish whaling and sealing fleet (1868).

\begin{tabular}{|l|c|c|c|l|}
\hline Port & \# of steamships & \# sailing vessels & Total & Remarks \\
\hline Peterhead & 4 & 8 & 12 & \\
\hline Fraserburgh & - & 2 & 2 & \\
\hline Dundee & 11 & 1 & 12 & \\
\hline Kirkaldy & $?$ & $?$ & 1 & 1 ship (means of propulsion are not specified) \\
\hline Hull & 1 & 1 & 2 & \\
\hline Total & 16 & 12 & 29 & \\
\hline
\end{tabular}

Meanwhile, similar developments took place in Germany. In 1865, F.W.A. Rosenthal of Hamburg constructed Albert, which was the first German steamship specifically built for the Arctic fisheries. When Albert left the wharf in Bremerhaven, the wooden 900-ton screw steamship with iron-plated bow and iron stern had a keel of 146 feet long, an overall length of 160 feet, a width of 34 feet, and a depth of over 18 feet. A strong steam engine supplied Albert with $90 \mathrm{HP}$ and it took about 100 tons of coal to complete a voyage. The value of this ship was estimated at about $f_{170,000 .}{ }^{424}$

In subsequent years, more whaleships left the German shipyards. In 1868, the whaling and sealing fleet amounted to four ships: the sailing vessels Hannover and Hudson from Weser, and Albert and Bienenkorb. The last ship was transformed from sail to steam, and was built and owned by Rosenthal, Hamburg. ${ }^{425}$

Around the same time, Norway experienced major changes with regard to whaling and sealing. Nineteenth-century Norwegian whaling may be linked almost solely with the accomplishments and endeavours of one man: Svend Foyn. Not only did he continuously try to improve the tools whalemen used for the hunt, but he also introduced steam engines to the Norwegian fleet. In 1863, he commissioned the construction of the steamship Spes et Fides. ${ }^{426}$ That year Dutch entrepreneur Nicolaas Brantjes from Purmerend equipped his whaleship Maria, sailing from Tønsberg, Norway, with a Norwegian crew under the Norwegian flag. Maria was one of a fleet of 16 vessels to leave for the Arctic. These ships were relatively small, measuring about 200

423. A.J. ten Brink, Blik op den hedendaagschen toestand der Europeesche Noordpool-Visscherij (Enkhuizen 1876), 3-5; 10-12.

424. Idem, 19.

425. Idem, 16-17.

426. For a fine, condensed overview of Foyn's involvement in inventing and improving hunting gear, see Robert Lloyd Webb, On the Northwest, 135-137. 
to 250 tons on average. A few years later in 1870 , the Norwegian fleet, leaving from Tønsberg, consisted of 18 ships, three of which had steam propulsion. Among the 18 ships were Brantjes' Maria and Rosenthal's Bienenkorb. ${ }^{427}$ During the 1870 , Brantjes had his Maria almost continuously sailing to the Arctic under the Norwegian flag. Because of bad results between 1872 and 1874, however, he decided to have Maria stay in Tønsberg harbour for the 1875 season. On this occasion, Brantjes revealed to Ten Brink the reason why these three seasons (1872 to 1874) had been so unsuccessful. In his article, Ten Brink refers to his contact with Brantjes:

"De enige reden hiervan ligt ook volgens hem [Brantjes] in de onmogelijkheid om tegen-
woordig met zeilschepen te visschen, daar de stoomschepen veel eerder en dieper in de
ijsvelden kunnen doordringen."
("The only reason according to him [Brantjes] as well lies in the impossibility today to
fish with sailing vessels, as the steamships can penetrate the ice fields much sooner and
deeper"). ${ }^{428}$

While this advantage of steam-driven whaleships over sailing ships may be paramount, there were also other advantages. More than ever before, whaling entrepreneurs could estimate how long it would take to get their ships and crew to the whaling grounds, how long it would take them to return to their home ports, and how much they would have to pay their crew in salaries. In the days before the introduction of the steam engine, the whales and seals swimming and floating about on the hunting grounds remained the wild card, as nobody could predict how much time it would take to catch an adequate number to make the expedition profitable. The invention and use of steam engines meant that ships could make two voyages per season instead of one. Steaming up to the Arctic, Scottish sailors, for instance, hunted seals between early March and late May. Returning to their respective home port, in early June, they would sell the oil and furs, and immediately return for the whaling season that lasted until mid- to late-September. ${ }^{429}$

Focusing on naval architectural developments in several countries, it is easy to conclude that the years around 1865 were of crucial importance in the transition from sail to steam propulsion in the whaling and sealing industries. As discussed in an earlier chapter, besides Nicolaas Brantjes, only one other Dutchman set out on whaling

427. Idem, 22-25.

428. Idem, 33. In his lengthy article on sperm whaling in Indian waters, S.C.J.W. van Musschenbroek also pointed to the necessity to use steam ships in the Arctic whale fishery. S.C.J.W. van Musschenbroek, 'CachelotVisscherij in den Nederlandsch Indischen archipel', Tijdschrift ter bevordering van Nijverheid, vol. XVIII, part 11 (Haarlem 1877), 14. Van Musschenbroek is familiar with Rosenthal and his whaling activities. Author's translation. 429. Idem, 12. To date, no evidence has been found of any Dutch whaling entrepreneur who followed this shrewd example of deploying ship and crew twice per season. 
expeditions during the 1870s: Captain C.J. Bottemanne. Also, W.B. Hornby Wellington built the auxiliary steamship Noordkaper near Tynemouth in $1870^{430}$ and this vessel was bought by De Nederlandsche Walvischvaart N.V. in 1870. According to its listing in Sweijs, the ship measured about 150 gross register ton, with an engine of $70 \mathrm{HP}$, and carried three boats: one starboard boat under the command of Bottemanne, one leeboard boat commanded by the first mate, and one boat located mid-ship under the command of the second mate. ${ }^{431}$ Each boat carried seven men: one harpooner, five rowers, and one boat steerer (helmsman). Under Bottemanne's supervision, Noordkaper was specifically adapted for whaling in the Arctic. The ship carried try-works; a furnace, located on deck behind the fore-hatchway, consisting of two iron pots with a capacity of about 1,00o litres of whale oil each. In this manner, the whales' blubber would be boiled down to oil to be stored in casks down below. Noordkaper was taken out of service in 1879 , only one decade after its construction.

\section{South Seas whaling}

\section{Size of the crew}

Personal accounts, crew lists, ship's journals, and newspaper articles provide the basis to assess the size of at least some Dutch whaling crews between 1810 and 1885 . The South Seas whale fishery will be discussed separately from the Arctic activities, as their organisation and handling differ. Vessels deployed in the South Seas whaling industry were much longer en route than ships destined for the East or West Greenland whaling. The size and rigs of the vessels involved were also quite different with consequences of the numbers of crew.

The first ship deployed by the NHM in South Seas whaling was the Americanbuilt Logan. Unfortunately, there are no specific figures concerning the size of the crew. This is the case with all South Seas voyages with one exception. Thanks to ref-

430. A former manager of Doxford's Shipyard Hornby Wellington came from Sunderland. He set up his own wharf in 1869 to build 'iron and composite ships' but had little success, selling out to Cole Brothers in 1872 . Some other ships that he built were: 1869 Alpha, Iron steam (I.S.) Schooner. 392 tons, for Bremen; 1870 Neptune, (I.S.) Schooner, 209 tons, for Bell of South Shields; 1870 Captain Cook, iron screw, 155 tons for the Whitby Steam Ship Company; 1871 Nellie, iron screw steamer (I S.S.), 847 tons, for Grey of Whitby. I am most grateful to Ian Whithead, keeper of Maritime History at Tyne \& Wear Museum, based at Discovery Museum, Newcastle upon Tyne, for sharing this information concerning Hornby Wellington. I also thank Mr. Ron French and Mr. Dick Keys, maritime historians in Newcastle upon Tyne, for their involvement in our quest for more information with regard to the Noordkaper. Except for an oil painting, no other pictorial or archival references to Noordkaper have been found, either at the museum mentioned above, or in the collections of the Tyne \& Wear Archives.

431. Sweijs, 1870, 139. 
erences in Handelsblad, it is known that on its departure from Amsterdam on $21 \mathrm{Au}-$ gust 1845, the large 509 ton-bark Zuidpool (ex-Proserpina) carried a crew of 36 hands.

While cruising Australian waters Zuidpool entered Sydney harbour on 10 December 1845. The reason for calling at Sydney was not so much to sell off its modest cargo. The officers had to take on new crew. Zuidpool could not leave the harbour until 19 January 1847. This late departure may have been caused by the difficulty that several agents had in searching for a sufficient number of new crew members. ${ }^{432}$

\section{Composition of the crew}

On its first voyage out, Logan's crew consisted of Americans (master and officers) and Dutchmen (able-bodied seamen). Upon its arrival at Hellevoetsluis on 11 January 1827, the NHM decided to equip the ship in this little harbour town and not in Rotterdam. According to Broeze,

"[in] the same time a full complement of Dutch sailors was engaged; [master] Coffin was willing to sail with an inexperienced crew and train them during the voyage. All agents of the N.H.M. and the Kweekschool voor de Zeevaart (Navigation School) of Amsterdam were informed, and apparently there were no difficulties in signing up a native crew". ${ }^{33}$

The sources at hand, however, presented a different picture. In the search for ablebodied seamen the NHM approached the Directors of the Kweekschool voor de Zeevaart (Nautical College) in Amsterdam. ${ }^{434}$ Their request that one or two pupils be placed aboard Logan was discussed in the Nautical College's Director's meeting of 31 January. A decision was postponed until the next meeting, on 7 February. Representing the NHM during this meeting, Landberg elaborated on the contents of the request, stipulating that the ship would sail under the American flag, not under the Dutch national ensign. In reply, the Directors of the College unambiguously stated that their pupils were simply not allowed to sail under a foreign flag. In other words, unless the NHM could arrange for a Dutch flag no pupils would be provided. Thereafter, archival records remain silent about the matter. It seems safe to conclude that no pupils from the Amsterdam School participated in this South Seas whaling expedition. ${ }^{435}$

432. The Shipping Gazette and Sydney General Trade List, 12, 19, and 26 December 1846; idem, 2, 9, 16, and 23 January 1847: quoted in Broeze, 'Whaling in the Southern Oceans', 104-105; note 147.

433. ARA (NA), Sch, NHM 28/10 (PVG), 3 February 1827, N 1, and 13/1830 G, letter from F. Gebhard, New York, 19 July 1830; quoted in Broeze, idem, 80, note 48. Note: 'native' was interpreted as being born and raised in the Netherlands.

434. De Jong, Oude Nederlandse walvisvaart, vol. II, 464-465.

435. Gemeentearchief Amsterdam (Municipal Archives Amsterdam, SAA), inventory nr. 949 (archief 
When in the seas around Japan, Captain Coffin sighted an abundance of sperm whales. He wrote to his employers that as a result of the inexperience of his crew, not one single whale was caught. ${ }^{436}$ The international character of the crew also caused major problems in New York when Logan needed to discharge of its cargo of sperm and black oil. Because of the fact that apart from the master and the officers the rest of the crew consisted of foreigners, the Logan - although built in Massachusetts and still in the hands of its American proprietors - according to American law it was no longer a national (i.e. an American) ship. Technically, importing whale oil was illegal, unless substantial duties be paid. The lack of vigilance on the part of the New York Customs' officers, however, saved the ship and cargo from confiscation. ${ }^{437}$

Another example of the international character of the crews of Dutch South Seas whaleships, and problems that could arise because of it, was provided by commander Horneman. At Cape Town, he had to recruit more men to fill out the crew of Eersteling. The newly-hired Englishmen, however, did not harmonise well with the rest of the crew, which consisted mostly of Americans. The outcome was that Horneman was forced to interrupt his expedition and hand over the rowdy bunch to the British authorities at St Helena. ${ }^{438}$

Archival sources in Amsterdam show that at least one fellow countryman joined Horneman on this voyage. In their meeting of 18 July 1832, the Directors of the Nautical College in Amsterdam discussed a request from correspondents in Rotterdam. By means of letters written on 10 and 17 July, they asked for a college student to join Horneman on a whaling voyage to the South Seas, and around 20 July, F. Tieman left for Rotterdam. Twenty months later this student returned to Amsterdam but on his way back Tieman turned 18. Because of his age, the pupil was dismissed upon his return to the College but his Captain displayed his satisfaction over the student's activities. ${ }^{439}$

So far, no other evidence of involvement from nautical colleges in South Seas

Kweekschool voor de Zeevaart), nr. 27 (minutes of meetings of Directors, 1824-1827), fos. 227 (meeting 31 January) and 229 (meeting 7 February). The archives related to the Kweekschool revealed that on a regular basis pupils were provided to participate in Arctic whaling expeditions under the Dutch flag. Their involvement was discussed in the paragraphs on Harlingen and Rotterdam. As early as 1819, the King had signed a law, granting the right to ship owners to request and receive special dispensation for bringing foreign ships under the Dutch flag. Apparently the NHM refrained from applying for this special dispensation. See Broeze, De Stad Schiedam, 2-3. See also Chapter 3 in this dissertation.

436. Broeze, 'Whaling in the Southern Oceans', 81

437. ARA (NA) Sch, NHM 13/1830 G. Letters from F. Gebhard, New York, 15, 19, 23, and 31 July, and 18 October 1830: quoted in Broeze, idem, 83, note 55 .

438. Netscher's report of 16 July 1836 is in ARA (NA), Staatssecretarie 4165, 18 August 1836, N 10. Quoted by Broeze, idem, 93

439. Gemeentearchief Amsterdam (SAA), archive nr. 949, inv. Nr. 29 (minutes of the Directors' meetings on 18 July 1832 , fo. 274 , and 25 July 1832, fo. 277); inv. Nr. 30 (minutes of Directors' meetings on 12 and 19 March 1834). 
whaling has been found. This should not come as a surprise: whaling voyages to the South Seas took many months - if not a few years - of a student's time, while it was the Directors' inclination to have their students be apprentices on at least two different vessels on two different voyages.

A few years later, in April 1844, Anna \& Louisa, briefly commanded by its first mate J. van der Mey and sailing for the Reelfs Brothers whaling company, received its English master in Nieuwe Diep. George Gray was an experienced whaling master, having led several whaling expeditions to the Pacific. Officers and harpooners also came from the United Kingdom. The rest of the crew were all Dutch. ${ }^{44^{\circ}}$ Initially, all went well. The international crew appeared to have worked together fairly well. Anna \& Louisa called twice at Kupang on the island of Timor in the Dutch East Indies. A British traveller and old acquaintance of Gray met them in that port during its second call, in October 1845. As a result of his relationship with Gray the traveller managed to receive some inside information concerning the Dutch ambitions with regard to South Seas whaling. A few months later, his account of the sad state in which he found the crew, together with a few lines regarding the goals of the Dutch whaling company Gray served, were published in an Australian newspaper. Part of this account reads as follows:

\footnotetext{
"The common seamen and chief officer [in all probability referring to J. van der Mey] were Dutchmen, while the second and third mates and all the headsmen were English. This mixture did not at all harmonise them, and instead of catching whales they were constantly quarrelling, wrangling, and sometimes fighting. From what we could learn there was not the most remote chance of their taking any fish during their voyage. Under all the circumstances, it is to be feared that unless the Dutch Company make [sic] a more judicious selection of men and masters for their ships than they had in this case, they will get but a sorry account of their capital, not to speak of dividends. During our stay here we had seen a good deal of the manner in which the Dutch manage their whaling concerns, and left with the impression that the failure of Dutch whaling is likely to be ... certain ....". ${ }^{441}$
}

Misfortune continued to pursue Gray. He lost several officers and probably some of his crew. He eventually died on 23 April 1846, while in the port of Menado. Second mate S. Ward took the helm and left for Surabaya and Batavia. Early in 1847, this illfated journey came to an end. In the Batavia roadstead, Anna \& Louisa was in such a deplorable state that it was condemned and auctioned off. ${ }^{442}$

440. Algemeen Handelsblad, 23 April 1844.

441. The Shipping Gazette and Sydney General Trade List, 3 January 1846; quoted in Broeze, idem, 102.

442. Algemeen Handelsblad, 3 February 1847; Javasche Courant, 5 and 19 August, 21 November, and 12 December 1846, and 27 January 1847; Broeze, idem, 103. 
Triggered by the initial success of Anna \& Louisa, Reelfs Brothers fitted out a second vessel, Zuidpool (ex-Proserpina). Again they decided to take in both foreigners and Dutchmen, but the majority of the 36 hands probably had Dutch nationality. On 16 August 1845, the crew gave the inhabitants of Amsterdam a final demonstration with their whaleboats and on 21 August they sailed for the South Seas. Interestingly, no liquor was allowed on board. ${ }^{443}$ On its voyage Zuidpool lost two whaleboats. It is most likely that during one of these incidents Captain T.A. (or A.F.) Brunn was killed. ${ }^{444}$ In January 1847, Zuidpool called at Sydney for provisioning. By that time, the name of the new master was revealed as A.J. Meyer. The ship was sold in San Francisco some time around August 1849. So far, no evidence of the composition of the crew has been found. ${ }^{445}$

Zuidpool was the last Dutch whaleship actively involved in South Seas whaling. In later years, ideas regarding resumption of this type of maritime enterprise were developed. Van Musschenbroek's idea to build and man ships in the Dutch East Indies instead of having them built in the Netherlands, with composite crews of Americans and Dutchmen, or British and Dutchmen, or Americans, British and Dutchmen combined, was a compelling one. ${ }^{446}$ As noted earlier, Van Musschenbroek envisioned the construction of six to ten schooners, each with a crew of 20 to 30 men. In other words, about 300 men were needed for the operation. According to Van Musschenbroek, neither the Netherlands nor the Dutch East Indies had sufficient and suitable seamen to fill the important positions of master, officers, and harpooners.

In his article Van Musschenbroek suggested that foreigners (Americans) be hired for a relatively short period of time, and that they instruct the indigenous people instead of Dutch sailors. Not only would these 'Indonesian children' (Van Musschenbroek's terminology) learn the ropes quite easily, they would also be content with little luxury and food. ${ }^{447}$ In other words, Van Musschenbroek focused attention on the cheap labour Dutch entrepreneurs could train and subsequently employed.

\section{Educational background}

In contrast with what will be discussed in the next chapter on Arctic whaling and sealing, no evidence has been found about any involvement from nautical colleges in the Netherlands with regard to the provisioning of inexpensive, young students for South Seas whaling. As Logan continued to fly the American flag, Directors of the Amster-

443. J. van Sluijs, Nederlandse koopvaardijschepen 1800-1860 (n.d. n.p.), 126; Broeze, idem, 104 .

444. Both initials were given. So far, it has been impossible to substantiate either of the two versions.

445. Broeze, idem, 105. Broeze assumed Brunn was recruited from the East Frisian Islands.

446. For the following, see Van Musschenbroek, 'Cachelot-Visscherij', 27-35.

447. In his article (34-35), Van Musschenbroek calculated the costs of a virtual whaleship (schooner) of 80 tons, with 30 hands. 
dam College did not see it fit to have any of their pupils being registered as crew. In other instances, when ships sailed the waters of the southern hemisphere under the Dutch flag, voyages may have taken much too long. Here, Arctic whaling and sealing with its seasonal character provided the harsh but nearly ideal circumstances to educate and train students in seafaring.

\section{Wages}

Data concerning wages on Dutch South Seas whaleships are less than satisfactory. Information is scarce and scattered. Contrary to Arctic whaling voyages, no crew lists of South Seas whaling vessels have been located to date. It is only from circumstantial evidence that reconstructing the system of payment for the crew is possible and to also extrapolate figures concerning the whalemen's income.

In his article on Dutch whaling in southern oceans, Broeze dwelled on the activities of the New Bedford whaleship Logan, exploited by the NHM. Upon its arrival in New York after a three-year voyage, F. Gebhard, the local agent of the NHM, managed to realise excellent prices for both sperm and black whale oil. Logan had half of its holds filled with 32,5691/2 gallons (123,764 litres) of sperm and 3,222 gallons (12,244 litres) of black oil. As a result of the long duration of the voyage and the failure to catch a full cargo, major problems arose regarding the settlement of accounts with the crew. Most had signed up for fractional shares, and it must have been obvious to all that revenues would be very disappointing. Finally, after long negotiations, the company agreed to satisfy the Dutch whalemen with a payment of \$30 each (at that time the equivalent of about $f 75$ ), which represented pay for more than three years of service.

In his calculations of provisioning costs, Broeze assumed that ordinary sailors received a daily payment of $f_{0,50 .} .^{48}$ For the sake of argument, this equates roughly to $f_{15}$ per month. When these sailors' monthly wages were compared with those of their colleagues working in the Arctic some 30 years later, it is easy to conclude that the monthly wages in the southern whale fishery were much lower than those enjoyed in the waters off Greenland. ${ }^{449}$

448. Broeze, 'Whaling in the Southern Oceans', 81, 83. This daily salary was commensurate with that of a labourer in the textile manufacturing ('weverijen') in Overijssel working without steam engines in 1841 $(f \circ, 52)$. See Van Zanden and Van Riel, Nederland 1780-1914, 294 (Table 6.11).

449. In 1860-1861, apart from the officers up to and including the cooper, all other crew members of Dirkje Adema made considerably less money per month. GAH, Archief Waterschout (WS) 4, 1861-1862, B XX: "Monstering den 22 Februarij 1861. Fregatschip Dirkje Adama (...) last bestemd ter robbe- en walvischvangst terug op Harlingen". Occasionally the name of the vessel was spelled Dirkje Adama. Throughout this work the more common spelling of Dirkje Adema is used. I thank Mr. F.G. Spits for allowing insight into his notes concerning the crew of this vessel. Through his genealogical research into the Spits-family, Mr. Spits provided a rich source of information. 


\section{Arctic whaling and sealing}

Small coastal communities in the Netherlands were heavily involved in whaling, as captains and crew members, or as wives and families. Over the years a number of sociological analyses of several of these local Dutch whaling communities have been found. Most if not all studies focus on the post-1650 era.${ }^{450}$ In later years, and especially after 1700 , crews were increasingly composed of men of foreign nationalities, from Scandinavia, the northern German provinces, and the East Frisian Islands. ${ }^{451}$ Interestingly, the pendulum seemed to have swung to the other side again during the last decades of the eighteenth century, when greater numbers of Dutchmen signed up for whaling expeditions. They consequently formed the majority on board these later vessels.

To date, not much has been written about the men employed in Dutch whaling and sealing in the nineteenth century. The little knowledge we have comes via newspaper clippings or an occasional remark in a journal. As noted earlier, whaling was conducted from three areas in the Netherlands: Amsterdam and vicinity (Wormerveer; Purmerend), Harlingen, and Rotterdam. Next, the discussion will focus on size and composition of the respective crews employed by entrepreneurs and companies with their bases in these locations.

\section{Amsterdam and vicinity}

In the case of the early voyages made by master Jacob Broertjes in the service of Barend van Spreekens, it was asserted that Broertjes made it a point of taking young lads on board of the Groenland to have them learn the ropes. ${ }^{452}$ Thus, should the assumption be that the majority of these young sailors were Dutch?453

450. See, among others, P. Dekker, Willem 't Hart, 1750-1830. Een Zijper zeevaarder in de nadagen der Republiek (Zaltbommel, 1966), 13; 91-92. The same author wrote: 'De walvisvaarders uit noordelijk NoordHolland van 1770-1803', West-Frieslands Oud en Nieuw (WFON), 40 $0^{\text {ste }}$ deel (1973), 29-90; 'De Helderse en Huisduiner bevelhebbers ter walvisvaart in de $18^{\mathrm{e}}$ eeuw. Het grootste commandeurs-domicilie', WFON, $41^{\text {ste }}$ deel (1974), 129-165; 'Van kooikers en commandeurs. De families Colterman en Hopman actief bij de vogel- en walvisvangst', WFON, 45 ${ }^{\text {ste }}$ deel (1978), 41-58; especially 48-49; 57. More recently, Piet Boon's dissertation Bouwers van de zee: zeevarenden van het Westfriese platteland, c. 1680-1720. Hollandse Historische Reek 26 (Den Haag, 1996) shed more light on both the origin of masters and crews and their respective offseasonal activities.

451. Harald Voigt, 'Auf den Spuren nordfriesischer Seeleute in der europäischen Handelsfahrt von 17401830', in: Robert Bohn (ed.), Nordfriesische Seefahrer in der frühen Neuzeit (Amsterdam, 1999), 11-23; L. Hacquebord, 'Niederländischer und Deutscher Walfang im 17. Jahrhundert', in: idem, 91-104; especially 99 passim.

452. De Jong, Oude Nederlandse walvisvaart, II, 452.

453. About the same time, the Dutch government by way of Minister of Economic Affairs A.R. Falck, requested William May, consul-general in London, to research whether or not British whaleship owners 
The municipal archives in Amsterdam provide the key to a better understanding of the size, composition, and nationalities of the crew employed by Barend van Spreekens and, at a later date, by Jan Vas \& Company. Crew lists of 1815, 1816, and the era 1819-1825 have survived and are held in these archives. Complete crew lists relating to Groenland are reproduced in Appendix 3.

On 5 April 1815, master Jacob Broertjes appeared before the Harbourmaster (Waterschout) of Amsterdam. The crew of the pink Groenland, destined for Greenland, amounted to 43 hands and most of them were Dutch. They frequently listed Den Helder as place of birth. One of the whalemen on the crew list was Klaas Hoekstra, who served as harpooner on the first two voyages of 1815 and 1816 and had a monthly wage of $f_{50}$. In 1815 Den Helder was named as his place of birth. ${ }^{454} \mathrm{~A}$ few whalemen on board Groenland came from Germany; a John Hood came from 'America'. 455

The following year (1816), 50 sailors were listed. The number of foreigners (especially from northern Germany) had increased, and there were two whalemen from Liverpool in the crew. An American by the name of Peter Miller had signed up as well. Most of the Dutch whalemen claimed Den Helder as their place of residence. ${ }^{456} \mathrm{~A}$ similar picture was presented with regard to 1819 , the last year in which Broertjes participated in the Greenland whale fishery. Out of a total crew of 50 , most of the Dutchmen came from Den Helder (16) and five were from Amsterdam. Most of the foreigners came from northern Germany, with an all-time high of four men from the Frisian island of Föhr. Seven were from Oldenburg. Carel J. Moreen from Finland joined the international crew as well. In these three years, crew members with Dutch nationality formed the majority. ${ }^{457}$

would like to have their ships partly fitted out in the Netherlands. May approached Samuel Enderby and Sons. One of the elements in May's request contained the phrase that one-quarter of the crew could (not should) consist of young Dutchmen, capable of speaking the English language. These were to be hired as rowers for the boats - in short, for unskilled, cheap labour. Thus, co-operation between the Dutch government and Enderby and Sons did not materialize; nor with other British whaling entrepreneurs, for that matter. When May's proposals passed the desks of influential employees of the Amsterdam Chamber of Commerce, they advised the government to reject his plans. According to the Chamber of Commerce, there were sufficient officers and crew within the Netherlands to fill four to six whaleships: numbers suggested by May. See De Jong, idem, 452-454.

454. The next year, 1816, the island of Texel was mentioned as such. Hoekstra was to serve the Sociëteit in Harlingen one decade later.

455. SAA, Archief van de Waterschout, inventory nr. 38; nr. 95 (15 April 1815).

456. SAA, Archief van de Waterschout, inventory nr. 38; nr. 99 (26 March 1816).

457. SAA, Archief van de Waterschout, inventory nr. 38; nr. 110 (22 March 1819). 
Table 5.2: Origin of crew recruited by Barend van Spreekens (1815-1819).

\begin{tabular}{|l|l|l|l|l|l|}
\hline Year & Ship & Dutchmen & Foreigners & Total crew & Sources \\
\hline 1815 & Groenland & $32 / 33$ & $\begin{array}{l}11 / 12 \\
\text { (America 1; Borkum 4; } \\
\text { Hessen 1; Lübeck 1; } \\
\text { Oldenburg 4) }\end{array}$ & 44 & $\begin{array}{l}\text { SAA, inv. nr. 38 } \\
\text { (Archief Water- } \\
\text { schout), nr. 95 } \\
\text { (15 April 1815) }\end{array}$ \\
\hline 1816 & Groenland & $\begin{array}{l}33 \\
\text { Number of Dutchmen in- } \\
\text { cludes Dirk B. Taats from } \\
\text { Flanders. }\end{array}$ & $\begin{array}{l}18 \\
\text { (America 1; Bergen 1; Fin- } \\
\text { land (Prussian) 1; Föhr 1; } \\
\text { Bremen 1; Götenborg 1; } \\
\text { Liverpool 2; Oldenburg 6; } \\
\text { Osnabrück 3; Wisby 1) }\end{array}$ & 51 & $\begin{array}{l}\text { SAA, inv. nr. 38 } \\
\text { (Archief Water- } \\
\text { schout) nr. 99 } \\
\text { (26 March 1816) }\end{array}$ \\
\hline 1819 & Groenland & 38 & $\begin{array}{l}\text { 13 } \\
\text { (Finland 1; Föhr 4; Gstad 1; } \\
\text { Oldenburg 7) }\end{array}$ & 51 & $\begin{array}{l}\text { SAA, inv. nr. 38 } \\
\text { (Archief Water- } \\
\text { schout), nr. 110 } \\
\text { (22 March 1819) }\end{array}$ \\
\hline
\end{tabular}

\section{Jan Vas \& Company}

The municipal archives in Amsterdam also contain records of the whaling voyages organized by Jan Vas \& Company. Crew lists of six whaling expeditions are available for analysis with a variety of data. Firstly, for the years 1820-1825, the size of the crew was consistent: 46 men including Captain Frans Oom would set sail for northern waters.

Secondly, compared to the relatively small number of places of residence mentioned in the crew lists of Van Spreekens' expeditions, the great number of little villages and fairly small towns both in the Netherlands and abroad (especially Germany) is remarkable. As in the case of Barend van Spreekens, the number of Dutch whalemen with Den Helder as their place of residence was high in 1820: 20 out of a total crew of 46 , including the captain. In later years this number declined to between five and nine men.

Thirdly, as opposed to the crew having served Van Spreekens, ships employed by Vas \& Company had whalemen from the islands of Terschelling and Ameland - with a high of 9 in 1822 and a low of 3 in 1825 for Terschelling, and a meagre 1 to 2 for Ameland. The number of whalemen from Amsterdam remained low, while the percentage of foreigners was much higher than in the case of Broertjes' crews. Foreigners even outnumbered the Dutch in the years 1823 to 1825 . 
Table 5.3: Origin of crew recruited by Jan Vas \& Company (1820-1825).

\begin{tabular}{|c|c|c|c|c|c|}
\hline Year & Ship & Dutchmen & Foreigners & Total crew & Sources \\
\hline 1820 & Groenland & $\begin{array}{l}35 \\
\text { Number of Dutchmen in- } \\
\text { cludes August de Bare (or } \\
\text { Baze) from Diest (South- } \\
\text { ern Netherlands?) }\end{array}$ & $\begin{array}{l}11 \\
\text { (Arendahl 1; } \\
\text { Basseld/Barteld 1; Bremen } \\
\text { 1; Bokkeberg 1; Dinklage 1; } \\
\text { Elsfleth 1; Landskrona 1; } \\
\text { Lemförde 1; Oldenburg 2; } \\
\text { Stokholm 1) }\end{array}$ & 46 & $\begin{array}{l}\text { SAA, inv. nr. } 38 \\
\text { (Archief Water- } \\
\text { schout), nr. } 113 \\
\text { (22 March 1820) }\end{array}$ \\
\hline 1821 & Groenland & 25 & $\begin{array}{l}21 \\
\text { (Bremen } 1 \text {; Emden } 1 \text {; Gent } \\
\text { 1; Hannover } 1 \text {; Oldenburg } \\
\text { and vicinity } 16)\end{array}$ & 46 & $\begin{array}{l}\text { SAA, inv. nr. } 38 \\
\text { (Archief Water- } \\
\text { schout), nr. } 116 \\
(23 \text { February } 1821 \text { ) }\end{array}$ \\
\hline 1822 & Groenland & 24 & $\begin{array}{l}22 \\
\text { (Gent } 1 \text {; Oldenburg and } \\
\text { vicinity } 21)\end{array}$ & 46 & $\begin{array}{l}\text { SAA, inv. nr. } 38 \\
\text { (Archief Water- } \\
\text { schout), nr. } 118 \\
(23 \text { February 1822) }\end{array}$ \\
\hline 1823 & Groenland & 21 & $\begin{array}{l}25 \\
\text { (Bremen 1; Föhr 1; Hude 3; } \\
\text { Oldenburg and vicinity 18; } \\
\text { Wasa 1) }\end{array}$ & 46 & $\begin{array}{l}\text { SAA, inv. nr. } 38 \\
\text { (Archief Water- } \\
\text { schout), nr. } 120 \\
\text { (7 March 1823) }\end{array}$ \\
\hline 1824 & Groenland & 21 & $\begin{array}{l}25 \\
\text { (Bremen 2; Föhr 1; Ham- } \\
\text { burg 1; Hude } 3 \text {; Oldenburg } \\
\text { and vicinity 17; Xanten } 1 \text { ) }\end{array}$ & 46 & $\begin{array}{l}\text { SAA, inv. nr. } 38 \\
\text { (Archief Water- } \\
\text { schout), nr. 122 } \\
(20 \text { February 1824) }\end{array}$ \\
\hline 1825 & Groenland & 21 & $\begin{array}{l}25 \\
\text { (Bremen 1; Föhr 2; Ham- } \\
\text { burg/Altona 1; Hude 2; } \\
\text { Oldenburg and vicinity 19) }\end{array}$ & 46 & $\begin{array}{l}\text { SAA, inv. nr. } 38 \\
\text { (Archief Water- } \\
\text { schout), nr. } 124 \\
(25 \text { February 1825) }\end{array}$ \\
\hline
\end{tabular}

\section{Nicolaas Brantjes \& Smit}

As was the case of Zeilmaker Company from Harlingen, Brantjes \& Smit also depended on a Norwegian crew and material in outfitting their ship Maria in 1863. This wooden brig of 265 tons was built in Gothenburg in 1856. As late as 1893, Maria was still part of Brantjes' fleet. That year, his fleet amounted to four ships, the same as Zeilmaker in Harlingen operating from Norway. ${ }^{458}$ Brantjes \& Smit were based in Tønsberg, located in southern Norway. In the last quarter of the nineteenth century, Tønsberg and Sandefjord were the main centres of modern whaling in the world. Despite the Norwegian presence and influence, the catch was brought to the Netherlands, tried out at the cookery near Purmerend, and sold to the Dutch market. In 1884, Maria left for her last whaling and sealing voyage in Arctic waters.

458. See for example: Lloyd's register of British and foreign shipping (London 1887), under Maria. These ships were Antelope (1,030 tons), Koophandel (613 tons), Maria (265 tons) and Willem Eggerts (1,276 tons). Lloyd's register (London 1893). Appendix, 26. 
Referring to the whaling and sealing firm of Brantjes \& Smit from Purmerend, Van Musschenbroek stated that there was hardly anything Dutch about Maria, as its crew consisted of Norwegians with a few Finns or Russians. ${ }^{459}$ Moreover, the Dutchman quoted his Norwegian acquaintance - who, having served on Dirkje Adema was thus employed by Dutch ship owners - and stipulated that many Norwegians could be easily trained for whaling purposes. Moreover, recruiting Norwegians would not be difficult at all as they would be tempted to join Dutch ships because of their comfort. Also, the Norwegian crewmen encountered fine treatment, which according to Van Musschenbroek's Norwegian acquaintance, easily surpassed the working and living conditions on Norwegian ships. ${ }^{460}$

In 1866, A.W. Stellwagen, a teacher and man-of-letters, visited Brantjes' cookery near Purmerend. He stated that Maria customarily carried a crew of between 40 and 45 seal hunters. ${ }^{461}$ Unfortunately, he gave no specific details with regard to the origin of these crew members. Considering the fact that the vessel stayed in or around Norway for most of the time, one is inclined to assume that most, if not all hands on board, were of Norwegian nationality. Table 5.4 provides data regarding the sizes of whaling crew of companies based in the Amsterdam region. Masters are included in the total number of crew members.

Table 5.4: Number of crew on board whaleships fitted out in the Amsterdam region and destined for the Arctic region (1815-1866).

\begin{tabular}{|l|l|l|l|}
\hline Year & Ship's name & Crew & Sources \\
\hline 1815 & Groenland & 44 & SAA, inv. nr. 38 (Archief Waterschout), nr. 95; De Jong, II, 451 \\
\hline 1816 & Groenland & 51 & SAA, inv. nr. 38 (Archief Waterschout), nr. 99; De Jong, II, 451 \\
\hline 1817 & Groenland & 45 & De Jong, II, 451 \\
\hline 1818 & Groenland & 45 & De Jong, II, 451 \\
\hline 1819 & Groenland & 51 & SAA, inv. nr. 38 (Archief Waterschout), nr. 110; De Jong, II, 451 \\
\hline 1820 & Groenland & 46 & SAA, inv. nr. 38 (Archief Waterschout), nr. 113 (22 March 1820) \\
\hline 1821 & Groenland & 46 & SAA, inv. nr. 38 (Archief Waterschout), nr. 116 (23 February 1821) \\
\hline 1822 & Groenland & 46 & SAA, inv. nr. 38 (Archief Waterschout), nr. 118 (23 February 1822) \\
\hline 1823 & Groenland & 46 & SAA, inv. nr. 38 (Archief Waterschout), nr. 120 (7 March 1823) \\
\hline 1824 & Groenland & 46 & SAA, inv. nr. 38 (Archief Waterschout), nr. 122 (20 February 1824) \\
\hline 1825 & Groenland & 46 & SAA, inv. nr. 38 (Archief Waterschout), nr. 124 (25 February 1825) \\
\hline 1866 & Maria & 40 à 45 & Stellwagen, 71-75 \\
\hline
\end{tabular}

459. When writing about the selling off of Dirkje Adema, Van Musschenbroek continued: "Er bleef ons sedert maar één robbenvanger over, een Purmerender of Edammer, doch eigenlijk niet eenmaal volbloed Nederlandsch, met eene geheel Noordsche equipage en een paar Finnen of Russen." (Ever since, all that remained was one seal hunter/sealing ship, from Purmerend or Edam, although actually not once purely Dutch, with a completely Norwegian crew with a few Finns or Russians). Author's translation. Van Musschenbroek, 'Cachelot-Visscherij', 10. 460. Van Musschenbroek, idem, 10-11.

461. A.W. Stellwagen, 'De Noorweegsche visscherijen in de IJszee', 71-75. During his lifetime, Stellwagen published profusely on a great variety of topics ranging from, for example, the way the Pope in Rome was 


\section{Harlingen}

In describing the disaster that befell Captain Ymke Jansz. Ruygh in 1825, the Amsterdamsche Courant provided information concerning the size of the crew. On its return voyage, the relatively small two-decked pink Willem de Eerste carried a crew of $466^{462}$ When, in the following year of 1826, Klaas Hoekstra had to abandon his newly-built galliot Harlingen, 45 men (and two dogs) followed his example. Fourteen ship's journals - eleven of which were kept by master Hendrik Rickmers aboard Spitsbergen (II) between 1830 and 1840, and the three remaining ones dated 1846-1848 - contain information about the size of the crew. ${ }^{463}$ For all of these years, the number of hands remained fairly stable at around 50 persons in total. A decade later, in 1857, the national newspaper Algemeen Handelsblad featured the departure from Harlingen of the fairly large frigate Dirkje Adema under command of the highly experienced O. Mehlen. The anonymous reporter claimed that the ship carried a crew of no fewer than 53 hands. This number, the reporter stated, was higher than in preceding years. ${ }^{464}$

Crew lists in the municipal archive of Harlingen confirmed this high figure. Between 1857 and 1864, ships owned by Barend Visser had an average crew of close to 53, which was again a clear example of the relatively large numbers of crew that these nineteenth-century Dutch whaleships carried. Table 5.5 shows the sizes of the crews. Masters are included in these totals.

Table 5.5: Number of crew on board whaleships fitted out in Harlingen and destined for the Arctic region (1825-1864).

\begin{tabular}{|l|l|l|l|}
\hline Year & Ship's name & Crew & Sources \\
\hline 1825 & Willem de Eerste & 46 & Amsterdamsche Courant, 24 October 1825 \\
\hline 1826 & Harlingen & 46 & Dagverhaal Hoekstra \\
\hline 1831 & Spitsbergen & 47 & Ship's journal, Dr .Carl-Häberlin-Friesenmuseum, Wyk auf Föhr \\
\hline 1833 & Spitsbergen & 48 & Ship's journal, Dr .Carl-Häberlin-Friesenmuseum, Wyk auf Föhr \\
\hline 1834 & Spitsbergen & 48 & Ship's journal, Dr .Carl-Häberlin-Friesenmuseum, Wyk auf Föhr \\
\hline 1835 & Spitsbergen & 49 & Ship's journal, Dr .Carl-Häberlin-Friesenmuseum, Wyk auf Föhr \\
\hline 1836 & Spitsbergen & 50 & Ship's journal, Dr .Carl-Häberlin-Friesenmuseum, Wyk auf Föhr \\
\hline
\end{tabular}

elected [together with H.J. Wurm, De pauskeuze: de gebruiken en plechtigheden bij de verkiezing van het Opperhoofd der Roomsche Kerk (Groningen 1903)] to a biography of Otto von Bismarck [Otto von Bismarck tot aan zijn optreden als staatsman (Utrecht 1914)] to many works related to Dutch literature [Proza: een leesboek voor school en thuis (Groningen 1879)], Letterkundige bespiegelingen (Amsterdam 1890). Stellwagen demonstrated a keen interest for history and geography as well.

462. Amsterdamsche Courant, 24 October 1825.

463. The Dr. Carl-Häberlin-Friesenmuseum, Wyk auf Föhr, birthplace of master Hendrik Rickmers, is the repository of these journals, which are stored under inventory numbers HF431 (1830-1840) and HF432 (18461848). The author thanks director Jutta Kollbaum-Weber and her staff for their hospitality and co-operation in facilitating research into these journals.

464. Algemeen Handelsblad, 27 February 1857. 


\begin{tabular}{|l|l|l|l|}
\hline Year & Ship's name & Crew & Sources \\
\hline 1837 & Spitsbergen & 49 & Ship's journal, Dr .Carl-Häberlin-Friesenmuseum, Wyk auf Föhr \\
\hline 1838 & Spitsbergen & 49 & Ship's journal, Dr .Carl-Häberlin-Friesenmuseum, Wyk auf Föhr \\
\hline 1839 & Spitsbergen & 49 & Ship's journal, Dr .Carl-Häberlin-Friesenmuseum, Wyk auf Föhr \\
\hline 1840 & Spitsbergen & 49 & Ship's journal, Dr .Carl-Häberlin-Friesenmuseum, Wyk auf Föhr \\
\hline 1846 & Spitsbergen & 44 & Ship's journal, Dr .Carl-Häberlin-Friesenmuseum, Wyk auf Föhr \\
\hline 1847 & Spitsbergen & 50 & Ship's journal, Dr .Carl-Häberlin-Friesenmuseum, Wyk auf Föhr \\
\hline 1848 & Spitsbergen & $?$ & Ship's journal, Dr .Carl-Häberlin-Friesenmuseum, Wyk auf Föhr \\
\hline 1857 & Dirkje Adema & 53 & Algemeen Handelsblad, 27 February 1857 \\
\hline 1858 & Dirkje Adema & 51 & GAH, WS 15a, 1858, no. 23; GAH, WS 2, 1858, fos. 23-24 \\
\hline 1859 & Dirkje Adema & 53 & GAH, WS 2, 1859, fos. 87-88 \\
\hline 1860 & Dirkje Adema & 53 & GAH, WS 3, 1860, fos. 10-11 \\
\hline 1861 & Dirkje Adema & 55 & GAH, WS 4, B XX \\
\hline 1862 & Dirkje Adema & 52 & GAH, WS 4, 1862, B29; GAH, WS 17, 1862, no. 29 \\
\hline 1863 & Dirkje Adema & 52 & GAH, WS 5, 1863, no. 13 \\
\hline
\end{tabular}

Fairly solid data survives concerning the sizes of crews. However, additional research should provide more data about the origin of the personnel. Chances are that during the initial phase of Arctic whaling (the 1820s and possibly the 1830s), officers and the majority of the crew came either from Harlingen and its immediate surroundings or from the Dutch Frisian Islands. In a promotional statement written in order to obtain both emotional and financial support for the establishment of a whaling company in Harlingen, the future directors of this company eloquently stated how beneficial support would be. They, of course, did not refrain from mentioning the premium of $f_{9}, 000$ per ship, to be issued by the Government in case of a whaleship returning empty. Also, an important feature was the strategic location of the port of Harlingen with its cookery. Finally, the directors remarked

"[dat] de Eilanden, in onze nabijheid gelegen, kweekscholen zijn voor de equipagien..."

("the Islands, so close at hand, are training fields for crews"). 465

The islands referred to were Texel, Ameland, Vlieland, and Schiermonnikoog. Islanders also found a place on board the vessels of the Sociëteit. Referring to the activities undertaken by the Sociëteit during the period 1825-1834, Anne Dijkstra bluntly stated that the majority of the crew on whaleships fitted out in Harlingen during the nineteenth century came from the Frisian Islands. According to Dijkstra the islands of Texel, Vlieland, Terschelling, and Ameland were best represented. ${ }^{466}$ This statement

465. Gemeentearchief Harlingen (GAH). Stukken betreffende het stadsbestuur van Harlingen, 1816-1924. Archiefstuk betreffende de Groenland- en Straat-Davids-visserij 1830 (1 omslag), nr. 3399. Author's translation. 466. Anne J. Dijkstra, 'De Groenlands- en Straat Davids-Visserij Sociëteit te Harlingen', Jaarboek Fries Scheepvaartmuseum en Oudheidkamer (1964/1965), 57. 
may also be true for the second half of the nineteenth century, an era not covered by Dijkstra, which will be discussed later.

Matters were apparently quite different during the early years of the Frisians' participation in the whaling and sealing industries. The lack of contemporary crew lists requires further investigation into secondary sources to understand the composition of the crew. Strong evidence for regional cooperation, with more or less experienced sailors (not strictly trained as whalemen) from these islands so close near Harlingen, was not found in the records from 1826/1827, particularly on board the ill-fated Harlingen, commanded by Klaas Hoekstra. In his Dagverhaal, Hoekstra mentioned the names of his crew. Their names and origin are listed in Table 5.6. Out of a ship's company of 46, including the captain, only one crewman can be considered a foreigner: Harmen Treking from Oldenburg (Germany). The remaining 45 came from little villages or towns near Harlingen, from Harlingen proper (5), Den Helder (1), and the Frisian Islands - Texel (5), Vlieland (2), and Ameland (1). Interestingly, no sailors from Terschelling were mentioned. ${ }^{467}$

Table 5.6: Origin of the crew members of the galliot Harlingen under Captain Klaas Hoekstra (1826).

\begin{tabular}{|l|l|}
\hline Origin & Names and rank \\
\hline Not specified $(30=67 \%)$ & $\begin{array}{l}\text { Adema, Job; Bakker, Evert; Dekker, M.; Dorpen, S. van; Es, M. van; Gor- } \\
\text { dijn, P.J. (surgeon); Graaf, Lieuwe de; Hannema, Jacob; Hassing, P. (boy); } \\
\text { Haverkost, Jan; Hoedfiller, Jan; Hoedfiller, Jan H.; Hoek, G.; Hoffius, Jur- } \\
\text { jen; Hovinga, Jan; Koudenburg, Folkert; Lange, Jan de; Langeveld, P. (boy); } \\
\text { Lemstra, Doede; Mores, Jan; Mores, Dirk; Oom, J. (first mate); Park, Jan; } \\
\text { Rab, Arie; Stavanga, Willem; Visser, Jan; Visser, Johannes; Visser, Jan Ol- } \\
\text { jers; Woude, P.F. van der }\end{array}$ \\
\hline Harlingen $(5=11 \%)$ & $\begin{array}{l}\text { Broesma, Nis (mastercarpenter); Hoek, Hartman; Hoekstra, Klaas } \\
(\text { captain); Hoekstra, Sijtse (son of Klaas); Koerse, Zwerus }\end{array}$ \\
\hline Den Helder $(1=2,2 \%)$ & Krul, Rijnier $\dagger$ (died during voyage) \\
\hline Texel $(5=11 \%)$ & $\begin{array}{l}\text { Bakker, Jan; Karsman, Jacob (cook's mate); Kok, Pieter; Kart, Abraham; } \\
\text { Schuil, Willem }\end{array}$ \\
\hline Vlieland $(2=4,3 \%)$ & Blom, Tjaard; Koudenburg, Adriaan \\
\hline Ameland $(1=2,2 \%)$ & Lolkes, Hendrik \\
\hline Oldenburg $($ Northern Germany) $(1=2,2 \%)$ & Treking, Harmen (second boatswain) \\
\hline Föhr (Northern Germany) $1=2,2 \%$ & Booijse, Booij \\
\hline
\end{tabular}

467. K. Hoekstra, Dagverhaal van het verongelukken van het galliot Harlingen in Straat Davis. De Togt van de Equipage met sloepen over en langs het ijs, en overwintering van deselve in het Noordelijk gedeelte van Groenland door den Kommandeur Klaas Hoekstra van Texel (Harlingen 1828). In 2005 an annotated and modernized version of Hoekstra's journal was delivered by Annie Douma and published by Uitgave Flevodruk in Harlingen. It showed, for example, that Ymke Ruygh, master of Willem de Eerste, had listed at least two inhabitants from the island of Terschelling on board, and he came from this island as well. Analyses of a small number of names from the large category "Not Specified (31 crew members)" through the website of the Tresoar in Leeuwarden has shown that many of the crewmen originated from small communities in the vicinity of Harlingen. 
In at least two instances captains had their children accompany them on their voyages. As discussed earlier, Klaas Hoekstra, sailing from Harlingen for the Arctic in March of 1826, took his oldest son Sytse on board his brand-new whaleship Harlingen, which got stuck in the ice of Baffin Bay. After many ordeals both men finally returned home safely. Other dramatic evidence that masters took their sons along on whaling expeditions was found in the case of Ymke Jansz. Ruygh. On 20 October 1825, Ruygh, who was employed by the Groenlandse en Straatdavidse Visscherij Sociëteit in Harlingen (as was Hoekstra), could almost see his little Frisian home port as his ship Willem de Eerste sank near the isle of Texel with no fewer than three of his sons on board. ${ }^{468}$ Ruygh was born on the island of Terschelling, as were Pieter Douwes Pronker and another, anonymous crew member of the vessel. Holding on to pieces of wood, these men survived the catastrophe of Willem de Eerste and made their way to the shore. ${ }^{469}$ At this point it is difficult to conclude whether these two examples of family connections were typical or exceptional.

More reliable data concerning the composition of the crews, and the presence of sailors from Terschelling hired by companies and entrepreneurs in Harlingen, are available for only a few years. There is one undated crew list, possibly compiled in 1845 or 1846, relating to Spitsbergen (II) and currently in the collection of the Friesenmuseum on Föhr. The municipal archives of Harlingen contain six crew lists that were compiled in the 1850 and 1860 . These lists refer to Dirkje Adema.

The 1845/1846 list contained only 35 names (see Table 5.7 below). ${ }^{470}$ All crewmen except one were listed with a place of residence. The number of whalemen from Harlingen and its vicinity was relatively small (five from the city, two from nearby Anjum, and one from Hindeloopen). Only nine whalemen (approximately $26.47 \%$ ) were from Terschelling and were deployed by Barend Visser \& Son. German whalemen were very well represented in the Spitsbergen expedition to the Arctic, as no fewer than seventeen sailors (50\%) were from Seestermühe, Heist, Gluckstadt (all located in SchleswigHolstein), and other places in northern Germany. ${ }^{471}$

468. Amsterdamsche Courant, 24 October 1825; De Reddingboot, no. 54 (Christmas 1942).

469. This statement was based on the report from Th. Bakker, farmer and former crew member of Dirkje Ade$m a$, who lived at Ooster-End on the island of Terschelling. Pronker had his residency on the same island, in Formerum. See G.A. Wumkes, Tusschen Flie en Borne. Schetsen uit de geschiedenis van Schellingerland (WesterSchelling 1900), 100. The facsimile-edition, introduced by Y. Poortinga and published in Leeuwarden in 1968, was used. In his book Wumkes pointed out that a few initiatives could not re-establish a flourishing whaling industry. According to Wumkes, around 1900, employment for most islanders had shifted from whaling and sealing to the herring fishery with its centres in Vlaardingen, Maassluis, and abroad in Emden. Op cit., 94; 100. 470. The document is damaged and probably incomplete. The actual number of crew members must have been higher. Topographical names were listed as found.

471. There is not a place of residency listed for T. Lohman. However, based on the spelling of his name it seems fair to assume that this man also came from Germany and will be listed as such in Table 5.9. To date, no information has been found to locate Robziel and Heit Gram. 
Table 5.7: Crew list of Spitsbergen (II) under Captain Johan Both (ca. 1845). ${ }^{472}$

\begin{tabular}{|c|c|}
\hline Origin & Names and rank \\
\hline Not specified $(1=2.8 \%)$ & Lohman, $\mathrm{T}$. \\
\hline Harlingen $(5=14.3 \%)$ & $\begin{array}{l}\text { Altar, J. (carpenter); Backer, Klaas; Both, Johann (captain); Both, M.; } \\
\text { Wielst, H. (cooper) }\end{array}$ \\
\hline Anjum $(2=5.6 \%)$ & Sjoordema, Siete L.; Walda, Riens \\
\hline Hindeloopen $(1=2.8 \%)$ & Droogen, S. van \\
\hline Terschelling (East: $1=2.8 \%$ ) & Ruig, G. \\
\hline Terschelling (West: $8=\mathbf{2 2 . 4} \%$ )) & $\begin{array}{l}\text { Baaker, L.; Jol, Feike [name is crossed out]; Keulen, W. van; Luidinga, J.; } \\
\text { Luidinga, W.; Roeland, Cornelis; Spits, Roelf J.; Zwart, D. }\end{array}$ \\
\hline Heist $(5=14 \cdot 3 \%)$ & $\begin{array}{l}\text { Bösh, C.; Hase, J. (flenser); Osenbrugen, Christoffer (1st mate); } \\
\text { Osenbrugen, W.; Siesefelt, Johann }\end{array}$ \\
\hline Seestermühe $(6=16.8 \%)$ & $\begin{array}{l}\text { Hulmann, Johann; Köllen, Frans; Lüders, Johann; Osenbrugen, H.; } \\
\text { Stohl, Pieter; Wrage, J. (flenser's mate) }\end{array}$ \\
\hline Gluckstadt $(2=5.6 \%)$ & Hanssen, H.; Hartz, J. (2nd mate) \\
\hline Robziel $(2=5.6 \%)$ & Leistra, P.; Zakers de Vries, J. (second boatswain) \\
\hline Heit Gram $(2=5.6 \%)$ & Bruhn, J.; Reder, E. \\
\hline
\end{tabular}

In later years, the participation of whalemen from Terschelling was overwhelming. This was demonstrated in the analyses of the crew employed on Dirkje Adema in the late 1850 os and early 1860s. In 1857 Dirkje Adema had a crew mainly consisting of 'inlanders' (indigenous Frisians). Dijkstra provided some names: Pieter G. Bos, Jan Wever, Willem Scroo, Jacob Jelle Spits, and Cornelis and Kees van Rees all came from Terschelling. Klaas Tot represented Vlieland. 473 In the archive of the Waterschout in Harlingen, the crew lists of Dirkje Adema for the years 1858 through 1863 were examined and a list of 313 names of whalemen was compiled. ${ }^{47}$ The complete lists of crews serving on the pink Dirkje Adema are presented in Appendix 4.

The sources also provided information regarding the residence or place of birth of the whalemen, their ages, their ranks and sources of income. This data, referring to all whalemen except for the masters, is presented in Table 5.8. This data explains why

472. As this crew list stands on its own and is not part of a series, it was decided to incorporate it into the main text.

473. Algemeen Handelsblad, 27 February 1857. C. de Jong, 'De "Dirkje Adema”, Nederlands laatste Groenlandvaarder', Jaarboek Fries Scheepvaartmuseum en Oudheidkamer (1964/1965), 41; Anne J. Dijkstra, 'De Groenlands- en Straat Davids-Visserij Sociëteit te Harlingen', Jaarboek Fries Scheepvaartmuseum en Oudheidkamer (1964/1965), 57. In 1894, Klaas Tot was one of the sailors on board the newly built frigate Nederland (1950 bruto tons), with Captain G. Bona from Germany. On its maiden voyage Nederland was destined for Batavia and the second voyage had San Francisco as its final destination. The frigate was built on the wharf Concordia in Amsterdam. Jan Houter, Al zwerf ik op de baren... Vlielandse zeevaarders van eind 16e tot eind 19e eeuw (Baarn 1978), 48-49.

474. GAH, Archief Waterschout (Harbourmaster-WS) 15a, 1858, no. 23; GAH, WS 2, 1858, fos. 23-24; GAH, WS 2, 1859, fos. 87-88; GAH, WS 3, 1860, fos. 10-11; GAH, WS 4, 1861, BXX; GAH, WS 4, 1862, B29; GAH, WS 17, 1862, no. 29; GAH, WS 5, 1863, no.13. 
the numbers for the years 1858 to 1863 add up to 313 (319 minus six masters). In discussing the origin of the crew of Dutch whaleships, it seems logical to focus on the data regarding residence or place of birth. The crew lists relating to these six years partly support Dijkstra's remark that the majority of whalemen on Dirkje Adema were islanders - in all cases, however, from Terschelling and not from the other Frisian Islands.

Table 5.8: Origin of crew members of Dirkje Adema (1858-1863). ${ }^{475}$

\begin{tabular}{|c|c|c|c|c|c|c|}
\hline Origin & 1858 & 1859 & 1860 & 1861 & 1862 & 1863 \\
\hline Harlingen & 25 & 16 & 12 & 10 & 9 & 13 \\
\hline Terschelling & 13 & 12 & 22 & 32 & 16 & 15 \\
\hline St. Annaparochie & 1 & 3 & 7 & 4 & 3 & 2 \\
\hline St. Jacobaparochie & 1 & 1 & & & 6 & 3 \\
\hline Anjum & 1 & 3 & 1 & 1 & 3 & 2 \\
\hline Sexbierum & 2 & 3 & 4 & 2 & 5 & 4 \\
\hline Oosterbierum & & 1 & & & & \\
\hline Grouw & & & & & & 1 \\
\hline Franeker & 1 & 1 & & 1 & 2 & 1 \\
\hline Bechtum & & & & & & 1 \\
\hline Pingjum & & & & & & 1 \\
\hline Minnertsga & & & & & & 1 \\
\hline IJlst & & & & & & 1 \\
\hline Weinaldum & & & & & & 1 \\
\hline Wierum & & & & & 1 & \\
\hline Zweins & & & & & 1 & \\
\hline Sneek & & & & & 3 & \\
\hline Bolsward & & & 1 & 1 & . & \\
\hline Roptazijl & & & & & 1 & \\
\hline O.Bildtzijl & & 3 & & & & \\
\hline Lemmer & & & 1 & & & \\
\hline Paesens & 1 & 1 & 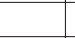 & & & \\
\hline Workum & 2 & 1 & 1 & & & \\
\hline Joure & 1 & 1 & & & & \\
\hline Ternaard & 1 & & & & & \\
\hline Leeuwarden & & 1 & & & & \\
\hline Holwerd & & & 1 & & & \\
\hline Kimswerd & & & & 1 & & \\
\hline Butgum [Beetgum, Friesland] & & & & & & 1 \\
\hline Loweins? & & & & & & 1 \\
\hline$?$ & & & & & & 2 \\
\hline Graft/De Rijp & & 1 & 1 & 1 & 1 & \\
\hline Amsterdam & & 1 & & 1 & & \\
\hline Leiden & & & & & & 1 \\
\hline GERMANY & & & & & & \\
\hline Uetersen (Schleswig-Holstein) & & 1 & & & & \\
\hline Seestermühe (Schleswig-Holstein) & & 2 & & & & \\
\hline Leipzig & 1 & & & 1 & & \\
\hline Hamburg & & 1 & 1 & & 1 & \\
\hline Totals & 50 & 53 & 52 & 55 & 52 & 51 \\
\hline
\end{tabular}

475. See Appendix 4 for a complete list of primary sources on which this table was based. 
That a large number of whalemen came from Harlingen should come as no surprise. On the contrary, one would expect higher numbers for this harbour town. The number of Terschellingers, however, is striking. In the years $1858,1859,1862$, and 1863 , these islanders made up about 20 to $30 \%$ of the crew. Exceptionally high figures for 1860 and 1861 push the figures up to about 40 and $60 \%$, respectively. Further, it is fair to conclude that Dutch whaling crews in these years had a rather provincial character. The great majority of the whalemen came from Harlingen and the island of Terschelling, or from smaller towns and villages within the province of Friesland, most of which are located close to Harlingen. Including the two instances where a question mark was placed for the place of residence, and adding to these the number of references of whalemen from other provinces (more specifically, from the provinces of North Holland and South Holland), the total number of non-Frisian Dutch whalemen does not exceed seven out of 313. In eight instances whalemen were from Germany, notably Uetersen, Seestermühe, Hamburg, and Leipzig. ${ }^{476}$

Thanks to these records, some insight into the average age of the whalemen on board Dirkje Adema during the years 1859-1863 can be given. The following data was based on the crew lists for this period and is presented in full in Appendix 4. For 1858, the crew list does not provide the whaleman's ages. Nevertheless, analysis of the remaining years presents an interesting picture. Here again, the average ages are based on data referring to all whalemen except the captains. Finally, it should be pointed out that for the year 1859 three names were listed without ages.

In 1859 , the average age of a whaleman was a little over 25 . In 1861, the average age was over 25 and one-half. ${ }^{477}$ The youngest member of the crew was 14; the oldest (Jacob Spits) was 44. From the crew list data, their ranks can also be discerned. That year, the commander headed for the whaling grounds with the first and second mate, a flenser (speksnijder), a boatswain, five harpooners, a second boatswain, a carpenter, a cooper, a cook, a cook's mate, a cabin boy, and 39 ordinary seamen. It should be noted that the second mate was a German.

Many of these whalemen knew one another. In more than one case they were also family-related. As was shown in the case of Ymke Jansz Ruygh and Klaas Hoekstra, kinsmen were not uncommon among crew members: Jacob Jelle Spits and Jacob Spitz

476. Albeit of utmost importance to our knowledge of the composition of the crews, these crew lists are, however, not the only source of information. Documents about the nationality of the crew of Dirkje Adema, during one of its many whaling expeditions, can be found from a rather unexpected, well-informed source. In his article, written to promote the start of sperm whaling operations under the Dutch flag in the Dutch East Indian archipelago, Van Musschenbroek referred to a conversation he had in 1865, when he learned about the abandonment of Dirkje Adema from one of his former co-travellers, a Norwegian harpooner who at one time had served on this ship. Van Musschenbroek, 'Cachelot-Visscherij', 10.

477. The absence of the ages of four men on the list had little or only marginal consequences to the average age. 
(sic), both from Terschelling, may have been related to one another. Eelke, Ietse, Arie, Jan, and Arie de Beer; Cornelis and Dirk van Rees; and Cornelis Ariens and Cornelis Thijssen Pals all originated from the same island. The same may account for Willem Hendrik, Hendrik and Jacob van Keulen, and for Hendrik and Jan van der Molk. ${ }^{478}$ The relationships among the whalemen deserves broader attention than can be provided here.

\section{Rotterdam}

During the 1820 sotterdam was involved in whaling and sealing in the Arctic as well. Between 1825 and 1827 two vessels - Rotterdam and Maasstroom - were deployed for that purpose. Indications about the composition of the crew, or at least about foreigners in the labour force of Dutch whaleships, can be found in the case of C.J. Bottemanne's Nederlandsche Walvischvaart N.V., established in 1869. Dissatisfied with the typical Dutch crew's lack of experience in the 1870 season, Bottemanne decided in 1871 to make a stopover in Lerwick (Shetland Islands) to sign on a crew of experts. He had to wait there several days for the Scottish seal hunters to return. As stated earlier, Scots were involved in both seal hunting and whaling, and treated them as two separate industries. They left their harbours to hunt seals (roughly between March and May) before setting out on whaling expeditions. ${ }^{479}$ There are no records, however, of Scots signing up as crew members on Bottemanne's Noordkaper. To date, no crew lists have been found. ${ }^{480}$

Table 5.9 contains an overview of data compiled from crew lists in the municipal archives of Amsterdam and Harlingen (as was presented separately in Tables 5.2, 5.3, 5.7, and 5.8). Masters are included in the totals. The number of Dutch crew members is compared with figures of foreigners employed by the whaling and sealing companies.

478. One held residency in Amsterdam and the other in St. Annaparochie (Friesland). Chances are that these men were related.

479. In his report vis-à-vis the second whaling expedition, Bottemanne clearly showed his great satisfaction about their performances. See C. de Jong, 'Twee scheepsjournalen van C.J. Bottemanne als laatste Nederlandse commandeur ter walvisvangst', Economisch-historisch Jaarboek. Bijdragen tot de economische geschiedenis van Nederland, vol. 30 (Den Haag 1965), 112.

480. Personal communication with Angus Johnson, Archival Services, Lerwick, Shetland Islands, Scotland. In an e-mail dated 16 February 2005, it was stated, "We are short of other sources to shed light on the problem [of size and composition of the crew]. I had a look in the Customs and Excise documents, and nothing came up. There aren't any harbour master reports, I'm afraid, and no navigation school at this point in time. Eyewitness accounts could turn up (though I expect not) - but I haven't noticed any at the moment. As for the crew - we have no records of anyone being recruited." 
Table 5.9: Origin of crew members on Arctic voyages, divided into Dutchmen and foreigners (1815-1884).

\begin{tabular}{|c|c|c|c|c|c|}
\hline Year & Ship & Dutchmen & Foreigners & Total crew & Sources \\
\hline 1815 & Groenland & $32 / 33$ & $\begin{array}{l}11 / 12 \\
(\text { America 1; Borkum 4; } \\
\text { Hessen 1; Lübeck 1; Olden- } \\
\text { burg 4) }\end{array}$ & 44 & $\begin{array}{l}\text { SAA, inv. nr. } 38 \\
\text { (Archief Water- } \\
\text { schout), nr. } 95 \\
\text { (15 April 1815) }\end{array}$ \\
\hline 1816 & Groenland & $\begin{array}{l}33 \\
\text { Number of Dutchmen in- } \\
\text { cludes Dirk B. Taats from } \\
\text { Flanders. }\end{array}$ & $\begin{array}{l}18 \\
\text { (America 1; Bergen 1; Fin- } \\
\text { land (Prussian) 1; Föhr 1; } \\
\text { Bremen 1; Götenborg 1; } \\
\text { Liverpool 2; Oldenburg 6; } \\
\text { Osnabrück 3; Wisby 1) }\end{array}$ & 51 & $\begin{array}{l}\text { SAA, inv. nr. } 38 \\
\text { (Archief Water- } \\
\text { schout), nr. } 99 \\
(26 \text { March 1816) }\end{array}$ \\
\hline 1819 & Groenland & 38 & $\begin{array}{l}13 \\
\text { (Finland 1; Föhr 4; Gstad 1; } \\
\text { Oldenburg 7) }\end{array}$ & 51 & $\begin{array}{l}\text { SAA, inv. nr. } 38 \\
\text { (Archief Water- } \\
\text { schout), nr. } 110 \\
\text { (22 March 1819) }\end{array}$ \\
\hline 1820 & Groenland & 35 & $\begin{array}{l}11 \\
\text { (Arendahl 1; Basseld/Barteld } \\
\text { 1; Bremen 1; Bokkeberg 1; } \\
\text { Dinklagen 1; Elsfleet 1; } \\
\text { Landskrona 1; Lemförde 1; } \\
\text { Oldenburg 2; Stokholm 1) }\end{array}$ & 46 & $\begin{array}{l}\text { SAA, inv. nr. } 38 \\
\text { (Archief Water- } \\
\text { schout), nr. } 113 \\
(22 \text { March 1820) }\end{array}$ \\
\hline 1821 & Groenland & 25 & $\begin{array}{l}21 \\
\text { (Bremen 1; Emden 1; Gent } \\
\text { 1; Hannover 1; Oldenburg } \\
\text { and vicinity 16) }\end{array}$ & 46 & $\begin{array}{l}\text { SAA, inv. nr. } 38 \\
\text { (Archief Water- } \\
\text { schout), nr. } 116 \\
(23 \text { February 1821) }\end{array}$ \\
\hline 1822 & Groenland & 24 & $\begin{array}{l}22 \\
(\text { Gent 1; Oldenburg and } \\
\text { vicinity 21) }\end{array}$ & 46 & $\begin{array}{l}\text { SAA, inv. nr. } 38 \\
\text { (Archief Water- } \\
\text { schout), nr. 118 } \\
(23 \text { February 1822) }\end{array}$ \\
\hline 1823 & Groenland & 21 & $\begin{array}{l}25 \\
(\text { Bremen 1; Föhr 1; Hude 3; } \\
\text { Oldenburg and vicinity 18; } \\
\text { Wasa 1) }\end{array}$ & 46 & $\begin{array}{l}\text { SAA, inv. nr. } 38 \\
\text { (Archief Water- } \\
\text { schout), nr. } 120 \\
\text { (7 March 1823) }\end{array}$ \\
\hline 1824 & Groenland & 21 & $\begin{array}{l}25 \\
\text { (Bremen 2; Föhr 1; Ham- } \\
\text { burg 1; Hude 3; Oldenburg } \\
\text { and vicinity 17; Xanten 1) }\end{array}$ & 46 & $\begin{array}{l}\text { SAA, inv. nr. } 38 \\
\text { (Archief Water- } \\
\text { schout), nr. 122 } \\
\text { (20 February 1824) }\end{array}$ \\
\hline 1825 & Groenland & 21 & $\begin{array}{l}25 \\
\text { (Bremen 1; Föhr 2; Ham- } \\
\text { burg/Altona 1; Hude } 2 \text {; } \\
\text { Oldenburg and vicinity 19) }\end{array}$ & 46 & $\begin{array}{l}\text { SAA, inv. nr. } 38 \\
\text { (Archief Water- } \\
\text { schout), nr. 124 } \\
(25 \text { February 1825) }\end{array}$ \\
\hline 1826 & Harlingen & 45 & $\begin{array}{l}1 \\
\text { (Oldenburg) }\end{array}$ & 46 & $\begin{array}{l}\text { Notebook Klaas } \\
\text { Hoekstra; K. Hoek- } \\
\text { stra, Dagverhaal }\end{array}$ \\
\hline $1845 / 46$ & Spitsbergen & 17 & $\begin{array}{l}18 \text { (includes T. Lohman, } \\
\text { place of residency un- } \\
\text { known) }\end{array}$ & 35 & $\begin{array}{l}\text { Crew list, Friesen- } \\
\text { museum, Wyk auf } \\
\text { Föhr }\end{array}$ \\
\hline 1858 & Dirkje Adema & $49 / 50$ & $\begin{array}{l}1 \\
\text { (Leipzig) + } 1 \text { (master } \\
\text { Mehlen??) }\end{array}$ & 51 & $\begin{array}{l}\text { GAH, WS 2, 1858, } \\
\text { fos. 23-24; GAH, } \\
\text { WS 15a, no. } 23\end{array}$ \\
\hline
\end{tabular}




\begin{tabular}{|c|c|c|c|c|c|}
\hline Year & Ship & Dutchmen & Foreigners & Total crew & Sources \\
\hline 1859 & Dirkje Adema & $52 / 53$ & $\begin{array}{l}1 \\
(\text { Hamburg })+1 \text { (master } \\
\text { Brinkmann??) }\end{array}$ & 54 & $\begin{array}{l}\text { GAH, WS 2, 1859, } \\
\text { fos. } 87-88\end{array}$ \\
\hline 1860 & Dirkje Adema & 52 & $\begin{array}{l}1 \\
\text { (Hamburg) }\end{array}$ & 53 & $\begin{array}{l}\text { GAH, WS } 3,1860 \text {, } \\
\text { fos. } 10-11\end{array}$ \\
\hline 1861 & Dirkje Adema & 55 & 1 & $56 ?$ & $\begin{array}{l}\text { GAH, WS 4, 1861, } \\
\text { BXX }\end{array}$ \\
\hline 1862 & Dirkje Adema & 52 & $\begin{array}{l}1 \\
\text { (Hamburg) }\end{array}$ & 53 & $\begin{array}{l}\text { GAH, WS 4, 1862, } \\
\text { B29 }\end{array}$ \\
\hline 1863 & Dirkje Adema & 52 & None & 52 & $\begin{array}{l}\text { GAH, WS 5, 1863, } \\
\text { no. } 13\end{array}$ \\
\hline 1870 & Noordkaper & ? & ? & ? & \\
\hline $\begin{array}{l}187 \mathrm{os} / \\
188 \mathrm{os}\end{array}$ & Maria & $?$ & $?$ & $?$ & \\
\hline
\end{tabular}

The contrast of the rather provincial, parochial Harlingen with cosmopolitan Amsterdam is striking. Arguably, as a result of the more internationally-oriented character of the city, Barend van Spreekens and other ship owners involved in whaling and sealing during the era 1815-1825 employed larger groups of whalemen from abroad. In the case of whaleships fitted out in Harlingen (data related to the years 1826, and 1858-1863), companies and entrepreneurs recruited a large number of 'locals' as crew members..$^{41}$

\section{Educational background}

This subsection deals with the educational background of the Dutch whalemen employed in the Arctic in the nineteenth century. The nature and criteria of navigational education, will be discussed. A comprehensive study of navigational education in the Netherlands still needs to be written. ${ }^{482}$

481. Here it seems as if the overall trend, started roughly around 1730, regarding the increasing numbers of foreigners aboard Dutch ships, was continued up to the 1850 . For a brief overview of foreign sailors aboard Dutch ships see P.C. van Royen, 'Employment aboard the Dutch merchant marine in the seventeenth and eighteenth centuries', Robert Bohn (ed.), Nordfriesische Seefahrer in der frühen Neuzeit (Amsterdam 1999), 114-118. It should be noted that the crew lists also provide information with respect to the crew's wages as well as additional sources of income. Financial matters will be discussed in Chapter 7.

482. In his introduction to the thematical issue of Tijdschrift voor Zeegeschiedenis (1985, no. 3: concerning navigational education in the Netherlands during the nineteenth and twentieth centuries), W.F.J. Mörzer Bruyns mentioned the lack of interest in navigational education in the field of the fisheries (p. 163). In the same volume J.P. van der Voort devoted 15 pages to this very topic: J.P. van der Voort, 'Het visserijonderwijs in Nederland in de 19e en vroeg 2oe eeuw. Een overzicht', Tijdschrift voor Zeegeschiedenis, vol. 4 (1985), no. 3, 220-234. In this chapter, the results of research C.A. Davids conducted was relied upon heavily. For a useful overview, see his 'Het zeevaartkundig onderwijs voor de koopvaardij in Nederland tussen 1795 en 1875. De rol van het Rijk, de lagere overheid en het particuliere initiatief, Tijdschrift voor Zeegeschiedenis, vol. 4 (1985), no. 3, 164-19o. 
King Willem I and his Ministers laid down the criteria for subsidizing navigational education in his KB of 12 October 1823 (nr. 65). Education was to be free to all students desiring a career either in the Royal Netherlands Navy or in the merchant marine. The criteria for the final exams to obtain the rank of fourth, third, second or first officer (mate) were formulated in this KB as well. ${ }^{83}$

In 1851 the liberal prime-minister J.R. Thorbecke left it to local authorities and private individuals to organise matters, and within a relatively short period of time navigational education was taught in a number of places. In 1854, Rotterdam took the lead. By 1858 Amsterdam, Dordrecht, Middelburg, Harlingen, Groningen, Veendam, Assen, and Delfzijl had followed.

In his article on the history of navigational education in the Netherlands, C.A. Davids focused on the problems one encounters when attempting to establish certainty about the refinement or completeness of the courses in navigation and mathematics taught at several institutions. These problems resulted from a lack of data concerning the courses themselves, the number and individual quality of the students following these courses, or - at worst - the combination of both elements. ${ }^{484}$ Davids' conclusions may be right for most nautical colleges. The Nautical College in Harlingen, however, was an exception. There, the archives contain important and hitherto little scrutinized data about its students and their progress during training. The register of these students forms the basis of this treatise on the level of education among the crew on board Dutch whaleships. Firstly, however, the role of the nautical college in Amsterdam in the manning of Dutch whaleships will de discussed.

\section{The Nautical College in Amsterdam}

In 1785 the Kweekschool voor de Zeevaart (Nautical College) was established in Amsterdam. The municipal archive in Amsterdam contains numerous records of this institution, among which are the important minutes of the meetings of the Directors of the College, relating to the period 1824-1832. The record of a meeting of the Directors on 18 May 1825, contains a long list of 303 pupils who followed their training at the institute after the re-installation of the Nautical College in 1815 . Oddly, none of these 303 cadets seems to have had any experience in the whaling business. ${ }^{485} \mathrm{Be}$ this as it may, the documents reveal that both the whaling company based in Rotterdam (during 1825-1827) and the Sociëteit in Harlingen (1825-1834) were supplied with pupils from

483. Davids, 'Zeevaartkundig onderwijs', 164-165.

484. Davids, idem, 174.

485. SAA, inv. nr. 949 (archief Kweekschool voor de Zeevaart), nr. 27 (1825), fos. 260-276 (Directors' meeting on 18 May). 


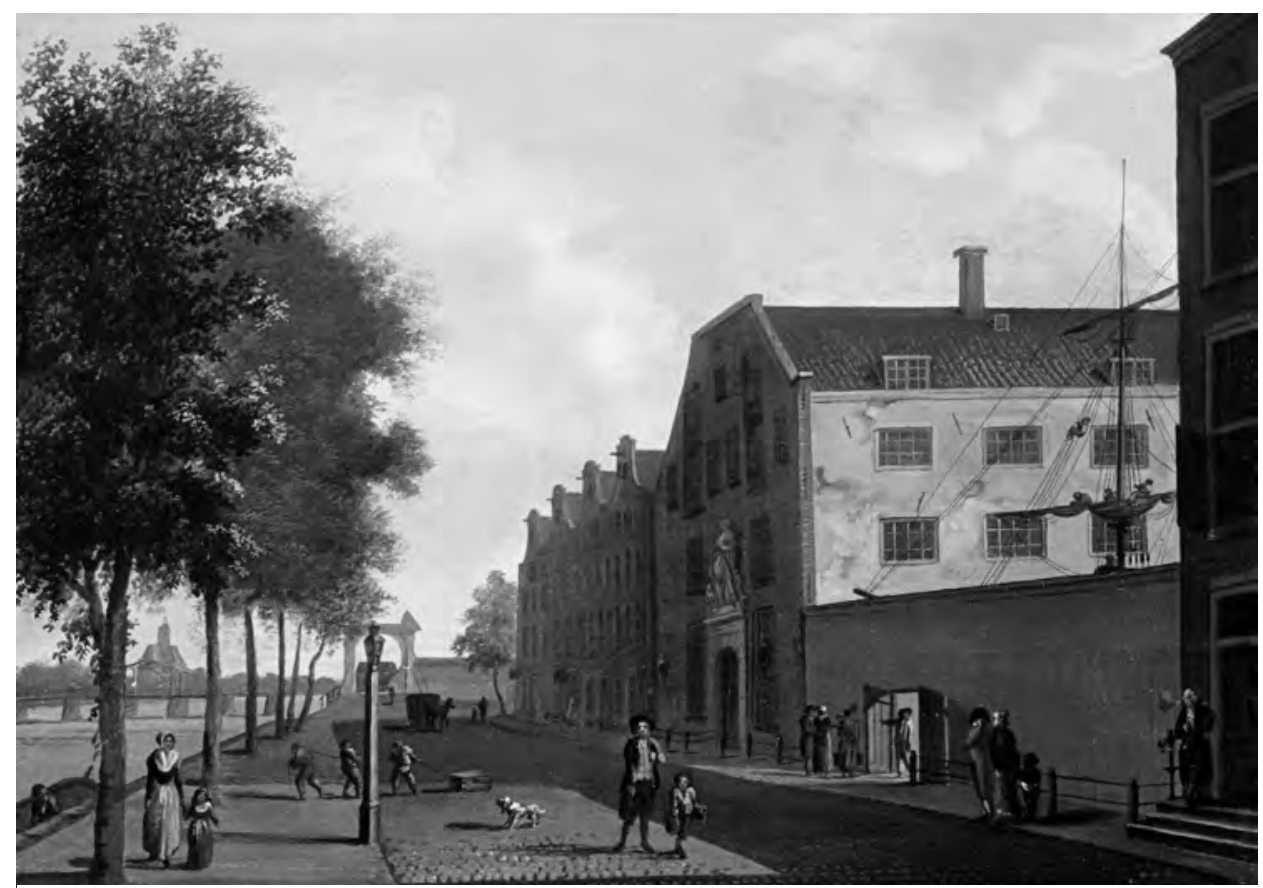

11. Depiction of the Nautical College in Amsterdam, ca. 1790. During the nineteenth century several whaling companies requested pupils from the Nautical College in Amsterdam. Painting on panel. Anonymous artist. Loan from the Vaderlandsch Fonds ter Aanmoediging van 's Lands Zeedienst. Nederlands Scheepvaartmuseum Amsterdam. Inventory number RB.0452.

the Amsterdam college. For obvious reasons the exchange was mutually beneficiary. In this way, the whaling companies were able to recruit well-trained (and relatively cheap) officers-to-be, while the pupils themselves could expand their professional horizons in the harsh, rough whaling and sealing industries, considered by many to be ideal cradles for a well-respected seaman.

Chapter 4 briefly discusses the recruitment of pupils by the Rotterdam-based Nederlandsche Maatschappij voor Walvischvangst. Requests for personnel were discussed in the biweekly Directors' meetings and Table 5.10 gives an overview of the young cadets hired by this whaling company. ${ }^{486}$

486. One of the founding fathers of the Rotterdam whaling company was Frans Smeer. A Mr. Smeer from Rotterdam was mentioned as 'Kommisaris-Korrespondent' (a kind of agent) for the Kweekschool in SAA, inv. nr. 949 (archief Kweekschool voor de Zeevaart), nr. 28 (1828), fo. 141 (Directors' meeting on 24 September). It is tempting to link Frans Smeer to the recruitment of Amsterdam pupils for whaleships fitted out in Rotterdam. 
Table 5.10: Pupils from the Amsterdam Nautical College employed by the Nederlandsche Maatschappij voor Walvischvangst (1825-1827). ${ }^{487}$

\begin{tabular}{|l|l|l|}
\hline Year & Names & Number \\
\hline 1825 & Berg, ? van den; Elias, J.; Vries, ? de; Walker, P.T. & 4 \\
\hline 1826 & Barnevelt, E.; Blad, J.; Elias, J.; Herderschée, D.; Retgers, J.W.; Veenstra, W.C. & 6 \\
\hline 1827 & Kreulen, G.; Veltkamp, P. & 2 \\
\hline
\end{tabular}

The relationship between the Amsterdam Kweekschool and the Sociëteit in Harlingen lasted a bit longer. The first reference to the Frisian whaling company was found in the minutes relating to the Directors' meeting of 17 January 1827. That day, the chairman referred to the gratitude displayed by a mister Vos (a correspondent for the Sociëteit), to the Nautical College for having provided pupils for their ships. In his minutes, Secretary L. Zegers Veeckens revealed that this system of recruitment has been effective for the Rotterdam-based company for two years. ${ }^{48}$

Two weeks later the Directors discussed a letter from the Sociëteit dated January 26, requesting three to four pupils for three whaleships and they decided to comply with the company's request. ${ }^{489}$ Eventually, four pupils travelled to Harlingen: J.W. van Schaik and T. Hagen, who joined the crew of Nederland under master J.J. Adriaan, and H.H.V.N. Schermerts and J.H. Manheim boarded the ill-fated Willem de Eerste under master J.C. Groendijk. Their monthly wages, to be decided by the Sociëteit, were to be commensurate with what the Rotterdam-based company usually paid. Able-bodied seamen received $f_{16}$ and green hands $f_{14} \cdot{ }^{490}$ On 8 August, the Directors discussed a letter from the Sociëteit dated August 6. In this letter the safe return of three pupils (Van Schaik, Hagen, and Schermerts) was mentioned. No word of Manheim was found. ${ }^{491}$

In 1828 two pupils from the Kweekschool were recruited by the Sociëteit and J.H. Veenhuizen and J.H. Schippers left for Harlingen some time in late February. Veenhuizen returned on 20 August. Interestingly, the records of the meetings of the Di-

487. SAA, inv. nr. 949 (archief Kweekschool voor de Zeevaart), nr. 27 (1825), fos. 223 (Directors' meeting on 16 March), 230 (idem, 30 March), 359 (idem, 17 August); nr. 27 (1826), fos. 7 (Directors' meeting on 18 January), 16 (idem, 8 March), 159 (idem, 16 August); nr. 27 (1827), fos. 233 (Directors' meeting on 21 February ), and 317-318 (idem, 29 August).

488. SAA, inv. nr. 949 (archief Kweekschool voor de Zeevaart), nr. 27 (1827), fos. 224-225 (Directors' meeting on 17 January).

489. SAA, inv. nr. 949 (archief Kweekschool voor de Zeevaart), nr. 27 (1827), fo. 227 (Directors' meeting on 31 January).

490. It should be noted that around that time (1827) able-bodied seamen involved in South Seas whaling were paid about $f 15$ in monthly wages. See Broeze, 'Whaling in the Southern Oceans', 81; 83.

491. SAA, inv. nr. 949 (archief Kweekschool voor de Zeevaart), nr. 27 (1827), fos. 230-231 (Directors' meeting on 14 February ), 235 (idem, 7 March), 236 (idem, 14 March), and 308 (idem, 8 August). Manheim returned home safely as well. On a later date (fo. 325), he was mentioned as one of the pupils joining the Dutch reformed Church. 
12. Portrait of a pupil from the Nautical College in Amsterdam, ca. 1830. Pupils involved in the whaling and sealing industries must have been dressed the way this anonymous pupil is portrayed. Lithograph by Jean Baptiste Madou (1796-1877). Nederlands Scheepvaartmuseum Amsterdam. Inventory number A.1080 (01).

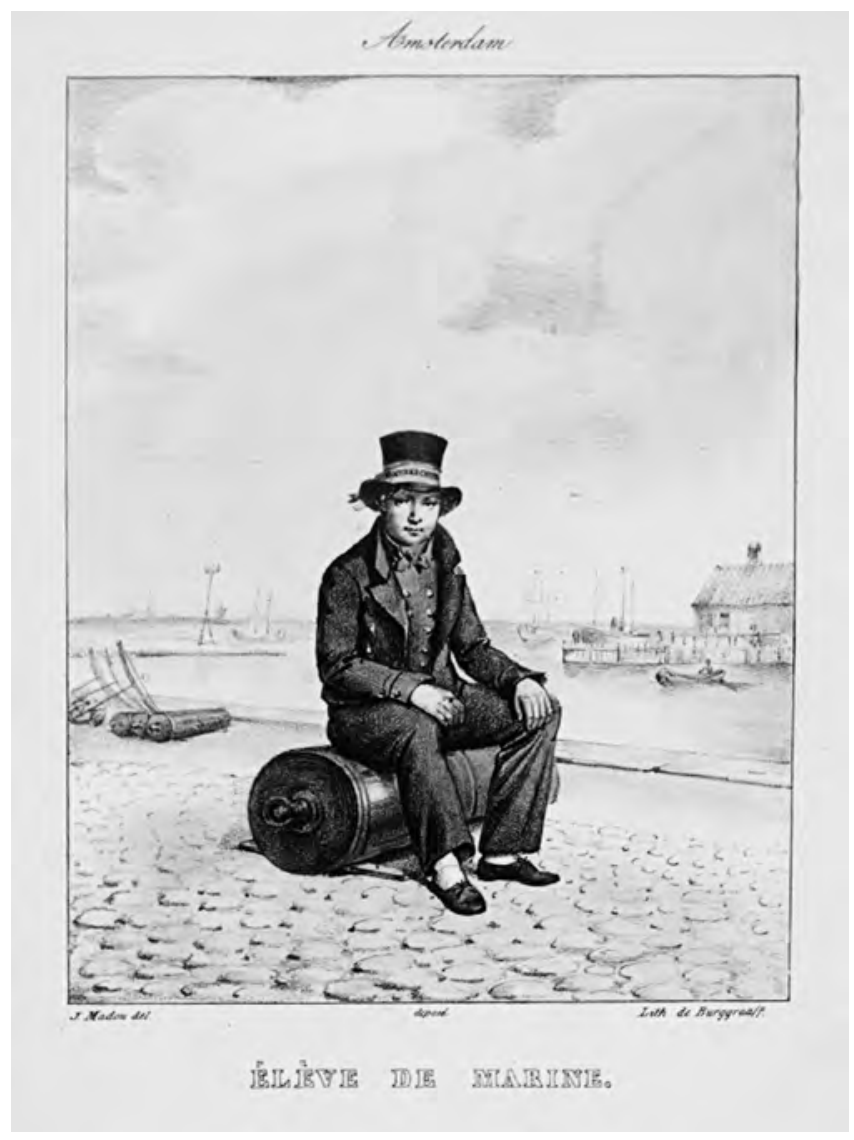

rectors referring to this year (1828) mentioned J.A. baron Van Zuylen van Nyevelt as fellow-Director and commissioner based in Haarlem. In later years, this person, in his function as Governor of Friesland, stimulated whaling endeavours in this province. ${ }^{492}$

The Harlingen Sociëteit continued to apply for pupils in Amsterdam. In late February of 1829, again two young lads were invited to come to Harlingen to join the crew of the whaleship Spitsbergen (II) with Captain "Rietmeijer" (should read Rickmers), destined for Greenland. J.H. Breukemeijer and the less-experienced G.A. Coster were 'the lucky ones'. Upon their return to Amsterdam, the pupils not only carried $f_{7} 8$ in wages, but also an affidavit certifying the Sociëteit's satisfaction with their performances. ${ }^{493}$

492. SAA, inv. nr. 949 (archief Kweekschool voor de Zeevaart), nr. 28 (1828), fos. 2 (Directors' meeting on 2 January), 31 (idem, 20 February), 35 (idem, 5 March), 134 (idem, 20 August).

493. SAA, inv. nr. 949 (archief Kweekschool voor de Zeevaart), nr. 28 (1829), fos. 192 (Directors'meeting on 25 February), 199 (idem, 11 March), 199 (idem, 25 March), 281-282 (idem, 12 August). 
The Kweekschool's involvement in the recruitment of crew for whaleships sailing from Harlingen was last mentioned in 1830. On 12 February, the Directors discussed a letter from the Sociëteit requesting the presence of two pupils, who, preferably, had participated in whaling voyages. Based on his request, F.W. Blomberg was chosen. Furthermore, the experienced J.H. Breukemeijer was sent to Harlingen as well. Blomberg was invited to join the crew of the Nederland under Captain Klaas Hoekstra. He returned to Amsterdam on 27 October. There is no information about J.H. Breukemeijer's fate. ${ }^{494}$

The records of the Nautical College in Amsterdam contain a number of names of pupils who participated in what was often called 'the cradle of good seamanship'. Their names are listed in Table 5.11. Neither the fact that the whaling company was Frisian, nor the fact that the college was based in Amsterdam, prevented either party from contacting each other and, in the case of the Rotterdam-based whaling company discussed above, to find mutually beneficial grounds for cooperation.

Table 5.11: Pupils from the Nautical College in Amsterdam employed by the Groenlandse en Straatdavidse Visscherij Sociëteit (1827-1830).

\begin{tabular}{|l|l|l|}
\hline Year & Names & Number \\
\hline 1827 & Hagen, T.; Manheim, J.H.; Schaik, J.W. van; Schermerts, H.H.V.N. & 4 \\
\hline 1828 & Schippers, J.H.; Veenhuizen, J.H. & 2 \\
\hline 1829 & Breukemeijer, J.H.; Coster, G.A. & 2 \\
\hline 1830 & Blomberg, F.W.; Breukemeijer, J.H. & 2 \\
\hline
\end{tabular}

In total, 22 pupils from the Nautical College in Amsterdam participated in whaling and sealing expeditions during the second part of the 1820s. Students J. Elias (1825/1826) and J.H. Breukemeijer (1829/1830) participated twice in whaling and sealing expeditions.

\section{The Nautical College in Harlingen}

In 1818, the local department of the so-called Maatschappij tot Nut van het Algemeen established the School voor Wis- en Zeevaartkunde (School for Mathematics and Navigation; hereafter referred to as the Nautical College). ${ }^{495}$ Fairly modest at the time of its establishment, this training institute grew gradually and steadily. Subsidized by the

494. SAA, inv. nr. 949 (archief Kweekschool voor de Zeevaart), nr. 28 (1830), fos. 334-335 (Directors' meeting on 12 February), 345 (idem, 10 March), 359 (idem, 14 April), 485 (idem, 27 October).

495. Earlier, here were also small, privately run schools on many of the Frisian islands, before the Nautical College, that were comparable with the one in Harlingen as to programming. All were formally established at a later date: on Vlieland around 1869, on Terschelling in 1875, on Ameland around 1850, and, finally, the one on Schiermonnnikoog in 1872 . See H.J. de Feyfer, Het licht der zeevaert. Friese bijdragen aan het zeevaartonderwijs (Leeuwarden 1974), 75-140. 
State, the province, and the municipality, the Nautical College was expanded in the early 1840 s. ${ }^{496}$ Three directors were appointed. Ysen Rodenhuis Pieterszoon was assigned by the delegates of the States of Friesland. The other two directors, D. Kraijer, bookkeeper of Barend Visser \& Son, and A. Harmens, a key player in the timber trade ${ }^{497}$ were appointed by the Maatschappij tot Nut van het Algemeen.

From the outset, the Nautical College had high standards regarding its education. Prior to 1818, first mate Pieter Kallenborn (1785-1858) had run a private class in navigation in Harlingen. A former student of Obbe Sickes Bangma (1768-1829) at the Nautical College in Amsterdam, Kallenborn became the first director and teacher at the College in Harlingen. He conducted his popular and apparently stimulating courses until 1852, when he became Trustee of the harbour pilots (Commissaris der binnenloodsen) in Harlingen. Kallenborn's successor was A.van Slee, who spent seven years at the Nautical College in Harlingen (1852-1859), during which he witnessed the decentralisation of navigational education in the Netherlands. On 23 February 1858, the City Council adopted a law entailing the examination of sailors by a local committee, the five members of which were to be appointed by the Council. ${ }^{498}$ In March of 1859 Van Slee moved from Harlingen to Amsterdam to accept the position of director and teacher at the Nautical College of the Zeemanshuis. ${ }^{499}$ Albertus J. Sissingh was his successor in Harlingen..$^{500}$

An interesting source of information concerning college students and their achievements at examination, and as of yet neglected, was found in the municipal archives of Harlingen. On 22 January 1856, the City Council established a local Committee for the examination of seamen (Commissie to thet examineren van varenslieden), to consist of three local ship owners, two other 'knowledgeable' men, and one captain still active in the merchant marine. The Committee remained in service until 1878. That year a similar 'national' Committee was established by Koninklijk Besluit. Its members were supposed to be appointed by national authorities and not by local or municipal officials.

The municipal archives in Harlingen contain the proceedings of the meetings of the local Committee, including examinations and results, as well as data about the staff

496. Davids, idem, 178. Quoting De Feyfer, Het licht der zeevaert, 59-60, Davids stated that the successful Nautical College in Harlingen was the first one in the Netherlands to receive frequent financial support from the State.

497. De Feyfer, Het licht der zeevaert, 59 .

498. De Feyfer, idem, 62.

499. For information about Kallenborn and Van Slee see De Feyfer, idem, 56-63; also Davids, 'Zeevaartkundig onderwijs', 182 passim; and finally S. Parma, 'Pieter Kallenborn en de Zeevaartschool te Harlingen', Gens Nostra, vol. 55 (2000), nr. 2, 61-66. I thank my colleague Diederick Wildeman for bringing the information about Kallenborn and Van Slee to my attention.

500. De Feyfer, Het licht der zeevaert, 63 . 
of the College..$^{01}$ In 1856, for instance, the Committee consisted of the following five gentlemen: J.P. Hoekstra, Chairman; Y. Rodenhuis Pietersz.; L. Alta; A. Harmens; and Secretary F. Fontein de Pietersz. The examination committee, in its turn, consisted of two members of the Committee, one captain in the merchant marine, and one academician. The very first exam took place on 27 March 1856. Rodenhuis and Alta were assisted by G.C. Tromp and F.C. Jaski, two examiners from Amsterdam. ${ }^{502}$ The fifth person was H.P. Schenk, a merchant marine captain from Oude Pekela. Shortly afterward, Tromp was replaced by J. Jonkhert, who in turn was replaced by L. Jansz. Dz. These three had all been affiliated with the Nautical College in Amsterdam. In his younger days Jaski had been a captain in the merchant fleet, and some twenty years later he acted as examiner on Terschelling. ${ }^{503}$ The last examination at the Nautical College in Harlingen, in its original form, was held in 1877 . Between 1856 and 1877 no fewer than 289 students passed their examinations in order to obtain the ranks of third, second, or first officer..$^{504}$

Due to the professional obligations of the pupils, education in navigation was seasonal, at least in Harlingen. Every year around the first week of October, the three directors of the Nautical College placed advertisements in the Leeuwarder Courant or in the local newspaper Harlinger Courant. In this way they could draw the attention of the potential clientele. Lessons in mathematics, navigation, and the English language started in early November, and were continued until the first or second week of March. Education was free of charge. These advertisements not only provide information concerning the number of months during which instruction was given, but also impart insights into the qualifications that potential candidates had to achieve. In order to be eligible for acceptance at the College, students were required to be no younger than fourteen years of age, be able to demonstrate written proof of their impeccable behaviour provided by the magistrates in their local community, and had to pass an examination in reading, writing, and mathematics. ${ }^{505}$

501. GAH, Commissie tot het examineren van Varenslieden, no. 4901: Notulen, examenverslagen en verzonden stukken, 1856-1878. De Feyfer does not mention this important source at all.

502. Despite the high numbers of pupils, the number of seamen being examined annually was fairly small. In 1856, for instance, Rodenhuis cum suis questioned nine sailors in total - six for their certificate of first mate (Willem Schenk, Dirk Lautenbach, Herman Kok Houwink, Lolke Zwaal, Daan Wellinga, and Simon Stoffels); and three in order to have them obtain the rank of second mate (Albertus Houwink, Willem Peereboom, and Barius Pyttersen). We do not know whether or not Willem Schenk was related to H.P. Schenk, one of the examiners that day. In 1856 , no less than 80 seamen took the courses at the Nautical College.

503. De Feyfer, Het licht der zeevaert, 93-94.

504. GAH, Commissie tot het examineren van Varenslieden, no. 4901: Notulen, examenverslagen en verzonden stukken, 1856-1878. Frequently the examiners organised more than one exam annually.

505. For advertisements see, for instance, Leeuwarder Courant, 20 October 1846 or Harlinger Courant, 7 October 1858 . 
About this time the College had developed into a daytime educational institute with a teaching programme that covered five months. Lessons started at 9 in the morning and went until 12, then resumed from 14.30 to 16.00 in the afternoon, as well as additional classes on Wednesday and Saturday evenings between 17.00 and 21.00. Religious instruction was given on Friday evenings. ${ }^{506}$

One book in these municipal archives related to the Nautical College contained an overview of all pupils having followed the courses between 1844 and 1910. The number of mariners who attended this school during this period is impressive: between 1844 and 1864 a total of 1,565 pupils received training in different branches of shipping. ${ }^{507}$ The names of these pupils were listed with their place of birth, age, duration of their stay at the school, and their activities after leaving school. Finally, in their overview of the students, the three directors wrote down their comments concerning both the behaviour and the intellectual skills ('vatbaarheid') of the sailors involved. From these lists, the names of no fewer than 60 students (close to $4 \%$ of the total of 1,565 ) who pursued careers in the relatively small-scale whaling industry, have been derived. The names, characteristics, and achievements of these 60 individuals appear in Appendix 4. ${ }^{508}$ In Table 5.12, the number of students annually employed in whaling is compared with the total number of students taking courses at the College in Harlingen.

506. De Feyfer, Het licht der zeevaert, 58.

507. GAH, School voor Wis- en Zeevaartkunde te Harlingen. SWZV1, no. 647: Register van de leerlingen der school, 1842-1910. The calligraphed title page of this book contains information about the history of the school and the names of its first board of directors. De Feyfer was mistaken - or too vague at best - with his statement that more than 1,500 persons visited the Nautical College during its existence (1818-1910). This number must be much higher. De Feyfer, Het licht der zeevaert, 64. The exact location of the School in Harlingen has recently been the subject of some discussion, but the provincial newspaper Leeuwarder Courant annually contained advertisements for the College. The advertisement in its issue of 20 October 1846, mentioned the class room at Havenpoort as the spot where potential pupils should announce themselves. Between 1856 and 1865 the Nautical College was located in the building of the former elementary school at Lanen. In 1856, the elementary school moved to a larger building at Grote Kerkhof (today called Kerkpoortstraat). When the elementary school moved out of this building, it seems plausible that again the Nautical College followed in its wake and filled this larger building with its seafaring pupils. See Paul Krooshof, 'De historie van een Harlinger Zeevaartschool', Oud Harlingen, no. 20 (2004), 40.

508. In 1842 and 1843 , Hendrik Wildst was the only student with a link with whaling. He is mentioned in the Appendix, but is not included in the listings on this page. 
Table 5.12: Number of pupils annually employed in whaling and sealing off Greenland and the total number of pupils at the Nautical College in Harlingen (1844-1864)..$^{09}$

\begin{tabular}{|l|l|l|l|}
\hline Year & Whaling/sealing & Total & $\%$ \\
\hline $1844-1845$ & 9 & 50 & 18 \\
\hline $1845-1846$ & 6 & 56 & 10.7 \\
\hline $1846-1847$ & 7 & 63 & 11.1 \\
\hline $1847-1848$ & 4 & 70 & $5 \cdot 7$ \\
\hline $1848-1849$ & 4 & 78 & $5 \cdot$ \\
\hline $1849-1850$ & 3 & 91 & $3 \cdot 3$ \\
\hline $1850-1851$ & 3 & 73 & $4 \cdot$ \\
\hline $1851-1852$ & 4 & 75 & $5 \cdot 3$ \\
\hline $1852-1853$ & - & 69 & - \\
\hline $1853-1854$ & 2 & 60 & $3 \cdot 3$ \\
\hline $1854-1855$ & - & 90 & - \\
\hline $1855-1856$ & $8-10$ & 80 & $10-12.5$ \\
\hline $1856-1857$ & - & 120 & - \\
\hline $1857-1858$ & 4 & 117 & $3 \cdot 1$ \\
\hline $1858-1859$ & 2 & 126 & 1.6 \\
\hline $1859-1860$ & 2 & 87 & 1.3 \\
\hline $1860-1861$ & - & 83 & - \\
\hline $1861-1862$ & - & 79 & - \\
\hline $1862-1863$ & - & 69 & - \\
\hline $1863-1864$ & - & 29 & - \\
\hline Totals & $58-60$ & 1,565 & Ca. 4 \\
\hline & & \\
\hline
\end{tabular}

With an average of a mere $4 \%$, the number of whalemen who attended the Nautical College in Harlingen is small in comparison with the total number of pupils. During the first three years of its existence, the College either attracted pupils who already had plans to join the crew of a whaleship, or it stimulated sailors to pursue careers in whaling. Between 1844 and 1847, both the absolute numbers and the percentages are high, ranging from 10.7 to $18 \%$. In later years, these numbers dwindled with only a brief boost in 1855 . This is a noteworthy development. As a result of the government abandoning premiums, effective as of 1855 , whaling operations became more expensive. It is tempting to assume that whaling entrepreneurs temporarily hired as many relatively cheap but well-educated pupils as possible in order to secure their whaling and sealing operations. There is no numerical data, however, to sustain this assumption.

In contrast, a general decrease in numbers of students is evident after 1857 . Here again, the costly whaling and sealing operations around this time may have prevented entrepreneurs to invest heavily in recruitment. Also, this trend may have been caused by the overall crisis with which the Dutch merchant marine was confronted. 
The reduction of the employment of personnel on sailing vessels between 1860 and 1880 was dramatic. For officers involved in navigation, Davids estimated a reduction of no less than $60 \%$ (from 5,000 to 2,000 jobs), whereas the growth in similar jobs on Dutch steamships rose marginally (from 170 to 320 )..$^{510}$

It should be noted, however, that during these years the number of vessels involved in Arctic whaling and sealing was extremely small, even more so when the small whaling fleet is compared with the large number of vessels assigned by the NHM to transport its commodities to the East Indies. Their claim on well-trained officers was impressive. ${ }^{511}$ Therefore, it should not come as a surprise that the opportunities for careers in whaling and sealing were limited. During the 1840 s and 1850 , only two vessels - Dirkje Adema and Spitsbergen (II) (until 1854) - sailed out for whaling and sealing. Considering the small number of officers on board these vessels, it is tempting to conclude that most, if not all captains and mates were educated in Harlingen. The lack of primary sources, crew lists in particular, prevents supporting this feeble assumption with solid facts.

The data gathered and presented in Appendix 5 enables a few statements about the quality of the crew employed on board the whaleships and about the level of theoretical knowledge that these crew members possessed when embarking on their voyages. It is striking to see the great number of ordinary seamen (matroos) in these listings. As stated earlier, it was not until 1858 that the merchant marine made training via several Nautical Colleges compulsory, that is, compulsory for officers desiring the rank of fourth, third, second, or first mate. This data was instrumental in characterizing the careers of the men who started out in whaling.

Appendix 6 lists 50 names of pupils who took courses in navigation, mathematics, and English at the Nautical College. The careers of these whalemen were analysed, and out of 50, at least eight students climbed the ranks to become captain - in some cases of their own vessel, but in most cases in the service of a Harlingen-based company. ${ }^{512}$ There was only one instance (Bauke van Smeden) where a former student was employed by the Amsterdam-based firm of Canne \& Balwé.

Table 5.13 concerns the level of practical experience of students at the Harlingenbased Nautical College, and provides the names listed in alphabetical order. The next columns supply information about their place of residence, the years they attended the

510. C.A. Davids, 'De zeevaartkunde en enkele maatschappelijke veranderingen in Nederland tussen 1850 en 1914', Mededelingen van de Nederlandse Vereniging voor Zeegeschiedenis, vols. 40/41 (1980), 63.

511. See S.P. L'Honoré Naber, Het leven van een vloothouder. Gedenkschriften van M.H. Jansen (Utrecht 1925), 85; quoted by K. Huyssen van Kattendijke-Frank (ed.), Met Prins Hendrik naar de Oost. De reis van W.J.C. Huyssen van Kattendijke naar Nederlands-Indië, 1836-1838 (Zutphen 2004), 51.

512. See Appendix 4. Their names were: Johan Both, Klaas de Groot, Wesselius Katoen, Meindert Meinsma, Jacob Ploeg, T.H. van Slooten, Bauke van Smeden, and Hendrik Wildst. 
College, the age at which they made their first voyage, and, finally, their number of years experience at sea prior to their admittance to the Nautical College. The last column cites the pages in the book at the municipal archives in Harlingen.

Table 5.13: Practical experience of students at the Nautical College in Harlingen who pursued careers in whaling (1844-1864). (The number of years experience at sea (fifth column) refers to their career prior to attending the College.)

\begin{tabular}{|c|c|c|c|c|c|}
\hline Name & $\begin{array}{l}\text { Place of birth } \\
\text { or residence }\end{array}$ & $\begin{array}{l}\text { Years } \\
\text { in College }\end{array}$ & \begin{tabular}{|l|}
$\begin{array}{l}\text { Age at the time } \\
\text { of first voyage }\end{array}$ \\
\end{tabular} & $\begin{array}{l}\text { Number of years } \\
\text { experience at sea }\end{array}$ & Source: GAH, SWZV1, no. 647 \\
\hline Bleijenga, Jacob & Sneek & 1 & \begin{tabular}{|l|l|}
18 \\
\end{tabular} & 1 & Fol. 28 , no. 45 \\
\hline Boer, Hans de & Harlingen & 3 & 15 & 1 & Fol. 20, no. 61; Fol. 33, no. 39 \\
\hline Both, Jacob & Seestermühe & 2 & 11 & 3 & Fol. 11, no. 18; Fol. 13, no. 15 \\
\hline Both, Johann & Seestermühe & 2 & 14 & 4 & Fol. 5, no. 3 \\
\hline Both, Michiel & Seestermühe & 4 & 11 & 4 & $\begin{array}{l}\text { Fol. } 5 \text {, no. } 6 \text {; Fol. } 7 \text {, no. } 2 \text {; Fol. 9, } \\
\text { no. } 6 \text {;Fol. } 12 \text {, no. } 38\end{array}$ \\
\hline Bouma, Gaele & Harlingen & 1 & 14 & 2 & Fol. 47, no. 31 \\
\hline Cromhout, R.C. & Harlingen & 1 & 19 & 2 & Fol. 42, no. 116 \\
\hline Dijkstra, Sybrand & Sneek & 1 & 18 & 1 & Fol. 23, no. 53 \\
\hline Drager, Willem & Franeker & 1 & 18 & none & Fol. 32, no. 21 \\
\hline Ebeling, Hendrikus & Harlingen & 1 & 15 & 3 & Fol. 33, no. 62 \\
\hline Elst, Johannes van der & Harlingen & 1 & 17 & 3 & Fol. 6 , no. 37 \\
\hline Grevenstuck, B. & Heerenveen & 1 & 17 & 1 & Fol. 5, no. 18 \\
\hline Groot, Klaas de & Harlingen & 1 & 21 & 5 & Fol. 8 , no. 39 \\
\hline Haenstra, U.W. & Oosterwierum & 1 & 17 & & Fol. 17, no. 57 \\
\hline Holstein, Nammele & Harlingen & 1 & 15 & 1 & Fol. 7, 27 \\
\hline Jager, D.W. & Harlingen & 1 & 12 & 6 & Fol. 5, no. 17 \\
\hline Jong, Jan de & Harlingen & 1 & 14 & & Fol. 47, no. 12 \\
\hline Katoen, Wesselius & Pietersbierum & 1 & 18 & 4 & Fol. 10, no. 38 \\
\hline Kiestra, Johannes & Harbayum & 1 & 28 & 4 & Fol. 27, no. 11 \\
\hline Meer, Pieter van der & Harlingen & 1 & 15 & 1 & Fol. 23 , no. 42 \\
\hline Meinsma, Meindert & Anjum & 2 & 15 & 9 & Fol. 33 , no. 55; Fol. 36, no. 62 \\
\hline Monsma, B. & Oosterhout & 3 & 13 & 9 & $\begin{array}{l}\text { Fol. 33, no. 57; Fol. 36, no. 66; } \\
\text { Fol. 41, no. } 105\end{array}$ \\
\hline Mulder, Frans & Harlingen & 1 & 16 & & Fol. 11, no. 13 \\
\hline Nauta, Evert & Harlingen & 1 & 16 & 1 & Fol. 40, no. 57 \\
\hline Ouwenbroek, A. & Harlingen & 1 & 16 & 6 & Fol. 22, no. 24 \\
\hline Ploeg, Jacob & Steggerde & 1 & 16 & 13 & Fol. 11, no. 27 \\
\hline Pronker, Mink & Harlingen & 1 & 19 & 4 & Fol. 33 , no. 40 \\
\hline Rooswinkel, Hendrik & Harlingen & 2 & 16 & none & Fol. 32, no. 33; Fol. 36, no. 58 \\
\hline Slooten, T.M./Th. van & Harlingen & 3 & 14 & 1 & $\begin{array}{l}\text { Fol. } 13 \text {, no. } 7 \text {; Fol. 17, no. 56; Fol. } \\
\text { 20, no. } 49\end{array}$ \\
\hline Smeden, B[au]ke van & Harlingen & 1 & 15 & & Fol. 18, no. 78 \\
\hline Steeksma, Syb & Harlingen & 1 & 18 & 4 & Fol. 10 , no. 60 \\
\hline Stenbeker [sic], Hendrik & Elmshorn & 2 & 14 & 21 & Fol. 33, no. 58; Fol. 36, no. 61 \\
\hline Stuur, Hendrik & Harlingen & 1 & 16 & 3 & Fol. 9, no. 2 \\
\hline Tigchelaar, E,C. & Harlingen & 1 & 14 & 1 & Fol. 20, no. 51 \\
\hline Tigchelaar, H. & Harlingen & 2 & 15 & 7 & Fol. 41, no. 93; Fol. 46, no. 110 \\
\hline Tigchelaar, Jelmer & Minnertsga & 2 & 14 & 2 & Fol. 5 , no. 15 \\
\hline Vellinga, Jan Jans & Witmarsum & 1 & 15 & 1 & Fol. 22 , no. 30 \\
\hline Visser, Klaas & Dokkum & 5 & 10 & 17 & Fol. 32, no. 3; Fol. 37, no. 74 \\
\hline
\end{tabular}




\begin{tabular}{|c|c|c|c|c|c|}
\hline Name & $\begin{array}{l}\text { Place of birth } \\
\text { or residence }\end{array}$ & $\begin{array}{l}\text { Years } \\
\text { in College }\end{array}$ & $\begin{array}{l}\text { Age at the time } \\
\text { of first voyage }\end{array}$ & $\begin{array}{l}\text { Number of years } \\
\text { experience at sea }\end{array}$ & Source: GAH, SWZV1, no. 647 \\
\hline Vries, Jan de & Harlingen & 1 & 14 & 3 & Fol. 33 , no. 64 \\
\hline Vries, Jan G. de & Franeker & 1 & 16 & & Fol. 7, no. 15 \\
\hline Vries, Jan S. de & Harlingen & $?$ & 14 & 2 & Fol. 10, no. 58 \\
\hline Vries, Joh. de & Makkum & $?$ & 16 & 6 & Fol. 45, no.103 \\
\hline Vries, Klaas de & Harlingen & $?$ & 12 & 7 & Fol. 6, no. 47 \\
\hline Wagenaar, Jan E. & Harlingen & 2 & 14 & 6 & Fol. 6, no. 39 \\
\hline Wagenaar, Petrus & Harlingen & $?$ & 20 & & Fol. 8, no. 53 \\
\hline Werf, Poppe W. v.d. & Harlingen & 3 & 17 & 2 & Fol. 10, no. 50 \\
\hline Wielen Miedema, S. v.d. & Leeuwarden & 1 & 16 & 1 & Fol. 14, no. 59 \\
\hline Wiersma, Nanne & Harlingen & 1 & 18 & 4 & Fol. 33, no. 78; Fol. 37, no. 97 \\
\hline Wildst, Hendrik & Sneek & $4-5^{513}$ & 39 & $?$ & $\begin{array}{l}\text { Fol. 1, no. 11; Fol. 3, no. 9; Fol. } 5 \text {, } \\
\text { no. 1; Fol. 8, no. 36; Fol. 9, no. } 34\end{array}$ \\
\hline Zwanenburg, Jan & Harlingen & $?$ & 18 & none & Fol. 15, no. 72 \\
\hline
\end{tabular}

Evidently, most of these students at the College in Harlingen were either born or at least resided in this little town. Of the 45 students listed, 21 (about 47\%) were Harlingen locals. The towns of Sneek ( 3 students) and Franeker (2 students) together accounted for about $11 \%$, while other little towns and villages each provided one student. None of the students who participated in a whaling expedition came from any of the Frisian Islands. This is bewildering, as it is noted earlier that the islanders made up a large percentage of the whaleship crew during these years. Three pupils from Seestermühe in Northern Germany (Jacob, Johann, and Michiel Both) were trained in Harlingen for whaling careers, while one listed Elmshorn as his place of residence.

As stated earlier, the average age of crew members was fairly low, about 25 years of age and many students started sailing at a very young age. Consequently, many students already had an impressive number of years of practical experience by the time they first started to obtain theoretical knowledge at the Nautical College.

\section{Dogwatch}

Most of the data about life on the whaleships was provided by Frisian sources, archival records, and personal accounts or reports that gave some insight into how these hardy whalemen lived their sailor's lives. The number of personal reports, journals, or correspondence shedding some light on the still relatively dark pages about the whaleman's life on shipboard is very small..$^{14}$ One source concerns Klaas Hoekstra's account

513. In the listings in the registers referring to $1845-1846$, and 1846-1847, respectively, Hendrik Wildst was mentioned as having spent four winters at the College. Assuming that the directors or their clerks made a mistake, four to five winters is used here.

514. K. Hoekstra, Dagverhaal; Deinse, A.B. van (introduction), Journaal der merkwaardige reizen van Jan Wever (van West-Terschelling) naar Turkije, Oost-Indië, China, Noord-en Zuid-Amerika, ter walvischvaart bij 
of the voyage of Harlingen and its dramatic aftermath, thus covering a period of about two years (1826 and 1827). Hoekstra, however, remained silent when it came to life on board the ship.

A second source was Jan Wever from Terschelling. Wever participated in two whaling and sealing expeditions on board Dirkje Adema - in 1860 under C. Brinkmann and in 1862, when Hendrik Wildst commanded the whaleship. In both years the ship was more involved in sealing than whaling. Wever wrote his autobiography in 1920 as a very old man and the booklet was published in 1946. Looking back almost 60 years, Wever supplied detailed information about the crew and equipment on board, and provided insight into technological aspects of the actual hunt as well as naval architecture.

A third source was provided by J. van der Weide Bzn. In 1921, he published a series of articles based on stories told by his father-in-law, Douwe de Boer, in the Tijdschrift van de Vereeniging Het Nederlandsche Zeewezen (Den Haag). These accounts are an entertaining and informative source. De Boer told his son-in-law about his shortlived career in the tile business, but that he wanted to become a sailor. Via the director of the tile factory, who was one of the stockholders in the company of Barend Visser \& Son, De Boer made the acquaintance of Captain Hendrik Wildst. In 1862, at the age of 16, De Boer signed up for the voyage and thus joined the crew of Dirkje Adema as cabin boy. ${ }^{515}$

Each year in January or February, the captain of a whaleship with his crew would stand before the directors of the company and the Waterschout. In the case of the 1862 voyage of Dirkje Adema under command of Hendrik Wildst, the complete crew of 52 hands in total (officers and a doctor included), gathered in one of the upper rooms of the Inn 'Beitschat', located in the Zuiderstraat in Harlingen. On this occasion, the whaling master mentioned the names, ages, and wages of his crew. The Waterschout or his clerk wrote down these names on the crew lists and also the terms under which these men agreed to serve. The Waterschout read out loud the rules and regulations, after which all present were treated to a drink and a cigar. ${ }^{516}$

The articles in the crew list are important sources to understanding life on shipboard. Several deal with how a captain and crew should act in case of desertion, or

Groenland, enz. Loopende van 1847-1904 (Den Haag 1946); J. van der Weide Bzn., 'Uit het leven van een Groenlandvaarder', Tijdschrift van de Vereeniging Het Nederlandsche Zeewezen, vol. 21 (Den Haag 1921).

515. On several occasions De Boer mentioned participating in a total of three whaling expeditions. See Van der Weide Bzn., 'Uit het leven van een Groenlandvaarder', 44; 77; 103. In archival sources, however, his name was encountered only twice. There is no crew list of the 1864 voyage of Dirkje Adema. De Boer was listed in the crew of Dirkje Adema of 1862 and 1863. See GAH, WS 4, 1862, B29; GAH, WS 17, 1862, no. 29; GAH, WS 5, 1863, no.13. Van der Weide Bzn., 'Uit het leven van een Groenlandvaarder', 19-20; 31.

516. Van der Weide Bzn., 'Uit het leven van een Groenlandvaarder', 32. 
what they should do in the event illness prevents a sailor from joining his mates on their journey home. Also, some articles pertain to the right of a captain to inspect the crew's bunks and chests for private trade goods. A captain had the right to inspect the personal belongings of his crew at any time, be it at embarkation or the end of the voyage. When still in port, the captain had the right to dismiss crew members if they reached for the bottle too frequently, provoked fights on a regular basis, or turned out to be unsuited for their task in other ways.

Crew worked in shifts. On the outward and homeward bound voyages, a system of watches of four hours each was put in place. The shifts were the first watch (20.00midnight), the second watch ('Hondewacht': midnight-4), morning watch ('Dagwacht': 4-8), the pre-afternoon watch (8-noon), the afternoon watch (12.00-16.00), and, finally, the evening shift ('Platvoet': 16.00-20.00). Under ideal circumstances, crew could get 8 hours of sleep per 24 hours. ${ }^{517}$

In the 1860 s the sailors who were supposed to spend several months on Dirkje Adema were promised to sleep in bunks, not in hammocks ('vaste kooien'). The presence of bunks is substantiated by whaleman Douwe de Boer. According to De Boer, there were three men in one bunk (not two, as was the case on board Hudson), with the youngest being the 'room maid' - in charge of making the bed. ${ }^{.18}$ It is revealing to note that while compiling the crew list, the Waterschout could fill in the blank space and indicate under what conditions sailors where to spend the night. In other words, bunks were probably not yet standard, at least not on whaleships.

\section{Wages}

As noted earlier, data concerning the wages of whalemen on Dutch ships heading for the South Seas are fairly scarce. A different picture can be presented regarding those men involved in nineteenth-century Arctic whaling. Crew lists of Groenland, relating to the decade 1815-1825, and of Dirkje Adema covering the period 1858-1863, provide clearer insight into the amounts received. Appendices 3 and 4 supply ample data regarding the crew and their wages.

517. Van der Weide Bzn., idem, 55. This schedule was identical to the one contemporary German whalemen used. On board the German whaleship Hudson, the master's quarters were located on the 'tweendeck (Zwischendeck) at the rear end of the vessel. For obvious reasons the weapons chest - containing the harpoons, flensing knives, and the like - was located rather close to this cabin. The first mate's cabin was located adjacent to the captain's, but more to the stem. All the way to the front end of the vessel one could find the bunks of the crew. Here, two men would share one bed. See Lindeman, 'Arktische Fischerei der Deutschen Seestädte', 80 passim.

518. Van der Weide Bzn., 'Uit het leven van een Groenlandvaarder', 66. 
Payments were stable and transparent in the case of the 1815-1825 expeditions. Crew received monthly salaries for their services. The monthly wages of masters were not listed. The first mate and flenser received $f_{70}$ per month; most harpooners $f_{50}$; whereas the cabin boy received $f 8$ (1815), $f 9$ (1816) and $f 6$ (1819). Being employed by Jan Vas \& Company was more beneficial for all ranks: in the case of first mate and flenser, their salaries rose from $f 70$ and $f 60$, respectively, in 1820 , to $f 90$ five years later. Harpooners saw their monthly salaries rise from $f_{50}$ to $f 60$. Cabin boys experienced an intriguing development in their wages, as they enjoyed between $f_{12}$ (1822; being a raise of $100 \%$ compared to the level of payment in 1819) and $f 8$ (1825). Their pay seems to have gone down.

In the crew lists of the 1850 s and 1860s, at least three categories of income were mentioned: money at hand (handgeld), money paid for a share (partgeld), and a monthly payment (maandgeld). The mere fact that partgeld was mentioned as one of the three categories suggests that Barend Visser \& Son, for which company Dirkje Adema sailed, worked with the usual lay system, whereby a certain share of the net revenues of the sale of the cargo was paid to the crew. In this regard, Jan Wever proved to be a valuable source. In his memoirs he related his first whaling expedition with Dirkje Adema in 1860. As he recalled, he received three months' pay in hand (handgeld) - in his case amounting to $f 24(3 \times f 8)$. Moreover, he discussed the system of partgeld: Wever was to receive $f_{0,40}$ on every 'kardeel' (kwarteel) surpassing the 100 kwartelen. ${ }^{519}$ In Dutch, the lay system is called 'varen in't kordeel'.

Introduced as an incentive to the crew to try to catch as many whales and seals as possible, this lay system seemed to work fairly well for those whalemen making relatively short voyages to the Arctic waters. In the margins of the crew lists, the financial status of all crew members other than officers (captains, mates, harpooners, flensers, coopers, and boatswains) was indicated. Here, several categories that are indicative for how these crewmen received their payments can be noted. Two categories of partgelders were mentioned, half partgelders, and quarter partgelders. Also maandgelders were mentioned. As noted with the whalemen who spent years on end in the South Seas, they were not always satisfied with this system..$^{520}$

Douwe de Boer's recollections, written down by J. van der Weide Bzn., proved to be another important source with regard to understanding the pay system. Like Jan Wever, he referred to the fact that next to his monthly wage every seaman would receive a certain percentage of the cargo. This percentage was decided by the sailor's rank. The cabin boy (De Boer's first rank in 1862) had his food for free. Moreover, he

519. Van Deinse, Journaal der merkwaardige reizen, 23. Wever's recollections were commensurate with the data presented in the 1860 crew list given in Appendix 4.

520. Broeze, 'Whaling in the Southern Oceans', 83. 
was paid about $f 2$ per week ( $f 8$ per month) per expedition as he had not yet received the status of being 'in de maand-gage ...' . De Boer's remark suggests that so-called maandgelders may have been recruited for more than one voyage. In 1862, according to De Boer, an able-bodied seaman would make about $f_{30}$ per month.

Upon departure the crew received one month's pay in advance. They were supposed to spend this money on provisions and clothing. During their absence in the ensuing months, those who were married could have their spouses come to the office of Barend Visser \& Son to collect one-half month's pay. Upon return from their icy expeditions, whalemen were frequently confronted by the grocery shopkeeper with unpaid bills. ${ }^{521}$

In 1861, the crew list of Dirkje Adema omitted financial data for Captain Hendrik Wildst. ${ }^{52}$ Looking at the wages of the two mates, it is easy to conclude that second mate Julius Kutschura from Leipzig settled for a lower payment in hand than first mate Klaas Visser ( $f_{32}$ instead of $f 60$ ), but a much higher monthly payment ( $f_{32}$ against Visser's $f_{16}$ ). Visser's partgeld, however, paid him $f_{1,-}$ per extra 'kardeel', as opposed to the $f 1,10$ Kutschura received. For the remaining officers - the flenser, boatswain, five harpooners, and one second boatswain - all payments were equal ( $f 45$ in hand, $f 0,75$ in shares, and $f_{16}$ as monthly payment). Interestingly, the carpenter not only enjoyed a fairly high payment in hand ( $\left.f_{3} 8\right)$, but also a very high monthly wage of $f_{3} 8$, being the highest monthly figure on the list. This possibly revealed both an appreciation of the carpenter's highly-skilled labour and a certain scarcity of ship's carpenters. The monthly wages of the $51 \mathrm{crew}$ members mentioned on the list added up to $f 2,137$, handgeld or partgeld excluded. This figure and others will be discussed in a later chapter where the costs of outfitting will be scrutinized (see Chapter 7 ).

In 1861 , next to the officers, the crew list contained the names of so-called $1 / 2$ partvaarders (six persons), $1 / 4$ partvaarders (seventeen persons), and maandvaarders (twelve sailors). Pieter Gorter, a fourteen-year-old boy from Harlingen, received the lowest pay of all: $f_{2}$ in hand, nothing in shares, and another $f_{2}$ per month.

It is hard to imagine that these wages, earned in a seasonal profession, would enable ordinary whalemen to make a decent living. For many there must have been additional sources of income. There is, however, no data available to support this. Chances are that some made additional money in a similar fashion as at least one contemporary anonymous German whaleman did. When visited by M. Lindeman, this fairly-well-paid flenser, who in 1868 served on the whaleship Hudson, provided information about his activities during the off-season for whaling and sealing. The flenser, apparently well-prepared to receive and be interviewed by the professor, wel-

521. Van der Weide Bzn., 'Uit het leven van een Groenlandvaarder', 54.

522. GAH, Archief Waterschout (WS) 4, 1861-1862, B XX. 
comed Lindeman with violin music and was accompanied by his son playing on the tuba. Recuperating from this surprise, Lindeman sat down. He then started to converse with the whaleman. As Lindeman eloquently evoked both the situation on board and the situation this man's life, no further words are needed other than to let the German professor paint the picture in his native tongue:

"In der Unterredung theilte er mir mit, dass er in Winter "Tanzmusik mache", sein eigentliches Instrument sei aber weder Violine noch Tuba, sondern der Brummbass. So spielt er denn im Winter den Oldenburger Bauernburschen und Mädchen lustig und unermüdlich zu frohem Reigen auf. Wenn aber der Februar herangekommen ist, dann tritt der Postbote in sein sauberes, wenn auch kleines Häuschen und bringt einen Brief von “Kummdeer" (Kommandeur), dass es Zeit ist “anzumustern für Grönland”. Dann wandern Brummbass und Tuba in die Ecke, die Kiste wird gepackt und fort geht's nach Bremerhafen und von da durch die wogende See ins Eismeer, um dort den Walfischen und Eisbären "Eins aufzuspielen". Solche eine Sommerfahrt in den Winter hinein lohnt, wenn das Glück einigermässen wohl will, ihm, der als Speckschneider einen der höchsten Antheile hat, immerhin 3- bis 400 Thlr [Thalers]"

("During our meeting he told me that he made dance music during the winter months, with his own instrument neither being the violin nor tuba, but the double-bass. In this way he played at the farmers' fair in Oldenburg during the winter, lustfully and indefatigable cheering up the girls. But when February came, then the postman entered his clean, small house and delivered a letter from the whaling master saying it was time to enrol for Greenland. Then double-bass and tuba were left in the corner, the chest will be packed, and off he goes to Bremerhaven, and from there via the lake to the Arctic Sea, to play with whales and polar bears. Such a summer voyage in Winter will pay him, when he is a bit lucky, as flenser with one of the highest shares, about 300 to 400 Thalers".) ${ }^{523}$

As this whaleman was one of the officers who managed to make a decent living, one may only imagine how most of the tens of thousands of Norwegian, German, British, French, or Dutch sailors - experts in hunting whales and seals in Arctic waters - made additional income. ${ }^{22}$ Some ideas concerning off-season activities of Dutch whalemen can be derived from Piet Boon's dissertation. As Boon convincingly demonstrated, a fair number of whalemen were involved in activities of a more agricultural nature when not involved in whaling or sealing on Jan Mayen Island, off Spitsbergen, or in the Davis Strait. ${ }^{225}$ Boon's research, however, related to a fairly limited period -1680 to 1720 - and was confined to a fairly limited geographical entity - Westfriesland, the area in the northeastern corner of the province of North Holland. Regardless of

523. Lindeman, 'Arktische Fischerei der Deutschen Seestädte', 79. Author's translation.

524. American whalemen were not included in this listing, as their business with its ubiquitous nature was organized in a fashion importantly different from most if not all European nations.

525. P. Boon, Bouwers van de zee: zeevarenden van het Westfriese platteland, ca. 1680-1720 (Den Haag 1996). 
whether dealing with green pastures or grey-blue whaling grounds, one cannot but conclude that this area of study - the off-seasonal activities of Dutch whalemen and seal hunters through the ages - is still Terra Incognita.

\section{Food}

Whaling and seal hunting is hard work and is often conducted under harsh conditions. In this respect Pieter Bos, one of the crew members of Dirkje Adema during the 1860 season, may be considered as a spokesman for many a Dutch whaleman. When asked to motivate his change in career from whaling to sailing to the tropics, he remarked,

"Het is beter, dat de zon je onderste boven schijnt, dan dat je scheef trekt van de kou"

("It's better to be shone upside down by the sun, than to warp by the cold")..$^{26}$

The provision of good meals on board must have been one of the most important requirements of a crew. Information about this is scattered, and the data comes from diverse years. The composition of the sailors' diet was stipulated in the crew lists compiled at the office of the Harbourmaster. Article V dictated the rations of drinks and of foodstuffs. Each day 4.75 jar ('kan') of water per person was to be issued. Salt, vinegar and mustard 'can be consumed to taste'. The provisions per week per person were: 2 Dutch pounds of bread, 2.1 cups of groats or rice, 1.5 Dutch pounds of meat, 0.75 Dutch pounds of bacon, 3.5 ons (= 100 grams) of butter, oil, or sugar, cheese according to what the master approved, 1.2 cups of green beans or white beans, 1.2 cups of yellow peas or brown beans, 0.8 kilograms of wheat-meal or grits-meal, 50 grams of tea, or any other foodstuffs.

The municipal museum Het Hannemuis in Harlingen contains a booklet with an inventory and a long list of provisions for the galliot Harlingen (1825).527 It not only provides insight into the number of spoons, forks, knives, cups, and plates on board, but also specifies a wide array of foodstuffs, certain types of bread including 'hard brood', 'wit brood', and 'zacht brood', peas ('grauwe erwte', 'groene erwte'), beans, dried cod ('stokvis'), cheese, beer (divided into so-called 'volksbier'and 'officiers bier'), coffee, tea, pepper and spices (clove, cinnamon, nutmeg, mace), potatoes, bacon, meat and ham, and chocolate. Apart from prunes, raisins, and lemon juice (four bottles), the list does not refer to any type of fruit.

526. Anne J. Dijkstra, 'De Groenlands- en Straat Davids-Visserij Sociëteit te Harlingen', Jaarboek Fries Scheepvaartmuseum 1964, 57. Author's translation.

527. Hannemahuis Harlingen (HH), Annotatie van het Galliootschip Harlingen en aldaar geboud in het jaar 1825 op de Landswerf voor den timmerbaas Johannis Alta - voor Rekening der Nederlandsche Groenlandsche Straatdavidsche visscherij Sociëteit te Harlingen waarop benoemd wurd tot kommandeur K. Hoekstra op den 9 Nov. 1825. 
Douwe de Boer, the cabin boy on the 1862 voyage of Dirkje Adema, under the command of Hendrik Wildst, informs us briefly about the division of foodstuffs. ${ }^{528}$ In the morning, the whalemen enjoyed a breakfast of hot groats with butter and one mug of light beer (either warm or cold). At noon the seamen had their lunch in shifts. Also, upon departure from Harlingen the whaleship carried a huge number of potatoes. Sauerkraut and potatoes with bacon or fish were served as well. On Sunday and Wednesday, so-called 'zakkoek' decorated the tables. 'Zakkoek' consisted of self-made yeast, derived from beer by the cook. On the evening before the day of consumption, the cook would hang a number of linen bags from the ceiling of his kitchen. These bags were filled with yeast and in this manner the cook fabricated his own batter (beslag). The remaining days the crew would enjoy pea soup, green peas, or beans. Being the youngest on board, De Boer with Sietse de Vries and two farm boys were appointed 'coffee boys' and were in charge of making coffee and cleaning the dishes. On Sundays, the youngest boy was responsible for pouring drinks after sermon. The men would all line up for a small glass of gin and two cigars. Frequently, some would re-dress, change their appearance, and walk up to the cabin boy holding the bottle in order to try to get a second round. After drinks, the Sunday meal was served, consisting of meat, potatoes, and groats with syrup. Life on shipboard, according to De Boer, was hard but relatively healthy.

Some data concerning rations on board a contemporary German whaleship survive. When departing from Bremerhaven, Hudson (229 lasts; $50 \mathrm{crew}$ ) carried provisions for seven to eight months. The most common foodstuffs on board were bread, coffee, beer, pork, beef, and, of course, beans in many varieties and colours (white, green, and yellow)..$^{52} \mathrm{All}$ in all, there seems to have been more variation in the menu on board Dutch whaleships than on those ships flying the German flag.

\section{Health}

The presence of surgeons on board Dutch whaleships fitted out in Harlingen has occasionally been established in the sources. In 1826, on his ill-fated voyage with Harlingen, Klaas Hoekstra had P.J. Gordijn as ship's surgeon. In 1862, when Hendrik Wildst had his crew registered at the office of the Waterschout in Harlingen, surgeon Du Saar was specifically mentioned. Unfortunately, no crew lists of the intermittent period of almost 40 years have survived.

Other sources in the municipal archives of Harlingen, however, shed some light

528. Van der Weide Bzn., 'Uit het leven van een Groenlandvaarder', 32-33.

529. Lindeman, 'Arktische Fischerei der Deutschen Seestädte', 79. 
on the presence and activities of medical practitioners on board. In a letter to the City Council, dated 2 October 1848 , the directors of Barend Visser \& Son shared their outrage over a report from the local medical service Committee. In their report, addressed to the Minister of the Interior and dated 1 September 1848, the Committee members filed a complaint against the owners of the whaleships for not having taken surgeons aboard their whaleships. In their defence the directors went out of their way to underline that there were no regulations as to the recruitment and subsequent employment of surgeons on board whaleships. Furthermore, they stated that from the outset in 1821 until the present day (1848), they had employed ships' surgeons on all vessels fitted for whaling voyages despite all the problems they had with finding suitable candidates. There was no difficulty in recruiting surgeons for ships heading to the East or West Indies. In the case of whaling expeditions, practitioners hardly gained experience, as, in the words of the directors, the climate, the work, and the ever-fresh and healthy food made sickness and death to be exceptional. ${ }^{530}$

\section{On the hunting grounds}

The journals of Hendrik Rickmers aboard Spitsbergen (II) in the 1830 s provide fairly detailed specifics of Dutch whaling destinations. Some of Rickmers' plottings are repeated here in full to present a complete picture of such journeys between 1830 and 1840, and for the period 1846-1848..$^{531}$

In general, ships left Harlingen harbour sometime in late February or early March. The captains first sailed to the waters near Jan Mayen Island. From this point, they roamed the ocean for seals for about one month. At the end of May they headed northeast, for Spitsbergen, where the men started to prepare for whaling: sails were set and the barrels for the lookouts were placed high in the mainmast. The whalers spent between two and three and one-half months on the grounds, and would then return to Harlingen.

Rickmers' 1830 journal starts on 8 April. Spitsbergen (II) sailed along the Norwegian coast. After a number of weeks, on 2 May, Rickmers and his crew passed Jan Mayen Island and then set course to Spitsbergen. On 12 May, Rickmers wrote that he had prepared ship and crew for whaling. They sighted the so-called Voorland of Spitsbergen around $77^{\circ} 36^{\prime}$ N.L. the next day, on 13 May. The following weeks they proceeded into higher latitudes, eventually reaching Kwade Hoek off Amsterdam Island ( $79^{\circ} 58^{\prime}$ N.L.) on 23 May. On 26 May, the crew tried to kill a whale but failed. Thereafter, Rickmers reset his priorities and hunted seals instead. They shot bears, seals, and so-called 'klap-

530. GAH, inv. nr. 1441, Oct. 2, 1848.

531. Friesenmuseum, Wyk auf Föhr, HF 431 (1830-1840), and HF 432 (1846-1848). 
mutsen' (hooded seal, or bladdernose seal; Cystophora cristata). They frequently sighted narwhals ('eenhoorns' or unicorns) as well. On 22 July, while working along the coast of Spitsbergen on approximately $78^{\circ} 35^{\prime}$ N.L., Rickmers decided to leave for home.

In 1831, Rickmers and his crew merely concentrated on hunting seals. They left Harlingen on 20 March. On 10 April they caught their first seal and, one week later, on $71^{\circ} 34^{\prime}$ N.L., more seals were captured and killed. Until their departure on 13 July, Rickmers and his crew cruised the hunting grounds between about $71^{\circ}$ and $79^{\circ}$, with exceptionally successful catches on $73^{\circ} 46^{\prime}$ N.L. (no fewer than 622 seals)..$^{532}$ Ship and crew returned to Harlingen in early August.

The 1832 expedition was quite eventful. After a problematic start from Harlingen harbour, and the loss of one whaleboat on account of heavy storms, Spitsbergen (II) became stuck in the ice between 28 May and 1 June, around $78^{\circ} 50^{\prime}$ N.L. As a counterbalance to all these ordeals, harpooner Hinrich Schieland managed to harpoon a whale on 17 June on $79^{\circ} 44^{\prime}$ N.L. Rickmers proudly illustrated his journal with a whale's flukes. Spitsbergen (II) returned to Harlingen on 27 July.

In 1833, Spitsbergen (II) and Nederland returned from the whaling and sealing grounds with disappointing catches. Overall it had been an exceptional season. Because of an English embargo on Dutch ships and shipping, both ships had left Harlingen a month later than usual. Rickmers provides additional information about the impact of the English embargo. Spitsbergen (II) departed from the hunting grounds on 13 July, and, instead of heading directly for Harlingen, set a course for Norway. On 25 July, a pilot came on board the whaleship to direct Spitsbergen (II) to Christiansand. The next day, Rickmers met with Sören Knodsen, Consul for the Netherlands in Norway. Knodsen told Rickmers that he could 'vrij varen', in other words, that it would be safe to continue his journey home.

In 1834, Spitsbergen (II) left Harlingen on 12 March and reached the ice three weeks later, on 2 April. It took Rickmers and his crew more than two weeks to kill the first two seals of that season. On 16 June, flenser Mathijs Suft, who had been successful the preceding year, hit a whale, but lost it. Later that night a second attempt was successful. On 20 June, flenser Suft again harpooned a whale but due to heavy ice floes the crew could not pursue it. Spitsbergen (II) became stuck in the ice on 30 June, close to Magdalena Bay, and the vessel was forced to stay there for 25 days in a row. On 23 July, Rickmers set sail for Harlingen.

In 1835 Spitsbergen (II) left Harlingen harbour on 19 March, again under the command of Hendrik Rickmers, and encountered bad weather on its outward bound voyage along the Norwegian coast, reached the ice about three weeks later on 8 April. Jan Mayen Island was sighted on 16 April and sealing was quite successful. Whaling, how-

532. H. Rickmers, Ship's journal Spitsbergen, 17 May 1831. Friesenmuseum, Wyk auf Föhr. 
13. Page from journal kept by master Hendrik Rickmers on board the whaleship Spitsbergen (II), 1832. Between 1830 and 1841, Rickmers served the Groenlandse en Straatdavidse Visscherij Sociëteit en Barend Visser \& Son. He kept journals of all his whaling voyages. Dr. Carl Häberlin Friesenmuseum, Wyk auf Föhr, Föhr (Germany).

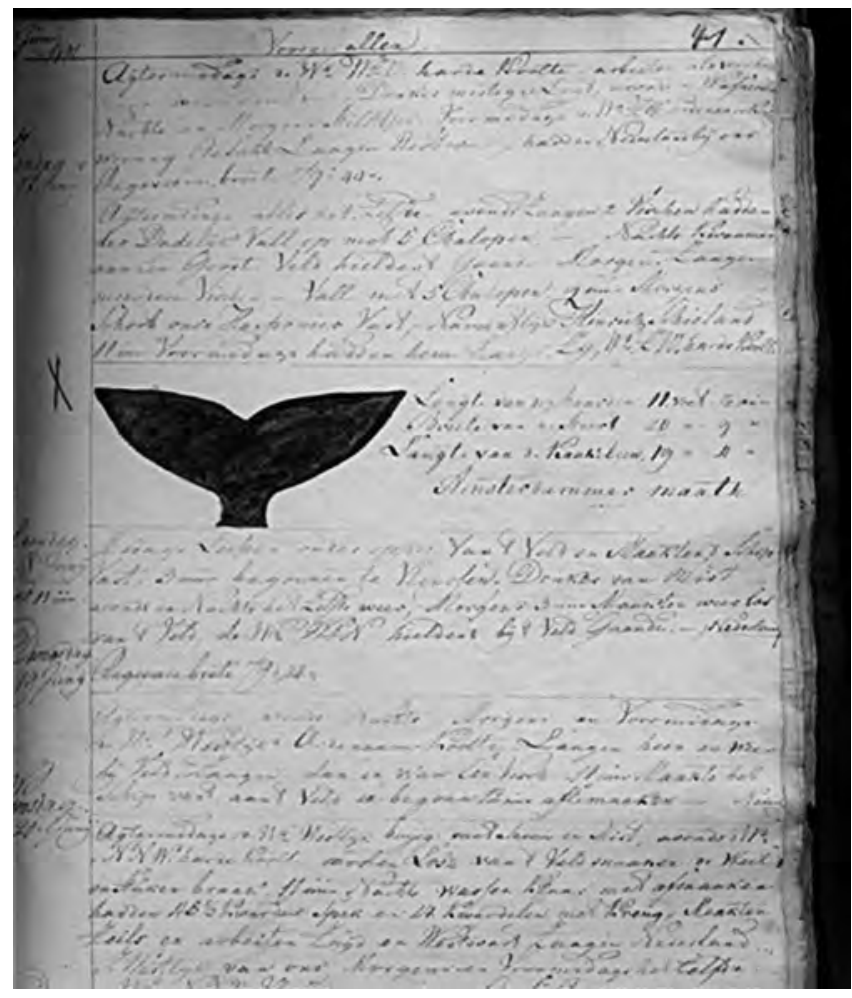

ever, turned out to be unproductive. On 21 July, Rickmers set his course to the Netherlands and returned to his home port on 6 August.

The vessel left Harlingen on 6 March 1836.533 On 8 April, Rickmers and his crew of 49 sighted the Beerenberg on Jan Mayen Island. From that day until 11 May, seals were caught on an almost daily basis. The total catch amounted to at least 1,622. ${ }^{534}$ Having sailed along the coast of Norway, Spitsbergen (II) moored in Harlingen on 25 August.

On 11 March 1837, Rickmers set sail again for the Arctic. A month later, on 8 April, Spitsbergen (II) reached the icepack not far from Jan Mayen Island on about $70^{\circ}$ N.L. The men had killed a few dozen seals when the ship was prepared for whaling on 2 May. At that time the vessel was cruising on $77^{\circ} 5^{\prime}$ N.L. On 18 May, harpooner Jacob Schiphorst killed a whale on $78^{\circ} 40^{\prime}$ N.L. Two days later he killed another one but had to let it go. For about a month Rickmers, in company with an international whaling fleet of

533. H. Rickmers, Ship's journal Spitsbergen, 6 March 1836. Friesenmuseum, Wyk auf Föhr. See also Leeuwarder Courant, 8 March 1836.

534. In his journal for 1836 , Rickmers did not present total catches. This number of at least 1,622 was compiled by the author and is based on remarks and figures in the journal. 
Scots from Peterhead (Commerce) and Germans from Hamburg (Jonge Martien; Hoffnung and others), sailed a northerly route. On 13 June, he decided to set a southerly course. Spitsbergen (II) eventually left for Harlingen on 18 July, and arrived at the home port in early in August.

Between 1838 and 1853, the company fitted out two vessels. In 1838, Spitsbergen (II) under command of Hendrik Rickmers left Harlingen on 23 March. 535 Three days later, Dirkje Adema sailed under command of Hendrik's son Hinrich Braren Rickmers (1810-1869). Rickmers, Jr., followed Spitsbergen (II) to the hunting grounds between Jan Mayen Island and Spitsbergen, and Spitsbergen (II) reached the ice on 14 April, on $69^{\circ} 37^{\prime}$ N.L. ${ }^{536}$ For about a month (until 17 May), Hendrik Rickmers and his crew focused on catching seals, killing 562 animals. After about one month, on $76^{\circ} 20^{\prime}$ N.L., they prepared for whaling. Two days later they saw Voorland near Spitsbergen. On 24 May, the first whale was killed by harpooner Hermann Stellmann. A week later a second whale was caught, thanks (again) to Jacob Schiphorst. In his entry for 3 June, Hendrik Rickmers referred to a whale being caught at $78^{\circ} 20^{\prime}$ N.L. by the crew of Dirkje Adema on 28 May. The second harpoon was thrown by his harpooner Schiphorst. A few days later the Captain gammed with his son Hinrich Braren and Commander Stokfleet. On 18 June, father and son Rickmers visited J. Okken's Hoffnung from Flensburg. A third whale was hit on 22 June and this time harpooner Christian Poppe was successful. Two days later Hermann Stellmann harpooned a whale, but lost it. On 5 and 6 July, Rickmers saw Voorland and passed the Zadelberg on Voorland ( $78^{\circ} 11^{\prime}$ N.L.). On 11 July they set sail for home and arrived on 29 July.

On 10 March 1839, Rickmers embarked for another Arctic whaling expedition. Three weeks later, on 30 March, the crow's nest was put in place on $66^{\circ} 3^{\prime}$ N.L. After an uneventful five weeks a higher crow's nest was installed (on 10 May). This season, Rickmers was far from successful in sealing and whaling. Spitsbergen (II) cruised about $78^{\circ}$ N.L. in company with the Hoffnung (Hamburg) and Perseverance (Peterhead) when harpooner Hermann Stellmann killed a narwhal on 6 June. The next day, harpooner Arend Oosterloo managed to do the same. On 4 August, Rickmers and his crew passed through the Zuiderbrug and reached Harlingen with disappointing catches.

In 1840, Spitsbergen (II) left Harlingen on 11 March in company with Dirkje Adema. One month later, on 12 April, Rickmers reached the icepack on $70^{\circ} 26^{\prime}$ N.L. A few seals were killed when the vessel reached the so-called "South Ice" on $77^{\circ} 19^{\text {'N.L. on } 13}$ May. From the end of June onward, both Dutch vessels held a southerly course. On

535. Leeuwarder Courant, 27 March 1838. Thanks are due to Frau Jutta Kollbaum-Weber of the Friesenmuseum, Wyk auf Föhr, and Herr Reinhardt Jannen, Archivist of the Ferring-Stiftung on the island of Föhr, for their assistance in establishing the relationship between Hinrich Rickmers and Hinrich Braren Rickmers. 536. Leeuwarder Courant, 3 April 1838 
18 July, they fired three shots with their small cannon to bid farewell to the other whalers and left the grounds for the home country. Spitsbergen (II) moored in Harlingen harbour three weeks later, on 8 August.

In the second pack of journals, the first voyage was dated 1846. Spitsbergen (II), under Johan Both, left on 27 February with a crew of 43. The next day, seven more whalemen were taken aboard. On the pages covering the period of 24 March to 9 May, a heading reads: "Journahl im Grönland auf der Robbenküste". All this time Spitsbergen (II) sailed the waters at about $71^{\circ}-72^{\circ}$ N.L. Commander Otto Mehlen of Dirkje Adema was mentioned several times and, after an unsuccessful trip, with $79^{\circ} 3^{\prime}$ N.L. as highest latitude, both decided to return to Harlingen. The keeper of the journal gives 2 August as the date of arrival.

Based on the 14 journals in the Dr. Carl Häberlin Friesenmuseum, located on the island of Föhr, it may be determined that seals were killed roughly between $70^{\circ} 24^{\prime}$ N.L. and $79^{\circ}$ N.L. After about one month, ships proceeded northerly. After passing approximately $75^{\circ}$ N.L., the time had come to prepare the whaling equipment. Whales were found and killed in higher latitudes than seals, between $78^{\circ} 20^{\prime}$ N.L. (1838) and $80^{\circ}$ N.L. (1834). Finally, a number of narwhals were caught somewhere between $77^{\circ}$ N.L. and $78^{\circ}$ N.L.

Interestingly, not once on the several hundred pages in the journals does Hendrik Rickmers (or do other journal keepers) refer to interaction between the whalemen and their natural surroundings in the Arctic. In contrast with the two centuries prior to the nineteenth century, there was not much stated about man's interference with ecology, nor about the consequences for the whales and seals. ${ }^{537}$ It is also interesting to note that the whalers did not bury their dead on land, but rather at sea. Judging from the journals the nineteenth-century Dutch whalemen unlike their seventeenth- and eighteenthcentury predecessors apparently did not go ashore on Jan Mayen Island or Spitsbergen.

Due to the lack of adequate sources, the focus of this narrative must take a major step forward in time and move to the early 1860s. Relating to his expeditions in 1862 and 1863 , the personal accounts by Douwe de Boer provide information about the course that the Harlingen-based whaleships followed toward the hunting grounds. The whaling company's aim was to have its ships sail from Harlingen harbour, the Zuiderhaven, in February. In 1862, Dirkje Adema passed de 'Blauwe Slenk', went through the 'Stortemelk' (in-between 't Vlie and Terschelling), and sailed on to the North Sea. While following the so-called 'Trechter', in-between the Norwegian coast and Iceland, the whaleship, according to Douwe de Boer, proceeded to the Atlantic

537. The whales' ecology in relation to whaling and climatological change was discussed in Louwrens Hacquebord and Jurjen Leinenga, 'De ecologie van de Groenlandse walvis in relatie tot walvisvaart en klimaatveranderingen in de zeventiende en achttiende eeuw', Tijdschrift voor Geschiedenis, vol. 107 (1994), 415-438. 


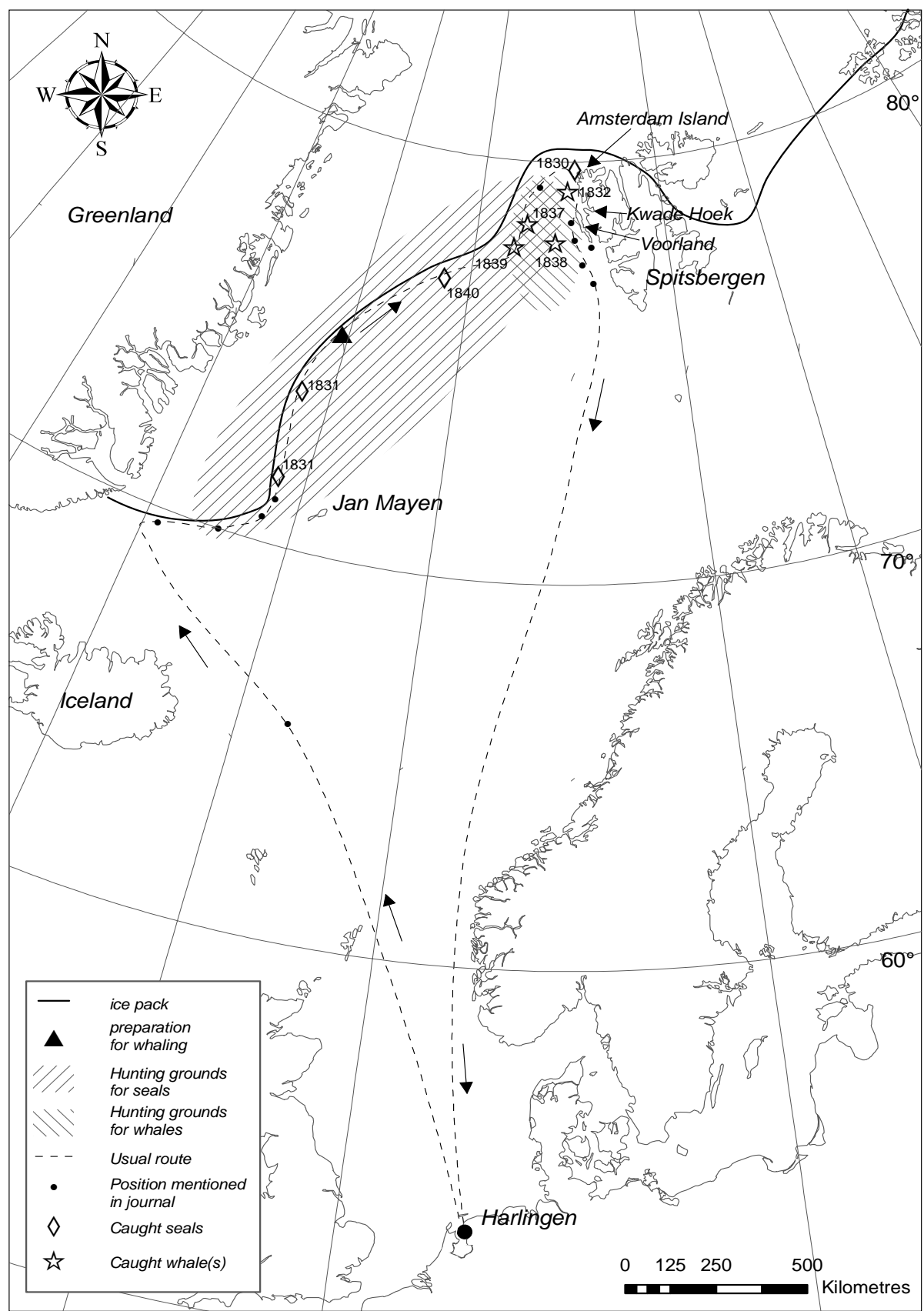

14. Map of the whaling and sealing grounds in the Arctic. This map, compiled by Jelle van Lottum, is based on data derived from the journals kept between 1830 and 1840 by Hendrik Rickmers. Rickmers only mentioned latitudes, no longitudes. Therefore, the locations indicated on this map are estimates. 
Ocean via the Northcape. Finally, the vessel reached the Davis Strait. Here the ship continued its course until it 'got stuck in the ice'. 538

When compared with the data provided by Rickmers about voyages made some twenty years earlier, these whaler's priority seems to have shifted. In Rickmer's voyages, the lookout was installed once the seal hunt was finished and whaling commenced. In De Boer's time, matters were handled differently. The very moment the ship had reached the icepack the crow's nest was installed - a large barrel with square top and bottom was brought up and fastened on the mainmast directly above the topgallant-mast. Relating from memory, Douwe de Boer provided more detail as follows. The bottom of the barrel had a narrow opening that could be closed with a little 'door' on hinges. In order to reach the crow's nest, the lookout had to climb the icy rigging, bounce his head against the little door to force access to the barrel, and stretch his arms while reaching for a handle to enable him to pull himself into the barrel. Inside the barrel was a small stool and a moveable fence to protect the lookout from the cold wind. An 'expensive' pair of binoculars facilitated the lookout's important task of sighting seals..$^{539}$

According to a remark made by Wever, in a similar manner to the 1830 and 1840 s Dutch Arctic sailors who first started out with the seal hunt, so did the whalers of the 1860s. At a later stage of the voyage, whaling activities were conducted. After elaborating on sealing, Wever continued,

"Toen het tijd was om naar de walvischvangst te gaan, maakten wij de sloepen klaar, de
lijnen werden in de sloep geschoten en het geweer en de harpoen voorop. Toen zetten
wij het om de noord, maar wij zagen geen walvisschen, alleen zagen wij eenige walrus-
sen. Daar mochten wij niet naar toe, dat was te gevaarlijk zei de Commandeur"
("When the time had come to hunt whales, we prepared our boats, the lines were placed
in the boat with gun and harpoon at the stem. Then we passed around the north, but
we did not sight whales, all we saw were a few walruses. We were not allowed to ap-
proach them, as the master considered this too dangerous"). ${ }^{540}$

It was of utmost importance for a successful seal hunt, Douwe de Boer stated, to reach the icepack in March, or April at the latest. During these weeks, the mother seals would give birth to their calves on the ice floes. The seal hunters selected the fat cows for killing and left the young puppies to their own fate. Occasionally, seal hunters brought the calves into the water, however, seal pups cannot swim when they are younger than six weeks. They consequently drowned. Vice versa, seals older than six weeks can swim and thus would be lost to the hunters.

538. Van der Weide Bzn., 'Uit het leven van een Groenlandvaarder', 42.

539. Van der Weide Bzn., idem, 42-43. Through the ink of Van der Weide Bzn.'s pen, Douwe de Boer unambiguously refers to the seal hunt as being the prime focus of attention. The crow's nest, he claims, was a splendid location for the lookout to see whether or not seals were present on the ice.

540. Van Deinse, Journaal der merkwaardige wijze, 26. Author's translation. 
The seal hunting season lasted only about six weeks at the longest. Old bulls were also shot. The best catches were made when the men worked on higher latitudes. Six boats were lowered, each equipped with a compass, and manned with eight hunters. In anticipation of losing sight of the ship, these boats carried foodstuffs and beer for several days. Warm clothing was an absolute necessity, as the seal hunters had to perform their duties in cold and wet circumstances. The crew rowed their boats and also dragged them over the ice floes with the carcasses of slaughtered seals piled in the boat.

When the hunters had a fully laden boat, they sought a strong ice floe to establish a so-called "slaughtery." The valuable seal furs were quickly but carefully stripped from the animal by experienced men as the tiniest cut would damage the fur and thus lower its value. Seals were also killed for their blubber, which yielded oil and during the slaughter, the men would fill up their boats, leave the ice floe, and return to the whaleship for the next stage of that process. On deck, the blubber was cut into long, narrow pieces. Sawdust was spread out over the deck to prevent it from getting too slippery from blood. The pieces of blubber were stowed in barrels. Meanwhile the cooper and his men (the so-called 'stuwers') were busy hauling up empty casks and filled-up barrels down into one of the three holds. The crew worked in three shifts.

Once sealing had finished, the time came to commence whaling. Wever described the sighting of a dead baleen whale floating, to which he attached his boat. Two more boats appeared on the scene. The crew members rowed the carcass to Dirkje Adema and brought it alongside the ship. At this point, Wever provides important data regarding the processing of the whale as follows. Two of the three boats were hoisted into the davits. One boat remained next to the whale to assist in case of emergency. The whalemen stood on top of the whale with spikes on the bottoms of their shoes or boots. The crew in the boat were supposed to come to the rescue in case one of the men fell into the water. The flensers cut in the blubber while others sliced the sections of blubber into smaller pieces to fit into the barrels. Once the baleen was taken from the upper jaw, the remains of the whale were left afloat. The crew then cleaned the bloody, slippery deck by scattering sawdust. ${ }^{541}$

Jan Wever's descriptions of whaling procedures are important. He described the way the Dutch around 1860 organised their business on the hunting grounds and how they thought about logistics and efficiency. Contrary to the Americans, the Dutch did not cut the blubber or the baleen from a cutting-stage, a wooden stand built on one side of the vessel from which two or three officers could cut-in the whale with their long blubber spades. Also in contrast with American practice, during the 1850 and 1860 s the trying-out of blubber did not generally take place on board. ${ }^{52}$ Pieces of blub-

541. Van Deinse, idem, 24; 29.

542. It was not until 1869 that Casper Josephus Bottemanne introduced try-works aboard a Dutch whaleship (Noordkaper). 
ber take up more space than blubber processed and transformed into oil. In other words, the holds of Dutch whaleships were filled with barrels that contained smaller quantities of oil than those on board American whaleships. Moreover, whale blubber does not keep very well. The pieces of fat in the casks easily decay when too much time passes between catching the whale and the processing of the blubber. So, when full (or even half-full), Dutch whaleships were forced to leave the grounds and sail to the Netherlands as fast as they could, where the ship owners had the blubber tried-out in local cookeries such as, for instance, De Herstelder in Harlingen.

\section{Liberty days}

Only a few journals, biographies, and autobiographies of nineteenth-century Dutch whalemen have survived. Therefore, it is a hazardous but challenging task to discover how these hardy men passed their spare time. Douwe de Boer gave a brief description of life aboard Dirkje Adema. ${ }^{543}$ Around 1862, he and his fellow whalemen filled their time on the return voyage with a variety of activities. When not on watch, men could spend time by repairing their wardrobe. Laundry was also done, buttons replaced, and holes in socks were mended. The socks were pulled over a coffee mug, and even the largest holes - the 'size of a potato' - were repaired. Sailors obviously knew how to use a needle and thread. Seal fur was used for making tobacco pouches, with a large seal's nail as a lock. They also made floor mats from ropes that were colourfully and intricately decorated with maritime symbols like anchors. Woodwork was one of the favourite pastime pleasures and De Boer referred to colleagues who were extremely cunning in cutting ship's models or making ships in bottles. Peeling potatoes was another activity that the men performed to fill their free hours, although one may ask whether or not this happened voluntarily. Most of this work was done at ease and jokes were told and retold.

Music seems to have played an important role in the whalemen's life. De Boer referred to 'harmonika's' (either concertinas or larger accordions), flutes, and 'shipmade' triangles that were fabricated from iron forks. This orchestra was then placed under the rhythmic beat of a large Turkish drum, which was an empty barrel, and two copper pan lids also served well. The noise must have been preponderantly present and pandemonium.

All these examples were initiated privately by the whalemen. Under the company's aegis, certain religious holidays and services were observed and celebrated. With Easter and Whitsuntide, the crew enjoyed soup with fresh meat from a frozen

543. Van der Weide Bzn., 'Uit het leven van een Groenlandvaarder', 54-56. 
cow that had been hanging from the mainmast. During Whitsuntide, these days were celebrated as if they were Sundays and every morning between 7 and 8, the master would read from De Christelijke Zeeman. Hymns were sung. On regular Sundays, the sermon would take a bit longer. Referring to his first voyage in 1860, Jan Wever recalled how every night before supper, after having had a washing, the crew, in clean clothing, would stand before master Wildst, who would read and have the crew sing a psalm or hymn..$^{544}$

One of the highlights on Sunday was the evening ball. On the homeward-bound passage, the 'orchestra' played music and the men danced enthusiastically and vividly. The evening ball always opened with a polonaise. The youngest boys would serve as 'dancing girls' for the older sailors. Furthermore, there would be singing and lecturing. ${ }^{545}$

Pleasure and pain sometimes travel together, on shore and on board, and De Boer described burials at sea. In 1862, during his first voyage, the crew lost two of its men, one who was from Tzummarum and the other was from Sexbierum, two small villages in the province of Friesland.546 The two had slipped into the ice-cold water and drowned. The ship's surgeon officially declared them dead by drowning and wrote a report of the circumstances and the procedures he had followed. Their bodies were placed inside one of the whaleboats on deck and covered by a sail and the Dutch flag. When time came to bury the two men, the boatswain had each body wrapped in sailcloth. Body and sail were then fastened to a plank, to which a heavy chunk of coal was attached. The sails were lowered, the beams were crossed, and the master would call all hands on deck. Captain Wildst led a brief sermon with reading and prayer. While singing a solemn psalm, the colleagues closest to the two dead carried the bodies to an opening on the ship's side. The men took off their hats and when the first mate commended "één, twee, drie, in Godsnaam" (One, two, three, in the name of God) the bodies were lowered and plunged into the ocean. From the moment the accident had occurred until the burial, the national flag was at half-mast. Once the dead were entrusted to the sea, the flag was moved three times between half-mast and the top of the pole. It was then raised completely. After the burial, the commander convened the crew and spoke a few more words. As a final farewell to their comrades, the crew raised a glass of gin..$^{54}$

\footnotetext{
544. Van Deinse, idem, 23-24

545. idem, 56 .

546. The crew list of Dirkje Adema, dated 1862, does not mention anyone from Tzummarum. There were, however, five seamen from Sexbierum. See GAH, WS 4, 1862, B29; GAH, WS 17, 1862, no. 29.

547. Van der Weide, 'Uit het leven van een Groenlandvaarder', 56.
} 


\section{Conclusions}

Data about the construction and deployment of whaleships is scarce. Sources that describe the origin, composition, and level of education of the whaling crew are scattered, as are sources that reveal the exact locations of the whaling grounds and the activities undertaken there. Nevertheless, a number of conclusions can be made. Throughout the nineteenth century relatively small-sized Dutch whaleships destined for Arctic waters carried relatively large crews. Interestingly, the situation in a number of other countries involved in whaling was exactly the opposite. In France, Germany, England, Scotland, and the United States, ships were often much larger with smaller crews. The crew of a Dutch whaleship in the southern oceans consisted of a small number of nationalities, and often British, American, and Dutch whalemen worked side-by-side.

Crews aboard whaleships deployed by Harlingen-based companies seem to have had a very local character. Crew lists compiled around 1845, and for the years 1858 to 1863, indicate that islanders from Terschelling cooperated with sailors from the Frisian mainland, but also with large numbers of Germans. The number of whalemen from other regions in the Netherlands was limited. Crew lists referring to whaleships fitted out in Amsterdam between 1815 and 1825 show that these ships had crews with a more international background. On these ships, Dutchmen, Germans, Scandinavians (Finnish and Swedes), British, and an occasional American worked together.

With regard to their level of education, Dutch whalemen can only be judged on the basis of a single source in the municipal archives of Harlingen: the personal observations of the directors of the Nautical College in Harlingen. The picture these gentlemen paint of their pupils going whaling during 1844 to 1864 is a colourful one, characterized by modesty, industrious behaviour, susceptibility, a willingness to learn, and an eagerness to perform well in school. It cannot be ascertained if these characteristics were applied on shipboard as well. It may be expected, however, that those traits were displayed at the risk of not being rehired, or endangering a poor report to the headmaster at the College.

Whaling and sealing must have been appealing to young sailors. Crew lists have enabled us to assess the average age of whalemen. The average age of a whaleman in Amsterdam signing up for an expedition with the pink Groenland in 1821 was close to 34 and one-half (see Appendix 3). Crew lists referring to voyages from Harlingen with Dirkje Adema made in the late-1850s and early-1860s present different figures. The average age of a whaleman was a little over 25 in 1859, and over 25 and one-half two years later, in 1861 . Despite a lack of success, whaling and sealing apparently attracted relatively young sailors.

The wages Dutch whalemen enjoyed were fairly high. Not only did the whaling 
companies pay monthly salaries, but the crew could augment their earnings through participation in the so-called lay-system. They were eligible to buy a share in the profits (and losses) of the expedition. Their benefits were also stipulated in the rules and regulations on board dictated in records kept by the Waterschout (Harbourmaster) and signed by the captain. Whalemen slept in bunks and enjoyed relatively varied and nutritious meals. On board they apparently lived in solidarity in both social and religious terms. According to one source, Hendrik Wildst, who commanded Dirkje Adema for several years in a row, they actively promoted religious tolerance. Referring to his whaling voyages Douwe de Boer stated,

“... bleek, dat zoolang wij aan boord waren, wij allen hetzelfde geloof hadden, Roomsch incluis"

(“..., that as long as we stayed aboard, we all had the same belief, Catholicism included"). .548

Covering a period of five or six consecutive years, the crew lists of Dirkje Adema showed a repetition of many names. In other words, a substantial part of the crew signed up for more than one expedition. They returned the following season to make another voyage to the Arctic. The social environment, the appreciation of know-how, and a substantial payment, were all factors that may have attributed to the professional satisfaction of the men involved. In his memoirs, Douwe de Boer referred to meeting one whaleman who had made no fewer than 24 voyages. ${ }^{549}$

As in most other countries, Dutch Arctic whaling was seasonal. Ships left Dutch ports sometime in March or April and returned in July or August. During the $1830 \mathrm{O}$ and 1840s, the whalemen initially sailed for Jan Mayen Island to hunt seals. Later in the season they proceeded to the northwestern part of Spitsbergen to hunt whales. In the journals at the Dr. Carl Häberlin Friesenmuseum on Föhr, Voorland and Kwade Hoek off Amsterdam Island were mentioned several times. Later, during the 1860s, whaling seems to have become of secondary importance to the captains, their crew, and the companies involved. To date, no evidence has been found of the whalemen's ecological interaction with their natural environment, other than the hunting and killing of polar bears, and sealing and whaling itself. Contrary to the two preceding centuries, there is also no information about reindeer hunting, or about the collecting of birds and eggs. Finally, there is not any data vis-à-vis the activities of the whaling crew when not actively involved in this industry. It seems worthwhile that these two new fields should be explored and charted in the future.

548. Van der Weide Bzn., 'Uit het leven van een Groenlandvaarder', 55. Author's translation.

549. Van der Weide Bzn., idem, 66. 


\section{Clients, Commodities, and Distribution}

\section{Introduction}

In previous chapters, the organisation of the whaling and sealing industries and the people who were involved in these maritime endeavours, either behind desks in offices on the quays and wharves, or actually on the decks of whaleships, was discussed. In short, the focus has been on the producers of commodities. In this chapter, the products and the consumers will be examined in detail. What products were derived from the whaling and sealing expeditions? Who were the clients of the various Dutch whaling companies? Were they also actively involved in whaling? Did they equip ships, provision crew, and invest in the business, or did they wait for the products to arrive in the companies' home ports? Finally, by scrutinizing the clientele for whaling and sealing products, can it be stated whether or not the distribution had a local, regional, national, or perhaps, even an international character?

Attention will also be given to distribution and the use of whaling and sealing products. Research into the final destination of the products is beyond the parameters of this study. Data is extremely scarce regarding the sale of the catches of the South Seas whale fishery. Basically, the only information available is what happened to Logan and its cargo of whale oil and baleen: the sale took place in New York. Information as to the distribution of these commodities and the identities of the clients remains unknown.

Again, most of the information concerning the buyers is related to Arctic whaling and sealing, and more specifically to the expeditions conducted from Harlingen. The results of a handful of public auctions organised between 1831 and 1834, and in 1838 are available, as those auctions were often presided by the local notaries, who apparently specialised in whaling and sealing affairs. ${ }^{550}$

550. Tresoar Leeuwarden (TL), Notary archives: Hanekuyk and Wijma, 49024 (repertoires), \#283 (October 1831); Wijma, 49025 (repertoires), \#253 (September 1832); Wijma, 49026 (repertoires), \#281 (October 1833); Hanekuyk, 51017 (repertoires), \#38 (September 1834); Wijma, 49031 (repertoires), \#191 (October 1838). 


\section{Sellers and buyers}

The notary records of the sales of whale and seal products pertain to the final years of the Groenlandsche of Straatdavidse Visscherij Sociëteit, based in Harlingen. The auctions of 1832, 1833, 1834, and 1838 were held at the inn 'Roma'. In 1831, buyers, sellers, and notaries gathered at Douwe Innema's Heeren Logement, located at the Voorstraat. Clients were required to pay in cash, in guilders, for their purchases. Whale oil and seal oil were sold by the barrel or - in the case of the 1838 auction - per 100 steekannen at 19.2 litres each. Furs of seals and polar bears were sold per piece, while baleen was auctioned off per Dutch pound. By products (tails and 'vinken') were sold per barrel as well. Interestingly, the records of the public auctions clearly stated that the buyers of waste material and furs were requested to empty the barrel, take out their share, and leave the empty barrel for the owners.

The archives in Leeuwarden preserved lists with the results of five auctions (see Appendix 7 for a complete overview). These lists contain many dozens of names of clients. Their occupations, unfortunately, were not mentioned. Through other sources, however, the composition, origin, and nature of the audiences present at the various auctions were reconstructed.

Commodities found their way to merchants in both Harlingen and Amsterdam. At the first four auctions (1831-1834) the vast majority of the buyers came from, or had their businesses in Harlingen. In 1834, the last year of the Sociëteit's existence, only a few Amsterdam clients managed to acquire a substantial number of barrels filled with whale and seal products. The profile of the buyers changed drastically in 1838. At that time, an auction took place upon the request of Barend Visser \& Son, and with few exceptions, the clientele was almost exclusively based in Amsterdam.

Next to Harlingen and Amsterdam the island of Terschelling was the residence of many clients. However, compared with their colleagues in the village and the city, merchants from this island played a minor role. Only in two instances did buyers indicate some other place of residence. Tjeerd Follema was from Arum and Cornelis de Haas was from Bolsward and both were listed in 1838. On the whole, particular patterns as to what commodities were purchased and by whom cannot be discerned.

From these facts it is easy to conclude that the direct distribution of whaling and sealing products from Harlingen had a regional or inter-provincial character. But did the whale and seal oil, the baleen, and furs all remain in the Netherlands? That is, did the whaling companies produce for the domestic market only? Or did the individual clients or firms mentioned on the lists only serve as temporary repositories where commodities briefly filled up storage space, only to be distributed over the rest of the Netherlands or maybe even beyond its borders? Similarly, it is far from easy to analyse the professional relationship of these clients with whaling in general or with the whal- 
ing companies in Harlingen in particular. The auction list of 1831 contained some interesting and familiar names. Barend van Spreekens - who personally did not equip any whaleships after 1819 - attended the auction in Harlingen and purchased dozens of barrels of seal oil, furs, whale oil, and baleen. His name does not appear again after 1831. Several directors of the local whaling company also showed a keen interest in buying up the whale and seal products. Dirk Cornelis Zijlstra, Jan IJzenbeek, and Jarig Mollema were mentioned frequently, as were representatives of the Rodenhuis family. Should their personal involvement be considered as a sign of confidence? Did they participate in the bidding to raise the price? Or is the mere fact that they - nota bene during a public auction - purchased fairly large quantities of whale and seal products a clear indication that the market for these commodities was increasingly weak?

From about 1839 onward, merchant Jarig Mollema appeared in the local archives as a soap manufacturer. ${ }^{51}$ For years, whale oil and seal oil were one of the main ingredients for making soap. Thus, it may be expected that Mollema was investing large sums of money to purchase these commodities. The figures presented in Appendix 7, however, clearly indicate that Jarig Cornelis Mollema had more interest in buying seal furs. He bought 90 pieces at the auction of 1833 and 120 pieces the following year. Oddly, he did not spend even one guilder at the auction of 1838, when one may have expected him to sit in the front row that year. ${ }^{552}$

The auction lists provide many dozens of names. In 1831, several names of clients stand out among the extensive clientele of the Sociëteit. Locally, Barend Visser \& Son, Bouwe Rodenhuis, and Fontein \& Roquette invested fairly heavily to obtain oil and other whale and seal products at auction. Outside of Harlingen the firms of Barend van Spreekens, Cornelder \& Zahn, and especially Catz \& Compagnie seem to have been the most important customers from Amsterdam. Compared to the firms in Harlingen, the Amsterdam-based companies spent considerably larger amounts on commodities. With all these results combined, the six companies listed in Table 6.1 made up about $80 \%$ of the total revenues of the auction. Their respective roles in all five auctions will be examined next. Tables 6.1 through 6.6 were derived from the data presented in Appendix 5.

551. GAH, Volkstelling 1839 .

552. This was because apparently Mollema started his soap manufacturing business around 1839. Again, additional research should be conducted to analyse the motives these individuals may have had. 
Table 6.1: Auction expenditures ('exp.') on whale and seal products by main customers (October 1831).

(Amounts in $f$. Seal oil and whale oil are given in barrels; furs are listed per piece. Percentage of total expenditure of firms reflects the share each company had in the revenues of the sale.)

\begin{tabular}{|c|c|c|c|c|c|c|c|c|c|}
\hline Company name & Seal oil & Exp. & $\begin{array}{l}\text { Polar bear } \\
\text { and seal } \\
\text { furs }\end{array}$ & Exp. & Whale oil & Exp. & $\begin{array}{l}\text { Baleen and } \\
\text { dried seal } \\
\text { furs } \\
\text { (pounds) }\end{array}$ & Exp. & $\begin{array}{l}\text { Total expen } \\
\text { ditures }\end{array}$ \\
\hline \multicolumn{10}{|l|}{ Harlingen } \\
\hline Barend Visser \& Son & 10 & 920 & 466 & 243.37 & 30 & $3,712.50$ & - & - & $4,875.87$ \\
\hline Bouwe Rodenhuis & 20 & 1,770 & - & - & 20 & $2,090.00$ & - & - & $3,860.00$ \\
\hline Fontein \& Roquette & 30 & 2,915 & 150 & 121.87 & - & - & 91 & 232.05 & $3,268.92$ \\
\hline \multicolumn{10}{|l|}{ Amsterdam } \\
\hline Barend van Spreekens & 90 & 8,345 & - & - & 89 & $10,564.25$ & 177 & 450.37 & $19,359.62$ \\
\hline Cornelder \& Zahn & 29 & 2,595 & 9 & 23.40 & 10 & $1,250.00$ & 445 & $1,371.62$ & $5,240.02$ \\
\hline Catz \& Compagnie & - & - & 3,366 & $2,596.34$ & 20 & $2,500.00$ & 190 & 169.10 & $5,265.44$ \\
\hline \multicolumn{9}{|c|}{ Total expenditure six firms } & $\begin{array}{r}41,887.87 \\
(\text { ca. } 80.2 \%)\end{array}$ \\
\hline \multicolumn{9}{|l|}{ Total revenues sales } & $51,669.00$ \\
\hline
\end{tabular}

Barend van Spreekens spent a small fortune on seal oil and whale oil, with the firms of Catz \& Compagnie and Cornelder \& Zahn following at a monetary distance. Combined, these three Amsterdam firms spent about $f_{30,000}$ at auction (circa 58\%).

Table 6.2: Auction expenditures ('exp.') on whale and seal products by main customers (September 1832).

(Amounts in $f$. Seal oil and whale oil are given in barrels; furs are listed per piece. Percentage of total expenditure of firms reflects the share each company had in the revenues of the sale.)

\begin{tabular}{|c|c|c|c|c|c|c|c|c|c|}
\hline Company name & Seal oil & Exp. & $\begin{array}{l}\text { Polar bear } \\
\text { and seal } \\
\text { furs }\end{array}$ & Exp. & Whale oil & Exp. & $\begin{array}{l}\text { Baleen and } \\
\text { dried seal } \\
\text { furs } \\
\text { (pounds) }\end{array}$ & Exp. & $\begin{array}{l}\text { Total expen- } \\
\text { ditures }\end{array}$ \\
\hline \multicolumn{10}{|l|}{ Harlingen } \\
\hline Barend Visser \& Son & 24 & 1,938 & - & - & 18 & 1,632 & $486(\mathrm{~B})$ & 1,165 & $4,735.00$ \\
\hline Bouwe Rodenhuis & - & - & 823 & 395.25 & 54 & 4,848 & - & - & $5,342.25$ \\
\hline Fontein (\& Roquette) & 30 & 2,442 & - & - & - & - & - & - & $2,442.00$ \\
\hline \multicolumn{10}{|l|}{ Amsterdam } \\
\hline Barend van Spreekens & - & - & - & - & - & - & - & - & - \\
\hline Cornelder \& Zahn & 6 & 480 & - & - & - & - & - & - & 480.00 \\
\hline Catz \& Compagnie & - & - & - & - & - & - & - & - & - \\
\hline Ankersmit & - & - & 1,108 & 368.00 & - & - & - & - & $1,108.00$ \\
\hline \multicolumn{9}{|c|}{ Total expenditure seven firms } & $\begin{array}{l}14,109.25 \\
(\text { ca. 54\%) }\end{array}$ \\
\hline \multicolumn{9}{|l|}{ Total revenues sales } & $25,779.00$ \\
\hline
\end{tabular}

These tables evidently reflect a change in the composition of the six largest customers. In 1831 and 1832, the grand old whaling firms such as the one linked to Barend Visser in Harlingen or Barend van Spreekens in Amsterdam, still had their representatives bid in the auction room. Van Spreekens did not appear in the listings after 1833. 
Table 6.3: Auction expenditures ('exp.') on whale and seal products by main customers (October 1833).

(Amounts in $f$. Seal oil and whale oil are given in barrels; furs are listed per piece. Percentage of total expenditure of firms reflects the share each company had in the revenues of the sale.)

\begin{tabular}{|l|r|r|r|r|r|r|r|r|r|}
\hline Company name & Seal oil & Exp. & $\begin{array}{c}\text { Polar bear } \\
\text { and seal } \\
\text { furs }\end{array}$ & Exp. & Whale oil & Exp. & $\begin{array}{l}\text { Baleen and } \\
\text { dried seal } \\
\text { furs } \\
\text { (pounds) }\end{array}$ & Exp. & $\begin{array}{l}\text { Total expen- } \\
\text { ditures }\end{array}$ \\
\hline Harlingen & & & & & & & & & \\
\hline Barend Visser \& Son & - & - & - & - & - & - & - & - & - \\
\hline Bouwe Rodenhuis & - & - & 14 & 17.50 & 28 & 1,902 & - & - & $1,919.50$ \\
\hline $\begin{array}{l}\text { Fontein \& Roquette/ } \\
\text { Fontein \& Tjallingii }\end{array}$ & - & - & - & - & 4 & 277 & - & - & 277.00 \\
\hline Dirk Cornelis Zijlstra & - & - & - & - & 60 & 4,050 & 500 & 990.00 & $4,140.00$ \\
\hline Amsterdam & & & & & & & & & \\
\hline Barend van Spreekens & - & - & - & - & - & - & - & - & - \\
\hline Cornelder \& Zahn & - & - & 303 & 201.50 & 18 & 1,248 & 300 & 580.00 & $2,029.50$ \\
\hline Simon Nijburg & - & - & - & - & - & - & 352 & 681.75 & 681.75 \\
\hline Catz \& Compagnie & - & - & - & - & - & - & - & - & - \\
\hline \begin{tabular}{l} 
Total expenditure eight firms \\
\hline
\end{tabular}
\end{tabular}

The data for 1833 introduced many new names: companies hitherto unknown to have been involved in whaling or sealing suddenly appear on the scene. Cornelder \& Zahn were still quite active. However, like Barend van Spreekens, Catz \& Compagnie seem to have disappeared from the scene. Simon Nijburg may have replaced them in the auction room at the Inn 'Roma' in Harlingen.

In Harlingen, Bouwe Rodenhuis remained the most affluent and influential customer, buying up fairly large percentages of the products offered. Modest at first, he later became a fairly important player. New competition came from an unexpected, though logical, source. Dirk Cornelis Zijlstra, one of the founding fathers of the Harlingen-based Sociëteit, purchased considerable quantities of whaling and sealing products. For instance, he purchased about $36.5 \%$ of the total number of barrels of whale oil. Moreover, he proved competitive in the sale of baleen, bidding seriously against Amsterdam-based parties. Some of his fellow Directors of the whaling company were also present at the auction: Jan IJzenbeek and Jarig Mollema acquired modest quantities of what their own ships had caught in the cold Arctic waters. Interestingly, in 1833 no seal oil was auctioned off. 
Table 6.4: Auction expenditures ('exp.') on whale and seal products by main customers (September 1834).

(Amounts in $f$. Seal oil and whale oil are given in barrels; furs are listed per piece. Percentage of total expenditure of firms reflects the share each company had in the revenues of the sale.)

\begin{tabular}{|c|c|c|c|c|c|c|c|c|c|}
\hline Company name & Seal oil & Exp. & $\begin{array}{l}\text { Polar bear } \\
\text { and seal } \\
\text { furs }\end{array}$ & Exp. & Whale oil & Exp. & $\begin{array}{l}\text { Baleen and } \\
\text { dried seal } \\
\text { furs } \\
\text { (pounds) }\end{array}$ & Exp. & $\begin{array}{l}\text { Total expen- } \\
\text { ditures }\end{array}$ \\
\hline \multicolumn{10}{|l|}{ Harlingen } \\
\hline Barend Visser \& Son & - & - & - & - & 5 & 315.00 & - & - & 315.00 \\
\hline $\begin{array}{l}\text { Bouwe Rodenhuis/ } \\
\text { Widow Rodenhuis \& } \\
\text { Sons }\end{array}$ & 14 & 854.00 & - & - & 26 & $1,677.50$ & $178(\mathrm{~B})$ & 316.65 & $2,838.15$ \\
\hline $\begin{array}{l}\text { Fontein \& Roquette/ } \\
\text { Fontein \& Tjallingii }\end{array}$ & - & - & 338 & 133.60 & 5 & 327.50 & 98 (B) & 169.05 & 630.15 \\
\hline \multicolumn{10}{|l|}{ Amsterdam } \\
\hline Barend van Spreekens & - & - & - & - & - & - & - & - & - \\
\hline Cornelder \& Zahn & - & - & - & - & - & - & - & - & - \\
\hline Simon Nijburg & - & - & - & - & - & - & $75(\mathrm{~B})$ & 121.45 & 121.45 \\
\hline Catz \& Compagnie & - & - & - & - & - & - & - & - & - \\
\hline \multicolumn{9}{|c|}{ Total expenditure seven firms } & $\begin{array}{r}3,904.75 \\
\text { (ca. 83\%) } \\
\end{array}$ \\
\hline \multicolumn{9}{|l|}{ Total revenues sales } & $4,731.60$ \\
\hline
\end{tabular}

Compared to previous years, the market for whale and seal products had become fairly small. In 1834 only a handful of private individuals and companies were present in the auction room. Amid the familiar bidders, two new names surface: Bernardus Leemkoel and Sipke van Slooten, who were both Harlingen residents. Leemkoel spent $f 655$ on whale oil, and his name also appeared on an auction list of a later date. As had been the case in former years, the firms of Barend Visser \& Son and Jarig Mollema were modestly active in their purchases. Bouwe Rodenhuis evidently died sometime between October 1833 and September 1834. The results of this auction show unambiguously that his widow continued the business with great vigour. Dirk Cornelis Zijlstra, the whaling company's director who had spent a small fortune the previous year, did not return to the auction in 1834. That year Simon Nijburg was the only Amsterdam-based firm present. By this time, Cornelder \& Zahn, Barend van Spreekens, and Catz \& Compagnie all had disappeared. A similar fate, to be discussed later, awaited Simon Nijburg just a few years later in 1838, when Frederik Dijkman from Amsterdam moved to the leading position in the field. 
Table 6.5: Auction expenditures ('exp.') on whale and seal products by main customers (October 1838).

(Amounts in $f$. Seal oil and whale oil are given in barrels; furs are listed per piece. Percentage of total expenditure of firms reflects the share each company had in the revenues of the sale.)

\begin{tabular}{|c|c|c|c|c|c|c|c|c|c|}
\hline Company name & Seal oil & Exp. & $\begin{array}{l}\text { Polar bear } \\
\text { and seal } \\
\text { furs }\end{array}$ & Exp. & Whale oil & Exp. & $\begin{array}{l}\text { Baleen and } \\
\text { dried seal } \\
\text { furs } \\
\text { (pounds) }\end{array}$ & Exp. & $\begin{array}{l}\text { Total expen- } \\
\text { ditures }\end{array}$ \\
\hline \multicolumn{10}{|l|}{ Harlingen } \\
\hline Barend Visser \& Son & - & - & - & - & - & - & - & - & - \\
\hline $\begin{array}{l}\text { Widow } \\
\text { Bouwe Rodenhuis }\end{array}$ & - & - & - & - & - & - & - & - & - \\
\hline Fontein \& Roquette & - & - & - & - & - & - & - & - & - \\
\hline Bernardus Leemkoel & - & - & & & 15 & $2,328.09$ & & & $2,328.09$ \\
\hline \multicolumn{10}{|l|}{ Amsterdam } \\
\hline Barend van Spreekens & - & - & - & - & - & - & - & - & - \\
\hline Cornelder \& Zahn & - & - & - & - & & & & & - \\
\hline Catz \& Compagnie & - & - & - & - & & & & & - \\
\hline Frederik Dijkman & - & - & - & - & 63 & $11,815.17$ & $2,274 \cdot 00^{1 / 2}$ & $4,455.97$ & $16,271,14$ \\
\hline Adam van der Minde & - & - & - & - & & & 600.00 & $1,168.00$ & $1,168,00$ \\
\hline \multicolumn{9}{|c|}{ Total expenditure nine firms } & $\begin{array}{l}19,767.23 \\
\text { (ca. } 89 \%)\end{array}$ \\
\hline \multicolumn{9}{|l|}{ Total revenues sales } & $22,247 \cdot 29^{1 / 2}$ \\
\hline
\end{tabular}

Seal oil and seal furs disappeared from the listings. Except for Bernardus Leemkoel, Jan Fontein and a few other smaller merchants from villages outside Harlingen (Arum and Bolsward), the trade in whaling and sealing products around 1838 seems to have been solely concentrated in Amsterdam. The familiar bidders - Cornelder \& Zahn, Catz \& Compagnie, Barend van Spreekens, but also Simon Nijburg - were replaced by two new ones: Frederik Dijkman and Adam van der Minde. These two men almost exclusively purchased the majority of the commodities offered at this auction. As can been seen in Table 6.5, Frederik Dijkman spent a small fortune on the harvest of the whaling activities conducted by the company of Barend Visser \& Son.

Research conducted on the occupation of the clients present at the auctions will be discussed next. As the clientele were from among the more affluent segment of society, it seems fair to assume that their names would also be listed in so-called Kohieren van Belasting op huurwaarde - documents related to taxes levied on rental property. Records in the municipal archives in Harlingen containing this type of information run from 1816 to 1852 . As these documents were compiled for tax purposes, a fair number - but not all - of the clientele of the whaling company were mentioned, as well as their occupation, the number and locations of the houses they owned, and the amount of money they were charged. For the purpose of this discussion, the records for 1833 proved to be very useful. The results are presented in Table 6.6. 
Table 6.6: Occupations of some of the Harlingen-based clients present at auctions (1831-1834, and 1838). 553

\begin{tabular}{|l|l|}
\hline Name & Occupation \\
\hline Bolman, Albert & Merchant ('koopman') \\
\hline Draaisma, Cornelis Piers & Merchant ('koopman') \\
\hline Fontein Janszoon, Freerk & Shipping merchant (zeehandelaar) 554 \\
\hline Hoekstra, Klaas & Whaling master ('commandeur') \\
\hline Ouendag, Hermanus & Hatmaker ('hoedenmaker') \\
\hline Rodenhuis, Bouwe & Shipping merchant ('zeehandelaar') \\
\hline Slooten, Sipke van & Merchant ('koopman') \\
\hline Stinstra, Simon & Captain of industry ('fabrigeur') \\
\hline Telsemeijer, Gerardus & Merchant ('koopman') \\
\hline Valckenier, Jan & Shipping merchant ('zeehandelaar') \\
\hline Vervoort, Hendrik & Merchant ('koopman') \\
\hline Wiarda, Ids and Simon & Agent ('makelaars') \\
\hline Zijlstra, Dirk Cornelis & Shipping merchant ('zeehandelaar') \\
\hline
\end{tabular}

\section{Commodities}

\section{Oil}

Seal oil and whale oil were highest in demand. Oil could be acquired through heating and boiling-down the blubber of these animals. This process, taking place at so-called traankokerijen (cookeries or try-works) was called trying-out. For this purpose, whales and seals were stripped with flensing tools. Seal furs were carefully handled, as they represented a considerable value. The layer of fat of these marine mammals was cut into smaller pieces that could be fairly easily handled and boiled down to oil in large ovens near the premises of the local whaling companies.

Ordinarily, these oils were used for lubrication and illumination of houses and streets. At the end of the eighteenth century, whale oil was also used extensively in lighthouses serving the coasts of the United States, England, and Scotland.555 It also

553. GAH, Kohieren van belasting op de huurwaarde, 1816-1852. No. 2295 (1833).

554. The term zeehandelaar is not easy to translate. At the end of the 'interview' with his son-in-law, whaleman Douwe de Boer related events about the post-whaling era. After 1863, he and his wife were involved in trade on inland waterways with their own tjalk De Vrouw Reintje. De Boer referred to himself as having been 'Schipper-handelaar'. See Van der Weide Bzn., 'Uit het leven van een Groenlandvaarder', 104. In Merchants, bankers, middlemen. The Amsterdam money market during the first half of the $19^{\text {th }}$ century (Amsterdam 1996), Joost Jonker explained the term zeehandelaar as being ship owner and merchant. Thus, my translation shipping merchant.

555. William T. O'Dea, The Social History of Lighting (London 1958), 200; 226. O'Dea also referred to other animal fats used for lighting. 
served as an industrial lubricant. Sperm oil served as the basis for spermaceti candles. So far, no evidence has been found to support the idea that lighthouses in the Netherlands depended on whale oil. This is also apparently true for the lighthouses on the mainland of Europe..$^{556}$

Moreover, it is generally accepted as a fact that animal fats were used in various industries, frequently related to shipping. Rope makers, soap makers, leather manufacturers, sailcloth manufacturers, wool textile manufacturers, but also shipbuilders benefited from importing whale oil and seal oil. None of the economically-oriented secondary sources, however, provided insight with respect to the exact use of whale and seal oil in the Netherlands during this era. In Michael Jansen's study of the industrial development of this country during the first-half of the nineteenth century, he discussed whale oil in passing:

"Het belangrijkste product van de olieslagerijen was raapolie. Dit was een van koolzaad of raapzaad gemaakte spijs- en lampolie. Tot de jaren zeventig van de negentiende eeuw waren deze producten zeer in trek. Spijsolie werd ondermeer gebruikt om naar verhouding dure boter te kunnen vervangen, terwijl walvistraan geen echte concurrent voor lampolie was. Met de introductie van margarine en petroleum in het laatste kwart van de vorige eeuw kwam hier verandering in en verdween de raapolie geleidelijk van het toneel"

("The most important product of the oil-crushers was turnip oil. This was cooking and lamp oil made from cole seed or turnip seed. These products were very popular until the seventies of the nineteenth century. Cooking oil was used, among other applications, to replace relatively expensive butter, whereas whale oil could not really compete with lamp oil. With the introduction of margarine and petroleum in the last quarter of the previous century, the situation changed and turnip oil gradually disappeared from the scene"). 557

In short, Jansen stated that whale oil could not compete with turnip oil. Moreover, it was not just regular whale oil, but sperm oil that served as fuel for wicks all over the globe, including the Netherlands. As discussed earlier, Dutch involvement in sperm whaling was a far cry from successful. Jansen's economic study is one of very few that mention whale oil. This neglect applies to a massive, six-volume series on the history of technology in the Netherlands during the nineteenth century. Several chapters in these volumes deal with the development of industries such as the fabrication of butter and margarine, and of candles, for which the use of whale and seal products must

556. Neither L. Crommelin and H. van Suchtelen, Nederlandse vuurtorens. Bouwgeschiedenis en organisatie (Nieuwkoop 1978), nor Friedrich-Karl Zemke, Leuchttürme der Welt. Three volumes (Herford 1992-1993) referred to whale oil as a source of illumination.

557. M. Jansen, De industriële ontwikkeling in Nederland, 1800-1850 (Amsterdam 1999), 199-200. Author's translation. 
have been important. ${ }^{558}$ None of the articles in the series, however, contains extensive reference to the scope or impact of the use of fat derived from sea mammals.

In the case of candle manufacturing, a distinction was made between the production of wax candles and so-called 'smeerkaarsen' (smear candles). Wax candles are based on beeswax. Smear candles - produced for the middle and lower classes - were manufactured from animal fat. Sheep fat and cattle fat were mentioned.559 Around 1830, the so-called stearine candle was introduced. This candle was produced from stearine, a chemical property found in all animal fats. Also, these candles did not drip or smoke.

Citizens belonging to the higher classes did use wax and spermaceti candles, and oil lamps that burned turnip oil. In Rotterdam, experiments with the use of whale oil in street lighting were short lived as in 1783, C. Aardenburg from Harlingen came forward with the first initiative. But whale oil turned thick in cold weather and, consequently, the thickening head of the wick eventually prevented the oil from burning. No evidence of later experiments was found. ${ }^{60}$ As early as September 1816, gas lighting was introduced in Amsterdam. On the occasion of a visit by King Willem I with the Prince and Princess of Orange to the reformed old Women's and Men's House along the river Amstel, gaslight was demonstrated for the very first time in the Netherlands. ${ }^{561}$

\section{Baleen}

Baleen (also referred to as whalebone) hangs from the upper jaw in the mouth of the so-called baleen whales, of which right, bowhead, and Noordkapers were the most important baleen whales. In composition, baleen is similar to toenails. The material is flexible yet sturdy, and, when heated, baleen can be bent into whatever form or shape is required.

Whalebone was used in the manufacture of corsets in England and France, how-

558. E.A.M. Berkers and E. Homburg, 'Stearine-kaarsen', H.W. Lintsen a.o. (eds.), Geschiedenis van de techniek in Nederland. De wording van een moderne samenleving 1800-189o. Six volumes (Zutphen 1992-1995). Vol. IV (Zutphen 1993), 241-242. See also M.S.C. Bakker, 'Boter', Lintsen, Geschiedenis van de techniek in Nederland. Vol I (Zutphen 1992), 103-133, and N.H.W. Verbeek, 'Margarine', Lintsen, Geschiedenis van de techniek in Nederland. Vol I (Zutphen 1992), 135-169.

559. Secondary sources in English on lighting and candles referred to spermaceti candles, which were made from the head matter of sperm whales. Among others, see O'Dea, Social History of Lighting, 216; H.W.M. Plettenburg, Licht in huis. Kienspaan - kaars-olielamp (Arnhem 1968), 14.

560. E. Berkers, 'Een nieuw licht', Lintsen, idem. Vol. III (Zutphen 1993), 92-93, 97. The use of whale oil as fuel for oil lamps was very briefly mentioned, however, no date was specified, in Plettenburg, Licht in huis, 35. 561. G.P. Zahn jr., De geschiedenis der verlichting van Amsterdam (Amsterdam n.d. [1911]), 26-27. See also Marius van Melle, 'Van vetkaars tot hogedruklamp. Vijf eeuwen straatverlichting', Ons Amsterdam, vol. 57, nr. 10 (Oktober 2005), 375-381. In an extensive, anonymous treatise on the history of the city of Utrecht, again no reference was made to the use of whale oil for street lighting. See Geschied-en oudheidkundige beschrijving van Utrechts pleinen, straten, stegen, waterleidingen, wedden, putten en pompen (Utrecht n.d. [1843]), 145 passim. 
ever, their Dutch counterparts seem to have depended more on wood and metal. Until about 1880, whalebone stays supported the corset on several strategically important locations (around the chest and midriff). ${ }^{562}$ As of about 1880, however, metal stays often replaced baleen stays on the sides. By 1904, all baleen stays (in at least French undergarment fashion) had been replaced by the cheaper metal stays. One contemporary Dutch source commented on this transition in material as follows:

"Echte baleinen zijn de beste, maar ook de duurste en men behelpt zich bij een eerste poging liever met gepolijste stalen baleinen, waaronder vooral de veerende, spiraalvormige baleinen aan te bevelen zijn. Zij geven, zonder te breken, mede met elke beweging van het lichaam, en zijn daarom voornamelijk zeer practisch over de heupwelvingen."

("Real baleen stays are the best, but also the most expensive and in a first attempt one would rather use stays of polished steel, among which especially the flexible, spiralshaped stays are recommended. Without breaking they follow every movement of the body, and are therefore particularly very practical around the hip's curves"). ${ }^{563}$

To date, there are apparently no other sources containing information about the use of baleen in Dutch society during the nineteenth century.

Furs

As shown in Tables 6.1 to 6.6, lists of persons who attended the auctions in Harlingen in the years 1831-1834 and 1838 were compiled. Most of this clientele had occupations relating to general commercial endeavours. The terms 'merchant' or 'captain of industry', for instance, do not provide much detail in order to scrutinize the nature of the whaling companies clients' businesses. Zeehandelaren (shipping merchants) were interested in whaling and sealing products as well. ${ }^{564}$ These businessmen at least had a more specific link with maritime exploitation and, subsequently, with trade in maritime products. Captain Klaas Hoekstra was discussed in Chapter 4 as having been in command of the ill-fated whaleship Harlingen (1826) and, more successfully, Nederland (1830). In 1831, Hoekstra spent $f 69$ on 69 pieces of seal fur. However, no trace of what happened to the products remains. ${ }^{565}$ It can be assumed that these merchants invested fairly heavily in the acquisition of products for the sole purpose of re-selling them.

562. D.J. List, 'het korset 1850-1910', J.N. de Vries, F. van der Laaken and D.J. List, Lijn in balein (Utrecht $1987), 13$.

563. H.J. van Wessem, Ik kan kostuumnaaien (Leiden n.d. [1905]), 40; quoted by List, op.cit., 13.

564. See Joost Jonker, Merchants, bankers, middlemen. The Amsterdam money market during the first half of the $19^{\text {th }}$ century (Amsterdam 1996), 40. Jonker specifically referred to the situation in the cosmopolitan capital. 565. Tresoar Leeuwarden (TL), Notary archives: Hanekuyk and Wijma, 49024 (repertoires), \#283 (October 1831). See also Appendix 5. 
As stated earlier, information about the use and distribution of furs is scarce. There is, however, one source that, more indirectly than directly, provide information about the use of seal furs after the products left the warehouses of the whaling company. So far, only one example was found of a private manufacturer who purchased whaling and sealing products specifically for his business. Harlingen-based hat maker Hermanus Ouendag first appeared in the auction room in September 1832. At that auction he spent $f_{30}$ on by-products: whale tails and vinken, which are small pieces of blubber that were only partially tried out. At that same auction, Ouendag paid $f_{120.75}$ for 325 pieces of seal fur. In total, Ouendag spent $f_{150.75}$, which was a small amount compared to the three major Harlingen-based merchants: Barend Visser \& Son, spent $f_{4,735}$; Bouwe Rodenhuis invested $f_{5,342}$; and Fontein \& Roquette spent $f 2,442$. In the following year (1833), Ouendag again attended the auction, but spent a modest $f_{19}$ on three polar bear furs. ${ }^{566}$

Additional information about the use of seal furs can be found in a series of articles published in Tijdschrift van de Vereeniging Het Nederlandsche Zeewezen in 1921. These articles, written by J. van der Weide Bzn., all refer to whaling in the early 1860 , based on personal stories related to Van der Weide by his father-in-law, Douwe de Boer. Also, De Boer clearly indicated the purposes of his first whaling expedition, in 1862: first to catch whales and seals in order to have their blubber yield oil, and secondly to bring back as many furs as possible, as they provided the material for cartridgeboxes used in the army. So far, this is the only known reference to the use of seal furs. ${ }^{567}$ Despite the time-gap (De Boer recalled events pertaining to the 1860 s), this may explain why Hermanus Ouendag invested in the acquisition of no fewer than 325 pieces of seal fur in 1832. Ouendag's immediate clientele in or near Harlingen surely must have been too few to require such a large number of furs, depending on the number of furs needed for the fabrication of one hat. The Ministry of Defence, however, may have been a substantial market.

566. Tresoar Leeuwarden (TL), Notary archives: Wijma, 49025 (repertoires), \#253 (September 1832); Notary archives: Wijma, 49026 (repertoires), \#281 (October 1833).

567. Here I express my gratitude to Ben Schoenmaker, researcher at the Nederlands Instituut voor Militaire Historie in The Hague and curators Mark van Hattem and Harm Steevens, both employed at the Legermuseum in Delft. Upon my request, these three men very kindly searched their collections and sources to look for examples to confirm de Boer's remarks about the use of seal furs in the Dutch army but, unfortunately, their efforts were in vain. The collection of Dr. Carl Häberlin Friesenmuseum on Föhr contains a whip made out of seal fur. Here I also express my thanks to Luuk Eekhout, director of the Nationaal Rijtuigmuseum in Leek, for confirming my assumption that in the Netherlands whips were not fabricated from seal furs but from leather or rope. 


\section{Distribution}

With regard to the distribution of whale and seal oil, many questions need to be answered. Did the barrels with whale oil and seal oil, the pounds of baleen, or the furs of seals end up on the premises of the clients listed on the auction lists? Or did they organise the distribution throughout the Netherlands and beyond? And if so, what were the logistics of the distribution?

As of 1823, Rotterdam and Amsterdam were the focal points of an intricate system of maritime infrastructural network. This network was maintained and expanded through the deployment of 'beurtveren', which were inland barges that shuttled back and forth between two set destinations to transport people and commodities. Among the many connections established in those years, Amsterdam became linked to Zaandam, Kampen, Harderwijk, and, last but not least, Harlingen. ${ }^{568}$

R. Filarski, in his dissertation on the infrastructure of the Netherlands and transport of commodities during the reign of King Willem I (1815-1839), was silent about the transport of 'traan'. In the subchapter on shipping on the inland transportation of commodities (Chapter 6.3), Filarski discussed a wide variety of products (beer, sugar, salt, soap, natural oils derived from plant seeds), but did not mention whale or seal products. $^{569}$

It is known from pamphlets with instructions for skippers of inland barges, however, that 'traen' was transported as early as $1709 .{ }^{570}$ Such lists do not differentiate between whale oil and seal oil, and prices for transport varied quite substantially. In 1782, skippers sailing between Amsterdam and Enkhuizen were instructed by their respective city councils to charge 10 stuivers $\left(f_{0}, 50\right)$ per kwarteel traan, and 34 stuivers $\left(f_{1,70}\right)$ per last (500 kilograms). Baleen ('walvisbaarden') was mentioned as well. In transporting baleen, the skipper should charge 1 stuiver and 8 pens (penningen) per 100 pounds. Nothing was stipulated regarding seal products. ${ }^{571}$

Another source dated 1806, with instructions for skippers sailing between Amsterdam and Utrecht, also contained references to the transport of whale products.

568. In 1827, Harlingen was the fourth-ranked harbour in the Netherlands after Amsterdam, Rotterdam, and Antwerp. R. Filarski, Kanalen van de Koning-Koopman. Goederenvervoer, binnenscheepvaart en kanalenbouw in Nederland en België in de eerste helft van de negentiende eeuw (Amsterdam 1995), 176-177.

569. Filarski, idem, especially 178-198.

570. See for instance: Reglement, waer na de commissaris van de ycker-schippers, varende tusschen Amsterdam en Gouda, zig zal hebben te gedragen (Gouda 1709), 27; Ordonnantie van de Gabelle of Tolle, Mitsgaders van het Vragt-Loon, gestelt op de Schuyten, Passagiers, reyzende Luyden en Beesten, den nieuwen Trekvaart en Wagenweg tusschen Haarlem en Amsterdam gebruykende (Amsterdam 1711), 24, 30.

571. Ordonnantie van de vracht-loonen waar na de schippers, varende tusschen Amsterdam en Enkhuizen, hun hebbende te reguleeren (Enkhuizen 1782), C2. 
That year, a skipper was supposed to charge a transport fee of 8 stuivers per kwarteel traan. Interestingly, whale blubber (walvisspek) was also mentioned with a transport fee of 6 stuivers per ton (1,000 kilograms)..$^{572}$

Similarly, a number of lists refer to the period discussed in this study. In 1816, prices for the transport of baleen from Amsterdam to Hamburg and Bremen were set at sixteen Bremer stuivers $\left(f_{1}\right)$ per 100 pounds, for both 'gesneden baleinen' (cut baleen) and 'walvischbaarden'. ${ }^{773}$ The transport fee of one kwarteel of oil amounted to four Bremer guilders (the equivalent of $f 6$ ). ${ }^{574} \mathrm{~A}$ similar distinction between 'baarden' and 'baleinen' can be discerned in regulations related to the transport of passengers and commodities between Rotterdam and Deventer via the Rhine and IJssel rivers. The instructions date from 1847. But prices had fallen considerably, as transport fees per 100 pounds amounted to $f_{0}, 50$ and $f 0,60$, respectively. One 'new' commodity in the long list of products to be transported was 'Walvischkaken' (whale jawbones). One had to pay $f_{1,50}$ per piece to have them transported from Rotterdam to Deventer, or vice versa. Finally, under the heading 'Traan' there was no specific reference to whale or seal oil. There were, however, several categories that may have been applicable, depending on the quantity that is being shipped. 575

Another instruction pertaining to 1848 documents the transport fees for whale products. That year, skippers sailing regularly between Groningen and Zutphen, and making stopovers at a number of towns in Friesland, were instructed to charge $f_{0}, 80$ per 100 pounds 'balijnen' (sic) or 'baarden'. Similar fees were charged for the transport of 100 pounds of elephant's tusks. 'Traan' could be charged per kwarteel $(f 1,15)$ or per aam $(f 0,75) .{ }^{576}$ Again, whale jawbones were quoted at a fee that amounted to $f_{2}$ per piece. Three categories of huiden (furs) were listed: 'huiden', 'kalfsvellen' (calfs' hides), and 'schapenvellen' (sheep's hides). There were no references to seals ('zeehonden' or 'robben') and products derived from these animals were also not mentioned. ${ }^{577}$

It was ascertained that oil, baleen, and even whale jawbones were transported by

572. Lyste van de Vragt-en Bestelloonen, van de Pakken, Goederen en andere Koopmanschappen, komende met de Utrechtse Schietschuiten, visa versa (Amsterdam 1806), 5-6.

573. The sources probably refer to baleen that was imported from abroad.

574. Ordonnantie [Amsterdam 1816], 1, 6. (Nederlands Scheepvaartmuseum Amsterdam, KIV31 (14)).

575. Reglement voor het beurtveer tusschen Rotterdam en Deventer, varende over den Rijn en IJssel (Deventer 1847), 12, 23-24. The transport and processing of these mandibles may have served medical purposes, as mandibles had been known to contain a specific type of oil (kneukolie) which was used to fight rheumatism.

576. One aam equals about 150 litres. See Verhoeff, Maten en gewichten, 99.

577. Reglement voor het beurtveer van Zutphen en Deventer over de Lemmer, Woudsend, Sneek en Leeuwarden naar Groningen, en terug van Groningen over Leeuwarden, Sneek, Woudsend en de Lemmer naar Deventer en Zutphen (Deventer 1848), 14, 18-19, 27, 28. 
beurtvaarders (small inland watercraft maintaining regular services between two locations) during the first half of the nineteenth century. A little later, beurtvaart as a maritime business became extinct. ${ }^{578}$ These products were not only distributed to the various provinces of the Netherlands, but also regular transport of oil to the neighbouring countries took place in the early years after the accession of King Willem I, as an untitled instruction of 1816 regarding fees for transportation of commodities from Amsterdam to the northern German towns of Hamburg and Bremen clearly shows. There is, however, no information about from where this oil originated.

\section{Conclusions}

It is as tantalising as it is tricky to draw conclusions based upon data limited both in time and scope. Nonetheless, a fair number of points may be discerned. But these points deserve additional research. The conclusions presented here, thus, must have a preliminary statement. In this chapter, the customers - those people interested in purchasing products derived from whaling and sealing, and imported into Harlingen by whaling companies during the years 1831-1834 and 1838 - were discussed. Also, a brief focus was given to the distribution of these products.

Through all the research and data collected, it must be concluded that the lion's share of the clientele at the local auctions came from Harlingen and Amsterdam. Furthermore, Bolsward, Arum and Terschelling were mentioned as the places of residence of the clientele bidding at auction. In all, in the case of the Harlingen-based whaling company, the acquisition of sealing and whaling products was restricted to a fairly small number of private individuals and companies and these clients were either based locally or came from Amsterdam.

With respect to the distribution of these products, it seems fair to assume that the seal oil and whale oil, the baleen, the furs from seals and polar bears, and the lessdesired products like tails and vinken were at first transported to the towns, villages, and cities where the clientele ran their business; and most likely - although no evidence has been found - that some of these commodities were then distributed to other areas in the Netherlands and, possibly, abroad. Regulations applying to regular shipping services among Amsterdam, Rotterdam, Haarlem, Utrecht, Deventer, Zutphen, Leeuwarden, and other, smaller villages in the various provinces reveal that these

578. Brugmans has stipulated that around 1850 competition from steamships and their regular services, but also from trains and carriages had increased to such extent that 'beurtvaart' became endangered. Most services were abandoned after 1860. I.J. Brugmans, Paardenkracht en mensenmacht. Sociaal-economische geschiedenis van Nederland, 1795-1940 ('s-Gravenhage 1976: reprint of 1960 edition), 99. 
products were indeed distributed all over the country. A source dated 1816 demonstrated the transport of oil from Amsterdam to Bremen and Hamburg. Much more research, however, is needed to understand the transport and distribution of whale and seal products. 
Chapter 7

\title{
Profitability of Dutch Involvement in the Whaling and Sealing Industries
}

\section{Introduction}

In 1844, Algemeen Handelsblad, one of the leading newspapers in the Netherlands, enthusiastically reviewed the prospectus compiled earlier that year by Brandligt and Marselis to generate interest in South Seas whaling. In the article, the reviewer stated that

\begin{abstract}
"The subscribers get the great probability of an equitable profit; but the certainty of contributing to a variety of industries that are immediately connected with the fitting out of these ships; the certainty of promoting the prosperity of all factories whose products could be used as means of exchange in the Indies; the certainty of reviving the trade in whale oil and bone, and supporting those factories that use those as raw materials; the certainty of spreading civilisation among the populations of the Indian archipelago" ${ }^{579}$
\end{abstract}

From these lines it is evident that the anonymous author of the article wanted the audience to focus on the certainties in the text. The 'great probability' of an 'equitable profit' in the South Seas whale fishery was presented as of secondary importance.

This chapter will deal with this very question: did these men follow the advice given in the newspaper article? How profitable did nineteenth-century Dutch whaling and sealing turn out to be for entrepreneurs? In order to come to grips with this issue, the elements connected with profitability - costs and revenues - will be the focus of the discussion.

Maritime trade - as trade in general - is stimulated by several fundamental factors related to input and output. On the input side factors include manpower, the skills to build the ships to pursue one's goals, and expenditure to realise these goals and the associated revenues. To explain developments in Dutch whaling in the nineteenth century, focus must be placed on both the ecological situation (the numbers of whales and seals, for instance) and on at least four economic factors - labour, technological

579. Algemeen Handelsblad, 15 March 1844. Article entitled 'Walvischvangst' (Whaling). Translated and quoted by Broeze, 'Whaling in Southern Oceans', 99-100. Broeze's italics. 
know-how, costs, and revenues. Labour and technological know-how, in this case meaning the state of the art with respect to shipbuilding, was discussed in previous chapters. The remaining two elements - costs and revenues - require more attention as they are the two cornerstones of calculations regarding profitability and will receive more detailed discussion here.

A number of factors determined the way costs of whaling expeditions were calculated. In the Tables presented below, the costs consist of the annual depreciation of the vessel (purchase price of the ship divided by the number of years of deployment), the total costs of employment (the total sum of monthly wages was multiplied by duration; that is, the number of months ship and crew were actually whaling and sealing), and overhead costs (management fees, salaries of personnel on shore, mortgage or rental costs on buildings, costs related to harbours, insurances, and the renewal of sails and rigging).

Revenues were determined by the value of the catches. Also, governmental subsidies played a part in calculating revenues. As discussed earlier, King Willem I and his government were consistent in their financial support of the whaling industry. $\mathrm{Mu}-$ nicipal archival sources at the town hall of Harlingen clearly help in understanding the procedure that whaling entrepreneurs had to follow to qualify for subsidies. Correspondence received by the City Council has survived and among several thousand letters there are many dozens related to the premiums issued by the King. These documents enable an analysis of the scope of the financial contributions of the Dutch government between 1826 and 1855. It should be stressed, however, that this financial support concerned the nineteenth-century Arctic whale fishery only. The results of this research can be found in Table 2.1. When applicable, these figures will also be used again in the overview of profits and losses.

The results of a handful of auctions held at the Inn 'Roma' in Harlingen were presented earlier. These results related to developments that took place in the 1830 . Next, the financial implications of the results of the five auctions will be scrutinized. The average value of the commodities auctioned off have been calculated, and these results will be used in the analysis of the profitability of the Dutch whaling and sealing industries in the nineteenth century as well.

Because of the inconsistency of the data, calculating profitability for all whaling and sealing expeditions, both to the South Seas and the Arctic, is virtually impossible. By applying the deciding factors of costs and revenues for the expeditions of the voyages organised by Barend van Spreekens and Jan Vas \& Company between 1815 and 1825 , as well as expeditions in the 183 os under the aegis of the Societeit and Barend Visser \& Son (I), an insightful examination was made (see Appendices 1 and 3). Other data complete the picture of a handful of voyages made at a later date. It should be noted that, as elsewhere, this chapter is divided into subsections: one concerning South Seas whaling and the other with Arctic whaling. 


\section{South Seas whaling (1827-1849)}

\section{Costs and revenues}

Data concerning investments and, particularly, revenues in South Seas whaling expeditions is scarce. Information about many factors crucial to an understanding of whether or not Dutch South Seas whaling was a failure or a success is scattered or hardly compatible. Still, an attempt to estimate factors such as costs for outfitting, wages, depreciation, value of the catches, and overhead were examined.

In his much-cited article, Broeze specified costs involved in the purchase and rigging of a number of whaleships. Not only did Broeze provide insight into the actual costs, but in the case of Logan (1827-1830) he also presented an alternative account if the expedition had been favourable in terms of duration and catch. ${ }^{50}$

Broeze also addressed the issue of the costs that the Nederlandsche Handel-Maatschappij (NHM) had to cover in order to deploy the New England-built Logan and its combined American and Dutch crew. The expedition seemed to have been badly handled from the outset, both from an organisational and financial perspective. The price of freight for Logan was set at $\$ 800$ per month, paid in biyearly increments. Thus, the whaleship would cost the NHM no less than $\$ 9,600$ per year (about $f 24,000$ ). All the other expenses (whaling gear and wages for the crew) fell to the NHM as well. The charter for Logan was arranged via the firm of J. Howland \& Co., which was based in New York and New Bedford. Acting on behalf of the principal owners, Thomas Mandell and Isaac and Gideon Howland, J. Howland \& Co. originally offered Logan for sale and the sum cost of the purchase was $\$ 30,000$ (about $f 75,000$ )..$^{51}$ Initially, negotiations about the purchase came to a halt when the NHM refrained from increasing its initial bid of $\$ 27,000$. Broeze rightly remarked,

"Ironically, the Logan was to make a voyage of 43 months, and the full charter price finally amounted to more than $\$ 36,000$, or 20 percent more than Howland's reserve price!" 582

In retrospect, the directors of the Dutch trading company must have realised - taking into consideration the freight price of $\$ 800$ per month, as well as anticipating a three- to four- year voyage (the average duration of a typical American whaling cruise at the time) - that they would have been much wiser to purchase the ship. Apart from this strong financial argument, it would also have been a wise decision from an eco-

580. Broeze, idem, 83 .

581. New Bedford, Custom House Records for 1826 and 1830 as quoted by Broeze, idem, 78 .

582. Broeze, idem, 79 . 
nomic and naval architectural point of view. Built in accordance with the latest and highest standards of shipbuilding, Logan could have provided the ideal standard for (whale) shipbuilding in the Netherlands. In this case the NHM proved to be pennywise but pound-foolish.

In the estimates of costs and revenues, presented in Table 7.1, Broeze's figures regarding the charter costs of Logan $\left(\$ 36,720=f_{91}, 800\right)$, the crew's wages (calculated by Broeze at $f 6,000=400$ days $\times 30$ men $\times f_{0}, 50$ per man per day), and the value of the sperm oil $\left(32,569^{1 / 2}\right.$ gallons $=123,764$ litres $)$ and black oil $(3,222$ gallons $=12,244$ litres $)$ were used . It should be noted, though, that his figures were based on the situation in the United States (in casu New York). Moreover, it is not known how the total sum presented by Broeze $(\$ 17,600=f 44,000)$ came about. In other words, all that is known is the total amount, on which it is not possible to determine the value of one litre of sperm oil or black oil.

The total figure is bewildering. According to Lance Davis and others, in New Bedford in 1830 , the price for one gallon of unrefined sperm oil amounted to $\$ 0.72 .{ }^{583}$ In the case of Logan, the figure would then be $\$ 22,750$ for all of the gallons of sperm oil alone. Unfortunately, in their listings of the process of unrefined whale oil, the same authors omitted differentiating between South Seas oil and Arctic oil. If the price per gallon quoted for 1830 (\$o.43) were used, the value of Logan's cargo of black oil would be approximately $\$ 1,300 .^{58}$ When sold on the New Bedford market the NHM would probably have fetched about $\$ 24,000(\$ 22,750+\$ 1,300)$, roughly the equivalent of $f 60,000$, for its oil - almost $40 \%$ more than the sum apparently obtained in New York. The net result of the voyage would, of course, still be a loss and amount to $f 37,800$ (about $38 \%$ ).

Finally, there is no data regarding governmental support through the premium system. Contrary to the Arctic voyages, the calculations regarding South Seas whaling covered the whole expedition over a number of years and not to individual years.

Table 7.1: Costs and revenues of whaling expeditions with Logan, Captain Reuben F. Coffin, to the South Seas (1827-1830). (Amounts are in $f$.)

\begin{tabular}{|l|l|l|l|l|l|l|l|l|l|}
\hline Years & $\begin{array}{l}\text { Charter } \\
\text { costs of } \\
\text { ship (1) }\end{array}$ & $\begin{array}{l}\text { Costs of } \\
\text { crew (2) }\end{array}$ & $\begin{array}{l}\text { Total costs } \\
(\mathbf{1}+\mathbf{2}=\mathrm{A})\end{array}$ & $\begin{array}{l}\text { Catches } \\
\text { (in litres) }\end{array}$ & $\begin{array}{l}\text { Revenues } \\
\text { of catches } \\
(\mathbf{3})\end{array}$ & $\begin{array}{l}\text { Govern- } \\
\text { mental } \\
\text { subsidy (4) }\end{array}$ & $\begin{array}{l}\text { Total } \\
\text { revenues } \\
(\mathbf{3}+\mathbf{4}=\mathbf{B})\end{array}$ & $\begin{array}{l}\text { Net results } \\
(\mathbf{C}=\mathbf{B}-\mathrm{A})\end{array}$ & Profits \% \\
\hline $1827-1830$ & 91,800 & 6,000 & 97,800 & $\begin{array}{l}123,764 \text { sperm } \\
\text { oil; } \\
12,244 \text { black oil }\end{array}$ & 44,000 & $?$ & 44,000 & $-/-53,800$ & $-/-55$ \\
\hline
\end{tabular}

There is no consensus in the literature with regard to the maximum loss the NHM must have suffered from this whaling adventure. Even in the most optimistic scenario as displayed in Table 7.1, however, the losses are substantial.

583. Davis, Gallman and Gleiter, In Pursuit of Leviathan, 370, table 9A.1.

584. Davis et alia, op. cit., 373, table 9A.2. 
On 12 February 1834, Captain H.F. Horneman with his Eersteling in the service of the merchant house of St. Martin \& Co. in Rotterdam returned from a whaling voyage that had barely lasted 15 months. ${ }^{585}$ Crew wages were calculated to an amount of about $f 6,000$ ( $=400$ days $\times 30$ crew at $f 0,50$ per day) and only a few whales were caught. In total, some 20,00o litres of black oil (South Seas oil) and 7,00o litres of sperm oil were auctioned off. ${ }^{586}$ The auction, however, was a financial disaster as only part of the black oil and none of the sperm oil was sold. The cumulative losses of this first expedition were estimated by the company to be approximately $f 27,000 . .^{87}$

On 17 August 1834, Horneman left Hellevoetsluis for his second voyage. According to Broeze, the shareholders "had paid up another $f 400$ per share [author's italics]" for the second expedition. ${ }^{58}$ Upon its return in Rotterdam on 20 April 20 1836, Eersteling had half a cargo of oil and baleen. The voyage took about 20 months, hence the listed costs for wages $(600 \times 30 \times f 0,50$ per day $=f 9,000)$. A little later, all 150,00o litres of whale oil and some 100 bundles of baleen were sold off. After deducting the wages

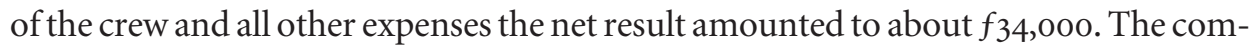
pany apparently did not offer returns to the shareholders concerning this voyage or the previous one.

Prior to the second voyage, the Dutch government had granted the whaling company a subsidy of $f 6,000$. Another governmental premium of $f 6,000$ was received after the ship's return. This double financial injection (amounting to a substantial $f_{12,000}$ ), indicated that in addition to the shareholders and directors of the company, the representatives from the Dutch government also had faith in the company's organisation and prospects. Table 7.2 contains the figures mentioned in this paragraph.

After two whaling expeditions, however, Captain Horneman left the whaling business to concentrate on trade with the Dutch East Indies. ${ }^{589}$ The successful Eersteling was sold and replaced by the old sloop-of-war Proserpina. 590

585. This company was established with a capital of $f 49,500$ divided into 55 shares of $f 900$ each. Letter from J. van der Wallen van Vollenhoven, a shareholder of the company, to the Nederlandsche Handel-Maatschappij, 13 July 1836, in ARA (NA), Sch, NHM 13/1836 W. Cited by Broeze, idem, 89, note 76.

586. Algemeen Handelsblad, 14 and 21 February, and 3 March 1834. See also Rotterdamsche Courant, 1 March 1834.

587. Algemeen Handelsblad, 10 March 1834. See also Broeze, 'Whaling in Southern Oceans', 91.

588. Broeze, idem, 92 .

589. About three weeks after his return from the second whaling expedition, Horneman left Rotterdam for Batavia (on 13 May 1836), as Captain of the merchant ship Johanna Cornelia.

590. Broeze, idem, 92; J.C. Westermann, Gedenkboek, samengesteld ter gelegenheid van het 125-jarig bestaan van de Kamer van Koophandel en fabrieken voor Amsterdam. Eerste deel: het tijdvak 1811-1922 (Amsterdam 1936), 254. 
Table 7.2: Costs and revenues of whaling expeditions to the South Seas fitted out by St. Martin \& Co (1832-1836). (Amounts are in $f$.)

\begin{tabular}{|c|c|c|c|c|c|c|c|c|c|}
\hline Years & $\begin{array}{l}\text { Costs of } \\
\operatorname{ship}(1)\end{array}$ & $\begin{array}{l}\text { Costs of } \\
\text { crew (2) }\end{array}$ & $\begin{array}{l}\text { Total costs } \\
(1+2=A)\end{array}$ & $\begin{array}{l}\text { Catches } \\
\text { (in litres) }\end{array}$ & $\begin{array}{l}\text { Revenues } \\
\text { of catches } \\
(3)\end{array}$ & \begin{tabular}{|l} 
Govern- \\
mental \\
subsidy (4)
\end{tabular} & $\begin{array}{l}\text { Total rev- } \\
\text { enues } \\
(3+4=B)\end{array}$ & $\begin{array}{l}\text { Net results } \\
(\mathrm{C}=\mathrm{B}-\mathrm{A})\end{array}$ & Profits \% \\
\hline $1832-1834$ & $\begin{array}{l}\text { Eersteling } \\
\text { No data }\end{array}$ & 6,000 & $?$ & $\begin{array}{l}\text { 7,00o sperm } \\
\text { oil; } 20,000 \\
\text { black oil }\end{array}$ & $?$ & $?$ & $?$ & $-/-27,000$ & $?$ \\
\hline $1834-1836$ & $\begin{array}{l}\text { Eersteling } \\
\text { No data }\end{array}$ & 9,000 & $?$ & $\begin{array}{l}\text { 150,ooo black } \\
\text { oil; } 100 \text { bundles } \\
\text { of baleen }\end{array}$ & ? & 12,000 & $?$ & $+1+34,000$ & $?$ \\
\hline 1836 & $\begin{array}{l}\text { Proserpina } \\
\text { No data }\end{array}$ & $?$ & $?$ & $\begin{array}{l}\text { 10,00o sperm } \\
\text { oil; 140,000 } \\
\text { black oil; } 5,000 \\
\text { kg baleen }\end{array}$ & ? & $?$ & $?$ & $?$ & $?$ \\
\hline
\end{tabular}

For the later years, no figures regarding the fitting out of both Anna \& Louisa and Zuidpool exist. As discussed earlier, Reelfs Brothers purchased the two-decked Anna $\&$ Louisa in 1843. By that time the vessel (319 tons) was about 16 years old. Reelfs Brothers spent staggering amounts fitting out of this vessel as shown below: ${ }^{591}$

1. Purchase, winter 1843

2. Additional expenses (repairs)

3. Additional costs

Total costs $f 19,200$

$f 34,500$

$\underline{f 59,500}$

Its first voyage lasted about 31 months, from April 1844 until November 1846 . Again, calculations of expenses of wages listed in Table 7.3 were based on 1827-1830 figures related to Logan. For this expedition costs of crew may have amounted to $f_{13,500}$ ( 900 days $\mathrm{x} 30$ crew $\mathrm{x} f 0,50$ per day). There is no direct information about the value of its cargo of 160 barrels of oil or about the type of oil - sperm oil or black oil. Assuming that one barrel equals one kwarteel (232.8 litres), the cargo consisted of about 37,250 litres of 'oil'.

In Michael Jansen's book on the industrial developments in the Netherlands during the first half of the nineteenth century, he calculated the average prices of a wide array of ship types around 1850 . Though not specified by the author, one may assume he referred to the prices of newly-built ships. Jansen also linked his calculations to the places of purchase. In Amsterdam, a 300-ton brig cost $f 64,500$ (= $f 215$ per ton). ${ }^{592}$ Reelfs spent much more for a relatively old vessel.

Likewise, Reelfs Brothers spent very large sums to purchase Zuidpool (ex-Proserpina) in 1845 . By that time the vessel was about 24 years old. The ship was re-rigged and

591. For information on these figures, see Algemeen Handelsblad, 25 and 27 September 1843; ARA (NA) Sch, NHM 20/14, Aanspraak President, 19 June 1844, 74-75; ARA (NA), Kabinet des Konings 246, 16 August 1844, N 7; Westermann, Gedenkboek, 254.

592. M. Jansen, De industriële ontwikkeling in Nederland, 1800-1850 (Amsterdam 1999), 287. 
underwent a major metamorphosis to become a much larger vessel, measuring a surprising 536 tons, compared with the original 184 lasts (about 370 tons). In total, the company spent no less than $f 87,000$ on this former sloop-of-war. ${ }^{593}$ This amount was more or less commensurate with the standard figure provided by Jansen ( $370 \times f 215$ $=f 79,550)$. Jansen referred to a new ship, however, not to an old one.

So far, costs of crew were based on the size of Logan (30 men aboard a 302-ton ship). Eersteling was a 291-ton bark and Proserpina measured about 184 lasts (roughly 370 tons). The two-decked ship Anna \& Louisa measured 319 tons. With its 536 tons, Zuidpool must have carried a larger crew, possibly 45 men or more. It seems fair to estimate the costs of crew were approximately $f_{31,500}$ (a four-year voyage of about 1,40o days x $45 \times$ fo, 50 ). There is no information regarding the ultimate fate of Zuidpool, let alone of the size and value of its cargo. ${ }^{594}$ Neither profits nor losses can be calculated, or even estimated. For all the existing data, Reelfs Brothers invested enormous sums of money in whaling voyages that were disasters. The losses must have been very considerable.

Table 7.3: Costs and revenues of whaling expeditions to the South Seas fitted out by Reederij voor de Zuidzee Walvischvangst (1844-1849). (Amounts are in $f$.)

\begin{tabular}{|c|c|c|c|c|c|c|c|c|c|}
\hline Years & $\begin{array}{l}\text { Costs of } \\
\text { ship (1) }\end{array}$ & $\begin{array}{l}\text { Costs of } \\
\text { crew (2) }\end{array}$ & $\begin{array}{l}\text { Total costs } \\
(1+2=A)\end{array}$ & $\begin{array}{l}\text { Catches } \\
\text { (in litres) }\end{array}$ & $\begin{array}{l}\text { Revenues } \\
\text { of catches } \\
\text { (3) }\end{array}$ & $\begin{array}{l}\text { Govern- } \\
\text { mental } \\
\text { subsidy (4) }\end{array}$ & $\begin{array}{l}\text { Total rev- } \\
\text { enues } \\
(3+4=B)\end{array}$ & $\begin{array}{l}\text { Net results } \\
(\mathrm{C}=\mathrm{B}-\mathrm{A})\end{array}$ & Profits \% \\
\hline $1844-1846$ & $\begin{array}{l}\text { Anna \& } \\
\text { Louisa } \\
113,700\end{array}$ & No data & $?$ & 37,250 of 'oil' & No data & No data & $?$ & $?$ & $?$ \\
\hline $1845-1849$ & $\begin{array}{l}\text { Zuidpool } \\
87,000\end{array}$ & 31,500 & 118,000 & No data & No data & No data & $?$ & $?$ & $?$ \\
\hline
\end{tabular}

Later in the century, optimistic views about Dutch whaling expeditions in the South Seas were expressed by A.J. ten Brink and S.J.C.W. van Musschenbroek. In his promotional brochure Ten Brink provided rather peculiar data concerning whaling in the northern Indian Ocean in 1867 [sic], when some 61 vessels under various flags had a total catch of 362 Greenland whales [sic]. This was an average of about six whales per ship. The total value of these six large whales amounted to about $f 40,000.595$ Referring to Captain C.J. Bottemanne's statements in a leading Dutch journal, Ten Brink stated

593. Westermann, Gedenkboek, 254.

594. Broeze, 'Whaling in the Southern Oceans', 105, note 153. Broeze checked the State Archives and State Library of California in Sacramento, the San Francisco Maritime Museum, and the Bancroft Library of the University of California at Berkeley.

595. Ten Brink, Noordpool-visscherij, 4-5. The author claimed to know that one of these 362 whales yielded no fewer than 310 barrels of oil, representing a value of between $f_{14,000}$ and $f_{15}, 000$. Ten Brink quoted Captain Kelly who made his inconceivable remarks about the catch of Greenland right whales in the northern Indian ocean in the Commercial Advertiser, published in Honolulu in July 1867. Kelly possibly referred to southern right whales. 
that around 1868 an average fin whale represented a value of $f_{3,000 .} .^{596}$ It should be noted that a fin whale yields less oil than a Greenland right whale, thus the substantial difference in value. Ten Brink's data with respect to the Arctic whale fishery will be discussed later in this chapter.

Van Musschenbroek presented a very optimistic account of the costs of construction $\left(f_{20}, 000\right)$, fitting out $\left(f_{2}, 500\right)$, and a one-year employment of an 80-ton schooner $(f 5,460)$ with a crew of 29 . His overview, compiled and published in 1877 , included interest on borrowed money $\left(f_{1}, 350\right)$ and allowed a $10 \%$ contingency reserve for unexpected costs of construction $(f 2,000)$. Furthermore, Van Musschenbroek reserved $f 1,800$ for provisions for one year. His total calculations amounted to $f_{31,310.597}$

These investments, according to Van Musschenbroek, could fairly easily be met by selling off the 'ideal' cargo of 300 barrels of oil, 25 barrels of spermaceti, and 400 sperm whale teeth (at $f 4$ on average). ${ }^{598}$ Moreover, in his view, the whale oil could be sold at $f 86$ per barrel, making the value of oil of the ideal cargo almost $f 26,000$ $(f 25,800)$. When presented to potential shareholders, this prospectus would surely have generated enthusiasm as projected initial investments would have been covered and profits made during the second and consecutive years. Van Musschenbroek, however, did not include the annual depreciation, the costs of re-rigging, overhead, insurance, or lay-over in the harbour. His ideas never left paper.

Thanks to the data presented by Broeze, Van Musschenbroek, Ten Brink, and others, some idea of the costs involved South Seas whaling can be conceived. Information about revenues, however, is scarce, thus making it virtually impossible to draw conclusions about the profitability of Dutch South Seas whaling. In this respect, data concerning Arctic whaling is more informative and will be discussed next.

\section{Arctic whaling (1815-1885)}

Whaling companies and individual entrepreneurs all used promotional brochures to promote general interest in their business, whether it was in Southern or Northern latitudes. In character these promotional brochures do not differ. For example, the five authors of a brochure dated 30 September 1824, to generate interest in the 'Groenlandse en Straatdavidse Visscherij Sociëteit' in Harlingen concluded:

596. Ten Brink, op. cit., 5-6; C.J. Bottemanne, 'Beschouwingen over de kleine visscherij', Economist, January 1870 . Both men referred to steam technology.

597. For this account see Van Musschenbroek, 'Cachelot-Visscherij', 34-35.

598. Van Musschenbroek, idem, 17 . Here, the author quoted prices per tooth ranging from $f 3,50$ to $f 8$. 


\begin{abstract}
"Welken uitslag ook de proef die wij nemen hebben moge, wij zullen alle moeite die het plan tot oprigting ons reeds veroorzaakte, ons getroosten, in de altijd blijvende innige bewustheid, dat wij met het beste oogmerk gelegenheid hebben gegeven, tot den herbloei onzer Nationale Visscherij, als eene zoo rijke bron van algemeene welvaart" ("Whatever the result of our experiment may be, we will do all we can in establishing this company, convinced as we continuously are that we act in the best interest in our attempt to provide the occasion to let blossom again our national fishery, once such a rich source to our general prosperity "). 599
\end{abstract}

It is notable that these authors combined idealism with romantic fatalism and entrepreneurial amateurism. Realism - or even opportunism - was absent. A little earlier in the brochure, the authors elaborated on the fact that the company could count on a financial injection of no less than $f_{9,000}$ per ship, regardless of how full or empty the vessel returned to its home port. According to the authors, even in the case of a totally unsuccessful trip with a ship returning completely empty (wanvangst), the loss of investments would be insignificant. ${ }^{600}$

Calculating the profitability of the well-documented seventeenth and eighteenthcentury whaling industry is very complex, if not impossible. In his study on Smeerenburg, Louwrens Hacquebord presented calculations regarding the total number of ships fitted out by the Noordsche Compagnie between 1612 and 1665 . He also mentioned the costs involved. Furthermore, he listed data regarding the catches near Spitsbergen and Jan Mayen Island between 1612 and 1642. Apparently this data (costs and revenue of catches) could not be compared, as Hacquebord did not provide figures concerning profitability. In general terms, he stated that bad and good years alternated, and that the Compagnie more often than not had to take losses that could not be counterbalanced by profitable years. More recently, Jurjen Leinenga provided data regarding profits and losses in eighteenth-century Dutch whaling in the Davis Strait. ${ }^{601}$

Calculating the profitability of the Dutch whaling and sealing industries in the nineteenth century is equally complex. The whalemen's wages were discussed earlier (see Chapter 5 and Appendices 3 and 4). Important sources about the developments in prices of whaling and sealing products are A.J. ten Brink and especially N.W. Posthumus, who provided useful information regarding the financial developments in the whaling industry. ${ }^{62}$ Unfortunately, Posthumus' work does not encompass the values of oil and furs from sealing.

599. My paraphrase of part of the last sentence of the typescript in municipal museum Het Hannemahuis in Harlingen, written by Pieter Rodenhuis et alia. Author's translation.

6oo. Typescript in Het Hannemahuis in Harlingen.

601. Hacquebord, Smeerenburg, 76-78. See also 239-240. Here, Hacquebord calculated the costs involved in running shore stations in Spitsbergen. Leinenga, Arctische walvisvangst, 111-123 passim.

602. A.J. ten Brink, Blik op den hedendaagschen toestand der Europeesche Noordpool-Visscherij (Enkhuizen 
The results of auctions of whale and seal products in Harlingen during the years 1831-1834 and 1838, however, were useful in calculating average prices. These averages will be used in the general overview regarding the successes and failures of nineteenthcentury Dutch Arctic whaling.

\section{Costs and revenues}

As in any industry, costs and revenues in the whale fishery and seal hunt were influenced by many factors. On the debit side, the costs of construction and maintenance of business-related equipment like ships and gear, must be noted. Also, the costs of labour such as crew's wages, salaries of personnel on shore, provisions and the costs of production at the cookeries, and distribution of the product must be included. Costs of labour (wages) were calculated by measuring the duration of the voyage (Appendix 1) and multiplied by monthly expenditures on wages (Appen$\operatorname{dix} 3)$.

Unfortunately, the available data falls short on a number of factors. So far, no information about the costs of food supplies for the crew on shipboard, or such management costs as benefits for ship owners and directors of whaling companies has been retrieved. On the credit side, revenue from the catch results and governmental financial subsidies must be incorporated into the balance.

Posthumus' analyses cover no less than 330 years (1585-1914), providing overviews of prices of whale oil during the years 1800 to 1807 , and 1818 to 1851 (Table 7.4). The average prices of whale and seal products, paid in Harlingen, were calculated and are given in Table 7.5 These averages were compared with the data given by Posthumus, but unfortunately, with regard to baleen, he presented information for only the very first few years of the century (1790-1802) as compared to the breadth of the years analysed in this work. For additional information about price developments of whale oil, seal oil, and baleen, Ten Brink's documentation must be used. In addition to these two authors, local newspapers (e.g., Amsterdamsche Mercuur), or broadsides, provide more information that should be used. Furthermore, while Posthumus calculated developments in prices of whale oil after the Napoleonic era, his figures covered a much longer period. The first data related to 1818 , but numerical data is lacking for the period 1819 to 1827 . In 1828 , the series was resumed and continued up to and including 1848. Data is lacking for the years $1837,1838,1842$, and 1849 . The series concluded with figures for 1850 and 1851 .

1876); N.W. Posthumus, Nederlandsche prijsgeschiedenis. Deel I: goederenprijzen op de beurs van Amsterdam, 1585-1914. Wisselkoersen te Amsterdam, 1609-1914. Internationale wetenschappelijke commissie voor prijsgeschiedenis (Leiden 1943). 
This data is presented in full in Table 7.4 and it should be noted that prices per $k w a r t e e l$ of oil were replaced by data referring to prices per vat (barrel) in 1832. According to Posthumus, there was no agreement on how kwartelen and vaten should be compared. ${ }^{603}$ As dry as this discussion about measurements regarding fluid contents may be, agreement on what standards to use is of utmost importance to the interpretation of quantities of commodities and, hence, the value of the products.

In 1837 an intriguing book about trade between the Netherlands and Hamburg appeared, with the authorships attributed only by the initials P.W.L. The author stated,

"Van Walvis- en Zuidzee-traan houden de zogenaamde kwardeelen 18 à 21 steekannen bijna 4 ned. vaten, ofschoon de maat van een kwardeel eigenlijk 12 steekannen is"

("So-called kwardelen Whale and South Sea oil of 18 à 21 steekannen hold almost 4

Dutch barrels, while one kwardeel normally contains 12 steekannen"). ${ }^{604}$

Here the author suggested that one kwarteel could either consist of 12 steekannen or of 18 or more. This statement was also put to the fore by Leinenga. Verhoeff, in his standard work on measurements and weights, equated one kwarteel to one "vat" (barrel $)^{605}$ and in the following calculations, this conversion will be used as the standard.

603. In two editions of his work, J.P. Ricard equated one kwarteel of whale oil to one barrel. S. Lootsma, however, in his ground-breaking study on the history of Dutch whaling, stated that two kwartelen (or two oxheads) should be equal to one-half barrel. In other words, according to Lootsma, four kwartelen equalled one barrel. But then, what contents should be attributed to what type of barrel? When a barrel for the transport of wine from Bordeaux was considered to have been the definitive standard and point of reference, Ricard was right. This barrel contained 232.8 litres, the equivalent of twelve 'steekannen' (= one kwarteel). Confusing information was provided when Posthumus referred to barrels for other French wines and olive oil. In that example, one barrel equalled four oxheads - and subsequently also four kwartelen! In comparison, bear in mind that olive oil from the city of Puglia found its way from the orchards in Italy to other regions in Europe in barrels containing 735 litres. For more on this discussion, see J.P. Ricard, Le négoce d'Amsterdam (Amsterdam 1722; Rouen 1723); S. Lootsma, Bijdrage tot de geschiedenis der Nederlandsche walvischvangst (meer speciaal de Zaansche) (Amsterdam 1937).

604. P.W.L., Bijdragen tot bekendmaking van de voornaamste zaken van den handel, der Nederlanden, en van dien van Hamburg etc. (Utrecht 1837), 3. With this book, addressed to Willem de Clerq, at the time director of the NHM, the author hoped to provide interdependent standards of references of both prices and commodities that were frequently traded between the Netherlands and Germany.

605. Leinenga, Arctische walvisvangst, 205. 
Table 7.4: Prices of whale oil ('Spektraan') in guilders $(f)$ per kwarteel (= 232.8 litres) and per barrel ('vat', as of 1832) (1818-1851).

(Figures between brackets "[...]" were estimated by Posthumus.) ${ }^{606}$

\begin{tabular}{|c|c|c|c|c|c|c|c|c|c|c|c|c|c|}
\hline Year & Jan. & Feb. & $\begin{array}{r}\text { March } \\
\text {. }\end{array}$ & Apr. & May & June & July & Aug. & Sept. & Oct. & Nov. & Dec. & $\begin{array}{l}\text { Annual } \\
\text { average }\end{array}$ \\
\hline 1818 & 155.00 & 155.00 & 155.00 & 155.00 & 155.00 & & & & & & & & 155.00 \\
\hline 1828 & 73.50 & 73.00 & 73.00 & 72.00 & 72.00 & 71.75 & 72.00 & 76.00 & 76.50 & {$[78.50]$} & 80.50 & 78.25 & 74.75 \\
\hline 1829 & 79.50 & 80.00 & 81.00 & 80.75 & 75.75 & 77.00 & 74.50 & 77.25 & 80.00 & 84.00 & {$[87.75]$} & 91.50 & 80.75 \\
\hline 1830 & 92.00 & 92.00 & 87.50 & 90.00 & 89.50 & 90.00 & 92.00 & 92.00 & 92.25 & {$[108.63]$} & 125.00 & & 95.53 \\
\hline 1831 & & & 126.00 & 120.00 & 112.00 & 106.00 & 100.00 & 100.00 & 100.00 & 120.00 & 125.00 & 120.00 & 112.90 \\
\hline \multirow[t]{2}{*}{1832} & 116.00 & 95.00 & 95.00 & 92.00 & 88.50 & 88.50 & 87.00 & 87.00 & 89.50 & 91.00 & 76.50 & & 91.45 \\
\hline & \multicolumn{3}{|c|}{$\downarrow$ Prices per barrel $\downarrow$} & & \multicolumn{3}{|c|}{$\downarrow$ Prices per barrel $\downarrow$} & & \multicolumn{3}{|c|}{$\downarrow \quad$ Prices per barrel $\downarrow$} & & \\
\hline 1832 & & & & & & & & & & & & 36.50 & 36.50 \\
\hline 1833 & 35.50 & 36.00 & 34.25 & 33.25 & 33.00 & 33.13 & 34.25 & 35.50 & 34.00 & 33.75 & 30.25 & 31.75 & 33.72 \\
\hline 1834 & 31.50 & 31.25 & 31.50 & 30.75 & 30.50 & 30.38 & 30.75 & 30.00 & 31.75 & 31.63 & 34.50 & 33.50 & 31.50 \\
\hline 1835 & 36.00 & 34.75 & 36.00 & 34.00 & 33.50 & 34.50 & 34.00 & 33.50 & 33.13 & 40.00 & 44.50 & 45.00 & 36.57 \\
\hline 1836 & 46.00 & 46.00 & 46.00 & 45.00 & & & & & & & & & 45.75 \\
\hline 1839 & 42.00 & 41.00 & 40.00 & 48.00 & 38.00 & 38.00 & 36.00 & 36.00 & & & & & 39.88 \\
\hline 1840 & & 37.00 & 40.00 & & & & & & & & 37.00 & [37.00] & 37.75 \\
\hline 1841 & [37.00] & {$[37.00]$} & {$[37.00]$} & 37.00 & 36.00 & 36.00 & 37.00 & & & & & & 36.71 \\
\hline 1843 & & & & & & & & 37.50 & 38.00 & {$[37.50]$} & & 37.00 & 37.50 \\
\hline 1844 & & & & 40.00 & 40.00 & 40.00 & 40.00 & 40.00 & [38.50] & & 37.00 & [37.00] & 39.06 \\
\hline 1845 & [37.00] & {$[37.00]$} & [37.00] & [37.00] & 37.00 & 37.00 & & & & 35.50 & 35.50 & & 36.63 \\
\hline 1846 & & & 36.50 & 35.00 & 34.00 & 34.00 & 33.50 & {$[33.75]$} & 34.00 & {$[34.25]$} & 34.50 & & 34.39 \\
\hline 1847 & & 34.00 & {$[34.00]$} & 34.00 & & & 33.50 & 33.50 & 33.00 & 31.00 & 33.00 & & 33.25 \\
\hline 1848 & & & 32.00 & & & & 29.00 & 28.50 & & & & & 29.83 \\
\hline 1850 & & & & & & & & 41.00 & & & & & 41.00 \\
\hline 1851 & & & & & & & & & 37.00 & {$[37.75]$} & 38.50 & & 37.75 \\
\hline
\end{tabular}

This table shows the wide range of prices. The highest price for whale oil was in 1818 ( $f 155$ per kwarteel) and the lowest was 30 years later in 1848 ( $f 29.83$ per barrel). Earlier in this text the results from auctions of whale and seal products held in the 1830 was discussed.

Attention should also be paid to baleen. 'Whalebone' and whale oil were the principal whale products in both the Dutch and European markets. Unfortunately, Posthumus provided data that for the most part referred to the seventeenth and eighteenth centuries. In fact, his figures ran from 1669, with several minor intervals, up to 1802. For the calculations here, data from the auctions in Harlingen in the 1830 s (see Table 7.5), were used.

The value of whale oil brought into the Netherlands from distant seas was discussed earlier. Now attention should be given to the achievements of the companies and individuals involved in this business. Pre-1831 figures will be used for those involved in whaling up to that year. The results of auctions in Harlingen in the 1830 s provide useful data about prices, paid locally by parties from Harlingen and Amsterdam.

606. Posthumus, Nederlandsche prijsgeschiedenis, vol. I, 84-85, table 43. 
Table 7.5: Average prices for whale and seal products purchased at auctions in Harlingen during the years 1831-1834, and 1838, compared with average prices quoted by Posthumus. ${ }^{607}$

\begin{tabular}{|c|c|c|c|c|}
\hline October 1831 & Total sales (in $f$ ) & \# of units (barrel, piece or pound) & Average price (in $f$ ) & $\begin{array}{l}\text { Average price } \\
\text { Posthumus (in } f)^{608}\end{array}$ \\
\hline Seal oil & 20,966 & 227 & 92.36 & - \\
\hline Whale oil & 22,466 & 189 & 118.80 & 120 (per kwarteel) \\
\hline Seal furs & 4,121 & 5,178 & 0.80 & - \\
\hline Baleen & 4,116 & 1,627 & 2.53 & - \\
\hline Totals & 51,669 & & & \\
\hline September 1832 & Total sales (in $f$ ) & \# of units (barrel, piece or pound) & Average price $(\operatorname{in} f)$ & $\begin{array}{l}\text { Average price } \\
\text { Posthumus (in } f \text { ) }\end{array}$ \\
\hline Seal oil & 8,934 & 131 & 68.80 & - \\
\hline Whale oil & 13,427 & 149 & 90.11 & 89.50 (per kwarteel) \\
\hline Seal furs & 1,473 & 3,560 & 0.43 & - \\
\hline Baleen & 1,945 & 800 & 2.43 & - \\
\hline Totals & 25,779 & & & \\
\hline October 1833 & Total sales (in $f$ ) & \# of units (barrel, piece or pound) & Average price (in $f$ ) & $\begin{array}{l}\text { Average price } \\
\text { Posthumus (in } f \text { ) }\end{array}$ \\
\hline Seal oil & - & - & - & - \\
\hline Whale oil & $10,828.75$ & 164 & 66.02 (per kwarteel) & 33.75 (per barrel) \\
\hline Seal furs & 277.50 & 407 & 0.68 & \\
\hline Baleen & $2,451.75$ & 1,252 & 1.96 & \\
\hline Totals & $13,558.00$ & & & \\
\hline September 1834 & Total sales (in $f$ ) & \# of units (barrel, piece or pound) & Average price (in $f$ ) & $\begin{array}{l}\text { Average price } \\
\text { Posthumus (in } f \text { ) }\end{array}$ \\
\hline Seal oil & 854.00 & 14 & 61.00 & - \\
\hline Whale oil & $2,794.00$ & 46 & 64.63 (per kwarteel) & 31.75 (per barrel) \\
\hline Seal furs & 164.80 & 458 & 0.36 & - \\
\hline Baleen & 607.15 & 351 & 1.73 & - \\
\hline Totals & $4,419.95$ & & & \\
\hline October 1838 & Total sales (in $f$ ) & \# of units (barrel, piece or pound) & Average price (in $f$ ) & $\begin{array}{l}\text { Average price } \\
\text { Posthumus (in } f \text { ) }\end{array}$ \\
\hline Seal oil & - & - & - & - \\
\hline Whale oil & 16,223 & 87 & 186.47 (per kwarteel) & - \\
\hline Seal furs & - & - & - & - \\
\hline Baleen & $6,013 \cdot 97^{1 / 2}$ & $3074^{1 / 2}$ & $1.96^{609}$ & - \\
\hline Totals & $22,337 \cdot 28^{1 / 2}$ & & & \\
\hline
\end{tabular}

607. Tresoar Leeuwarden (TL), Notary records. Wijma, 49024 (repertoires), \#283, October 1831; Notary records. Wijma, 49025 (repertoires), \#253, September 1832; Notary records. Wijma, 49026 (repertoires), \#281, October 1833; Notary records. Hanekuyk, 51017 (repertoires), \#38, September 1834; Notary records. Wijma, 49031 (repertoires), \#191, October 1838.

608. N.W. Posthumus, Nederlandsche prijzengeschiedenis. Deel I: goederenprijzen op de beurs van Amsterdam, 1585-1914. Wisselkoersen te Amsterdam, 1609-1914. Internationale wetenschappelijke commissie voor prijsgeschiedenis (Leiden 1943), 84-85, table 43. The average quoted here referred to the specific month of auction. Contemporaneous data for seal oil, seal furs, and baleen were not given in this work.

609. Calculated at $f_{195.608}$ per 100 pounds. 
Table 7.5 presents the average prices paid for barrels of seal oil, whale oil, and for seal furs and pounds of baleen in the 1830s. These prices were compared to the figures Posthumus collected for these same months and years.

Average prices for whaling and sealing commodities vary substantially over a very short period of time. For all of the commodities quoted here, stability in price levels was not discernable. In Harlingen, the price of a barrel of seal oil dropped by about onethird between 1831 and 1834 (from $f 92.36$ to $f 61.00$ ). The reduction in the average price of a barrel of whale oil was even more drastic in this same three-year period, about $46 \%$. Miraculously, the price almost tripled between 1834 and 1838 ( $f 186.47$ in 1838 against $f 64.63$ four years earlier). Interestingly, average prices in Harlingen in 1831 and 1832 were commensurate with the data from Posthumus. In contrast, the average prices of whale oil in Harlingen in 1833 and 1834 differ significantly from figures related to national developments. Seal furs lost about $50 \%$ of their value within one year $(f 0.80$ per piece in 1831 against $f_{0} .43$ in 1832 ). Prices rose again in 1833 ( $\left.f \circ .68\right)$, but with a similarly negative development the following year ( $f 0.36$ in 1834; again a drop of almost $50 \%$ ). Finally, average prices for a pound of baleen reflect equally substantial differences, ranging from $f 2.53$ per pound in 1831 to $f 1.73$ in 1834 . These averages will be used to calculate losses and profits of the participants in nineteenth-century Dutch Arctic whaling.

\section{Barend van Spreekens}

In Table 7.6, total expenses and total revenues per expedition were calculated. The figures were based both on assumptions and on hard facts. Basically, costs consist of two elements: the annual depreciation of the vessel and the wages of crew. The investments Van Spreekens made to acquire a ship of over fifty years old, Groenland of 200 lasts, is familiar data. Between 1815 and 1819 this vessel made five voyages under command of Jacob Broertjes. ${ }^{610}$ In order to calculate depreciation of Groenland, the following method was used: the price Van Spreekens paid at auction in $1815\left(f_{16,700)}\right.$, minus the sum received when the vessel was sold some five years later $(f 6,000)$, and the remaining sum $\left(f_{10}, 700\right)$ divided by the number of years Broertjes used this vessel on the Arctic whaling grounds (five years). Thus, the annual depreciation was $f 2,140$. As information concerning costs of insurance, overhead, and gear (boats, ropes, harpoons, etc.) is lacking, depreciation for these factors could not be calculated.

For the early years of Arctic whaling, data concerning wages and others sources of income for the crew is scarce. Calculations of costs of wages were based on crew lists in the municipal archives of Amsterdam (see Appendix 3). It is known from these figures that in 1815 Van Spreekens spent about $f_{1,103}$ per month on wages (wages of the

610. For information on sources see Appendix 3. 
master excluded). Here, it was assumed that the other voyages may have lasted until mid-August, as was the case with the 1816 expedition. Captain Broertjes showed up at the office of the Harbourmaster on April 5. It seems fair to set the duration of this first voyage at about four and one-half months $\left(4^{1 / 2} \times f 1,103=f 4,963,50\right)$. For the 1816 whaling expedition, the number of days involved (126 days) is known, as Broertjes sailed on 7 April and returned to Harlingen on 15 August. The crew list was compiled on 26 March. Thus, twelve more days must be added to the number of 126 calculated above. All in all, the crew was hired for about four and one-half months. ${ }^{611}$ Again, Appendix 3 provides insight into the monthly expenses Van Spreekens had to meet to keep his vessel afloat. These expenses amounted to $f_{1,237}$ grosso modo investment in crew in 1816 was approximately $f 5,566,50$. Costs of insurance, use of the harbour, provisions for the crew, and other overhead, were not included. For 1817 and 1818, there is no information about size and costs of crew. Therefore, the duration of voyages as well as the size and costs of crew were assumed to be comparable to those of the two preceding years. Costs of crew were calculated as $f_{5,250}$, or roughly the average of what was spent on wages in 1815 and 1816 .

There is no knowledge concerning the duration of the other voyages. Therefore, only estimated calculations of costs related to crew could be made. This was done for the year 1815 and in a similar fashion, for 1819. Once again it was assumed that Groenland returned home around mid-August. The crew list was compiled on $22 \mathrm{March}$ and, therefore, the duration of the voyage was calculated as about five months at

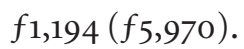

The revenue was determined by catches and by premiums. Two broadsides in the Kendall Collection of the New Bedford Whaling Museum (New Bedford, Massachusetts) provided information regarding to the prices of oil imported into Amsterdam in 1817 and 1826 , respectively. ${ }^{612}$ As hazardous as this approach may be, data of 1817 is more or less applicable to the catch results of the expeditions under the aegis of Barend van Spreekens. According to the broadside dated 1817, prices per 12 steekannen (= one kwarteel) for imported white whale oil (as opposed to black whale

611. For the calculations regarding wages, it was assumed that the men were paid from the day they signed up. To date, no evidence indicating that men were paid from the day the ship sailed has been found. Customarily, the difference between these two dates amounted to about 15 to 20 days, or about 7 to $10 \%$ of the total expenses in wages. In the event that one would prefer that the calculations be based on the latter assumption (that men were paid from the day the ship sailed), it is suggested that these differences be applied to the profits mentioned.

612. Kendall Collection, New Bedford Whaling Museum. Broadsides, Folder 3: oil prices at Amsterdam 1817; Amsterdam, 7 February 1826. A major problem arises when catch results are compared with prices of specified quantities of oil. Catch results were (almost without exception) quoted in kwartelen or barrels, whereas these broadsides cite prices per number of 'stek' (this should read 'steekan': 1 steekan is about 5 to $5^{1 / 4}$ gallon = circa 19 to 19.95 litres). In order to facilitate calculations, one kwarteel $=232.8$ litres $=$ circa 12 steekan was used. 
oil, i.e., oil from whales caught in the South Seas), were between $f_{90}$ and $f_{91}$. Here, the average of $f 90.50$ was used to estimate the revenues of catches of the 1816 expedition. In the years 1815, 1817, and 1818 Groenland returned with its hold empty. Based on the premium system for wanvangst, it was assumed that for these three years Van Spreekens was compensated for his loss by either the full premium $\left(f_{4}, 000\right)$ or halfpremium $\left(f_{2}, 000\right)$, with another $f_{5}, 000$ for wanvangst. ${ }^{613}$ When Broertjes returned with an empty ship in 1815 , Van Spreekens may have received the full premium for wanvangst $\left(f_{5}, 000\right)$. In this way, some idea about the profitability of the whaling industry is presented. It should be noted that Van Spreekens received modest subsidies for both years, and probably for all five years in which he was active. ${ }^{614}$ The calculations for 1819 were based on the price of whale oil in 1818, quoted by Posthumus (see Table 7.4).

Table 7.6: Costs and revenues of whaling expeditions fitted out by Barend van Spreekens (18151819). ${ }^{615}$

(Amounts are in $f$; estimates are placed between brackets $[\ldots]$; one kwarteel $=$ one barrel.)

\begin{tabular}{|c|c|c|c|c|c|c|c|c|c|}
\hline Year & $\begin{array}{l}\text { Deprecia- } \\
\text { tion of ship } \\
\text { (1) }\end{array}$ & $\begin{array}{l}\text { Costs of } \\
\text { crew (2) }\end{array}$ & $\begin{array}{l}\text { Total costs } \\
(1+2=A)\end{array}$ & Catches & $\begin{array}{l}\text { Revenue of } \\
\text { catches } \\
\text { (3) }\end{array}$ & $\begin{array}{l}\text { Govern- } \\
\text { mental } \\
\text { subsidy (4) }\end{array}$ & $\begin{array}{l}\text { Total rev- } \\
\text { enues } \\
(3+4=B)\end{array}$ & $\begin{array}{l}\text { Net results } \\
(C=B-A)\end{array}$ & Profits \% \\
\hline 1815 & 2,140 & $4,963.50$ & $7,103.50$ & $\begin{array}{l}\text { Returned } \\
\text { empty }\end{array}$ & Nihil & $\begin{array}{l}2,000 \text { to } \\
4,000+ \\
5,000\end{array}$ & $\begin{array}{l}2,000 \text { to } \\
4,000\end{array}$ & $\begin{array}{l}-/-3,103.50 \\
\text { to } \\
-/-5,103.50\end{array}$ & $\begin{array}{l}-/-43.7 \\
\text { to } \\
-/-71.9\end{array}$ \\
\hline 1816 & 2,140 & $5,566.50$ & $7,706.50$ & $\begin{array}{l}2 \text { whales/ } \\
40 \text { kwarte- } \\
\text { len of oil }\end{array}$ & $\begin{array}{l}40 \times f_{90.50} \\
=f_{3}, 620,-\end{array}$ & $\begin{array}{l}{\left[60 \times f_{50}=\right.} \\
3,000]\end{array}$ & $6,620+?$ & $\begin{array}{l}-/- \\
f_{1}, 086.50\end{array}$ & $-/-14.1$ \\
\hline 1817 & 2,140 & {$[5,250]$} & {$[7,390]$} & $\begin{array}{l}\text { Returned } \\
\text { empty }\end{array}$ & Nihil & $\begin{array}{l}2,000 \text { to } \\
4,000+ \\
5,000\end{array}$ & $\begin{array}{l}7,000 \text { to } \\
9,000\end{array}$ & $\begin{array}{l}{[+/+1,610} \\
\text { to } \\
-/-390]\end{array}$ & $\begin{array}{l}{[+/+21.8} \\
\text { to } \\
-/-52.7]\end{array}$ \\
\hline 1818 & 2,140 & {$[5,250]$} & {$[7,390]$} & $\begin{array}{l}\text { Returned } \\
\text { empty }\end{array}$ & Nihil & $\begin{array}{l}2,000 \text { to } \\
4,000+ \\
5,000\end{array}$ & $\begin{array}{l}7,000 \text { to } \\
9,000\end{array}$ & $\begin{array}{l}{[+/+1,610} \\
\text { to } \\
-/-390]\end{array}$ & $\begin{array}{l}{[+/+21.8} \\
\text { to } \\
-/-52.7]\end{array}$ \\
\hline 1819 & 2,140 & 5,970 & 8,110 & $\begin{array}{l}2 \text { whales/ } \\
70 \text { barrels }\end{array}$ & $\begin{array}{l}70 \times f_{155}= \\
f_{10,850}\end{array}$ & $\begin{array}{l}2,000 \text { to } \\
4,000+ \\
2,500\end{array}$ & $\begin{array}{l}15,350 \text { to } \\
17,350\end{array}$ & $\begin{array}{l}+/+7,240 \\
\text { to } \\
+/+9,240\end{array}$ & $\begin{array}{l}+/+89.4 \\
\text { to } \\
+/+114\end{array}$ \\
\hline Totals & 10,700 & 27,000 & 37,700 & & & $\begin{array}{l}31,000 \text { to } \\
39,000\end{array}$ & $\begin{array}{l}37,970 \text { to } \\
45,970\end{array}$ & $\begin{array}{l}+/+270 \text { to } \\
+/+8,270\end{array}$ & $\begin{array}{l}+/+0.7 \text { to } \\
+/+24.5\end{array}$ \\
\hline
\end{tabular}

613. De Jong, Oude Nederlandse walvisvaart, vol. II, 454.

614. Unlike the municipal archives in Harlingen (in the cases of the Groenlandse en Straatdavidse Visscherij Sociëteit and Barend Visser \& Son), the archives in Amsterdam apparently do not contain records concerning Van Spreekens' applications for premiums.

615. De Jong, Oude Nederlandse walvisvaart, vol. II, 454; Kendall collection, Broadside (price level of 1817); Van Sluis, Nederlandse koopvaardijschepen, 205; De Jong, Idem, vol. III, 155; Posthumus, Nederlandsche prijsgeschiedenis, table 43, 84 (pricelevel of 1818); Van Sluis, Nederlandse koopvaardijschepen, 205. 
Several preliminary conclusions may be made from these estimates. First, whaling masters had to catch fairly large numbers of whales (or, in any case, large quantities of oil) in order not to be eligible for the governmental half-premium. Assuming that the price of $f 22.50$ per kwarteel is a fair estimate, the minimal catch in order to 'avoid' the minimum premium for wanvangst would have been about 89 kwartelen of oil the maximum, of course, being double this figure (178 kwartelen of oil). In other words, the incentive to catch many whales was almost non-existent as governmental financial support was easily granted.

Second, despite the lack of information regarding the duration of voyages and, consequently, with respect to the expenses of wages and foodstuffs (and despite the lack of data regarding catch results), it must be concluded that the profitability of these five voyages may be disregarded. These five voyages could hardly have been profitable, as the yearly depreciation of the vessel $\left(f_{2,140}\right)$ and the minimum governmental premium $\left(f_{2}, 000\right)$, outbalance any profit or loss.

With a daily total expenditure of $f 37.50$ in salaries as a point of reference, this would mean that voyages should not have lasted longer than about 185 days (or about six months) in order to make the premium the decisive factor for profit or loss. Again it should be stressed that costs of foodstuffs were not incorporated in the figures. ${ }^{616} \mathrm{Un}$ fortunately, only an estimate of the total expenses and revenues for 1816 can be made. With this expedition Van Spreekens suffered an estimated loss of $f_{1}, 086,50$. In the calculations presented here, Van Spreekens may have performed better in 1816 than in the preceding year. The last voyage (1819) may, at last, have yielded a profit of between $f 7,240$ to $f 9,240$; grosso modo 89 to 114 per cent of his expenses.

\section{Jan Vas \& Company}

Similar calculations can be made for Jan Vas \& Company in Wormerveer (see Table 7.7), however, scrutiny of investments and revenues for this firm is cumbersome. First of all, data concerning only the money Jan Vas spent to acquire Groenland from Barend van Spreekens is available. Vas paid $f 6,000$ for the fifty-year-old whaleship and the annual depreciation of the vessel would thus be $f_{750}$ (the price at purchase of $f 6,000$ divided by eight years). Crew lists in the municipal archives in Amsterdam refer to the expeditions of 1820-1825 (see Appendix 3). As in the case of Barend van Spreekens, these lists were proven to be extremely helpful in calculating costs of crew. ${ }^{617}$ Contrary to Van Spreekens' expeditions, data regarding the du-

616. The average daily investments in salaries for 1815,1816 , and 1819 were $f_{33}, 50, f_{41}$ and $f_{38}$, respectively. Hence the average of $f 37,50$ per day.

617. See Appendix 3 for sources and exact figures. 
ration of some of the voyages fitted out by Vas \& Company is available. But figures are lacking for 1820 . According to the information available, the vessel left Texel roadstead on 4 April. For the sake of the calculations, it was assumed that the duration of the 1820 voyage probably (more or less) equalled that of the 1822 to 1824 voyages, an average of about six and one-half months ( 6 months, 18 days). This figure was multiplied by the monthly costs of wages $(f 1,131)$. The 1821 voyage took a very long time. Master Oom showed up at the Harbourmaster's office on 23 February. He probably left about one or two weeks later and returned around 10 November. All in all, this expedition may have lasted about eight and one-half months. Costs of salaries amounted to $f_{1,246}$ per month, thus, a figure of $f_{10,591}$ for crew-related expenses.

The 1822 voyage was no shorter than 216 days (about seven months). Costs of crew amounted to $7 \mathrm{x} f 1,244=f 8,708$. In 1823 the voyage took 198 days (about six and one-half months). That year, Vas \& Company spent $f 1,246$ per month on wages, thus totalling about $f 8,099$. For 1824 and 1825, the figures were 7 months ( 6 months, 29 days) $x f_{1,176}$, and 7 and one-half months ( 7 months, 18 days) $x f_{1,190}$, respectively. Again, costs of foodstuffs were not included.

Similarly, there are problems on the credit side. Catch results were given in barrels of blubber, not in barrels of oil. In one instance (1823), both the number of barrels of blubber and the number of barrels of oil were mentioned. This data provided a ratio of 2,07:1. ${ }^{618}$ For the sake of simplicity, a ratio of $2: 1$ will be used in further calculations.

As was the case with the calculations of successes and failures of Barend van Spreekens, the nominal value of one kwarteel was determined as $f 22.50$. In these calculations, it was assumed that the government paid the firm $90 \times f_{50}\left(=f_{4,500}\right)$ in compensation.

There is no direct information concerning premiums paid by the King and his government to Vas \& Company In those instances, where an estimate of the level of payments for empty returns (wanvangst) was made, the percentages of full premiums and half-premiums were quoted and incorporated in the calculations. Price levels were derived from Posthumus (see Table 7.4).

618. De Jong, Oude Nederlandse walvisvaart, vol. III, 288 quotes Tegenwoordige Staat der Vereenigde Nederlanden, vol. I (Amsterdam 1739), 6oo passim. This book, published about 100 years earlier than the period discussed, revealed that customarily the quantity of blubber increased by about $30 \%$ when cooked to oil. In other words, the ratio of barrels of blubber to barrels of oil is 1: 1,3 (10o barrels of blubber yield 130 barrels of oil). This source seems to contradict the ratio mentioned above. 
Table 7.7: Costs and revenues of whaling expeditions fitted out by Jan Vas \& Company (18201825). ${ }^{619}$

(Amounts are in $f$; estimates are placed between brackets [...]; one kwarteel $=$ one barrel.)

\begin{tabular}{|c|c|c|c|c|c|c|c|c|c|}
\hline Year & $\begin{array}{l}\text { Deprecia- } \\
\text { tion of ship } \\
(1)\end{array}$ & $\begin{array}{l}\text { Costs of } \\
\text { crew (2) }\end{array}$ & $\begin{array}{l}\text { Total costs } \\
(1+2=A)\end{array}$ & Catches & \begin{tabular}{|l|} 
Revenue of \\
catches \\
(3)
\end{tabular} & $\begin{array}{l}\text { Govern- } \\
\text { mental } \\
\text { subsidy (4) }\end{array}$ & $\begin{array}{l}\text { Total rev- } \\
\text { enues } \\
(3+4=B)\end{array}$ & $\begin{array}{l}\text { Net results } \\
(\mathrm{C}=\mathrm{B}-\mathrm{A})\end{array}$ & Profits \% \\
\hline 1820 & 750 & {$[7,351.50]$} & {$[8,101.50]$} & No whales & nihil & \begin{tabular}{|l|}
2,000 \\
to \\
4,000
\end{tabular} & \begin{tabular}{|l|}
2,000 \\
to \\
4,000
\end{tabular} & $\begin{array}{l}{[-/-4,101.50} \\
\text { to } \\
-/-6,101.50]\end{array}$ & $\begin{array}{l}{[-/-50.6} \\
\text { to } \\
-/-75.3]\end{array}$ \\
\hline 1821 & 750 & 10,591 & 11,341 & $\begin{array}{l}\text { Caught } 6 \\
\text { whales; yield- } \\
\text { ing } 9 \text { o barrels } \\
\text { of blubber/ } \\
\text { ca. } 45 \text { barrels } \\
\text { of oil }\end{array}$ & $\begin{array}{l}45 \times 155= \\
6,975\end{array}$ & $\mid \begin{array}{l}{[2,000} \\
\text { to } \\
4,000]\end{array}$ & $\begin{array}{l}{[8,975} \\
\text { to } \\
10,975]\end{array}$ & $\begin{array}{l}{[-/-2,366} \\
\text { to } \\
-/-366]\end{array}$ & $\begin{array}{l}{[-/-20.9} \\
\text { to } \\
-/-3.2]\end{array}$ \\
\hline 1822 & 750 & 8,708 & 9,458 & $\begin{array}{l}\text { Caught } 2 \\
\text { whales, yield- } \\
\text { ing } 110 \text { barrels } \\
\text { of blubber/ } \\
\text { ca. } 55 \text { barrels } \\
\text { of oil }\end{array}$ & $\begin{array}{l}55 \times 155= \\
8,525\end{array}$ & $\begin{array}{l}{[23 \times 50=} \\
1,150]\end{array}$ & {$[9,675]$} & {$[+/+227]$} & {$[+/+2.4]$} \\
\hline 1823 & 750 & 8,099 & 8,849 & $\begin{array}{l}\text { Caught } 11 \\
\text { whales, yield- } \\
\text { ing } 207 \text { barrels } \\
\text { of blubber/ } \\
\text { over 10o } \\
\text { kwartelen of } \\
\text { oil }\end{array}$ & $\begin{array}{l}>100 \times 155 \\
=>15,500\end{array}$ & {$[0,000]$} & $>15,500 ?$ & $+/+6,651$ & +/+75.6 \\
\hline 1824 & 750 & 8,232 & 8,982 & No whales & Nihil & \begin{tabular}{|l|}
2,000 \\
to \\
4,000
\end{tabular} & \begin{tabular}{|l|}
2,000 \\
to \\
4,000
\end{tabular} & $\begin{array}{l}-/-4,982 \\
\text { to } \\
-/-6,982\end{array}$ & $\begin{array}{l}-/-55.9 \\
\text { to } \\
-/-78.4\end{array}$ \\
\hline 1825 & 750 & 8,925 & 9,675 & $\begin{array}{l}\text { No whales/ } 50 \\
\text { barrels of } \\
\text { blubber/ca. } 25 \\
\text { barrels of oil }\end{array}$ & $\begin{array}{l}25 \times 155= \\
3,875\end{array}$ & {$[4,500]$} & {$[8,375]$} & {$[-/-1,310]$} & {$[-/-13.6]$} \\
\hline Totals & 4,500 & $51,906.50$ & $56,406.50$ & & 34,875 & $\begin{array}{l}11,650 \\
\text { to } \\
17,650\end{array}$ & \begin{tabular}{|l}
46,525 \\
to \\
52,525
\end{tabular} & $\begin{array}{l}-/-9,881.50 \\
\text { to } \\
-/-3,881.50\end{array}$ & $\begin{array}{l}-/-17.5 \\
\text { to } \\
-/-6.9\end{array}$ \\
\hline
\end{tabular}

According to these figures, in some cases estimated calculations, gains for the company were evident for only two consecutive years (1822 and 1823), with an extraordinarily high gain for 1823 . Calculations for the remaining seasons showed substantial losses for the firm.

\section{Groenlandse en Straatdavidse Visscherij Sociëteit, 1825-1834}

The Groenlandse en Straatdavidse Visscherij Sociëteit was discussed more extensively than most companies by contemporaneous authors as well as by historians of later date. Not only is a fair amount of quantitative data available, but it is known from

619. De Jong, Oude Nederlandse walvisvaart, vol. III, 155-161; 164 (table 5); 168 (table 6); Van Sluijs, 205-206; Honig, Uit den gulden Bijenkorf, 39; Posthumus, Nederlandsche prijsgeschiedenis, table 43, 84. 
the issuing of shares how much money the Societeit carried at the time of its establishment. ${ }^{620}$ Finally, correspondence in the municipal archives in Harlingen enabled calculations with acceptable accuracy as to the financial support the government provided over the years. The results of these calculations were presented earlier (see Chapter 2, Table 2.1). The figures concerning the years at hand (1825 to 1834) were incorporated into Table 7.9.

When the directors formulated their founding regulations they stipulated (in Article 6) that a minimum number of 200 shares with a nominal value of $f_{500}$ per share must be sold in order to establish the company and make the initial investments in ships, gear, and personnel. ${ }^{621}$ Also, in their founding regulations these gentlemen specifically included that the whaling company would reconsider its mission - evaluate its results, assets, and so on - after ten years. It should be kept in mind that many more shares were issued. As early as April 1825,433 shares at $f_{500}$ were sold, including ten to King Willem I. The entrepreneurs, however, were obviously prepared to settle for less. In other words, the five directors assumed that a starting capital of $f 100,000$ would be sufficient to cover expenses for these ten years, regardless of the revenues of their expeditions. As noted earlier, they managed to raise more than double this amount.

In some years the company had more than one ship involved in whaling. In some cases the individual catch results were given and are represented in Table 4.4. In other cases, the total catch results of two or more ships were mentioned. The broadsides at the New Bedford Whaling Museum cited above, provide information with respect to whale and sea elephant oil in 1826 . That year, between $f_{51}$ and $f_{52}$ were paid at the Amsterdam Exchange for 12 steekannen of whale oil, or the equivalent of one kwarteel of oil. Thanks to the records in the municipal archives in Harlingen dating from 1830, exact data concerning the then-current prices of seal oil cooked in Harlingen exist. Here, one kwarteel represented a value of $f_{50}$. Unfortunately, there are no unambiguous figures indicating what the conversion of barrels of seal blubber into barrels of seal oil should be. The only data referred to the trying-out of 39 barrels of seal blubber brought in by Hendrick Rickmers and his crew in 1830, which yielded 38 kwartelen of oil. ${ }^{622}$ It seems plausible to use a ratio of circa 1,025:1 to convert numerical data about seal blubber into seal oil. The try-works yield, however, also depended on the level of expertise of those involved in the processing.

620. Through the issuing of shares in early 1825 , the company had about $f 216,500$ in the bank. It is not known whether or not the Sociëteit received interest over this amount, thus the company's starting capital was incorporated in these calculations.

621. De Jong, Oude Nederlandse walvisvaart, vol. II, 457; Dijkstra, 'Groenlands- en Straat davids-Visserij Sociëteit', 55 .

622. Municipal Archives Harlingen, Stukken betreffende het stadsbestuur van Harlingen, 1816-1924. Archiefstuk betreffende de Groenland- en Straat-Davids-Visserij 1830 (1 omslag), nr. 3399. 
A different story can be told with respect to the conversion of the numbers of seals into kwartelen oil. In 1827, 88 seals yielded 30 kwartelen of oil. A few years later, in 1833, 406 seals yielded 150 kwartelen. These figures indicate that 100 seals could roughly yield 35 to 37 kwartelen oil. This suggests that the average yield of one seal must have been between 0,27 and 0,29 kwarteel. Using the average of the three price-levels per kwarteel quoted above $\left(f_{50}, f_{51}\right.$, and $\left.f_{52}\right)$, it can be calculated that one seal - when processed - represented a value of between $f_{13} .50$ and $f_{14.50}$. Consequently, the average value per processed seal of $f 14$ will be used. ${ }^{623}$

Again, with respect to purchase price of vessels, the research conducted by Michael Jansen was used. The Boissevain archive at the Municipal Archives of Amsterdam as his primary source, Jansen provided information about the price of brigs purchased in Amsterdam ( $f_{228}$ per ton), kofs ( $f_{140}$ per ton), and frigates (ranging from $f_{241}$ to $f_{304}$ ) purchased elsewhere in the Netherlands. ${ }^{624}$ His figures pertain to new ships, to merchantmen, and to the situation around 1825, and include the value of provisions. Therefore, Jansen's figures can hardly be used for calculating the annual depreciation of vessels newly built on behalf of the Sociëteit: Willem de Eerste, pink, built at Johan Alta, Harlingen in 1823; Harlingen, galliot, built at Johan Alta, Harlingen in 1826; Willem de Eerste (II), frigate measuring 242 lasts, built at Johan Alta, Harlingen in 1826; and Spitsbergen (II), pink, measuring 251 tons, built at Johan Alta in 1829. There is no data about the costs of construction and/or purchase of old vessels like Nederland (later deployed as Dirkje Adema). Jansen's calculations can be applied only to the frigate Willem de Eerste (II), although this vessel was constructed on Alta's yard in Harlingen. ${ }^{625}$ In summary, it must be concluded that calculating costs for the Sociëteit remains speculative.

To calculate revenues and assess levels of profitability, the portion of the overview of governmental financial support for the Harlingen-based whaling companies (see Table 7.8) must be recalled. At an earlier stage (in Chapter 2), the government premium system and the amounts granted to Harlingen-based whaling companies active between 1822 and 1856 were discussed. The subsidies issued by King Willem I and his government to the Harlingen-based Sociëteit between 1825 and 1834 amounted to about $f 110,000$. According to estimates, approximately one-third of all governmen-

623. Obviously the author is well aware of the over-generalisations put to the fore in this section. However, for this period (the 1820 s and 1830s), straight and ambiguous figures concerning conversions and net value of one whale or seal are missing.

624. Barend van Spreekens and Jan Vas \& Company both deployed second-hand vessels. Therefore, Jansen's figures were not applied to the calculations regarding these two companies.

625. Jansen, Industriële ontwikkeling, 287: table II.3.2. If it was assumed that 242 lasts roughly equals 450 tons, the construction of Willem de Eerste (II) at any yard in Amsterdam may have cost the company somewhere between $f_{108,000}$ and $f_{137,000}$. 
tal subsidies granted to support whaling and sealing between 1815 and 1855 went to the short-lived Sociëteit.

Table 7.8: Governmental subsidies issued for whaling expeditions fitted out by the Groenlandse en Straatdavidse Visscherij Sociëteit in Harlingen (1825-1834). ${ }^{626}$

(Amounts are in $f$; estimates are placed between brackets [...].)

\begin{tabular}{|c|c|c|c|c|c|}
\hline Year & $\begin{array}{l}\text { Amounts men- } \\
\text { tioned } \\
\text { in sources }\end{array}$ & Taxes levied & Remarks & Minimum & Maximum \\
\hline \multirow[t]{2}{*}{1825} & 2,000 & & Premium 2 for Spitsbergen & 4,050 & \\
\hline & 2,050 & & Premium 3 for Spitsbergen & & \\
\hline \multirow[t]{2}{*}{1826} & 6,850 & & $\begin{array}{l}\text { Premiums } 1 \text { (GAH } 1376 \text { refers to premium 2) and } 3 \text { for } \\
\text { Willem de Eerste }\end{array}$ & 14,500 & 14,850 \\
\hline & 8,000 & & $\begin{array}{l}\text { Premium } 2 \text { (GAH refers to premium } 1 \text { ) for Spitsbergen, } \\
\text { Nederland, Harlingen and Willem de Eerste }\end{array}$ & & \\
\hline \multirow[t]{2}{*}{1827} & 10,850 & & & 15,850 & 15,850 \\
\hline & 5,000 & $-/-12,50$ & Premium 3 due to loss of Willem de Eerste & & \\
\hline \multirow[t]{2}{*}{1828} & 2,000 & & Premium 1 for Nederland & 4,000 & 4,850 \\
\hline & 2,850 & $-/-15,00$ & Premium $2+$ part of premium 3 & & \\
\hline \multirow[t]{3}{*}{1829} & 4,000 & & Premium 1 for two vessels & 9,750 & 9,750 \\
\hline & 2,000 & $-/-5,00$ & Premium 2 for one vessel (Spitsbergen (II)) & & \\
\hline & $2,000+1,750$ & & Premium 2 for other vessel $($ Nederland $)+$ premium 3 & & \\
\hline \multirow[t]{2}{*}{1830} & 3,750 & & Premium 2 [sic] + part of premium 3 for Nederland & 7,750 & 7,750 \\
\hline & 4,000 & $-1-9,50$ & Premium 1 for Spitsbergen (II) and Nederland & & \\
\hline \multirow[t]{4}{*}{1831} & 3,900 & & $\begin{array}{l}\text { Premium } 1+\text { part of premium } 3 \text { (N.B.: in their letter, } \\
\text { the directors of the company refer to request for pre- } \\
\text { mium } 2 \text { for Spitsbergen (II), not premium 1) }\end{array}$ & 18,600 & 18,600 \\
\hline & 6,700 & $-/-26,50$ & Premium 2 (for two ships) + part of premium 3 & & \\
\hline & 4,000 & & Premium 1 for two ships & & \\
\hline & 4,000 & $-/-10,00$ & Premium 2 & & \\
\hline \multirow[t]{2}{*}{1832} & 4,000 & & Premium 1 (for two ships) & 8,000 & 8,000 \\
\hline & 4,000 & & Premium 2 (for two ships - no premium 3?) & & \\
\hline \multirow[t]{4}{*}{1833} & {$[3,750]$} & & [Part of premium 3 for Nederland] relates to 1832 ?] & 11,450 & 15,200 \\
\hline & 4,000 & & Premium 1 for two ships & & \\
\hline & 4,000 & & Premium 2 for two ships & & \\
\hline & 3,450 & $-/-19,69$ & Part of premium 3 for Nederland & & \\
\hline \multirow[t]{3}{*}{1834} & 4,000 & $-/-10,62$ & Premium 1 for two ships & 15,150 & 15,150 \\
\hline & 4,000 & & Premium 2 for two ships & & \\
\hline & 7,150 & $-/-28,94$ & Premium 3 for Nederland and Spitsbergen (II) & & \\
\hline Totals & & & & 109,100 & 109,800 \\
\hline
\end{tabular}

Table 7.9 presents an overview of the revenues obtained by the Sociëteit. Data regarding the years 1825,1828 , and 1829 were too incomplete to be incorporated. The table is based on a variety of sources, mentioned in conjunction with Table 2.1. These include correspondence between whaling entrepreneurs, delegates at the States of Friesland and the City Council of Harlingen; from revenues of sales mentioned in the

626. For sources, see Chapter 2, Table 2.1. The sources were incorporated into this table but could not easily be copied and pasted here because of the high number of citations. 
Leeuwarder Courant; and the results of sales at auction during the years 1831-1834 (the total revenues of these auctions were cited as well).

As the notary costs were deducted from these totals, the figures differ somewhat from those presented previously. It was stated before, however, that the first sources (correspondence with the City Council) do not incorporate governmental subsidies granted in 1833 and 1834. In short, the figures for two years out of ten (1831 and 1832) were ascertained. The minimum and maximum total revenues will both be included in the overall calculations concerning profits and losses in the sealing and whaling industries at the end of this chapter.

Table 7.9: Revenues of whaling and sealing expeditions to Spitsbergen and the Davis Strait fitted out by the Groenlandse en Straatdavidse Visscherij Sociëteit in Harlingen (1826-1834).

(In the case of more than one vessel, totals are given in the third column; amounts are in $f$; estimates are placed between brackets $[\ldots]$.

\begin{tabular}{|c|c|c|c|c|c|c|c|c|}
\hline Year & Ship & $\begin{array}{l}\text { Catches + } \\
\text { revenues }\end{array}$ & $\begin{array}{l}\text { Total revenues } \\
\text { of catches of all } \\
\text { voyages per } \\
\text { year combined } \\
\text { (3) }\end{array}$ & $\begin{array}{l}\text { Minimum } \\
\text { govern- } \\
\text { mental } \\
\text { subsidy } \\
\text { (4) }\end{array}$ & \begin{tabular}{|l|} 
Maximum \\
govern- \\
mental \\
subsidy \\
$(5)$
\end{tabular} & $\begin{array}{l}\text { Minimum } \\
\text { Total Rev- } \\
\text { enues } \\
(3+4=B)\end{array}$ & $\begin{array}{l}\text { Maximum } \\
\text { Total Rev- } \\
\text { enues } \\
(3+5=C)\end{array}$ & Sources \\
\hline \multirow[t]{4}{*}{1826} & Harlingen & $\begin{array}{l}\text { Lost in } \\
\text { Davis Strait }\end{array}$ & {$[65,182]$} & 14,500 & 14,850 & 73,182 & 80,032 & $\begin{array}{l}\text { GAH, 1644: nrs. 127, 135, } \\
\text { 218, 228, 258; GAH, 1414: } 6 \\
\text { July, 1 August; GAH, 1376: } \\
\text { nr. } 2 \text { (27 July 1826) }\end{array}$ \\
\hline & $\begin{array}{l}\text { Willem de } \\
\text { Eerste (II) }\end{array}$ & No catches & & & & & & \\
\hline & Spitsbergen & 3,124 seals & {$[40,612]$} & & & & & \\
\hline & Nederland & 1,890 seals & {$[24,570]$} & & & & & \\
\hline \multirow[t]{2}{*}{1827} & $\begin{array}{l}\text { Willem de } \\
\text { Eerste (II) }\end{array}$ & $\begin{array}{l}\text { Lost near } \\
\text { Greenland. } \\
\text { Insurance } \\
\text { covered } \\
98 \% \text { of loss } \\
- \\
\text { figure un- } \\
\text { known. }\end{array}$ & None & 15,850 & 15,850 & $15,850+?$ & $15,850+?$ & $\begin{array}{l}\text { GAH, 1644: nr. 48: GAH, } \\
\text { 1416: } 7 \text { February; GAH, } \\
\text { 1644: nrs. 416, 440, 447; } \\
\text { GAH, 1417: } 24 \text { November, } 1 \\
\text { December; Mentioned by } \\
\text { Hoekstra, Dagverhaal, } 5 \text {. } \\
\text { Municipal Archives Rot- } \\
\text { terdam (MAR), } 1 \text { March } \\
\text { 1827 (insurance paid on } 24 \\
\text { September 1826) }\end{array}$ \\
\hline & Nederland & $\begin{array}{l}5 \text { whales } \\
\text { yielding 160 } \\
\text { barrels of } \\
\text { fat/blubber }\end{array}$ & $?$ & & & & & Typescript A.J. Dijkstra \\
\hline 1830 & $\begin{array}{l}\text { Spitsbergen } \\
\text { (II) }\end{array}$ & $\begin{array}{l}\text { Combined } \\
\text { results of } \\
\text { these two } \\
\text { ships: } \\
38+94= \\
132 \text { kwarte- } \\
\text { len seal oil }\end{array}$ & $\begin{array}{l}6,600 \\
\text { (acknowledged } \\
\text { by GS in 1831) }\end{array}$ & 7,750 & 7,750 & 14,350 & 14,350 & $\begin{array}{l}\text { GAH, 1645: nrs. 31, 64; } \\
\text { GAH, 1422: } 23 \text { January, } 30 \\
\text { January: GAH, 1645: nr. } \\
\text { 339; GAH, 1422: 1 June: } \\
\text { Nederlandsche Hermes, III, } \\
\text { 78; Leeuwarder Courant, } \\
\text { 20 April 1830; Leeuwarder } \\
\text { Courant, 17 Aug. 1830; } \\
\text { document GAH (oil tried } \\
\text { out at cookery De Her- } \\
\text { stelder, Harlingen, Sep- } \\
\text { tember 1830) }\end{array}$ \\
\hline & Nederland & & & & & & & \\
\hline
\end{tabular}




\begin{tabular}{|c|c|c|c|c|c|c|c|c|}
\hline Year & Ship & $\begin{array}{l}\text { Catches + } \\
\text { revenues }\end{array}$ & $\begin{array}{l}\text { Total revenues } \\
\text { of catches of all } \\
\text { voyages per } \\
\text { year combined } \\
\text { (3) }\end{array}$ & \begin{tabular}{|l|} 
Minimum \\
govern- \\
mental \\
subsidy \\
$(4)$
\end{tabular} & \begin{tabular}{|l|} 
Maximum \\
govern- \\
mental \\
subsidy \\
$(5)$
\end{tabular} & $\begin{array}{l}\text { Minimum } \\
\text { Total Rev- } \\
\text { enues } \\
(3+4=B)\end{array}$ & $\begin{array}{l}\text { Maximum } \\
\text { Total Rev- } \\
\text { enues } \\
(3+5=C)\end{array}$ & Sources \\
\hline \multirow[t]{2}{*}{1831} & $\begin{array}{l}\text { Spitsbergen } \\
\text { (II) }\end{array}$ & \begin{tabular}{|l|} 
Combined \\
results of \\
these two \\
ships: 3 \\
whales, 5,349 \\
seals yielding \\
500 barrels \\
of seal oil \\
and whale \\
oil; 5,00o seal \\
furs; and \\
2,500 pounds \\
of baleen ${ }^{627}$
\end{tabular} & $51,858,71$ & 18,600 & 18,600 & $70,458,71$ & $70,458,71$ & $\begin{array}{l}\text { GAH, 1645: nr. 136; GAH, } \\
\text { 1423: 16 March, 17 March: } \\
\text { GAH, 1645: nr. 136; GAH, } \\
\text { 1423: 16 March: GAH, } \\
\text { 1645: nr. 235; GAH, 1423: } \\
\text { 18 March: GAH, 1787: Fo- } \\
\text { lio 62, nr. } 310 \text { (19 May): } \\
\text { GAH, 1645: nr. 451; GAH, } \\
\text { 1423: 8 November; GAH, } \\
\text { 1787: Folio 62, nr. 633 (8 } \\
\text { November): Leeuwarder } \\
\text { Courant, 6 September } \\
\text { 1831; Leeeuwarder Courant, } \\
\text { 17 July 1832; TL, Notary } \\
\text { archives, 49024 (reper- } \\
\text { toires), \#283; GAH, 1644, } \\
\text { nrs. 235 and 451 }\end{array}$ \\
\hline & Nederland & & & & & & & \\
\hline \multirow[t]{2}{*}{1832} & $\begin{array}{l}\text { Spitsbergen } \\
\text { (II) }\end{array}$ & \begin{tabular}{|l|} 
Combined \\
results of \\
these two \\
ships: \\
2 whales, \\
$3,520 / 3,560$ \\
seals. The \\
catch yielded \\
149 barrels of \\
whale oil, 131 \\
barrels of \\
seal oil, 3,560 \\
seal furs, and \\
800 pounds \\
of baleen \\
\end{tabular} & $25,859,41$ & 8,000 & 8,000 & $33,859,41$ & $33,859,41$ & $\begin{array}{l}\text { GAH, 1645: nr. 299; } \\
\text { GAH, 1424: 28 May; } \\
\text { GAH, 1788: Folio 62, nr. } \\
\text { 307 (28 May): GAH, 1645: } \\
\text { nr. 481; GAH, 1788: Folio } \\
\text { 62, nr. 539 (1 October): } \\
\text { Leeuwarder Courant, } 16 \\
\text { July 1833; TL, Notary } \\
\text { archives, 49025 (reper- } \\
\text { toires), \#253; GAH, 1644, } \\
\text { nrs. } 299 \text { and 481 }\end{array}$ \\
\hline & Nederland & & & & & & & \\
\hline 1833 & $\begin{array}{l}\text { Spitsbergen } \\
\text { (II) }\end{array}$ & \begin{tabular}{|l|} 
Combined \\
results of \\
these two \\
ships: 4 \\
whales, 406 \\
seals yielding \\
150 kwartelen \\
oil/about 160 \\
oxheads of \\
whale oil, \\
about 2,ooo \\
pounds of \\
baleen, and \\
about 400 \\
seal furs (and \\
some bear \\
furs)
\end{tabular} & $14,018,10$ & 11,450 & 15,200 & {$[22,018,10]$} & {$[22,018,10]$} & $\begin{array}{l}\text { GAH, 1645: nr. 132; GAH, } \\
\text { 1425: 21 February; GAH, } \\
\text { 1788: Folio 62, nr. } 176 \text { (22 } \\
\text { February): GAH, } 1788: \\
\text { Folio 62, nr. 381 (25 May): } \\
\text { GAH, 1788: Folio 62, nr. } \\
\text { 463 (24 June): GAH, 1645: } \\
\text { nr. 775; GAH, 1425: } 7 \text { No- } \\
\text { vember; GAH, 1788: Fo- } \\
\text { lio 62, nr. 776 (11 Novem- } \\
\text { ber): Leeuwarder } \\
\text { Courant, 13 September } \\
\text { 1833; TL, Notary archives, } \\
\text { 49026 (repertoires), \#281 }\end{array}$ \\
\hline
\end{tabular}

627. Scrutinizing the archival records, which had information about the sales at auction, the calculated figures differ from those cited in the newspapers. According to Tresoar Leeuwarden (TL), Notary archives, nr. 49024 (repertoires), \#283, the figures should read: 436 barrels of seal oil (227) and whale oil (209); 5,178 seal furs; and 1,627 pounds of baleen - however, baleen was put in the same category as dried seal furs, so this figure may be an estimate. In the table, the payment to the notaries $\left(f_{352,49}\right)$ was subtracted from the total revenues of sales $\left(f_{52,211,20}\right)$. The same calculations were used for the years 1832,1833 , and 1834 .

628. TL, Notary archives, nr. 49026 (repertoires), \#281 lists more precise figures: no seal oil; 164 barrels of 


\begin{tabular}{|c|c|c|c|c|c|c|c|c|}
\hline Year & Ship & $\begin{array}{l}\text { Catches + } \\
\text { revenues }\end{array}$ & $\begin{array}{l}\text { Total revenues } \\
\text { of catches of all } \\
\text { voyages per } \\
\text { year combined } \\
\text { (3) }\end{array}$ & \begin{tabular}{|l|} 
Minimum \\
govern- \\
mental \\
subsidy \\
(4)
\end{tabular} & \begin{tabular}{|l|} 
Maximum \\
govern- \\
mental \\
subsidy \\
$(5)$
\end{tabular} & $\begin{array}{l}\text { Minimum } \\
\text { Total Rev- } \\
\text { enues } \\
(3+4=B)\end{array}$ & $\begin{array}{l}\text { Maximum } \\
\text { Total Rev- } \\
\text { enues } \\
(3+5=C)\end{array}$ & Sources \\
\hline & Nederland & & & & & & & $\begin{array}{l}\text { Haagsma, 'Friesland's } \\
\text { Groenlandvaart', 51; } \\
\text { Leeuwarder Courant, } 8 \\
\text { October 1833; Leeuwarder } \\
\text { Courant, } 1 \text { July } 1834\end{array}$ \\
\hline 1834 & $\begin{array}{l}\text { Spitsbergen } \\
\text { (II) }\end{array}$ & $\begin{array}{l}\text { Combined } \\
\text { results of } \\
\text { these two } \\
\text { ships: } 46 \text { bar- } \\
\text { rels of whale } \\
\text { oil, } 14 \text { barrels } \\
\text { of seal oil, } 351 \\
\text { pounds of } \\
\text { baleen, } 458 \\
\text { pieces of seal } \\
\text { furs, and } 5 \\
\text { barrels of } \\
\text { waste prod- } \\
\text { ucts }\end{array}$ & $4,673,71$ & 15,150 & 15,150 & {$[12,673,71]$} & {$[12,673,71]$} & $\begin{array}{l}\text { TL, Notary archives, } \\
\text { 51017 (repertoires), \#38: } \\
\text { GAH, 1645: nr. 376; GAH, } \\
\text { 1426: 14 May; GAH, 1788: } \\
\text { Folio 62, nr. } 346 \text { (20 } \\
\text { May): GAH, 1645: nr. } \\
\text { 776; GAH, 1426: 12 No- } \\
\text { vember: GAH, 1645: nr. } \\
\text { 776; GAH, 1426: 12 } \\
\text { November; GAH, 1788: } \\
\text { Folio 62, nr. 726 (13 } \\
\text { November) }\end{array}$ \\
\hline & Nederland & & & & & & & \\
\hline Totals & & & $168,191,93$ & 91,300 & 95,400 & $242,391,93$ & $249,241,93$ & \\
\hline
\end{tabular}

In comparison with the entrepreneurs and companies discussed earlier, the Sociëteit's whaling and sealing activities apparently resulted in substantial revenues, amounting to about $f 28$, ooo per year. However, as definitive, unambiguous data regarding costs are lacking the total scope of expenditures on ships and costs of wages cannot be calculated. ${ }^{629}$ These costs must have been very high, as the Sociëteit must have invested heavily, for instance, in newly built ships. With the size of its fleet, the operation on land (the buildings and the cookery with its personnel), and the consequential size of the crews, it seems fair to doubt that the Sociëteit managed to conduct its business with this margin in mind.

Despite the substantial revenues, there is no indication that the Sociëteit paid any dividends to its shareholders. All that is known is that at the time of the company's dissolution, the shareholders received a meagre $f_{70}$ on their initial investment of $f_{500}$.

\section{Barend Visser \& Son, 1835-1864 (Part II)}

Harlingen-based merchants Barend Visser \& Son resumed whaling and sealing in the mid-183os. Of all the companies and entrepreneurial individuals involved in whaling and/or sealing during the nineteenth century, this firm is the best documented, both

whale oil; 1,252 pounds of baleen; and 407 seal furs (and 6 polar bear furs).

629. Thanks to the ship's journals in the collection of the Friesenmuseum on Föhr, information regarding the numbers of the crews exist. No crew lists with data about their wages, however, have survived. 
regarding the nature and duration of its expeditions and with respect to the costs and revenues they encountered in their long Arctic involvement. Before analysing expenditures and revenues, it seems fitting to stress that the firm's name fills many pages of the Leeuwarder Courant, especially during the 1830s. Visser \& Son spent money on the construction of the local orphanage and apparently spread the risks of entrepreneurship by investing in the timber trade and in foodstuff commodities.

Despite the many sources at hand regarding whaling and sealing conducted by this firm between 1835 and 1864, unambiguous data about catch revenues pertain to only one year: 1838. That year, the catch was sold at auction in Harlingen. For later years (1858-1863), other sources must used. In Ten Brink's promotional pamphlet containing an overview of the state of the art of international whaling and sealing activities around 1876/1877, he regularly quoted A. Petermann's contemporary Mitteilungen and Lindeman's Arktische Fischerei. It was not without reason that Ten Brink brought to the fore the results of the research conducted by these two German scholars. In his search for spiritual and financial support for the founding of 'his' Nieuwe Noordsche Compagnie ter uitoefening van de robben en walvischvangst (New Nordic Company for conducting sealing and whale fishery), Ten Brink must have felt the need to make potential investors wet their lips in sheer anticipation of future fortune. Both Petermann and Lindeman presented a wealth of data concerning the profitability of the sealing industry - for Scotland and Norway, however, not for the Netherlands.

Lindeman presented a statistical analysis of Norwegian catch results for the period 1864 to 1868 , and Ten Brink's calculations were based on Lindeman's data. ${ }^{630}$ In those five years, about 15 to 16 ships, carrying about 700 sailors in total, brought in catches that on average yielded dividends of $14 \%$. In later years, these percentages were even higher (about $16 \%$ for 1869 and about $22 \%$ for 1870 ). ${ }^{631}$ Successes during the late 1860 s were not only reserved for seal hunting, and also not only for Norwegian crews. A report in the Dundee Advertiser of September 1873, revels in the achievements of the Scottish whaling fleet. That year, 10 whaleships brought in 152 whales, yielding 1,240 tons of oil. This cargo had a value of an astounding $f 840,000$ at auction. ${ }^{632}$

630. M. Lindeman, Die Arktische Fischerei der Deutschen Seestädte 1620-1868 in vergleichender Darstellung. Ergänzheft No. 26 zu Petermann's Geographischen Mitteilungen (Gotha 1869), 86 passim.

631. Ten Brink, Noordpool-visscherij, 21-25; Petermann, Mitteilungen (1871), 341. Ten Brink referred to the achievements of the steam whaler Franklin. In 1871 this vessel returned with 14,00o seals. The shareholders of the company were very satisfied when, after sales, a dividend of $57 \%$ was paid.

632. Quoted by Ten Brink, op. cit., 28. It should be noted that Scottish whalers and sealers hunted in Frobisher Sound and Hudson Bay, whereas the Norwegians and Dutch continued to hunt near Jan Mayen Island and Spitsbergen. Thanks are due to Professor L. Hacquebord for bringing this to my attention. 
In this series of publications, Petermann provided insight into fluctuations in prices of baleen and both whale oil and seal oil. Earlier, Van Musschenbroek was quoted regarding the price of a barrel of black oil (South Seas oil). According to that author, who was writing in 1877 , one barrel should make about $f 86$. But the difference between that figure and the average price of a barrel of Arctic whale oil was substantial. According to Ten Brink, a barrel would sell for about $f 40 .{ }^{633}$

Petermann also gave information regarding the average price of baleen for the year 1867 . That year, one had to pay about $f 270$ for 100 kilograms of whalebone. ${ }^{634}$ Ten Brink provided the values of seals as well. Young seals were valued at about $f_{5}$ and adults roughly at $f 12 .{ }^{635}$ With these figures in hand, estimated values can be made for the Dutch whaling and sealing industry of the 186os, keeping in mind that Ten Brink's figures were about ten years apart (referring to the situation around 1876), whereas Petermann referred to prices of seals in 1867 . The catch data available does not specify the ages of the seals caught; hence both values were used in the calculations for Barend Visser \& Son (see Table 7.10).

Table 7.10: Overview of total revenues of whaling and sealing expeditions fitted out by Barend Visser \& Son (1838; 1858-1863).

(Amounts are in $f$; estimates are between brackets [...].)

\begin{tabular}{|c|c|c|c|c|c|c|c|}
\hline Year & Ship & Catches & $\begin{array}{l}\text { Total Revenue } \\
\text { of catches (3) }\end{array}$ & $\begin{array}{l}\text { Minimum gov- } \\
\text { ernmental sub- } \\
\text { sidy (4) }\end{array}$ & $\begin{array}{l}\text { Maximum gov- } \\
\text { ernmental sub- } \\
\text { sidy (5) }\end{array}$ & $\begin{array}{l}\text { Minimum To- } \\
\text { tal Revenues } \\
(3+4=\mathrm{B})\end{array}$ & $\begin{array}{l}\text { Maximum To- } \\
\text { tal Revenues } \\
(3+5=\mathrm{C})\end{array}$ \\
\hline \multirow[t]{2}{*}{1838} & Spitsbergen (II) & $\begin{array}{l}\text { Results of two } \\
\text { ships com- } \\
\text { bined: } 87 \text { bar- } \\
\text { rels of whale oil; } \\
\text { and } 3,074^{1 / 2} \\
\text { pounds of } \\
\text { baleen }\end{array}$ & $22,237.28$ & 8,000 & 8,000 & $30,237.28$ & $30,237.28$ \\
\hline & Dirkje Adema & & & & & & \\
\hline 1858 & Dirkje Adema & 100 seals & {$[500$ to 1,200$]$} & & & {$[500]$} & {$[1,200]$} \\
\hline 1859 & Dirkje Adema & 1, ooo seals & $\begin{array}{l}{[5,000} \\
\text { to } 12,000]\end{array}$ & & & {$[5,000]$} & {$[12,000]$} \\
\hline 1860 & Dirkje Adema & & & & & & \\
\hline 1861 & Dirkje Adema & $\begin{array}{l}560 \text { seals/100 } \\
\text { kwartelen seal } \\
\text { blubber }\end{array}$ & {$[2,800$ to 6,720$]$} & & & {$[2,800]$} & {$[6,000]$} \\
\hline 1862 & Dirkje Adema & $>400$ seals & $\begin{array}{l}{[2,000+?} \\
\text { to } 4,800+?]\end{array}$ & & & {$[2,000+?]$} & {$[4,800+?]$} \\
\hline 1863 & Dirkje Adema & 900 seals & $\begin{array}{l}{[4,500 \text { to }} \\
10,800]\end{array}$ & & & {$[4,500]$} & {$[10,800]$} \\
\hline Totals & & & & & & $45,037.28$ & $65,037.28$ \\
\hline
\end{tabular}

633. Van Musschenbroek, 'Cachelot-visscherij', 17; Ten Brink, op. cit., 14.

634. A. Petermann, Mitteilungen (1867), 418, 420; quoted by Ten Brink, op. cit., 13.

635. Ten Brink, Noordpool-visscherij, 18. 
In Table 7.11, data regarding costs and revenues of whaling and sealing voyages initiated by the company of Barend Visser \& Son between 1858 and 1863 is presented. The average value of one seal was calculated at $f 8.50$. In 1835 the company purchased two vessels from the discontinued Groenlandse en Straatdavidse Visscherij Sociëteit. As stated earlier, Visser paid $f 15,227$ for the six-year-old Spitsbergen (II) and $f 6,635$ for the 35-year-old Nederland (re-christened Dirkje Adema). Again, costs and revenues will be analysed along the lines drawn above. First, the depreciation of the two ships should be discussed. Under the management of Visser, Spitsbergen made 18 whaling voyages in 18 years (1835-1852). The vessel was sold in June, 1853, to an unknown firm involved in the Norwegian timber trade. As the purchase price is not known, the annual depreciation of the vessel was calculated as $f_{15,227}$ divided by the number of years in service (18), indicating an annual depreciation of $f 846(f 845,94)$. Calculations with regard to Dirkje Adema are more complex, as Barend Visser \& Son purchased the vessel for $f 6,635$ and sold the grand old lady after 27 years of service for $f 9,000$ to a Norwegian firm. ${ }^{66}$ Thus, its annual depreciation cannot be calculated. However, as Visser made a profit of $f 2,365$ on the sale, dividing this profit by 30 (years of possession) and adding the amount $\left(f_{2,365: 30=f 79)}\right.$ to the credit side of the balance can be done. ${ }^{637}$ It is not known, however, how much was paid annually for maintenance.

For the years prior to 1838 , figures of auction results were used to calculate average values of catches. Also, figures presented by Posthumus (see Table 7.4) were used when calculating anticipated revenues from sales of kwartelen, or barrels of oil.

Problems arise on the debit side, as data regarding costs of crew are lacking - except for the years 1858-1863. Crew lists for these six years provided information about the total monthly investment in wages (see Appendix 4). For a number of years, some information about the duration of the expedition was found; for the remaining ones it was decided to use an average of 5 months - thus the multiplication of monthly wages by five in the third column of the table. It should be stressed once more, however, that these calculations are estimates. With regard to crew's salaries, attention was focused solely upon monthly wages. Due to a lack of data calculating the scope of extra sources of income (for instance, the share the whalemen had in selling off their cargo), was unsuccessful.

636. Visser purchased the vessel in 1835. Its first documented whaling voyage, however, did not take place until 1838 .

637. Actual sum: $f 78.83$. 
Table 7.11: Overview of costs and revenues of whaling and sealing expeditions fitted out by Barend Visser \& Son (1858-1863). ${ }^{638}$

(Average price of seals $=f 8.50$; value was based on the 1867 price; amounts are in $f$; estimates are placed between brackets [...].)

\begin{tabular}{|c|c|c|c|c|c|c|c|c|c|}
\hline Year & $\begin{array}{l}\text { Costs of } \\
\text { ship (1) }\end{array}$ & $\begin{array}{l}\text { Costs of } \\
\text { crew (2) }\end{array}$ & $\begin{array}{l}\text { Total costs } \\
(1+2=A)\end{array}$ & Catches & $\begin{array}{l}\text { Revenues of } \\
\text { catches } \\
(3)\end{array}$ & $\begin{array}{l}\text { Revenue } \\
\text { of ship } \\
(4)\end{array}$ & $\begin{array}{l}\text { Total rev- } \\
\text { enues }(5) \\
(3+4+5=B)\end{array}$ & $\begin{array}{l}\text { Net results } \\
(\mathrm{C}=\mathrm{B}-\mathrm{A})\end{array}$ & $\begin{array}{l}\text { Profits } \\
\%\end{array}$ \\
\hline 1858 & - & $\begin{array}{l}4.5 \times 553= \\
2,488\end{array}$ & 2,488 & 100 seals & {$[850]$} & 79 & {$[929]$} & {$[-/-1,559]$} & {$[-/-62.3]$} \\
\hline 1859 & - & $\begin{array}{l}5.25 \times 584= \\
3,066\end{array}$ & 3,066 & 1,000 seals & {$[8,500]$} & 79 & {$[8,579]$} & {$[+/+5,513]$} & {$[+/+183.7]$} \\
\hline 1860 & - & $\begin{array}{l}{[5 \times 536=} \\
2,680]\end{array}$ & {$[2,680]$} & & & 79 & & & \\
\hline 1861 & - & $\begin{array}{l}{[5 \times 578=} \\
2,890]\end{array}$ & {$[2,890]$} & $\begin{array}{l}560 \text { seals/ } \\
100 \text { kwarte- } \\
\text { len seal } \\
\text { blubber }\end{array}$ & {$[8,760]$} & 79 & {$[8,839]$} & {$[+/+5,949]$} & {$[+/+205.1]$} \\
\hline 1862 & - & $\begin{array}{l}{[5 \times 569=} \\
2,845]\end{array}$ & {$[2,845]$} & $>400$ seals & {$[3,400+?]$} & 79 & {$[3,479+?]$} & $\begin{array}{r}{[+/+634} \\
+?]\end{array}$ & {$[+/+22.6]$} \\
\hline 1863 & - & $\begin{array}{l}{[5 \times 534=} \\
1,670]\end{array}$ & {$[1,670]$} & 900 seals & {$[7,650]$} & 79 & {$[7,729]$} & {$[+/+6,059]$} & {$[+/+362.8]$} \\
\hline Totals & & 15,639 & $15,639+?$ & 2,960 & $29,160+?$ & 474 & $29,555+?$ & 13,916 & $+/+89.2$ \\
\hline
\end{tabular}

For Barend van Spreekens and Jan Vas \& Company, profit rates differed enormously. It appears that results for 1858 were disappointing, whereas 1859, 1861, and 1863 in particular should be considered extraordinarily successful years. One must be careful in interpreting the results, as costs must have run much higher than indicated. However, if investments were raised by a completely arbitrary $50 \%$, profits would still be quite considerable - ranging from $15.1 \% 1862$ to $202 \%$ in 1863 and with $119.8 \%$ and $138.3 \%$, respectively, for 1859 and 1861 .

\section{Nicolaas Brantjes \& Smit}

During the 1860 s and 1870s, Brantjes \& Smit in Purmerend and Captain C.J. Bottemanne's Rotterdam-based whaling company were the only two firms still whaling and sealing under the Dutch flag. Earlier in the text, the whaling and sealing expeditions undertaken by Brantjes \& Smit were discussed (see Chapter 4). The results were presented in Table 4.7. In Table 7.12, the name of the master, the name of the ship (sailing brig Maria), and the destination were left out for the sake of clarity. An important source for data, regarding catches and revenues, was the Staatkundig en staathuishoudkundig jaarboekje, published between 1849 and 1884. The volume published in 1877 contained an overview of the numbers of seals caught between 1855 and 1874 , and the gross revenues. Unfortunately, this source does not specify whether these revenues

638. Typescript A.J. Dijkstra; Wumkes, Tusschen Flie en Borne, 100; C. Nielsen, 'Uit de geschiedenis van de Harlinger walvisvaart', 25. 
were obtained from the sale of furs, oil, or of these two commodities combined. In Table 7.12, the data was incorporated and listed next to the catches mentioned by Bottemanne, Ten Brink, and De Jong. The differences are striking. For future calculations, the figures presented in the jaarboekje, an independent and thus more reliable source, will be used.

In their correspondence with Ten Brink, the company firmly stated that their whaling and sealing expeditions were advantageous to them on average 'for over 20 years' - that is, from the very first year onward. ${ }^{639}$ It should be noted that Ten Brink stayed in close correspondence with F.W. Rosenthal, who was a master shipwright and whaleship owner in Hamburg. Around 1875, Rosenthal wrote to Ten Brink, informing him that a catch of between 2,00o to 2,500 seals should be sufficient to cover a sealing expedition with a steamship. This statement will be used later in the calculations regarding Bottemanne's expeditions. ${ }^{640}$ Table 7.12 clearly shows that these figures were not met by Brantjes - not in 1873 or 1874 .

Finally, it should be stated that the scope of Brantjes' expenditures in whaling and sealing activities - in ships, food, wages for the crew, in establishing and operating the cookery between 1850 and 1875 - is unknown and, therefore, cannot be deducted from the estimated value of gross revenues.

Table 7.12: Overview of catches and revenues of whaling and sealing voyages fitted out by Nicolaas Brantjes \& Smit (1855-1884). ${ }^{641}$

Amounts are in $f$.

\begin{tabular}{|l|c|c|c|c|}
\hline Year & $\begin{array}{l}\text { Catches (Bottemanne, } \\
\text { Ten Brink, De Jong) }\end{array}$ & $\begin{array}{l}\text { Catches (Staatkundig en } \\
\text { staathuishoudkundig jaarboekje) }\end{array}$ & $\begin{array}{l}\text { Gross revenues (Staatkundig en } \\
\text { staathuishoudkundig jaarboekje) }\end{array}$ & $\begin{array}{l}\text { Average value } \\
\text { per seal }\end{array}$ \\
\hline 1855 & 4,000 seals & 1,217 & 13,628 & 11.20 \\
\hline 1856 & 9,300 seals & 5,702 & 49,850 & 10.50 \\
\hline 1857 & & 4.238 & 24,405 & 10.63 \\
\hline 1858 & & 3,871 & 13,675 & 6.30 \\
\hline 1859 & & 1,959 & 5,998 & 6.98 \\
\hline 1860 & & 415 & & 14.45 \\
\hline 1861 & & Did not sail & 37,460 & 11.61 \\
\hline 1862 & & Did not sail & 8,580 & 10.47 \\
\hline 1863 & & 3,226 & 33,200 & 11.00 \\
\hline 1864 & & 819 & 33,100 & 8.20 \\
\hline 1865 & & 4,018 & & \\
\hline 1866 & & & & \\
\hline
\end{tabular}

639. Ten Brink, op. cit., 33 .

640. Ten Brink, op. cit., 9. Using the 1874 price level for seals as cited in Staatkundig en staathuishoudkundig jaarboekje (1877), 6o, the average price of one seal can be calculated as $f 9.28$. This means that the costs of fitting out a steamship for sealing must have cost somewhere between $f_{18,560}$ and $f_{23,200}$.

641. Staatkundig en staathuishoudkundigjaarboekje (1858), 83; Idem (1877), 60; Ten Brink, Europeesche Noordpoolvisscherij, 9, 18; De Jong, II, 461-462; Bottemanne, 'Economische nalezingen en berigten', 344. 


\begin{tabular}{|c|c|c|c|c|}
\hline Year & $\begin{array}{l}\text { Catches (Bottemanne, } \\
\text { Ten Brink, De Jong) }\end{array}$ & $\begin{array}{l}\text { Catches (Staatkundig en } \\
\text { staathuishoudkundig jaarboekje) }\end{array}$ & $\begin{array}{l}\text { Gross revenues (Staatkundig en } \\
\text { staathuishoudkundig jaarboekje) }\end{array}$ & $\begin{array}{l}\text { Average value } \\
\text { per seal }\end{array}$ \\
\hline 1867 & & 6,500 & 60,670 & 9.33 \\
\hline 1868 & & 7,600 & 63,200 & 8.32 \\
\hline 1869 & & 4,234 & 35,900 & 8.48 \\
\hline 1870 & $\begin{array}{l}3,000 \text { young seals }+ \\
1,700 \text { adult seals }\end{array}$ & 4,677 & 40,600 & 8.68 \\
\hline 1871 & 1 fin whale & 7,524 & $\begin{array}{c}51,044 \\
(+3,000 \text { value of whales })\end{array}$ & 6.78 \\
\hline 1872 & 13 fin whales & 2,683 & $\begin{array}{c}27,860 \\
(+39,000 \text { value of whales })\end{array}$ & 10.38 \\
\hline 1873 & & 323 & 2,640 & 8.17 \\
\hline 1874 & & 1,440 & 13,360 & 9.28 \\
\hline 1884 & 7,ooo seals & & & \\
\hline Totals & $\begin{array}{l}25,000 \text { seals } \\
14 \text { whales }\end{array}$ & 63,480 & 570,220 & 8.98 \\
\hline $\begin{array}{l}\text { Average } \\
\text { per year }\end{array}$ & & 3,527 & 31,678 & \\
\hline
\end{tabular}

Brantjes seems to have done quite well, with an average annual revenue of about

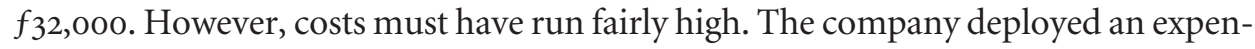
sive ship and ran a cookery in Purmerend. According to Jansen, the brig Maria - if purchased in or near Amsterdam - may have cost about f64,500. ${ }^{642}$ Moreover, the company employed expensive whaling and sealing experts from Norway. Owing to a lack of sources, numerical data regarding the total costs arising from Brantjes \& Smit's expeditions to northern waters cannot be provided. All one can do is present rough estimates. Based on data derived from Barend Visser \& Son regarding costs of crew in the 1850 and 1860 s, it seems fair to assume that Brantjes may have spent about $f 4,000$ on wages. The ship's annual depreciation may be calculated to have amounted to about $f 2,500$ (its value divided by 30 years of deployment in whaling and sealing). Insurances, overhead, and costs related to any layover in Norwegian harbours may have amounted to an additional $f 5,000$. If this hypothetical calculation has some merit at all it would mean that the company, with about $f_{11,500}$ in annual costs and $f_{32,000}$ in yearly revenues, made an estimated profit of roughly $f_{20}, 000$ per annum. With the highest catch figure of 63,480 seals, Brantjes \& Smit were probably responsible for about $40 \%$ (39.4\%) of the total seals killed by Dutch firms in Arctic waters between 1815 and 1884 (see Appendix 2). The company, it may be concluded, did extraordinarily well. ${ }^{643}$

642. Jansen, Industriële ontwikkeling, 287, table II.3.3. The deployment of a steamship may have caused a decrease in the profit.

643. As a result of the unique character of the catch, the value of the whales - amounting to an impressive $f_{42,000}$ for the years 1871 and 1872 combined - was not included in this calculation. 


\section{Nederlandsche Walvischvaart N.V.}

As there is some contemporaneous data concerning the value of oil and baleen, a similarly tangential analysis can be made regarding the activities of master Bottemanne and his whaling company Nederlandsche Walvischvaart N.V. in the early 1870 (see Table 7.13). This data was presented earlier (see Chapter 4, Table 8). As was done in the case of Brantjes \& Smit, the name of the master, the ship's name, its type, and destination were omitted and substituted with a rough estimate of the value of the catches. There is no data concerning the size of the crews and consequential costs. One fin whale represented a value of $f_{3}, 000$.

Table 7.13: Overview of costs and revenues of whaling expeditions to Iceland, fitted by the $\mathrm{Ne}$ derlandsche Walvischvaart N.V. (1870-1872). ${ }^{644}$

(Amounts are in $f$; rough estimates.)

\begin{tabular}{|c|c|c|c|c|c|}
\hline Year & $\begin{array}{l}\text { Costs of fitting out } \\
\text { auxiliary steam ship (A) }\end{array}$ & Catches & $\begin{array}{l}\text { Estimated revenues } \\
\text { (B) }\end{array}$ & $\begin{array}{l}\text { Net results } \\
\text { (B-A) }\end{array}$ & $\begin{array}{l}\text { Profits } \\
\%\end{array}$ \\
\hline 1870 & $\begin{array}{l}18,560 \text { to } 23,200 \\
{[\text { average }=20,980]}\end{array}$ & $\begin{array}{l}\text { one small fin whale, } \\
\text { yielding } 77^{1 / 2} \text { barrels of } \\
\text { oil, and } 250 \text { kilograms } \\
\text { of baleen }\end{array}$ & $\begin{array}{l}3,775 \\
(=3,100+675)\end{array}$ & $\begin{array}{l}-/-14,785 \\
\text { to } \\
-/-19,425\end{array}$ & $\begin{array}{l}-/-70.8 \\
\text { to } \\
-/-92.9\end{array}$ \\
\hline 1871 & $\begin{array}{l}18,560 \text { to } 23,200 \\
{[\text { average }=20,980]}\end{array}$ & $\begin{array}{l}\text { Thirteen whales } \\
\text { (species unspecified) }\end{array}$ & $\begin{array}{l}39,000 \\
\text { (in case of fin whales) }\end{array}$ & $\begin{array}{l}+/+15,800 \\
\text { to } \\
+/+20,440\end{array}$ & $\begin{array}{l}+1+75.6 \\
\text { to } \\
+1+97.8\end{array}$ \\
\hline 1872 & $\begin{array}{l}18,560 \text { to } 23,200 \\
{[\text { average }=20,980]}\end{array}$ & 'Some' whales & $\begin{array}{l}9,000 \text { to } 18,000 \\
\text { (based on the assump- } \\
\text { tion that 'some' refers } \\
\text { to more than three but } \\
\text { less than six thus an av- } \\
\text { erage }=13,500 \text { ) }\end{array}$ & $\begin{array}{l}-/-5,060 \\
\text { to } \\
-/-21,850\end{array}$ & $\begin{array}{l}-/-24.2 \\
\text { to } \\
-/-104.5\end{array}$ \\
\hline Totals & $\begin{array}{l}55,680 \text { to } 69,600 \\
{[\text { average }=62,640 \text { ] }}\end{array}$ & $14+$ ? whales & 51,775 to 60,775 & $\begin{array}{l}-/-17,825 \text { to } \\
+/+5,095\end{array}$ & $\begin{array}{l}-/-28.5 \text { to } \\
+/+8.1\end{array}$ \\
\hline
\end{tabular}

There is no information about the price the company paid when it acquired Noordkaper. The costs of fitting out the auxiliary steamship were based on calculations presented above. These calculations, however, referred to the season of 1874-1875, and not the years 1870-1872. ${ }^{645}$ Similarly, there is no information with regard to the size of the crews and their wages, although Bottemanne recruited his men in Scotland. These sealers and whalers were expensive experts in their respective fields, much the same as the Norwegians in the case of Brantjes. As data regarding overhead, insurances, and

644. Petermann, Mitteilungen (1867), 418, 420; Ten Brink, Europeesche Noordpool-visscherij, 7, 13-14; Bottemanne, 'Economische nalezingen en berigten', (1873), 344; De Jong, II, 484-486. Costs of fitting out are based on calculations for $1874 / 1875$ mentioned in note 638 .

645. Costs of fitting out are based on calculations for 1874-1875 mentioned in note 640 . 
other shipping-related costs were lacking, conclusions are based on one simple fact: despite his own experience, despite the strong financial basis on which he started his whaling adventure (a starting capital of $f 80,000$ ), and in spite of the expert crew he managed to recruit for his state-of-the art steamship, Bottemanne did not manage to conduct his expeditions for very long. Despite what seems to have been a reasonably good year (1871), the estimated value of catches, somewhere between $f_{51,000}$ and $f 61,000$, did not meet the investments made in the beginning. After three seasons the company went belly-up.

In an attempt to calculate overall expenditures, revenues, and profits or losses of all companies involved in Arctic whaling between 1815 and 1884, the results of the preceding tables are listed in Table 7.14. The figures in the columns reflecting total costs and total revenues were based on the averages of the figures presented in Tables 7.6 through 7.13. Consequently, the figure in the profit/loss column is an average as well.

Table 7.14: Overview of costs and revenues of Dutch whaling in the Arctic (1815-1884). (Amounts are in $f$.)

\begin{tabular}{|l|r|r|r|c|}
\hline Company & \multicolumn{1}{l|}{ losts } & \multicolumn{1}{l|}{ Revenues } & Profit/loss in $f$ & Profit/loss in \% \\
\hline Barend van Spreekens & $37,700.00$ & $42,470.00$ & $+/+4,770.00$ & $+/+12.6$ \\
\hline Jan Vas \& Company & $56,406.50$ & $49,525.00$ & $-/-6,881.50$ & $-/-12.2$ \\
\hline Sociëteit & $?$ & $245,816.93$ & - & - \\
\hline Barend Visser \& Son (II) & $15,639.00+?$ & $29,555.00$ & $+/+13,916.00$ & $+/+89.2$ \\
\hline Brantjes \& Smit ${ }^{646}$ & $230,000.00$ & $570,220.00$ & $+/+340,220.00$ & $+/+148$ \\
\hline Nederlandsche Walvischvaart N.V. & $62,640.00$ & $56,225.00$ & $-/-6,415.00$ & $-/-10.2$ \\
\hline Totals & $402,385.50$ & $993,811.93$ & & \\
\hline
\end{tabular}

Unfortunately, as a result of the lack of data regarding the costs the Sociëteit had to cover to conduct its operations, the profitability of Dutch whaling and sealing as a whole cannot be calculated.

\section{Conclusions}

In this chapter, two basic principles in entrepreneurship were analysed - costs and revenues - and applied to Dutch South Seas whaling and Arctic whaling and sealing. The completeness of the overviews of profitability was determined by the availability of crew lists, information about their wages, knowledge about the duration of voyages, data concerning catches, and estimated values of commodities (not only of whale and seal products, but also of the vessels deployed) at any given time during the period 1815-1885. Ideally, data regarding other expenses like no-

646. Figures referred to the period 1855-1874. 
taries, management, and overhead costs on shore should have been incorporated.

With regard to whaling voyages south of the equator, the lack of solid data prevented any definitive statements about profitability of Dutch South Seas whaling expeditions during the period 1827-1849. The analyses of data related to its northern counterpart were slightly more successful. A number of Arctic whaling companies were scrutinized in terms of numerical data regarding catches and prices. In this manner, it was hoped to state 'beyond reasonable doubt' whether or not nineteenth-century Dutch whaling and sealing was profitable. Too frequently, however, data was missing or conflicted with other sources of information.

For a number of companies, it was only possible to estimate total revenues. In the case of Barend Visser \& Son (I), the Groenlandse en Straatdavidse Visscherij Sociëteit, but also for Nicolaas Brantjes \& Smit, calculating the total expenditure was impossible. For three companies, however, plausible estimates of the annual (or total) costs and revenues were managed. These figures related to whaling and sealing activities conducted by Barend van Spreekens and Jan Vas \& Company during the years 18151825 (Tables 7.6 and 7.7). For later years, fair estimates pertaining to the activities of Barend Visser \& Son (II), for which crew lists have survived (1858-1863), were done. In all three instances, gains and losses varied widely. According to estimates calculated here, Van Spreekens' maximum loss amounted to $71.9 \%$ in 1815 , whereas the maximum gain reached an astounding $89.4 \%$ in 1819 . Similar extremes were discerned in the case of Jan Vas with an all-time low of $-78.4 \%$ in 1824 and an all-time high of $75.6 \%$ in 1823. Calculations regarding profitability of expeditions organised by Barend Visser \& Son showed unprecedented ranges in the level of profits. Interestingly, four out of six years were extremely lucrative (see Table 7.10). Brantjes \& Smit were also apparently very successful throughout the years of their involvement in sealing.

The Groenlandse en Straatdavidse Visscherij Sociëteit and Nederlandsche Maatschappij voor de Walvisvaart N.V., both specifically established for the purpose of resuming whaling and sealing, were hardly successful at all. Shareholders of the Sociëteit had to wait a long time before dividends were issued. At the end of it all they faced a disastrous devaluation of their stocks. Similar developments were witnessed in the case of the Rotterdam whaling company. Many of their shareholders must have realised that it would have been more profitable to put their money in the bank and receive interest than to invest in whaling.

Governmental financial support with bounties or premiums was of substantial significance to all parties involved. In Chapter 2 it was calculated that during the years 1822 through 1855 between $f_{200}, 000$ and $f 250,000$ was issued to subsidise whaling and sealing from Harlingen alone. Adding roughly $f_{30}, 000$ as the sum of all premiums paid to the company in Rotterdam (1825-1827), it may safely be stated that $f 250,000$ to $f_{300,000}$ was invested in support of these two companies - about half of the total 
sum of revenues for Nicolaas Brantjes \& Smit during the years 1855-1874 (about $f_{570,000)}$. This may be only the tip of the iceberg, as tens of thousands of guilders must be added for the sums paid during the 1820s, 1830s, and 1840s as premiums to Barend van Spreekens, Jan Vas \& Company, and so many other entrepreneurs involved in both Arctic and South Seas whaling.

For several companies whaling was not, nor did it ever become, their 'core business'. Barend Visser \& Son, Zeilmaker Company, but also the Purmerend-based firm of Nicolaas Brantjes all had vested interests in other maritime trades such as the timber trade with the Baltic, or the production of pottery. It is tempting to assume that this diversification of risk enabled these companies for a fair number of years to prolong their involvement in whaling and sealing - two maritime industries that were only seldom profitable and were, for so many, so difficult to conduct. 
06 hst 7 19-02-2008 14:06 Pagina 268 


\section{Summaries}

\section{Summary}

This study describes and analyses a wide array of initiatives leading to the hunt, by Dutch whalemen, of whales and seals in Arctic waters, the temperate zones of the South Pacific and the waters of the Dutch East Indies. After an introductory chapter, analyses were presented of the formal financial arrangement on which whaling and sealing expeditions were based. Thanks to the personal involvement of King Willem I from 1815 onward, most of these initiatives found fertile ground. The King and his ministers were instrumental in stimulating whaling and sealing expeditions. Not only did Willem I invest heavily in shares of the respective companies, his government, in accordance with the Koninklijk Besluiten (Royal Decrees) of 1815 and 1816, spent considerable amounts of money on fitting out ships and on financial guarantees in case ships returned empty or with disappointing catches (wanvangst). The total premium could amount to $f 9,000$ per ship per voyage, as compared to a modest $f_{500}$ per buis or hoeker setting sail for the herring fishery.

While discussing the governmental budget for 1850 members of Parliament (Tweede Kamer) brought to the fore that for the last several years prior to 1850 the annual subsidies for the herring fisheries amounted to $f_{200,000 .}{ }^{1}$ The total sum of subsidies related to whaling and sealing in the nineteenth century must have amounted

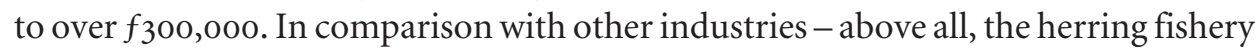
- governmental support for whaling cannot be considered impressive, that is, from the government's perspective. The fairly small-scale whaling companies, however, must have considered the investments to be substantial. As shown in Table 2.1, these premiums were paid almost systematically.

The King's personal commitment was not the only driving force behind winds of change. As of the early 1820 , political leaders in Europe became influenced by liber-

1. G. Pons, De bakens verzet. Een analyse van de Hollandse pekelharingvisserij met kielschepen in de periode 1814-1885 (n.p. 1996), 34 . 
alisation. They first reduced and eventually abolished import tariffs. The Netherlands followed their example. Around 1850, protectionism and mercantilism made way for a continent-wide accepted form of free market. In line with these global macroeconomic developments, the first signs of a reduced premium system for the Dutch whaling industry can be discerned in the early 1850 s. From 1851 onwards, successive announcements of Koninklijke Besluiten in the Staatscourant indicated a decreased inclination to support whaling and sealing financially. A substantial reduction was proclaimed in 1853. That year the premium was reduced no less than 50\% ("met vijftig ten honderd verminderd"). ${ }^{2}$

About one hundred years ago, D. Wanjon commented on the premium system for whaling and sealing as follows:

"Bij geen tak van industrie misschien heeft zich het gemis aan heldere begrippen op economisch gebied meer doen gevoelen dan hier [de visserij]. Het oude stelsel van bescherming en weldra ook van reglementeering van overheidswege heeft belet, dat de visscherij weer de goudmijn werd van vroeger. Omdat verschillende bepalingen in vroeger eeuwen goed werkten, toen wij de markt beheerschten, moesten dadelijk na 1813 die oude bepalingen weer ingevoerd worden, zonder dat men lette op de veranderde omstandigheden. [...] Kwam een walvisvaarder terug, zonder iets gevangen te hebben, dan beliep de premie niet minder dan $f_{9000}$; desniettemin is het bedrijf der walvischvangst geheel te gronde gegaan"

("In no other branch of industry did the lack of clear economic concepts have as severe consequences as here [the fisheries]. The traditional system of governmental protection and soon thereafter regulation has prevented the fishery from returning to its earlier status - goldmine. In earlier times, when we were in control of the market, certain regulations had worked very well; immediately after 1813, these old regulations were simply re-issued, without paying attention to the changed circumstances.... When a whaleship returned empty, the premium amounted to no less than $f_{9000}$; however, the whale fishery has completely disappeared"). ${ }^{3}$

In his statements Wanjon blamed the government for its financial support as, in his opinion, this support prevented the whaling industry from blossoming to its fullest. This statement may be too strong. Research has demonstrated that despite governmental support none of the Dutch whaling entrepreneurs felt inclined to modernise their fleet to meet new technological standards set by foreign competition. Most if not all entrepreneurs and ship owners held on to traditional values regarding the operational side of the two industries - whaling and sealing.

2. See for a series of Koninklijke Besluiten (KB) Staatscourant of 27 February 1851 (no. 77); 10 January 1852 (no. 16); 7 January 1853 (no. 51). These decrees were also announced in leading maritime journals. See for instance J. Swart (ed.), Verhandelingen en berigten betrekkelijk het Zeewezen en de Zeevaartkunde, vol. 6 (1853), 191-192.

3. D. Wanjon, Geschiedenis van den Nederlandschen handel sedert 1795 (Haarlem 1900), 65. 
The history of Dutch involvement in the South Seas whale fishery is characterised by trial and error. Despite the entrepreneurship among wealthy and influential individuals, the Dutch government did not develop a policy commensurate with the wishes and ambitions of these adventurous men. The determination of a handful of merchants and captains from Amsterdam and Rotterdam was tested. South Seas whaling was very different from Arctic whaling. Contrary to the voyages to East and West Greenland, expeditions to the Southern Hemisphere took many months, if not several years. Dutch whalemen had no expertise whatsoever in enduring these long-lasting whaling voyages. Their unfamiliarity with sperm whale fishery should be stressed as well. In several instances (in the case of the Nederlandsche Handel-Maatschappij (Dutch Trading Company), and in the case of the company of Reelfs Brothers, for example), the directors of the companies showed an interest in hiring expertise from abroad. Americans, but also British whalemen were hired to teach the ropes to Dutch sailors - without much financial success. More than once fighting broke out among the international crews.

The South Seas whaling adventures under the Dutch flag lasted only about two decades (1827-1849). During the 23-year period six expeditions were fitted out. There were six years during which no South Seas whaling expeditions sailed from Dutch harbours. As such, Dutch participation in South Seas whaling can be considered to have been a small-scale, yet financially intensive activity. Or, to put it less mildly, Dutch participation in South Seas whaling should be characterised as haphazard, scattered, overly expensive, and half-heartedly supported. Data regarding numbers of whales caught are lacking. The only data available are rather unimpressive numbers of barrels of oil and kilograms of baleen. ${ }^{4}$

In this respect the analysis of its northern counterpart - the Arctic whale fishery presents a picture of a more dynamic and fairly well-managed industry. Here, whaling and sealing were controlled and conducted by a small number of individuals or by stockholding companies. Individual entrepreneurs ruled not only in large urban communities like Amsterdam and Rotterdam, but also in smaller communities - in casu: the town of Harlingen - where entrepreneurs joined both forces and talents in order to establish relatively strong (though short-lived) whaling companies. During the 1802-1885 era, entrepreneurs organised 113 whaling and sealing expeditions to Jan Mayen Island, the Davis Strait, and Spitsbergen. They invested at least $f 400,000$ and the revenues amounted close to $f 1,000,000$. This study estimates that Dutch whalemen may have killed more than 100 whales and approximately 162,000 seals.

Dutch Arctic whaling entrepreneurs had most of their ships built in the Nether-

4. The total number of barrels of sperm oil and black oil, acquired in four long, and expensive whaling voyages equals the results of one successful American whaling voyage. 
lands. Only in a few instances was shipbuilding expertise from abroad imported into the realm of Dutch entrepreneurs, captains, and shipwrights. Dirkje Adema was built in Itzehoe, Germany, in 1800 and Noordkaper left the yard of Hornby Wellington in Tynemouth in 1869. Most of the other ships were constructed in Dutch yards. Compared with the average French whaleship of the 1830 ( 400 tons) or with the smallest and largest vessels in the American whaling fleet in 1849 ( 81 tons and 616 tons, respectively), the Dutch vessels were fairly small, measuring 250 to 350 tons. The Dutch started out with fluitschepen, later to be complemented with or replaced by pinken, brigs (251 to 256 tons), an occasional galliot, a frigate (349 tons), and one iron auxiliary steamship (150 tons). With the exception of this Noordkaper all ships used sails as their sole means of propulsion.

Throughout the nineteenth century, relatively small-sized Dutch whaleships roaming the Arctic grounds carried relatively large crews. Interestingly, the situation in many other countries like France, Germany, England, Scotland, and the United States, was the exact opposite, where larger ships carried smaller crews. Thus they were able to take on larger catches with less crew expense, probably resulting in greater profitability.

Crews sailing to the southern oceans were composed of several nationalities. British, American, and Dutch whalemen often worked side by side. Arctic whaleships operating from Amsterdam seem to have been manned by sailors of many different nationalities as well. Sailors from Germany, Scandinavia (Finland and Sweden), and a few from the United States were mentioned in the crew lists. Thus, the international crews mirrored Amsterdam's cosmopolitan character. Ships sailing from Harlingen carried almost exclusively local sailors who lived in or near Harlingen. Next to these Frisian crew members a fair number of Germans signed up for whaling voyages conducted from Harlingen. The number of whalemen from other regions in the Netherlands was very small.

Dutch whalemen seem to have enjoyed the living and working conditions in the whale fishery. In the crew lists of Dirkje Adema, for example, many names are repeated. In other words, a substantial portion of the crew did not sign up for just one expedition. They returned the following season to make another voyage to the Arctic grounds. In more than one instance were they accompanied by brothers.

Contrary to South Seas whaling, the Arctic whale fishery was seasonal. Ships left Dutch ports sometime in March or April, and returned in July or August. During the 1830 and 1840 s the whalemen initially sailed for Jan Mayen Island to hunt seals. Later in the season they proceeded to the north-western part of Spitsbergen to hunt whales. During the 1860 , whaling seems to have become of secondary importance as sealing had become the main industry.

Companies with ships and crew provided commodities that were purchased by 
clients. In the provincial archives in Leeuwarden data regarding auctions organised in Harlingen during the years 1831-1834 and 1838 shed light on these phenomena. An overwhelming majority of the clients at the local auctions came from Harlingen, its vicinity and Amsterdam. It may be assumed that the seal oil and whale oil, the baleen, the furs from seals and polar bears, and the waste products like tails and vinken were first transported to the cities, towns, and villages where the clientele ran their businesses. Additional research may broaden our horizon.

The sources at hand - the results of Harlingen auction sales for the period 18311834 and 1838 - give us at least some knowledge about the average value of one barrel of whale oil, one barrel of seal oil, one pound of baleen, and an individual seal pelt. This data is important for our understanding of the profits and losses in the whaling and sealing industries. When analysing their profitability, one must be aware that figures are scattered, far from trustworthy, or incompatible with other numerical data. Conclusions were drawn about profitability of the industries related to the voyages dating from the 1815-1825 era and both gains and losses seem to have been extremely high, making whaling and sealing an adventurous, if not extremely risky, field of investment for shareholders.

For a number of companies and merchants, whaling was something they conducted 'on the side'. In other words, they did not consider it their "core" business. Some of these companies had vested interests in other maritime trades like the timber trade with the Baltic region, or the wine trade with France and the Iberian Peninsula, thereby diversifying the risks of their operations. Other companies were specifically established for the sole purpose of conducting whaling and sealing, but they were hardly successful. Shareholders of the Groenlandse en Straatdavidse Visscherij Sociëteit in Harlingen had to wait a long time before dividends were issued. At the end of the day they faced a substantial devaluation of their stocks. There were similar developments in the case of the Rotterdam whaling company. Many shareholders must have realised at one point that it would have been more profitable to put money in a bank account and receive interest than to invest in whaling and sealing.

If this was the case, a fundamental question remains: why did entrepreneurs continue to invest time, energy, and money in whaling and sealing expeditions? Their motives seem to have been both social and economic. The revival of whaling and sealing meant employment for large cities (Amsterdam and Rotterdam) and, proportionally even more so, for much smaller communities (Harlingen). Highly indicative in this respect were the joyful announcements made by the Governor of Friesland upon the occasion of the continuation, in 1835, of whaling from Harlingen by the firm of Barend Visser \& Son.

Shortly after around 1855, the heyday of Dutch whaling appears to have ended. At the expense of whaling the seal hunt turned out to be more important. The numbers 
of ships deployed decreased, as did the number of entrepreneurs involved in the industries. As of about 1860, Dutch shipping and shipbuilding in general showed a downward trend that coincided with the one noted for whaling and sealing in particular. Around 1885 shipping and shipbuilding in the Netherlands had recovered from serious crises. The economic recovery was mainly initiated by booming developments on inland waterways. ${ }^{5}$ By that time, however, the days of Dutch whaling on the high seas had come to an end.

5. De Jonge, Industrialisatie in Nederland, 146-155. 


\section{Summary (Dutch)}

Over Nederlandse walvisvaart in de zeventiende en achttiende eeuw, maar ook over de grootschalige ontwikkelingen in de twintigste eeuw is relatief veel gepubliceerd. Uit de literatuur en bronnenonderzoek kan zo een beeld worden verkregen over de ontwikkelingen, bemanningen en technologische aanpassing voor die betreffende periodes. Over de tussenliggende periode is, afgezien van twee belangrijke, maar incomplete bijdragen bijzonder weinig steekhoudends geschreven.

Van oudsher hebben walvisvaarders hun walvissen en zeehonden gezocht in de Noordelijke IJszee, en dan vooral rond Spitsbergen en Groenland. Zo ook in de negentiende eeuw. Nieuwe vangstgronden vormden Nederlands-Indische wateren en de Stille Oceaan. Het verschil in walvisgronden - met baleinwalvissen in het hoge noorden en overwegend potvissen in het zuiden - had grote gevolgen voor de bedrijfsvoering en vangsttechniek. De Nederlandse Staat speelde een belangrijke rol bij het stimuleren van deelname aan beide bedrijfstakken.

Gedurende de zeventiende en achttiende eeuw is op grote schaal door Nederlanders gejaagd op walvissen, walrussen en zeehonden. Tot omstreeks 1750 hadden Nederlandse walvisvaarders de hegemonie. Hoezeer de ondernemingsgeest ook waarde door de burelen van reders en commandeurs, uiteindelijk moest de Nederlandse walvisvaart - zo lang zo superieur ten opzichte van de Franse, Duitse en Engelse - wijken voor de zwaar van regeringswege gesubsidieerde Engelse walvisvangst. De Engelse regering verschafte vanaf 1749 premies op gevangen walvissen en belastte de invoer op buitenlandse walvisproducten. Winstmarges werden aanmerkelijk kleiner, en de Nederlandse overheid hield zich afzijdig toen het ging om het geven van financiële prikkels. Pas vanaf 1777 stelt een door de Nederlandse regering in het leven geroepen Raad van Gecommitteerden der Groenlandsche en Straat Davissche Visscherij een premie beschikbaar van $f_{30}$,- voor elke opvarende van een walvisvaartschip. Binnenlandse onrust en diverse oorlogen te land en ter zee - met als dieptepunten de Vierde Engelse Oorlog (1781-1784) en de Napoleontische oorlogen - maakten dat het effect van deze financiële steun nauwelijks werd gevoeld. Omstreeks 1800 was van de eens zo glorieuze maritieme bedrijfstak bijna niets meer over.

Gedurende de negentiende eeuw kwamen in Nederland vele initiatieven los om de harpoen weer ter hand te nemen. Koning-Koopman Willem I heeft een belangrijke rol gespeeld bij het hernieuwen van belangstelling voor walvisvaart. Na zijn troonsbestijging toonde koning Willem I zich op vele terreinen van de nationale economie een grote instigator: keer op keer maakte de koning gemeenschapsgeld vrij - of tastte hij in zijn eigen beurs - om takken van nijverheid van de grond te krijgen, te stimuleren en nieuw élan te verschaffen. Scheepvaart was één van die terreinen. Met nimmer aflatende ijver bedacht de koning maatregelen om ondernemers te prikkelen 
tot het nemen van initiatieven. Bij Koninklijk Besluit van 12 januari 1816 werden premies ingesteld ten behoeve van de walvisvaart. Individuen of maatschappijen ontvingen vanaf dat moment tegemoetkomingen in de kosten van uitreding.

Deze premies bedroegen $2 \times f 2.000$ per uitgereed schip. Het eerste deel van het bedrag werd uitgekeerd bij vertrek, het tweede deel bij terugkeer. Bovendien - zo vloeide uit het KB voort - ontvingen ondernemers compensatie in het geval van 'wanvangst': wanneer een schip met tegenvallende vangstresultaten was teruggekeerd in de thuishaven. Op basis van verklaringen van door het Rijk aangestelde personen over de hoeveelheid traan die uit walvis- en robbenspek was gekookt werd de premie berekend. De compensatie bedroeg $f_{50}$,- per vat traan, waarbij 100 vaten als referentiepunt werd gehanteerd. Had een schip bijvoorbeeld zoveel spek van walvissen (en zeehonden) aangevoerd dat na het koken van de spek 34 vaten met traan konden worden gevuld, dan ontving de rederij c.q. eigenaar een compensatie van $100-34=66 \times f_{50}$ $=f 3.300$.

Vanaf het midden van de jaren 20 van de negentiende eeuw kwamen initiatieven op gang voor het bedrijven van walvisvaart in zuidelijke wateren. In Amerika en het Verenigd Koninkrijk was deze visserij al veel eerder gestart - met formidabele resultaten. Koopman Gerrit Boon uit Rotterdam was de eerste die met een uitgewerkt plan aanklopte bij koning en kabinet. In zijn Memorie en Concept-Plan tot oprichting van een Walvisch en Robben Visserij in de Zuid-Stille en Indische Zeeën ontvouwde Boon zijn idee: het uitrusten van een vloot van niet minder dan tien grote schepen, ieder met een bemanning van 70 à 80 personen. Hij berekende hiervoor $f 2$ miljoen nodig te hebben. Al wat hij kreeg was nul op rekest.

Boon was niet de enige die brood zag in deze nieuwe walvisvaart. Op verzoek van Willem I persoonlijk vatte de directie van de Nederlandsch Handel-Maatschappij het plan op ter walvisvaart te gaan. Het getuigt van visie dat de agent van de NHM in Amerika, P. Landberg, werd ingeschakeld om daar een walvisschip en bemanning te regelen. Via de firma John Howland \& Company in New Bedford wist Landberg de hand te leggen op het schip Logan (302 ton), gebouwd nabij deze stad. De ervaren commandeur Reuben F. Coffin van Nantucket kreeg het bevel over het door de NHM gehuurde schip. Coffin diende met het schip vanuit Amerika naar Rotterdam komen, daar de rest van de bemanning en victualiën aan boord te nemen, en vervolgens koers te zetten naar Nederlands-Indië en de Japanse Zee. Doordat het schip onder Amerikaanse vlag bleef varen verliep het recruteren van Nederlandse bemanning via de Kweekschool voor de Zeevaart in Amsterdam uiterst stroef.

Vroeg in 1827 vertrok de Logan uit Hellevoetsluis. Uiteindelijk kwam de Logan in juli 1830 - na een reis van $3^{1 / 2}$ jaar - aan in New York, waar de lading werd verkocht, en de bemanning afgemonsterd. Al met al is de reis voor de Maatschappij sterk verliesgevend geweest. Het idee om expertise van buiten te halen was uitstekend gezien 
de onbekendheid onder Nederlanders met de potvisjacht. Echter, op geen enkele wijze heeft de NHM geprobeerd - via het laten vervaardigen van een scheepsmodel bijvoorbeeld - de Amerikaanse scheepsbouwtechnische kennis vast te leggen.

$\mathrm{Na}$ het nogal desastreus verlopen avontuur van de NHM bleef het rondom walvisvangst in de Stille Zuidzee even stil in Nederland. In december 1832 ontving de regering een aanvraag voor subsidie van de Rotterdamse firma St. Martin \& Co. Kort daarvoor was door hen de Vereeniging tot Walvischvangst om de Zuid opgericht, met een via de emissie van aandelen verkregen startkapitaal van ongeveer $f_{50.000}$. In november was hun schip Eersteling onder bevel van de Groninger koopvaardijkapitein H.F. Horneman naar Batavia gezeild (aankomst september 1833). Al met al verbleef Horneman slechts anderhalve maand op de walvisgronden. Ondanks forse verliezen werd een tweede reis op touw gezet - dit maal met Amerikaanse officieren aan boord. Eersteling was ongeveer 20 maanden afwezig (augustus 1834-april 1836). De resultaten van de tweede expeditie waren aanmerkelijk gunstiger: de lading bracht na de veiling een winst op van $f_{34.000}$. Voor een derde expeditie was de Eersteling vervangen door het 15-jaar oude bombardeerkorvet Proserpina. Onder commandeur J.P. Smith maakte een gemêleerde bemanning van Amerikanen, Britten en Nederlanders een succesvolle reis.

Een laatste hoofdstuk in de geschiedenis van Nederlandse deelname aan de Zuidzeevisserij is geschreven door twee Duitsers met hun handelsfirma. Johann Anton en Johann Hayen Reelfs uit Heppens (nabij Oldenburg) hebben zich kort na 1815 in Amsterdam gevestigd. Aanvankelijk concentreerden zij zich op de handel met Suriname en Madeira. Aangemoedigd door de premies van de kant van de overheid begaven de gebroeders Reelfs zich op het terrein van de walvisvaart. In 1843 kwamen zij met een plan voor twee walvisvaartexpedities. Schepen werden voor veel geld aangekocht, en voor heel veel geld verbouwd tot walvisvaarders. Bemanning kwam grotendeels uit Schotland en Engeland. Verder waren er Nederlanders aan boord.

Al tijdens de eerste reis stapelden problemen zich op: bemanningsleden kregen ruzie, het schip Anna \& Louisa liep bij Ternate aan de grond, en verliezen waren groot. Koning Willem II schoot de gebroeders te hulp bij de aankoop van een tweede schip. Het eerder genoemde schip Proserpina werd aangeschaft, en vervolgens zeer grondig verbouwd. Onder de naam Zuidpool vertrok het schip in april 1845 onder bevel van commandeur Brunn naar Nieuw-Zeeland en Tasmanië. Tussen maart 1847 en juli 1849 deed de Zuidpool onder andere nog Honolulu, de baai van Kamchatka, weer Honolulu en San Francisco aan. Na 1849 is niets meer van schip of bemanning vernomen. Mogelijk heeft de Goldrush een grote aantrekkingskracht uitgeoefend. De gebroeders Reelfs lijken na deze twee uiterst kostbare mislukkingen hun leergeld te hebben betaald. Na 1850 is - voor zover bekend - geen Nederlands schip meer ter walvisvaart ten zuiden van de evenaar vertrokken. 
Walvisvaart in de Stille Zuidzee was voor Nederlanders een onbekende bedrijfstak. In ons land ontbrak de expertise. Deze moest worden aangevoerd vanuit het buitenland. Regelmatig is er sprake geweest van onlusten aan boord vanwege de diverse nationaliteiten. Schepen vertrokken vanuit Amsterdam en Rotterdam. Keer op keer geven de korte geschiedenissen van de maatschappijen die bij deze walvisvaart betrokken zijn geweest te zien dat enorme investeringen waren gemoeid met het aanpassen van schepen aan de onbekende, zware taak die hen wachtte. Bovendien is het boekhoudkundig gezien uiterst ingewikkeld om alle transacties en scheepsbewegingen goed te kunnen volgen. Uiteindelijk is het bij slechts 6 expedities gebleven, en gaven Nederlandse ondernemers liever de pijp aan walvisvaarders uit de VS of het Verenigd Koninkrijk.

Anders was het gesteld met de negentiende-eeuwse Nederlandse Arctische walvisvaart. De allereerste ondernemer in Nederland die brood zag in het door de koning ontwikkelde premiestelsel was de Amsterdamse koopman Barend van Spreekens. Onder zijn verantwoordelijkheid maakte de ervaren commandeur Jacob Broertjes tussen 1815 en 1819 vijf walvisvaartexpedities naar Groenland en Straat Davis. Vangstresultaten vielen sterk tegen. Slechts door toedoen van de overheidspremies - door Van Spreekens probleemloos ontvangen in 1815, 1816 en 1817 - kon het verlies nog enigszins worden opgevangen. Uiteindelijk beëindigde Van Spreekens in 1819 actieve deelname aan de walvisvaart.

In februari 1820 kocht de Wormerveerse koopman Jan Vas de walvisvaarder Groenland van Barend van Spreekens. Vanaf het prille begin van zijn walvisvaartactiviteiten had Vas contact gezocht met de invloedrijke Zaandammer Cornelis Claasz. Honig. Honig was koopman, moleneigenaar en erg actief lid van de doopsgezinde gemeente in Koog aan de Zaan. Tussen 1820 en 1825 zou de Groenland onder bevel van commandeur Frans Oom zes reizen naar Groenland en Straat Davis maken.

In totaal zijn in het Gemeentearchief in Amsterdam acht monsterrollen teruggevonden van de Groenland onder directie van Vas \& Co. Het betreft hier de zes walvisvaartreizen, en twee handelsexpedities naar Noorwegen en Nerwa. Deze laatste twee reizen zijn in 1826 gemaakt onder directie van de weduwe Jan Vas. Ook nu valt op dat de samenstelling van de bemanning veel overeenkomsten vertoont met die zoals gemonsterd door Barend van Spreekens. In totaal staan 270 namen in de rollen genoemd. Grote hoeveelheden zeelieden komen uit Noord-Duitsland (streek rond Oldenburg), maar ook komt een enkeling uit Finland, Stockholm of Gent. Onder Vas \& Co. was de Nederlandse walvisvaart succesvoller dan onder Van Spreekens. Niettemin waren de resultaten nog steeds bedroevend. Voor een aantal jaren biedt de Amsterdamsche Courant inzicht in de vangstresultaten. Na Jans dood (1824) is nog één reis naar het Noorden gemaakt.

Rond deze tijd meldden ondernemers uit Rotterdam zich op de gronden. In ja- 
nuari 1825 werd in de Maasstad de Nederlandsche Maatschappij voor Walvischvangst opgericht. Koning Willem I en het stadsbestuur besteedden enkele duizenden guldens aan aandelen. Tussen 1825 en 1827 voeren twee schepen uit: de Rotterdam en de Maasstroom. In 1825 en 1826 vertrok de Rotterdam naar Straat Davis. Beide keren kwam het schip leeg terug, en genoten de eigenaren dus de maximale premie van $f 9.000$ per reis. De Maasstroom was meer succesvol. Na een desastreus seizoen in 1825 keerde het schip in 1826 terug met 2.800 zeehondenvellen aan boord. De robbenslag had gunstig uitgepakt. Walvisvaart was echter op een fiasco uitgelopen. Eind 1827 werd het schip verkocht, en de maatschappij opgedoekt. De verliezen voor stad en koning waren groot: slechts $8 \%$ van de nominale waarde van de aandelen werd uitgekeerd!

Zonder twijfel hebben ondernemers uit Harlingen de grootste stempel gedrukt op aard en omvang van de Nederlandse walvisvaart in het onderhavige tijdvak. Al vanaf 1760 heeft de firma Barend Visser \& Zoon schepen ter walvisvaart uitgereed. Over die vroege periode is weinig bekend. Op de activiteiten van Barend Visser \& Zoon komt meer licht na de Franse Tijd. In 1822 kocht een aantal directeuren namens de firma de brig Spitsbergen. In 1822 en 1823 opereerde de Spitsbergen in Groenlandse wateren. In beide jaren diende de firma via het stadsbestuur te Harlingen aanvragen in voor ontvangst van premies bij de Staten van Friesland. Op last van de koning en zijn kabinet werden alle premies toegekend. De firma Barend Visser \& Zoon bedreef walvisvaart, maar was daarnaast bij nogal wat andere maritieme activiteiten betrokken. Zo had het bedrijf belangen in de houthandel vanuit Noorwegen, handelde de firma kwesties rond strandvonderij af, en droeg men zorg voor transport van voedingsmiddelen als graan, tarwe en rogge. Kortom: walvisvaart was geen 'core business'.

Daartoe aangezet door de redelijke vangstresultaten van Barend Visser \& Zoon besloot een aantal lokale notabelen over te gaan tot de oprichting van een gespecialiseerde maatschappij ter walvisvaart. Op 4 augustus 1824 bekrachtigde koning Willem I met een Koninklijk Besluit (KB) de oprichting van een dergelijke rederij. De oprichters publiceerden enkele weken later, op 30 september, een promotionele brochure om potentiële aandeelhouders over de streep te trekken. Op 1 januari 1825 schreef Harlingen geschiedenis met de officiële oprichting van de Groenlandse en Straatdavidse Visscherij Sociëteit. Een maand later, op 2 februari 1825, had de eerste aandeelhoudersvergadering plaats. Weer later, begin april, waren 433 aandelen verkocht. De Sociëiteit had dus $f 216.500$ op de bank staan als startkapitaal. In de stad was inmiddels de vereiste infrastructuur aangelegd. Er stond een traankokerij, De Herstelder. Bovendien had de maatschappij - nota bene van één der directeuren - onroerende goederen gekocht: een pakhuis met grote zolders en een enorme kelder, een schuur op de Zuidzijde, en een stuk grond van ongeveer 1500 vierkante meter naast de Westerkerk.

Echter, vanaf het prille begin was het met de walvisvaartactiviteiten van de So- 
ciëteit slecht gesteld. Omstreeks 1822 had de Harlinger scheepswerf van Johan Dirkszoon Alta de tweedekker pink Willem de Eerste gebouwd. Dit speciaal voor de walvisvaart gebouwde schip voer in 1825 uit ter walvisvaart en robbenslag. Vangsten vielen zwaar tegen. Op 21 september aanvaardde de ervaren commandeur Ymke Janszoon Ruygh, die voor deze reis drie zonen had meegenomen, de terugreis naar Nederland. Uiteindelijk moest de Sociëteit een zware tol betalen voor deze eerste reis onder haar vlag: van de 46 opvarenden verdwenen 31 personen tijdens een zware storm voor Kijkduin (bij Den Helder) in de golven. Onder de slachtoffers bevonden zich commandeur Ymke Janszoon Ruygh en zijn drie jongens.

Het jaar daarop reedde de maatschappij niet minder dan vier schepen uit: de in Itzehoe (Duitsland) gebouwde Nederland (later beter bekend geraakt als Dirkje Adema), de Spitsbergen, een nieuwe Willem de Eerste en het bij Alta in 1826 van de helling gelopen galjoot Harlingen. Op 23 augustus 1826 raakte de Harlingen onder bevel van commandeur Klaas Hoekstra vast in het ijs van Melville-baai in Baffin Bay. De nabijgelegen Engelse walvisvaarder Dundee, commandeur David Duncan, schoot Hoekstra en zijn mannen te hulp en bood hen onderdak. De Dundee kwam op een gegeven moment eveneens vast te zitten. De Nederlanders moesten toen het Engelse schip verlaten. Een barre tocht over poolijs, via Duitsers en Denen die zich in de kustgebieden van Groenland hadden gevestigd bracht hen uiteindelijk per schip naar Kopenhagen. Hiervandaan kwam Hoekstra een jaar na het vastraken in het ijs met een deel van zijn bemanning aan in Harlingen.

Ook in latere jaren heeft de Harlinger Sociëiteit te kampen gehad met grote problemen. Vangsten bleven tegenvallen. Niettemin getroostte de walvisvaartmaatschappij zich aanzienlijke financiële inspanningen om het bedrijf draaiende te houden. Nieuwe schepen werden gebouwd. Bovendien verschafte de overheid iedere keer weer forse premies voor uitredingen en wanvangsten, waardoor de Sociëiteit zich in ieder geval verzekerd wist van één vaste bron van inkomsten.

De slechte resultaten kunnen niet alleen worden geweten aan onervarenheid van de bemanningen. In de tijd dat de maatschappij walvisvaart bedreef speelde de Belgische afscheidingskwestie. Diverse keren spreken de bronnen over de grote negatieve invloed die de uit de kwestie voortgevloeide Frans/Engelse blokkade van Nederlandse havens en zeegaten op de scheepvaart en handel heeft gehad. Walvisvaart is sterk seizoensgebonden: het is daarom van het grootste belang dat schepen op tijd arriveren op de vangstgronden. Blokkades zorgden juist voor ernstige vertraging. Interne factoren speelden eveneens een rol. Aandeelhouders hadden sinds hun eerste inleg nog geen dividenduitkering ontvangen. Gemor was groot. Op 21 oktober 1834 had de laatste aandeelhoudersvergadering plaats. Tijdens die bijeenkomst werd besloten de Sociëteit op te heffen. Gebouwen, gereedschap en schepen werden verkocht. De twee schepen van de Sociëteit, Nederland en Spitsbergen (II), kwamen via een veiling in Am- 
sterdam op 26 januari 1835 voor bijna $f 24.000$ weer in handen van de firma Barend Visser \& Zoon.

Bij in dienststelling kreeg de in 1800 gebouwde Nederland de oorspronkelijke naam Dirkje Adema. Tot 1864 zou dit schip trouwe dienst verrichten. In dat jaar is Dirkje Adema aan Noorwegen verkocht. Een jaar later ging het schip in een storm voor het eiland Rügen verloren. Ook Spitsbergen (II) (gebouwd in 1828/29) wist nog betrekkelijk lange tijd deel te nemen aan het veeleisende walvisvaartbedrijf. In 1852 nam Barend Visser \& Zoon de Spitsbergen (II) uit de vaart.

Zonder twijfel is deze firma van alle maatschappijen die in de negentiende eeuw vanuit Nederlandse havens naar het Hoge Noorden zijn vertrokken het best gedocumenteerd. In gemeentelijke en provinciale archieven zijn talloze documenten aangetroffen die gezamenlijk een beeld geven van aard, organisatie en omvang van de walvisvaart en robbenslag. Door de aanwezigheid in het onuitputtelijke gemeentearchief te Harlingen van een aantal prachtige bronnen is een en ander bekend over de samenstelling en het opleidingsniveau van de bemanningsleden. Bovendien zijn in het buitenland journalen van veertien reizen bewaard gebleven. Ook zijn voor enkele jaren lijsten met resultaten van veilingen bewaard gebleven. Voor een aantal jaren (1831-1834, 1838) zijn via het notariële archief te Leeuwarden bovendien gegevens bekend over de opkopers van walvis- en zeehondenproducten als traan, balein, of vellen. De door hen betaalde bedragen zijn eveneens genoemd, zodat calculaties over inkomsten van maatschappijen kunnen worden gemaakt. Hoewel voor de genoemde jaren over het algemeen in Harlingen woonachtige kapitaalkrachtigen de meerderheid vormden, moet hier ook worden gewezen op de rol die Amsterdamse kooplieden bij de afname hebben gespeeld.

Verhoudingsgewijs is de firma succesvol geweest. Niet alleen zijn onder de vlag van de rederij bijna dertig jaar lang dezelfde twee schepen schepen naar Groenland en Straat Davis vertrokken. Afschrijvingen waren dientengevolge laag. De vangsten lagen over het algemeen relatief hoog. Bovendien heeft de Nederlandse overheid tot 1855 jaarlijks aanzienlijke bedragen aan premies en compensatie betaald, waardoor de financiële positie van de rederij vrij constant bleef.

Vergeleken met walvisvaart bedreven vanuit Duitsland, Frankrijk of Engeland zetten Nederlandse maatschappijen gedurende de gehele negentiende eeuw vrij kleine schepen in, met relatief grote bemanningen. Men zou verwachten dat dit verschijnsel alleen zou gelden voor de beginperiode, door onervarenheid met het bedrijf. Vreemd genoeg zien wij in de loop van de eeuw een groei in omvang van bemanningen, met een uitschieter in 1861, toen Dirkje Adema uitvoer met een bemanning van 55 koppen.

Ook over herkomst en opleidingsniveau van de bij de Harlinger walvisvaart betrokken zeelieden valt één en ander te zeggen. In tegenstelling tot de oude Nederlandse walvisvaart van de zeventiende en achttiende eeuw was het aantal buitenlanders onder de bemanningen zeer laag. Aan boord van de zo jammerlijk verloren gegane Har- 
lingen onder Klaas Hoekstra (1826) bevond zich één buitenlander: Harmen Treking uit Oldenburg. De overige 45 kwamen van de Waddeneilanden (Texel, Vlieland, Ameland), Den Helder en Harlingen. Monsterrollen van de Dirkje Adema zijn bewaard gebleven voor de periode 1858-1863. Duidelijk blijkt dat ook in de nadagen van de Harlinger walvisvaart het bedrijf niet alleen aan de wal, maar ook aan boord door Friezen werd gerund. Sporadisch komen niet-Friezen èn buitenlanders voor in de lijsten (zie Appendix 4). Wel zijn voor nogal wat jaren commandeurs uit het buitenland gerekruteerd. Het Duitse Waddeneiland Föhr was geboorteplaats voor vader en zoon Hendrick en Hendrick Braren Rickmers. Deze heren hebben jaren achtereen de firma Barend Visser \& Zoon gediend.

Uit correspondentie tussen maatschappijen en stadsbestuur, maar ook uit de jaarlijkse rapporten van de gouverneur van deze provincie zijn grotendeels vangstresultaten gedestilleerd. Op basis van calculaties waarbij kosten voor schepen, uitrusting en bemanningen zijn afgezet tegen vangstresultaten en veilingopbrengsten lijkt het gerechtvaardigd te concluderen dat walvisvaart en robbenslag voor Friese ondernemers niet erg rendabel is geweest. Niettemin hebben enkelen het erg lang volgehouden. Voor deze personen of firma's - Barend Visser \& Zoon en de firma Zeilmaker - was walvisvaart slechts een van vele activiteiten: risico's of tegenvallende resultaten in deze bedrijfstak konden kennelijk worden opgevangen door de handel in hout, graan of andere producten.

Na 1850 kwamen ook weer in Noord-Holland initiatieven los voor de organisatie van walvisvaart expedities. Tot in het midden van de negentiende eeuw verdiende Nicolaas Brantjes (1793-1862) te Purmerend zijn geld met het redersbedrijf, met handel in walvistraan, en met de houthandel vanuit Noorwegen en het Oostzeegebied. Vanaf het begin van de jaren 1850 raakte Brantjes bij walvisvaart en - vooral - robbenslag betrokken. In 1851 vertrok zijn schip Martha naar Jan Mayen voor robbenslag. In 1854 volgde het tweede schip, Maria. Het moment waarop Brantjes besloot zijn eerste stappen te zetten in deze bedrijfstak was slecht getimed: juist in deze jaren besloot de Nederlandse overheid de subsidies stop te zetten. De kosten voor de ondernemer namen navenant toe.

Niettemin maakte de firma het beste van de situatie. Zoals blijkt uit het overzicht waren de vangstresultaten van de robbenjacht indrukwekkend. Voor de jaren waarover gegevens zijn teruggevonden liggen de aantallen op enkele duizenden per seizoen. Brantjes had zijn eigen traankokerij nabij Purmerend, langs het Noordhollands Kanaal. Tot ongeveer 1875 is deze kokerij in gebruik geweest. In dat jaar bleef Maria - na een drietal uiterst teleurstellende seizoenen - in de haven van het Noorse Tønsberg achter. Tegenover A.J. ten Brink, leraar aan de HBS in Enkhuizen en pleitbezorger van de Nederlandse walvisvaart, verklaarde Brantjes dit gebrek aan succes als volgt: 
"De enige reden hiervan ligt ook volgens hem [Brantjes] in de onmogelijkheid om tegenwoordig met zeilschepen te visschen, daar de stoomschepen veel eerder en dieper in de ijsvelden kunnen doordringen. ${ }^{6}$

Inmiddels was door het inzetten van Noorse bemanningsleden en het laten overwinteren van de vloot in Tønsberg en Sandefjord, de Nederlandse walvisvaart en robbenslag veel minder 'Nederlands' geworden. De schepen voeren nog wel onder $\mathrm{Ne}$ derlandse vlag, en brachten hun vangsten naar de kokerij bij Purmerend - om daarna de Noorse havens op te zoeken voor de winter. In 1884 maakte Maria de laatste reis naar het Noorden. Het schip bracht niet minder dan 7.000 zeehonden terug. Totale inkomsten werden geschat op $f 70.000$. In totaal heeft Brantjes in de bijna dertig jaar dat zijn firma zich ook had toegelegd op walvisvaart en - vooral zeehondenjacht ruim 63.000 van deze dieren gevangen. Dit is ongeveer $40 \%$ van het geschate totaal aantal gedode zeehonden.

Tot het laatste moment had Brantjes gebruik gemaakt van een brik, een zeilschip van 265 ton. Door allerhande technologische ontwikkelingen waren vele buitenlandse concurrenten - de Noren voorop - al vanaf het midden van de jaren 1860 overgegaan tot het inzetten van stoomschepen. Hierdoor konden de jagers vroeger op de vangstgronden arriveren, een langer seizoen maken, dieper in het ijs komen, gemakkelijker nieuwe gronden exploreren, en natuurlijk veel sneller terugkeren in de thuishaven. Brantjes moest niets van deze vernieuwingen hebben. Zo werd uiteindelijk nieuwe spek in verouderde vaten aangeleverd, waardoor na enkele decennia de firma zich uit de walvisvaart terugtrok.

De laatste in de betrekkelijk lange reeks van personen die betrokken zijn geweest bij de herleving van de Nederlandse walvisvaart was Casper Josephus Bottemanne. Gedurende zijn vaartijd in Nederlands-Indië zag Bottemanne vele Amerikaanse walvisvaarders de potvisjacht bedrijven. Mogelijk is in die jaren zijn belangstelling gewekt. In 1865 zeilde hij met de schoener Jan \& Albert naar een walvisvangststation in de Seydisfjördur op IJsland. Dit station werd gerund door de Amerikanen Thomas Welcome Roys en G. Lilliendahl. Tussen 1866 en 1869 was Bottemanne in dienst van deze heren, en leerde hij het klappen van de zweep kennen. In 1869 benaderde de Nederlandse regering hem met het verzoek een walvisvaartmaatschappij naar Amerikaans model op te richten. Na een voorlichtingsbijeenkomst in Rotterdam haalde Bottemanne f20.000 op, genoeg om als startkapitaal te dienen voor de Nederlandsche Walvischvaart N.V. Rotterdamse captains of industry Hendrik Veder en H. van Vollenhove waren directeuren, Bottemanne was bedrijfsleider.

Pogingen van Bottemanne om samen te werken met Brantjes en Smit in Pur-

6. A.J. ten Brink, Blik op den hedendaagschen toestand der Europeesche Noordpool-Visscherij (Enkhuizen 1876), 33 . 
merend liepen op niets uit. Datzelfde jaar kocht de maatschappij bij de werf van Hornby Wellington in Tynemouth, nabij Newcastle, het zeilschip met stoomvermogen Noordkaper. Het 150 ton metende schip werd voortgestuwd door een motor van 70 PK. Uniek waren de twee ovens aan boord, waardoor ook op volle zee spek tot traan kon worden verwerkt.

In totaal maakte Noordkaper drie reizen naar IJsland. In 1870 werd een kleine vinvis gevangen. Twee walvissen waren gedood, maar gingen verloren. In 1871 was men - met een grotendeels Schotse bemanning - meer succesvol met een vangst van dertien walvissen (ook zijn er dertien verloren). Voor 1872 zijn geen gegevens beschikbaar. In december 1872 werd de maatschappij opgeheven.

Arctische walvisvangst en robbenslag zijn vanuit Amsterdam, Rotterdam, Wormerveer, Purmerend, en Harlingen bedreven. Vooral die laatste plaats heeft in de negentiende-eeuwse Nederlandse walvisvaart een cruciale, leidende rol gespeeld. Niet alleen zijn bijna een halve eeuw lang, tussen 1815 en 1864, onafgebroken diverse ondernemers betrokken geweest bij de walvisvaart en robbenslag. Tot 1853 werden jaarlijks werden minstens twee schepen uitgereed, met uitschieters naar vier ten tijde van de Groenlandse en Straatdavidse Visscherij Sociëiteit. Met deze aantallen - hoe gering zo op het eerste gezicht dan ook - wist Harlingen een absolute koppositie te bekleden. Dit gold eveneens voor wat betreft het aantal gedode walvissen en zeehonden.

In tegenstelling tot de walvisvaart zoals die vanuit Amsterdam en Wormerveer werd georganiseerd was de Friese walvisvaart en robbenslag meer provinciaal of zelfs lokaal van aard: veel bemanningsleden kwamen uit Harlingen, of dorpen in de directe nabijheid.

Vanaf 1816 tot 1855 heeft de Nederlandse overheid de walvisvaart met aanzienlijke bedragen gesteund. In 1855 maakte de liberale minster-president J.R. Thorbecke een eind aan de subsidiëring. In totaal is tussen 1822 en 1855 alleen al aan Friese ondernemers tussen $f_{200.000 ~ e n ~} f_{250}$.000 aan premie uitgekeerd. Deze premies maakten dat het ondernemersrisico doorgaans gering was. Bovendien konden ondernemers met hun schepen werkgelegenheid creëren in het door de Franse bezetting economisch zo uitgeholde land. Vooral voor een kleine plaats als Harlingen (en omliggende dorpjes) mag de sociale rol die walvisvaartreders hebben gespeeld niet worden onderschat. Op basis van berekeningen kan worden gesteld dat vanuit financieel-economisch oogpunt bezien walvisvangst en robbenslag uiterst grillige bedrijfstakken lijken te zijn geweest. Grote verliezen konden worden gecompenseerd met grote winsten. Ruwe schattingen geven aan dat tussen 1802 en 1885 ten behoeve van 113 walvisvaart en robbenslag expedities in de Noordelijke IJszee minstens $f 400.000$ aan investeringen zijn gedaan, terwijl de opbrengsten op basis van de voor handen zijnde gegevens worden geschat tenminste bijna $f_{1}$ miljoen te hebben bedragen. In de periode zijn ruim 100 walvissen gevangen, en 162.000 zeehonden gedood. 
Uiteindelijk lijkt de conclusie gerechtvaardigd dat zowel de walvisvangst in de Stille Zuidzee als die in de Noordelijke IJszee tot stilstand is gekomen door conservatisme onder reders. Lang, zeer lang gebruikte men houten zeilschepen, en voer men naar van oudsher bekende walvisvaartgronden. In tegenstelling tot ontwikkelingen in het omringende buitenland (Schotland, Engeland, Duitsland, Noorwegen) werd in Nederland stoom als middel voor voorstuwing niet ingezet bij de vangst. C.J. Bottemanne was de enige die omstreeks 1870 daadwerkelijk de noodzaak inzag van technologische vernieuwing: hij stond hierin echter alleen. 


\section{Zusammenfassung \\ (translated from the English summary by drs Barend Verkerk)}

Diese Doktorarbeit beschreibt und analysiert eine ganze Reihe von Initiativen, die zum Wal- und Robbenfang in den arktischen Gewässern, den gemäßigten Zonen des Südpazifiks und in den Gewässern von Niederländisch Indien geführt haben. Nach einem einführenden Kapitel wurden die formalen finanziellen Regelungen, die den Wal- und Robbenexpeditionen zu Grunde lagen, analysiert. Dank der persönlichen Beteiligung des Königs Willem I. vom Jahre 1815 an, fielen die meisten dieser Initiativen auf einen fruchtbaren Boden. Der König und seine Minister waren an der Förderung der Wal- und Robbenfangexpeditionen maßgeblich beteiligt. Nicht nur investierte Willem I. viel Geld in Aktien der betreffenden Firmen, auch seine Regierung gab, den Koninklijke Besluiten (Königlichen Beschlüssen) aus den Jahren 1815 und 1816 entsprechend, ansehnliche Beträge aus für die Ausrüstung der Schiffe und für finanzielle Entschädigung, falls Schiffe leer oder mit einem enttäuschenden Fangresultat (wanvangst) zurückkehrten. Die Gesamtprämie konnte sich auf eine Summe von $f_{9000}$ pro Schiff pro Fahrt belaufen, dagegen nur eine bescheidene Summe von $f_{500}$ je buis oder hoeker, die für den Heringsfang ausfuhren.

Die Gesamtsumme der Förderbeträge des Wal- und Robbenfangs im neunzehnten Jahrhundert muss sich wohl auf mehr als $f_{300}$.ooo belaufen haben. Im Vergleich zu anderen Wirtschaftszweigen - besonders dem Heringsfang - kann man die Unterstützung des Walfangs durch die Regierung nicht als beeindruckend betrachten, das heißt aus dem Blickwinkel der Regierung gesehen. Die verhältnismäßig kleinen Walfangunternehmen dahingegen haben die Investierungen wohl als beträchtlich angesehen. Wie aus Tafel 2.1 ersichtlich, wurden diese Prämien in fast regelmäßigen Abständen ausgezahlt.

Während der Haushaltsverhandlungen für das Jahr 1850 bringen die Abgeordneten des Parlaments (Tweede Kamer) vor, dass in mehreren 1850 vorangehenden Jahren die alljährlichen Subventionen für den Heringsfang sich auf $f_{200,000}$ beliefen. ${ }^{7}$

Der persönliche Einsatz des Königs war nicht die einzige treibende Kraft hinter den Winden der Veränderung. Etwa ab den frühen zwanziger Jahren des 18. Jahrhunderts kamen die europäischen Politiker auf den Gedanken der Handelsfreiheit. Zuerst schraubten sie die Einfuhrzölle zurück und hoben sie schließlich auf. Die Niederlande folgten ihrem Beispiel. Um 1850 schafften die Schutzzollpolitik und der Merkantilismus freie Bahn für eine gesamtkontinentale anerkannte Form von freier Marktwirtschaft. Im Einklang mit diesen weltweiten makrökonomischen Entwick-

7. G. Pons, De bakens verzet. Een analyse van de Hollandse pekelharingvisserij met kielschepen in de periode 1814-1885 (n.p. 1996), 34. 
lungen gibt es erste Anzeichen einer Reduzierung des finanziellen Förderungssystems für die niederländische Walfangindustrie zu verspüren in den ersten Jahren ab 1850. Ab 1851 deuteten aufeinanderfolgende Bekanntmachungen der Koninklijke Besluiten in der Staatscourant auf eine verringerte Tendenz zur finanziellen Unterstützung des Wal- und Robbenfangs hin. Im Jahre 1853 wurde eine erhebliche Reduzierung angeordnet. In diesem Jahr wurde die Prämie sogar um 50 \% reduziert ("met vijftig ten honderd verminderd"). ${ }^{8}$

Vor hundert Jahren etwa gab D.Wanjon den nun folgenden Kommentar zu dem Prämiensystem für den Wal- und Robbenfang:

"Bij geen tak van industrie misschien heeft zich het gemis aan heldere begrippen op economisch gebied meer doen gevoelen dan hier [de visserij]. Het oude stelsel van bescherming en weldra ook van reglementeering van overheidswege heeft belet, dat de visscherij weer de goudmijn werd van vroeger. Omdat verschillende bepalingen in vroeger eeuwen goed werkten, toen wij de markt beheerschten, moesten dadelijk na 1813 die oude bepalingen weer ingevoerd worden, zonder dat men lette op de veranderde omstandigheden. [...]. Kwam een walvisvaarder terug, zonder iets gevangen te hebben, dan beliep de premie niet minder dan $f_{9000}$; desniettemin is het bedrijf der walvischvangst geheel te gronde gegaan"

("In keinem anderen Industriezweig vielleicht ist der Mangel an klaren wirtschaftlichen Auffassungen mehr spürbar gewesen als hier [die Fischereiwirtschaft]. Das alte System von Staatsschutz und allmählich von Regulierung seitens der Obrigkeit hat verhindert, dass die Fischerei wieder, wie früher, zu einer Goldgrube wurde. Da mehrere Regelungen in vorangehenden Jahrhunderten sehr gut funktionierten, als wir den Markt beherrschten, mussten gleich nach 1813 diese alten Regelungen neu eingeführt werden, ohne jedoch die geänderten Umstände im Auge zu behalten. Wenn ein Walschiff leer zurückkehrte, betrug die Prämie nicht weniger als $f_{9000}$; trotzdem ist die Walfangwirtschaft völlig zu Grunde gegangen"). ${ }^{9}$

In seinen Aussagen warf Wanjon der Regierung vor, die Walfangwirtschaft finanziell unterstützt und dadurch, nach seiner Auffassung, deren volle Blüte verhindert zu haben. Diese Aussage dürfte nicht zutreffen. Forschung hat ergeben, dass trotz der Unterstützung seitens der Regierung keiner der niederländischen Walfangunternehmer sich veranlasst gesehen hat, seine Flotte zu modernisieren und sie auf den durch ausländische Konkurrenz vorgegebenen neuesten technologischen Stand zu bringen. Die meisten, wenn nicht alle Unternehmer und Reeder, hielten fest an herkömmlichen Ansichten hinsichtlich der betriebswirtschaftlichen Durchführung der beiden Industriezweige.

8. Siehe für eine Reihe von Koninklijke Besluiten (KB) Staatscourant vom 27. Februar 1851 (Nr. 77); 10. Januar 1852 (Nr. 16); 7. Januar 1853 (Nr. 51). Diese Beschlüsse wurden auch in führenden maritimen Zeitschriften veröffentlicht. Siehe zum Beispiel J. Swart (Hrsg.), Verhandelingen en berigten betrekkelijk het Zeewezen en de Zeevaartkunde, Bd. 6 (1853), 191-192.

9. D. Wanjon, Geschiedenis van den Nederlandschen handel sedert 1795 (Haarlem 1900), 65. 
Die Geschichte der niederländischen Beteiligung an dem Walfang in südlichen Meeren wird durch Prüfungen und Fehlschläge gekennzeichnet. Trotz des Unternemertums unter vermögenden und einflussreichen Privatpersonen entwickelte die niederländische Regierung keine Strategie, die den Wünschen und Ambitionen dieser abenteuerlichen Menschen entsprach. Die Entschlossenheit einiger weniger Kaufleute und Kapitäne aus Amsterdam und Rotterdam wurde auf die Probe gestellt. Walfang in südlichen Meeren war in bedeutendem Maße anders als der arktische Walfang. Im Gegensatz zu den Fahrten nach Ost- und West-Grönland dauerten Expeditionen in die südliche Hemisphäre viele Monate. Niederländische Walfänger hatten überhaupt keine Erfahrung, diese längeren Walfangfahrten auszuhalten. Auch die Tatsache, dass sie mit dem Pottwalfang nicht vertraut waren, muss hier betont werden. Bei mehreren Gelegenheiten [im Falle der Nederlandsche Handel-Maatschappij (Niederländische Handelsgesellschaft) und im Falle der Reelfs Brothers zum Beispiel] haben die Direktoren der Firmen Interesse daran gezeigt, Expertise aus dem Ausland anzuwerben. Amerikanische, aber auch englische Walfänger wurden angeheuert, um den niederländischen Seeleuten die Kniffe des Fachs beizubringen - ohne bedeutenden finanziellen Erfolg. Mehr als einmal hat es Schlägereien unter der internationalen Schiffsbesatzung gegeben.

Die Walfangabenteuer in den südlichen Meeren unter niederländischer Flagge dauerten etwa zwei Jahrzehnte (1827-1849). In einer Periode von 23 Jahren wurden sechs Expeditionen ausgerüstet. Sechs Jahre hat es keinerlei Walfangexpeditionen aus niederländischen Häfen gegeben. Die niederländische Beteiligung am Walfang in südlichen Meeren muss also an und für sich als gering angesehen werden, dabei aber war es eine finanziell intensive Aktivität. Wenn man so will, kann man es auch etwas schärfer formulieren: das niederländische Walfangunternehmen muss gekennzeichnet werden als willkürlich, unregelmäßig, viel zu teuer und zudem wurde es kaum unterstützt. Daten zu der Anzahl gefangener Wale fehlen, nur Daten zu einer nicht sehr beeindruckenden Anzahl von Fässern mit Öl und Kilos Fischbein liegen vor. ${ }^{10}$

In dieser Hinsicht zeigt die Analyse des nördlichen Gegenstücks - die arktische Walfischerei - uns das Bild eines dynamischeren, ordentlich geführten Wirtschaftszweigs. Hier wurden Wal- und Robbenfang beherrscht und betrieben von einer kleinen Anzahl von Einzelpersonen oder von Firmen die zugleich Aktionäre waren. Individuelle Unternehmer hatten das Sagen nicht nur in den großen städtischen Gemeinden wie Amsterdam und Rotterdam, sondern auch in kleineren Gemeinden wie - in casu: der Stadt Harlingen. Hier taten die Unternehmer mit ihren Kräften und Talenten sich zusammen zur Gründung verhältnismäßig starker (wiewohl kurzlebiger)

10. Die Gesamtzahl an Fässern mit Walratöl und Tran, erworben auf vier langen, Geld verschlingenden Walfangexpeditionen entspricht dem Ertrag eines einzigen amerikanischen Walfangschiffs. 
Walfangfirmen. Im Zeitraum zwischen 1802 und 1885 organisierten die Unternehmer 113 Wal- und Robbenfangexpeditionen zu der Insel Jan Mayen, zur Davis Strait und Spitzbergen. Sie investierten mindestens $f 400.000$ und die Einnahmen betrugen nahe an die f1.000.00o. Nach meinen Schätzungen dürften niederländische Walfänger etwa 100 Wale und zirka 162.00o Robben erlegt haben.

Niederländische Walfangunternehmer ließen die meisten ihrer Schiffe in den Niederlanden bauen. Es gibt nur einige Beispiele dafür, dass in das Reich der Firmeneigentümer, Kapitäne und Schiffsbauer, Schiffsbauexpertise aus dem Ausland zugelassen wurde. Die Dirkje Adema wurde 1800 in Itzehoe (Deutschland) gebaut und die Noordkaper wurde 1869 bei Hornby in Tynemouth (England) vom Stapel gelassen. Die meisten Schiffe wurden auf niederländischen Werften gebaut. Im Vergleich zum üblichen französischen Walschiff aus den dreißiger Jahren des 18. Jahrhunderts. (400 Tonnen) oder zu den kleinsten und größten Schiffen in der amerikanischen Walfangflotte aus dem Jahre 1849 ( 81 bzw. 616 Tonnen) waren die niederländischen Schiffe mit ihren 250 bis 350 Tonnen ziemlich klein. Die Niederländer fingen an mit fluitschepen, später ergänzt oder ersetzt durch pinken, Briggen (251 bis 256 Tonnen), mal eine Galione, eine Fregatte (349 Tonnen) und ein eisernes Hilfsfahrzeug, ein Dampfschiff (150 Tonnen). Mit Ausnahme dieser Noordkaper waren all diese Schiffe nur mit Segeln zum Antrieb ausgerüstet.

Während des ganzen neunzehnten Jahrhunderts hatten verhältnismäßig kleine niederländische Walschiffe die die Arktis durchquerten verhältnismäßig viel Besatzung an Bord. Interessanterweise war die Situation in vielen anderen Ländern wie Frankreich, Deutschland, England, Schottland und den Vereinigten Staaten genau das Gegenteil: größere Schiffe hatten eine kleinere Besatzung. So konnten sie einen gröBeren Fang mit weniger Ausgaben für die Besatzung erzielen, wahrscheinlich mit einem größeren Gewinn als Ergebnis.

Bemannungen, die zu den südlichen Ozeanen fuhren, setzten sich zusammen aus verschiedenen Nationalitäten. Britische, amerikanische und niederländische Walfänger arbeiteten oft nebeneinander. Schiffe aus Amsterdam, die in die Arktis segelten, hatten wahrscheinlich auch eine sehr international zusammengesetzte Besatzung. Seefahrer aus Deutschland, Skandinavien (Finnland und Schweden) sowie einige aus den Vereinigten Staaten wurden in den Mannschaftslisten verzeichnet. Diese internationalen Bemannungen widerspiegelten den kosmopolitischen Charakter von Amsterdam. Schiffe aus Harlingen hatten fast ausschließlich Seeleute an Bord, die entweder in Harlingen oder in der Nähe wohnten. Neben diesen friesischen Besatzungsmitgliedern meldete sich eine beträchtliche Anzahl von Deutschen für die Walfangfahrten an, die von Harlingen aus unternommen wurden. Die Zahl der Walfänger aus anderen Gegenden in den Niederlanden war sehr gering.

Niederländische Walfänger hatten offenbar ihren Gefallen an den Lebens- und 
Arbeitsbedingungen in dem Walfangbetrieb. In den Mannschaftslisten der Dirkje Adema, zum Beispiel, findet man wiederholt die gleichen Namen. Mit anderen Worten, sie kehrten in der nächsten Saison wieder, um noch einmal in die Arktis abzufahren. In mehr als einem Fall schlossen sich Brüder zusammen an.

Im Gegensatz zu dem Walfang in südlichen Meeren, war der arktische Walfangbetrieb saisonabhängig. Die Schiffe liefen irgendwann im März oder April aus den niederländischen Häfen aus und kehrten im Juli oder August zurück. Während der 30er und 40-er Jahre des 18. Jahrhunderts segelten die Walfänger zur Insel Jan Mayen, um dort auf Robben zu jagen. Später in der Saison fuhren sie weiter zum nordwestlichen Teil Spitzbergens, um dort auf Wale zu jagen. Während der Jahre nach 1860 hat anscheinend der Walfang allmählich die Zweitstelle eingenommen hinter dem immer wichtiger werdenden Robbenfang.

Unternehmen mit Schiffen und Bemannung lieferten Bedarfsgüter, die von Kunden abgekauft wurden. Im Landesarchiv zu Leeuwarden gibt es Daten von Versteigerungen, die in Harlingen während der Jahre 1831-1834 und 1838 organisiert wurden. Sie geben Aufschluss über dieses Phänomen. Die überwältigende Mehrheit der Kunden bei diesen lokalen Versteigerungen kam aus Harlingen oder der nahen Umgebung und aus Amsterdam. Man kann in etwa annehmen, dass das Öl von Robben und Walen, das Fischbein, das Pelzwerk von Robben und Eisbären und die Abfallprodukte wie Schwänze und vinken zuerst in die großen und kleinen Städte und Dörfer transportiert wurden, wo die Kundschaft ihre Geschäfte betrieb. Weitere Forschung kann unseren Horizont vielleicht noch erweitern.

Die vorliegenden Quellen - die Verkaufsergebnisse der Harlinger Versteigerungen der Periode 1831-1834 und 1838 - lassen uns zumindest einigermaßen bekanntwerden mit dem Durchschnittswert eines Fasses mit Walöl oder Robbenöl oder von einem Pfund Fischbein oder eines einzigen Robbenpelzes. Diese Daten sind wichtig, um verstehen zu können, welche Renditen und Verluste die Wal- und Robbenfangindustrie erbrachte. Beim Analysieren deren Ertragslage muss man erkennen, dass das Zahlenmaterial mangelhaft ist, nicht sehr zuverlässig oder im Widerspruch zu anderen Zahlenangaben. Schlüsse wurden gezogen über die Rentabilität der Industriezweige, die mit den Fahrten der Jahre 1815-1825 zusammenhängen. Sowohl Gewinne als Verluste waren anscheinend außerordentlich groß, und dadurch wurde der Walund Robbenfang zu einem abenteuerlichen, wenn nicht gar extrem riskanten Investierungszweig für Aktionäre.

Für eine Anzahl von Firmen und Kaufleuten war der Walfang etwas, das man 'nebenbei ' betrieb. Mit anderen Worten, man hat es nicht als ihr Kerngeschäft angesehen. Einige dieser Firmen hatten schon Interessen in anderen maritimen Geschäftszweigen wie dem Holzhandel mit den baltischen Gebieten oder dem Weinhandel mit Frankreich und der iberischen Halbinsel und hatten dadurch die Risiken ihrer Tätig- 
keiten verteilt. Andere Unternehmen waren mit dem einzigen Ziel gegründet worden, den Wal- und Robbenfang zu betreiben, aber sie waren nicht sehr erfolgreich. Aktionäre der Groenlandse en Straatdavidse Visscherij Sociëteit in Harlingen mussten lange warten, bevor Dividenden ausgezahlt wurden. Am Ende wurden sie mit einer beträchtlichen Abwertung ihrer Anteile konfrontiert. Ähnliche Entwicklungen gab es in dem Rotterdamer Walfangunternehmen. Viele Aktionäre haben zu einem gewissen Zeitpunkt wohl eingesehen, dass es ihnen mehr genutzt hätte, ihr Geld auf die Bank zu bringen und Zinsen zu bekommen als in den Wal- und Robbenfang zu investieren.

Wie auch immer, es bleibt noch eine wesentliche Frage zu beantworten: warum haben Unternehmer weiterhin Zeit, Energie und Geld in die Expeditionen zum Walund Robbenfang investiert? Ihre Beweggründe scheinen sozialer und wirtschaftlicher Art gewesen zu sein. Das Wiederaufleben vom Wal- und Robbenfang bedeutete Arbeitsplätze für große Städte (Amsterdam and Rotterdam) und, verhältnismäßig noch mehr, für viel kleinere Gemeinschaften (Harlingen). Sehr bezeichnend in diesem Zusammenhang waren 1835 die erfreuten Aussagen des Gouverneurs der Provinz Friesland anlässlich der Weiterführung des Walfangs aus Harlingen durch die Firma Barend Visser \& Sohn.

Kurz nach etwa 1855 hat die Glanzzeit des niederländischen Walfangs anscheinend ihr Ende gefunden. Auf Kosten des Walfangs hat sich der Robbenjagd als wichtiger erwiesen. Die Zahl der eingesetzten Schiffe sowie der im Geschäftszweig tätigen Unternehmer verringerte sich. Ab 1860 etwa hat die niederländische Schiffahrt und der Schiffsbau im allgemeinen einen Abgang verzeichnet, der mit dem des Wal- und Robbenfangs insbesondere zusammenfällt. Um 1885 hatten sich die Schiffahrt und der Schiffsbau in den Niederlanden wieder von den schweren Krisen erholt. Der wirtschaftliche Aufschwung wurde hauptsächlich angeregt durch aufwärtsstrebende Entwicklungen auf den Wasserstraßen im Inland. ${ }^{11}$ Um diese Zeit aber war es mit dem niederländischen Hochsee-Walfang zu Ende.

11. De Jonge, Industrialisatie in Nederland, 146-155. 
07 summaries 19-02-2008 14:07 Pagina 292 


\section{Appendices}

\section{Appendix 1}

Overview of Nineteenth-Century Arctic Whaling and Sealing Expeditions Under Dutch Ownership (1802-1884)

\begin{tabular}{|c|c|c|c|c|c|c|c|c|}
\hline Year & $\begin{array}{l}\text { Owner/ } \\
\text { Company }\end{array}$ & Master & Ship & Rig & Destination & Results & Remarks & Sources \\
\hline 1802 & $?$ & $\begin{array}{l}\text { Broertjes, } \\
\text { Jacob }\end{array}$ & Eendracht & $\begin{array}{l}\text { Fluitschip, } \\
114 \mathrm{ft}, 30 \mathrm{ft} 4 \\
\text { duim, } 12 \mathrm{ft} 10 \\
\text { duim. }\end{array}$ & $?$ & $?$ & $\begin{array}{l}\text { Sold at auc- } \\
\text { tion in Am- } \\
\text { sterdam on } 9 \\
\text { April } 1810-\text { at } \\
\text { that time un- } \\
\text { der command } \\
\text { of Claas } \\
\text { Broertjes }\end{array}$ & $\begin{array}{l}\text { SAA, Archief v.d. } \\
\text { Waterschout } 38, \\
\text { inv. nr. 61, } \\
25 \text { March } 1802 \text {; } \\
\text { Amsterdamsche } \\
\text { Courant, } 27 \text { Fe- } \\
\text { bruary } 1810 \text {; Van } \\
\text { Sluijs, Nederlandse } \\
\text { koopvaardijsche- } \\
\text { pen, } 4\end{array}$ \\
\hline 1802 & $?$ & $\begin{array}{l}\text { Clorn, } \\
\text { Cornelis }\end{array}$ & Alida & & $?$ & $?$ & & $\begin{array}{l}\text { SAA, Archief v.d. } \\
\text { Waterschout } 38, \\
\text { inv. nr. } 61,31 \\
\text { March } 1802\end{array}$ \\
\hline 1802 & $\begin{array}{l}\text { Vas \& Dekker, } \\
\text { Wormerveer }\end{array}$ & $\begin{array}{l}\text { Boekjes, } \\
\text { Cornelis }\end{array}$ & Vriendschap & $\begin{array}{l}\text { Fluitschip, } \\
113 \mathrm{ft}, 29 \mathrm{ft} 1 \\
\text { duim, } 12 \mathrm{ft} \text {, } \\
\text { verdek } 6 \mathrm{ft} 8 \\
\text { duim. }\end{array}$ & $?$ & $\begin{array}{l}1 \text { whale, } \\
\text { 1o barrels of } \\
\text { blubber }\end{array}$ & $\begin{array}{l}\text { Sold at auc- } \\
\text { tion in Am- } \\
\text { sterdam on } 21 \\
\text { April } 1800 \text { for } \\
f \text { 11,400, whal- } \\
\text { ing equip- } \\
\text { ment for } \\
f_{3,350}\end{array}$ & $\begin{array}{l}\text { SAA, Archief v.d. } \\
\text { Waterschout } 38 \text {, } \\
\text { inv. nr. 61, } 31 \\
\text { March } 1802 ; \text { Am- } \\
\text { sterdamsche Cou- } \\
\text { rant, } 10 \text { April } 1800 ; \\
\text { Nederlandsche } \\
\text { Mercuur } 1800,198 ; \\
\text { Van Sluijs, Neder- } \\
\text { landse koopvaar- } \\
\text { dijschepen, } 108,114\end{array}$ \\
\hline 1802 & $\begin{array}{l}\text { Simon Jonge- } \\
\text { waard Jr., } \\
\text { Westzaan }\end{array}$ & $\begin{array}{l}\text { Tromp, } \\
\text { Tjelling }\end{array}$ & $\begin{array}{l}\text { sLands Wel- } \\
\text { varen }\end{array}$ & Fluitschip & $?$ & $?$ & & $\begin{array}{l}\text { SAA, Archief v.d. } \\
\text { Waterschout } 38, \\
\text { inv.nr. 62,3 April } \\
\text { 1802; Van Sluijs, } \\
\text { Nederlandse wal- } \\
\text { visvaarders, } 373\end{array}$ \\
\hline 1802 & $?$ & $\begin{array}{l}\text { Castricum, } \\
\text { Jan Claasz }\end{array}$ & $\begin{array}{l}\text { Onderne- } \\
\text { ming }\end{array}$ & $?$ & $?$ & $?$ & & $\begin{array}{l}\text { SAA, Archief v.d. } \\
\text { Waterschout } 38 \text {, } \\
\text { inv. nr. 62, } 4 \text { April } \\
1802\end{array}$ \\
\hline
\end{tabular}




\begin{tabular}{|c|c|c|c|c|c|c|c|c|}
\hline Year & $\begin{array}{l}\text { Owner/ } \\
\text { Company }\end{array}$ & Master & Ship & Rig & Destination & Results & Remarks & Sources \\
\hline 1802 & $\begin{array}{l}\text { Frank van den } \\
\text { Schoor \& } \\
\text { Zonen, } \\
\text { Dordrecht }\end{array}$ & $\begin{array}{l}\text { Hogerzijl, } \\
\text { Johannes }\end{array}$ & Groenlandia & $?$ & $?$ & $?$ & & $\begin{array}{l}\text { SAA, Archief v.d. } \\
\text { Waterschout } 38, \\
\text { inv.nr. 62, } 5 \text { April } \\
\text { 1802; Van Sluijs, } \\
\text { Nederlandse wal- } \\
\text { visvaarders, } 169\end{array}$ \\
\hline 1802 & $?$ & $\begin{array}{l}\text { Broertjes, } \\
\text { Jacob }\end{array}$ & Zaandam & $?$ & $?$ & $\begin{array}{l}4^{1 / 2} \text { whale, } \\
8 \text { o barrels of } \\
\text { blubber }\end{array}$ & & $\begin{array}{l}\text { SAA, Archief v.d. } \\
\text { Waterschout } 38, \\
\text { inv.nr. 62, } 5 \text { April } \\
\text { 1802; Van Sluijs, } \\
\text { Nederlandse wal- } \\
\text { visvaarders, } 677\end{array}$ \\
\hline 1802 & $\begin{array}{l}\text { Conelis } \\
\text { Cardinaal, } \\
\text { Zaandam }\end{array}$ & $\begin{array}{l}\text { Ruig, Pieter } \\
\text { Cornelisz. }\end{array}$ & Avontuur & $?$ & $?$ & $\begin{array}{l}1 \text { whale, } \\
17 \text { barrels of } \\
\text { blubber }\end{array}$ & & $\begin{array}{l}\text { SAA, Archief v.d. } \\
\text { Waterschout } 38, \\
\text { inv. nr. 62, } 5 \text { April } \\
1802 ; \text { Van Sluijs, } \\
\text { Nederlandse wal- } \\
\text { visvaarders, } 33\end{array}$ \\
\hline 1802 & $\begin{array}{l}\text { Jan de Cherro, } \\
\text { Amsterdam }\end{array}$ & $\begin{array}{l}\text { Mooij, } \\
\text { Maarten }\end{array}$ & $\begin{array}{l}\text { Franken- } \\
d a(a) l\end{array}$ & Fluitschip & $?$ & $?$ & & $\begin{array}{l}\text { SAA, Archief v.d. } \\
\text { Waterschout 38, } \\
\text { inv. nr. 62, } 6 \text { April } \\
\text { 1802; Van Sluijs, } \\
\text { Nederlandse wal- } \\
\text { visvaarders, } 128\end{array}$ \\
\hline 1802 & $\begin{array}{l}\text { Pieter de Jong } \\
\text { \& Zn., } \\
\text { Nieuwendam }\end{array}$ & $\begin{array}{l}\text { Cornelisz., } \\
\text { Hendrik }\end{array}$ & $\begin{array}{l}\text { Hoop op de } \\
\text { Walvisvangst }\end{array}$ & $\begin{array}{l}\text { Fluitschip, } \\
113 \mathrm{ft}, 29 \text { el } \\
7 \text { duim, } 12 \mathrm{el}, \\
71 / 2 \text { duim, } \\
\text { 'nieuw uitge- } \\
\text { haald' } 1764\end{array}$ & $?$ & $\begin{array}{l}5 \text { whales, } \\
\text { 10o barrels } \\
\text { blubber }\end{array}$ & $\begin{array}{l}\text { Sold at auc- } \\
\text { tion in Am- } \\
\text { sterdam on } \\
15 \text { April for } \\
f 8,865\end{array}$ & $\begin{array}{l}\text { Van Sluijs, Neder- } \\
\text { landse walvisvaar- } \\
\text { ders, } 206\end{array}$ \\
\hline 1802 & $\begin{array}{l}\text { Nicolaas Gef- } \\
\text { ken \& Zn, } \\
\text { Amsterdam }\end{array}$ & Gaauw, Jacob & $\begin{array}{l}\text { Visschers- } \\
\text { hoop }\end{array}$ & $?$ & $?$ & $\begin{array}{l}4 \text { whales, } \\
80 \text { barrels }\end{array}$ & & $\begin{array}{l}\text { Van Sluijs, Neder- } \\
\text { landse walvisvaar- } \\
\text { ders, } 561\end{array}$ \\
\hline 1803 & $?$ & Clorn, Pieter & $\begin{array}{l}\text { sLands Wel- } \\
\text { varen }\end{array}$ & $?$ & $?$ & $?$ & & $\begin{array}{l}\text { SAA, Archief v.d. } \\
\text { Waterschout } 38 \text {, } \\
\text { inv.nr. } 68,16 \text { April } \\
1803\end{array}$ \\
\hline 1803 & $?$ & $\begin{array}{l}\text { Clorn, } \\
\text { Cornelis }\end{array}$ & Alida & $?$ & $?$ & $?$ & & $\begin{array}{l}\text { SAA, Archief v.d. } \\
\text { Waterschout } 38 \text {, } \\
\text { inv.nr. 68, } 16 \text { April } \\
1803\end{array}$ \\
\hline 1803 & $?$ & Castricum, Jan & $\begin{array}{l}\text { Onderne- } \\
\text { ming }\end{array}$ & $?$ & $?$ & $?$ & & $\begin{array}{l}\text { SAA, Archief v.d. } \\
\text { Waterschout 38, } \\
\text { inv.nr. 68, } 16 \text { April } \\
1803\end{array}$ \\
\hline 1803 & $?$ & $\begin{array}{l}\text { Cornelisz., } \\
\text { Hendrik }\end{array}$ & $\begin{array}{l}\text { Hoop op de } \\
\text { Walvisvangst }\end{array}$ & $?$ & $?$ & $?$ & & $\begin{array}{l}\text { SAA, Archief v.d. } \\
\text { Waterschout } 38, \\
\text { inv.nr. } 68,16 \text { April } \\
1803\end{array}$ \\
\hline 1803 & $?$ & $\begin{array}{l}\text { Ruig, Pieter } \\
\text { Cornelisz. }\end{array}$ & Avontuur & $?$ & $?$ & $?$ & & $\begin{array}{l}\text { SAA, Archief v.d. } \\
\text { Waterschout } 38 \text {, } \\
\text { inv.nr. } 68, \\
18 \text { April } 1803\end{array}$ \\
\hline
\end{tabular}




\begin{tabular}{|c|c|c|c|c|c|c|c|c|}
\hline Year & $\begin{array}{l}\text { Owner/ } \\
\text { Company }\end{array}$ & Master & Ship & Rig & Destination & Results & Remarks & Sources \\
\hline 1803 & $?$ & Gaauw, Jacob & Visschershoop & $?$ & $?$ & $?$ & \begin{tabular}{|l|} 
Returning \\
from Green- \\
land confiscat- \\
ed and deport- \\
ed to \\
Liverpool \\
\end{tabular} & $\begin{array}{l}\text { SAA, Archief v.d. } \\
\text { Waterschout } 38 \text {, } \\
\text { inv.nr. 68, } 20 \text { April } \\
\text { 1803; Amsterdam- } \\
\text { sche Courant, } \\
8 \text { September } 1803 \text {; } \\
\text { Van Sluijs, Neder- } \\
\text { landse walvisvaar- } \\
\text { ders, } 561 ; \text { Van Sluijs, } \\
\text { Nederlandse koop- } \\
\text { vaardijschepen, } 40\end{array}$ \\
\hline 1803 & $\begin{array}{l}\text { Vas \& Dekker, } \\
\text { Wormerveer }\end{array}$ & $\begin{array}{l}\text { Boekjes, } \\
\text { Cornelis }\end{array}$ & Vriendschap & Fluitschip & 'Greenland' & $\begin{array}{l}\text { Returned } \\
\text { empty from } \\
\text { Greenland; } \\
\text { sent to } \\
\text { Greenland } \\
\text { again }\end{array}$ & & $\begin{array}{l}\text { Van Sluijs, Neder- } \\
\text { landse koopvaardij- } \\
\text { schepen, } 114\end{array}$ \\
\hline 1804 & $?$ & $\begin{array}{l}\text { Broertjes, } \\
\text { Jacob }\end{array}$ & $?$ & $?$ & $?$ & $?$ & & $\begin{array}{l}\text { MAA, Archief v.d. } \\
\text { Waterschout 38, } \\
\text { inv.nr. 73, } \\
12 \text { April } 1804\end{array}$ \\
\hline 1804 & $\begin{array}{l}\text { Jan de Cherro, } \\
\text { Amsterdam }\end{array}$ & Mooij, Marten & $\begin{array}{l}\text { Franken- } \\
d a(a) l\end{array}$ & $\begin{array}{l}\text { Fluitschip. } \\
\text { 'Nieuw uitge- } \\
\text { haald' in } \\
1760,113 \mathrm{ft}, 30 \\
\mathrm{ft}, 13 \mathrm{ft}\end{array}$ & ? & $?$ & $\begin{array}{l}\text { Sold at auction } \\
\text { in Amsterdam } \\
\text { on } 9 \text { April } 1810\end{array}$ & $\begin{array}{l}\text { Amsterdamsche } \\
\text { Courant, } 31 \text { March } \\
\text { 1810; Van Sluijs, } \\
\text { Nederlandse walvis- } \\
\text { vaarrders, } 128\end{array}$ \\
\hline 1805 & $\begin{array}{l}\text { Frank van den } \\
\text { Schoor \& } \\
\text { Zonen, } \\
\text { Dordrecht }\end{array}$ & $\begin{array}{l}\text { Hogerzijl, } \\
\text { Johannes }\end{array}$ & Groenlandia & $\begin{array}{l}\text { Fluitschip. } \\
\text { 'Nieuw uitge- } \\
\text { haald' in } \\
1764,115 \mathrm{ft}, \\
29 \mathrm{ft} 6 \text { duim, } \\
12 \mathrm{ft} 7 \text { duim }\end{array}$ & $?$ & $?$ & \begin{tabular}{|l|} 
Sold at auction \\
in Dordrecht \\
on 29 April \\
1805 \\
\\
\end{tabular} & $\begin{array}{l}\text { Amsterdamsche } \\
\text { Courant, 20 April } \\
1805 ; \text { Van Sluijs, } \\
\text { Nederlandse walvis- } \\
\text { vaarders, 169; Van } \\
\text { Sluijs, Nederlandse } \\
\text { koopvaardijschepen, } \\
205\end{array}$ \\
\hline 1810 & $?$ & $\begin{array}{l}\text { Broertjes, } \\
\text { Jacob }\end{array}$ & $\begin{array}{l}\text { Zaandam } \\
\text { Whaleship? } \\
1796\end{array}$ & Fluitschip & $?$ & $?$ & & \\
\hline 1815 & $\begin{array}{l}\text { Spreekens, } \\
\text { Barend van, } \\
\text { Amsterdam }\end{array}$ & $\begin{array}{l}\text { Broertjes, } \\
\text { Jacob }\end{array}$ & $\begin{array}{l}\text { Groenland } \\
\text { Built }<1764\end{array}$ & Fluitschip & $\begin{array}{l}\text { 'Eastern } \\
\text { Greenland' }\end{array}$ & $?$ & & $\begin{array}{l}\text { SAA, Archief van } \\
\text { de Waterschout, } \\
\text { inventory number } \\
\text { 38; nr. 95 (5 April } \\
\text { 1815); Van Sluis, } \\
\text { Nederlandse koop- } \\
\text { vaardijschepen, 205; } \\
\text { De Jong, III, } 155\end{array}$ \\
\hline 1816 & $\begin{array}{l}\text { Spreekens, } \\
\text { Barend van, } \\
\text { Amsterdam }\end{array}$ & $\begin{array}{l}\text { Broertjes, } \\
\text { Jacob } \\
7 \text { April- } \\
15 \text { August }\end{array}$ & Groenland & Fluitschip & $\begin{array}{l}\text { 'Eastern } \\
\text { Greenland' }\end{array}$ & $\begin{array}{l}2 \text { whales/ } \\
40 \text { kwarte- } \\
\text { len oil/ } \\
57 \text { barrels of } \\
\text { oil }\end{array}$ & & $\begin{array}{l}\text { SAA, Archief van } \\
\text { de Waterschout, } \\
\text { inventory number } \\
38 ; \text { nr. } 99 \text { (26 } \\
\text { March 1816);Van } \\
\text { Sluis, Nederlandse } \\
\text { koopvaardijschepen, } \\
\text { 205; De Jong, III, } \\
155\end{array}$ \\
\hline 1817 & $\begin{array}{l}\text { Spreekens, } \\
\text { Barend van, } \\
\text { Amsterdam }\end{array}$ & $\begin{array}{l}\text { Broertjes, } \\
\text { Jacob }\end{array}$ & Groenland & Fluitschip & $\begin{array}{l}\text { 'Eastern } \\
\text { Greenland' }\end{array}$ & $?$ & & $\begin{array}{l}\text { Van Sluis, Neder- } \\
\text { landse koopvaardij- } \\
\text { schepen, 205; De } \\
\text { Jong, III, } 155\end{array}$ \\
\hline
\end{tabular}




\begin{tabular}{|c|c|c|c|c|c|c|c|c|}
\hline Year & $\begin{array}{l}\text { Owner/ } \\
\text { Company }\end{array}$ & Master & Ship & Rig & Destination & Results & Remarks & Sources \\
\hline 1818 & $\begin{array}{l}\text { Spreekens, } \\
\text { Barend van, } \\
\text { Amsterdam }\end{array}$ & $\begin{array}{l}\text { Broertjes, } \\
\text { Jacob }\end{array}$ & Groenland & Fluitschip & $\begin{array}{l}\text { 'Eastern } \\
\text { Greenland' }\end{array}$ & $?$ & & $\begin{array}{l}\text { Van Sluis, Neder- } \\
\text { landse koopvaardij- } \\
\text { schepen, 205; De } \\
\text { Jong, III, } 155\end{array}$ \\
\hline 1819 & $\begin{array}{l}\text { Spreekens, } \\
\text { Barend van, } \\
\text { Amsterdam }\end{array}$ & $\begin{array}{l}\text { Broertjes, } \\
\text { Jacob }\end{array}$ & Groenland & Fluitschip & $\begin{array}{l}\text { 'Eastern } \\
\text { Greenland' }\end{array}$ & $\begin{array}{l}2 \text { whales/ } \\
70 \text { barrels }\end{array}$ & & $\begin{array}{l}\text { SAA, Archief van } \\
\text { de Waterschout, } \\
\text { inventory number } \\
38 ; \text { nr. } 110 \text { (22 } \\
\text { March 1819); Van } \\
\text { Sluis, Nederlandse } \\
\text { koopvaardijschepen, } \\
\text { 205; De Jong, III, } \\
\text { 155; De Jong, II, } 451\end{array}$ \\
\hline 1820 & $\begin{array}{l}\text { Vas \& Co., } \\
\text { Wormerveer }\end{array}$ & $\begin{array}{l}\text { Oom, Frans } \\
4 \text { April, Texel }\end{array}$ & Groenland & Pink & $\begin{array}{l}\text { 'Eastern } \\
\text { Greenland' }\end{array}$ & No whales & & $\begin{array}{l}\text { SAA, Archief van } \\
\text { de Waterschout, } \\
\text { inventory number } \\
38 \text {; nr. } 113 \text { (22 } \\
\text { March 1820); De } \\
\text { Jong, III, 155; Van } \\
\text { Sluijs, 205-206 }\end{array}$ \\
\hline 1821 & $\begin{array}{l}\text { Vas \& Co., } \\
\text { Wormerveer }\end{array}$ & $\begin{array}{l}\text { Oom, Frans } \\
\text { Ret. 9/10 No- } \\
\text { vember, Texel }\end{array}$ & Groenland & Pink & Davis Strait & \begin{tabular}{|l|} 
Caught \\
6 whales \\
yielding \\
90 barrels of \\
blubber
\end{tabular} & & $\begin{array}{l}\text { SAA, Archief van } \\
\text { de Waterschout, } \\
\text { inventory number } \\
38 \text {; nr. } 116(23 \mathrm{Fe}- \\
\text { bruary, 1821); De } \\
\text { Jong, III, 155; Van } \\
\text { Sluijs, 205-206 }\end{array}$ \\
\hline \multirow[t]{2}{*}{1822} & $\begin{array}{l}\text { Vas \& Co., } \\
\text { Wormerveer }\end{array}$ & $\begin{array}{l}\text { Oom, Frans } \\
\text { Dep.3 March, } \\
\text { Texel }\end{array}$ & Groenland & Pink & Davis Strait & \begin{tabular}{|l|} 
Caught \\
2 whales \\
yielding \\
110 barrels of \\
blubber
\end{tabular} & $\begin{array}{l}\text { De Jong, III, } \\
156 \text { gives crew } \\
\text { numbers for } \\
\text { one ship }\end{array}$ & $\begin{array}{l}\text { SAA, Archief van } \\
\text { de Waterschout, } \\
\text { inventory number } \\
38 \text {; nr. } 118 \text { (23 Fe- } \\
\text { bruary } 1822) \text {; Van } \\
\text { Sluijs, 205-206; Ho- } \\
\text { nig, Gulden Bijkorf, } \\
39\end{array}$ \\
\hline & $\begin{array}{l}\text { Barend Visser } \\
\text { \& Son, } \\
\text { Harlingen }\end{array}$ & $\begin{array}{l}\text { Rab, Willem } \\
\text { Dep. } 13 \text { April } \\
1822\end{array}$ & Spitsbergen & $\begin{array}{l}\text { Brig } \\
\text { Two-decks }\end{array}$ & $\begin{array}{l}\text { 'Western } \\
\text { Greenland' }\end{array}$ & $\begin{array}{l}\text { Walruses/ } \\
\text { seals }\end{array}$ & & $\begin{array}{l}\text { Amsterdamsche } \\
\text { Courant, } 14 \text { April } \\
\text { 1822; De Jong, II, } \\
\text { 456; III, } 156\end{array}$ \\
\hline \multirow[t]{2}{*}{1823} & $\begin{array}{l}\text { Vas \& Co., } \\
\text { Wormerveer }\end{array}$ & $\begin{array}{l}\text { Oom, Frans } \\
\text { Dep. } 25 \\
\text { March, Texel. } \\
\text { Ret. 29 Sep- } \\
\text { tember, Texel }\end{array}$ & Groenland & Pink & Davis Strait & \begin{tabular}{|l|} 
Returned \\
with \\
11 whales \\
and 207 bar- \\
rels of blub- \\
ber, yielding \\
$>100$ barrels \\
of oil
\end{tabular} & & $\begin{array}{l}\text { SAA, Archief van } \\
\text { de Waterschout, } \\
\text { inventory number } \\
\text { 38; nr. } 120 \text { (7 March } \\
\text { 1823); De Jong, III, } \\
\text { 156; Van Sluijs, 205- } \\
\text { 206; De Jong, III, } \\
\text { Table 5, } 164\end{array}$ \\
\hline & $\begin{array}{l}\text { Barend Visser } \\
\text { \& Son, } \\
\text { Harlingen }\end{array}$ & $\begin{array}{l}\text { Ruygh, Ymke } \\
\text { Janzs. } \\
\text { Ret. 25 August }\end{array}$ & Spitsbergen & Brig & $\begin{array}{l}\text { 'Western } \\
\text { Greenland' }\end{array}$ & \begin{tabular}{|l} 
Caught \\
193 seals \\
yielding \\
$63 / 4$ kwarte- \\
len of oil
\end{tabular} & & $\begin{array}{l}\text { GAH, 1644, no. 284: } \\
\text { 14 December 1824; } \\
\text { De Jong, II, 456; De } \\
\text { Jong, III, } 156\end{array}$ \\
\hline 1824 & Vas \& Co & $\begin{array}{l}\text { Oom, Frans } \\
\text { Dep. about } 1 \\
\text { March } \\
\text { Ret. 30 Sep- } \\
\text { tember }\end{array}$ & Groenland & Pink & Davis Strait & No whales & $\begin{array}{l}\text { De Jong, III, } \\
152 \text { mentions } \\
\text { one ship for } \\
1824, \text { but crew } \\
\text { numbers for } \\
\text { two (See De } \\
\text { Jong, II, 451) }\end{array}$ & $\begin{array}{l}\text { SAA, Archief van } \\
\text { de Waterschout, } \\
\text { inventory number } \\
38 \text {; nr. 122 (20 Fe- } \\
\text { bruary 1824) }\end{array}$ \\
\hline
\end{tabular}




\begin{tabular}{|c|c|c|c|c|c|c|c|c|}
\hline Year & $\begin{array}{l}\text { Owner/ } \\
\text { Company }\end{array}$ & Master & Ship & Rig & Destination & Results & Remarks & Sources \\
\hline & $\begin{array}{l}\text { Barend Visser } \\
\text { \& Son, } \\
\text { Harlingen }\end{array}$ & $\begin{array}{l}\text { Ruygh, Ymke } \\
\text { Janzs. }\end{array}$ & Spitsbergen & Brig & Davis Strait & $?$ & & \\
\hline \multirow[t]{5}{*}{1825} & $\begin{array}{l}\text { Widow } \\
\text { Jan Vas, } \\
\text { Wormerveer }\end{array}$ & $\begin{array}{l}\text { Oom, Frans } \\
\text { Dep. about } 3 \\
\text { March } \\
\text { Ret. } 21 \text { Octo- } \\
\text { ber }\end{array}$ & Groenland & Pink & Davis Strait & $\begin{array}{l}\text { No whales; } \\
50 \text { barrels of } \\
\text { blubber }\end{array}$ & $\begin{array}{l}\text { De Jong, III, } \\
152 \text { mentions } \\
\text { no ships for } \\
\text { this year, but } \\
\text { gives crew } \\
\text { numbers for } \\
\text { one ship (III, } \\
156) \text {. }\end{array}$ & $\begin{array}{l}\text { SAA, Archief van } \\
\text { de Waterschout, } \\
\text { inventory number } \\
38 ; \text { nr. } 124 \text { (25 Fe- } \\
\text { bruary 1825) }\end{array}$ \\
\hline & $\begin{array}{l}\text { Groenlandse } \\
\text { en Straatda- } \\
\text { vidse Vissche- } \\
\text { rij Sociëteit, } \\
\text { Harlingen }\end{array}$ & $\begin{array}{l}\text { Groendijk, Jan } \\
\text { Cornelisz. }\end{array}$ & Spitsbergen & Brig & $?$ & $\begin{array}{l}58 \text { kwartelen } \\
\text { of oil }\end{array}$ & & $\begin{array}{l}\text { GAH 1375, nr. } 14 \text { (14 } \\
\text { December); GAH } \\
\text { 1376, nr. } 13 \text { (14 Feb- } \\
\text { ruary 1826) }\end{array}$ \\
\hline & $\begin{array}{l}\text { Groenlandse } \\
\text { en Straatda- } \\
\text { vidse Vissche- } \\
\text { rij Sociëteit, } \\
\text { Harlingen }\end{array}$ & $\begin{array}{l}\text { Ruygh, Ymke } \\
\text { Jansz.† }\end{array}$ & $\begin{array}{l}\text { Willem de } \\
\text { Eerste } \\
\text { (Built in } \\
1822 / 23 \text { by } \\
\text { Johan Alta, } \\
\text { Harlingen) }\end{array}$ & $\begin{array}{l}\text { Pink } \\
\text { (two-decks) }\end{array}$ & $?$ & $\begin{array}{l}3 \text { barrels of } \\
\text { blubber } \\
\text { aboard }\end{array}$ & $\begin{array}{l}20 \text { October } \\
1825: \text { lost off } \\
\text { Texel. } 30 \text { per- } \\
\text { sons drowned } \\
(29 \mathrm{crew}+\text { pi- } \\
\text { lot })\end{array}$ & $\begin{array}{l}\text { GAH } 1376, \text { nrs. } 5 \text { ( } 21 \\
\text { February } 21 \text { ) and } 27 \\
\text { (10 February); } \\
\text { Leeuwarder Cou- } \\
\text { rant, } 25 \text { and } 28 \text { Oc- } \\
\text { tober } 1825\end{array}$ \\
\hline & $\begin{array}{l}\text { Nederland- } \\
\text { sche Maat- } \\
\text { schappij voor } \\
\text { Walvisch- } \\
\text { vangst }\end{array}$ & Keller, Jacob & Rotterdam & $?$ & Davis Strait & $\begin{array}{l}\text { Returned } \\
\text { empty }\end{array}$ & & De Jong, II, 460 \\
\hline & $\begin{array}{l}\text { Nederland- } \\
\text { sche Maat- } \\
\text { schappij voor } \\
\text { Walvisch- } \\
\text { vangst }\end{array}$ & $\begin{array}{l}\text { Cupido, } \\
\text { Douwe Jansz. }\end{array}$ & Maasstroom & $\begin{array}{l}\text { Pink } \\
\text { (294 ton) }\end{array}$ & $?$ & Bad catch & & De Jong, II, 460 \\
\hline 1826 & $\begin{array}{l}\text { Groenlandse } \\
\text { en Straatda- } \\
\text { vidse Vissche- } \\
\text { rij Sociëteit, } \\
\text { Harlingen }\end{array}$ & $\begin{array}{l}\text { Hoekstra, } \\
\text { Klaas }\end{array}$ & Harlingen & Galliot & Davis Strait & & $\begin{array}{l}\text { Lost in the } \\
\text { Davis Strait, } 23 \\
\text { August } 1826\end{array}$ & $\begin{array}{l}\text { Leeuwarder Cou- } \\
\text { rant, } 22 \text { June } 1827, \\
\text { contains reference } \\
\text { to disaster }\end{array}$ \\
\hline & $\begin{array}{l}\text { Groenlandse } \\
\text { en Straatda- } \\
\text { vidse Vissche- } \\
\text { rij Sociëteit, } \\
\text { Harlingen }\end{array}$ & $\begin{array}{l}\text { Groendijk, Jan } \\
\text { Cornelisz. }\end{array}$ & $\begin{array}{l}\text { Willem de } \\
\text { Eerste (I) }\end{array}$ & $?$ & Davis Strait & \begin{tabular}{|l|} 
Returned \\
empty. Car- \\
go yielded 43 \\
kwartelen of \\
oil after \\
boiling \\
down
\end{tabular} & & $\begin{array}{l}\text { GAH 1376, nr. } 11 \text { ( } 31 \\
\text { January } 1827) ; \\
\text { Leeuwarder Cou- } \\
\text { rant, } 31 \text { January } \\
1826 \text { refers to } \\
\text { Willem de Eerste (I) } \\
\text { being replaced by } \\
\text { frigate of } 242 \text { lasts }\end{array}$ \\
\hline & $\begin{array}{l}\text { Groenlandse } \\
\text { en Straatda- } \\
\text { vidse Vissche- } \\
\text { rij Sociëteit, } \\
\text { Harlingen }\end{array}$ & Rickmers, H. & Spitsbergen & Brig & Spitsbergen & $\begin{array}{l}\text { Returned } \\
\text { with } 3,124 \\
\text { seals }\end{array}$ & & $\begin{array}{l}\text { Leeuwarder Cou- } \\
\text { rant, } 4 \text { August 1826; } \\
\text { De Jong, II, } 458\end{array}$ \\
\hline & $\begin{array}{l}\text { Groenlandse } \\
\text { en Straatda- } \\
\text { vidse Vissche- } \\
\text { rij Sociëteit, } \\
\text { Harlingen }\end{array}$ & $\begin{array}{l}\text { Adriaan, J.J. } \\
\text { (Jacob) }\end{array}$ & $\begin{array}{l}\text { Nederland } \\
\text { (formerly } \\
\text { Dirkje Ade- } \\
\text { ma, built } \\
1800 \text { ) }\end{array}$ & \begin{tabular}{|l} 
Pink \\
363 tons \\
$(29,55 \times 5,8 \mathrm{x}$ \\
$4,77 \mathrm{el})$
\end{tabular} & $?$ & $?$ & & \\
\hline & $\begin{array}{l}\text { Nederland- } \\
\text { sche Maat- } \\
\text { schappij voor } \\
\text { Walvisch- } \\
\text { vangst }\end{array}$ & Keller, Jacob & Rotterdam & $?$ & Davis Strait & $\begin{array}{l}\text { Returned } \\
\text { empty. Tak- } \\
\text { en out of } \\
\text { service }\end{array}$ & & De Jong, II, 460 \\
\hline
\end{tabular}




\begin{tabular}{|c|c|c|c|c|c|c|c|c|}
\hline Year & $\begin{array}{l}\text { Owner/ } \\
\text { Company }\end{array}$ & Master & Ship & Rig & Destination & Results & Remarks & Sources \\
\hline & $\begin{array}{l}\text { Nederland- } \\
\text { sche Maat- } \\
\text { schappij voor } \\
\text { Walvisch- } \\
\text { vangst }\end{array}$ & $\begin{array}{l}\text { Cupido, } \\
\text { Douwe Jansz. } \\
\text { Ret. } 11 \text { August } \\
\text { to Rotterdam }\end{array}$ & Maasstroom & Pink & $?$ & $\begin{array}{l}2,800 \text { seals, } \\
\text { yielding } 128 \\
\text { barrels of } \\
\text { blubber }\end{array}$ & & De Jong, II, 460 \\
\hline \multirow[t]{3}{*}{1827} & $\begin{array}{l}\text { Groenlandse } \\
\text { en Straatda- } \\
\text { vidse Vissche- } \\
\text { rij Sociëteit, } \\
\text { Harlingen }\end{array}$ & $\begin{array}{l}\text { Adriaan, J.J. } \\
\text { (Jacob) }\end{array}$ & Nederland & \begin{tabular}{|l} 
Pink \\
363 tons \\
$(29,55 \times 5,8 x$ \\
$4,77 \mathrm{el})$
\end{tabular} & Spitsbergen & $\begin{array}{l}5 \text { whales; } \\
160 \text { barrels } \\
\text { of fat/ } \\
\text { blubber }\end{array}$ & $\begin{array}{l}\text { 28 July 1827: } \\
\text { Texel }\end{array}$ & $\begin{array}{l}\text { SAA, inv.nr. } 949 \\
\text { (archief Kweek- } \\
\text { school voor de Zee- } \\
\text { vaart), nr. } 27 \text { (1827), } \\
\text { fo. } 308 \text {; Leeuwarder } \\
\text { Courant, } 7 \text { August } \\
1827\end{array}$ \\
\hline & $\begin{array}{l}\text { Groenlandse } \\
\text { en Straatda- } \\
\text { vidse Vissche- } \\
\text { rij Sociëteit, } \\
\text { Harlingen }\end{array}$ & $\begin{array}{l}\text { Groendijk, } \\
\text { Jan Cornelisz. }\end{array}$ & $\begin{array}{l}\text { Willem de } \\
\text { Eerste (II) }\end{array}$ & $?$ & Davis Strait & $?$ & $\begin{array}{l}\text { Dep. from 't } \\
\text { Vlie on March } \\
\text { 27. Lost on } \\
\text { May } 27 \text { near } \\
\text { Greenland. } \\
\text { Crew transfer- } \\
\text { red to D.J. Cu- } \\
\text { pido's Maas- } \\
\text { stroom. } \\
\text { Groendijk + } 14 \\
\text { hands trans- } \\
\text { ported to Ne- } \\
\text { therlands by } \\
\text { J.J. Adriaan, } \\
\text { master Neder- } \\
\text { land }\end{array}$ & $\begin{array}{l}\text { Mentioned in } \\
\text { Hoekstra, Dagver- } \\
\text { haal, } 5 \text {. }\end{array}$ \\
\hline & $\begin{array}{l}\text { Nederland- } \\
\text { sche Maat- } \\
\text { schappij voor } \\
\text { Walvisch- } \\
\text { vangst }\end{array}$ & $\begin{array}{l}\text { Cupido, } \\
\text { Douwe Jansz. } \\
\text { Ret. 10 August } \\
\text { to Brielle }\end{array}$ & $\begin{array}{l}\text { Maasstroom } \\
\text { (auctioned } \\
\text { off on } 23 \text { Oc- } \\
\text { tober) }\end{array}$ & Pink & Davis Strait & \begin{tabular}{|l|}
800 seals, \\
yielding 30 \\
kwartelen of \\
oil
\end{tabular} & & $\begin{array}{l}\text { Amsterdamsche } \\
\text { Courant, } 22 \text { August } \\
\text { 1827; De Jong, II, } \\
460 \text { mentions } 35 \\
\text { kwartelen }\end{array}$ \\
\hline 1828 & $\begin{array}{l}\text { Groenlandse } \\
\text { en Straatda- } \\
\text { vidse Vissche- } \\
\text { rij Sociëteit, } \\
\text { Harlingen }\end{array}$ & $\begin{array}{l}\text { Adriaan, J.J. } \\
\text { (Jacob) }\end{array}$ & Nederland & $\begin{array}{l}\text { Pink } \\
363 \text { tons } \\
(29,55 \times 5,8 \mathrm{x} \\
4,77 \mathrm{el})\end{array}$ & $?$ & $?$ & & \\
\hline 1829 & $\begin{array}{l}\text { Groenlandse } \\
\text { en Straatda- } \\
\text { vidse Vissche- } \\
\text { rij Sociëteit, } \\
\text { Harlingen }\end{array}$ & $\begin{array}{l}\text { Adriaan, J.J. } \\
\text { (Jacob) }\end{array}$ & Nederland & \begin{tabular}{|l|} 
Pink \\
363 tons \\
$(29,55 \times 5,8 \times 4,7$ \\
$7 \mathrm{el})$
\end{tabular} & ? & $?$ & & \\
\hline 1830 & $\begin{array}{l}\text { Groenlandse } \\
\text { en Straatda- } \\
\text { vidse Vissche- } \\
\text { rij Sociëteit, } \\
\text { Harlingen }\end{array}$ & $\begin{array}{l}\text { Rickmers, } \\
\text { Hendrik }\end{array}$ & $\begin{array}{l}\text { Spitsbergen II } \\
\text { Built 1829; } \\
\text { Joh. Alta; }\end{array}$ & \begin{tabular}{|l} 
Brig \\
251 tons
\end{tabular} & $\begin{array}{l}\text { Jan Mayen } \\
\text { Spitsbergen }\end{array}$ & \begin{tabular}{|l|} 
Caught \\
1,411 seals \\
yielding \\
62 kwartelen \\
of oil
\end{tabular} & $\begin{array}{l}\text { Oil tried out at } \\
\text { cookery De } \\
\text { Herstelder, } \\
\text { Harlingen, } \\
\text { September } \\
1830\end{array}$ & $\begin{array}{l}\text { Nederlandsche Her- } \\
\text { mes, III, 78; Leeu- } \\
\text { warder Courant, } 17 \\
\text { August 1830; docu- } \\
\text { ment GAH; Ship's } \\
\text { journal, Friesen- } \\
\text { museum, Wyk auf } \\
\text { Föhr }\end{array}$ \\
\hline & $\begin{array}{l}\text { Groenlandse } \\
\text { en Straatda- } \\
\text { vidse Vissche- } \\
\text { rij Sociëteit, } \\
\text { Harlingen }\end{array}$ & $\begin{array}{l}\text { Hoekstra, } \\
\text { Klaas }\end{array}$ & Nederland & \begin{tabular}{|l|} 
Pink \\
363 tons \\
$(29,55 \times 5,8 \mathrm{x}$ \\
$4,77 \mathrm{el})$ \\
\end{tabular} & Davis Strait & $?$ & $\begin{array}{l}\text { Oil tried out at } \\
\text { cookery De } \\
\text { Herstelder, } \\
\text { Harlingen, De- } \\
\text { cember } 1830\end{array}$ & $\begin{array}{l}\text { Leeuwarder Cou- } \\
\text { rant, } 20 \text { April 1830; } \\
\text { document GAH }\end{array}$ \\
\hline
\end{tabular}




\begin{tabular}{|c|c|c|c|c|c|c|c|c|}
\hline Year & $\begin{array}{l}\text { Owner/ } \\
\text { Company }\end{array}$ & Master & Ship & Rig & Destination & Results & Remarks & Sources \\
\hline \multirow[t]{2}{*}{1831} & $\begin{array}{l}\text { Groenlandse } \\
\text { en Straatda- } \\
\text { vidse Vissche- } \\
\text { rij Sociëteit, } \\
\text { Harlingen }\end{array}$ & $\begin{array}{l}\text { Rickmers, } \\
\text { Hendrik }\end{array}$ & Spitsbergen II & $\begin{array}{l}\text { Brig } \\
251 \text { tons }\end{array}$ & $\begin{array}{l}\text { Jan Mayen } \\
\text { Spitsbergen }\end{array}$ & $\begin{array}{l}\text { Caught } \\
4,421 \text { seals } \\
\text { yielding } \\
187 \text { kwarte- } \\
\text { len of oil } \\
\end{array}$ & & $\begin{array}{l}\text { Leeuwarder Cou- } \\
\text { rant, } 6 \text { September } \\
\text { 1831; Leeuwarder } \\
\text { Courant, } 17 \text { July } \\
\text { 1832; Ship's journal, } \\
\text { Friesenmuseum, } \\
\text { Wyk auf Föhr }\end{array}$ \\
\hline & $\begin{array}{l}\text { Groenlandse } \\
\text { en Straatda- } \\
\text { vidse Vissche- } \\
\text { rij Sociëteit, } \\
\text { Harlingen }\end{array}$ & $\begin{array}{l}\text { Hoekstra, } \\
\text { Klaas }\end{array}$ & Nederland & $\begin{array}{l}\text { Pink } \\
363 \text { tons } \\
(29,55 \times 5,8 \mathrm{x} \\
4,77 \mathrm{el})\end{array}$ & $\begin{array}{l}\text { Jan Mayen } \\
\text { Spitsbergen }\end{array}$ & $?$ & & \\
\hline \multirow[t]{2}{*}{1832} & $\begin{array}{l}\text { Groenlandse } \\
\text { en Straatda- } \\
\text { vidse Vissche- } \\
\text { rij Sociëteit, } \\
\text { Harlingen }\end{array}$ & $\begin{array}{l}\text { Rickmers, } \\
\text { Hendrik }\end{array}$ & Spitsbergen II & $\begin{array}{l}\text { Brig } \\
251 \text { tons }\end{array}$ & $\begin{array}{l}\text { Jan Mayen } \\
\text { Spitsbergen }\end{array}$ & \begin{tabular}{|l} 
Caught \\
1 whale, \\
3,500 seals \\
yielding \\
227 kwarte- \\
len of oil
\end{tabular} & & $\begin{array}{l}\text { Leeuwarder Cou- } \\
\text { rant, } 3 \text { August 1832: } \\
\text { Leeuwarder Cou- } \\
\text { rant, } 16 \text { July } 1833 ; \\
\text { Ship's journal, } \\
\text { Friesenmuseum, } \\
\text { Wyk auf Föhr }\end{array}$ \\
\hline & $\begin{array}{l}\text { Groenlandse } \\
\text { en Straatda- } \\
\text { vidse Vissche- } \\
\text { rij Sociëteit, } \\
\text { Harlingen }\end{array}$ & $\begin{array}{l}\text { Hoekstra, } \\
\text { Klaas }\end{array}$ & Nederland & $\begin{array}{l}\text { Pink } \\
363 \text { tons } \\
(29,55 \times 5,8 \mathrm{x} \\
4,77 \mathrm{el})\end{array}$ & Spitsbergen & $\begin{array}{l}\text { Caught } \\
1 \text { whale, } \\
166 \text { seals } \\
\text { yielding } \\
46 \text { kwartelen } \\
\text { of oil }\end{array}$ & & $\begin{array}{l}\text { GAH } 1378, \text { nrs. } 5 \text { (15 } \\
\text { September) and } \\
12 / 98 \text { (25 Septem- } \\
\text { ber); Leeuwarder } \\
\text { Courant, } 3 \text { August } \\
\text { 1832: Leeuwarder } \\
\text { Courant, } 16 \text { July } \\
1833\end{array}$ \\
\hline \multirow[t]{2}{*}{1833} & $\begin{array}{l}\text { Groenlandse } \\
\text { en Straatda- } \\
\text { vidse Vissche- } \\
\text { rij Sociëteit, } \\
\text { Harlingen }\end{array}$ & $\begin{array}{l}\text { Rickmers, } \\
\text { Hendrik }\end{array}$ & Spitsbergen II & $\begin{array}{l}\text { Brig } \\
251 \text { tons }\end{array}$ & $\begin{array}{l}\text { Jan Mayen } \\
\text { Spitsbergen }\end{array}$ & $\begin{array}{l}3 \text { whales, } \\
150 \text { seals } \\
\text { yielding } \\
129^{3 / 4} \text { kwar- } \\
\text { telen of oil }\end{array}$ & & $\begin{array}{l}\text { Leeuwarder Cou- } \\
\text { rant, } 13 \text { September } \\
\text { 1833; Ship's journal, } \\
\text { Friesenmuseum, } \\
\text { Wyk auf Föhr }\end{array}$ \\
\hline & $\begin{array}{l}\text { Groenlandse } \\
\text { en Straatda- } \\
\text { vidse Vissche- } \\
\text { rij Sociëteit, } \\
\text { Harlingen }\end{array}$ & $\begin{array}{l}\text { Hoekstra, } \\
\text { Klaas }\end{array}$ & Nederland & $\begin{array}{l}\text { Pink } \\
363 \text { tons } \\
(29,55 \times 5,8 \mathrm{x} \\
4,77 \mathrm{el})\end{array}$ & $\begin{array}{l}\text { Jan Mayen } \\
\text { Spitsbergen }\end{array}$ & \begin{tabular}{|l}
1 small \\
whale/ \\
256 seals \\
Combined \\
results \\
$(1833)$ : \\
4 whales + \\
406 seals \\
yielding \\
150 kwarte- \\
len oil, \\
about 2,00o \\
pounds of \\
baleen, \\
about 400 \\
seal furs
\end{tabular} & & $\begin{array}{l}\text { Leeuwarder Cou- } \\
\text { rant, } 13 \text { September } \\
1833 ; \text { Leeuwarder } \\
\text { Courant, } 8 \text { October } \\
1833 ; \text { Leeuwarder } \\
\text { Courant, } 1 \text { July } \\
\text { 1834; Haagsma, } \\
\text { 'Friesland's Groen- } \\
\text { landvaart', } 51\end{array}$ \\
\hline 1834 & $\begin{array}{l}\text { Groenlandse } \\
\text { en Straatda- } \\
\text { vidse Vissche- } \\
\text { rij Sociëteit, } \\
\text { Harlingen }\end{array}$ & $\begin{array}{l}\text { Rickmers, } \\
\text { Hendrik }\end{array}$ & Spitsbergen II & $\begin{array}{l}\text { Brig } \\
251 \text { tons }\end{array}$ & $\begin{array}{l}\text { Jan Mayen } \\
\text { Spitsbergen }\end{array}$ & \begin{tabular}{|l|} 
Caught \\
1 whale, \\
about 105 \\
seals. Com- \\
bined results \\
amounted \\
to 57 kwar- \\
telen of oil
\end{tabular} & & $\begin{array}{l}\text { Ship's journal, } \\
\text { Friesenmuseum, } \\
\text { Wyk auf Föhr; } \\
\text { GAH 1378, nrs. } 6 \\
\text { (14 October) and } \\
\text { D/98 (20 October) }\end{array}$ \\
\hline & $\begin{array}{l}\text { Groenlandse } \\
\text { en Straatda- } \\
\text { vidse Vissche- } \\
\text { rij Sociëteit, } \\
\text { Harlingen }\end{array}$ & $\begin{array}{l}\text { Hoekstra, } \\
\text { Klaas }\end{array}$ & Nederland & $\begin{array}{l}\text { Pink } \\
363 \text { tons } \\
\text { (29,55x5,8x } \\
4,77 \mathrm{el})\end{array}$ & Spitsbergen & & & \\
\hline
\end{tabular}




\begin{tabular}{|c|c|c|c|c|c|c|c|c|}
\hline Year & $\begin{array}{l}\text { Owner/ } \\
\text { Company }\end{array}$ & Master & Ship & Rig & Destination & Results & Remarks & Sources \\
\hline \multirow[t]{2}{*}{1835} & $\begin{array}{l}\text { Barend Visser } \\
\text { \& Son, } \\
\text { Harlingen }\end{array}$ & $\begin{array}{l}\text { Hoekstra, } \\
\text { Klaas }\end{array}$ & $\begin{array}{l}\text { Dirkje Ade- } \\
\text { ma }\end{array}$ & $\begin{array}{l}\text { Frigate } \\
349 \text { tons }\end{array}$ & Did not sail & & $\begin{array}{l}\text { Visser paid } \\
\text { f6,635 at auc- } \\
\text { tion, Jan. } 26 \text {, } \\
\text { Amsterdam }\end{array}$ & $\begin{array}{l}\text { Handelsblad, Jan. } \\
\text { 26, 1835; J. van } \\
\text { Sluijs, Nederlandse } \\
\text { Koopvaardijschepen } \\
\text { 180o-186o (n.p. } \\
\text { n.d.), } 43,16 \\
\end{array}$ \\
\hline & $\begin{array}{l}\text { Barend Visser } \\
\text { \& Son, } \\
\text { Harlingen }\end{array}$ & $\begin{array}{l}\text { Rickmers, } \\
\text { Hendrik } \\
\text { Dep. 18 March } \\
\text { Ret. } 6 \text { August }\end{array}$ & Spitsbergen II & $\begin{array}{l}\text { Bark } \\
251 \text { tons }\end{array}$ & $\begin{array}{l}\text { Jan Mayen } \\
\text { Spitsbergen }\end{array}$ & $\begin{array}{l}\text { Rickmers } \\
\text { caught a } \\
\text { 'consider- } \\
\text { able' num- } \\
\text { ber of seals }\end{array}$ & $\begin{array}{l}\text { Visser paid } \\
f 15,227 \text { at auc- } \\
\text { tion, 26 Janua- } \\
\text { ry, Amster- } \\
\text { dam }\end{array}$ & $\begin{array}{l}\text { Leeuwarder Cou- } \\
\text { rant, } 24 \text { March 1835; } \\
\text { Leeuwarder Cou- } \\
\text { rant, } 14 \text { July } 1835 ; \\
\text { Leeuwarder Cou- } \\
\text { rant, } 11 \text { August } 1835 ; \\
\text { Handelsblad, } 26 \\
\text { January } 1835 ; \\
\text { Leeuwarder Cou- } \\
\text { rant, } 12 \text { July } 1836 \text {; } \\
\text { Ship's journal, } \\
\text { Friesenmuseum, } \\
\text { Wyk auf Föhr; J. } \\
\text { van Sluijs, Neder- } \\
\text { landse Koopvaardij- } \\
\text { schepen 18oo-186o } \\
\text { (n.p. n.d.), } 43,16\end{array}$ \\
\hline 1836 & $\begin{array}{l}\text { Barend Visser } \\
\text { \& Son, Harlin- } \\
\text { gen }\end{array}$ & $\begin{array}{l}\text { Rickmers, } \\
\text { Hendrik } \\
\text { Dep. March } 6 \\
\text { Ret.Aug. } 25\end{array}$ & Spitsbergen II & $\begin{array}{l}\text { Bark } \\
251 \text { tons }\end{array}$ & $\begin{array}{l}\text { Jan Mayen } \\
\text { Spitsbergen }\end{array}$ & $\begin{array}{l}>3, \text { ooo seals, } \\
\text { yielding } \\
\text { substantial } \\
\text { amount of } \\
\text { oil }\end{array}$ & & $\begin{array}{l}\text { Leeuwarder Cou- } \\
\text { rant, March } 8,1836 ; \\
\text { Leeuwarder Cou- } \\
\text { rant, July 4, 1837; } \\
\text { Ship's journal, } \\
\text { Friesenmuseum, } \\
\text { Wyk auf Föhr }\end{array}$ \\
\hline 1837 & $\begin{array}{l}\text { Barend Visser } \\
\text { \& Son, } \\
\text { Harlingen }\end{array}$ & $\begin{array}{l}\text { Rickmers, } \\
\text { Hendrik } \\
\text { Dep. 11 March; } \\
\text { Ret. } 11 \text { August }\end{array}$ & Spitsbergen II & \begin{tabular}{|l} 
Bark \\
251 tons
\end{tabular} & $\begin{array}{l}\text { Jan Mayen } \\
\text { Spitsbergen }\end{array}$ & $\begin{array}{l}\text { Caught } \\
1 \text { whale, } \\
53 \text { seals }\end{array}$ & $\begin{array}{l}\text { premium for } \\
\text { wanvangst }\end{array}$ & $\begin{array}{l}\text { Leeuwarder Cou- } \\
\text { rant, } 21 \text { March 1837; } \\
15 \text { August } 1837 ; \\
\text { Ship's journal, } \\
\text { Friesenmuseum, } \\
\text { Wyk auf Föhr }\end{array}$ \\
\hline 1838 & $\begin{array}{l}\text { Barend Visser } \\
\text { \& Son, } \\
\text { Harlingen }\end{array}$ & $\begin{array}{l}\text { Rickmers, } \\
\text { Hendrik } \\
\text { Dep. 23 } \\
\text { March; } \\
\text { Ret. 30 July }\end{array}$ & Spitsbergen II & $\begin{array}{l}\text { Brig/bark } \\
251 \text { tons }\end{array}$ & $\begin{array}{l}\text { Jan Mayen } \\
\text { Spitsbergen }\end{array}$ & $\begin{array}{l}3 \text { whales; } \\
6 \text { oo seals }\end{array}$ & & $\begin{array}{l}\text { Leeuwarder Cou- } \\
\text { rant, } 27 \text { March } 1838 \text {; } \\
\text { Leeuwarder Cou- } \\
\text { rant, } 7 \text { August } 1838 ; \\
\text { Leeuwarder Cou- } \\
\text { rant, } 2 \text { July } 1839 \text {; } \\
\text { Ship's journal, } \\
\text { Friesenmuseum, } \\
\text { Wyk auf Föhr }\end{array}$ \\
\hline & $\begin{array}{l}\text { Barend Visser } \\
\text { \& Son, } \\
\text { Harlingen }\end{array}$ & $\begin{array}{l}\text { Rickmers, } \\
\text { Hendrik B. } \\
\text { Dep. } 26 \\
\text { March; } \\
\text { Ret. 28 July }\end{array}$ & $\begin{array}{l}\text { Dirkje Ade- } \\
\text { ma }\end{array}$ & $\begin{array}{l}\text { Frigate/pink } \\
\text { (LC) } \\
349 \text { tons }\end{array}$ & $\begin{array}{l}\text { Jan Mayen } \\
\text { Spitsbergen }\end{array}$ & $\begin{array}{l}4 \text { whales; } \\
\text { 130 seals } \\
\\
\\
\text { Combined } \\
\text { results: } \\
\text { 10o,ooo } \\
\text { kannen oil } \\
\text { (=circa } 8,333 \\
\text { kwartelen } \\
\text { oil); } 5,500 \\
\text { pounds of } \\
\text { baleen; } 800 \\
\text { seal furs }\end{array}$ & & $\begin{array}{l}\text { Leeuwarder Cou- } \\
\text { rant, } 3 \text { April } 1838 ; \\
\text { Leeuwarder Cou- } \\
\text { rant, } 31 \text { July } 1838 ; \\
\text { Leeuwarder Cou- } \\
\text { rant, } 2 \text { July } 1839 ; \\
\text { Leeuwarder Cou- } \\
\text { rant, } 2 \text { October } 1838\end{array}$ \\
\hline
\end{tabular}




\begin{tabular}{|c|c|c|c|c|c|c|c|c|}
\hline Year & $\begin{array}{l}\text { Owner/ } \\
\text { Company }\end{array}$ & Master & Ship & Rig & Destination & Results & Remarks & Sources \\
\hline \multirow[t]{2}{*}{1839} & $\begin{array}{l}\text { Barend Visser } \\
\text { \& Son, } \\
\text { Harlingen }\end{array}$ & $\begin{array}{l}\text { Rickmers, } \\
\text { Hendrik } \\
\text { Dep. 10 } \\
\text { March; } \\
\text { Ret. 4 August }\end{array}$ & Spitsbergen II & $\begin{array}{l}\text { Bark } \\
251 \text { tons }\end{array}$ & $\begin{array}{l}\text { Jan Mayen } \\
\text { Spitsbergen }\end{array}$ & $\begin{array}{l}\text { Caught } \\
252 \text { seals; } \\
2 \text { narwals }\end{array}$ & & $\begin{array}{l}\text { Leeuwarder Cou- } \\
\text { rant, } 19 \text { March 1839; } \\
\text { Leeuwarder Cou- } \\
\text { rant, } 13 \text { August } \\
\text { 1839; Ship's journal, } \\
\text { Friesenmuseum, } \\
\text { Wyk auf Föhr }\end{array}$ \\
\hline & $\begin{array}{l}\text { Barend Visser } \\
\text { \& Son, } \\
\text { Harlingen }\end{array}$ & $\begin{array}{l}\text { Rickmers, } \\
\text { Hendrik B. } \\
\text { Dep. } 8 \text { March; } \\
\text { Ret. 4 August }\end{array}$ & $\begin{array}{l}\text { Dirkje Ade- } \\
\text { ma }\end{array}$ & $\begin{array}{l}\text { Frigate/pink } \\
349 \text { tons }\end{array}$ & $\begin{array}{l}\text { Jan Mayen } \\
\text { Spitsbergen }\end{array}$ & $\begin{array}{l}\text { Combined } \\
\text { results: } \\
\text { 1 small } \\
\text { whale; } \\
\text { 1,ooo seals. } \\
\text { Bad catch; } \\
\text { premium } \\
\text { for wan- } \\
\text { vangst }\end{array}$ & & $\begin{array}{l}\text { Leeuwarder Cou- } \\
\text { rant, } 19 \text { March 1839; } \\
\text { Leeuwarder Cou- } \\
\text { rant, } 13 \text { August } 1839 \\
\text { Leeuwarder Cou- } \\
\text { rant, } 14 \text { July } 1840 ; \\
\text { Ship's journal, } \\
\text { Friesenmuseum, } \\
\text { Wyk auf Föhr }\end{array}$ \\
\hline \multirow[t]{2}{*}{1840} & $\begin{array}{l}\text { Barend Visser } \\
\text { \& Son, } \\
\text { Harlingen }\end{array}$ & \begin{tabular}{l|} 
Rickmers, \\
Hendrik \\
Dep. 17 March; \\
Ret. 8 August
\end{tabular} & Spitsbergen II & $\begin{array}{l}\text { Bark } \\
251 \text { tons }\end{array}$ & $\begin{array}{l}\text { Jan Mayen } \\
\text { Spitsbergen }\end{array}$ & $\begin{array}{l}\text { Caught } \\
1,186 \text { seals }\end{array}$ & & $\begin{array}{l}\text { Leeuwarder Cou- } \\
\text { rant, 17 March } \\
\text { 1840; Leeuwarder } \\
\text { Courant, } 11 \text { August } \\
\text { 1840; Ship's jour- } \\
\text { nal, Friesenmuse- } \\
\text { um, Wyk auf Föhr } \\
\text { (11 March - } 6 \text { Au- } \\
\text { gust) }\end{array}$ \\
\hline & $\begin{array}{l}\text { Barend Visser } \\
\text { \& Son, } \\
\text { Harlingen }\end{array}$ & $\begin{array}{l}\text { Rickmers, } \\
\text { Hendrik B. } \\
\text { Dep. 11 March; } \\
\text { Ret. 10 August }\end{array}$ & $\begin{array}{l}\text { Dirkje Ade- } \\
\text { ma }\end{array}$ & $\begin{array}{l}\text { Frigate/pink } \\
349 \text { tons }\end{array}$ & $\begin{array}{l}\text { Jan Mayen } \\
\text { Spitsbergen }\end{array}$ & $\begin{array}{l}\text { 1,80o seals. } \\
\text { Bad catch; } \\
\text { premium } \\
\text { for wan- } \\
\text { vangst }\end{array}$ & & $\begin{array}{l}\text { Leeuwarder Cou- } \\
\text { rant, 17 March } \\
\text { 1840; Leeuwarder } \\
\text { Courant, 18 August } \\
\text { 1840; Ship's jour- } \\
\text { nal, Friesenmu- } \\
\text { seum, Wyk auf } \\
\text { Föhr }\end{array}$ \\
\hline \multirow[t]{2}{*}{1841} & $\begin{array}{l}\text { Barend Visser } \\
\text { \& Son, } \\
\text { Harlingen }\end{array}$ & \begin{tabular}{|l|} 
Rickmers, \\
Hendrik \\
Dep. 9 March; \\
Ret. 27 July \\
\end{tabular} & Spitsbergen II & $\begin{array}{l}\text { Bark } \\
251 \text { tons }\end{array}$ & $\begin{array}{l}\text { Jan Mayen } \\
\text { Spitsbergen }\end{array}$ & $?$ & & $\begin{array}{l}\text { Leeuwarder Cou- } \\
\text { rant, } 16 \text { March 1841; } \\
\text { Leeuwarder Cou- } \\
\text { rant, } 3 \text { August } 1841\end{array}$ \\
\hline & $\begin{array}{l}\text { Barend Visser } \\
\text { \& Son, } \\
\text { Harlingen }\end{array}$ & $\begin{array}{l}\text { Mehlen, O. } \\
\text { Dep. 9 March; } \\
\text { Ret. 27 July }\end{array}$ & $\begin{array}{l}\text { Dirkje Ade- } \\
\text { ma }\end{array}$ & $\begin{array}{l}\text { Frigate/pink } \\
349 \text { tons }\end{array}$ & $\begin{array}{l}\text { Jan Mayen } \\
\text { Spitsbergen }\end{array}$ & $?$ & & $\begin{array}{l}\text { Leeuwarder Cou- } \\
\text { rant, } 16 \text { March 1841; } \\
\text { Leeuwarder Cou- } \\
\text { rant, } 3 \text { August } 1841\end{array}$ \\
\hline \multirow[t]{2}{*}{1842} & $\begin{array}{l}\text { Barend Visser } \\
\text { \& Son, } \\
\text { Harlingen }\end{array}$ & $\begin{array}{l}\text { Both, J. } \\
\text { Dep. 10 } \\
\text { March; } \\
\text { Ret. ? }\end{array}$ & Spitsbergen II & $\begin{array}{l}\text { Bark } \\
251 \text { tons }\end{array}$ & $\begin{array}{l}\text { Jan Mayen } \\
\text { Spitsbergen }\end{array}$ & $\begin{array}{l}\text { Total catch } \\
8,700 \text { seals; } \\
\text { whaling } \\
\text { failed }\end{array}$ & & $\begin{array}{l}\text { Leeuwarder Cou- } \\
\text { rant, } 22 \text { March } \\
\text { 1842; Leeuwarder } \\
\text { Courant, } 11 \text { July } \\
1843\end{array}$ \\
\hline & $\begin{array}{l}\text { Barend Visser } \\
\text { \& Son, } \\
\text { Harlingen }\end{array}$ & $\begin{array}{l}\text { Mehlen, O. } \\
\text { Dep. 10 } \\
\text { March; } \\
\text { Ret.? }\end{array}$ & $\begin{array}{l}\text { Dirkje Ade- } \\
\text { ma }\end{array}$ & $\begin{array}{l}\text { Frigate/pink } \\
349 \text { tons }\end{array}$ & $\begin{array}{l}\text { Jan Mayen } \\
\text { Spitsbergen }\end{array}$ & $?$ & & $\begin{array}{l}\text { Leeuwarder Cou- } \\
\text { rant, } 22 \text { March } 1842\end{array}$ \\
\hline \multirow[t]{2}{*}{1843} & $\begin{array}{l}\text { Barend Visser } \\
\text { \& Son, } \\
\text { Harlingen }\end{array}$ & $\begin{array}{l}\text { Both. Johan } \\
\text { Dep. 5 March; } \\
\text { Ret. 6 August }\end{array}$ & Spitsbergen II & $\begin{array}{l}\text { Bark } \\
251 \text { tons }\end{array}$ & $?$ & $?$ & & $\begin{array}{l}\text { Leeuwarder Cou- } \\
\text { rant, } 14 \text { March } 1843 ; \\
\text { Leeuwarder Cou- } \\
\text { rant, } 15 \text { August } 1843\end{array}$ \\
\hline & $\begin{array}{l}\text { Barend Visser } \\
\text { \& Son, } \\
\text { Harlingen }\end{array}$ & $\begin{array}{l}\text { Mehlen, O. } \\
\text { Dep.? } \\
\text { Ret.3o July }\end{array}$ & $\begin{array}{l}\text { Dirkje Ade- } \\
\text { ma }\end{array}$ & $\begin{array}{l}\text { Frigate/pink } \\
349 \text { tons }\end{array}$ & $?$ & $?$ & & $\begin{array}{l}\text { Leeuwarder Cou- } \\
\text { rant, } 8 \text { August } 1843\end{array}$ \\
\hline
\end{tabular}




\begin{tabular}{|c|c|c|c|c|c|c|c|c|}
\hline Year & $\begin{array}{l}\text { Owner/ } \\
\text { Company }\end{array}$ & Master & Ship & Rig & Destination & Results & Remarks & Sources \\
\hline \multirow[t]{2}{*}{1844} & $\begin{array}{l}\text { Barend Visser } \\
\text { \& Son, } \\
\text { Harlingen }\end{array}$ & $\begin{array}{l}\text { Both. J. } \\
\text { Dep.? } \\
\text { Ret. 31 July }\end{array}$ & Spitsbergen II & $\begin{array}{l}\text { Bark } \\
251 \text { tons }\end{array}$ & $?$ & $\begin{array}{l}\text { Caught } \\
450 \text { seals }\end{array}$ & & $\begin{array}{l}\text { Leeuwarder Cou- } \\
\text { rant, } 12 \text { April 1844; } \\
\text { Leeuwarder Cou- } \\
\text { rant, } 6 \text { August 1844; } \\
\text { typoscript A.J. } \\
\text { Dijkstra }\end{array}$ \\
\hline & $\begin{array}{l}\text { Barend Visser } \\
\text { \& Son, } \\
\text { Harlingen }\end{array}$ & $\begin{array}{l}\text { Mehlen, O. } \\
\text { Dep.? } \\
\text { Ret. } 27 \text { July }\end{array}$ & $\begin{array}{l}\text { Dirkje Ade- } \\
\text { ma }\end{array}$ & $\begin{array}{l}\text { Frigate/pink } \\
349 \text { tons }\end{array}$ & $?$ & $?$ & & $\begin{array}{l}\text { Leeuwarder Cou- } \\
\text { rant, } 12 \text { April 1844; } \\
\text { Leeuwarder Cou- } \\
\text { rant, } 30 \text { July } 1844\end{array}$ \\
\hline \multirow[t]{2}{*}{1845} & $\begin{array}{l}\text { Barend Visser } \\
\text { \& Son, } \\
\text { Harlingen }\end{array}$ & $\begin{array}{l}\text { Both. J. } \\
\text { Dep.? } \\
\text { Ret. 13 August }\end{array}$ & Spitsbergen II & $\begin{array}{l}\text { Bark } \\
251 \text { tons }\end{array}$ & $?$ & $\begin{array}{l}\text { Caught } \\
1,934 \text { seals/ } \\
1 \text { small } \\
\text { whale }\end{array}$ & & $\begin{array}{l}\text { Leeuwarder Cou- } \\
\text { rant, } 8 \text { April 1845; } \\
\text { Leeuwarder Cou- } \\
\text { rant, } 19 \text { August } \\
\text { 1845; Leeuwarder } \\
\text { Courant, } 14 \text { July } \\
1846\end{array}$ \\
\hline & $\begin{array}{l}\text { Barend Visser } \\
\text { \& Son, } \\
\text { Harlingen }\end{array}$ & $\begin{array}{l}\text { Mehlen, O. } \\
\text { Dep.? } \\
\text { Ret. } 6 \text { August }\end{array}$ & $\begin{array}{l}\text { Dirkje Ade- } \\
\text { ma }\end{array}$ & $\begin{array}{l}\text { Frigate/pink } \\
349 \text { tons }\end{array}$ & $?$ & $\begin{array}{l}\text { Caught } \\
2,076 \text { seals/ } \\
8 \text { small } \\
\text { whales }\end{array}$ & & $\begin{array}{l}\text { Leeuwarder Cou- } \\
\text { rant, } 8 \text { April } 1845 ; \\
\text { Leeuwarder Cou- } \\
\text { rant, } 12 \text { August } \\
\text { 1845; Leeuwarder } \\
\text { Courant, } 14 \text { July } \\
\text { 1846; typoscript } \\
\text { A.J. Dijkstra }\end{array}$ \\
\hline \multirow[t]{2}{*}{1846} & $\begin{array}{l}\text { Barend Visser } \\
\text { \& Son, } \\
\text { Harlingen }\end{array}$ & $\begin{array}{l}\text { Both. J. } \\
\text { Dep. } 3 \text { March }\end{array}$ & Spitsbergen II & \begin{tabular}{|l} 
Bark \\
251 tons
\end{tabular} & $\begin{array}{l}\text { Jan Mayen } \\
\text { Spitsbergen }\end{array}$ & $\begin{array}{l}\text { Caught } 300 \\
\text { to } 400 \text { seals }\end{array}$ & & $\begin{array}{l}\text { Leeuwarder Cou- } \\
\text { rant, 10 March } \\
\text { 1846; Leeuwarder } \\
\text { Courant, 19 July } \\
\text { 1847; Ship's journal, } \\
\text { Friesenmuseum, } \\
\text { Wyk auf Föhr; } \\
\text { C. Nielsen, 'Uit de } \\
\text { geschiedenis van de } \\
\text { Harlinger walvis- } \\
\text { vaart', } 25\end{array}$ \\
\hline & $\begin{array}{l}\text { Barend Visser } \\
\text { \& Son, } \\
\text { Harlingen }\end{array}$ & $\begin{array}{l}\text { Mehlen, O. } \\
\text { Dep. } 3 \text { March; } \\
\text { Ret. 28 July }\end{array}$ & $\begin{array}{l}\text { Dirkje Ade- } \\
\text { ma }\end{array}$ & $\begin{array}{l}\text { Frigate/pink } \\
349 \text { tons }\end{array}$ & $\begin{array}{l}\text { Jan Mayen } \\
\text { Spitsbergen }\end{array}$ & $\begin{array}{l}\text { Caught } 300 \\
\text { to } 400 \text { seals }\end{array}$ & & $\begin{array}{l}\text { Leeuwarder Cou- } \\
\text { rant, 10 March } \\
\text { 1846; Leeuwarder } \\
\text { Courant, } 4 \text { August } \\
1846\end{array}$ \\
\hline 1847 & $\begin{array}{l}\text { Barend Visser } \\
\text { \& Son, } \\
\text { Harlingen }\end{array}$ & $\begin{array}{l}\text { Both. J. } \\
\text { Dep. } 4 \text { Febru- } \\
\text { ary; } \\
\text { Ret. } 31 \text { July }\end{array}$ & Spitsbergen II & $\begin{array}{l}\text { Bark } \\
251 \text { tons }\end{array}$ & $\begin{array}{l}\text { Jan Mayen } \\
\text { Spitsbergen }\end{array}$ & $\begin{array}{l}\text { Caught } \\
5,500 \text { seals/ } \\
1 / 2 \text { whale }\end{array}$ & & $\begin{array}{l}\text { Leeuwarder Cou- } \\
\text { rant, } 9 \text { March 1847; } \\
\text { Leeuwarder Cou- } \\
\text { rant, } 10 \text { August } \\
\text { 1847; Ship's journal, } \\
\text { Friesenmuseum, } \\
\text { Wyk auf Föhr }\end{array}$ \\
\hline & $\begin{array}{l}\text { Barend Visser } \\
\text { \& Son, } \\
\text { Harlingen }\end{array}$ & $\begin{array}{l}\text { Mehlen, O. } \\
\text { Dep. } 8 \text { Febru- } \\
\text { ary; } \\
\text { Ret. } 12 \text { July }\end{array}$ & $\begin{array}{l}\text { Dirkje Ade- } \\
\text { ma }\end{array}$ & $\begin{array}{l}\text { Frigate } \\
349 \text { tons }\end{array}$ & $\begin{array}{l}\text { Jan Mayen } \\
\text { Spitsbergen }\end{array}$ & $\begin{array}{l}\text { Caught } \\
8,900 \text { seal }\end{array}$ & & $\begin{array}{l}\text { Leeuwarder Cou- } \\
\text { rant, } 9 \text { March } 1847 \text {; } \\
\text { Leeuwarder Cou- } \\
\text { rant, } 20 \text { July } 1847 ; \\
\text { Leeuwarder Cou- } \\
\text { rant, } 11 \text { July } 1848 \\
\text { (Governor's annual } \\
\text { report, p. 37) }\end{array}$ \\
\hline
\end{tabular}




\begin{tabular}{|c|c|c|c|c|c|c|c|c|}
\hline Year & $\begin{array}{l}\text { Owner/ } \\
\text { Company }\end{array}$ & Master & Ship & Rig & Destination & Results & Remarks & Sources \\
\hline \multirow[t]{2}{*}{1848} & $\begin{array}{l}\text { Barend Visser } \\
\text { \& Son, } \\
\text { Harlingen }\end{array}$ & $\begin{array}{l}\text { Both. J. } \\
\text { Dep.? } \\
\text { Ret.? }\end{array}$ & Spitsbergen II & $\begin{array}{l}\text { Bark } \\
251 \text { tons }\end{array}$ & $\begin{array}{l}\text { Jan Mayen } \\
\text { Spitsbergen }\end{array}$ & $\begin{array}{l}\text { Caught } \\
\text { 10o seals }\end{array}$ & & $\begin{array}{l}\text { GAH 1648, fo. } 125 \text {, } \\
\text { reg. nr. } 1037 \text { ( } 25 \text { Au- } \\
\text { gust); Leeuwarder } \\
\text { Courant, } 13 \text { July } \\
\text { 1849; Ship's jour- } \\
\text { nal, Friesenmuse- } \\
\text { um, Wyk auf Föhr }\end{array}$ \\
\hline & $\begin{array}{l}\text { Barend Visser } \\
\text { \& Son, } \\
\text { Harlingen }\end{array}$ & $\begin{array}{l}\text { Mehlen, O. } \\
\text { Dep.? } \\
\text { Ret. 30 July }\end{array}$ & $\begin{array}{l}\text { Dirkje Ade- } \\
\text { ma }\end{array}$ & $\begin{array}{l}\text { Frigate } \\
349 \text { tons }\end{array}$ & $\begin{array}{l}\text { Jan Mayen } \\
\text { Spitsbergen }\end{array}$ & $\begin{array}{l}\text { Empty/ } \\
9 \text { seals }\end{array}$ & & $\begin{array}{l}\text { GAH 1648, fo. } 125, \\
\text { reg. nr. } 991 \text { (12 Au- } \\
\text { gust); Leeuwarder } \\
\text { Courant, } 8 \text { August } \\
1848 ; \text { Leeuwarder } \\
\text { Courant, } 13 \text { July } \\
1849\end{array}$ \\
\hline \multirow[t]{2}{*}{1849} & $\begin{array}{l}\text { Barend Visser } \\
\text { \& Son, } \\
\text { Harlingen }\end{array}$ & Both. J. & Spitsbergen II & $\begin{array}{l}\text { Bark } \\
251 \text { tons }\end{array}$ & $?$ & \begin{tabular}{|l|} 
Caught 700 \\
seals yield- \\
ing 40 kwar- \\
telen of oil
\end{tabular} & & $\begin{array}{l}\text { GAH 1442, reg. nr. } \\
987 \text { (18 August); ty- } \\
\text { poscript A.J. Dijk- } \\
\text { stra }\end{array}$ \\
\hline & $\begin{array}{l}\text { Barend Visser } \\
\text { \& Son, } \\
\text { Harlingen }\end{array}$ & Mehlen, $\mathrm{O}$. & $\begin{array}{l}\text { Dirkje Ade- } \\
\text { ma }\end{array}$ & $\begin{array}{l}\text { Frigate } \\
349 \text { tons }\end{array}$ & $?$ & \begin{tabular}{|l|} 
Caught 1,100 \\
seals yield- \\
ing 64 kwar- \\
telen of oil \\
\end{tabular} & & $\begin{array}{l}\text { GAH 1442, reg. nr. } \\
987 \text { (18 August); ty- } \\
\text { poscript A.J. Dijk- } \\
\text { stra }\end{array}$ \\
\hline \multirow[t]{2}{*}{1850} & $\begin{array}{l}\text { Barend Visser } \\
\text { \& Son, } \\
\text { Harlingen }\end{array}$ & Nagel, P. & Spitsbergen II & $\begin{array}{l}\text { Bark } \\
251 \text { tons }\end{array}$ & $?$ & $\begin{array}{l}\text { Caught } \\
1 \text { whale, } \\
4, \text { ooo seals }\end{array}$ & & $\begin{array}{l}\text { typoscript A.J. } \\
\text { Dijkstra }\end{array}$ \\
\hline & $\begin{array}{l}\text { Barend Visser } \\
\text { \& Son, } \\
\text { Harlingen }\end{array}$ & Mehlen, O. & $\begin{array}{l}\text { Dirkje Ade- } \\
\text { ma }\end{array}$ & $\begin{array}{l}\text { Frigate } \\
349 \text { tons }\end{array}$ & $?$ & $\begin{array}{l}\text { Caught } \\
9,000 \text { seals }\end{array}$ & & $\begin{array}{l}\text { typoscript A.J. } \\
\text { Dijkstra }\end{array}$ \\
\hline \multirow[t]{2}{*}{1851} & $\begin{array}{l}\text { Barend Visser } \\
\text { \& Son, } \\
\text { Harlingen }\end{array}$ & Nagel, P. & Spitsbergen II & $\begin{array}{l}\text { Bark } \\
251 \text { tons }\end{array}$ & $?$ & $\begin{array}{l}\text { Caught 90o } \\
\text { seals yield- } \\
\text { ing about } \\
58.7 \text { kwarte- } \\
\text { len of oil }\end{array}$ & & $\begin{array}{l}\text { GAH 1444, reg.nr. } \\
849 \text { (21 August); ty- } \\
\text { poscript A.J. Dijk- } \\
\text { stra }\end{array}$ \\
\hline & $\begin{array}{l}\text { Barend Visser } \\
\text { \& Son, } \\
\text { Harlingen }\end{array}$ & Mehlen, O. & $\begin{array}{l}\text { Dirkje Ade- } \\
\text { ma }\end{array}$ & $\begin{array}{l}\text { Frigate } \\
349 \text { tons }\end{array}$ & $?$ & $\begin{array}{l}\text { Caught } 1 \\
\text { whale, } 3,500 \\
\text { seals }\end{array}$ & & $\begin{array}{l}\text { typoscript A.J. } \\
\text { Dijkstra }\end{array}$ \\
\hline \multirow[t]{2}{*}{1852} & $\begin{array}{l}\text { Barend Visser } \\
\text { \& Son, } \\
\text { Harlingen }\end{array}$ & Stockfleet, H. & Spitsbergen II & $\begin{array}{l}\text { Bark } \\
251 \text { tons }\end{array}$ & $?$ & \begin{tabular}{|l|} 
Catches not \\
known; \\
23 barrels of \\
blubber \\
yielded \\
49 kwartelen \\
of oil
\end{tabular} & & $\begin{array}{l}\text { GAH } 1445 \text {, reg. nr. } \\
817 \text { (18 August) }\end{array}$ \\
\hline & $\begin{array}{l}\text { Barend Visser } \\
\text { \& Son, } \\
\text { Harlingen }\end{array}$ & Mehlen, O. & $\begin{array}{l}\text { Dirkje Ade- } \\
\text { ma }\end{array}$ & $\begin{array}{l}\text { Frigate } \\
349 \text { tons }\end{array}$ & $?$ & $\begin{array}{l}\text { Catches not } \\
\text { known; } \\
11 \text { barrels of } \\
\text { blubber } \\
\text { yielded } 34^{1 / 2} \\
\text { barrels of oil } \\
\end{array}$ & & $\begin{array}{l}\text { GAH 1445, reg. nr. } \\
817 \text { (18 August) }\end{array}$ \\
\hline 1853 & $\begin{array}{l}\text { Barend Visser } \\
\text { \& Son, } \\
\text { Harlingen }\end{array}$ & Stockfleet, H. & Spitsbergen II & $\begin{array}{l}\text { Bark } \\
251 \text { tons }\end{array}$ & $?$ & $\begin{array}{l}\text { Caught } 900 \\
\text { seals }\end{array}$ & $\begin{array}{l}\text { Sold at auction } \\
\text { in Harlingen } \\
\text { on June 29, } \\
\text { 1853; re-named } \\
\text { Triton }\end{array}$ & $\begin{array}{l}\text { typoscript A.J. } \\
\text { Dijkstra; S. Zee- } \\
\text { man, 'Harlingen en } \\
\text { de walvisvaart', } 19\end{array}$ \\
\hline & $\begin{array}{l}\text { Barend Visser } \\
\text { \& Son, } \\
\text { Harlingen }\end{array}$ & Mehlen, O. & $\begin{array}{l}\text { Dirkje Ade- } \\
\text { ma }\end{array}$ & $\begin{array}{l}\text { Frigate } \\
349 \text { tons }\end{array}$ & $?$ & $\begin{array}{l}\text { Caught } \\
4,500 \text { seals }\end{array}$ & & $\begin{array}{l}\text { typoscript A.J. } \\
\text { Dijkstra }\end{array}$ \\
\hline
\end{tabular}




\begin{tabular}{|c|c|c|c|c|c|c|c|c|}
\hline Year & $\begin{array}{l}\text { Owner/ } \\
\text { Company }\end{array}$ & Master & Ship & Rig & Destination & Results & Remarks & Sources \\
\hline 1854 & $\begin{array}{l}\text { Barend Visser } \\
\text { \& Son, } \\
\text { Harlingen }\end{array}$ & Mehlen, O. & $\begin{array}{l}\text { Dirkje Ade- } \\
\text { ma }\end{array}$ & $\begin{array}{l}\text { Frigate } \\
349 \text { tons }\end{array}$ & $?$ & $\begin{array}{l}\text { Catches not } \\
\text { known: } \\
6 \text { barrels of } \\
\text { blubber } \\
\text { yielded } \\
\text { about } 17^{1 / 4} \\
\text { kwartelen of } \\
\text { oil }\end{array}$ & & $\begin{array}{l}\text { The Governor's an- } \\
\text { nual report printed } \\
\text { in Leeuwarder Cou- } \\
\text { rant, } 6 \text { July } 1855 \\
\text { does not refer to } \\
\text { any whaling activi- } \\
\text { ties; GAH } \\
\text { 1448/1449, reg. nr. } \\
850 \text { (14 August) }\end{array}$ \\
\hline 1855 & $\begin{array}{l}\text { Barend Visser } \\
\text { \& Son, } \\
\text { Harlingen }\end{array}$ & Mehlen, O. & $\begin{array}{l}\text { Dirkje Ade- } \\
\text { ma }\end{array}$ & $\begin{array}{l}\text { Frigate } \\
349 \text { tons }\end{array}$ & $?$ & $\begin{array}{l}\text { Returned } \\
\text { with living } \\
\text { polar bear; } \\
\text { catches not } \\
\text { known; } \\
4 \text { barrels of } \\
\text { blubber } \\
\text { yielded } \\
\text { about } \\
8 \text { kwartelen } \\
\text { of oil }\end{array}$ & & $\begin{array}{l}\text { GAH 1450, reg. nr. } \\
928 \text { (25 August); ty- } \\
\text { poscript A.J. Dijk- } \\
\text { stra }\end{array}$ \\
\hline & \begin{tabular}{|l} 
Nicolaas \\
Brantjes \& \\
Smit, \\
Purmerend
\end{tabular} & & Maria & $\begin{array}{l}\text { Brig } \\
265 \text { tons } \\
\text { Built } \\
\text { Gothenburg, } \\
1856\end{array}$ & $?$ & $\begin{array}{l}\text { Caught } \\
4,000 \text { seals }\end{array}$ & & $\begin{array}{l}\text { Staatkundigen } \\
\text { staathuishoudkun- } \\
\text { dig Jaarboekje } \\
(1858), 83 \text {; De Jong, } \\
\text { II, } 461\end{array}$ \\
\hline 1856 & $\begin{array}{l}\text { Barend Visser } \\
\text { \& Son, } \\
\text { Harlingen }\end{array}$ & Mehlen, O. & $\begin{array}{l}\text { Dirkje Ade- } \\
\text { ma }\end{array}$ & $\begin{array}{l}\text { Frigate } \\
349 \text { tons }\end{array}$ & $?$ & & & \\
\hline & \begin{tabular}{|l} 
Nicolaas \\
Brantjes \& \\
Smit, \\
Purmerend
\end{tabular} & & Maria & Brig & $?$ & $\begin{array}{l}\text { Caught } \\
9,300 \text { seals }\end{array}$ & & $\begin{array}{l}\text { Staatkundigen staat- } \\
\text { huishoudkundig } \\
\text { Jaarboekje (1858), 83; } \\
\text { De Jong, II, 461 }\end{array}$ \\
\hline 1857 & $\begin{array}{l}\text { Barend Visser } \\
\text { \& Son, } \\
\text { Harlingen }\end{array}$ & Mehlen, $\mathrm{O}$. & $\begin{array}{l}\text { Dirkje Ade- } \\
\text { ma }\end{array}$ & $\begin{array}{l}\text { Frigate } \\
349 \text { tons }\end{array}$ & $?$ & $\begin{array}{l}\text { Caught } \\
1,300 \text { seals }\end{array}$ & & $\begin{array}{l}\text { typoscript A.J. } \\
\text { Dijkstra }\end{array}$ \\
\hline 1858 & $\begin{array}{l}\text { Barend Visser } \\
\text { \& Son, } \\
\text { Harlingen }\end{array}$ & Mehlen, $\mathrm{O}$ & $\begin{array}{l}\text { Dirkje Ade- } \\
\text { ma }\end{array}$ & $\begin{array}{l}\text { Frigate } \\
349 \text { tons }\end{array}$ & $?$ & $\begin{array}{l}\text { Caught } \\
100 \text { seals }\end{array}$ & & $\begin{array}{l}\text { Harlinger Courant, } \\
4 \text { March 1858; Har- } \\
\text { linger Courant, } 27 \\
\text { July } 1858 \text {; C. de } \\
\text { Jong, 'De Dirkje } \\
\text { Adema', 42; typo- } \\
\text { script A.J. Dijkstra; } \\
\text { C. Nielsen, 'Uit de } \\
\text { geschiedenis van de } \\
\text { Harlinger walvis- } \\
\text { vaart', } 25\end{array}$ \\
\hline 1859 & $\begin{array}{l}\text { Barend Visser } \\
\text { \& Son, } \\
\text { Harlingen }\end{array}$ & Brinkman, C. & $\begin{array}{l}\text { Dirkje Ade- } \\
\text { ma }\end{array}$ & $\begin{array}{l}\text { Frigate } \\
349 \text { tons }\end{array}$ & $?$ & $\begin{array}{l}\text { Caught } \\
1, \text { ooo seals }\end{array}$ & & $\begin{array}{l}\text { Harlinger Courant, } \\
23 \text { February } 1859 ; \\
\text { typoscript A.J. } \\
\text { Dijkstra erroneous- } \\
\text { ly mentions } 27 \mathrm{Au}- \\
\text { gust as date of re- } \\
\text { turn }\end{array}$ \\
\hline 1860 & $\begin{array}{l}\text { Barend Visser } \\
\text { \& Son, } \\
\text { Harlingen }\end{array}$ & Wildst, $\mathrm{H}$. & $\begin{array}{l}\text { Dirkje Ade- } \\
\text { ma }\end{array}$ & $\begin{array}{l}\text { Frigate } \\
349 \text { tons }\end{array}$ & $?$ & $\begin{array}{l}\text { Caught seals } \\
\text { and two po- } \\
\text { lar bears }\end{array}$ & & $\begin{array}{l}\text { typoscript A.J. } \\
\text { Dijkstra }\end{array}$ \\
\hline 1861 & $\begin{array}{l}\text { Barend Visser } \\
\text { \& Son, } \\
\text { Harlingen }\end{array}$ & Wildst, $\mathrm{H}$. & $\begin{array}{l}\text { Dirkje Ade- } \\
\text { ma }\end{array}$ & $\begin{array}{l}\text { Frigate } \\
349 \text { tons }\end{array}$ & $?$ & $\begin{array}{l}\text { Caught } 560 \\
\text { seals; } 100 \\
\text { kwartelen } \\
\text { seal blubber }\end{array}$ & & $\begin{array}{l}\text { Wumkes, Tusschen } \\
\text { Flie en Borne, 100; } \\
\text { typoscript A.J. } \\
\text { Dijkstra }\end{array}$ \\
\hline
\end{tabular}




\begin{tabular}{|c|c|c|c|c|c|c|c|c|}
\hline Year & $\begin{array}{l}\text { Owner/ } \\
\text { Company }\end{array}$ & Master & Ship & Rig & Destination & Results & Remarks & Sources \\
\hline 1862 & $\begin{array}{l}\text { Barend Visser } \\
\text { \& Son, } \\
\text { Harlingen }\end{array}$ & Wildst, H. & $\begin{array}{l}\text { Dirkje Ade- } \\
\text { ma }\end{array}$ & $\begin{array}{l}\text { Frigate } \\
349 \text { tons }\end{array}$ & $?$ & $\begin{array}{l}\text { Caught } \\
2,800 \text { seals }\end{array}$ & & $\begin{array}{l}\text { C. Nielsen, 'Uit de } \\
\text { geschiedenis van de } \\
\text { Harlinger walvis- } \\
\text { vaart', } 25\end{array}$ \\
\hline 1863 & $\begin{array}{l}\text { Barend Visser } \\
\text { \& Son, } \\
\text { Harlingen }\end{array}$ & Wildst, $\mathrm{H}$. & $\begin{array}{l}\text { Dirkje Ade- } \\
\text { ma }\end{array}$ & $\begin{array}{l}\text { Frigate } \\
349 \text { tons }\end{array}$ & $?$ & $\begin{array}{l}\text { Caught } 900 \\
\text { seals }\end{array}$ & & $\begin{array}{l}\text { typoscript A.J. } \\
\text { Dijkstra }\end{array}$ \\
\hline 1864 & $\begin{array}{l}\text { Barend Visser } \\
\text { \& Son, } \\
\text { Harlingen } \\
\text { discontinued }\end{array}$ & Wildst, H. & $\begin{array}{l}\text { Dirkje Ade- } \\
\text { ma }\end{array}$ & $\begin{array}{l}\text { Frigate } \\
349 \text { tons }\end{array}$ & $?$ & & $\begin{array}{l}\text { Ship sold to } \\
\text { Norway for } \\
f_{9,000 ;} \\
\text { grounded near } \\
\text { German island } \\
\text { of Rügen, } 1865\end{array}$ & $\begin{array}{l}\text { J. van Sluis, Koop- } \\
\text { vaardijschepen, } 80\end{array}$ \\
\hline \multirow[t]{2}{*}{1870} & $\begin{array}{l}\text { Nederland- } \\
\text { sche Walvisch- } \\
\text { vaart N.V. }\end{array}$ & $\begin{array}{l}\text { Bottemanne, } \\
\text { C.J. }\end{array}$ & $\begin{array}{l}\text { Noordkaper } \\
\text { Built 1869/70 } \\
\text { by W.B. } \\
\text { Hornby } \\
\text { Wellington, } \\
\text { Tynemout, } \\
\text { Northum- } \\
\text { berland }\end{array}$ & $\begin{array}{l}\text { Three- } \\
\text { masted } \\
\text { sailing ship, } \\
\pm 150 \text { tons, } \\
\text { with steam } \\
\text { engine; car- } \\
\text { ried three } \\
\text { whaleboats }\end{array}$ & Iceland & $\begin{array}{l}\text { one small fin } \\
\text { whale, yield- } \\
\text { ing } 77^{1 / 2} \\
\text { barrels of } \\
\text { oil, and } \\
250 \text { kilo- } \\
\text { grams of } \\
\text { baleen }\end{array}$ & & De Jong, II, 484 \\
\hline & $\begin{array}{l}\text { Nicolaas Bran- } \\
\text { tjes \& Smit, } \\
\text { Purmerend }\end{array}$ & & Maria & Brig & $?$ & $\begin{array}{l}\text { Caught } \\
4,700 \text { seals }\end{array}$ & $\begin{array}{l}\text { Based in Tøns- } \\
\text { berg, Norway }\end{array}$ & $\begin{array}{l}\text { Ten Brink, Euro- } \\
\text { peesche Noordpool- } \\
\text { visscherij, 9; De } \\
\text { Jong, III, note } 60\end{array}$ \\
\hline \multirow[t]{2}{*}{1871} & $\begin{array}{l}\text { Nederland- } \\
\text { sche Walvisch- } \\
\text { vaart N.V. }\end{array}$ & $\begin{array}{l}\text { Bottemanne, } \\
\text { C.J. }\end{array}$ & Noordkaper & $\begin{array}{l}\text { Three- } \\
\text { masted } \\
\text { sailing ship, } \\
\pm 150 \text { tons, } \\
\text { with steam } \\
\text { engine; car- } \\
\text { ried three } \\
\text { whaleboats }\end{array}$ & Iceland & $\begin{array}{l}\text { Thirteen } \\
\text { whales; } \\
\text { species not } \\
\text { specified }\end{array}$ & & De Jong, II, 485 \\
\hline & $\begin{array}{l}\text { Nicolaas Bran- } \\
\text { tjes \& Smit, } \\
\text { Purmerend }\end{array}$ & & Maria & Brig & $?$ & $\begin{array}{l}\text { Caught } 1 \text { fin } \\
\text { whale }\end{array}$ & & $\begin{array}{l}\text { Bottemanne, 'Eco- } \\
\text { nomische nalezin- } \\
\text { gen en berigten', } \\
344\end{array}$ \\
\hline \multirow[t]{2}{*}{1872} & $\begin{array}{l}\text { Nederland- } \\
\text { sche Walvisch- } \\
\text { vaart N.V. }\end{array}$ & $\begin{array}{l}\text { Bottemanne, } \\
\text { C.J. }\end{array}$ & Noordkaper & $\begin{array}{l}\text { Three- } \\
\text { masted } \\
\text { sailing ship, } \\
\pm 150 \text { tons, } \\
\text { with steam } \\
\text { engine; car- } \\
\text { ried three } \\
\text { whaleboats }\end{array}$ & Iceland & $\begin{array}{l}\text { 'Some' } \\
\text { whales }\end{array}$ & & De Jong, II, 486 \\
\hline & $\begin{array}{l}\text { Nicolaas Bran- } \\
\text { tjes \& Smit, } \\
\text { Purmerend }\end{array}$ & & Maria & Brig & $?$ & 13 fin whales & & $\begin{array}{l}\text { Bottemanne, 'Eco- } \\
\text { nomische nalezin- } \\
\text { gen en berigten', } \\
344\end{array}$ \\
\hline 1884 & \begin{tabular}{|l|} 
Nicolaas \\
Brantjes \& \\
Smit, \\
Purmerend
\end{tabular} & Larsen, L.A. & Maria & Brig & $?$ & $\begin{array}{l}\text { Caught } \\
7,000 \text { seals }\end{array}$ & $\begin{array}{l}\text { Based in Tøns- } \\
\text { berg, Norway. } \\
\text { Registered in } \\
\text { the Nether- } \\
\text { lands. Whal- } \\
\text { ing and sealing } \\
\text { discontinued }\end{array}$ & De Jong, II, 462 \\
\hline
\end{tabular}




\section{Appendix 2 \\ Numerical Overview of Dutch Arctic Whaling and Sealing Expeditions \\ (1802-1884)}

( $A=$ number of ships deployed per year; $B=$ number of expeditions per year; $C=$ number of whales caught; $\mathrm{D}=$ number of barrels of whale blubber; $\mathrm{E}=$ number of kwartelen of whale oil; $\mathrm{F}=$ quantity of baleen; $\mathrm{G}=$ number of seals caught; $\mathrm{H}=$ number of barrels of seal blubber; $\mathrm{I}=\mathrm{kwartelen}$ of seal oil; $J=$ number of seal furs; $\mathrm{K}=$ kwartelen of unspecified oil. For sources, see Appendix 1 and Chapter 4$)$.

\begin{tabular}{|c|c|c|c|c|c|c|c|c|c|c|c|}
\hline Year & A & B & C & D & $E$ & $F$ & G & $\mathrm{H}$ & I & $\mathrm{J}$ & $\mathrm{K}$ \\
\hline 1802 & 11 & 11 & $15^{1 / 2}$ & 287 & - & - & - & - & - & & \\
\hline 1803 & 7 & 7 & - & - & - & - & - & - & - & & \\
\hline 1804 & 2 & 2 & - & - & - & - & - & - & - & & \\
\hline 1805 & 1 & 1 & - & - & - & - & - & - & - & & \\
\hline 1810 & 1 & 1 & - & - & - & & - & - & & & \\
\hline 1815 & 1 & 1 & - & - & - & & - & - & & & \\
\hline 1816 & 1 & 1 & 2 & & $\begin{array}{l}40 / 57 \\
\text { barrels }\end{array}$ & & - & - & & & \\
\hline 1817 & 1 & 1 & - & - & - & & - & - & & & \\
\hline $1818 ?$ & 1 & 1 & - & - & - & & - & - & & & \\
\hline 1819 & 1 & 1 & 2 & 70 & - & & - & - & & & \\
\hline 1820 & 1 & 1 & - & - & - & & - & - & & & \\
\hline 1821 & 1 & 1 & 6 & - & 90 & & - & - & & & \\
\hline 1822 & 2 & 2 & some & - & - & & Some & - & & & \\
\hline 1823 & 2 & 2 & 11 & 207 & $>100$ & & - & - & & & \\
\hline 1824 & 2 & 2 & & & & & & & & & \\
\hline 1825 & 5 & 5 & - & some & - & & - & $\begin{array}{l}\text { 40 kwar- } \\
\text { telen }\end{array}$ & & & \\
\hline 1826 & 6 & 6 & & & & & 7,814 & & & & 43 \\
\hline 1827 & 3 & 3 & 5 & 160 & & & 800 & & 30 & & \\
\hline 1828 & 1 & 1 & & & & & $>3,000$ & & & & \\
\hline 1829 & 1 & 1 & & & $40 ?$ & & & & & & \\
\hline 1830 & 2 & 2 & & & & & 1,411 & 39 & 62 & & \\
\hline 1831 & 2 & 2 & 3 & $\begin{array}{l}500 \text { (seal } \\
+ \text { whale } \\
\text { oil) }\end{array}$ & $\begin{array}{l}500 \text { (seal } \\
+ \text { whale } \\
\text { oil) }\end{array}$ & 2,500 & 4,421 & & 187 & & \\
\hline 1832 & 2 & 2 & 2 & & & & 3,666 & & 227 & & 46 \\
\hline 1833 & 2 & 2 & 4 & & & 2,000 & 406 & & & $\begin{array}{l}\text { About } \\
400\end{array}$ & 150 \\
\hline 1834 & 2 & 2 & 1 & & & & 105 & & & & 57 \\
\hline 1835 & 1 & 1 & & & & & 2,500 & & & & \\
\hline 1836 & 1 & 1 & & & & & $>3,000$ & & & & \\
\hline 1837 & 1 & 1 & 1 & & & & 53 & & & & \\
\hline 1838 & 2 & 2 & 7 & & & 5,500 & 730 & & & 800 & 8,333 \\
\hline 1839 & 2 & 2 & 1 & & & & 1,000 & & & & \\
\hline 1840 & 2 & 2 & & & & & 2,986 & & & & \\
\hline 1841 & 2 & 2 & & & & & & & & & \\
\hline 1842 & 2 & 2 & & & & & 8,700 & & & & \\
\hline
\end{tabular}




\begin{tabular}{|c|c|c|c|c|c|c|c|c|c|c|c|}
\hline Year & A & B & C & D & E & F & G & $\mathrm{H}$ & I & $\mathrm{J}$ & $\mathrm{K}$ \\
\hline 1843 & 2 & 2 & & & & & & & & & \\
\hline 1844 & 2 & 2 & & & & & 450 & & & & \\
\hline 1845 & 2 & 2 & 9 & & & & 4,010 & & & & \\
\hline 1846 & 2 & 2 & & & & & \begin{tabular}{|l|}
600 to \\
800 \\
(average \\
$=700$ )
\end{tabular} & & & & \\
\hline 1847 & 2 & 2 & $1 / 2$ & & & & 15,400 & & & & \\
\hline 1848 & 2 & 2 & & & & & 109 & & & & \\
\hline 1849 & 2 & 2 & 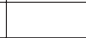 & & & & 1,800 & & 104 & & \\
\hline 1850 & 2 & 2 & 1 & & & & 13,000 & & & & \\
\hline 1851 & 2 & 2 & 1 & & & & 9,900 & & 58.7 & & \\
\hline 1852 & 2 & 2 & & & & & & & & & 83.5 \\
\hline 1853 & 2 & 2 & & & & & 5,400 & & & & \\
\hline 1854 & 1 & 1 & & & & & & & & & 17.25 \\
\hline 1855 & 2 & 2 & & & & & 1,217 & & & & 8 \\
\hline 1856 & 2 & 2 & & & & & 5,702 & & & & \\
\hline 1857 & 1 & 1 & & & & & 4,238 & & & & \\
\hline 1858 & 1 & 1 & & & & & 3,871 & & & & \\
\hline 1859 & 1 & 1 & & & & & 1,959 & & & & \\
\hline 1860 & 1 & 1 & & & & & 415 & & & & \\
\hline 1861 & 1 & 1 & & & & & & $\begin{array}{l}\text { loo } \\
\text { kwarte- } \\
\text { len }\end{array}$ & & & \\
\hline 1862 & 1 & 1 & & & & & & & & & \\
\hline 1863 & 1 & 1 & & & & & 3,226 & & & & \\
\hline 1864 & - & 2 & - & & & & 819 & & & & \\
\hline 1865 & & & & & & & 3,018 & & & & \\
\hline 1866 & & & & & & & 4,034 & & & & \\
\hline 1867 & & & & & & & 6,500 & & & & \\
\hline 1868 & & & & & & & 7,600 & & & & \\
\hline 1869 & & & & & & & 4,234 & & & & \\
\hline 1870 & 2 & 1 & 1 & & 77.5 & 500 & 4,677 & & & & \\
\hline 1871 & 1 & 1 & 14 & & & & 7,524 & & & & \\
\hline 1872 & 1 & 1 & $\begin{array}{l}13+ \\
\text { some }\end{array}$ & & & & 2,683 & & & & \\
\hline 1873 & & & & & & & 323 & & & & \\
\hline 1874 & & & & & & & 1,440 & & & & \\
\hline 1884 & 1 & 1 & & & & & 7,000 & & & & \\
\hline Totals & & 113 & $100+?$ & & & & 161,841 & & & & \\
\hline
\end{tabular}




\section{Appendix 3 \\ Crew Lists of Groenland (1815-1825)}

Source: Municipal Archives Amsterdam (SAA)

Archive Waterschout 38

Nr. 95, 5 April 1815. Pink Groenland, 43 crew, destined for Greenland.

\begin{tabular}{|c|c|c|c|}
\hline Rank & Name & Place of birth & Monthly wage (in $f$ ) \\
\hline Master & Broertjes, Jacob & & \\
\hline $1^{\text {st }}$ mate & Mooij, Corneles [B: capt] & Den Helder & 70,00 \\
\hline Flenser & Schaagen, Dirk [B: capt] & Den Helder & 70,00 \\
\hline Flenser's mate & Hoogerdijk, Jacob [idem] & Den Helder & 60,00 \\
\hline Harpooner & Zeeuw, Cornelis [idem] & Den Helder & 50,00 \\
\hline Harpooner & Keuken, Lauwrens [idem] & Den Helder & 50,00 \\
\hline Harpooner & Hoekstra, Klaas [idem] & Den Helder & 50,00 \\
\hline Boatswain & Moses, Jan [idem] & Den Helder & 30,00 \\
\hline Second boatswain & Glas, Jan [idem] & Den Helder & 30,00 \\
\hline Cook & Os, Floris van [idem] & Den Helder & 30,00 \\
\hline Meester & Schutte, W. & Deventer & 33,00 \\
\hline Carpenter & Veenman, Dirk [B: capt en ik] & Amsterdam & 40,00 \\
\hline Cooper & Gans, Jan J. & Hessen & 30,00 \\
\hline 2nd carpenter & Heijden, Willem van den & Weesep & 22,00 \\
\hline 2nd cooper & Wiese, Heerman & Oldenburg & 20,00 \\
\hline Boatswain's mate & Wolff, Johan B. [B: capt] & Lübeck & 25,00 \\
\hline Seaman & Hood, John & America & 20,00 \\
\hline & Schage, Jan [B: A. Riebe] & Texel & 20,00 \\
\hline & Jansz., Klaas Bol [B: capt] & Beverwijk & 20,00 \\
\hline & Schaasbergen, Hendrik & Deventer & 20,00 \\
\hline & Hinghaus, Frans $\mathrm{H}$. & Oldenburg & 20,00 \\
\hline & Kupen, Johannes B. & Oldenburg & 20,00 \\
\hline & Griek, Pieter G. [B: capt] & Den Helder & 20,00 \\
\hline & Klaasen, Wiebe & Borcum & 20,00 \\
\hline & Lippe, Wiebe & Borcum & 20,00 \\
\hline Ordinary seaman & Bregman, Fulp [B: capt] & Den Helder & $18, \mathrm{oo}$ \\
\hline & Brouwer, Jan [idem] & Den Helder & 18,00 \\
\hline & Keuken, Klaas [idem] & Den Helder & 18,00 \\
\hline & Borst, Jan [idem] & Den Helder & 18,00 \\
\hline & Manas, Pieter H. & Amsterdam & 19,00 \\
\hline & Vroom, Jacob [idem] & Den Helder & 18,00 \\
\hline & Klorn, Klaas [idem] & Den Helder & 17,00 \\
\hline & Been, Klaas [B: B. Kroese signate] & Oldenburg & 18,00 \\
\hline & Pieters, Hendrik [B: B: Boodsman] & Ameland & 18,00 \\
\hline & Zee, Andries H. van der & Knip $[\ldots .]$. & 19,00 \\
\hline & Bakker, Jan [B: A. Riebe] & Texel & 18,00 \\
\hline & Beerends, Wiebe & Borcum & 19,00 \\
\hline & Gerrits, Michiel & Borcum & 17,00 \\
\hline & Meijer, Roelof [B: capt.] & Amsterdam & 14,00 \\
\hline & Hart, Joost [B: capt.] & Texel & 19,00 \\
\hline & Esink, H.B. & Amsterdam & 17,00 \\
\hline Cook's mate & Moses, Pieter C. [B: capt.] & Den Helder & 12,00 \\
\hline Steward & Veenstra, Sijbrand [B: capt] & Texel & 8,00 \\
\hline Cabin boy & Zaameren, Cornelis van [idem] & Den Helder & 8,00 \\
\hline \multicolumn{2}{|c|}{ Total (wages of master excluded) } & & 1103/month \\
\hline
\end{tabular}


Source: Municipal Archives Amsterdam (SAA)

Archive Waterschout 38

Nr. 99, 26 March 1816. Pink Groenland, 50 crew, destined for Greenland. Bookkeeper B. van Spreekens.

\begin{tabular}{|c|c|c|c|}
\hline Rank & Name & Place of birth & Monthly wage (in $f$ ) \\
\hline Master & Broertjes, Jacob & & \\
\hline $1^{\text {st }}$ mate & Mooij, Corneles & Den Helder & 70,00 \\
\hline Flenser & Keuken, Louwrens & Alkmaar & 70,00 \\
\hline Flenser's mate & Moses, Jan & Den Helder & 60,00 \\
\hline Harpooner & Hoekstra, Klaas & Texel & 50,00 \\
\hline Harpooner & Hoogerduin, Jacob & Den Helder & 50,00 \\
\hline Harpooner & Zeeuw, Cornelis & Den Helder & 50,00 \\
\hline Harpooner & Clorn, Jacob & Den Helder & 50,00 \\
\hline Meester [?] & Kloet, Nicolaas H. van der & Amsterdam & 35,00 \\
\hline Cooper & Voogelaar, Johannes & Amsterdam & 30,00 \\
\hline Cook & Vas, Jacob & Den Helder & 30,00 \\
\hline Second boatswain & Bol, Klaas Jansz/Jansz., Klaas Bol & Wijk aan Zee & 30,00 \\
\hline Boatswain & Hoek, Gerrit & Den Helder & 30,00 \\
\hline Boatswain's mate & Griek, Pieter P. & Den Helder & 25,00 \\
\hline Carpenter & Dunke, Harm H. & Oldenburg & 40,00 \\
\hline 2nd carpenter & Olander, Johan & Wisby & 26,00 \\
\hline 2nd cooper & $\begin{array}{l}\text { Kalker, Johann H. } \\
\text { [B: J. Alberding \& Jacob Strout] }\end{array}$ & Oldenburg & 20,00 \\
\hline Seaman & Swainson, Richard & Liverpool & 20,00 \\
\hline & Wilson, John & Liverpool & 20,00 \\
\hline & Tomsen, Ol Andres & Bergen & 20,00 \\
\hline & Hart, Joost & Texel & 20,00 \\
\hline & Bol, Corneles & Santvoort & 20,00 \\
\hline & Brouwer, Dirk & Den Helder & 20,00 \\
\hline & Hoofding, Henrich & Breemen & 20,00 \\
\hline & Herman, Mathias [B: B. Kroese] & Pruis. Finland & 20,00 \\
\hline & Haverbeck, Anton [B: B. Kroese] & Oldenburg & 20,00 \\
\hline & Schröder, J. & Gottenburg & 20,00 \\
\hline & Jensen, Johannes & Föhr & 20,00 \\
\hline & Siemons, Hendk. & Osnabrug & 20,00 \\
\hline & Wehming, Jacob [B: H. Olberding] & Osnabrug & 18,00 \\
\hline & Brouwer, Jan & Den Helder & 19,00 \\
\hline & Brugman, Fulps J. & Den Helder & 19,00 \\
\hline & Jager, Reijer R. de & Den Helder & 18,00 \\
\hline & Vos, Willem F. de & Amsterdam & 19,00 \\
\hline & Brandt, Jan L. & Den Helder & 17,00 \\
\hline & Flehaus, J. Berend [B: H.Olberding & Oldenburg & 17,00 \\
\hline & Harberr, Johan T. [B: H. Olberding] & Oldenburg & 18,00 \\
\hline & Bolke, Bernd [B: H. Olberding] & Osnabrug & 17,00 \\
\hline & Bolke, Johan B. [B: B. Kroese] & Oldenburg & 16,00 \\
\hline & Doornbos, Gerrit E. & Stavoorn & 19,00 \\
\hline & Eeleman, Dirk A. & Texel & 16,00 \\
\hline & Rob, Barend & Medemblik & 14,00 \\
\hline & Helenius, Michiel J. & Texel & 14,00 \\
\hline & Zeeuw, Arien & Den Helder & 10,00 \\
\hline & Miller, Peter & America & 17,00 \\
\hline & Taats, Dirk B. & Sluis in Vlaanderen & 17,00 \\
\hline & Esink, Herman B. & Amsterdam & 19,00 \\
\hline Cook's mate & Zaameren, Corneles van & Den Helder & 9,00 \\
\hline Cabin boy & Veenstraa, Sijbrand & Texel & 9,00 \\
\hline Steward & Zaameren Broertjes, Gerrit Klaaszen van & Den Helder & 9,00 \\
\hline \multicolumn{2}{|c|}{ Total (wages of master excluded) } & & $1237 /$ month \\
\hline
\end{tabular}


Source: Municipal Archives Amsterdam (SAA)

Archive Waterschout 38

Nr. 110, 22 March 1819. Pink Groenland, 50 crew, destined for Greenland. Bookkeeper B. van Spreekens.

\begin{tabular}{|c|c|c|c|}
\hline Rank & Name & Place of birth & Monthly wage (in $f$ ) \\
\hline Master & Broertjes, Jacob & & \\
\hline $1^{\text {st }}$ mate & Hoek, Gerrit & Den Helder & 70,00 \\
\hline Flenser & Keuken, Louwrens & Alkmaar & 70,00 \\
\hline Flenser's mate & Clorn, Pieter & Den Helder & 60,00 \\
\hline Harpooner & Moses, Jan & Den Helder & 50,00 \\
\hline Harpooner & Telleman, Leendert & Den Helder & 50,00 \\
\hline Harpooner & Spierdijk, Klaas & Den Helder & 50,00 \\
\hline Harpooner & Petersen, Johannes & Amsterdam & 36,00 \\
\hline Master cooper & Jonkman, Abraham & Amsterdam & 30,00 \\
\hline Cook & Vos, Jacob & Den Helder & 30,00 \\
\hline Second boatswain & Brouwer, Jan & Den Helder & 30,00 \\
\hline Boatswain & Griek, Pieter G. & Texel & 30,00 \\
\hline Boatswain's mate & Broertjes Gerit Klaaszen & Den Helder & 22,00 \\
\hline Carpenter & Donker, Harm H. & Oldenburg & 40,00 \\
\hline 2nd carpenter & Jurgens, Bord & Föhr & 24,00 \\
\hline 2nd cooper & Vries, Arie de & Amsterdam & 26,00 \\
\hline \multirow[t]{15}{*}{ Seaman } & Visser, Pieter & Eiland Marken & 19,00 \\
\hline & Brugman, Fulp & Den Helder & 19,00 \\
\hline & Keuken, Klaas & Den Helder & 19,00 \\
\hline & Brand, Jan L. & Den Helder & 19,00 \\
\hline & Griek, Albert & Texel & 19,00 \\
\hline & Bakker, Klaas & Texel & 19,00 \\
\hline & Slot, Gerrit & Texel & 19,00 \\
\hline & Moreen, Carel J. & Finland & 19,00 \\
\hline & Olufs, Nanning & Föhr & 19,00 \\
\hline & Arfsten, Nahmen & Föhr & 19,00 \\
\hline & Willems, Klaas & Sloten in Friesland & 19,00 \\
\hline & Ocken, Jung N. & Föhr & 19,00 \\
\hline & Ottens, Antan [B: B. Kroese] & Oldenburg & 19,00 \\
\hline & $\begin{array}{l}\text { Westrell, Andries } \\
\text { [B: A. Verhoeks - schippers Avootje?] }\end{array}$ & Gstad & 19,00 \\
\hline & Bruin, Douwe & 't Vlie & 19,00 \\
\hline \multirow[t]{18}{*}{ Ordinary seaman } & Hart, Joost & Texel & 18,00 \\
\hline & Bohmer, Harm H. & Oldenburg & 18,00 \\
\hline & Bolke, Berend [B: H. Olberding] & Oldenburg & 17,00 \\
\hline & Dekker, Jacob & Den Helder & 17,00 \\
\hline & Siedenburg, George Frederik & Amsterdam & 16,00 \\
\hline & Veenstra, Sybrand & Texel & 16,00 \\
\hline & Zaameren, Corneles van & Den Helder & 16,00 \\
\hline & Leen, Jan & Texel & 16,00 \\
\hline & Kuijper, Ijsbrand & Den Helder & 16,00 \\
\hline & Smaal, Jacob & Den Helder & 15,00 \\
\hline & Datcher, Frederich & Den Helder & 15,00 \\
\hline & Bakker, Dirk Corneles & 't Vlie & 15,00 \\
\hline & Hanz, Jan Klaas & Texel & 13,00 \\
\hline & Smit, Jacob Jans [B: DWD Haak] & Bovenkarspel & 14,00 \\
\hline & Bolke, Johan H. & Oldenburg & 13,00 \\
\hline & Kruise, Johan H. [B: Olberding] & Oldenburg & 13,00 \\
\hline & Streker, Frederich & Oldenburg & 13,00 \\
\hline & Nolte, Hendrik Christoffel & Amsterdam & 12,00 \\
\hline Cook's mate & Koedijk, Rijk & Alkmaar & 12,00 \\
\hline Cabin boy & Veenstra, Korneles & Texel & 6,00 \\
\hline \multicolumn{2}{|c|}{ Total (wages of master excluded) } & & $1194 /$ month \\
\hline
\end{tabular}


Source: Municipal Archives Amsterdam (SAA)

Archive Waterschout 38

Nr. 113, 22 March 1820. Pink Groenland, $45 \mathrm{crew}$, destined for Greenland. Bookkeeper: mr. J. Vas \& Comp.

\begin{tabular}{|c|c|c|c|}
\hline Rank & Name & Place of birth & Monthly wage (in $f$ ) \\
\hline Master & Oom, Frans & & \\
\hline $1^{\text {st }}$ mate & Bouwen, Sijmen & Den Helder & 70,00 \\
\hline Flenser & Moses, Jan & Den Helder & 60,00 \\
\hline Flenser's mate & Hogerduin, Jacob & Den Helder & 60,00 \\
\hline Harpooner & Telleman, Leendert & Den Helder & 50,00 \\
\hline Harpooner & Spierdijk, Klaas & Den Helder & 50,00 \\
\hline Harpooner & Hoek, Gerrit & Den Helder & 50,00 \\
\hline Carpenter & Kolk, Harmen & Elsfleth & 42,00 \\
\hline Boatswain & Sleebom, Willem & Amsterdam & 30,00 \\
\hline Second boatswain & Bregman, Fulps & Den Helder & 30,00 \\
\hline Cooper & Tameling, Dirk & Dinklagen & 30,00 \\
\hline Harpooner & Bare/Baze, August de & Diest & 30,00 \\
\hline Cook & Rijkers, Jakop & Den Helder & 30,00 \\
\hline Boatswain's mate & Brandt, Jan & Den Helder & 24,00 \\
\hline 2nd carpenter & Willems, Dirk & Slooten & 22,00 \\
\hline 2nd cooper & Drayer, Karel H. & Lemförde & 16,00 \\
\hline \multirow[t]{13}{*}{ Seaman } & Mandemaker, Corneles & Den Helder & 20,00 \\
\hline & Oortman, Niclaas & Stokholm & 20,00 \\
\hline & Wolgreem, Peter [B. Kerschau] & Landskrona & 20,00 \\
\hline & Bensting, Henderik [B: N: Engeland] & Bokkeberg & 20,00 \\
\hline & Dahl, Niels T. & Arendahl & 20,00 \\
\hline & Mindel, Hendk. & Groningen & 20,00 \\
\hline & Blauwboer, Jan [de Van Wildeman] & Den Helder & 20,00 \\
\hline & Willems, Klaas & Slooten & 20,00 \\
\hline & Pitersen, Klaas [B: Kerschau] & Ameland & 20,00 \\
\hline & Mijer, Herman [B: De Bruijn] & Oldenburg & 20,00 \\
\hline & Spleet, Hendrik Janse & Ameland & 20,00 \\
\hline & Gierke, Diederich W. & Breemen & 20,00 \\
\hline & Borst, Jan & Den Helder & 20,00 \\
\hline \multirow[t]{14}{*}{ Ordinary seaman } & Wehming, Jacob & Oldenburg & 19,00 \\
\hline & Lievendag, Matthijs & Warmenhuisen & 19,00 \\
\hline & Witt, Leendert de & Den Helder & 19,00 \\
\hline & Kuijper, Ijsbrand & Den Helder & 29,00 \\
\hline & Hart, Joost & Texel & 19,00 \\
\hline & Dosker, Frederik [B: G. Franke] & Den Helder & 19,00 \\
\hline & Wit, Jacob de & Den Helder & 16,00 \\
\hline & Krul, Reinier & Den Helder & 14,00 \\
\hline & Evers, Hendrik & Den Helder & 15,00 \\
\hline & Napels Jan Willem ten & Zuiderwou & 12,00 \\
\hline & Visser, Piter & Huisduinen & 17,00 \\
\hline & Jong, Klaas de & Huisduinen & 15,00 \\
\hline & Bakker, Hendrik & Den Helder & 15,00 \\
\hline & Koster, Herman & Basseld/Barteld & 16,00 \\
\hline Cook's mate & Brandt, Hendrik [B: De Bok] & Zaandijk & 13,00 \\
\hline Cabin boy & Boots, Johannes/Jan & Den Helder & 10,00 \\
\hline Cabin boy & Krijt, Gijsbert & De Wormer & 10,00 \\
\hline \multicolumn{2}{|c|}{ Total (wages of master excluded) } & & 1131/month \\
\hline
\end{tabular}


Source: Municipal Archives Amsterdam (SAA)

Archive Waterschout 38

Nr. 116, 23 February 1821. Pink Groenland, 45 crew, destined for Davis Strait. Bookkeeper: mr. J. Vas \& Comp.

\begin{tabular}{|c|c|c|c|c|}
\hline Rank & Name & Age & Place of birth & Monthly wage (in $f$ ) \\
\hline Master & Oom, Frans & & & \\
\hline $1^{\text {st }}$ mate & Ruijge, Imke J. & 57 & Terschelling & 90,00 \\
\hline Flenser & Schiphorst, Johann H. & 64 & Olderk in Oldenburg & 80,00 \\
\hline Flenser's mate & Segelke, Albert [B: captn] & 45 & Pletjenwaerde Hanover & 70,00 \\
\hline Harpooner M & Bare, August de & 32 & Gent & 32,00 \\
\hline Harpooner & Krousen, Johann & 40 & Gunderkeze Prus. & 60,00 \\
\hline Harpooner & Merens, Barend & 58 & Dikshouten Oldenburg & 60,00 \\
\hline Harpooner & Boer, Corneles de & 42 & Terschelling & 60,00 \\
\hline Boatswain & Stöver, Harm H. & 48 & Havekost & 30,00 \\
\hline Carpenter & Krayenheden, Dirk & 50 & Badbergen Hanover & 44,00 \\
\hline Second boatswain & Biersteker, Pieter J. & 43 & Den Helder & 30,00 \\
\hline Cooper & Menkes, Gerd & 55 & Delmenhorst Oldenburg & 60,00 \\
\hline Boatswain's mate & Ruijgh, Corneles Y. & 31 & Terschelling & 24,00 \\
\hline 2nd carpenter & Oom, Jan & 28 & Den Helder & 24,00 \\
\hline Cook & Groendijk, Corneles J. & 49 & Terschelling & 30,00 \\
\hline 2nd cooper $\mathrm{M}$ & Menkes, Klaas & 18 & Delmenhorst & 16,00 \\
\hline \multirow[t]{9}{*}{ Seaman } & Hennings, Frerik & 31 & Wahrflette Oldenburg & 20,00 \\
\hline & Menner, Dirk [B: Zeeberg] & 29 & Emden & 20,00 \\
\hline & Gercke, Diederich W. & 30 & Breemen & 20,00 \\
\hline & Douwes, Kunnen & 42 & Terschellingen & 20,00 \\
\hline & Masson, Andries & 23 & Vlaardingen & 20,00 \\
\hline & Plump, Henrich & 30 & Gunderkese Oldenburg & 20,00 \\
\hline & Wolldin, Johann & 30 & Ulenborg Prus? & 20,00 \\
\hline & Sanders, Johann B. & 25 & Havekost Oldenburg & 20,00 \\
\hline & Piters, Tierk & 53 & Ameland & 20,00 \\
\hline \multirow[t]{3}{*}{$\mathrm{M}$} & Vörsten, Diederich & 35 & Gunderkese Oldenburg & 20,00 \\
\hline & Saalfelt, Johann C. & 45 & Hengsterholts Oldenburg & 20,00 \\
\hline & Wedemeijer, Hendrik & 54 & Dammen Oldenburg & 20,00 \\
\hline \multirow[t]{5}{*}{$\mathrm{M}$} & Wehming, Jacob & 42 & Dammen Oldenburg & 20,00 \\
\hline & Hart, Joost & 51 & Texel & 19,00 \\
\hline & Wilkens, Frederik & 52 & Hogenböcken Oldenburg & 19,00 \\
\hline & Krul, Reinier [B: Zegelke] & 22 & Den Helder & 18,00 \\
\hline & Groeneveld, Lammert & 24 & Den Helder & 18,00 \\
\hline \multirow[t]{6}{*}{ Ordinary seaman } & Pals, Thijs Jans & 26 & Terschelling & 17,00 \\
\hline & Bergveldt, Jan & 24 & Amsterdam & 16,00 \\
\hline & Bakker, Anne H. & 20 & Terschelling & 17,00 \\
\hline & Schulten, Dierk & 18 & Gunderkese & 20,00 \\
\hline & Boots, Jan/Johannes [B: Segelken] & 17 & Den Helder & 16,00 \\
\hline & Gauw, Jacob & 20 & Den Helder & 16,00 \\
\hline \multirow[t]{6}{*}{ Cook's mate } & Dronken, Pieter & 20 & Den Helder & 13,00 \\
\hline & Krijt, Gijsbert & 17 & De Wormer & 12,00 \\
\hline & Ruigg, Gerrit Imkes & 15 & Terschelling & 10,00 \\
\hline & Boer, Luitje A. de & 23 & Harlingen & 19,00 \\
\hline & Bakker, Hendrik [B: T. de Vries] & 22 & Den Helder & 16,00 \\
\hline & Doets, Jacob & - & Middellie & 20,00 \\
\hline Cabin boy & Vries, Pieter Gerrit de & 15 & Wieringerwaard & 10,00 \\
\hline \multicolumn{2}{|c|}{ Total (wages of master excluded) } & $\begin{array}{l}34.43 \\
\text { (average) }\end{array}$ & & $1246 /$ month \\
\hline
\end{tabular}


Source: Municipal Archives Amsterdam (SAA)

Archive Waterschout 38

Nr. 118, 23 February 1822. Pink Groenland, 45 crew, destined for the Davis Strait.

\begin{tabular}{|c|c|c|c|}
\hline Rank & Name & Place of birth & Monthly wage (in $f$ ) \\
\hline Master & Oom, Frans & & \\
\hline $1^{\text {st }}$ mate & Ruygh, Imke Jansz. & Terschellingen & 90,00 \\
\hline Flenser & Landwehr, Johan H. & Schonemoer & 80,00 \\
\hline Flenser's mate & Hashaagen, Johann [B Zegelken] & Luijgtenborg & 70,00 \\
\hline $1^{\text {st }}$ harpooner & Boer, Cornelis den [B: Zegelken] & Terschellingen & 60,00 \\
\hline 2nd harpooner & Kroese, Johann & Gunderkeze & 60,00 \\
\hline 3rd harpooner & Menkes, Geerd & Schonemoer & 80,00 \\
\hline 4th harpooner/cooper & Baren, Augustei den [B: Zegelke] & Gend & 32,00 \\
\hline Boatswain & Biersteker, Pieter J. & Den Helder & 30,00 \\
\hline Boatswain's mate & Vörsteen, Diederick & Gunderkeze & 24,00 \\
\hline Carpenter & Oom, Jan & Den Helder & 44,00 \\
\hline 2nd carpenter & Bakenkohler, Herman & Huden & 22,00 \\
\hline ? & Groendijk, Jan & Terschellingen & 30,00 \\
\hline 2nd cooper & Menkes, Claus & Schonemoer & 22,00 \\
\hline Cook & Groendijk, Corneles J. & Terschellingen & 30,00 \\
\hline \multirow[t]{2}{*}{ Seaman } & Visser, Pieter & Marken & 20,00 \\
\hline & Hutfilter, Johann H. & Gunderkeze & 20,00 \\
\hline \multirow[t]{21}{*}{ M } & Heurman, Johann Heinrich [B: Zegelke] & Gunderkeze & 20,00 \\
\hline & Blieferman, Teunes [B: dito] & Copendorf & 20,00 \\
\hline & Auffert, Heinrich [B: dito] & Gunderkeze & 20,00 \\
\hline & Heins, Arend [B: dito] & Vegezak & 20,00 \\
\hline & Seggern, Johann van [B: dito] & Schönemoer & 20,00 \\
\hline & Spleet, Hendk.J. & Ameland & 20,00 \\
\hline & Witt, Leendert den & Den Helder & 20,00 \\
\hline & Boots, Jan & Den Helder & 19,00 \\
\hline & Wilkens, Frederik & Hohenböken & 20,00 \\
\hline & Sanders, Johann B. [B: dito] & Gunderkeze & 20,00 \\
\hline & Koomen, Corneles & Den Helder & 20,00 \\
\hline & Meyer, Harmen H. [B: DWD Oudenes] & Gunderkeze & 19,00 \\
\hline & Bergveld, Jan [B: Zegelke] & Amsterdam & 19,00 \\
\hline & Schulten, Dirck & Gunderkeze & 19,00 \\
\hline & Bakker, Anne Hendrikszoon [B: dito] & Terschellingen & 19,00 \\
\hline & Douwes, Kunnen & Terschellingen & 29,00 \\
\hline & Doets, Jan & Middellie & 18,00 \\
\hline & Warnaar, Johannes & Middellie & 18,00 \\
\hline & Smit, Jacob Jan & Bovenkarspel & 18,00 \\
\hline & Woude, Johannes L. van der [B: A. Blom] & Heereveen & 18,00 \\
\hline & Lunurs, Alrich [B: Waalstra] & Deedersdorff & 18,00 \\
\hline \multirow[t]{2}{*}{ M } & Schmit, Gerrit [B: Zegelke] & Huden & 16,00 \\
\hline & Mester, Hermann [B: dito] & Hasbergen & 16,00 \\
\hline \multirow[t]{3}{*}{ M } & Menkes, Geert H. [B: dito] & Huden & 16,00 \\
\hline & Groendijk, Jan Corneles [B: dito] & Terschellingen & 16,00 \\
\hline & Krijt, Gijsbert & Der Wormen & 14,00 \\
\hline Cook's mate & Pals, Leendert Jans & Terschellingen & 14,00 \\
\hline Cabin boy & Vries, Pieter G. den & Wieringerwaard & 12,00 \\
\hline Ordinary seaman & Ruijgh, Gerrit Imkesz. & Terschellingen & 12,00 \\
\hline \multicolumn{2}{|c|}{ Total (wages of master excluded) } & & $1244 /$ month \\
\hline
\end{tabular}


Source: Municipal Archives Amsterdam (SAA)

Archive Waterschout 38

Nr. 120, 7 March 1823. Pink Groenland, master Frans Oom, 45 crew, destined for the Davis Strait.

\begin{tabular}{|c|c|c|c|}
\hline Rank & Name & Place of birth & Monthly wage (in $f$ ) \\
\hline Master & Oom, Frans & & \\
\hline $1^{\text {st }}$ mate & Hoek, Gerrit & Den Helder & 90,00 \\
\hline Flenser & Landwehr, Johann H. & Schonemoer & 80,00 \\
\hline Flenser's mate & Kroesen, Johann & Gunderkezee & 70,00 \\
\hline $1^{\text {st }}$ harpooner & Boer, Cornelis de & Terschellingen & 60,00 \\
\hline $2^{\text {nd }}$ harpooner & Boijsen, Boij & Föhr & 60,00 \\
\hline $3^{\text {rd }}$ harpooner & Zegelken, Albert & Lutjemwerde & 60,00 \\
\hline $4^{\text {th }}$ harpooner & Feijerabend, Hendrik [B: Zegelken] & Haarlem & 32,00 \\
\hline Carpenter & Oom, Jan & Den Helder & 44,00 \\
\hline Boatswain & Brand, Jan Luit & Den Helder & 30,00 \\
\hline Second boatswain & Rijkers, Jacob & Den Helder & 30,00 \\
\hline Cooper & Menkes, Geerd & Schönemoer & 30,00 \\
\hline Cook & Groendijk, Cornelis Jansen & Terschellingen & 30,00 \\
\hline $2^{\text {nd }}$ carpenter & Bakenkohler, Herman & Hude & 22,00 \\
\hline $2^{\text {nd }}$ cooper & Vörsteen, Diederich & Gunderkezee & 24,00 \\
\hline Boatswain's mate M & Menkes, Claus & Schönemoer & 22,00 \\
\hline \multirow[t]{3}{*}{ Seaman } & Willems, Claas & SLooten & 20,00 \\
\hline & Spleet, Hendrik Jans & Ameland & 20,00 \\
\hline & Herman, Matthias & Wasa & 20,00 \\
\hline $\begin{array}{l}\text { [ontscheept }= \\
\text { disembarked] }\end{array}$ & Hoomen, Corneles & Den Helder & 20,00 \\
\hline Harfes, Cord & Breemen & 20,00 & \\
\hline Visser, Pieter & Marken & 20,00 & M \\
\hline Bijman, Andreas & Börnema & 20,00 & \\
\hline Wilkens, Frederich [B: & Carl Martin] & Höckenböecken & 20,00 \\
\hline \multirow[t]{6}{*}{$\mathrm{M}$} & Mendelts, Mendelt H. & Grooningen & 20,00 \\
\hline & Plump, Johann H. & Havelkost & 20,00 \\
\hline & Heins, Arend & Breemen & 20,00 \\
\hline & Huttefilter, Johann H. & Gunderkezee & 20,00 \\
\hline & Willembrink, Henrich A. & Steinfeld & 20,00 \\
\hline & Zweeken, Jan Frederik & Amsterdam & 20,00 \\
\hline \multirow[t]{4}{*}{ Ordinary seaman } & Roos, Willebrand & Hoorn & 20,00 \\
\hline & Meyer, Harm H. & Gunderkezee & 19,00 \\
\hline & Kool, Coenraad & Den Helder & 19,00 \\
\hline & Liers, Allerich & Deederdorff & 19,00 \\
\hline \multirow[t]{3}{*}{$\mathrm{M}$} & Dekker, Jacob & Den Helder & 19,00 \\
\hline & Schulten, Dierk & Gunderkezee & 19,00 \\
\hline & Dronken, Pieter & Den Helder & 18,00 \\
\hline \multirow[t]{2}{*}{$\mathrm{M}$} & Schmidt, Gerd & Hude & 17,00 \\
\hline & Krijt, Gijsbert & Wormer & 16,00 \\
\hline \multirow[t]{5}{*}{$\mathrm{M}$} & Menkes, Gerd H. & Hude & 16,00 \\
\hline & Kooijman, Klaas Reltjes & Terschellingen & 16,00 \\
\hline & Mester, Herman & Harsbergen & 15,00 \\
\hline & Schulten, Arend [B: A. Ottens] & Gunderkeze & 15,00 \\
\hline & Juchter, Tanjes Henrich & Schönemoer & 12,00 \\
\hline Cook's mate & Wilkens, Henrich & Oldenburg & 12,00 \\
\hline Cabin boy & Bos, Jan Daniels & Terschellingen & 10,00 \\
\hline Seaman & Hohenholt, Jan D. & Schönemoer & 20,00 \\
\hline \multicolumn{2}{|c|}{ Total (wages of master excluded) } & & 1246/month \\
\hline
\end{tabular}


Source: Municipal Archives Amsterdam (SAA)

Archive Waterschout 38

Nr. 122, 20 February 1824. Pink Groenland, master Frans Oom, 45 crew, destined for the Davis Strait.

\begin{tabular}{|c|c|c|c|}
\hline Rank & Name & Place of birth & Monthly wage (in $f$ ) \\
\hline Master & Oom, Frans & & \\
\hline $1^{\text {st }}$ mate & Hoek, Gerrit & Huisduinen & 90,00 \\
\hline Flenser & Kransen, Johann & Gunderkeze[e] & 80,00 \\
\hline Flenser's mate & Boijsen, Boij & Föhr & 70,00 \\
\hline $1^{\text {st }}$ harpooner & Segelken, Albert & Platjenwerbe & 60,00 \\
\hline $2^{\text {nd }}$ harpooner & Umland, Pieter & Hamburg & 60,00 \\
\hline $3^{\text {rd }}$ harpooner & Hemming, Johann H. & Xanten & 32,00 \\
\hline Boatswain's mate & Vorsteen, Diederich & Gunderkeze[e] & 24,00 \\
\hline Carpenter/harpooner & Oom, Jan & Den Helder & 44,00 \\
\hline Boatswain & Brand, Jan Luit & Den Helder & 30,00 \\
\hline Second boatswain & Rijkers, Jacob & Den Helder & 30,00 \\
\hline Cooper & Menkes, Geerd & Schöenemoer & 30,00 \\
\hline $2^{\text {nd }}$ carpenter & Krijt, Gijsbert & Wormer & 19,00 \\
\hline Cook & Groendijk, Cornelis Jansen & Terschellingen & 30,00 \\
\hline $2^{\text {nd }}$ cooper & Menkes, Gerd Henrich & Hude & 19,00 \\
\hline \multirow[t]{2}{*}{ Seaman } & Willembrink, Henrich A. & Steinfeld & 20,00 \\
\hline & Willembrink, Carl H. [B: Meulman] & Steinfeld & 20,00 \\
\hline \multirow[t]{8}{*}{$\mathrm{M}$} & Wesseling, Henrich & Schönemaer & 20,00 \\
\hline & Veen, Gerrit F. van der & Warnke & 20,00 \\
\hline & Boekenkohler, Herm & Hude & 20,00 \\
\hline & Hutfilter, Johann H. [B: zegelken] & Hazenboken & 20,00 \\
\hline & Ruijg, Iemke Jans & Terschellingen & 20,00 \\
\hline & Overbeek, Jan Jansen & Ooltgensplaat & 20,00 \\
\hline & Harfes, Cord & Breemen & 20,00 \\
\hline & Zweeke, Jan Frederik & Buiksloot & 20,00 \\
\hline \multirow[t]{6}{*}{$\mathrm{M}$} & Hoenholt, Dirk & Schönemoer & 20,00 \\
\hline & Schulten, Dierk & Gunderkezee & 20,00 \\
\hline & Boots, Jan & Den Helder & 20,00 \\
\hline & Vas, Klaas & Den Helder & 20,00 \\
\hline & Heins, Arend & Breemen & 20,00 \\
\hline & Kool, Coenraad [B: zegelken] & Den Helder & 20,00 \\
\hline \multirow[t]{2}{*}{ Ordinary seaman } & Bergveld, Jan & Amsterdam & 19,00 \\
\hline & Krul, Reinier & Den Helder & 19,00 \\
\hline \multirow[t]{2}{*}{$\mathrm{M}$} & Dekker, Jacob & Den Helder/Huisduinen & 19,00 \\
\hline & Kuijt, Willem & Wormerveer & 19,00 \\
\hline M & Douwes, Ruurd & Terschellingen & 18,00 \\
\hline \multirow[t]{7}{*}{$\mathrm{M}$} & Schmidt, Gerd & Hude & 18,00 \\
\hline & Mester, Herman & Hasbergen & 17,00 \\
\hline & Schulten, Arend & Gunderkezee & 16,00 \\
\hline & Pauw, Arie & Den Helder & 16,00 \\
\hline & Kooijman, Klaas Reltjes & Terschellingen & 16,00 \\
\hline & Vries, Pieter de & Schage & 15,00 \\
\hline & Juchter, Tanjes Henrich & Schönemoer & 13,00 \\
\hline Cook's mate & Harfst, Gerd Hinrich & Bookhorn & 13,00 \\
\hline Cabin boy & Eykel, Henderik & Wormerveer & 10,00 \\
\hline Ordinary seaman & Bos, Jan Daniels & Terschellingen & 10,00 \\
\hline \multicolumn{2}{|c|}{ Total (wages of master excluded) } & & $1176 /$ month \\
\hline
\end{tabular}


Source: Municipal Archives Amsterdam (SAA)

Archive Waterschout 38

Nr. 124, 25 February 1825. Pink Groenland, master Frans Oom, 45 crew, destined for the Davis Strait. Bookkeeper: The widow (DWDwe) J. Vas \& Comp.

\begin{tabular}{|c|c|c|c|}
\hline Rank & Name & Place of birth & Monthly wage (in $f$ ) \\
\hline Master & Oom, Frans & & \\
\hline $1^{\text {st }}$ mate & Boijsen, Boij & Föhr & 90,00 \\
\hline Flenser & Krausen, Johann & Gunderkezee & 90,00 \\
\hline Flenser's mate & Segelken, Albert & Platjemwurde & 70,00 \\
\hline $1^{\text {st }}$ harpooner & Fedders, Nickels & Föhr & 60,00 \\
\hline $2^{\text {nd }}$ harpooner & Morits, Johann & Altonesch & 60,00 \\
\hline $3^{\text {rd }}$ harpooner & Eichler, Barend Adrianus & Amsterdam & 32,00 \\
\hline Boatswain & Biersteeker, Pieter & Den Helder & 30,00 \\
\hline Boatswain's mate & Rijk, Frederik van & Amsterdam & 24,00 \\
\hline Carpenter & Oom, Jan & Den Helder & 44,00 \\
\hline $2^{\text {nd }}$ carpenter & Krijt, Gijsbert & Wormer & 24,00 \\
\hline Second boatswain & Willembrink, Hendrik Arend & Steinfeld & 30,00 \\
\hline Cooper & Menkes, Geert & Schönemoer & $50,00 / 60,00$ \\
\hline Cook & Groendijk, Cornelis Jansen & Terschellingen & 30,00 \\
\hline $2^{\text {nd }}$ cooper & Menkes, Gerd. Henrich & Hude & 29,00 \\
\hline Seaman & Hutfitter, Johann H. & Hohenboken & 20,00 \\
\hline \multirow[t]{5}{*}{$\mathrm{M}$} & Wesseling, Henrich & Schönemoer & 20,00 \\
\hline & Harfes, Cord & Breemen & 20,00 \\
\hline & Krul, Reinier & Den Helder & 20,00 \\
\hline & Pel, Maarten & Krommenie & 20,00 \\
\hline & Willembring, Berend Henrich & Steinfeld & 20,00 \\
\hline \multirow[t]{2}{*}{$\mathrm{M}$} & Hutfitter, Johann [B: A. Meulmeijer] & Gunderkezee & 20,00 \\
\hline & Seggeren, Ahlerd van & Schönemoer & 20,00 \\
\hline \multirow[t]{2}{*}{$\mathrm{M}$} & Wurdeman, Henrich & Schönemoer & 20,00 \\
\hline & Sanders, Johann Berend & Havekast & 20,00 \\
\hline \multirow[t]{5}{*}{$\mathrm{M}$} & Hohnholt, Dirk & Schönemoer & 20,00 \\
\hline & Kool, Coenraad & Den Helder & 20,00 \\
\hline & Bergveldt, Jan & Amsterdam & 20,00 \\
\hline & Vries, Lauwrens de & Buiksloot & 20,00 \\
\hline & Pieper, Diederich & Berne & 20,00 \\
\hline \multirow[t]{13}{*}{ Ordinary seaman $\mathrm{M}$} & Schmidt, Gerd & Hude & 19,00 \\
\hline & Klattenhoff, Johann Berend & Schönemoer & 18,00 \\
\hline & Schulten, Arend & Gunderkezee & 18,00 \\
\hline & Steenhuisen, Bernardus Johannes & Amsterdam & 18,00 \\
\hline & Kooijman, Klaas Eeltjes & Terschellingen & 17,00 \\
\hline & Pauw, Arie & Den Helder & 17,00 \\
\hline & Vries, Pieter de & Schagen op Wieringerwaard & 16,00 \\
\hline & Woud, Cornelis & Wormer & 15,00 \\
\hline & Lemaire, Jan & Amsterdam & 15,00 \\
\hline & Huizeling, Lammert & Karketeden & 15,00 \\
\hline & Ohlenbusch, Arend & Rethorn & 14,00 \\
\hline & Groendijk, Leendert Corneles & Terschellingen & 14,00 \\
\hline & Koorn, Thomas & Den Helder & 10,00 \\
\hline Cook's mate & Budeker, Arend Hinrich & Rethorn & 13,00 \\
\hline Cabin boy & Hoekstra, Sietse & Texel & 8,00 \\
\hline \multicolumn{2}{|c|}{ Total (wages of master excluded) } & & 119o/month \\
\hline
\end{tabular}




\section{Appendix 4}

\section{Crew Lists of pink Dirkje Adema (1858-1863)}

1858. Sources: GAH, WS 15a, 1858, no. 23; GAH, WS 2, 1858, fos. 23-24

\begin{tabular}{|c|c|c|c|c|c|c|}
\hline Rang & Name & Residence & Age & Handgeld & Partgeld & $\begin{array}{l}\text { Monthly } \\
\text { wage (in } f \text { ) }\end{array}$ \\
\hline Master & Mehlen, Otto & & & & & \\
\hline 1st mate & Steenbecker, H. & Harlingen & & $60,-$ & $1,-$ & $16,-$ \\
\hline $2^{\text {nd }}$ mate & Visser, K. & Harlingen & & $55,-$ & 1,90 & $16,-$ \\
\hline 3 rd mate & Pöhlitz, A. & Leipzig & & $32,-$ & 1,15 & $32,-$ \\
\hline Boatswain & Meinsma, Meindert & Harlingen & & $48,-$ & 1,80 & $16,-$ \\
\hline Harpooner & [unreadable] & Anjum & & $45,-$ & 1,75 & $16,-$ \\
\hline Idem & Pals, J.A. & Terschelling & & $45,-$ & 1,75 & $16,-$ \\
\hline Idem & Vries, Sijtse de ${ }^{\star}$ & Harlingen & & $45,-$ & 1,75 & $16,-$ \\
\hline Idem & Wortel, Cornelis & Terschelling & & $45,-$ & 1,75 & $16,-$ \\
\hline Carpenter & Alta, Jan & Harlingen & & $45,-$ & 1,40 & $38,-$ \\
\hline Cooper & Zwaan, J. de & Harlingen & & $45,-$ & 1,70 & $20,-$ \\
\hline Cook & Veen, M. van der & Harlingen & & $36,-$ & 1,60 & $12,-$ \\
\hline $1 / 2$ partvaarder & Wiersma, Nanne & Harlingen & & $33,-$ & 1,55 & $11,-$ \\
\hline Idem & Bakker, G. & Terschelling & & $33,-$ & 1,55 & $11,-$ \\
\hline Idem & Dijkstra, J. & Sexbierum & & $33,-$ & 1,55 & $11,-$ \\
\hline Idem & Walda, Hette & Paesens & & $33,-$ & 1,55 & $11,-$ \\
\hline Idem & Monsma, L. & Harlingen & & $33,-$ & 1,55 & $11,-$ \\
\hline Idem & Akkerboom, Sebaldus & Harlingen & & $33,-$ & 1,55 & $11,-$ \\
\hline Second boatswain & Bosje, G.G. & St. Anna & & $36,-$ & 1,60 & $12,-$ \\
\hline $2^{\text {nd }}$ cooper & Hoeksma, F. & Workum & & $22,-$ & 1,60 & $22,-$ \\
\hline $2^{\text {nd }}$ carpenter & Geerts, G. & Joure & & $16,-$ & 1,60 & $16,-$ \\
\hline $1 / 4$ partvaarder & Bakker, M. & Harlingen & & $30,-$ & 1,50 & $10,-$ \\
\hline Idem & Baanstra, Pier & Harlingen & & $27,-$ & 1,45 & $10,-$ \\
\hline Idem & Delft (?), G.G. & Terschelling & & $27,-$ & 1,45 & $10,-$ \\
\hline Idem & Bierman, H. & Terschelling & & $27,-$ & 1,45 & $10,-$ \\
\hline Idem & Beer, Jetse & Terschelling & & $27,-$ & 1,45 & $10,-$ \\
\hline Idem & Alkema, J. & Harlingen & & $27,-$ & 1,45 & $9,-$ \\
\hline Idem & Tigchelaar, H. & Harlingen & & $27,-$ & 1,45 & $9,-$ \\
\hline Idem & Visser, W. & Terschelling & & $24,-$ & 1,40 & $8,-$ \\
\hline Idem & Knop, P. & Terschelling & & $24,-$ & 1,40 & $8,-$ \\
\hline Idem & Spits, H. & Terschelling & & $24,-$ & 1,40 & $8,-$ \\
\hline Idem & Jong, E. de & Harlingen & & $21,-$ & 1,40 & $7,-$ \\
\hline Idem & Veldheer, A. & Workum & & $18,-$ & 1,30 & $6,-$ \\
\hline Idem & Krijl, H.S. & Harlingen & & $18,-$ & 1,30 & $6,-$ \\
\hline Idem & Wit, D.L. de ${ }^{\star}$ & Harlingen & & $18,-$ & 1,30 & $6,-$ \\
\hline Idem & Boer, W. de & Harlingen & & $18,-$ & 1,30 & $6,-$ \\
\hline Idem & Monsma, Leendert ${ }^{*}$ & Harlingen & & $18,-$ & 1,30 & $6,-$ \\
\hline Idem & Post, Jan & Terschelling & & $15,-$ & 1,25 & $5,-$ \\
\hline Idem & Bierman, J. & Terschelling & & $15,-$ & 1,25 & $5,-$ \\
\hline Idem & Nauta, Evert S. & Harlingen & & $15,-$ & 1,25 & $5,-$ \\
\hline Idem & Nauta, Gerardus S. & Harlingen & & $18,-$ & 1,30 & $6,-$ \\
\hline Green hand & Bolt, K. & Ternaard & & $8,-$ & 1,30 & $8,-$ \\
\hline Idem & Meekma, J.D. & St. Jacob & & $8,-$ & 1,30 & $8,-$ \\
\hline Idem & Drukker, D. & Sexbierum & & $8,-$ & 1,30 & $8,-$ \\
\hline Idem & Kuijpers, Christiaan ${ }^{\star}$ & Terschelling & & $10,-$ & 1,30 & $10,-$ \\
\hline Idem & Groot, Dirk de ${ }^{*}$ & Franeker & & $9,-$ & 1,30 & $9,-$ \\
\hline Partvaarder & Beer, Jan de ${ }^{\star}$ & Terschelling & & $15,-$ & 1,25 & $5,-$ \\
\hline Idem & Kromhout, R.C. & Harlingen & & $18,-$ & 1,30 & $6,-$ \\
\hline Boy & Bolman, Albert & Harlingen & & $5,-$ & 1,30 & $5,-$ \\
\hline Partvaarder & Wet, J.J. de & Harlingen & & $18,-$ & 1,30 & $6,-$ \\
\hline Green hand & Jong, J.de & Harlingen & & $8,-$ & 1,30 & $8,-$ \\
\hline Totals & $51 \mathrm{crew}$ & & & & & 553/month \\
\hline
\end{tabular}

Revenue in guilders. The asterisk $\left.{ }^{*}\right)$ next to a name refers to the fact that in the manuscript signatures were represented by a cross - an indication that these whalemen were unable to write their name. In all totals the wages of the master is excluded. 
1859. Sources: GAH, WS 2, 1859, fos. $87-88$

\begin{tabular}{|c|c|c|c|c|c|c|}
\hline Rang & Name & Residence & Age & Handgeld & Partgeld & $\begin{array}{l}\text { Monthly } \\
\text { wage (in } f \text { ) }\end{array}$ \\
\hline Master & Brinkmann, C. & & & & & \\
\hline $1^{\text {st }}$ mate & Steenbecker, H. & Harlingen & 39 & $60,-$ & $1,-$ & $16,-$ \\
\hline $2^{\text {nd }}$ mate & Meinsma, $\mathrm{M}$. & Harlingen & 28 & $55,-$ & 1,90 & $16,-$ \\
\hline $3^{\text {rd }}$ mate & Schünemond, W. & Hamburg & & $32,-$ & 1,15 & $32,-$ \\
\hline Flenser & Gühlke, C. & Sestermuhle & & $55,-$ & 1,90 & $16,-$ \\
\hline Boatswain & Diers, C. & Sestermuhle & & $55,-$ & 1,90 & $16,-$ \\
\hline Harpooner & Pals, Jan A. & Terschelling & 33 & $45,-$ & 1,75 & $16,-$ \\
\hline Idem & Wortel, C. & Terschelling & 36 & $45,-$ & 1,75 & $16,-$ \\
\hline Idem & [unreadable] & Anjum & & $45,-$ & 1,75 & $16,-$ \\
\hline Idem & Vries, Sytse de & Harlingen & 28 & $45,-$ & 1,75 & $16,-$ \\
\hline $1^{\text {st }}$ carpenter & Pik, Willem & Graft & 30 & $38,-$ & 1,75 & $38,-$ \\
\hline $1^{\text {st }}$ cooper & Zwaan, J. de & Harlingen & 37 & $45,-$ & 1,70 & $20,-$ \\
\hline Second boatswain & Beer, E.Y. de & Terschelling & 21 & $36,-$ & 1,60 & $12,-$ \\
\hline Cook & Veen, S.Y. van der & Harlingen & 39 & $36,-$ & 1,60 & $12,-$ \\
\hline $1 / 2$ partvaarder & Dijkstra, Jacobus Sybrens & Sexbierum & 31 & $33,-$ & 1,55 & $11,-$ \\
\hline Idem & Hette, Walda & Paesens & 35 & $33,-$ & 1,55 & $11,-$ \\
\hline Idem & Alkema, J. & Harlingen & 22 & $33,-$ & 1,55 & $11,-$ \\
\hline Idem & Monsma, L. & Harlingen & 28 & $33,-$ & 1,55 & $11,-$ \\
\hline Idem & Wiersma, Nanne & Harlingen & 25 & $33,-$ & 1,55 & $11,-$ \\
\hline Idem & Bakker, M.J. & Harlingen & 33 & $33,-$ & 1,55 & $11,-$ \\
\hline Idem & Beer, Jan de & Terschelling & 26 & $30,-$ & 1,50 & $10,-$ \\
\hline 2nd cooper & Kolk, H. van de & Amsterdam & 38 & $22,-$ & 1,50 & $22,-$ \\
\hline 2nd carpenter & Geerts, G.S. & Joure & 26 & $16,-$ & 1,50 & $16,-$ \\
\hline 1/4 partvaarder & Baanstra, Pier & Harlingen & 25 & $30,-$ & 1,50 & $10,-$ \\
\hline Idem & Tigchelaar, H. & Harlingen & 27 & $30,-$ & 1,50 & $10,-$ \\
\hline Idem & Ebbeling, $\mathrm{H}$. & Harlingen & 21 & $27,-$ & 1,45 & $9,-$ \\
\hline Idem & Palma, Pieter & Oosterbierum & 27 & $24,-$ & 1,40 & $8,-$ \\
\hline Idem & Cupido, Jan C. & Terschelling & 20 & $24,-$ & 1,40 & $8,-$ \\
\hline Idem & Leenstra, Johannes & Harlingen & 24 & $21,-$ & 1,35 & $7,-$ \\
\hline Idem & Beer, Jan de & Terschelling & 19 & $18,-$ & 1,30 & $6,-$ \\
\hline Idem & Rijkeboer, G.C. & Terschelling & 29 & $18,-$ & 1,30 & $6,-$ \\
\hline Idem & Dekker, C.K. & Terschelling & 23 & $18,-$ & 1,30 & $6,-$ \\
\hline Idem & Kuipers, Christiaan & Terschelling & 18 & $18,-$ & 1,30 & $6,-$ \\
\hline Idem & Vries de Wit, Jan de & Harlingen & 22 & $18,-$ & 1,30 & $6,-$ \\
\hline Idem & Monsma, Leonardus & Harlingen & 22 & $18,-$ & 1,30 & $6,-$ \\
\hline Idem & Veen, Johannes van der & Leeuwarden & 24 & $15,-$ & 1,25 & $5,-$ \\
\hline Idem & Zieman, Willem & Harlingen & 19 & $15,-$ & 1,25 & $5,-$ \\
\hline Idem & Drukker, D. & Sexbierum & 18 & $15,-$ & 1,25 & $5,-$ \\
\hline Idem & Groot, Dirk de & Franeker & 20 & $15,-$ & 1,25 & $5,-$ \\
\hline Green hand & Schot, Fedde Reinder & St. Anna & 16 & $8,-$ & 1,25 & $8,-$ \\
\hline Idem & Kuiken, G. & St. Jacob & 25 & $8,-$ & 1,25 & $8,-$ \\
\hline Idem & Jong, Dirk G. de & O.Bildtzijl & 26 & $8,-$ & 1,25 & $8,-$ \\
\hline Idem & Dijkstra, 'Anseke' K. & O.Bildtzijl & 24 & $8,-$ & 1,25 & $8,-$ \\
\hline Idem & Grond, G.B.F.P. & St. Anna & 19 & $8,-$ & 1,25 & $8,-$ \\
\hline Idem & Wijngaarden, S.J. & Workum & 21 & $8,-$ & 1,25 & $8,-$ \\
\hline Idem & Brink, A. van den & O.Bildtzijl & 19 & $8,-$ & 1,25 & $8,-$ \\
\hline Idem & Ploeg, S. van de & Terschelling & 21 & $8,-$ & 1,25 & $8,-$ \\
\hline Idem & Hamstra, H. & Anjum & 24 & $8,-$ & 1,25 & $8,-$ \\
\hline Idem & Visser, F. & Anjum & 29 & $8,-$ & 1,25 & $8,-$ \\
\hline Idem & Spanjer, G.G. & Terschelling & 19 & $8,-$ & 1,25 & $8,-$ \\
\hline Idem & Roos, C.C. & Terschelling & 16 & $8,-$ & 1,25 & $8,-$ \\
\hline Idem & Brinkmann, $\mathrm{H}$. & Uetersen & 16 & $8,-$ & 1,25 & $8,-$ \\
\hline Idem & Dijkstra, H.A. & Sexbierum & 22 & $8,-$ & 1,25 & $8,-$ \\
\hline Idem & Wielinga, Jan A. & St. Anna & 18 & $8,-$ & 1,25 & $8,-$ \\
\hline Totals & $53(54-1)$ crew & & $\begin{array}{l}25.06 \\
\text { (average) }\end{array}$ & & & $584 /$ month \\
\hline
\end{tabular}


1860. Source: GAH, WS 3, 1860, fols. 10-11

\begin{tabular}{|c|c|c|c|c|c|c|}
\hline Rang & Name & Residence & Age & Handgeld & Partgeld & $\begin{array}{l}\text { Monthly } \\
\text { wage (in } f \text { ) }\end{array}$ \\
\hline Master & Wildst, Hendrik & & & & & \\
\hline $1^{\text {st }}$ mate & Visser, Klaas & Harlingen & 31 & $60,-$ & $1,-$ & $16,-$ \\
\hline $2^{\text {nd }}$ mate & Sorgdrager, Cornelis & Terschelling & 32 & $50,-$ & 1,35 & 16 \\
\hline $3^{\text {rd }}$ mate & Harnach, Carl & Hamburg & 28 & $28,-$ & $1,08^{3 / 4}$ & $28,-$ \\
\hline Flenser & Wortel, Cornelis & Terschelling & 37 & $45,-$ & 1,75 & $16,-$ \\
\hline Boatswain & Keulen, Willem H. van & Terschelling & 34 & $45,-$ & 1,75 & $16,-$ \\
\hline Harpooner & Wiersma, Nanne & Harlingen & 26 & $45,-$ & 1,75 & $16,-$ \\
\hline Idem & Sjordema, Fieke & Anjum & 38 & $45,-$ & 1,75 & $16,-$ \\
\hline Idem & Vries, Sijtse de & Harlingen & 29 & $45,-$ & 1,75 & $16,-$ \\
\hline Idem & Bosje, Gerrit & St. Anna & 31 & $45,-$ & 1,75 & $16,-$ \\
\hline Idem & Dijkstra, Jacob & Sexbierum & 32 & $45,-$ & 1,75 & $16,-$ \\
\hline Carpenter & Pik, Willem & Graft & 31 & $38,-$ & 1,15 & $38,-$ \\
\hline Cook & Stegenga, Foppe & Harlingen & 37 & $33,-$ & 1,55 & $11,-$ \\
\hline Second boatswain & Boer, Eelke de & Terschelling & 32 & $36,-$ & 1,60 & $12,-$ \\
\hline $1 / 2$ partvaarder & Alkema, Johannes & Harlingen & 23 & $33,-$ & 1,55 & $11,-$ \\
\hline Idem & Zwart, Douwe & Terschelling & 39 & $33,-$ & 1,55 & $11,-$ \\
\hline Idem & Oepkes, Dirk & Terschelling & 34 & $30,-$ & 1,50 & $10,-$ \\
\hline Idem & Roorda, Pieter & Terschelling & 40 & $30,-$ & 1,50 & $10,-$ \\
\hline Idem & Lettinga, Pieter & Terschelling & 39 & $30,-$ & 1,50 & $10,-$ \\
\hline Idem & Boer, Jetses de & Terschelling & 26 & $30,-$ & 1,50 & $10,-$ \\
\hline Idem & Palma, Pieter & Sexbierum & 28 & $30,-$ & 1,50 & $10,-$ \\
\hline $1 / 4$ partvaarder & Keulen, Hendrik van & Terschelling & 24 & $27,-$ & 1,45 & $9,-$ \\
\hline Idem & Schroo, Pieter & Terschelling & 35 & $27,-$ & 1,45 & 9,- \\
\hline Idem & Cupido, Jan Cornelis & Terschelling & 21 & $27,-$ & 1,45 & $9,-$ \\
\hline Idem & Wever, Jan & Terschelling & 24 & $24,-$ & 1,40 & $8,-$ \\
\hline Idem & Bierman, Jan & Terschelling & 19 & $21,-$ & 1,35 & $7,-$ \\
\hline Idem & Bakker, Thijs & Terschelling & 24 & $21,-$ & 1,35 & 7,- \\
\hline Idem & Leeman, Willem & Harlingen & 20 & $18,-$ & 1,30 & $6,-$ \\
\hline Idem & Post, Mint & Terschelling & 19 & $18,-$ & 1,30 & $6,-$ \\
\hline Idem & Wijngaarden, Sijbren & Workum & 22 & $18,-$ & 1,30 & 6,- \\
\hline Idem & Schokker, Hendrik & Lemmer & 26 & $18,-$ & 1,30 & $6,-$ \\
\hline Idem & Schat, Fidde R. & St. Anna & 17 & $15,-$ & 1,25 & $5,-$ \\
\hline Idem & Keulen, Jacob van & Terschelling & 20 & $15,-$ & 1,25 & $5,-$ \\
\hline Idem & Grond, Gerben & St. Anna & 20 & $15,-$ & 1,25 & $5,-$ \\
\hline $1 / 4$ partvaarder & Groendijk, Jan & Terschelling & 17 & $15,-$ & 1,25 & $5,-$ \\
\hline Idem & Jong, Dick de & St. Anna & 27 & $15,-$ & 1,25 & $5,-$ \\
\hline Idem & Wijbenga, Jan & St. Anna & 19 & $15,-$ & 1,25 & $5,-$ \\
\hline Idem & Dijkstra, Hendrik & St. Anna & 23 & $15,-$ & 1,25 & $5,-$ \\
\hline $2^{\text {nd }}$ carpenter & Hettema, Yde & Bolsward & 23 & $12,-$ & 1,25 & $12,-$ \\
\hline $2^{\text {nd }}$ cooper & Rickers, Heinrick Carl & Harlingen & 17 & $12,-$ & 1,25 & $12,-$ \\
\hline Maandvaarder & Machiela, Jacob & Holwerd & 21 & $9,-$ & 1,25 & $9,-$ \\
\hline Idem & Vries, Jacob de & Terschelling & 19 & $9,-$ & 1,25 & $9,-$ \\
\hline Idem & Keulen, Hilbrand van & Terschelling & 16 & 9,- & 1,25 & 9,- \\
\hline Idem & Meer, Willem van der & Harlingen & 17 & $8,-$ & 1,25 & $8,-$ \\
\hline Idem & Breed, Gerrit de & Terschelling & 16 & $8,-$ & 1,25 & $8,-$ \\
\hline Idem & Visser, Hendrik de & Harlingen & 19 & $8,-$ & 1,25 & $8,-$ \\
\hline Idem & Kolk, Jan van de & St. Anna & 20 & $8,-$ & 1,25 & $8,-$ \\
\hline Idem & Beer, Arie Pieter de & Terschelling & 25 & $8,-$ & 1,25 & $8,-$ \\
\hline Idem & Bouma, Gade & Harlingen & 16 & $8,-$ & 1,25 & $8,-$ \\
\hline Idem & Scheltema, Ernst O. & Sexbierum & 17 & $8,-$ & 1,25 & $8,-$ \\
\hline Idem & Folsma, PieterJohannes & Sexbierum & 16 & $8,-$ & 1,25 & $8,-$ \\
\hline Boy & Jong, Jan de & Harlingen & 14 & $4,-$ & 1,25 & $4,-$ \\
\hline Boy & Loon, Anne van & Harlingen & 15 & $4,-$ & 1,25 & $4,-$ \\
\hline Totals & $53(54-1) \mathrm{crew}$ & & $\begin{array}{l}24.42 \\
\text { (average) }\end{array}$ & & & 536/month \\
\hline
\end{tabular}


1861. Sources: GAH, WS 4, 1861, BXX

\begin{tabular}{|c|c|c|c|c|c|c|}
\hline Rang & Name & Residence & Age & Handgeld & Partgeld & $\begin{array}{l}\text { Monthly } \\
\text { wage (in } f \text { ) }\end{array}$ \\
\hline Master & Wildts, Hendrik & Harlingen & & & & \\
\hline $1^{\text {st }}$ mate & Visser, Klaas & Harlingen & 32 & $60,-$ & $1,-$ & $16,-$ \\
\hline $2^{\text {nd }}$ mate & Kutschura, Julius & Leipzig & 41 & $32,-$ & 1,10 & $32,-$ \\
\hline Flenser & Wortel, Cornelis & Terschelling & 39 & $45,-$ & 1,75 & $16,-$ \\
\hline Boatswain & Meulen, Willem Hendrik van & Terschelling & 35 & $45,-$ & 1,75 & $16,-$ \\
\hline Harpooner & Bosje, Gerrit Gerrits & St. Anna & 33 & $45,-$ & 1,75 & $16,-$ \\
\hline Idem & Sjoordema, Fieke & Anjum & 41 & $45,-$ & 1,75 & $16,-$ \\
\hline Idem & Vries, Sijtze de & Harlingen & 30 & $45,-$ & 1,75 & $16,-$ \\
\hline Idem & Wiersma, Nanne & Harlingen & 27 & $45,-$ & 1,75 & $16,-$ \\
\hline Idem & Dijkstra, Jacob & Sexbierum & 33 & $45,-$ & 1,75 & $16,-$ \\
\hline Second boatswain & Beer, Eelke de & Terschelling & 33 & $45,-$ & 1,75 & $16,-$ \\
\hline Carpenter & Pik, Willem & De Rijp & 32 & $38,-$ & 1,15 & $38,-$ \\
\hline Cooper & Molm, Hendrik van der & Amsterdam & 40 & $30,-$ & 1,15 & $30,-$ \\
\hline Cook & Stegenga, Poppe & Harlingen & 38 & $36,-$ & 1,60 & $12,-$ \\
\hline $1 / 2$ partvaarder & Zwart, Douwe & Terschelling & 40 & $33,-$ & 1,55 & $11,-$ \\
\hline Idem & Beer, Ietse de & Terschelling & 28 & $33,-$ & 1,55 & $11,-$ \\
\hline Idem & Kettinga, Pieter & Terschelling & 39 & $33,-$ & 1,55 & $11,-$ \\
\hline Idem & Zwart, Berend? & Terschelling & 31 & $30,-$ & 1,50 & $10,-$ \\
\hline Idem & Meulen, Hendrik van & Terschelling & 25 & $30,-$ & 1,50 & $10,-$ \\
\hline Idem & Spitz, Jacob & Terschelling & 44 & $30,-$ & 1,55 & $10,-$ \\
\hline Idem & Knop, Steven & Terschelling & 29 & $27,-$ & 1,45 & $9,-$ \\
\hline Idem & Beer, Arie de & Terschelling & 24 & $27,-$ & 1,45 & $9,-$ \\
\hline Idem & Kuiper, Christiaan & Terschelling & 21 & $27,-$ & 1,45 & 9,- \\
\hline Idem & Bakker, Klaas Lucas & Terschelling & 24 & $27,-$ & 1,45 & $9,-$ \\
\hline Idem & Kuipers, IJsbrand & Terschelling & 25 & $27,-$ & 1,45 & $9,-$ \\
\hline Idem & Drukker, Derk & Sexbierum & 20 & $27,-$ & 1,45 & $9,-$ \\
\hline Idem & Zuidmulder, Gerrit (?) & Terschelling & 32 & $27,-$ & 1,45 & $9,-$ \\
\hline Idem & Hassenaar, Gerrit & Harlingen & 28 & $24,-$ & 1,40 & $8,-$ \\
\hline Idem & Beer, Jan de & Terschelling & 21 & $24,-$ & 1,40 & $8,-$ \\
\hline Idem & Spitz, Jacob Jelle & Terschelling & 24 & $24,-$ & 1,40 & $8,-$ \\
\hline Idem & Bos, Pieter Gerrits & Terschelling & 24 & $24,-$ & 1,40 & $8,-$ \\
\hline Idem & Keulen, Jan van & Terschelling & 19 & $15,-$ & 1,25 & $5,-$ \\
\hline Idem & Vries, Jacob Jansz. de & Terschelling & 20 & $18,-$ & 1,30 & $6,-$ \\
\hline Idem & Hettema, J. & Bolsward & & $18,-$ & 1,30 & $6,-$ \\
\hline $1 / 4$ partvaarder & Keulen, Jacob van & terschelling & 21 & $18,-$ & 1,30 & $6,-$ \\
\hline Idem & Ploeg, Sytse van der & Franeker & 23 & $18,-$ & 1,30 & $6,-$ \\
\hline Idem & Bakker, Douwe Pieters & Terschelling & 18 & $15,-$ & 1,25 & $5,-$ \\
\hline Idem & Molk, Jan van der & St. Anna & 21 & $18,-$ & 1,30 & $6,-$ \\
\hline Idem & Hek, Jan Cornelis & Terschelling & 19 & $15,-$ & 1,25 & $5,-$ \\
\hline Idem & Rees, Cornelis van & Terschelling & 21 & $15,-$ & 1,25 & $5,-$ \\
\hline Idem & Visser, Hendrik & Harlingen & 21 & $15,-$ & 1,25 & $5,-$ \\
\hline Maandvaarder & Roos, Klaas Alberts & Terschelling & 19 & $9,-$ & 1,25 & $9,-$ \\
\hline Idem & Rees, Dirk van & Terschelling & 17 & $9,-$ & 1,25 & $9,-$ \\
\hline Idem & Pals, Cornelis Ariens & Terschelling & 17 & $9,-$ & 1,25 & $9,-$ \\
\hline Idem & Pals, Cornelis Thijssen & Terschelling & 23 & $9,-$ & 1,25 & $9,-$ \\
\hline Idem & Kok, Auke Gerrits & St. Anna & 24 & $8,-$ & 1,25 & $8,-$ \\
\hline Idem & Boomsma, Wijhe & St. Anna & 25 & $8,-$ & 1,25 & $8,-$ \\
\hline Idem & Geus, Jan Cornelis & Terschelling & 15 & $8,-$ & 1,25 & $8,-$ \\
\hline Idem & Meulen, Jacob van der & Terschelling & 17 & $8,-$ & 1,25 & $8,-$ \\
\hline Idem & Beer, Arie de & Terschelling & 26 & $8,-$ & 1,25 & $8,-$ \\
\hline Cook's mate & Struiksma, Egbert & Harlingen & 14 & $8,-$ & 1,25 & $8,-$ \\
\hline Maandvaarder & Schaafsma, Jan Feyes & Harlingen & 19 & $8,-$ & 1,25 & $8,-$ \\
\hline Idem & Volbeda, Jan & Kimswerd & 17 & $9,-$ & 1,25 & $9,-$ \\
\hline Boy & Gorter, Pieter & Harlingen & 14 & $2,-$ & 1,25 & $2,-$ \\
\hline Maandvaarder & Haan, Iemke Jokts & Terschelling & 17 & $6,-$ & 1,25 & $6,-$ \\
\hline Totals & $55(56-1)$ crew & & $\begin{array}{l}25.62 \\
\text { (average) }\end{array}$ & & & $578 /$ month \\
\hline
\end{tabular}


1862. Source: GAH, WS 4, 1862, B29; GAH, WS 17, 1862, no. 29

\begin{tabular}{|c|c|c|c|c|c|c|}
\hline Rang & Name & Residence & Age & Handgeld & Partgeld & $\begin{array}{l}\text { Monthly } \\
\text { wage (in } f \text { ) }\end{array}$ \\
\hline Master & Wildts, Hendrik & & & & & \\
\hline $1^{\text {st }}$ mate & Visser, Klaas R. & Harlingen & 33 & $60,-$ & $1,-$ & $16,-$ \\
\hline $2^{\text {nd }}$ mate & Dietrich, Wilhelm & Hamburg & 25 & $32,-$ & 1,10 & $32,-$ \\
\hline Boatswain & Keulen, Willem Hendrik van & Terschelling & 36 & $45,-$ & 1,75 & $16,-$ \\
\hline Harpooner & Wiersma, Nanne & Harlingen & 28 & $45,-$ & 1,75 & $16,-$ \\
\hline Idem & Sjoordema, F.L. & Anjum & 42 & $45,-$ & 1,75 & $16,-$ \\
\hline Idem & Wortel, Cornelis G. & Terschelling & 40 & $45,-$ & 1,75 & $16,-$ \\
\hline Idem & Beer, Eelke de & Terschelling & 34 & $45,-$ & 1,75 & $16,-$ \\
\hline Idem & Vries, Sytse & Harlingen & 31 & $45,-$ & 1,75 & $16,-$ \\
\hline Idem & Dijkstra, Jacob* & Sexbierum & 34 & $45,-$ & 1,75 & $16,-$ \\
\hline Idem & Bosje, Gerrit Gerrits & St. Jacob & 34 & $45,-$ & 1,75 & $16,-$ \\
\hline Carpenter & Pik, Willem & De Rijp & 33 & $38,-$ & 1.15 & $38,-$ \\
\hline Second boatswain & Leistra, Pieter & Roptazijl & 38 & $36,-$ & 1,60 & $12,-$ \\
\hline Cook & Bakker, Maerius & Harlingen & 36 & $33,-$ & 1,55 & $11,-$ \\
\hline Cooper & Lichthart, Jelle & Harlingen & 41 & $24,-$ & 1,20 & $24,-$ \\
\hline $1 / 2$ partvaarder & Zwart, Douwe & Terschelling & 41 & $33,-$ & 1,55 & $11,-$ \\
\hline Idem & Beer, Jetze de & Terschelling & 29 & $33,-$ & 1,55 & $11,-$ \\
\hline Idem & Lettinga, Pieter ${ }^{*}$ & Terschelling & 40 & $33,-$ & 1,55 & $11,-$ \\
\hline Idem & Zwart, Ruurd K. & Terschelling & 32 & $30,-$ & 1,50 & $10,-$ \\
\hline Idem & Knop, Steven & Terschelling & 30 & $30,-$ & 1,50 & $10,-$ \\
\hline Idem & Spits, Jacob* & Terschelling & 45 & $30,-$ & 1,50 & $10,-$ \\
\hline Idem & Bakker, Thijs P. & Terschelling & 26 & $30,-$ & 1,50 & $10,-$ \\
\hline Idem & Drukker, Dirk Dirks. & Sneek & 21 & $30,-$ & 1,50 & $10,-$ \\
\hline Idem & Wever, Jan & Terschelling & 26 & $30,-$ & 1,50 & $10,-$ \\
\hline Idem & Kuipers, IJsbrand & Terschelling & 26 & $30,-$ & 1,50 & $10,-$ \\
\hline Idem & Andringa, Jacob Klaas & Sexbierum & 30 & $27,-$ & 1,45 & $9,-$ \\
\hline Idem & Haan, Jelle de & Sneek & 32 & $24,-$ & 1,40 & $8,-$ \\
\hline $2^{\text {nd }}$ Carpenter & Drager, Rinke & Franeker & 24 & $24,-$ & 1,40 & $8,-$ \\
\hline $1 / 2$ partvaarder & Leeman/Lieman, Willem & Harlingen & 22 & $24,-$ & 1,40 & $8,-$ \\
\hline Idem & Vries, Klaas de & Sneek & 23 & $24,-$ & 1,40 & $8,-$ \\
\hline Idem & Volbeda, Jan K. & Harlingen & 18 & $24,-$ & 1,40 & $8,-$ \\
\hline Idem & Grond, Gerben F. & St. Anna & 22 & $24,-$ & 1,40 & $8,-$ \\
\hline Idem & Rijpstra, Klaas Marten & Terschelling & 27 & $21,-$ & 1,35 & 7,- \\
\hline Idem & Radema, R. & Sexbierum & 30 & $21,-$ & 1,35 & $7,-$ \\
\hline Idem & Visser, Hendrik $^{*}$ & Harlingen & 21 & $21,-$ & 1,35 & $7,-$ \\
\hline Idem & Folsma, Pieter & Sexbierum & 18 & $18,-$ & 1,30 & $6,-$ \\
\hline Idem & Roos, Klaas Alberts & Terschelling & 20 & $15,-$ & 1,25 & $5,-$ \\
\hline Idem & Wever, Willem & Terschelling & 20 & $15,-$ & 1,25 & $5,-$ \\
\hline Idem & Drager, Willem & Franeker & 24 & $15,-$ & 1,25 & $5,-$ \\
\hline Idem & Kok, Auke & St. Jacob & 25 & $15,-$ & 1,25 & $5,-$ \\
\hline Idem & Boomsma, Wybe Peers & St. Jacob & 26 & $15,-$ & 1,25 & 5, \\
\hline Maandvaarder & Grond, Cornelis F. & St. Anna & 19 & $8,-$ & 1,25 & $8,-$ \\
\hline Idem & Wagenaar, Pieter K. & St. Jacob & 21 & $8,-$ & 1,25 & $8,-$ \\
\hline Idem & Boomsma, Pieter $^{\star}$ & St. Jacob & 22 & $8,-$ & 1,25 & $8,-$ \\
\hline Idem & Dijk, Pieter van & Anjum & 21 & $8,-$ & 1,25 & $8,-$ \\
\hline Idem & Bouma, Cornelis & Zwiens & 21 & $8,-$ & 1,25 & $8,-$ \\
\hline Idem & Elzinga, Melle & Wierum & 24 & $8,-$ & 1,25 & $8,-$ \\
\hline Idem & Hovinga, Lieuwe P. & Anjum & 19 & $8,-$ & 1,25 & $8,-$ \\
\hline Idem & Andringa, Waling K. & Sexbierum & 19 & $8,-$ & 1,25 & $8,-$ \\
\hline Idem & Kuiken, Klaas Kornelis & St. Anna & 16 & $8,-$ & 1,25 & $8,-$ \\
\hline Idem & Boer, Douwe de & Harlingen & 16 & $8,-$ & 1,25 & $8,-$ \\
\hline Idem & Keulen, Kornelis A. van & Terschelling & 16 & $8,-$ & 1,25 & $8,-$ \\
\hline Idem & Dijkstra, Marten Klaas & St. Jacob & 25 & $8,-$ & 1,25 & $8,-$ \\
\hline Total & $53(54-1)$ crew & & $\begin{array}{l}26.83 \\
\text { (average) }\end{array}$ & & & $569 /$ month \\
\hline
\end{tabular}


1863. Sources: GAH, WS 5, 1863, no. 13

\begin{tabular}{|c|c|c|c|c|c|c|}
\hline Rang & Name & Residence & Age & Handgeld & Partgeld & $\begin{array}{l}\text { Monthly } \\
\text { wage (in } f \text { ) }\end{array}$ \\
\hline Master & Wildts, Hendrik & & & & & \\
\hline $1^{\text {st }}$ mate & Ste(e)nbecker, Hendrik & Harlingen & 42 & $60,-$ & $1,-$ & $16,-$ \\
\hline $2^{\text {nd }}$ mate & Dusaat (?), Johannes Cornelis & Leyden & 40 & $32,-$ & $1,-$ & $32,-$ \\
\hline Flenser & Wortel, Cornelis & Terschelling & 41 & $45,-$ & 1,75 & $16,-$ \\
\hline Harpooner & Sjoordema, Fieke & Anjum & 43 & $45,-$ & 1,75 & $16,-$ \\
\hline Idem & Vries, Sytse de & Harlingen & 32 & $45,-$ & 1,75 & $16,-$ \\
\hline Idem & Wiersma, Nanne & Harlingen & 29 & $45,-$ & 1,75 & $16,-$ \\
\hline Idem & Dijkstra, Jacob & Sexbierum & 34 & $45,-$ & 1,75 & $16,-$ \\
\hline Idem & Bosje, Gerrit Gerrits & St. Jacob & 35 & $45,-$ & 1,75 & $16,-$ \\
\hline Second boatswain & Leijstra, Pieter & Wijnaldum & 39 & $45,-$ & 1,75 & $16,-$ \\
\hline Carpenter & Droogsma, Jouke & IJlst & 27 & $38,-$ & 1,15 & $38,-$ \\
\hline Cook & Bakker, Muevius & Harlingen & 37 & $36,-$ & 1,60 & $12,-$ \\
\hline $1 / 2$ partvaarder & Alkema, Johannes & Harlingen & 26 & $33,-$ & 1,55 & $11,-$ \\
\hline Idem & Bakker, Klaas Lucas & Terschelling & 27 & $30,-$ & 1,50 & $10,-$ \\
\hline Idem & Oepkes, Dirk & Terschelling & 37 & $30,-$ & 1,50 & $10,-$ \\
\hline Idem & Beer, Arie de & Terschelling & 27 & $30,-$ & 1,50 & $10,-$ \\
\hline Idem & Zuidmuller, Gerrit & Terschelling & 34 & $30,-$ & 1,50 & $10,-$ \\
\hline Idem & Spitz, Jacob & Terschelling & 42 & $30,-$ & 1,50 & $10,-$ \\
\hline Idem & Spitz, Jacob Jelles & Terschelling & 26 & $30,-$ & 1,50 & $10,-$ \\
\hline Idem & Andringa, Jacob Klaas & Sexbierum & 31 & $30,-$ & 1,50 & $10,-$ \\
\hline Idem & Leeman, Willem & Harlingen & 23 & $27,-$ & 1,45 & $9,-$ \\
\hline Idem & Volbeda, Jan K. & Harlingen & 19 & $27,-$ & 1,45 & $9,-$ \\
\hline Idem & Vries, Hendrik de & ..bidlum & 36 & $27,-$ & 1,45 & $9,-$ \\
\hline $2^{\text {nd }}$ carpenter & Kerkhof, Rijk & Harlingen & 28 & $24,-$ & 1,40 & $8,-$ \\
\hline Partvaarder & Radema, Rommelt (?) & Wijnaldum & 38 & $24,-$ & 1,40 & $8,-$ \\
\hline Idem & Rijpstra, Klaas Marten & Wijnaldum & 28 & $24,-$ & 1,40 & $8,-$ \\
\hline Idem & Rees, Cornelis van & Terschelling & 22 & $24,-$ & 1,40 & $8,-$ \\
\hline Idem & Groendijk, Jan & Terschelling & 20 & $24,-$ & 1,40 & $8,-$ \\
\hline Idem & Zuitmuller, Cornelis & Terschelling & 23 & $24,-$ & 1,40 & $8,-$ \\
\hline Idem & Schroo, Wilem & Terschelling & 22 & $21,-$ & 1,35 & $8,-$ \\
\hline Idem & Grond, Cornelis & St. Jacob & 20 & $18,-$ & 1,25 & $6,-$ \\
\hline Idem & Kuiken, Klaas & St. Jacob & 17 & $15,-$ & 1,25 & $5,-$ \\
\hline Idem & Hoving, Lieuwe & Anjum & 20 & $15,-$ & 1,25 & $5,-$ \\
\hline Idem & Bakker, Geert Gerrit & Grouw & 23 & $15,-$ & 1,25 & $5,-$ \\
\hline Idem & Klein, Teunes & Terschelling & 22 & $21,-$ & 1,35 & 7,- \\
\hline Idem & Boer, Douwe de & Harlingen & 17 & $15,-$ & 1,25 & $5,-$ \\
\hline Idem & Keulen, Cornelis A. van & Terschelling & 17 & $15,-$ & 1,25 & $5,-$ \\
\hline Maandvaarder & Struiksma, Egbert & Harlingen & 16 & $8,-$ & 1,25 & $8,-$ \\
\hline Idem & Baron, Albert & Harlingen & 17 & $8,-$ & 1,25 & $8,-$ \\
\hline Idem & Herlinga (?), Gerben & Butgum & 18 & $8,-$ & 1,25 & $8,-$ \\
\hline Idem & Hibma, Tjalling & Franeker & 17 & $8,-$ & 1,25 & $8,-$ \\
\hline Idem & Visser, Pieter & St. Anna & 19 & $10,-$ & 1,25 & $10,-$ \\
\hline Idem & Bruinsma, Pieter Y. & St. Anna & 19 & $8,-$ & 1,25 & $8,-$ \\
\hline Idem & Breed, Klaas de & Minnertsga & 16 & $8,-$ & 1,25 & $8,-$ \\
\hline Idem & Bouma, Franciscus & Liveins (?) & 16 & $8,-$ & 1,25 & $8,-$ \\
\hline Idem & Tot, Klaas & Terschelling & 16 & $8,-$ & 1,25 & $8,-$ \\
\hline Idem & Woudema, Gerrit & Sexbierum & 22 & $8,-$ & 1,25 & $8,-$ \\
\hline Idem & Souverein, Klaas & Harlingen & 20 & $8,-$ & 1,25 & $8,-$ \\
\hline Idem & Wouda, Syds & Beetjum & 25 & $8,-$ & 1,25 & $8,-$ \\
\hline Idem & Veersma, Jan & Pingjum & 20 & $8,-$ & 1,25 & $8,-$ \\
\hline Idem & Boonstra, Pieter & Harlingen & 15 & $8,-$ & 1,25 & $8,-$ \\
\hline Partvaarder & Bakker, Douwe & Terschelling & 24 & $24,-$ & 1,35 & $8,-$ \\
\hline Total & $52(53-1)$ crew & & $\begin{array}{l}25.46 \\
\text { (average) }\end{array}$ & & & 534/month \\
\hline
\end{tabular}




\section{Appendix 5 \\ Overview of Pupils of the Nautical College in Harlingen (1842-1864)}

The comments by the directors of the Nautical College in Harlingen on behaviour and level of understanding are categorized. The qualifications vary. For the sake of clarity, the numbers of these qualifications were added. In the case of behaviour, they ranged from lively ('levendig' -1) to troublesome ('lastig' -9). In the case of the level of understanding, qualifications ranged from quick ('zeer vlug -1) to difficult in learning ('moeilijk van begrip' - 6). As some categories are almost identi$\mathrm{cal}$, the total number of categories was reduced. The following categories were thus created:

Behaviour (B):

1. $=$ lively (levendig)

2. $=$ orderly (orderlijk)

3. $=$ modest and very industrious (bescheiden and zeer vlijtig)

4. $=$ modest (bescheiden)

5. = fairly modest and fairly industrious (matig bescheiden and matig vlijtig)

6. = quiet (stil/bescheiden)

7. $=$ becoming $($ redelijk/betamelijk $)$

8. = slow (traag)

9. $=$ troublesome (lastig)

Level of understanding (LOU):

1. = quick (overall term for zeer vlug and vlug)

2. $=$ susceptible (vatbaar)

3. $=$ reasonably susceptible (redelijk vatbaar)

4. $=$ hardly susceptible (nauwelijks vatbaar)

5. = slow (overall term for matig vlug and zeer langzaam)

6. $=$ difficult in learning (moeilijk van begrip)

The archival record from the Nautical College contains important information about the skills of the students. The three directors of the College frequently checked up on the progress of their pupils. They provided data about the knowledge their pupils had with regard to mathematical and navigational matters. Unfortunately, there is not unequivocal, unambiguous information about the exact content of the courses given by Kallenborn. The content of the courses may be deduced by analysing the progress mentioned in the records. It should noted that the remarks are commensurate with, or at least contain elements equal to, the categories first developed by O.S. Bangma in his capacity as teacher at the Nautical College in Amsterdam. Here again, it should be kept in mind that Pieter Kallenborn was trained by Bangma. In Amsterdam, Bangma introduced five categories, or disciplines, in his courses and all needed to be mastered by the students in order to be eligible to pass the exam for first mate. The categories were: 1. simple calculations up to and including decimal fractions; 2 . proportions and logarithms; 3 . trigonometry and navigation; 4 . measuring the altitude of the Sun, measuring magnetic declination by single or double amplitude observation, general rules for the Sun's ascension and declination, hour angle, measuring magnetic declination by azimuth observation and compass corrections, plane sailing and Mercator sailing 
with the aid of traverse tables, and compound courses; and 5. astronomical navigation, determining a ship's position by solar, lunar, and star observations. ${ }^{12}$

Overview of pupils at the Nautical College in Harlingen and their achievements (1842-1864). Source: GAH, SWZV1, no. $647 .^{13}$

\begin{tabular}{|c|c|c|c|c|c|c|c|c|c|c|c|c|}
\hline Year & Name & $\begin{array}{l}\text { Place of } \\
\text { birth }\end{array}$ & Age & $\begin{array}{l}\text { Years } \\
\text { of ex- } \\
\text { peri- } \\
\text { ence }\end{array}$ & $\begin{array}{l}\text { Arrival } \\
\text { at school }\end{array}$ & $\begin{array}{l}\text { Depar- } \\
\text { ture } \\
\text { from } \\
\text { school }\end{array}$ & $\begin{array}{l}\text { Years of } \\
\text { educa- } \\
\text { tion }\end{array}$ & $\begin{array}{l}\text { Voyage/ } \\
\text { rank }\end{array}$ & B & LOU & Progress & Source \\
\hline 1842 & $\begin{array}{l}\text { Wildst, } \\
\text { Hendrik }\end{array}$ & Sneek & 39 & - & - & - & - & - & 3 & 3 & $\begin{array}{l}\text { Allows for cur- } \\
\text { rents, calculates } \\
\text { the true courses } \\
\text { steered and dis- } \\
\text { tances run. }\end{array}$ & $\begin{array}{l}\text { Fol. 1, } \\
\text { no. } 11\end{array}$ \\
\hline $\begin{array}{l}1843^{-} \\
1844\end{array}$ & $\begin{array}{l}\text { Wildst, } \\
\text { Hendrik }\end{array}$ & Sneek & 40 & 5 & - & - & - & - & 3 & 3 & $\begin{array}{l}\text { Calculates the } \\
\text { true courses } \\
\text { steered and dis- } \\
\text { tances run and al- } \\
\text { lows for currents. }\end{array}$ & $\begin{array}{l}\text { Fol. } 3 \text {, } \\
\text { no. } 9\end{array}$ \\
\hline \multirow[t]{8}{*}{$\begin{array}{l}1844^{-} \\
1845\end{array}$} & $\begin{array}{l}\text { Wildts, } \\
\text { Hendrik }\end{array}$ & Sneek & 41 & 6 & & & $\begin{array}{l}3 \text { win- } \\
\text { ters }\end{array}$ & $\begin{array}{l}\text { Left for } \\
\text { Greenland }\end{array}$ & 3 & 3 & $\begin{array}{l}\text { Has received suf- } \\
\text { ficient theoretical } \\
\text { training in navi- } \\
\text { gation. Calculates } \\
\text { longitude at sea } \\
\text { by chronometer } \\
\text { etc. }\end{array}$ & $\begin{array}{l}\text { Fol. } 5 \text {, } \\
\text { no. } 1\end{array}$ \\
\hline & Both, Johann & $\begin{array}{l}\text { Seester- } \\
\text { mühe }\end{array}$ & 18 & 1 & & & $\begin{array}{l}2 \text { win- } \\
\text { ters }\end{array}$ & $\begin{array}{l}\text { Idem after } \\
\text { passing } \\
\text { exam as } \\
\text { 1st mate }\end{array}$ & 3 & 2 & $\begin{array}{l}\text { Has received suf- } \\
\text { ficient theoretical } \\
\text { training in navi- } \\
\text { gation. Calculates } \\
\text { longitude at sea } \\
\text { by lunar distances } \\
\text { in various ways. }\end{array}$ & $\begin{array}{l}\text { Fol. } 5 \text {, } \\
\text { no. } 3\end{array}$ \\
\hline & Both, Michiel & $\begin{array}{l}\text { Seester- } \\
\text { mühe }\end{array}$ & 15 & 3 & & & 1 winter & \begin{tabular}{|l|} 
Left for \\
Greenland
\end{tabular} & 5 & 2 & $\begin{array}{l}\text { Calculates the } \\
\text { compound cours- } \\
\text { es. }\end{array}$ & $\begin{array}{l}\text { Fol. } 5 \text {, } \\
\text { no. } 6\end{array}$ \\
\hline & $\begin{array}{l}\text { Tigchelaar, } \\
\text { Jelmer }\end{array}$ & $\begin{array}{l}\text { Minnerts- } \\
\text { ga }\end{array}$ & 16 & 2 & & & $\begin{array}{l}2 \text { win- } \\
\text { ters }\end{array}$ & Idem & 5 & 3 & $\begin{array}{l}\text { Calculates the } \\
\text { spherical trian- } \\
\text { gles. }\end{array}$ & $\begin{array}{l}\text { Fol. } 5 \text {, } \\
\text { no. } 15\end{array}$ \\
\hline & Jager, D.W. & Harlingen & 18 & 6 & & & $\begin{array}{l}3 \text { win- } \\
\text { ters }\end{array}$ & Idem & 5 & 3 & $\begin{array}{l}\text { Calculates the } \\
\text { true courses } \\
\text { steered and dis- } \\
\text { tances run. }\end{array}$ & $\begin{array}{l}\text { Fol. } 5 \text {, } \\
\text { no. } 17\end{array}$ \\
\hline & Grevenstuck, B. & $\begin{array}{l}\text { Heeren- } \\
\text { veen }\end{array}$ & 18 & 1 & & & & Idem & 5 & 2 & $\begin{array}{l}\text { Calculates the } \\
\text { plane oblique-an- } \\
\text { gled triangles. }\end{array}$ & $\begin{array}{l}\text { Fol. } 5 \text {, } \\
\text { no. } 18\end{array}$ \\
\hline & $\begin{array}{l}\text { Elst, Johannes } \\
\text { van der }\end{array}$ & Harlingen & 20 & 3 & & & & Idem & 5 & 2 & $\begin{array}{l}\text { Calculates lati- } \\
\text { tude at sea by star } \\
\text { altitude. }\end{array}$ & $\begin{array}{l}\text { Fol. 6, } \\
\text { no. } 37\end{array}$ \\
\hline & $\begin{array}{l}\text { Wagenaar, Jan } \\
\text { E. }\end{array}$ & Harlingen & 20 & 6 & & & $\begin{array}{l}2 \text { win- } \\
\text { ters }\end{array}$ & Idem & 5 & 3 & $\begin{array}{l}\text { Calculates the } \\
\text { true courses } \\
\text { steered and dis- } \\
\text { tances run }\end{array}$ & $\begin{array}{l}\text { Fol. 6, } \\
\text { no. } 39\end{array}$ \\
\hline
\end{tabular}

12. De Feyfer, Het licht der zeevaert, 51, note 12.

13. I am indebted to prof. dr. C.A. Davids (Vrije Universiteit Amsterdam), for his assistance in translating the technical terms regarding the state of navigational knowledge among the pupils. Thanks are also due to Willem Mörzer Bruyns. 


\begin{tabular}{|c|c|c|c|c|c|c|c|c|c|c|c|c|}
\hline Year & Name & $\begin{array}{l}\text { Place of } \\
\text { birth }\end{array}$ & Age & $\begin{array}{l}\text { Years } \\
\text { of ex- } \\
\text { peri- } \\
\text { ence }\end{array}$ & $\begin{array}{l}\text { Arrival } \\
\text { at school }\end{array}$ & $\begin{array}{l}\text { Depar- } \\
\text { ture } \\
\text { from } \\
\text { school }\end{array}$ & $\begin{array}{l}\text { Years of } \\
\text { educa- } \\
\text { tion }\end{array}$ & $\begin{array}{l}\text { Voyage/ } \\
\text { rank }\end{array}$ & B & LOU & Progress & Source \\
\hline & Vries, Klaas de & Harlingen & 19 & 7 & & & & Idem & 5 & 2 & $\begin{array}{l}\text { Has received suf- } \\
\text { ficient theoretical } \\
\text { training in navi- } \\
\text { gation. Calculates } \\
\text { longitude at sea } \\
\text { by chronometers. }\end{array}$ & $\begin{array}{l}\text { Fol. } 6 \text {, } \\
\text { no. } 17\end{array}$ \\
\hline \multirow[t]{6}{*}{$\begin{array}{l}1845^{-} \\
1846\end{array}$} & Both, Michiel & $\begin{array}{l}\text { Seester- } \\
\text { mühe }\end{array}$ & 16 & 1 & Nov. 3 & Feb. 16 & $\begin{array}{l}2 \text { win- } \\
\text { ters }\end{array}$ & Idem & 5 & 3 & $\begin{array}{l}\text { Calculates the } \\
\text { compound cours- } \\
\text { es and sailings. }\end{array}$ & $\begin{array}{l}\text { Fol. } 7 \text {, } \\
\text { no. } 2\end{array}$ \\
\hline & Vries, Jan G. de & Franeker & 16 & & Idem & Idem & {$[1]$} & Idem & & & $\begin{array}{l}\text { Calculates the } \\
\text { rhumb-line } \\
\text { tracks. }\end{array}$ & $\begin{array}{l}\text { Fol. } 7 \\
\text { no. } 15\end{array}$ \\
\hline & $\begin{array}{l}\text { Holstein, } \\
\text { Nammele }\end{array}$ & Harlingen & 16 & 1 & Nov. 13 & Idem & 1 winter & Idem & 3 & 2 & Idem & Fol. 7, 27 \\
\hline & $\begin{array}{l}\text { Wildts, Hen- } \\
\text { drik }\end{array}$ & Sneek & 42 & 7 & Dec. 2 & Idem & $\begin{array}{l}1 \text { win- } \\
\text { ters }\end{array}$ & Idem & 3 & 2 & $\begin{array}{l}\text { Has received suffi- } \\
\text { cient theoretical } \\
\text { training in naviga- } \\
\text { tion. Calculates } \\
\text { longitude at sea by } \\
\text { lunar distances. }\end{array}$ & $\begin{array}{l}\text { Fol. } 8 \text {, } \\
\text { no. } 36\end{array}$ \\
\hline & Groot, Klaas de & Harlingen & 21 & 5 & Dec. 8 & Idem & $\begin{array}{l}3 \text { win- } \\
\text { ters }\end{array}$ & Idem & 3 & 3 & $\begin{array}{l}\text { Calculates the co- } \\
\text { incidence of the } \\
\text { right ascensions of } \\
\text { the Sun and Moon. }\end{array}$ & $\begin{array}{l}\text { Fol. } 8 \text {, } \\
\text { no. } 39\end{array}$ \\
\hline & $\begin{array}{l}\text { Wagenaar, } \\
\text { Petrus }\end{array}$ & Harlingen & 20 & & Jan. 6 & Idem & & Idem & 5 & 3 & $\begin{array}{l}\text { Calculates the } \\
\text { plane oblique-an- } \\
\text { gled triangles. }\end{array}$ & $\begin{array}{l}\text { Fol. } 8 \text {, } \\
\text { no. } 53\end{array}$ \\
\hline \multirow[t]{7}{*}{$\begin{array}{l}1846- \\
1847\end{array}$} & Stuur, Hendrik & Harlingen & 19 & 3 & Nov. 2 & Feb. 23 & $\begin{array}{l}2 \text { win- } \\
\text { ters }\end{array}$ & Idem & 5 & 2 & $\begin{array}{l}\text { Has received suffi- } \\
\text { cient theoretical } \\
\text { training in naviga- } \\
\text { tion. Calculates } \\
\text { longitude at sea by } \\
\text { chronometers. }\end{array}$ & $\begin{array}{l}\text { Fol. } 9 \text {, } \\
\text { no. } 2\end{array}$ \\
\hline & Both, Michiel & $\begin{array}{l}\text { Seester- } \\
\text { mühe }\end{array}$ & 17 & 5 & Idem & Idem & $\begin{array}{l}3 \text { win- } \\
\text { ters }\end{array}$ & Idem & 5 & 2 & $\begin{array}{l}\text { Has received suffi- } \\
\text { cient theoretical } \\
\text { training in naviga- } \\
\text { tion. Calculates } \\
\text { longitude at sea by } \\
\text { chronometers. }\end{array}$ & $\begin{array}{l}\text { Fol. } 9 \text {, } \\
\text { no. } 6\end{array}$ \\
\hline & Wildts, Hendrik & Sneek & 43 & 8 & Nov. 23 & Idem & 1 winters & Idem & 3 & 2 & $\begin{array}{l}\text { Has received suffi- } \\
\text { cient theoretical } \\
\text { training in naviga- } \\
\text { tion. Calculates } \\
\text { longitude at sea by } \\
\text { chronometers. }\end{array}$ & $\begin{array}{l}\text { Fol. 9, } \\
\text { no. } 31\end{array}$ \\
\hline & $\begin{array}{l}\text { Katoen, } \\
\text { Wesselius }\end{array}$ & $\begin{array}{l}\text { Pieters- } \\
\text { bierum }\end{array}$ & 22 & 1 & Dec. 7 & March 1 & & Idem & 5 & 2 & $\begin{array}{l}\text { Calculates the } \\
\text { compound cours- } \\
\text { es. }\end{array}$ & $\begin{array}{l}\text { Fol. 10, } \\
\text { no. } 38\end{array}$ \\
\hline & $\begin{array}{l}\text { Werf, Poppe W. } \\
\text { v.d. }\end{array}$ & Harlingen & 19 & 2 & Dec. 11 & March 1 & $\begin{array}{l}3 \text { win- } \\
\text { ters }\end{array}$ & Idem & 5 & 2 & $\begin{array}{l}\text { Calculates latitude } \\
\text { from the moon in } \\
\text { the meridian. }\end{array}$ & $\begin{array}{l}\text { Fol. 10, } \\
\text { no. 50 }\end{array}$ \\
\hline & Vries, Jan S. de & Harlingen & 16 & 2 & Dec. 28 & March 2 & & Idem & 5 & 2 & $\begin{array}{l}\text { Calculates the } \\
\text { plane right-angled } \\
\text { triangles. }\end{array}$ & $\begin{array}{l}\text { Fol. 10, } \\
\text { no. } 58\end{array}$ \\
\hline & Steeksma, Syb & Harlingen & 22 & 1 & Jan. 5 & March 1 & 1 winter & Idem & 5 & 2 & $\begin{array}{l}\text { Calculates the } \\
\text { East-West sail- } \\
\text { ings. }\end{array}$ & $\begin{array}{l}\text { Fol. } 10 \text {, } \\
\text { no. } 60\end{array}$ \\
\hline
\end{tabular}




\begin{tabular}{|c|c|c|c|c|c|c|c|c|c|c|c|c|}
\hline Year & Name & $\begin{array}{l}\text { Place of } \\
\text { birth }\end{array}$ & Age & $\begin{array}{l}\text { Years } \\
\text { of ex- } \\
\text { peri- } \\
\text { ence }\end{array}$ & $\begin{array}{l}\text { Arrival } \\
\text { at school }\end{array}$ & $\begin{array}{l}\text { Depar- } \\
\text { ture } \\
\text { from } \\
\text { school }\end{array}$ & $\begin{array}{l}\text { Years of } \\
\text { educa- } \\
\text { tion }\end{array}$ & $\begin{array}{l}\text { Voyage/ } \\
\text { rank }\end{array}$ & B & LOU & Progress & Source \\
\hline \multirow[t]{4}{*}{$\begin{array}{l}1847^{-} \\
1848\end{array}$} & Mulder, Frans & Harlingen & 16 & & Nov. 1 & Feb. 22 & 1 winter & Idem & 5 & 3 & $\begin{array}{l}\text { Calculates the } \\
\text { plane oblique-an- } \\
\text { gled triangles. }\end{array}$ & $\begin{array}{l}\text { Fol. 11, } \\
\text { no. 13 }\end{array}$ \\
\hline & Both, Jacob & $\begin{array}{l}\text { Seester- } \\
\text { mühe }\end{array}$ & 14 & 3 & Nov. 6 & Feb. 21 & 1 winter & Idem & 5 & 2 & $\begin{array}{l}\text { Calculates the } \\
\text { spherical oblique- } \\
\text { angled triangles. }\end{array}$ & $\begin{array}{l}\text { Fol. 11, } \\
\text { no. } 18\end{array}$ \\
\hline & Ploeg, Jacob & Steggerde & 29 & 13 & Nov. 15 & March 1 & 1 winter & Idem & 5 & 3 & $\begin{array}{l}\text { Calculates latitude } \\
\text { by means of the } \\
\text { double altitude } \\
\text { method in various } \\
\text { ways. }\end{array}$ & $\begin{array}{l}\text { Fol. 11, } \\
\text { no. } 27\end{array}$ \\
\hline & Both, Michiel & $\begin{array}{l}\text { Seester- } \\
\text { mühe }\end{array}$ & 18 & 6 & Dec. 6 & Feb. 19 & 1 winters & Idem & 3 & 2 & $\begin{array}{l}\text { Has received suffi- } \\
\text { cient theoretical } \\
\text { training in naviga- } \\
\text { tion. Calculates } \\
\text { longitude by solar } \\
\text { distance, or stellar } \\
\text { distance. }\end{array}$ & $\begin{array}{l}\text { Fol. 12, } \\
\text { no. } 38\end{array}$ \\
\hline \multirow[t]{4}{*}{$\begin{array}{l}1848- \\
1849\end{array}$} & $\begin{array}{l}\text { Slooten, T.M. } \\
\text { van }\end{array}$ & Harlingen & 15 & 1 & Nov.9 & Feb. 19 & 2 years & Idem & 6 & 3 & $\begin{array}{l}\text { Calculates the } \\
\text { rhumb-line } \\
\text { tracks. }\end{array}$ & $\begin{array}{l}\text { Fol. 13, } \\
\text { no. } 7\end{array}$ \\
\hline & Both, Jacob & $\begin{array}{l}\text { Seester- } \\
\text { mühe }\end{array}$ & 15 & 1 & Nov. 16 & Feb. 19 & 1 year & Idem & 6 & 3 & $\begin{array}{l}\text { Calculates the } \\
\text { spherical oblique- } \\
\text { angled triangles. }\end{array}$ & $\begin{array}{l}\text { Fol. 13, } \\
\text { no. } 15\end{array}$ \\
\hline & $\begin{array}{l}\text { Wielen Miede- } \\
\text { ma, S. v.d. }\end{array}$ & $\begin{array}{l}\text { Leeuwar- } \\
\text { den }\end{array}$ & 17 & 1 & Dec. 11 & Feb. 22 & 1 year & Idem & 4 & 3 & $\begin{array}{l}\text { Calculates latitude } \\
\text { by meridian alti- } \\
\text { tude. }\end{array}$ & $\begin{array}{l}\text { Fol. 11, } \\
\text { no. } 59\end{array}$ \\
\hline & $\begin{array}{l}\text { Zwanenburg, } \\
\text { Jan }\end{array}$ & Harlingen & 18 & none & Dec. 21 & Feb. 19 & & Idem & 4 & 2 & $\begin{array}{l}\text { Calculates the } \\
\text { spherical oblique- } \\
\text { angled triangles. }\end{array}$ & $\begin{array}{l}\text { Fol. } 15 \\
\text { no. } 72\end{array}$ \\
\hline \multirow[t]{3}{*}{$\begin{array}{l}1849^{-} \\
1850\end{array}$} & $\begin{array}{l}\text { Sloten, T.M. } \\
\text { van }\end{array}$ & Harlingen & 17 & 3 & Dec. 1 & Feb. 16 & 1 years & $\begin{array}{l}\text { To Green- } \\
\text { land } \\
\text { fishery }\end{array}$ & 4 & 3 & $\begin{array}{l}\text { Calculates the } \\
\text { rhumb-line } \\
\text { tracks. }\end{array}$ & $\begin{array}{l}\text { Fol. } 17 \\
\text { no. } 56\end{array}$ \\
\hline & Haenstra, U.W. & $\begin{array}{l}\text { Oosterwie- } \\
\text { rum }\end{array}$ & 17 & & Idem & Feb. 18 & & Idem & 4 & 3 & $\begin{array}{l}\text { Calculates the } \\
\text { North-South sail- } \\
\text { ings. }\end{array}$ & $\begin{array}{l}\text { Fol. 17, } \\
\text { no. } 57\end{array}$ \\
\hline & $\begin{array}{l}\text { Smeden, } \\
\text { B[au]ke van }\end{array}$ & Harlingen & 15 & & Dec. 27 & Feb. 16 & 1 year & Idem & 6 & 3 & $\begin{array}{l}\text { Calculates the } \\
\text { spherical oblique- } \\
\text { angled triangles. }\end{array}$ & $\begin{array}{l}\text { Fol. 18, } \\
\text { no. } 78\end{array}$ \\
\hline \multirow[t]{3}{*}{$\begin{array}{l}1850- \\
1851\end{array}$} & Slooten, Th. van & Harlingen & 17 & 1 & Nov. 19 & Feb. 17 & $\begin{array}{l}5 \text { win- } \\
\text { ters }\end{array}$ & $\begin{array}{l}\text { To Green- } \\
\text { land }\end{array}$ & 4 & 3 & $\begin{array}{l}\text { Calculates } \\
\text { rhumb-line } \\
\text { tracks. }\end{array}$ & $\begin{array}{l}\text { Fol. 20, } \\
\text { no. } 19\end{array}$ \\
\hline & Tigchelaar, E.C. & Harlingen & 15 & 1 & Nov. 25 & Feb. 21 & $\begin{array}{l}\text { One } \\
\text { winter }\end{array}$ & Idem & 6 & 3 & $\begin{array}{l}\text { Calculates the } \\
\text { spherical oblique- } \\
\text { angled triangles. }\end{array}$ & $\begin{array}{l}\text { Fol. 20, } \\
\text { no. } 51\end{array}$ \\
\hline & Boer, Hans de & Harlingen & 16 & 1 & Dec. 9 & Feb. 26 & $\begin{array}{l}2 \text { win- } \\
\text { ters }\end{array}$ & Idem & 4 & 3 & $\begin{array}{l}\text { Calculates the } \\
\text { rhumb-line } \\
\text { tracks. }\end{array}$ & $\begin{array}{l}\text { Fol. 20, } \\
\text { no. } 61\end{array}$ \\
\hline \multirow[t]{3}{*}{$\begin{array}{l}1851^{-} \\
1852 \\
\end{array}$} & $\begin{array}{l}\text { Ouwenbroek, } \\
\text { A. }\end{array}$ & Harlingen & 22 & 6 & Nov. 12 & Feb. 16 & 1 winters & Idem & 4 & 3 & $\begin{array}{l}\text { Calculates the } \\
\text { spherical triangles. }\end{array}$ & $\begin{array}{l}\text { Fol. 22, } \\
\text { no. 21 }\end{array}$ \\
\hline & $\begin{array}{l}\text { Vellinga, Jan } \\
\text { Jans }\end{array}$ & $\begin{array}{l}\text { Witmar- } \\
\text { sum }\end{array}$ & 16 & 1 & Nov. 18 & Feb. 21 & 1 winter & Idem & 1 & 2 & $\begin{array}{l}\text { Calculates the alti- } \\
\text { tude corrections. }\end{array}$ & $\begin{array}{l}\text { Fol. 22, } \\
\text { no. 30 }\end{array}$ \\
\hline & $\begin{array}{l}\text { Meer, Pieter van } \\
\text { der }\end{array}$ & Harlingen & 16 & 1 & Nov. 21 & Dec. 21 & 1 winter & Idem & 4 & 2 & $\begin{array}{l}\text { Calculates the } \\
\text { spherical right- } \\
\text { angled triangles. }\end{array}$ & $\begin{array}{l}\text { Fol. 23, } \\
\text { no. } 12\end{array}$ \\
\hline
\end{tabular}




\begin{tabular}{|c|c|c|c|c|c|c|c|c|c|c|c|c|}
\hline Year & Name & $\begin{array}{l}\text { Place of } \\
\text { birth }\end{array}$ & Age & $\begin{array}{l}\text { Years } \\
\text { of ex- } \\
\text { peri- } \\
\text { ence }\end{array}$ & $\begin{array}{l}\text { Arrival } \\
\text { at school }\end{array}$ & $\begin{array}{l}\text { Depar- } \\
\text { ture } \\
\text { from } \\
\text { school }\end{array}$ & $\begin{array}{l}\text { Years of } \\
\text { educa- } \\
\text { tion }\end{array}$ & $\begin{array}{l}\text { Voyage/ } \\
\text { rank }\end{array}$ & B & LOU & Progress & Source \\
\hline & $\begin{array}{l}\text { Dijkstra, } \\
\text { Sybrand }\end{array}$ & Sneek & 19 & 1 & Dec. 11 & Feb. 21 & 1 winter & Idem & 4 & 3 & $\begin{array}{l}\text { Calculates the } \\
\text { plane oblique-an- } \\
\text { gled triangles. }\end{array}$ & $\begin{array}{l}\text { Fol. 23, } \\
\text { no. } 53\end{array}$ \\
\hline $\begin{array}{l}1852- \\
1853\end{array}$ & $\begin{array}{l}\text { No names relat- } \\
\text { ed to whaling }\end{array}$ & & & & & & & & & & & \\
\hline \multirow[t]{2}{*}{$\begin{array}{l}1853^{-} \\
1854\end{array}$} & $\begin{array}{l}\text { Kiestra, } \\
\text { Johannes }\end{array}$ & Harbayum & 32 & 1 & Nov. 1 & Feb. 6 & $\begin{array}{l}2 \text { win- } \\
\text { ters }\end{array}$ & $\begin{array}{l}\text { To Green- } \\
\text { land } \\
\text { fishery }\end{array}$ & 6 & 3 & $\begin{array}{l}\text { Calculates com- } \\
\text { pass error. }\end{array}$ & $\begin{array}{l}\text { Fol. } 27 \text {, } \\
\text { no. } 11\end{array}$ \\
\hline & Bleijenga, Jacob & Sneek & 19 & 1 & Dec. 12 & $\begin{array}{l}\text { March } \\
20\end{array}$ & 1 winter & $\begin{array}{l}\text { To Green- } \\
\text { land as } \\
\text { boy }\end{array}$ & 6 & 5 & $\begin{array}{l}\text { Calculates the } \\
\text { right-angled tri- } \\
\text { angles. }\end{array}$ & $\begin{array}{l}\text { Fol. } 28 \text {, } \\
\text { no. } 15\end{array}$ \\
\hline $\begin{array}{l}1854^{-} \\
1855\end{array}$ & $\begin{array}{l}\text { No names relat- } \\
\text { ed to whaling }\end{array}$ & & & & & & & & & & & \\
\hline \multirow[t]{11}{*}{$\begin{array}{l}1855^{-} \\
1856\end{array}$} & Visser, Klaas & Dokkum & 27 & 17 & Nov. 1 & Feb. 2 & 1 winters & \begin{tabular}{|l|}
$2^{\text {nd }}$ mate to \\
Greenland
\end{tabular} & 2 & 2 & $\begin{array}{l}\text { Made so much } \\
\text { progress that he } \\
\text { may be examined. }\end{array}$ & $\begin{array}{l}\text { Fol. 32, } \\
\text { no. } 3\end{array}$ \\
\hline & Drager, Willem & Franeker & 18 & none & Nov. 1 & Feb. 11 & & $\begin{array}{l}\text { Ordinary } \\
\text { seaman to } \\
\text { Greenland }\end{array}$ & 6 & 3 & $\begin{array}{l}\text { Calculates the } \\
\text { plane oblique-an- } \\
\text { gled triangles. }\end{array}$ & $\begin{array}{l}\text { Fol. } 32 \text {, } \\
\text { no. } 21\end{array}$ \\
\hline & $\begin{array}{l}\text { Rooswinkel, } \\
\text { Hendrik }\end{array}$ & Harlingen & 16 & none & Nov. 12 & Feb. 11 & $\begin{array}{l}2 \text { win- } \\
\text { ters }\end{array}$ & $\begin{array}{l}\text { Boy to } \\
\text { Greenland }\end{array}$ & 6 & 2 & $\begin{array}{l}\text { Familiar with the } \\
\text { entire art of plane } \\
\text { sailing. }\end{array}$ & $\begin{array}{l}\text { Fol. } 32 \text {, } \\
\text { no. } 33\end{array}$ \\
\hline & Boer, Hans de & Harlingen & 20 & 6 & Nov. 22 & Feb. 2 & $\begin{array}{l}3 \text { win- } \\
\text { ters }\end{array}$ & $\begin{array}{l}\text { Ordinary } \\
\text { seaman to } \\
\text { Greenland }\end{array}$ & 1 & 3 & $\begin{array}{l}\text { Idem and latitude } \\
\text { measurement. }\end{array}$ & $\begin{array}{l}\text { Fol. } 33 \text {, } \\
\text { no. } 39\end{array}$ \\
\hline & Pronker, Mink & Harlingen & 23 & 1 & Nov. 21 & idem & & idem & 1 & 2 & Idem & $\begin{array}{l}\text { Fol. } 33 \\
\text { no. } 10\end{array}$ \\
\hline & $\begin{array}{l}\text { Meinsma, } \\
\text { Meindert }\end{array}$ & Anjum & 23 & 8 & Dec. 11 & Feb. 2 & 1 & $\begin{array}{l}\text { Boatswain } \\
\text { to Green- } \\
\text { land }\end{array}$ & 6 & 2 & $\begin{array}{l}\text { Is familiar with } \\
\text { the entire art of } \\
\text { plane sailing. }\end{array}$ & $\begin{array}{l}\text { Fol. } 33 \text {, } \\
\text { no. } 55\end{array}$ \\
\hline & Monsma, Bart & $\begin{array}{l}\text { Ooster- } \\
\text { hout }\end{array}$ & 22 & 7 & idem & idem & & $\begin{array}{l}\text { Ordinary } \\
\text { seaman to } \\
\text { Greenland }\end{array}$ & 2 & 3 & $\begin{array}{l}\text { Calculates plane } \\
\text { compound } \\
\text { courses. }\end{array}$ & $\begin{array}{l}\text { Fol. } 33 \text {, } \\
\text { no. } 57\end{array}$ \\
\hline & $\begin{array}{l}\text { Stenbeker, } \\
\text { Hendrik }\end{array}$ & Elmshorn & 35 & 20 & idem & idem & & $\begin{array}{l}\text { Mate to } \\
\text { Greenland }\end{array}$ & 6 & 3 & $\begin{array}{l}\text { Is familiar with } \\
\text { the entire art of } \\
\text { plane sailing. }\end{array}$ & $\begin{array}{l}\text { Fol. } 33 \\
\text { no. } 58\end{array}$ \\
\hline & $\begin{array}{l}\text { Ebeling, } \\
\text { Hendrikus }\end{array}$ & Harlingen & 18 & 3 & idem & Feb. 11 & & $\begin{array}{l}\text { Ordinary } \\
\text { seaman to } \\
\text { Greenland }\end{array}$ & 6 & 3 & $\begin{array}{l}\text { Calculates the } \\
\text { compound } \\
\text { courses. }\end{array}$ & $\begin{array}{l}\text { Fol. } 33 \text {, } \\
\text { no. } 62\end{array}$ \\
\hline & Vries, Jan de & Harlingen & 17 & 3 & Nov. 17 & Feb. 2 & 1 & $\begin{array}{l}\text { Ordinary } \\
\text { seaman to } \\
\text { Greenland }\end{array}$ & 9 & 3 & $\begin{array}{l}\text { Calculates the } \\
\text { rhumb-line } \\
\text { tracks. }\end{array}$ & $\begin{array}{l}\text { Fol. 33, } \\
\text { no. } 61\end{array}$ \\
\hline & $\begin{array}{l}\text { Wiersma, } \\
\text { Nanne }\end{array}$ & Harlingen & 22 & 1 & Jan. 2 & Feb. 2 & & $\begin{array}{l}\text { Ordinary } \\
\text { seaman to } \\
\text { Greenland }\end{array}$ & & & $\begin{array}{l}\text { Calculates the } \\
\text { compound cours- } \\
\text { es. }\end{array}$ & $\begin{array}{l}\text { Fol. 33, } \\
\text { no. } 78\end{array}$ \\
\hline \multirow[t]{3}{*}{$\begin{array}{l}1856- \\
1857\end{array}$} & $\begin{array}{l}\text { Rooswinkel, } \\
\text { Hendrik }\end{array}$ & Harlingen & 17 & 1 & Dec. 1 & Feb. 10 & $\begin{array}{l}3 \text { win- } \\
\text { ters }\end{array}$ & $\begin{array}{l}\text { Boy with } \\
\text { capt. O. } \\
\text { Mehlen }\end{array}$ & 4 & $1+$ & $\begin{array}{l}\text { Is familiar with } \\
\text { the entire art of } \\
\text { Mercator sailing. }\end{array}$ & $\begin{array}{l}\text { Fol. } 36 \text {, } \\
\text { no. } 58\end{array}$ \\
\hline & $\begin{array}{l}\text { Stenbeker [sic], } \\
\text { Hendrik }\end{array}$ & Elmshorn & 36 & 21 & Dec. 1 & Feb. 10 & 1 winter & $\begin{array}{l}\text { Mate with } \\
\text { capt. O. } \\
\text { Mehlen }\end{array}$ & 6 & 2 & $\begin{array}{l}\text { Is familiar with } \\
\text { the art of plane } \\
\text { sailing. }\end{array}$ & $\begin{array}{l}\text { Fol. 36, } \\
\text { no. } 61\end{array}$ \\
\hline & Meinsma, M. & Anjum & 21 & 9 & Dec. 1 & Feb. 10 & $\begin{array}{l}2 \text { win- } \\
\text { ters }\end{array}$ & $\begin{array}{l}\text { Boatswain } \\
\text { with capt. } \\
\text { O. Mehlen }\end{array}$ & 6 & 3 & Idem. & $\begin{array}{l}\text { Fol. } 36 \text {, } \\
\text { no. } 62\end{array}$ \\
\hline
\end{tabular}




\begin{tabular}{|c|c|c|c|c|c|c|c|c|c|c|c|c|}
\hline Year & Name & $\begin{array}{l}\text { Place of } \\
\text { birth }\end{array}$ & Age & $\begin{array}{l}\text { Years } \\
\text { of ex- } \\
\text { peri- } \\
\text { ence }\end{array}$ & $\begin{array}{l}\text { Arrival } \\
\text { at school }\end{array}$ & $\begin{array}{l}\text { Depar- } \\
\text { ture } \\
\text { from } \\
\text { school }\end{array}$ & $\begin{array}{l}\text { Years of } \\
\text { educa- } \\
\text { tion }\end{array}$ & $\begin{array}{l}\text { Voyage/ } \\
\text { rank }\end{array}$ & B & LOU & Progress & Source \\
\hline & Monsma, Bart & $\begin{array}{l}\text { Ooster- } \\
\text { hout }\end{array}$ & 23 & 8 & Dec. 2 & Feb. 10 & 1 & $\begin{array}{l}\text { Ordinary } \\
\text { seaman } \\
\text { with capt. } \\
\text { O. Mehlen }\end{array}$ & 1 & 5 & $\begin{array}{l}\text { Calculates the } \\
\text { compound } \\
\text { courses. }\end{array}$ & $\begin{array}{l}\text { Fol. } 36 \text {, } \\
\text { no. } 66\end{array}$ \\
\hline & Visser, Klaas & Dokkum & 28 & 18 & Dec. 8 & Feb. 10 & $\begin{array}{l}5 \text { win- } \\
\text { ters }\end{array}$ & $\begin{array}{l}2^{\text {nd }} \text { mate } \\
\text { with capt. } \\
\text { O. Mehlen }\end{array}$ & 6 & 2 & $\begin{array}{l}\text { Is familiar with } \\
\text { the entire art of } \\
\text { Mercator sailing. }\end{array}$ & $\begin{array}{l}\text { Fol. 37, } \\
\text { no. } 71\end{array}$ \\
\hline & $\begin{array}{l}\text { Wiersma, } \\
\text { Nanne }\end{array}$ & Harlingen & 23 & 5 & \begin{tabular}{|l} 
Jan. 3, \\
1857
\end{tabular} & Feb. 10 & 1 & \begin{tabular}{|l|} 
Ordinary \\
seaman \\
with capt. \\
O. Mehlen
\end{tabular} & 7 & 3 & $\begin{array}{l}\text { Calculates the } \\
\text { compound } \\
\text { courses. }\end{array}$ & $\begin{array}{l}\text { Fol. } 37 \\
\text { no. } 97\end{array}$ \\
\hline \multirow[t]{5}{*}{$\begin{array}{l}1857^{-} \\
1858\end{array}$} & Nauta, Evert & Harlingen & 17 & 1 & Nov. 28 & Feb. 6 & 1 & $\begin{array}{l}\text { Ordinary } \\
\text { seaman } \\
\text { with O. } \\
\text { Mehlen } \\
\text { (Dirkje } \\
\text { Adema) }\end{array}$ & 8 & 3 & $\begin{array}{l}\text { Calculates the } \\
\text { plane triangles. }\end{array}$ & $\begin{array}{l}\text { Fol. 10, } \\
\text { no. } 57\end{array}$ \\
\hline & Tigchelaar, H. & Harlingen & 22 & 7 & $\begin{array}{l}\text { Jan. } 1, \\
1858\end{array}$ & Feb. 12 & & $\begin{array}{l}\text { Ordinary } \\
\text { seaman } \\
\text { with O. } \\
\text { Mehlen }\end{array}$ & 6 & 3 & $\begin{array}{l}\text { Calculates the } \\
\text { compound } \\
\text { courses. }\end{array}$ & $\begin{array}{l}\text { Fol. 11, } \\
\text { no. } 93\end{array}$ \\
\hline & Monsma, Bart & $\begin{array}{l}\text { Ooster- } \\
\text { hout }\end{array}$ & 23 & 8 & Dec. 2 & Feb. 10 & 1 & $\begin{array}{l}\text { Ordinary } \\
\text { seaman } \\
\text { with capt. } \\
\text { O. Mehlen }\end{array}$ & 1 & 5 & $\begin{array}{l}\text { Calculates the } \\
\text { compound } \\
\text { courses. }\end{array}$ & $\begin{array}{l}\text { Fol. } 36 \text {, } \\
\text { no. } 66\end{array}$ \\
\hline & Visser, Klaas & Dokkum & 28 & 18 & Dec. 8 & Feb. 10 & $\begin{array}{l}5 \text { win- } \\
\text { ters }\end{array}$ & $\begin{array}{l}2^{\text {nd }} \text { mate } \\
\text { with capt. } \\
\text { O. Mehlen }\end{array}$ & 6 & 2 & $\begin{array}{l}\text { Is familiar with } \\
\text { the entire art of } \\
\text { Mercator sailing. }\end{array}$ & $\begin{array}{l}\text { Fol. 37, } \\
\text { no. } 71\end{array}$ \\
\hline & $\begin{array}{l}\text { Wiersma, } \\
\text { Nanne }\end{array}$ & Harlingen & 23 & 5 & $\begin{array}{l}\text { Jan. 3, } \\
1857\end{array}$ & Feb. 10 & 1 & $\begin{array}{l}\text { Ordinary } \\
\text { seaman } \\
\text { with capt. } \\
\text { O. Mehlen }\end{array}$ & 7 & 3 & $\begin{array}{l}\text { Calculates the } \\
\text { compound } \\
\text { courses. }\end{array}$ & $\begin{array}{l}\text { Fol. 37, } \\
\text { no. } 97\end{array}$ \\
\hline \multirow[t]{4}{*}{$\begin{array}{l}1857^{-} \\
1858\end{array}$} & Nauta, Evert & Harlingen & 17 & 1 & Nov. 28 & Feb. 6 & 1 & $\begin{array}{l}\text { Ordinary } \\
\text { seaman } \\
\text { with O. } \\
\text { Mehlen } \\
\text { (Dirkje } \\
\text { Adema) }\end{array}$ & 8 & 3 & $\begin{array}{l}\text { Calculates the } \\
\text { plane triangles. }\end{array}$ & $\begin{array}{l}\text { Fol. 10, } \\
\text { no. } 57\end{array}$ \\
\hline & Tigchelaar, H. & Harlingen & 22 & 7 & $\begin{array}{l}\text { Jan. } 1, \\
1858\end{array}$ & Feb. 12 & & $\begin{array}{l}\text { Ordinary } \\
\text { seaman } \\
\text { with O. } \\
\text { Mehlen }\end{array}$ & 6 & 3 & $\begin{array}{l}\text { Calculates the } \\
\text { compound } \\
\text { courses. }\end{array}$ & $\begin{array}{l}\text { Fol. 11, } \\
\text { no. 93 }\end{array}$ \\
\hline & Monsma, B. & $\begin{array}{l}\text { Ooster- } \\
\text { hout }\end{array}$ & 21 & 9 & \begin{tabular}{|l} 
Jan. 11, \\
1858
\end{tabular} & Feb. 12 & 2 & $\begin{array}{l}\text { Ordinary } \\
\text { seaman } \\
\text { with O. } \\
\text { Mehlen }\end{array}$ & 7 & 3 & $\begin{array}{l}\text { Calculates the } \\
\text { compound } \\
\text { courses. }\end{array}$ & $\begin{array}{l}\text { Fol. 11, } \\
\text { no. 105 }\end{array}$ \\
\hline & Cromhout, R.C. & Harlingen & 21 & 2 & $\begin{array}{l}\text { Feb. 13, } \\
1858\end{array}$ & Feb. $18 \mathrm{t}$ & & $\begin{array}{l}\text { Ordinary } \\
\text { seaman } \\
\text { with O. } \\
\text { Mehlen }\end{array}$ & 7 & 3 & $\begin{array}{l}\text { Has not spent } \\
\text { enough time in } \\
\text { school to make } \\
\text { any progress. }\end{array}$ & $\begin{array}{l}\text { Fol. 12, } \\
\text { no. } 116\end{array}$ \\
\hline $\begin{array}{l}1858^{-} \\
1859\end{array}$ & Vries, Joh. de & Makkum & 22 & 6 & Dec. 27 & Feb. 8 & & $\begin{array}{l}\text { Ordinary } \\
\text { seaman } \\
\text { with } \\
\text { Brinkman } \\
\text { (Dirkje } \\
\text { Adema?) }\end{array}$ & 6 & 3 & $\begin{array}{l}\text { Calculates the } \\
\text { plane sailings. }\end{array}$ & $\begin{array}{l}\text { Fol. 15, } \\
\text { no. } 103\end{array}$ \\
\hline
\end{tabular}




\begin{tabular}{|c|c|c|c|c|c|c|c|c|c|c|c|c|}
\hline Year & Name & $\begin{array}{l}\text { Place of } \\
\text { birth }\end{array}$ & Age & $\begin{array}{l}\text { Years } \\
\text { of ex- } \\
\text { peri- } \\
\text { ence }\end{array}$ & $\begin{array}{l}\text { Arrival } \\
\text { at school }\end{array}$ & $\begin{array}{l}\text { Depar- } \\
\text { ture } \\
\text { from } \\
\text { school }\end{array}$ & $\begin{array}{l}\text { Years of } \\
\text { educa- } \\
\text { tion }\end{array}$ & $\begin{array}{l}\text { Voyage/ } \\
\text { rank }\end{array}$ & B & LOU & Progress & Source \\
\hline & Tigchelaar, H. & Harlingen & 23 & 8 & $\begin{array}{l}\text { Jan. 3, } \\
1859\end{array}$ & Feb. 8 & 1 winter & $\begin{array}{l}\text { Ordinary } \\
\text { seaman } \\
\text { with } \\
\text { Brinkman } \\
\text { (Dirkje } \\
\text { Adema?) }\end{array}$ & 6 & 3 & $\begin{array}{l}\text { Calculates the po- } \\
\text { sition at noon by } \\
\text { plane sailing. }\end{array}$ & $\begin{array}{l}\text { Fol. } 16 \text {, } \\
\text { no. } 110\end{array}$ \\
\hline $\begin{array}{l}1859- \\
1860\end{array}$ & Jong, Jan de & Harlingen & 11 & & Nov. 1 & Feb. 7 & & $\begin{array}{l}\text { Boy with } \\
\text { H. Wildts } \\
\text { (Dirkje } \\
\text { Adema) }\end{array}$ & 1 & 3 & $\begin{array}{l}\text { Calculates algebra } \\
\text { and practical } \\
\text { geometry. }\end{array}$ & $\begin{array}{l}\text { Fol. } 17 \text {, } \\
\text { no. } 12\end{array}$ \\
\hline & Bouma, Gaele & Harlingen & 16 & 2 & Nov. 12 & Feb. 9 & $\begin{array}{l}2 \text { win- } \\
\text { ters }\end{array}$ & $\begin{array}{l}\text { Ordinary } \\
\text { seaman } \\
\text { with } \\
\text { Wildts }\end{array}$ & 1 & 3 & $\begin{array}{l}\text { Calculates the } \\
\text { rhumb-line } \\
\text { tracks. }\end{array}$ & $\begin{array}{l}\text { Fol. } 17 \text {, } \\
\text { no. } 31\end{array}$ \\
\hline $\begin{array}{l}1860- \\
1861 \\
\end{array}$ & $\begin{array}{l}\text { No names relat- } \\
\text { ed to whaling }\end{array}$ & & & & & & & & & & & \\
\hline \begin{tabular}{l|}
$1861-$ \\
1862
\end{tabular} & $\begin{array}{l}\text { No names relat- } \\
\text { ed to whaling }\end{array}$ & & & & & & & & & & & \\
\hline \begin{tabular}{l|}
$1862-$ \\
1863
\end{tabular} & $\begin{array}{l}\text { No names relat- } \\
\text { ed to whaling }\end{array}$ & & & & & & & & & & & \\
\hline $\begin{array}{l}1863^{-} \\
1864\end{array}$ & $\begin{array}{l}\text { No names relat- } \\
\text { ed to whaling }\end{array}$ & & & & & & & & & & & \\
\hline
\end{tabular}




\section{Appendix 6 \\ Careers of Whalemen Educated at the Nautical College in Harlingen (1811-1861)}

To obtain insight into the assumed relation between the education the pupils received at the Nautical College in Harlingen and their careers, research was focused on the students who pursued careers in whaling. In the table below they are listed in alphabetical order. The years they spent at the Nautical College in Harlingen are presented in the second column with the total number of years between brackets $[\ldots]$. This number of total years at the college was copied from the data in the registers of students at the Nautical College in Harlingen. The folio numbers refer to this source.

Occasionally these totals do not coincide with the total number they should have. If, for instance, a pupil is listed as having spent the years 1818 to 1821 at the Nautical College, then the number between brackets should read [3] for the total of the seasons spent in school. At the time this list was completed, however, attention was focused solely on the person with the remark that they left school for Greenland whaling. It may well be that the whaleman who, according to the listings, spent the years 1818 through 1821 at school may in fact have spent more seasons at the school but were instead pursuing non-whaling careers. In that case, the total presented in the book was not [3] but was given, as done in the table below, as, for example, [5]. The non-whaling years mentioned were not included. Additional research may show for example that many students who went whaling first tried their luck in shipping to the East Indies, or perhaps in coastal trade with the Baltic.

Where applicable, an overview is given of their careers: the rank they had when they attended their first courses, their age at that time, the rank they reached at the end of their career, and their age when they obtained that highest rank. Finally, an attempt was made to link these students at their highest rank with the ships they sailed on. In this manner, a picture of the career of these 60 or so students can be deduced.

Careers of students at the Nautical College of Harlingen pursuing careers in whaling (1811-1861).

\begin{tabular}{|c|c|c|c|c|c|c|c|c|c|}
\hline Name & $\begin{array}{l}\text { Years in } \\
\text { College }\end{array}$ & First rank & Age & $\begin{array}{l}\text { Highest } \\
\text { Rank }\end{array}$ & Age & Ships & Owners & Years & Sources \\
\hline $\begin{array}{l}\text { Bleijenga, } \\
\text { Jacob }\end{array}$ & $1853-1854$ [1] & $\begin{array}{l}\text { To Greenland } \\
\text { as a cabin boy }\end{array}$ & 19 & $?$ & $?$ & $?$ & $?$ & $?$ & Fol. 28, no. 15 \\
\hline Boer, Hans de & $1850-1856[3]$ & $\begin{array}{l}\text { Ordinary sea- } \\
\text { man (matroos) } \\
\text { to Greenland }\end{array}$ & 16 & $?$ & $?$ & $?$ & $?$ & $?$ & $\begin{array}{l}\text { Fol. 20, no. } \\
\text { 61; Fol. 33, } \\
\text { no. } 39\end{array}$ \\
\hline Both, Jacob & $1847-1849$ [2] & $?$ & 11 & $?$ & $?$ & $?$ & $?$ & $?$ & $\begin{array}{l}\text { Fol. 11, no. } \\
\text { 18; Fol. 13, } \\
\text { no. } 15\end{array}$ \\
\hline Both, Johann ${ }^{14}$ & 1844 [1] & $\begin{array}{l}\text { To Greenland } \\
\text { in unknown } \\
\text { rank after pass- } \\
\text { ing exam as 1st } \\
\text { mate }\end{array}$ & 18 & Skipper & $\begin{array}{l}\mathrm{Ca} . \\
33\end{array}$ & \begin{tabular}{|l|} 
1859, $1860:$ \\
schooner koff \\
Barend (176 \\
tons). $1862-$ \\
$1865:$ schooner \\
koff Harmonie \\
(175 tons). 1866, \\
$1867,1868,1869$, \\
$1870:$ brig Mer- \\
curius ( 271 tons)
\end{tabular} & $\begin{array}{l}\text { Barend Visser } \\
\text { \& Son }\end{array}$ & $\begin{array}{l}1859- \\
1870\end{array}$ & $\begin{array}{l}\text { Fol.5, no. 3; } \\
\text { Sweijs 1859- } \\
1870 \text { [Both, } \\
\text { J.] }\end{array}$ \\
\hline
\end{tabular}

14. Because of his age, it appears that this Johan(n) Both and the Johan Both who became known as master of the whaleship Spitsbergen between 1841-1848 are not the same person. 


\begin{tabular}{|c|c|c|c|c|c|c|c|c|c|}
\hline Name & $\begin{array}{l}\text { Years in } \\
\text { College }\end{array}$ & First rank & Age & $\begin{array}{l}\text { Highest } \\
\text { Rank }\end{array}$ & Age & Ships & Owners & Years & Sources \\
\hline Both, Michiel & $1844-1848$ [4] & $?$ & 15 & $?$ & $?$ & $?$ & $?$ & $?$ & $\begin{array}{l}\text { Fol. } 5 \text {, no. } 6 \text {; } \\
\text { Fol. } 7 \text {, no. } 2 \text {; } \\
\text { Fol. 9, no. } 6 \text {; } \\
\text { Fol. } 12 \text {, no. } 38\end{array}$ \\
\hline Bouma, Gaele & $1859-1860[1]$ & $\begin{array}{l}\text { Ordinary sea- } \\
\text { man with H. } \\
\text { Wildts }\end{array}$ & 16 & ? & $?$ & $?$ & $?$ & $?$ & Fol. 17, no. 31 \\
\hline $\begin{array}{l}\text { Cromhout, } \\
\text { R.C. }\end{array}$ & $1857-1858[1]$ & $\begin{array}{l}\text { Ordinary sea- } \\
\text { man with } \\
\text { O. Mehlen }\end{array}$ & 21 & $?$ & $?$ & $?$ & $?$ & $?$ & $\begin{array}{l}\text { Fol. 12, no. } \\
116\end{array}$ \\
\hline $\begin{array}{l}\text { Dijkstra, } \\
\text { Sybrand }\end{array}$ & $1851-1852[1]$ & $?$ & 19 & $?$ & $?$ & $?$ & $?$ & $?$ & Fol. 23, no. 53 \\
\hline $\begin{array}{l}\text { Drager, } \\
\text { Willem }\end{array}$ & $1855-1856[1]$ & $\begin{array}{l}\text { Ordinary sea- } \\
\text { man to Green- } \\
\text { land }\end{array}$ & 18 & $?$ & $?$ & $?$ & $?$ & $?$ & Fol. 32 , no. 21 \\
\hline $\begin{array}{l}\text { Ebeling, } \\
\text { Hendrikus }\end{array}$ & $1855-1856[1]$ & $\begin{array}{l}\text { Ordinary sea- } \\
\text { man (matroos) } \\
\text { to Greenland }\end{array}$ & 18 & $?$ & $?$ & $?$ & $?$ & $?$ & $\begin{array}{l}\text { Fol. 33, no. } \\
62\end{array}$ \\
\hline $\begin{array}{l}\text { Elst, Johannes } \\
\text { van der }\end{array}$ & $1844-1845[1]$ & $?$ & 20 & $?$ & $?$ & $?$ & $?$ & $?$ & Fol. 6, no. 37 \\
\hline $\begin{array}{l}\text { Grevenstuck, } \\
\text { B. }\end{array}$ & $1844-1845$ [1] & $?$ & 18 & $?$ & $?$ & $?$ & $?$ & $?$ & Fol. 5 , no. 18 \\
\hline $\begin{array}{l}\text { Groot, Klaas } \\
\text { de }\end{array}$ & $1845-1846[1]$ & $?$ & 21 & Skipper & $\begin{array}{l}\text { Ca. } \\
31\end{array}$ & \begin{tabular}{|l|}
$1855-1862:$ \\
schooner koff \\
Drie Gezusters \\
(125 tons). \\
1863, 1865: \\
brig Drie Gezus- \\
ters (ex-Triton; \\
217 tons). $1866-$ \\
1869: brigantine \\
Mercurius (ex- \\
Maria Margare- \\
tha; 118 tons). \\
1871-1873: \\
schooner brig \\
Victoria (153 \\
tons). \\
1871-1876: \\
schooner brig \\
Baudina Elisa- \\
beth (187 tons). \\
Bark Harlingen \\
(ex-James M. \\
Churchill; 339 \\
tons)
\end{tabular} & $\begin{array}{l}\text { H. van Schou- } \\
\text { wenburg (1855- } \\
\text { 1863); J. Noijon } \\
(1865) ; \text { Hubert } \\
\text { Jans \& Co. } \\
\text { (1866-1869; } \\
\text { 1871-1877) }\end{array}$ & $\begin{array}{l}1855^{-} \\
1877\end{array}$ & $\begin{array}{l}\text { Fol. 8, no. 39; } \\
\text { Sweijs 1855- } \\
1877 \text { [Groot, } \\
\text { K. de]; Van } \\
\text { Sluis, } 55\end{array}$ \\
\hline $\begin{array}{l}\text { Haenstra, } \\
\text { U.W. }\end{array}$ & $1849-1850[1]$ & $?$ & 17 & $?$ & $?$ & $?$ & $?$ & $?$ & Fol. 17, no. 57 \\
\hline $\begin{array}{l}\text { Holstein, } \\
\text { Nammele }\end{array}$ & $1845-1846[1]$ & $?$ & 16 & $?$ & $?$ & $?$ & $?$ & $?$ & Fol. 7, 27 \\
\hline Jager, D.W. & $1844-1845$ [1] & $?$ & 18 & $?$ & $?$ & $?$ & $?$ & $?$ & Fol. 5, no. 17 \\
\hline Jong, Jan de & $1859-1860$ & $\begin{array}{l}\text { Boy with } \\
\text { Wildts (Dirkje } \\
\text { Adema) }\end{array}$ & 11 & $?$ & $?$ & $?$ & $?$ & $?$ & Fol. 17 , no. 12 \\
\hline
\end{tabular}




\begin{tabular}{|c|c|c|c|c|c|c|c|c|c|}
\hline Name & $\begin{array}{l}\text { Years in } \\
\text { College }\end{array}$ & First rank & Age & $\begin{array}{l}\text { Highest } \\
\text { Rank }\end{array}$ & Age & Ships & Owners & Years & Sources \\
\hline $\begin{array}{l}\text { Katoen, } \\
\text { Wesselius }\end{array}$ & $1846-1847[1]$ & $?$ & 22 & Skipper & $\begin{array}{l}\mathrm{Ca} . \\
33\end{array}$ & $\begin{array}{l}\text { 1855: koff Gijs- } \\
\text { bert Jan (ex- } \\
\text { Jantina Marga- } \\
\text { retha; } 1856: \\
\text { Trekvogel; } 1857^{-} \\
\text {1858: galliot Re- } \\
\text { milia Geertruida } \\
\text { (115 tons). 1859- } \\
\text { 1866: schooner } \\
\text { koff Remelia } \\
\text { Geertruida (ex- } \\
\text { Goede Verwach- } \\
\text { ting; } 113 \text { tons) }\end{array}$ & $\begin{array}{l}\text { Repko \& Co } \\
\text { (1855); ....(1856); } \\
\text { Hubert Jans \& } \\
\text { Co. (1857-1866) } \\
\end{array}$ & $\begin{array}{l}1857^{-} \\
1866\end{array}$ & $\begin{array}{l}\text { Fol. 10, no. } \\
\text { 38; Sweijs } \\
1857-1866 \\
\text { [W.A. Ka- } \\
\text { toen]; Par- } \\
\text { ma, 21; Van } \\
\text { Sluis, } 19\end{array}$ \\
\hline $\begin{array}{l}\text { Kiestra, } \\
\text { Johannes }\end{array}$ & $1853-1851$ & $?$ & 32 & $?$ & $?$ & $?$ & $?$ & $?$ & Fol. 27, no. 11 \\
\hline $\begin{array}{l}\text { Meer, Pieter } \\
\text { van der }\end{array}$ & $1851-1852[1]$ & $?$ & 16 & $?$ & $?$ & $?$ & $?$ & $?$ & Fol. 23, no. 12 \\
\hline $\begin{array}{l}\text { Meinsma, } \\
\text { Meindert }\end{array}$ & $1855-1857[2]$ & $\begin{array}{l}\text { Boatswain } \\
\text { with capt. } \\
\text { O. Mehlen to } \\
\text { Greenland }\end{array}$ & 23 & Skipper & $\begin{array}{l}\mathrm{Ca} . \\
56\end{array}$ & $\begin{array}{l}\text { 1888-1891: three- } \\
\text { masted schooner } \\
\text { Willem } \\
\text { (ex-Urd, ex-Zel- } \\
\text { denrust;, ex-Bal- } \\
\text { tya Pidde; } 302 \\
\text { tons). -1906: } \\
\text { Zeemansvoor- } \\
\text { zorg }\end{array}$ & captain/owner & $\begin{array}{l}1888- \\
1891\end{array}$ & $\begin{array}{l}\text { Fol. 33, no. } \\
\text { 55; Fol. 36, } \\
\text { no. 62; } \\
\text { Sweijs, 1888- } \\
\text { 1891; } \\
\text { Bouma, 7; } \\
\text { Parma, 29 }\end{array}$ \\
\hline Monsma, B. & $1855-1858[3]$ & $\begin{array}{l}\text { Ordinary sea- } \\
\text { man to Green- } \\
\text { land/ Ordinary } \\
\text { seaman with } \\
\text { O. Mehlen }\end{array}$ & 22 & $?$ & $?$ & $?$ & $?$ & $?$ & $\begin{array}{l}\text { Fol. 33, no. } \\
57 \text { Fol. 36, } \\
\text { no. 66; Fol. } \\
11, \text { no. 105 } \\
\text { Mulder, }\end{array}$ \\
\hline Frans & $1847-1848[1]$ & Idem & 16 & $?$ & $?$ & $?$ & $?$ & $?$ & Fol. 11, no. 13 \\
\hline Nauta, Evert & $1857-1858[1]$ & $\begin{array}{l}\text { Ordinary sea- } \\
\text { man with O. } \\
\text { Mehlen (Dirkje } \\
\text { Adema) }\end{array}$ & 17 & $?$ & $?$ & $?$ & $?$ & ? & Fol. 10, no. 57 \\
\hline $\begin{array}{l}\text { Ouwenbroek, } \\
\text { A. }\end{array}$ & $1851-1852[1]$ & Idem & 22 & $?$ & $?$ & $?$ & $?$ & $?$ & Fol. 22, no. 21 \\
\hline Ploeg, Jacob & $1847-1848[1]$ & Idem & 29 & Skipper? & $\begin{array}{l}\mathrm{Ca} . \\
32\end{array}$ & $\begin{array}{l}\text { 1850-1859: smak } \\
\text { Vertrouwen (30 } \\
\text { tons); -1867: } \\
\text { Zeemansvoor- } \\
\text { zorg }\end{array}$ & captain/owner & $\begin{array}{l}1850- \\
1859\end{array}$ & $\begin{array}{l}\text { Fol. 11, no. } \\
\text { 27; Sweijs, } \\
\text { 1855-1859 [Ja- } \\
\text { cob G. } \\
\text { Ploeg]; } \\
\text { Bouma, 8; } \\
\text { Parma, } 36\end{array}$ \\
\hline Pronker, Mink & $1855-1856[1]$ & idem & 23 & $?$ & $?$ & $?$ & $?$ & $?$ & Fol. 33, no. 10 \\
\hline $\begin{array}{l}\text { Rooswinkel, } \\
\text { Hendrik }\end{array}$ & $1855-1857$ [2] & $\begin{array}{l}\text { Boy to Green- } \\
\text { land }\end{array}$ & $16-17$ & $?$ & $?$ & $?$ & $?$ & $?$ & $\begin{array}{l}\text { Fol. 32, no. } \\
33 ; \text { Fol. 36, } \\
\text { no. } 58\end{array}$ \\
\hline $\begin{array}{l}\text { Slooten, T.H. } \\
\text { van }\end{array}$ & $1848-1851[3]$ & $\begin{array}{l}\text { Greenland } \\
\text { fishery }\end{array}$ & $15-17$ & Skipper & $\begin{array}{l}\mathrm{Ca} . \\
26\end{array}$ & \begin{tabular}{|l|} 
1859-1875: \\
schooner Cas- \\
par de Robles \\
$(162$ tons $) .1878-$ \\
1881 : bark Cas- \\
par de Robles \\
(ex-Maria Hele- \\
na; 310 tons)
\end{tabular} & $\begin{array}{l}\text { Zeilmaker \& Co } \\
(1859-1875) \text {; Jan } \\
\text { Fontein (1878- } \\
1881) \\
\end{array}$ & $\begin{array}{l}1859- \\
1881\end{array}$ & $\begin{array}{l}\text { Fol. 13, no. 7; } \\
\text { Fol. 17, no. } \\
\text { 56; Fol. 20, } \\
\text { no. 19; Swei- } \\
\text { js, 1859-1881; } \\
\text { Bouma, 9; } \\
\text { Parma, 12 }\end{array}$ \\
\hline
\end{tabular}




\begin{tabular}{|c|c|c|c|c|c|c|c|c|c|}
\hline Name & $\begin{array}{l}\text { Years in } \\
\text { College }\end{array}$ & First rank & Age & $\begin{array}{l}\text { Highest } \\
\text { Rank }\end{array}$ & Age & Ships & Owners & Years & Sources \\
\hline $\begin{array}{l}\text { Smeden, } \\
\text { B[au] ke van }\end{array}$ & $1849-1850[1]$ & Idem & 15 & Skipper & $\begin{array}{l}\mathrm{Ca} . \\
38\end{array}$ & $\begin{array}{l}\text { 1873: three- } \\
\text { masted } \\
\text { schooner Jo } \\
\text { hanna Elisabeth } \\
\text { (ex-Lotus; } 173 \\
\text { tons). 1878- } \\
\text { 1886: three- } \\
\text { masted bark } \\
\text { Friesland }\end{array}$ & $\begin{array}{l}\text { J. van 't Vliet } \\
(1873) \text {; Canne } \\
\text { \& Balwé (Ams- } \\
\text { ter } \\
\text { dam, 1878-1886) }\end{array}$ & $\begin{array}{l}1873^{-} \\
1886\end{array}$ & $\begin{array}{l}\text { Fol. 18, no. } \\
78 ; \\
\text { Sweijs, } \\
\text { 1873; Bouma, } \\
\text { 10; Parma, } 12\end{array}$ \\
\hline Steeksma, Syb & $1846-1847$ [1] & Idem & 22 & $?$ & $?$ & $?$ & $?$ & $?$ & $\begin{array}{l}\text { Fol. 10, no. } \\
60\end{array}$ \\
\hline $\begin{array}{l}\text { Stenbeker }[\mathrm{sic}], \\
\text { Hendrik }\end{array}$ & $1855-1857[2]$ & $\begin{array}{l}\text { Mate to Green- } \\
\text { land/ with capt. } \\
\text { O. Mehlen }\end{array}$ & $\begin{array}{l}35^{-} \\
36\end{array}$ & $?$ & $?$ & $?$ & $?$ & $?$ & $\begin{array}{l}\text { Fol. } 33 \text {, no. } \\
\text { 58; Fol. } 36 \text {, } \\
\text { no. } 61\end{array}$ \\
\hline $\begin{array}{l}\text { Stuur, } \\
\text { Hendrik?? }\end{array}$ & $1846-1847$ [1] & Idem & 19 & $?$ & $?$ & $?$ & $?$ & $?$ & Fol. 9, no. 2 \\
\hline $\begin{array}{l}\text { Tigchelaar, } \\
\text { E.C. }\end{array}$ & $1850[1]$ & Idem & 15 & $?$ & $?$ & $?$ & $?$ & $?$ & Fol. 20, no. 51 \\
\hline Tigchelaar, H. & $1857-1859[2]$ & $\begin{array}{l}\text { Ordinary sea- } \\
\text { man with Brink- } \\
\text { man (Dirkje } \\
\text { Adema?) }\end{array}$ & $\begin{array}{l}22- \\
23\end{array}$ & $?$ & $?$ & $?$ & $?$ & $?$ & $\begin{array}{l}\text { Fol. 11, no. } \\
\text { 93; Fol. 16, } \\
\text { no. } 110\end{array}$ \\
\hline $\begin{array}{l}\text { Tigchelaar, } \\
\text { Jelmer }\end{array}$ & $1844-1845$ [2] & Idem & 16 & $?$ & $?$ & $?$ & $?$ & $?$ & Fol. 5 , no. 15 \\
\hline $\begin{array}{l}\text { Vellinga, Jan } \\
\text { Jans }\end{array}$ & $1851-1852[1]$ & Idem & 16 & $?$ & $?$ & $?$ & $?$ & $?$ & $\begin{array}{l}\text { Fol. 22, no. } \\
30\end{array}$ \\
\hline $\begin{array}{l}\text { Visser, Klaas } \\
\text { [= Klaas R. } \\
\text { Visser?] }\end{array}$ & $1855-1857[5]$ & $\begin{array}{l}2^{\text {nd }} \text { mate Dirkje } \\
\text { Adema to } \\
\text { Greenland } \\
\text { (both voyages) }\end{array}$ & $\begin{array}{l}27- \\
28\end{array}$ & $?$ & $?$ & $?$ & $?$ & $?$ & $\begin{array}{l}\text { Fol. } 32 \text {, no. } 3 \text {; } \\
\text { Fol. } 37 \text {, no. } 71\end{array}$ \\
\hline Vries, Jan de & $1855-1856[1]$ & $\begin{array}{l}\text { Ordinary sea- } \\
\text { man to Green- } \\
\text { land }\end{array}$ & 17 & $?$ & $?$ & $?$ & $?$ & $?$ & Fol. 33, no. 61 \\
\hline $\begin{array}{l}\text { Vries, Jan G. } \\
\text { de }\end{array}$ & $1845-1846$ [1] & Idem & 16 & $?$ & $?$ & $?$ & $?$ & $?$ & Fol. 7, no. 15 \\
\hline Vries, Jan S. de & $1846-1847$ [?] & Idem & 16 & $?$ & $?$ & $?$ & $?$ & $?$ & $\begin{array}{l}\text { Fol. 10, no. } \\
58\end{array}$ \\
\hline Vries, Joh. de & $1858-1859$ [?] & $\begin{array}{l}\text { Ordinary sea- } \\
\text { man with } \\
\text { Brinkman } \\
\text { (Dirkje Ade- } \\
\text { ma?) }\end{array}$ & 22 & $?$ & $?$ & $?$ & $?$ & $?$ & $\begin{array}{l}\text { Fol. 15, } \\
\text { no.103 }\end{array}$ \\
\hline Vries, Klaas de & 1844-1845 [?] & Idem & 19 & $?$ & $?$ & $?$ & $?$ & $?$ & Fol. 6, no. 17 \\
\hline $\begin{array}{l}\text { Wagenaar, Jan } \\
\text { E. }\end{array}$ & $1844-1845$ [2] & Idem & 20 & $?$ & $?$ & $?$ & $?$ & $?$ & $\begin{array}{l}\text { Fol. 6, no. } 39 \\
\text { Wagenaar, }\end{array}$ \\
\hline Petrus & $1845-1846$ [?] & Idem & 20 & $?$ & $?$ & $?$ & $?$ & $?$ & $\begin{array}{l}\text { Fol. } 8, \text { no. } 53 \\
\text { Werf, Poppe }\end{array}$ \\
\hline W. v.d. & $1846-1847$ [3] & Idem & 19 & $?$ & $?$ & $?$ & $?$ & $?$ & $\begin{array}{l}\text { Fol. 10, no. } \\
50\end{array}$ \\
\hline $\begin{array}{l}\text { Wielen Miede- } \\
\text { ma, S. v.d. }\end{array}$ & $1818-1819[1]$ & Idem & 17 & $?$ & $?$ & $?$ & $?$ & $?$ & $\begin{array}{l}\text { Fol. 11, no. } 59 \\
\text { Wiersma, }\end{array}$ \\
\hline Nanne & $1855-1857[1]$ & $\begin{array}{l}\text { Ordinary sea- } \\
\text { man to Green- } \\
\text { land/ with capt. } \\
\text { O. Mehlen }\end{array}$ & $\begin{array}{l}22- \\
23\end{array}$ & $?$ & $?$ & $?$ & $?$ & $?$ & $\begin{array}{l}\text { Fol. 33, no. } \\
78 ; \text { Fol. } 37 \\
\text { no. } 97\end{array}$ \\
\hline
\end{tabular}




\begin{tabular}{|l|l|l|l|l|l|l|l|l|l|}
\hline Name & $\begin{array}{l}\text { Years in } \\
\text { College }\end{array}$ & First rank & Age & $\begin{array}{l}\text { Highest } \\
\text { Rank }\end{array}$ & Age & Ships & Owners & Years & Sources \\
\hline $\begin{array}{l}\text { Wildst, } \\
\text { Hendrik }\end{array}$ & $\begin{array}{l}1842-1847 \\
{[4-5]}\end{array}$ & - & $39-13$ & Skipper & $\begin{array}{l}\text { Ca. } \\
56\end{array}$ & $\begin{array}{l}1859-1863: \\
\text { three-masted } \\
\text { frigate Dirkje } \\
\text { Adema (319 } \\
\text { tons })\end{array}$ & $\begin{array}{l}\text { Barend Visser \& } \\
\text { Son (1859-1863) }\end{array}$ & $\begin{array}{l}1859- \\
1863\end{array}$ & $\begin{array}{l}\text { Fol. 1, no. 11; } \\
\text { Fol. 3, no. 9; } \\
\text { Fol. 5, no. } 1 ; \\
\text { Fol. } 8, \text { no. 36; } \\
\text { Fol. 9, no. 31 }\end{array}$ \\
\hline $\begin{array}{l}\text { Zwanenburg, } \\
\text { Jan }\end{array}$ & $1848-1849[?]$ & Idem & 18 & $?$ & $?$ & $?$ & $?$ & Fol. 15, no. 72 \\
\hline
\end{tabular}

Sources: The folio numbers refer to the archival record of the School voor Wis- en Zeevaartkunde te Harlingen. SWZV1, no. 617: Register van de leerlingen der school, 1812-1910; Sweijs, 1855-1891; G.N. Bouma, Lijst van Harlinger koopvaardijkapiteins (unpublished manuscript. Haren 1997); S. Parma, Harlinger koopvaardijkapiteins en Harlinger reders uit de tweede helft van de negentiende eeuw (Hilversum 1999); J. van Sluis, Nederlandsche kapiteins ter koopvaardij 1800-1900 (unpublished manuscript. N.p., n.d. [1935-1955]).

Insight into the careers of these sailors is limited in two ways. Sources were used that provide information about those men who became captains of their ships. These sources do not, however, provide data concerning the lower ranks. In other words, many of the men listed above may have reached the fairly high rank of second or first mate on board a merchant vessel. Moreover, these sources relate to the merchant marine only. They do not reflect any developments regarding the Royal Netherlands Navy.

15. In the listings in the registers of the College records that refer to 1845-1846 and 1846-1847, respectively, Hendrik Wildst was listed as having spent 4 winters at the College. Assuming that the directors or their clerks made a mistake, it is presented here as 4 to 5 winters. 
Appendix 7

\section{Results of Auctions of Whale and Seal Products (1831-1838) (in $f$ )}

1831 (Source: Tresoar Leeuwarden, Notary archives, 19021 (repertoires), \# 283). Note: listed are the major players in the aution room. Totals given are as represented in the sources. They are not commensurate with the sum of the figures listed here.

\begin{tabular}{|c|c|c|c|}
\hline Barrels of seal oil & Buyer & Place of residence & Amount (in guilders) \\
\hline 9 & Cornelder en Zahn & Amsterdam & 720 \\
\hline 10 & Van Spreekens & Amsterdam & 830 \\
\hline 10 & idem & idem & 810 \\
\hline 10 & idem & idem & 870 \\
\hline 10 & Jan Fontein & Harlingen & 870 \\
\hline 10 & Bouwe Rodenhuis & Harlingen & 880 \\
\hline 10 & Cornelder en Zahn & Amsterdam & 880 \\
\hline 10 & Bouwe Rodenhuis & Harlingen & 890 \\
\hline 10 & Simon Stinstra & Harlingen & 885 \\
\hline 10 & Barend Visser \& Zoon & Harlingen & 920 \\
\hline 10 & Pieter Altema & Amsterdam & 920 \\
\hline 10 & Barend van Spreekens & Amsterdam & 930 \\
\hline 10 & Idem & idem & 950 \\
\hline 10 & Dijkman & Amsterdam & 950 \\
\hline 10 & Barend van Spreekens & idem & 965 \\
\hline 10 & Idem & idem & 975 \\
\hline 10 & Fontein en Roquette & Harlingen & 970 \\
\hline 10 & Idem & idem & 970 \\
\hline 10 & Idem & idem & 975 \\
\hline 1 & Sybrand Tjallinga & idem & 396 \\
\hline 10 & Barend van Spreekens & Amsterdam & 990 \\
\hline 10 & Idem & idem & 995 \\
\hline 10 & Cornelder en Zahn & Amsterdam & 995 \\
\hline 1 & Jan Fontein & Harlingen & 100 \\
\hline \multicolumn{4}{|l|}{227} \\
\hline Seal fur & Buyer & Place of residence & Amount (in guilders) \\
\hline 39 & Jan IJzenbeek & Harlingen & 31.20 \\
\hline 150 & Catz en Compagnie & Amsterdam & 86.25 \\
\hline 39 & Ankersmit & Amsterdam & 35.10 \\
\hline 36 & Catz en Compagnie & Amsterdam & 30.60 \\
\hline 69 & Hoekstra & Harlingen & 69.00 \\
\hline 10 & Catz en Compagnie & Amsterdam & 36.00 \\
\hline 70 & Idem & idem & 56.00 \\
\hline 12 & Idem & idem & 18.30 \\
\hline 39 & Idem & idem & 39.00 \\
\hline 37 & Idem & idem & 38.85 \\
\hline 110 & Idem & idem & 81.00 \\
\hline 17 & Idem & idem & 50.50 \\
\hline 38 & Idem & idem & 39.90 \\
\hline 68 & Idem & idem & 10.80 \\
\hline 10 & Dijkman & Amsterdam & 11.00 \\
\hline 11 & Catz en Compagnie & Amsterdam & 15.10 \\
\hline 39 & idem & idem & 12.90 \\
\hline 10 & Dijkman & Amsterdam & 13.00 \\
\hline 10 & Catz en Compagnie & Amsterdam & 12.00 \\
\hline 17 & Ankersmit & Amsterdam & 51.70 \\
\hline 37 & Catz en Compagnie & Amsterdam & 10.70 \\
\hline
\end{tabular}




\begin{tabular}{|c|c|c|c|}
\hline 38 & Ankersmit & Amsterdam & 11.80 \\
\hline 10 & Catz en Compagnie & Amsterdam & 16.00 \\
\hline 37 & Ankersmit & Amsterdam & 10.70 \\
\hline 37 & Catz en Compagnie & Amsterdam & 11.10 \\
\hline 150 & idem & idem & 112.50 \\
\hline 36 & Ankersmit & Amsterdam & 11.10 \\
\hline 152 & Catz en Compagnie & Amsterdam & 121.60 \\
\hline 85 & Dijkman & Amsterdam & 89.25 \\
\hline 150 & Catz en Compagnie & Amsterdam & 120.00 \\
\hline 150 & Fontein en Roquette & Harlingen & $121.87^{1 / 2}$ \\
\hline 151 & Dijkman & Amsterdam & 119.35 \\
\hline 150 & idem & idem & $111.37^{1 / 2}$ \\
\hline 150 & Catz en Compagnie & Amsterdam & 120.00 \\
\hline 150 & Barend Visser \& Zoon & Harlingen & $111.37^{1 / 2}$ \\
\hline 150 & Catz en Compagnie & Amsterdam & 127.50 \\
\hline 150 & idem & idem & 120.00 \\
\hline 150 & idem & idem & 116.25 \\
\hline 156 & Barend Visser \& Zoon & Harlingen & 117.00 \\
\hline 160 & idem & idem & 128.00 \\
\hline 150 & Catz en Compagnie & Amsterdam & $111.37^{1 / 2}$ \\
\hline 153 & idem & idem & 122.10 \\
\hline 111 & Moses Wolff & Harlingen & 115.20 \\
\hline 113 & Catz en Compagnie & Amsterdam & 71.50 \\
\hline 135 & idem & idem & 71.25 \\
\hline 18 & Ankersmit & Amsterdam & 26.10 \\
\hline 100 & Catz en Compagnie & Amsterdam & 77.50 \\
\hline 18 & idem & idem & 35.10 \\
\hline 103 & idem & idem & 82.10 \\
\hline 105 & idem & idem & $81.37^{1 / 2}$ \\
\hline 105 & idem & idem & 81.00 \\
\hline 100 & Dijkman & Amsterdam & 77.50 \\
\hline 71 & Catz en Compagnie & Amsterdam & 19.70 \\
\hline 170 & idem & idem & 85.00 \\
\hline 87 & idem & idem & 69.60 \\
\hline 130 & Dijkman & Amsterdam & 101.00 \\
\hline 9 polar bear furs & Cornelder en Zahn & Amsterdam & 23.10 \\
\hline 3 idem & Ankersmit & Amsterdam & 16.20 \\
\hline 1 idem & Altena & & 20.00 \\
\hline Barrels of whale oil & Buyer & Place of residence & Amount (in guilders) \\
\hline 10 & Bouwe Rodenhuis & Harlingen & 1020 \\
\hline 10 & Barend van Spreekens & Amsterdam & 1020 \\
\hline 10 & Bouwe Rodenhuis & Harlingen & 1070 \\
\hline 10 & Altena & & 1100 \\
\hline 10 & Barend van Spreekens & Amsterdam & 1110 \\
\hline 10 & idem & idem & 1160 \\
\hline 10 & idem & idem & 1180 \\
\hline 10 & Barend Visser \& Zoon & Harlingen & 1200 \\
\hline 10 & Barend van Spreekens & Amsterdam & 1202.50 \\
\hline 10 & idem & idem & 1212.50 \\
\hline 10 & Idem & idem & 1212.50 \\
\hline 10 & Cornelder en Zahn & Amsterdam & 1250 \\
\hline 10 & Catz en Compagnie & Amsterdam & 1250 \\
\hline 10 & idem & idem & 1250 \\
\hline 10 & Barend van Spreekens & Amsterdam & 1252.50 \\
\hline 10 & Dijkman & Amsterdam & 1250 \\
\hline 10 & Barend Visser \& Zoon & Harlingen & 1212.50 \\
\hline 10 & idem & idem & 1270 \\
\hline
\end{tabular}




\begin{tabular}{|c|c|c|c|}
\hline 9 & Barend van Spreekens & Amsterdam & 1151.25 \\
\hline 7 barrels tails & Gerhardus Telsemeyer & Harlingen & 57.75 \\
\hline 10 barrels vinken & idem & idem & 13 \\
\hline 10 barrels vinken & idem & idem & 50 \\
\hline 3 barrels of 'scheptraan' & Altena & & 161 \\
\hline Pounds of baleen & Buyer & Place of residence & Amount (in guilders) \\
\hline 91 & Cornelder en Zahn & Amsterdam & 230.30 \\
\hline 90 & Dijkman & Amsterdam & 231.00 \\
\hline 91 & Fontein en Roquette & Harlingen & 232.05 \\
\hline 95 & Cornelder en Zahn & Amsterdam & $239.87^{1 / 2}$ \\
\hline 81 & Nyburg & Amsterdam & 212.15 \\
\hline 92 & idem & idem & 231.60 \\
\hline 89 & idem & idem & 226.95 \\
\hline 92 & idem & idem & 231.15 \\
\hline 95 & Barend van Spreekens & Amsterdam & $239.87^{1 / 2}$ \\
\hline 87 & Nyburg & Amsterdam & 221.85 \\
\hline 97 & Dijkman & Amsterdam & 212.50 \\
\hline 87 & Cornelder en Zahn & Amsterdam & 218.58 \\
\hline 92 & Barend van Spreekens & Amsterdam & 235.75 \\
\hline 87 & Nyburg & Amsterdam & 219.30 \\
\hline 90 & Cornelder en Zahn & Amsterdam & $227.12^{1 / 2}$ \\
\hline 87 & idem & idem & 218.60 \\
\hline 85 & Barend van Spreekens & Amsterdam & $211.62^{1 / 2}$ \\
\hline 93 & Cornelder en Zahn & Amsterdam & 237.15 \\
\hline 76 pieces of dried seal fur & Catz en Compagnie & Amsterdam & 83.60 \\
\hline 111 pieces of dried seal fur & idem & idem & 85.50 \\
\hline
\end{tabular}

Total result of sales: $\mathbf{5 2 , 2 1 1 . 2 0 1 / 2}$.

Payment to notaries: $1 \frac{2}{2} \%$ rechten (rights) (261.10) + opcenten (extra premium). Total: 352.19 .

1832 (Source: Tresoar Leeuwarden, Notary archives, 19025 (repertoires), \# 253)

\begin{tabular}{|c|c|c|c|}
\hline Barrels of whale oil & Buyer & Place of business & Amount (in guilders) \\
\hline 6 & Bouwe Rodenhuis & Harlingen & 516.00 \\
\hline 6 & Bouwe Rodenhuis & idem & 516.00 \\
\hline 6 & Barend Visser \& Zoon & idem & 528.00 \\
\hline 6 & Bouwe Rodenhuis & idem & 516.00 \\
\hline 6 & Barend Visser \& Zoon & idem & 552.00 \\
\hline 6 & Bernardus Leemkoel & idem & 558.00 \\
\hline 6 & Jan IJzenbeek & idem & 552.00 \\
\hline 6 & Bouwe Rodenhuis & idem & 558.00 \\
\hline 6 & Gerhard Telsemeijer & Amsterdam & 516.00 \\
\hline 6 & Bouwe Rodenhuis & Harlingen & 558.00 \\
\hline 6 & Barend Visser \& Zoon & idem & 552.00 \\
\hline 6 & Jan IJzenbeek & idem & 510.00 \\
\hline 6 & Jan IJzenbeek & idem & 510.00 \\
\hline 6 & Bouwe Rodenhuis & idem & 516.00 \\
\hline 6 & Bouwe Rodenhuis & idem & 531.00 \\
\hline 6 & Jan IJzenbeek & idem & 522.00 \\
\hline 6 & Bouwe Rodenhuis & idem & 510.00 \\
\hline 6 & Bouwe Rodenhuis & idem & 531.00 \\
\hline 6 & Freerk Fontein Janszoon & idem & 528.00 \\
\hline 6 & Beijer en Hompe & Amsterdam & 528.00 \\
\hline 3 & Bernardus Leemkoel & Harlingen & 273.00 \\
\hline 6 & Simon Stinstra & idem & 516.00 \\
\hline 6 & Simon Stinstra & idem & 510.00 \\
\hline
\end{tabular}




\begin{tabular}{|c|c|c|c|}
\hline 6 & Bouwe Rodenhuis & idem & 558.00 \\
\hline 1 & Simon Stinstra & idem & 360.00 \\
\hline 1 & Jan Calckenier & idem & 356.00 \\
\hline \multicolumn{4}{|l|}{119} \\
\hline Barrels of seal oil & Buyer & Place of business & Amount (in guilders) \\
\hline 6 & Fontein & Harlingen & 198.00 \\
\hline 6 & Barend Visser \& Zoon & idem & 186.00 \\
\hline 6 & Bernardus Leemkoel & idem & 186.00 \\
\hline 6 & Pieter Altena & Amsterdam & 180.00 \\
\hline 6 & Fontein & Harlingen & 192.00 \\
\hline 6 & Sipke van Slooten & idem & 180.00 \\
\hline 6 & Albert Bolman & idem & 168.00 \\
\hline 6 & Barend Visser \& Zoon & idem & 186.00 \\
\hline 6 & Bernardus Leemkoel & idem & 186.00 \\
\hline 6 & Cornelder en Zahn & Amsterdam & 180.00 \\
\hline 6 & Fontein & Harlingen & 192.00 \\
\hline 6 & Bernardus Leemkoel & idem & 180.00 \\
\hline 6 & Fontein & idem & 180.00 \\
\hline 6 & Barend Visser \& Zoon & idem & 186.00 \\
\hline 6 & Altena & Amsterdam & 180.00 \\
\hline 6 & Bernardus Leemkoel & Harlingen & 180.00 \\
\hline 6 & Fontein & idem & 180.00 \\
\hline 6 & Barend Visser \& Zoon & idem & 180.00 \\
\hline 3 & Bernardus Leemkoel & idem & 231.00 \\
\hline \multicolumn{4}{|l|}{131} \\
\hline Barrels of vinken and tails & Buyer & Place of business & Amount (in guilders) \\
\hline \multicolumn{4}{|l|}{10 vinken/1 barrel of 'lijm- } \\
\hline $\begin{array}{l}\text { water' }(=\text { walschot=sperma- } \\
\text { ceti??) }\end{array}$ & Jacob Tjibbes de Jong & Terschelling & 102.00 \\
\hline 2 tails & Hermanus Ouendag & Harlingen & 18.00 \\
\hline 3 vinken & Hermanus Ouendag & idem & 12.00 \\
\hline 1 tails & Jacob Tjibbes de Jong & Terschelling & 7.00 \\
\hline \multicolumn{4}{|l|}{13 vinken/3 tails/1 lijmwater } \\
\hline Seal fur & Buyer & Place of business & Amount (in guilders) \\
\hline 162 & Bouwe Rodenhuis & Harlingen & 67.00 \\
\hline 151 & Jacob Tjibbes de Jong & Terschelling & 65.50 \\
\hline 170 & Bouwe Rodenhuis & Harlingen & 71.50 \\
\hline 183 & Bouwe Rodenhuis & Harlingen & 78.00 \\
\hline 166 & Gerardus Telsemeijer & Amsterdam & 71.75 \\
\hline 133 & Bouwe Rodenhuis & Harlingen & 56.75 \\
\hline 115 & Ankersmit & Amsterdam & 58.00 \\
\hline 118 & Bernardus Leemkoel & Harlingen & 59.25 \\
\hline 110 & Wytse Westra & idem & 63.00 \\
\hline 136 & Ankersmit & Amsterdam & 51.50 \\
\hline 176 & Bernardus Leemkoel & Harlingen & 71.00 \\
\hline 132 & Hermanus Ouendag & idem & 53.00 \\
\hline 131 & Cornelis Piers Draaisma & idem & 52.50 \\
\hline 130 & Ankersmit & Amsterdam & 32.50 \\
\hline 136 & Ankersmit & idem & 11.00 \\
\hline 150 & Ankersmit & idem & 52.50 \\
\hline 126 & Bermardus Leemkoel & Harlingen & 11.25 \\
\hline 128 & Ankersmit & Amsterdam & 18.00 \\
\hline 118 & Ankersmit & idem & 55.50 \\
\hline
\end{tabular}


Appendices

\begin{tabular}{llll}
193 & Hermanus Ouendag & Harlingen & 67.75 \\
136 & Wytse Westra & idem & 51.50 \\
10 & Jacob Tjibbes de Jong & Terschelling & 26.00 \\
11 & Bouwe Rodenhuis & Harlingen & 28.75 \\
53 & Bouwe Rodenhuis & idem & 39.75 \\
87 & Jacob Tjibbes de Jong & Terschelling & 78.50 \\
56 & Bouwe Rodenhuis & Harlingen & 39.25 \\
10 & Ankersmit & Amsterdam & 26.00 \\
95 & Ankersmit & idem & \\
25 & Bouwe Rodenhuis & Harlingen & 11.25 \\
1 bear furs & Jacob Tjibbes de Jong & Terschelling & 20.00 \\
& & & \\
Pounds of baleen & Buyer & Place of business & Amount in guilders \\
\hline 106 & Pieter Altena & Amsterdam & 260.00 \\
101 & Cornelder en Zahn & idem & 211.50 \\
101 & Albert Bolman & Harlingen & 260.00 \\
101 & Cornelder en Zahn & Amsterdam & 260.00 \\
101 & Fontein en Tjallingii & Harlingen & 260.00 \\
101 & Cornelder en Zahn & Amsterdam & 219.75 \\
101 & Cornelder en Zahn & idem & 219.75 \\
35 & Cornelder en Zahn & idem & 81.00 \\
35 & Cornelder en Zahn & idem & 77.00 \\
\hline 800 & & & \\
\hline
\end{tabular}

Total result of sales: $f 25,975.25$.

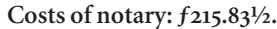

1833 (Source: Tresoar Leeuwarden, Notary archives, 19026 (repertoires), \# 281)

\begin{tabular}{|c|c|c|c|}
\hline Barrels of whale oil & Buyer & Place of business & Amount (in guilders) \\
\hline 6 & Ids and Simon Wiarda & Harlingen & 108.00 \\
\hline 6 & Dirk Cornelis Zijlstra & idem & 108.00 \\
\hline 6 & Dirk Cornelis Zijlstra & idem & 108.00 \\
\hline 6 & Dirk Cornelis Zijlstra & idem & 108.00 \\
\hline 6 & Dirk Cornelis Zijlstra & idem & 102.00 \\
\hline 6 & Simon Stinstra & idem & 111.00 \\
\hline 6 & Dirk Cornelis Zijlstra & idem & 396.00 \\
\hline 6 & Simon Stinstra & idem & 111.00 \\
\hline 6 & Ids and Simon Wiarda & idem & 102.00 \\
\hline 6 & Dirk Cornelis Zijlstra & idem & 390.00 \\
\hline 6 & Bouwe Rodenhuis & idem & 396.00 \\
\hline 6 & Dirk Cornelis Zijlstra & idem & 102.00 \\
\hline 6 & Bouwe Rodenhuis & idem & 396.00 \\
\hline 6 & Freerk Fontein Janszoon & idem & 111.00 \\
\hline 6 & Dirk Cornelis Zijlstra & idem & 108.00 \\
\hline 6 & Freerk Fontein janszoon & idem & 108.00 \\
\hline 6 & Jan IJzenbeek & idem & 108.00 \\
\hline 6 & Bouwe Rodenhuis & idem & 111.00 \\
\hline 6 & Dirk Cornelis Zijlstra & idem & 108.00 \\
\hline 6 & Simon Stinstra & idem & 108.00 \\
\hline 6 & Bouwe Rodenhuis & idem & 120.00 \\
\hline 1 & Bouwe Rodenhuis & idem & 276.00 \\
\hline 2 & Bernardus Leemkoel & idem & 207.75 \\
\hline 6 & Cornelder en Zahn & Amsterdam & 111.00 \\
\hline 6 & Cornelder en Zahn & idem & 120.00 \\
\hline 6 & Dirk Cornelis Zijlstra & Harlingen & 120.00 \\
\hline
\end{tabular}




\begin{tabular}{|c|c|c|c|}
\hline 6 & Cornelder en Zahn & Amsterdam & 111.00 \\
\hline 1 & Fontein en Tjallingii & Harlingen & 277.00 \\
\hline 1 & Jan IJzenbeek & idem & 276.00 \\
\hline $\begin{array}{l}161 \\
2 \text { barrels of baliespruit/ } \\
\text { baliesprut??? }\end{array}$ & Zacharias Vellekoper & idem & 11.00 \\
\hline Pounds of baleen & Buyer & Place of business & Amount (in guilders) \\
\hline 100 & Dirk Cornelis Zijlstra & Harlingen & 200.00 \\
\hline 100 & Albert Bolman & idem & 200.00 \\
\hline 100 & Dirk Cornelis Zijlstra & idem & 195.00 \\
\hline 100 & Cornelder en Zahn & Amsterdam & 190.00 \\
\hline 100 & Cornelder en Zahn & idem & 200.00 \\
\hline 100 & Dirk Cornelis Zijlstra & Harlingen & 200.00 \\
\hline 100 & Dirk Cornelis Zijlstra & idem & 195.00 \\
\hline 100 & Nijburg & Amsterdam & 195.00 \\
\hline 100 & Cornelder en Zahn & idem & 190.00 \\
\hline 100 & Dirk Cornelis Zijlstra & Harlingen & 200.00 \\
\hline 100 & Nijburg & Amsterdam & 200.00 \\
\hline 70 & Nijburg & idem & 133.00 \\
\hline 11 & Nijburg & idem & 77.90 \\
\hline 11 & Nijburg & idem & 75.85 \\
\hline \multicolumn{4}{|l|}{1252} \\
\hline Seal fur & Buyer & Place of business & Amount (in guilders) \\
\hline 137 & Cornelder en Zahn & Amsterdam & 82.20 \\
\hline 11 & Bouwe Rodenhuis & Harlingen & 17.50 \\
\hline 90 & Cornelder en Zahn & Amsterdam & 58.50 \\
\hline 90 & Jarig Mollema & Harlingen & 58.50 \\
\hline 76 & Cornelder en Zahn & Amsterdam & 60.80 \\
\hline \multicolumn{4}{|l|}{107} \\
\hline 1 dried polar bearfur & Hendrik Vervoort & Harlingen & 8.00 \\
\hline 1 dried polar bearfur & Jan Valckenier & Amsterdam & 9.25 \\
\hline 1 dried polar bearfur & Hendrik Vervoort & Harlingen & 3.10 \\
\hline 2 polar bear furs & Hermanus Ouendag & Idem & 12.50 \\
\hline 1 polar bearfur & Hermanus Ouendag & Idem & 6.50 \\
\hline \multicolumn{4}{|l|}{6 polar bear furs } \\
\hline Barrels of vinken and tails & Buyer & Place of business & Amount (in guilders) \\
\hline 5 vinken & Gerardus Telsemeijer & Harlingen & 30.00 \\
\hline 1 vinken & Gerardus Telsemeijer & Idem & 38.00 \\
\hline 2 vinken & Cornelder en Zahn & Amsterdam & 9.00 \\
\hline \multicolumn{4}{|l|}{11} \\
\hline 1 tails & Gerardus Telsemeijer & Harlingen & 29.00 \\
\hline 1 tails & Cornelder en Zahn & Amsterdam & 3.15 \\
\hline
\end{tabular}

Total result of sales: $f \mathbf{1 1 , 1 2 8 . 5 0}$.

Costs of notary: $f \mathbf{~} 110.10$.

1831 (Source: Tresoar Leeuwarden, Notary archives, 51017 (repertoires), \# 38)

\begin{tabular}{lllc} 
Barrels of whale oil & Buyer & Place of business & Amount (in guilders) \\
\hline 5 & Widow Rodenhuis \& Zonen & Harlingen & 325.00 \\
5 & Bernardus Leemkoel & idem & 327.50
\end{tabular}


Widow Rodenhuis Fontein en Tjallingii Widow Rodenhuis Bernardus Leemkoel Widow Rodenhuis Barend Visser \& Zoon Widow Rodenhuis

$\begin{array}{ll}\text { idem } & 335.00 \\ \text { idem } & 327.50 \\ \text { idem } & 330.00 \\ \text { idem } & 327.50 \\ \text { idem } & 312.50 \\ \text { idem } & 315.00 \\ \text { Idem } & 375.00\end{array}$

16

\begin{tabular}{llll} 
Barrels of seal oil & Buyer & \multicolumn{2}{l}{ Place of businessAmount (in guilders) } \\
\hline 5 & Widow Rodenhuis & Harlingen & 305.00 \\
5 & Widow Rodenhuis & idem & 305.00 \\
1 & Widow Rodenhuis & idem & 211.00 \\
\hline $\mathbf{1 1}$ & & &
\end{tabular}
11

\begin{tabular}{llll} 
Pounds of baleen & Buyer & Place of busniessAmount (in guilders) \\
\hline 19 & Widow Rodenhuis & Harlingen & 88.20 \\
19 & Widow Rodenhuis & idem & 88.20 \\
19 & Fontein en Tjallingii & idem & 88.20 \\
19 & Widow Rodenhuis & idem & 90.65 \\
19 & Simon Nijburg & Amsterdam & 75.95 \\
19 & Fontein en Tjallingii & Harlingen & 80.85 \\
31 & Widow Rodenhuis & idem & 19.60 \\
26 & Simon Nijburg & Amsterdam & 15.50 \\
\hline
\end{tabular}

351

\begin{tabular}{llll} 
Seal fur & Buyer & Place of businessAmount (in guilders) \\
\hline 91 & Fontein en Tjallingii & Harlingen & 15.50 \\
80 & Fontein en Tjallingii & idem & 32.00 \\
120 & Fontein en Tjallingii & idem & 12.00 \\
17 & Fontein en Tjallingii & idem & 11.10 \\
120 & Jarig Mollema & idem & 31.20 \\
\hline $\mathbf{1 5 8}$ & & & \multirow{2}{*}{ Amount (in guilders) } \\
Barrels of vinken & Buyer & Place of business & 10.00 \\
\hline 5
\end{tabular}

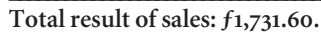

Costs of notary: $f_{57.89}$.

1838 (Source: Tresoar Leeuwarden, Notary archives, 19031 (repertoires), \# 191)

\begin{tabular}{lllc} 
Barrels of whale oil & Buyer & Place of business & Amount (in guilders) \\
\hline 3 & Bernardus Leemkoel & Harlingen & 750.80 \\
1 & Frederik Dijkman & Amsterdam & 931.80 \\
6 & Bernardus Leemkoel & Harlingen & 815.19 \\
1 & Tjeerd Follema & Arum & 913.82 \\
1 & Frederik Dijkman & Amsterdam & 1005.60 \\
6 & Frederik Dijkman & idem & 716.82 \\
5 & Frederik Dijkman & idem & 858.00 \\
6 & Bernardus Leemkoel & Harlingen & $761.801 / 2$ \\
1 & Frederik Dijkman & Amsterdam & 810.00 \\
1 & Frederik Dijkman & idem & 681.06 \\
3 & Frederik Dijkman & idem & 601.38 \\
2 and 1 barrel 'droes' & Frederik Dijkman & idem & 527.28
\end{tabular}




\begin{tabular}{|c|c|c|c|}
\hline 7 & Frederik Dijkman & idem & 696.10 \\
\hline 5 & Frederik Dijkman & idem & 829.11 \\
\hline 2 & Cornelis de Haas & Bolsward & 287.11 \\
\hline 3 & Frederik Dijkman & Amsterdam & 681.72 \\
\hline 3 & Frederik Dijkman & idem & 691.61 \\
\hline 1 & Jan Fontein & Harlingen & $818.92^{1 / 2}$ \\
\hline 1 & Frederik Dijkman & Amsterdam & 782.80 \\
\hline 1 & Frederik Dijkman & idem & 876.90 \\
\hline 3 & Frederik Dijkman & idem & 769.97 \\
\hline 1 & Frederik Dijkman & idem & 315.56 \\
\hline \multicolumn{4}{|l|}{87} \\
\hline Pounds of baleen & Buyer & Place of business & Amount (in guilders) \\
\hline$\overline{100}$ & Frederik Dijkman & Amsterdam & 180.00 \\
\hline 100 & Frederik Dijkman & idem & 179.00 \\
\hline 100 & Frederik Dijkman & idem & 182.00 \\
\hline 100 & Melchior Schrage & Harlingen & 185.00 \\
\hline 100 & Frederik Dijkman & Amsterdam & 187.00 \\
\hline 100 & Adam van der Minde & idem & 187.00 \\
\hline 100 & Frederik Dijkman & idem & 192.00 \\
\hline 100 & Adam van der Minde & idem & 183.00 \\
\hline 100 & Adam van der Minde & idem & 178.00 \\
\hline 100 & Frederik Dijkman & idem & 190.00 \\
\hline 100 & Frederik Dijkman & idem & 185.00 \\
\hline 100 & Frederik Dijkman & idem & 195.00 \\
\hline 100 & Frederik Dijkman & idem & 200.00 \\
\hline 100 & Frederik Dijkman & idem & 200.00 \\
\hline 100 & Frederik Dijkman & idem & $111.52^{1 / 2}$ \\
\hline 100 & Frederik Dijkman & idem & 195.00 \\
\hline 100 & Adam van der Minde & idem & 205.00 \\
\hline 100 & Frederik Dijkman & idem & 205.00 \\
\hline 100 & Frederik Dijkman & idem & 205.00 \\
\hline 100 & Frederik Dijkman & idem & 205.00 \\
\hline 100 & Adam van der Minde & idem & 205.00 \\
\hline 100 & Frederik Dijkman & idem & 210.00 \\
\hline 100 & Frederik Dijkman & idem & 220.00 \\
\hline 100 & Frederik Dijkman & idem & 220.00 \\
\hline 100 & Dreves/Doeves/Dieves? Jonker & Harlingen & 215.00 \\
\hline 100 & Frederik Dijkman & Amsterdam & 195.00 \\
\hline 100 & Frederik Dijkman & idem & 200.00 \\
\hline 100 & Adam van der Minde & idem & 210.00 \\
\hline 100 & Frederik Dijkman & idem & 205.00 \\
\hline 100 & Frederik Dijkman & idem & 205.00 \\
\hline $71^{1 / 2}$ & Frederik Dijkman & idem & 156.15 \\
\hline
\end{tabular}

$3071^{1 / 2}$

Total result of sales: $f 22,217 \cdot 29^{1 / 2}$.

Costs of notary: $1 / 2 \%$ à $f_{22,217.29} \frac{1 / 2}{2}=f_{112.25}+f_{25.59}$ (opcenten) $=f_{136.81}$. 


\section{Bibliography}

\section{Manuscripts/unpublished sources}

\section{A. Archives}

1. National Archives (NA)

- Sch, NHM 28/10 (PVG), 3 February 1827, N 1, and 13/1830 G, letter from F. Gebhard, New York, 19 July 1830

- Sch, NHM 13/1830 G. Letter from F. Gebhard, New York, 15, 19, 23 and 31 July 1830, and 18 October 1830

- NHM archives, inv.nr. 922. Correspondence from P. Landberg regarding Coffin and Logan of New Bedford; 8 December 1826; 17 March 1827 + appendix

- NHM archives, inv.nr. 926. Corespondence from R. Coffin regarding Logan of New Bedford; 6 November 1828; 26 April 1829

- Staatssecretarie 4165, August 18, 1836, N 10 (Netscher's report of 16 July 1836)

- Collectie Van den Bosch 862, letter Van der Houven, 2 October 1839

- NHM 20/11, Aanspraak President, 19 June, 1844, 71-75

- Kabinet des Konings 216, 16 August 1844, N 7

2. Stadsarchief Amsterdam (Municipal Archives Amsterdam - SAA)

- Archief Waterschout (WS; crewlists post-180o), 38; inv. nrs. 61, 62, 68 and 73

- Archief Kweekschool voor de Zeevaart, inventory nr. 949; nrs. 27 (minutes of meetings of Directors, 1824-1827), 28 (minutes of meetings of Directors, 1828-1830), 391 (cash registry, 1810-1832)

3. Gemeentearchief Rotterdam (Municipal Archives Rotterdam - GAR)

- Resoluties gemeenteraad, inv.nr. 444.01, nr. 13 (1825), fos. 20 verso (13 April), and 29 verso (2 May); nr. 16 (1828), fo.66 recto et verso (10 October)

- Repertorium Stadsbestuur, inv.nr. 444.01, nr. 3715 (1825), fo. 278; idem, nr. 3716 (1826), fo. 275 


\section{Tresoar Leeuwarden (Provincial Archives of Friesland - TL) \\ Notary archives: \\ - Sjoerd Simons Wijma. Repertoires 49026. Minuut-akten 49021 (1831), 283; 49025 (1832), 253; 49026 (1833), 281; 49028 (1835), 25; 49030 (1837), 1; 49031 (1838), 191. \\ - Jacob Hanekuyk. Repertoires 51030, 51031. Minuut-akten 51014 (1825), 78, 106; 51015 (1827), 102; 51017 (1831), 38}

\section{Gemeentearchief Harlingen (Municipal Archives Harlingen - GAH)}

- Archief Waterschout (WS). Registers van aanmonstering op zeeschepen, 1858-1896. WS 15a, 1858, no. 23; WS 2, 1858, fos. 23-24. WS 2, 1859, fos. 87-88. WS 3, 1860, fols. 10-11. WS 4, 1861, B XX. WS 4, 1862, B29; WS 5, 1863, no.13

- Archief Waterschout (WS). Monsterrollen, 1861-1924. WS 17, 1862, no. 29

- School voor Wis- en Zeevaartkunde te Harlingen. SWZV1, no. 647: Register van de leerlingen der school, 1842-1910

- nr. 4901: Commissie tot het examineren van Varenslieden. Notulen, examenverslagen en verzonden stukken, 1856-1878

- Archief Weeshuis. Registers betreffende de wezen, 1725-1925. No. 4858: 1846-1863

- Burgelijke standsregisters Harlingen, 1820/1823/1825/1826/1830/1840 huwelijk.

- Burgelijke standsregisters Harlingen, 1818 huwelijken; 1826, 1834, 1850 1851, 1880 overlijden

- Burgelijke standsregisters Harlingen, 1828

- Burgerlijke standsregisters Harlingen, 1814/1819/1820 huwelijken (marriages), 1837 overlijden (deceased)

- Burgerlijke standsregisters 1827

- Bevolkingsregister Harlingen 1851 A-17

- Volkstelling 1839: Wijk (district) F-144

- Stukken betreffende het stadsbestuur van Harlingen, 1816-1924. Archiefstuk betreffende de Groenland- en Straat-Davids-visserij 1830 (1 omslag), nr. 3399 (oprichtingsstatuten van de Groenlandse en Straat Davidse Sociëteit, Gemeentehuis Harlingen)

- Archief van het stadsbestuur van Harlingen. Indices op de ingekomen stukken. Nos. 1643 (1817-1823), 1644 (1824-1828), 1645 (1829-1837), 1646 (1837-1841), 1647 (1842-1846), 1648 (18471849), 1649 (1850-1856), 1650 (1857-1885)

- Archief van het stadsbestuur van Harlingen. Ingekomen stukken. Nos. 1414 (1826), 1415 (1826), 1416 (1827), 1417 (1827), 1418 (1828), 1419 (1828), 1420 (1829), 1421 (1829), 1422 (1830), 1423 (1831), 1421 (1832), 1425 (1833), 1426 (1834), 1427 (1835), 1428 (1836), 1429 (1837), 1430 (1838), 1431 (1839), 1432 (1840), 1433 (1841), 1431 (1842), 1435 (1843), 1436 (1844), 1437 (1845), 1438 (1846), 1439 (1847), 1440 (1847), 1441 (1848), 1442 (1849), 1443 (1850)

- Archief van het stadsbestuur van Harlingen. Indices op verzonden stukken. Nos. 1787 (1831), 1788 (1832-1834), 1789 (1835-1841), 1790 (1843-1846)

- Book numbers 45, 204, 650, 1133, 1138, 1139, 1140, 1141

- Afschriften van resoluties van Gedeputeerde Staten van Fiesland, 1815-1867. Nos. 1375 (18221825), 1376 (1826-1828), 1377 (1829-1831), 1378 (1832-1836), 1379 (1837-1840), 1380 (1841-1843), 1381 (1844-1846), 1382 (1847), 1383 (1848), 1384 (1849), 1385 (1850), 1386 (1851), 1387 (1852), 1388 (1853), 1389 (1851), 1390 (1855), 1391 (1856)

- Kohieren van belastingen op de huurwaarde, 1816-1852. No. 2295 (1833) 


\section{Gemeentearchief Grootegast \\ - Doopregister Grootegast 1769}

\section{Archives Vereeniging Nederlandsch Historisch Scheepvaart Museum (VNHSM), Amsterdam \\ - Correspondence. Letter from ds. W.A. Poort, agendanumber 16340}

8. Archival sources New Bedford, Massachusetts

- New Bedford, Custom House Records for 1826 and 1830

\section{B. Museum collections}

Netherlands

\section{Nederlands Scheepvaartmuseum, Amsterdam}

- Arriëns, P., Journaal, aantekeningen en aanmerKingen van mijne reize in Celebes, Ternate, Ambon en Banda. Library Nederlands Scheepvaartmuseum Amsterdam, manuscript collections AIV2-117II

- Lyste van de Vragt- en Bestelloonen, van de Pakken, Goederen en andere Koopmanschappen, komende met de Utrechtse Schietschuiten, visa versa (Amsterdam 1806). KIV31 (3)

- Octroy, Bericht en Plan van de geoctrooyeerde Africaansche Visschery Sociëteit (K II 34)

- Ordonnantie van de Gabelle of Tolle, Mitsgaders van het Vragt-Loon, gestelt op de Schuyten, Passagiers, reyzende Luyden en Beesten, den nieuwen Trekvaart en Wagenweg tusschen Haarlem en Amsterdam gebruykende (Amsterdam 1711). KIV31 (6)

- Ordonnantie van de vracht-loonen waar na de schippers, varende tusschen Amsterdam en Enkhuizen, hun hebbende te reguleeren (Enkhuizen 1782). KIV31 (2)

- Ordonnantie [Amsterdam 1816]. KIV31 (14)

- Reglement, waer na de commissaris van de ycker-schippers, varende tusschen Amsterdam en Gouda, zig zal hebben te gedragen (Gouda 1709). KIV31 (1)

- Reglement voor het beurtveer tusschen Rotterdam en Deventer, varende over den Rijn en IJssel (Deventer 1847). KIV31 (4)

- Reglement voor het beurtveer van Zutphen en Deventer over de Lemmer, Woudsend, Sneek en Leeuwarden naar Groningen, en terug van Groningen over Leeuwarden, Sneek, Woudsend en de Lemmer naar Deventer en Zutphen (Deventer 1848). KIV31 (8)

\section{Gemeentemuseum Het Hannemahuis, Harlingen}

- Handwritten booklet with poetry and prose written on the occasion of the construction, voyage and disaster of the Harlingen by A. Hoekstra. Hannemahuis, documents collection, E1H69a

- Typoscript Hannemahuis, number 2330, appendices, article 2

- Annotatie van het Galliootschip Harlingen en aldaar geboud in het jaar 1825 op de Landswerf voor den timmerbaas Johannis Alta - voor Rekening der Nederlandsche Groenlandsche Straatdavidsche visscherij Sociëteit te Harlingen waarop benoemd wurd tot kommandeur K. Hoekstra op den 9 Nov. 1825. 
Abroad

1. Kendall Collection, New Bedford Whaling Museum, New Bedford, Massachusetts (USA)

2. Dr. Carl-Häberlin-Friesenmuseum in Wyk aufFöhr, Northern Germany.

- Archiv A3M 131, Ship's journals of Spitsbergen, kept by H. Rickmers 1830-1840.

- Archiv A3M 132, Ship's journals of Spitsbergen, [kept by C. Osenburger?] 1846-1848.

\section{Newspapers}

Amsterdamsche Courant, 20 April 1805; 27 February 1810; 15 April 1825; 20 October 1825; 24 October 1825; 22 August 1827

Haarlemsche Courant, 18 October 1821

Algemeen Handelsblad, 26 January 1835; 15 May 1836; 31 May 1836; 12 October 1838; 25 and 27 September 1843; 15 March 1844; 23 April 1844; 3 February 1847; 27 February 1857

Harlinger Courant, 6 January 1858; 12 January 1859; 19 January 1859; 18 January 1860; January 1862; 5 January 1864; 13 and 14 January 1864

Leeuwarder Courant, 1831-1864

Nieuwe Noordhollandsche Courant, 24 February 1947

Javasche Courant, 5 and 19 August 1846; 21 November 1846; 12 December 1846; 27 January 1847

\section{Periodicals}

De Nederlandse Hermes, tijdschrift voor de Koophandel, Zeevaart en Nijverheid, 1826-1828

De Reddingboot, no. 51 (Christmas 1942)

The Shipping Gazette and Sydney General Trade List, 3 January 1846; 12, 19, and 26 December 1846; $2,9,16$, and 23 January 1847

Staatkundig en staathuishoudkundig jaarboekje, 1849-1884

Staatsblad, Koninklijk Besluit, 4 August 1824, no. 101

Sweijs, H., Neêrlands vloot en reederijen, 1855-1891

Tijdschrift van het Aardrijkskundig Genootschap, 1876-1966

Tijdschrift toegewijd aan het Zeewezen, 1831-1852

Verhandelingen en berigten betrekkelijk het zeewezen en de zeevaartkunde, 1853-1870

Zeetijdingen, 29 October 1865

\section{Websites}

homeo1.wxs.nl/ corkruk/par_wig/par_wig.htm

http://www.camerama.demon.nl/vas

home.tiscali.nl/ ti128393/conijn/647.htm - 3k 


\section{Published Sources}

Akveld, L.M., 'Noordzeevisserij', F.J.A. Broezen, J.R.Bruijn and F.S. Gaastra (eds.), Maritieme Geschiedenis der Nederlanden (MGN).Vol. 3 (Bussum 1977), 318-334

Ankun, L.A. et al. (eds.), Encyclopedie van de Zaanstreek. Vol. 2 (Wormerveer/Zaanstad 1991)

Anon., 'Bofors new whaling-gun', Norsk Hvalfangst-tidende (NHT), vol. 36, nr. 12 (December 1947), 444-447

Anon., 'Modern whaling. Short historical review', NHT, vol. 36, nr. 6 (June 1947), 202-209

Aten, Jan, Wormerveer langs weg en Zaan (Wormerveer 1967)

Bakker, M.S.C., 'Boter', H.W. Lintsen a.o. (eds.), Geschiedenis van de techniek in Nederland. De wording van een moderne samenleving 1800-1890. Six volumes (Zutphen 1992-1995). Vol II (Zutphen 1992), 103-133

Berkers, E., 'Een nieuw licht', H.W. Lintsen a.o. (eds.), Geschiedenis van de techniek in Nederland. De wording van een moderne samenleving 1800-1890. Six volumes (Zutphen 1992-1995). Vol. III (Zutphen 1993), 91-105

Berkers, E.A.M. and E. Homburg, 'Stearine-kaarsen', H.W. Lintsen a.o. (eds.), Geschiedenis van de techniek in Nederland. De wording van een moderne samenleving 1800-189o. Six volumes (Zutphen 1992-1995). Vol. IV (Zutphen 1993), 241-257

Boelen Joh.zoon, J., Reize naar de Oost- en Westkust van Zuid-Amerika en, van daar, naar de Sandwichs- en Philippijnsche Eilanden, China enz. gedaan, in de jaren 1826, 1827, 1828 en 1829, met het koopvaardijschip Wilhelmina en Maria. Three volumes (Amsterdam 1835-1836)

Boer, M.G. de, Leven en bedrijf van Gerhard Moritz Roentgen. Grondvester van de Nederlandsche Stoomboot-Maatschappij thans Maatschappij voor scheeps- en werktuigbouw 'Fijenoord' 18231923 (Rotterdam 1923)

Bohn, Robert (ed.), Nordfriesische Seefahrer in der frühen Neuzeit (Amsterdam 1999)

Boomgaard, P., L. Noordegraaf a.o. (eds.), Excercities in ons verleden. Twaalf opstellen over de economische en sociale geschiedenis van Nederland en koloniën 1800-1950 (Assen 1981)

Boon, Piet, Bouwers van de zee: zeevarenden van het Westfriese platteland, ca. 1680-1720 (Den Haag 1996)

Bouma, G.N., Sailing vessels visiting the port of Harlingen 1818-1918 [Haren 1994]

Idem, Lijst van Harlinger koopvaardijkapiteins [Unpublished manuscript. Haren 1997]

Idem, Lijst van Nederlandse koopvaardijschepen, alsmede hun gezagvoerders en thuishavens 18201900 (Hoorn 1998)

Booy, H.Th. de, Strandrovers, jutters en redders. Voorgeschiedenis en geboorte van het reddingwezen (Den Haag 1959)

Bottemanne, C.J., 'Beschouwingen over de kleine visscherij', J.L. de Bruyn Kops (ed.), De Economist (1870). Part I, 113-128

Idem, 'Economische nalezingen en berigten. Walvischvangst', J.L. de Bruyn Kops (ed.), De Economist (1872). Part I, 344

Braam, A. van, 'Over de omvang van de Zaandamse scheepsbouw in de $17^{\mathrm{e}}$ en $18^{\mathrm{e}}$ eeuw', Holland, vol. 21 (1992), 33-49

Idem, Bloei en verval van het economisch leven in de Zaan (Wormerveer 1944)

Brander, Jan, Jan Mayen in heden en verleden (Middelburg 1955)

Brandligt, C., Geschiedkundige beschouwing van de Walvisch-visschery (Amsterdam 1843) 
Brandt, Karl, Whale oil. An economic analysis. Fats and oil studies no. 7, June 1940 (Stanford University Press 1940)

Brink, A.J. ten, Blik op den hedendaagschen toestand der Europeesche Noordpool-visscherij (Enkhuizen 1876)

Broeze, F.J.A., 'Whaling in the Southern Oceans. The Dutch quest for Southern whaling in the nineteenth century', Economisch- en sociaal-historisch Jaarboek, vol. 10 (1977), 66-112

Idem, De stad Schiedam. De Schiedamse Scheepsreederij en de Nederlandse vaart op Oost-Indiëomstreeks 1840. Werken uitgegeven door de Linschoten-Vereeniging LXXX ('s-Gravenhage 1978)

Idem (transl., intr., annot.), A merchant's perspective: Captain Jacobus Boelen's narrative of his visit to Hawai' i in 1828 (Honolulu1988)

Brown, James Templeman, 'Whalemen, vessels and boats, apparatus, and methods of the whale fishery', in: George Brown Goode, The fisheries and fishery industries of the United States. Section V; History and methods of the fisheries. Vol. II, part XV: The whale-fishery (Washington 1887), 219-293

Brugmans, I.J., Paardenkracht en mensenmacht. Sociaal-economische geschiedenis van Nederland 1795-1940 ('s-Gravenhage; reprint 1976)

Bruijn, J.R. and C.A. Davids, 'Jonas vrij: de Nederlandse walvisvaart, in het bijzonder de Amsterdamse, in de jaren 1640-1664', Economisch-en sociaal-historisch jaarboek (ESHJ) 38 (1975), $141-178$

Bruijn, J.R., 'De Nederlandsche Maatschappij voor de Walvischvaart, 1946-1967', ESHJ 48 (1985), 233-257

Idem, 'De walvisvaart: de ontplooiing van een nieuwe bedrijfstak', in: W. Vroom and L. Hacquebord (eds.), Walvisvaart in de Gouden Eeuw (Amsterdam, 1988), 16-21

Idem, 'The Netherlands', John B. Hattendorf (ed.), Ubi Sumus? The State of Naval and Maritime History (Newport 1994), 227-243

Idem, 'A small North Frisian Island and the decline of the Dutch whaling trade c. 1780', S. Marzagalli and H. Bonin (eds.), Négoce, Ports et Océans, XVIe-XXe siècles. Mélanges offerts à Paul Butel (Bordeaux 2000), 171-180

Bruyn Kops, J.L. de (ed.), De Economist (1852-1871)

Burton, V.C., 'Apprenticeship Regulation and Maritime Labour in the Nineteenth Century British Merchant Marine', International Journal of Maritime History, vol. I, no. 1 (June 1989), 29-49

Cheever, Henry T., The whale and his captors (New York 1864)

Clark, A. Howard, 'History and present condition of the fishery', in: George Brown Goode, The fisheries and fishery industries of the United States. Section V; History and methods of the fisheries. Vol. II, part XV: The whale-fishery (Washington 1887), 3-218

Coffin, Louis, The Coffin Family (Nantucket 1962)

Crommelin L., and H. van Suchtelen, Nederlandse vuurtorens. Bouwgeschiedenis en organisatie (Nieuwkoop 1978)

Dalgård, S., Dansk-Norsk hvalfangst, 1615-1660 (Copenhagen 1962)

Davids, C.A., and J.R. Bruijn; zie Bruijn, J.R.

Davids, C.A., 'De zeevaartkunde en enkele maatschappelijke veranderingen in Nederland tussen 1850 en 1914', Mededelingen van de Nederlandse Vereniging voor Zeegeschiedenis, vols. 40/41 (1980), 51-83 
Idem, 'Het zeevaartkundig onderwijs voor de koopvaardij in Nederland tussen 1795 en 1875. De rol van het Rijk, de lagere overheid en het particuliere initiatief, Tijdschrift voor Zeegeschiedenis, vol. 4 (1985), no. 3, 164-190

Idem, 'The transfer of technology between Britain and The Netherlands, 1700-1850', J.R. Bruijn and W.F.J. Mörzer Bruyns (eds.), Anglo-Dutch mercantile marine relations 1700-1850 (Amsterdam/Leiden 1991), 7-23

Davis, Lance E., Robert E. Gallman, and Karin Gleiter, In pursuit of Leviathan. Technology, institutions, productivity and profits in American whaling, 1816-1906 (Chicago/London 1997)

O'Dea, Wiliam T., The Social History of Lighting (London 1958)

Dijkstra, Anne J., 'De Groenlands- en Straat Davids-Visserij Sociëteit te Harlingen', Jaarboek Fries Scheepvaartmuseum en Oudheidkamer, (1964/1965), 54-58

Deinse, A.B. van, (introduction), Journaal der merkwaardige reizen van Jan Wever (van West-Terschelling) naar Turkije, Oost-Indië, China, Noord- en Zuid-Amerika, ter walvischvaart bij Groenland, enz. Loopende van 1847-1904 (Den Haag 1946).

Dekker, P., Willem 't Hart, 1750-1830. Een Zijper zeevaarder in de nadagen der Republiek (Zaltbommel, 1966)

Idem, 'De walvisvaarders uit noordelijk Noord-Holland van 1770-1803', West-Frieslands Oud en Nieuw (WFON), vol. 40, (1973), 29-90

Idem, 'De Helderse en Huisduiner bevelhebbers ter walvisvaart in de 18 e eeuw. Het grootste commandeurs-domicilie', WFON, vol. 41 (1971), 129-165

Idem, 'De Terschellinger arctische ruilhandel en walvisvangst', It Beaken, XXXVII (1975), 167-188

Idem, 'Van kooikers en commandeurs. De families Colterman en Hopman actief bij de vogel- en walvisvangst', WFON, vol. 45 (1978), 41-58

Idem, 'De Nederlandse arctische walvisvaart tijdens de Bataafse Republiek', Mededelingen van de Nederlandse Vereniging voor Zeegeschiedenis, no. 38 (August 1979), 40-70

Dissel, A.M.C. van, and J.E. Oosterling, 'Aan boord van de 'Willem Barendsz.' Enkele sociale aspecten van de Nederlandse walvisvaart, 1916-1961', Tijdschrift voor Zeegeschiedenis, vol. 5, nr. 2 (oktober 1986), 146-164

Dow, George Francis, Whaleships and Whaling. A Pictorial History (New York 1985; republication of 1925 edition)

Elliot, G., 'Whaling 1937-1967: The International Control of Whalestocks', Kendall Whaling Museum Monograph Series no. 10 (Sharon, Mass. 1997)

Enno van Gelder, H., De Nederlandse munt (Utrecht/Antwerpen 1972)

Fasseur, C., Indischgasten (Amsterdam 1997)

Feyfer, H.J. de, Het licht der zeevaert. Friese bijdragen aan het zeevaartonderwijs. Fryske Akademy nr. 169 (Leeuwarden 1974)

Filarski, R., Kanalen van de Koning-Koopman. Goederenvervoer, binnenscheepvaart en kanalenbouw in Nederland en België in de eerste helft van de negentiende eeuw (Amsterdam 1995)

Fock, A, a.o., 'Verslag bij gelegenheid van het vijf-en-twintig-jarig bestaan van de Noord- en ZuidHollandsche Reddeing-Maatschappij', G.A. Tindal and J. Swart (eds.), Verhandelingen en berigten betrekkelijk het Zeewezen en de Zeevaartkunde, vol. 3 (1850), 32-48

Gaastra, F.S., Vragen over de koopvaardij. De 'Enquête omtrent den toestand van de Nederlandse koopvaardijvloot' uit 1871 en de achteruitgang van de handelsvloot. Inaugurele rede (Leiden 2001) 
Geschied- en oudheidkundige beschrijving van Utrechts pleinen, straten, stegen, waterleidingen, wedden, putten en pompen (Utrecht n.d. [1843])

Goode, George Brown, The Fisheries and Fishery Industries of the United States. Section V: History and Methods of the Fisheries (Washington 1887)

Groenewegen, Gerrit, Verzameling van vier en tachtig stuks Hollandsche schepen. Geteekend en in koper gebracht door G. Groenewegen (Z.pl. z.j.; herdruk van editie Rotterdam 1789)

Groot, S.J. de, 'Het voorkomen en de vangst van walvissen en walvisachtigen in de Indo-Australische archipel, en de zaak van de walvisvaarder "Costa Rica Packet" (1891-1897)', Mededelingen van de Nederlandse Vereniging voor Zeegeschiedenis, vol. 30 (1975), 20-29

Haagsma, S., 'Friesland's Groenlandvaart', Het Nederlandsche Zeewezen, vol. 3 (1901), 310-311; republished in Jaarboek Fries Scheepvaatmuseum en Oudheidkamer (1964/1965), 41-53

Hacquebord, L., 'De walvisvaart: geschiedenis van een bedrijfstak', E. Naayer (ed.), Smeerenburg: Holland op z'n koudst. Mededelingen van het Arctisch Centrum nr. 7 (z.pl. z.d. [Groningen 1983]), 13-28

Idem, Smeerenburg. Het verblijf van Nederlandse walvisvaarders op de westkust van Spitsbergen in de $17^{\circ}$ eeuw (Amsterdam/Groningen 1984)

Idem, 'Van Noordse Compagnie tot Matschappij voor de Walvisvaart. Honderd jaar onderzoek naar de geschiedenis van de Nederlandse walvisvaart', Tijdschrift voor Zeegeschiedenis, vol. 13 (1994), no. 1, 19-40

Idem, and Jurjen Leinenga, 'De ecologie van de Groenlandse walvis in relatie tot walvisvaart en klimaatveranderingen in de zeventiende en achttiende eeuw', Tijdschrift voor Geschiedenis, vol. 107 (1991), 415-438

Idem, 'Niederländischer und Deutscher Walfang im 17. Jahrhundert', Robert Bohn (ed.), Nordfriesische Seefahrer in der frühen Neuzeit (Amsterdam, 1999) 91-104

Idem, 'Basken en Nederlanders aan boord van 17 de eeuwse walvisvaarders, een wereld van verschil?', A. Huussen, J. de Jonge, G. Prince (eds.), Cultuurcontacten. Ontmoetingen tussen culturen in historisch perspectief. Historische Studies IV (Groningen 2001), 37-47

Halberstma, H., 'Uit het zeemansleven van Geert Oenes Dolstra (1792-1886)', Jaarboek Fries Scheepvaartmuseum en Oudheidkamer (1964/1965), 59-61

Hardenberg, H., 'Het handelshuis Osy', Rotterdams jaarboekje (1954), 154-176

Hart, S., 'De eerste Nederlandse tochten ter walvisvaart', Jaarboek Genootschap Amstelodamum, vol. 49 (1957), 27-64

Heijer, H.J. den, De geoctrooieerde Compagnie: de VOC en de WIC als voorlopers van de naamloze vennootschap (Amsterdam/Deventer 2005)

Herwaarden (ed.), J. van, Lof der historie. Opstellen over geschiedenis en maatschappij (Rotterdam 1973)

Hoekstra, K., Dagverhaal van het verongelukken van het galliot Harlingen in Straat Davis. De Togt van de Equipage met sloepen over en langs het ijs, en overwinteringvan deselve in het Noordelijk gedeelte van Groenland door den Kommandeur Klaas Hoekstra van Texel (Harlingen 1828)

Honig, G.J., Stamboek familie Smit (Koog aan de Zaan 1935)

Idem, 'Sociëteit van de blauwselfabriek te Westzaan', Die Zaende: maandblad gewijd aan de historie, folklore en genealogie van de Zaanstreek, vol. 5 (1950)

Idem, Uit den gulden bijkorf. Genealogisch-historisch-economische studiën over Zaansche families. Uitgegeven als vervolgdeel op het stamboek Smit (Koog aan de Zaan 1952) 
L'Honoré Naber, S.P., Het leven van een vloothouder. Gedenkschriften van M.H. Jansen (Utrecht 1925)

Houter, Jan, Alzwerfik op de baren... Vlielandse zeevaarders van eind 16e tot eind 19e eeuw (Baarn 1978)

Höver, O., Von der Galliot zum Fünfmaster. Unsere Segelschiffe in der Weltschiffahrt 1780-1930 (Bremen 1931; reprinted at Norderstedt 1974)

Huizinga, J.J., L.G. Jansma and C.H.A. Verhaar (eds.), Harlingen. Bijdragen tot de geschiedenis van de laatste twee eeuwen (Leeuwarden 1989)

Huizinga, J.J., 'De geschiedenis van Harlingen', Huizinga, J.J., L.G. Jansma and C.H.A. Verhaar (eds.), Harlingen. Bijdragen tot de geschiedenis van de laatste twee eeuwen (Leeuwarden 1989), 15-37

Hunt, Freeman (ed.), The merchant's magazine and commercial review, vol. 20, January-June 1849 (New York 1849)

Huyssen van Kattendijke-Frank, Katrientje (ed.), Met Prins Hendrik naar de Oost. De reis van W.J.C. Huyssen van Kattendijke naar Nederlands Indië, 1836-1838. Werken uitgegeven door de Linschoten-Vereeniging CII (Zutphen 2004)

Jackson, G., The British whaling trade (London 1978; second edition St. John's, Newfoundland 2005)

Jacobs, E.M., 'Met alleen woorden als wapen. De Nederlandse poging tot openstelling van Japanse havens voor de internationale handel (1844)', Bijdragen en mededelingen betreffende de geschiedenis der Nederlanden (BMGN), vol. 105 (1990), nr. 1, 54-77

Jansen, M., De industriële ontwikkeling in Nederland 1800-1850 (Amsterdam 1999)

Johnsen, Arne Odd, 'The shell harpoon', Norsk Hvalfangst-tidende (NHT) vol. 29, nr. 9 (September 1940), 222-212

Idem, 'Sokkeprest Morten Thrane Esmark og den moderne hvalfangsten', NHT, vol. 32, nr. 6 (June 1943), 81-93

Idem, 'Causation problems of modern whaling', NHT, vol. 36, nr. 8 (August 1947), 281-294

Jong, C. de, 'Twee scheepsjournalen van C.J. Bottemanne als laatste Nederlandse commandeur ter walvisvangst', Economisch-historisch Jaarboek. Bijdragen tot de economische geschiedenis van Nederland, dertigste deel (Den Haag 1965), 77-117

Idem, 'De Dirkje Adema, Nederlands laatste Groenlandvaarder', Jaarboek Fries Scheepvaartmuseum en Oudheidkamer (1964/1965),

Idem, Geschiedenis van de oude Nederlandse walvisvaart. Three volumes (Pretoria/Johannesburg 1972;1976-1978)

Idem, 'Walvisvaart' in: Maritieme Geschiedenis der Nederlanden (MGN), volume III (Bussum 1976-1978), 335-352

Idem, Westerse walvisvaart in Oost-Indië in de 19e eeuw (n.p. 1995)

Jonge, J.A. de, De industrialisatie in Nederland tussen 1850 en 1914 (Amsterdam 1968)

Jonker, Joost, Merchants, bankers, middlemen. The Amsterdam money market during the first half of the $19^{\text {th }}$ century (Amsterdam 1996)

Idem, 'Roeien tegen de stroom, 1813-1860. De geschiedenis van Insinger \& Co., deel 2', Amstelodamum, Jaarboek 96 (Amsterdam 2004), 135-155

Idem, and Keetie Sluyterman, Thuis op de wereldmarkt. Nederlandse handelshuizen door de eeuwen heen (Den Haag 2000)

Kan, C.M., and N.W. Posthumus (eds.), Tijdschrift van het Aardrijkskundig Genootschap, vol. 2 (1877), 65-66 
Kane, Robert, 'Sailors and whalers; Lakemen of Pultneyville', The American Neptune. A quarterly journal of maritime history (AN), vol. XXXIV, no. 1 (October 1971), 243-248

Klaver, P.M., 'De bevolkingsontwikkeling van Harlingen 1800-1980', J.J. Huizinga, L.G. Jansma \& C.H.A. Verhaar (eds.), Harlingen. Bijdragen tot de geschiedenis van de laatste twee eeuwen (Leeuwarden 1989), 39-54

Idem, 'Bouwen en wonen 1800-1980', J.J. Huizinga, L.G. Jansma \& C.H.A. Verhaar (eds.), Harlingen. Bijdragen tot de geschiedenis van de laatste twee eeuwen (Leeuwarden 1989), 55-68

Idem, 'Ontwikkeling van de nijverheid in Harlingen in de $19^{\text {de }}$ en $20^{\text {ste }}$ eeuw', J.J. Huizinga, L.G. Jansma and C.H.A. Verhaar (eds.), Harlingen. Bijdragen tot de geschiedenis van de laatste twee eeuwen (Leeuwarden 1989), 69-102

Kranenburg, H.A.H., De zeevisscherij van Holland in den tijd der Republiek (Amsterdam 1946)

Krooshof, Paul, 'De historie van een Harlinger Zeevaartschool', Oud Harlingen, no. 20 (2004)

L., P.W., Bijdragen tot bekendmaking van de voornaamste zaken van den handel, der Nederlanden, en van dien van Hamburg etc. (Utrecht 1837)

Lacroix, L., Les derniers baleiniers français (Nantes 1938)

Leinenga, Jurjen R., and L. Hacquebord; see Hacquebord, L.

Leinenga, J.R., Arctische walvisvangst in de achttiende eeuw: de betekenis van Straat Davis als vangstgebied (Amsterdam 1995)

Lindeman, M., 'Die Arktische Fischerei der Deutschen Seestädte 1620-1868. In vergleichender Darstellung', in: A. Petermann, Mitteilungen aus Justus Perthes' Geographischer Ausstalt über wichtige neue Erforschungen auf dem Gesamtgebiet der Geographie. Ergänzungsband VI, 18691871 (Gotha 1871)

Lintsen, H.W., a.o. (eds.), Geschiedenis van de techniek in Nederland. De wording van een moderne samenleving 1800-189o. Six volumes (Zutphen 1992-1995)

Idem, 'Concepts for the study of innovation: evaluation of the Dutch shipbuilding industry in historical perpective', Paul C. van Royen, Lewis R. Fischer, David Williams (eds.), Frutta di mare. Evolution and revolution in the Maritime World in the $19^{\text {th }}$ and $20^{\text {th }}$ Centuries. Proceedings of the Second International Congress of Maritime History, 5-8 June 1996, Amsterdam and Rotterdam, the Netherlands (Amsterdam 1998), 115-121

Lootsma, S., Bijdrage tot de geschiedenis der Nederlandsche walvischvangst (meer speciaal de Zaansche) (Amsterdam 1937).

Lubbock, B., The Arctic whalers (Glasgow 1937)

Lund, Judith Navas, Whaling Masters and Whaling Voyages sailing from American Ports (New Bedford/Sharon/Gloucester 2001)

Lythe, S.G.E., 'The Dundee whale fishery', Scottish journal of political economy, vol. 11 (1964), 158-169

Malloy, M., African Americans in the maritime trades: a guide to resources in New England. Kendall Whaling Museum Monograph Series no. 6 (Sharon 1990)

Mansvelt, W.M.F., Geschiedenis van de Nederlandsche Handel-Maatschappij. Two volumes (Haarlem 1924-1926)

Meere, J.M.M. de, Economische ontwikkeling en levensstandaard in Nederland gedurende de eerste helft van de negentiende eeuw. Aspecten en trends. Cahiers Sociale Geschiedenis I ('s-Gravenhage 1982)

Melle, Marius van, 'Van vetkaars tot hogedruklamp. Vijf eeuwen straatverlichting', Ons Amsterdam, vol. 57, nr. 10 (oktober 2005), 375-381 
Molhuysen, P.C., and P.J. Blok (eds.), Nieuw Biographisch Woordenboek. Ten volumes (Leiden 1911-1937)

Musschenbroek, S.C.J.W., 'Cachelot-Visscherij in den Nederlandsch Indischen Archipel', Tijdschrift ter bevrodering van Nijverheid, vol. XVIII, part 11 (Haarlem 1877)

Nielsen, C., 'Uit de geschiedenis van de Harlinger walvisvaart', Oud Harlingen, vol. 6, no. 6 (1991), 22-26

Obreen, H.T., 'Harlingen', Bulletin van de Koninklijke Nederlandse Oudheidkundige Bond, vol. 69 (1970), no. 2, 73-88

Otsen, J., 'Cement in Purmerend. Van schelpzandmolen tot portlandcementfabriek (1616-1890)', Nederlandse Historiën, vol. 27, no. 6 (December 1993), 123-133.

Parma, S., Harlinger koopvaardijkapiteins en Harlinger reders uit de tweede helft van de negentiende eeuw (Hilversum 1999)

Idem, 'Pieter Kallenborn en de Zeevaartschool te Harlingen', Gens Nostra, vol. 55 (2000), nr. 2, 61-66

Petermann, A.H., Dr. A. Petermanns Mittheilungen aus Justus Perthes geographischer Anstalt (Gotha 1875-1937)

Plettenburg, H.W.M., Licht in huis. Kienspaan - kaars - olielamp (Arnhem 1968)

Pons, G., De bakens verzet. Een analyse van de Hollandse pekelharingvisserij met kielschepen in de periode 1814-1885 (n.p. 1996)

Poort Jzn, J., Harlingen in de loop der eeuwen (Harlingen 1954)

Posthumus, N.W., Nederlandsche prijsgeschiedenis. Deel I: goederenprijzen op de beurs van Amsterdam, 1585-1911. Wisselkoersen te Amsterdam, 1609-1914. Internationale wetenschappelijke commssie voor prijsgeschiedenis (Leiden 1943)

Ricard, J.P., Le négoce d'Amsterdam (Amsterdam 1722; Rouen 1723)

Roncière, Ch. de la, Histoire de la marine française. Six volumes (Paris 1900-1924)

Ross, W.G., Whaling and Eskimos: Hudson Bay, 1860-1915 (Ottawa 1975)

Royen P.C. van, 'Employment aboard the Dutch merchant marine in the seventeenth and eighteenth centuries', Robert Bohn (ed.), Nordfriesische Seefahrer in der frühen Neuzeit (Amsterdam 1999), 113-128

Scammon, Charles M., The Marine Mammals of ther Northwestern Coast of North America. Together with an account of the American Whale-Fishery (New York 1968; republication of 1874 edition)

Schmitt, Frederick P., de Jong, Cornelis and Winter, Frank H., Thomas Welcome Roys. America's Pioneer of Modern Whaling (Newport News 1980)

Schokkenbroek, J.C.A., 'Koning Willem II schrijft een brief aan de Japanse shogun', R. Daalder (ed.), Maritieme geschiedenis van Nederland in 70 hoogtepunten, 1500-200o (Amsterdam/ Zutphen 2001), 116-118

Idem, 'Cartografie op hout. De scheepskist van walvisvaartcommandeur Jan Cornelisz. Buijs (ca. 16971768)', R. Daalder a.o. (eds.), Koersvast.Vijf eeuwen navigatie op zee (Zaltbommel 2005), 241-252

Idem, 'Walvisvaarder', R. Daalder (ed.), Schepen van de Gouden Eeuw (Zutphen 2005), 67-74

Sluijs, J. van, Lijst van Nederlandse reders, ca. 1800-1860 (Unpublished listings: n.p. 1935-1955. In Nederlands Scheepvaartmuseum Amsterdam)

Idem, Nederlandse Koopvaardijschepen 1800-1860 (Unpublished listings: n.p. n.d. In Nederlands Scheepvaartmuseum Amsterdam) 
Idem, Nederlandse kapiteins ter koopvaardij (Unpublished listings: n.p. n.d. In Nederlands Scheepvaartmuseum Amsterdam)

Smit, J.G.V., Whales, wood and water. American whalers in the Dutch East Indies, 1830-1880 (unpublished M.A. thesis. Leiden 1989)

Stackpole, R.A., American whaling in Hudson Bay, 1861-1919 (Mystic 1969)

Starbuck, A., History of the American Whale Fishery (Reprint of the 1878 edition; Secaucus 1989)

Stellwagen, A.W., 'De Noorweegsche visscherijen in de IJszee', Onze Tijd, nieuwe serie, jaargang 7 (1872), deel 1, 15-75

Stikker A.H., Een familie van galjootpers, commandeurs op Groenland en Friese vermaners. BaskeHoekstra-Veenstra (unpublished typoscript in the collection of the Nederlands Scheepvaartmuseum Amsterdam. No date [ca. 1965])

Swart, J., 'De Stille Zuidzee en de Nederlandse ontdekkingen daarin gedaan, benevens een blik op de toekomstige bestemming dier zee', G.A. Tindal and J. Swart (eds.), Verhandelingen en berigten betrekkelijk het Zeewezen en de Zeevaartkunde, vol. 4 (1851), 257-287

Swart, J. (ed.), Verhandelingen en berigten betrekkelijk het Zeewezen en de Zeevaartkunde, vol. 6 (1853), 191-192

Idem, Verhandelingen en berigten betrekkelijk het Zeewezen en de Zeevaartkunde, vol. 10 (1857), 455, message no. 83

Teijl, J., 'Brandstofaccijns en nijverheid in Nederland gedurende de periode 1834-1864', J. van Herwaarden (ed.), Lof der historie. Opstellen over geschiedenis en maatschappij (Rotterdam 1973), 155-183

Tønnesen, J.N. and A.O. Johnson, The History of Modern Whaling (Berkeley 1982).

Tower, Walter S., A History of the American Whale Fishery. Series in Political Economy and Public Law, no. 20 (Philadelphia 1907)

Tuck, James A. and Robert Grenier, Red Bay, Labrador. World Whaling Capital A.D. 1550-160o (St. John's 1989)

Vaughan, R., 'Historical survey of the European whaling industry', H.K.'s Jacob, K. Snoeijing and R. Vaughan (eds.), Arctic whaling: proceedings of the international symposium Arctic whaling: February 1983 (Groningen 1983), 121-134

Verhoeff, J.M., De oude Nederlandse maten en gewichten. Publikaties van het P.J. Meertens-Instituut, deel 3 (Amsterdam 1982)

Verbeek, N.H.W., 'Margarine', Lintsen, Geschiedenis van de techniek in Nederland. Dewording van een moderne samenleving 1800-189o. Six volumes (Zutphen 1992-1995).Vol II, 135-169

Veritas, 1862

Verslag van den staat der Nederlandsche Zeevisscherijen over 1868 ('s-Gravenhage 1869)

Verslag van den staat der Nederlandsche Zeevisscherijen over 1872 ('s-Gravenhage 1873)

Vliet, A. P. van, Vissers en kapers. De zeevisserij vanuit het Maasmondgebied en de Duinkerker kapers (ca. 1580-1648) (Den Haag 1994)

Idem, 'The sea fishery as an opportunity for investment in the Dutch Republic or the relation between the sea fishery and the money-box', Leo M. Akveld, Fits R. Loomeijer and Morten Hahn-Pedersen (eds.), Financing the Maritime Sector. Proceedings from the Fifth North Sea History Conference. Fiskeri- og Søfartsmuseets studieserie, nr. 13 (Esbjerg 2002), 131-145

Voigt, Harald, 'Auf den Spuren nordfriesischer Seeleute in der europäischen Handelsfahrt von 1710-1830', Robert Bohn (ed.), Nordfriesische Seefahrer in der frühen Neuzeit (Amsterdam 1999), 11-23 
Voort, J.P. van, 'Het visserijonderwijs in Nederland in de $19^{\mathrm{e}}$ en vroeg $20^{\mathrm{e}}$ eeuw. Een overzicht', Tijdschrift voor Zeegeschiedenis, vol. 4 (1985), no. 3, 220-234

Vries, J.N. de, F. van der Laaken, and D.J. List, Lijn in balein (Utrecht 1987)

Vroom, W., and L. Hacquebord (eds.), Walvisvaart in de Gouden Eeuw (Amsterdam 1988)

Wanjon, D., Geschiedenis van den Nederlandschen handel sedert 1795 (Haarlem 1900)

Webb, Robert Llloyd, On the Northwest. Commercial Whaling in the Pacific Northwest, 1790-1967 (Vancouver 1988)

Weide Bzn., J. van der, 'Uit het leven van een Groenlandvaarder', Tijdschrift van de Vereeniging Het Nederlandsch Zeewezen, vol. 21 (Den Haag 1921), 17-20; 30-33; 42-44; 53-56; 66; 77-79; $92-$ 93; 103-104

Westermann, J.C., Gedenkboek, samengesteld ter gelegenheid van het 125-jarig bestaan van de Kamer van Koophandel en fabrieken voor Amsterdam. Eerste deel: het tijdvak 1811-1922 (Amsterdam 1936)

Wumkes, G.A., Tusschen Flie en Borne. Schetsen uit de geschiedenis van Schellingerland (WesterSchelling 1900)

Zahn jr., G.P., De geschiedenis der verlichting van Amsterdam (Amsterdam n.d. [1911])

Zanden, J.L. van, and A. van Riel, Nederland 1780-1914. Staat, instituties en economische ontwikkeling (Amsterdam 2000)

Zappey, W.M., 'Het Fonds voor de Nationale Nijverheid 1821-1846', P. Boomgaard, L. Noordegraaf a.o. (eds.), Excercities in ons verleden. Twaalf opstellen over de economische en sociale geschiedenis van Nederland en koloniën 180o-1950 (Assen 1981), 27-42

Zeeman, S., 'Harlingen en de walvisvaart', Spiegel der zeilvaart, vol. 6. no. 9 (november 1982), 1519

Zemke, Friedrich-Karl, Leuchttürme der Welt. Three volumes (Herford 1992-1993)

Zwart, B.C.E., De Kamer van Koophandel en Fabrieken te Amsterdam. Overzicht van hare handelingen gedurende het tijdvak 1811-1911 (Amsterdam n.d. [1911]) 


\section{Curriculum vitae}

Joost Schokkenbroek (1961) holds a degree in History from Leiden University, the Netherlands. After graduation he worked for the Ministery of Foreign Affairs in The Hague and at the Kendall Whaling Museum in Sharon, Massachussetts (USA, 19881990). In 1991 Schokkenbroek returned to the Netherlands to work as Curator at the Nederlands Scheepvaartmuseum in Amsterdam. He serves as the Advisory Curator for the Kendall Whaling Museum and (as of 2001) the New Bedford Whaling Museum. Schokkenbroek was Secretary-General for the Netherlands Association of Maritime History between 1992 and 1998 and was Senior Editor for the The Oxford Encyclopedia of Maritime History (4 volumes: Oxford/New York 2007). 


\section{Index}

ship's names in italics

bold page numbers refer to illustrations

Aardenburg, C. 226

Adema, Dirkje 124

Administrateur van de Nationale Nijverheid 55, 80

Adriaan, J.J. (or J.G.) 109, 188, 297, 298

Afrikaanse Visscherij Sociëteit (African Fishery Socie-

ty) $41-42,68$

Alaska 52

Albert 50, 163

Alida 43, 44, 293, 294

Alpha 165

Alta, Dirk Johannes 105

Alta, Johan 105, 108, 111, 118-119, 161, 253

Alta, L. 192

Alta's wharf see also: Welgelegen 105, 111, 161, 253

ambergris 52

Ameland 121, 173, 177, 178, 190

Amsterdam 29, 32, 93-95, 105, 101, 118, 124, 134, 135, $166,167,169,185,186,189,218,219,222,223,226,229$, $231,238,244,249$

Amsterdam Island (Spitsbergen) 28, 111, 205

Amsterdamsche Haringreederij 56

Andersen, N.A. 146

Anjer present day Anjer Lor (West-Java) 83

Ankersmit 220

Anna 154

Anna \& Louisa 85-86, 87, 88, 168, 238, 239

Antelope 174

Antoinetta Jacoba 125

Argonaut 143

Ariens, Cornelis 183

Arius Johannes 108

Arriëns, P. 80, 84

Assen 186

Atlas 51

auctions 114, 115, 117-118, 123, 124, 129, 132, 135, 217-224, $227,228,234,237,242,258$

- results 220-223, 335-342

August 49

Avontuur 43, 44, 294

Baffin Bay 161, 179
Bakker, Th. 179

baleen $26,27,28,31,35,46,52,75,76,77,80,87,88$, 95, $114,116,129,151,212,217,218,219,220,221,222,223$, 227-228, 229, 230, 237, 242, 244, 245-246, 259, 264, 306-307

Baltic region 19, 34, 35, 99, 102, 125, 143, 267, 330

Baltimore 78

Bangma, Obbe Sickes 191, 323

Bare (also spelled Baze), August de 174

Barentsz., Willem 26

Barnevelt, E. 122, 188

Batavia (Dutch East Indies) 70, 71, 75, 86, 168, 180

Batavian Navy 77, 79

Baud, Jean Chrétien baron 79, 80, 83

Bay of Kamchatka 87

bay-whaling 28, 29, 31, 33

Bear Island 26

Beaujon, A. 22, 39-40

Beer, Arie de 183

Beer, Eelke de 183

Beer, Ietse de 183

Beer, Jan de 183

Beitschat (inn) 198

Bellona 80

Beerenberg (Jan Mayen) 126, 207

Berndina 132

Berg, first name onknown Van den 121, 188

Bergen (Norway) 42

Bering Sea 51

Bienenkorb 50, 163, 164

Blaauw, Dirk 96

black oil see: oil-whale

Blad, J. 122, 188

bladdernose seals see: klapmutsen

Blanckenheym, C.J. 68-69

Blik, K. 113

Blomberg, F.W. 190

Boekhout, J. 147

Boekjes, Cornelis 43, 44, 97, 293, 295

Boelen Jhz., Jacobus 74-75, 77

Boer, Douwe de 198-201, 204, 209, 211, 213, 214, 216, 224, 228

Bolman, Albert 224

bomb harpoon gun see: vuurpijlbomharpoenkanon 
Bona, G. 180

Boon, Gerrit 68-69

Boon, Jacob O. 113

Boon, P. 33, 171, 202

Boot, W.J.J. 20

bootschip 31, 32

Booy, H.Th. de 95

Bos, Pieter G. 180, 203

Both, Jacob 197

Both, Johan(n) 130-134, 139-140, 180, 195, 197, 209, 301, 302, 303

Both, Michiel 197

Bottemanne, Caspar Josephus 145, 146-153, 147, 154, $162,165,183,239,261,262-263,264,305$

Bouma, G.N. 130, 134

bounties see: subsidies

Boven, first name unknown Van 80

Braam, A. van 30, 31

Brandligt, C. 22-23, 81-84, 157, 233

Brantjes \& Smit, Nicolaas 143-146, 148, 174-175, 261$263,264,265,304,305$

Brantjes, Margaretha Johanna 143

Brantjes, Maria Anna 143

Brantjes, Nicolaas 143, 145, 163, 164, 267

Brazil 78

Bremen 40, 49, 50, 88, 109, 230, 231

Bremerhaven 163, 202, 204

Breukemeijer, J.H. 189,190

Brijde(r), C.M. 145,146

Brink, A.J. ten 22-23, 153-154, 156, 164, 239, 240, 241, $242,258,262-263$

Brinkman(n), C. $136,141,198,304$

Broertjes, Jacob 43, 44, 94, 96, 171, 172, 246, 247, 248, 293, 294, 295, 296

Broeze, F.J.A. 19-23, 52, 71, 76, 78-79, 159, 166, 188, 235, 240

Brugmans, I.J. 19, 60, 159, 231

Bruijn, J.R. 20-21, 23

Bruine, Adriaan de 95, 96

Brunn, T.A. (also A.F.) $86-87,88,90,169$

burials see: crews - burials

Burmania baron Rengers, R.H.S.G.J. van 129

Buzzard's Bay (Massachusetts) 50

Canne \& Balwé 195

Canton present day Guangzhou (China) 78, 79

Cape Colony 41

Cape Horn 46, 73, 82

Cape of Good Hope 41

Cape Town 41-42, 76, 167

captain's rights 198-199

Captain Cook 165

Cardinaal, Cornelis 43, 294

Castricum, Jan Claesz. 43, 44, 293, 294

catch results $46,49,72,74,75,87,91,94,97,100,102$, $103,105,110,112,113,114,115,118-120,122,123,126$, $127,128,129,130,131,132,135,136,145,146,151,152$, $153,206,207,234,236,238,242,248,250,255-257$. $258,259,261,264,265,293-305,306-307$
Catz \& Compagnie 219, 220, 221, 222, 223

Cherro, Jan de 44, 294, 295

Christiansand (Norway) 116, 206

Clark, Howard A. 47

claw diver see: klauwduiker

Clorn, Cornelis 43, 44, 293, 294

Clorn, Pieter 44, 294

Cock \& Frère, N.J. de 74

Cock, Nicolaes de 77

Coffin, Reuben F. 69-74, 76, 77, 88, 90, 166, 167, 236

Cole Brothers 165

Comet 50

commandeur, responsibilities of the 34

Commerce 208

Committee for the Dutch sea fisheries 148

Concordia (ex-Zylke, ex-Jantina Jetsjkalina) 147

Concordia (wharf) 180

Conijn, Hendricus Johannes 143

Cook, Lyman B. 71

cookeries see also: try-works 28, 32, 38, 49, 55, 103, 112, $113,144,174,175,213,224,263$

- costs 242, 257

Cornelder \& Zahn 219, 220, 221, 222, 223

Cornelisz., Hendrik 44, 294

Corsair 72

Coster, G.A. 189,190

costs and revenues of whaling expeditions 87,101 , $234,235-240,242-265$

crews

- activities in spare time 72, 204, 213-214

- burials and burial procedure 115, 136, 209, 214

- composition of 76, 157, 165, 166-169

- foreign $35,48,88,166-169,171,173,184-185$

- from Amsterdam and vicinity 171,173

- from the Basque provinces 29, 34

- from the Dutch East Indies 169

- from the East Frisian Islands 34, 171

- from England 76, 85, 167, 168, 169, 172

- from the Frisian Islands 103, 177-180, 182, 183

- from Harlingen and vicinity, 177, 178, 179

- from Northern Germany 34, 171, 172, 179

- from Norway 171, 175, 263

- from Rotterdam 121

- from Scandinavia 34, 163

- from Scotland 151, 264

- from the United States of America 69, 75, 76, 166, $167,169,172$

- health and medical care 86, 204-205

- life on board 72, 197-199, 204, 213-214

- payment system see: wages - payment system

- recruiting 34, 48, 70-71, 75, 76, 162, 188, 190, 205

- rules and regulations 198-199, 203, 205

- shifts 199, 212

- size of $157-158,165-166,172,173,174,175,176-177$

- wages see: wages

crow's nest see also: lookout 205, 208, 211

Cupido, Douwe Jansz. 109, 121-123, 297, 298

Cyrus 72 
Damme, D.H. van 121

Danzig 35

Dartmouth (Massachusetts) 69, 160

Davids, C.A. $185,186,191,195$

Davis Strait 27, 29, 35-36, 39, 40, 41, 46, 47, 48, 56, 98, $100,101,103,105,113,122,162,211,241$

Davis, Lance 236

De Gouverneur Baron van Zuylen van Nyevelt 130

De Jonge Martien 127, 208

De Kleine Hendrik 127

De Vrouwe Reintje 224

Dekker, P. 20, 33, 171

Delft 29

Delfzijl 186

Delphine 77

Den Helder 172, 173, 178

Denmark 35

Deventer 230

Diana 70

Dijkman, Frederik 222, 223

Dijkstra, Anne J. 22, 104, 177, 180, 181

Diligentia 76

Dirkje Adema (ex-Nederland) 65, 66, 107, 124-142, 143 $153,160,162,170,175,176,179,180,181,182,184,185$, $195,198,199,200,201,203,204,208,209,212,213$, $253,259,260,300,301,302,303,304,305$

- crew lists 187, 317-322

Dissel, A.M.C. van 21

distribution of whaling and sealing products 80,81 , 229-231

- costs 229-231, 242

Doggersbank 76

Dolstra, Geert Oenes 22, 42

Dordrecht 93, 146, 186

Doxford's Shipyard 165

Draaisma, Cornelis Piers 224

Drift, Pieter Adrianus van de 143

Duivenbode, M.D. van 80

Duncan, David 108

Dundee 107, 108

Dundee (Scotland) 47, 162, 163

Dunkirk (France) 69

Dutch East India Company 26, 30, 40

Dutch Trading Company see: Nederlandsche HandelMaatschappij (NHM)

Duyts, C.E. 85

Eendracht 43, 293

Eersteling 75-76, 77, 162, 167, 237, 239

Eger 143

Ehlers, Jan Diedrichs 106

Elias Schorel, L.H. 104

Elias, J. 121, 122, 188, 190

Elizabeth I 27

Elmshorn (Germany) 49, 197

Elsfleth (Germany) 49

embargo

- English 75, 116, 206,

- French 75
Emilia 46

Enderby and Sons, Samuel 172

Enderby, Samuel 46

Enkhuizen 29, 229

Euterpe 78

Everts, D. 147

Falck, A.R. 171

Falklands 82

Feyfer, H.J. de 190, 191, 193

Fijenoord (shipyard) 159

Filarski, R. 229

fin whales $144,148,240,264$

Finland 172

Finnafjördur (Iceland) 150

Fisher, Lorenzo 87

Flora 127

fluitschip 28, 31, 32, 93

Fock, Abraham 95

Föhr 107, 111, 172

Follema, Tjeerd 218

Fonds ter aanmoediging van de Nationale Nijverheid 53,56

Fontein \& Roquette 219, 220, 223, 228

Fontein \& Tjallingii (v/h Fontein \& Roquette) 221, 222

Fontein, Jan 223

Fontein de Pietersz., F. 104, 117, 124, 192

Fontein Janszoon, Freerk 224

Fontein Pieterszoon, Dirk

food see: provisions

Fotel, C. 148

Foyn, Sven 163

fractional ownership 39, 149

Frankenda(a)l 44, 294, 295

Fraserburgh (Scotland) 163

Friesland

- Admiralty of 100

- Governor of the Province of 58-60, 114, 116, 124, $125,129,132,189$

- States of 45, 56-57, 58-62, 101-102, 114, 128

furs

- polar bear 114, 116, 218, 219, 220, 221, 222, 223, 228

- seal 114, 116, 126, 129, 212, 213, 218, 219, 220, 221, 222, $223,224,227-228,245-246,306-307$

Gaastra, F.S. 159

Gaauw, Jacob 44, 294, 295

Gebhard, F. 170

Gecommiteerde Raden voor de walvisvaart 36-37

Gefken \& Son, Nicolaas 44, 294

Gillieron, Anna Maria Louisa Elisabeth 94

Glückstadt (Germany) 49

Goedkoop, Jan 118

Gordijn, P.J. 204

Gorter, Pieter 201

Gothenburg (Sweden) 174

Gray, George 85-86, 88, 90, 168

Greenland 35-36, 39, 40, 42, 46, 56, 93, 94, 97, 116, 121, 
$122,133,134,142,162,172,189,194,202$

Greenland Company see: Groenlandsche Compagnie Greenland oil 32

Greenland right whale see: whales - Greenland right whales

Grey of Whitby (shipyard) 165

Groendijk, Jan Cornelisz. 108, 118-119, 122, 188, 297, 298

Groenland 94, 96, 98, 99, 100, 105, 160, 171, 173, 184, 199, 246, 247, 248, 249, 295, 296, 297

- crew lists 308-316

Groenlandia 43, 44, 93, 294, 295

Groenlandsche Compagnie (Greenland Company) $27,29,39,48,241$

Groenlandse en Straatdavidse Visscherij Sociëteit 57, $61,62,103-120,123,124,160,177,179,187,188,189$, $218,221,234,240,251-257,260,265,297-299$

Groningen 186, 230

Groot, Klaas de 195

Groot, S.J. de 23

Groot Lankum 130

Grouw 130

Guangzhou see: Canton

Haagsma, S. 22, 116, 124

Haas, Cornelis de 218

Hacquebord, L. 19, 28, 39, 153, 241

Hagen, Teunis 110, 188, 190

Hagens, first name unknown 50

Halbertsma, H. 22, 42

Hamburg 40, 49, 50, 107, 109, 163, 230, 231, 243, 262

Hanekuyk, Jacob 104, 114, 117

Hannover 50, 163

Harderwijk 229

Harlingen 100-120, 124-137, 142-143, 176-183, 185, 186, $189,218,229,242,244,246$

- auctions in 217-224, 227, 228, 244, 245, 335-342

- City Council 45, 58-66, 101-102, 104, 133, 134, 191, 234

- crews from 171,182

- harbour and Zuiderhaven 100, 102, 103, 105, 107, 115, $117,126,130,177,205,206,209$

Harlingen 60, 63, 104, 107, 107, 108, 113, 118, 160, 161, $176,178,179,184,198,203,253,255,297$

- crew lists 178

Harlingen whaling company see: Groenlandse en Straatdavidse Visscherij Sociëteit

Harmens, A. 191, 192

Harmonie 137

Harris, David 72

Hart, S. 20, 30

Hashagen, H. 50

Hawai'i 75,78

Heemskerk brothers 85

Heep, H. 116, 132

Heep, J.J. 132

Heeren Logement (inn) 110, 218

Heide, Johannes Eeuwes van der 113

Heijer, H.J. den 149

Hellevoetsluis 70, 74, 75, 76, 166, 237
Helmers, H. 137

Hendrik, Prince of the Netherlands 80

Heppens (Germany) 84

Herderschée, D. 122, 188

Herstelder, De (cookery) 61, 112, 113, 177, 213

Hetscher, H.I. 73

Hillenius, Jantje Jans 108

Hobart (Tasmania) 86

Hoboken, Anthony van 68-69

Hodhon, Joan 95

Hoekstra, A. 108

Hoekstra, J.P. 192

Hoekstra, Klaas Sytses 107, 108, 109, 110, 111, 113, 114, $115,118-120,161,172,176,178,179,182,190,197,204$, $224,227,297,298,299,300$

Hoekstra, Sytse 179

Hoffman, M.A.F.H. 68-69, 121

Hoffnung (Flensburg) 128, 208

Hoffnung (Hamburg) 127, 208

Hogerzijl, Johannes 43, 44, 294, 295

Holbou, Carl Peter 161

Holland oil 32

Hollmann, Johann 133

Honig family (Zaandam) 39

Honig, Cornelis Claesz. 97, 99

Honig, G.J. 97, 98

Honig, M.K. 99

Honolulu 53, 87

Hood, John 172

Hoop op de Walvisvangst 44, 294

Hoop, De (herring fishery company) 56

Hoorn 29

Hornby Wellington, W.B. 149, 165

Horneman, H.F. 75-76, 77, 90, 162, 167, 237

Hortense 73

Houter, Jan 180

Houwink, Albertus 192

Howland \& Co., John 70, 235

Howland, Isaac and Gideon 235

Hudson 50, 199, 201, 204

Hudson Bay 52, 258

Hull (Scotland) 47, 98, 162, 163

hunting grounds see: whaling grounds

Hussey, Benjamin R. 73

Huyssen van Kattendijke-Frank, Katrientje 80

Hysco 70

Iceland $35,147,148,149,150,153,209,264$

ice-whaling 29, 31

IJzenbeek, Jan Sikkes 104, 117, 219, 221

import tariffs 36

Indian Ocean 52, 68, 77, 82, 90, 239

Innema, Douwe 218

Insinger \& Co. 78

Insinger, Herman Albrecht 78

Insinger, Johannes 77-78

Inuit 35, 40, 52, 99

Isle de Richelieu also: Jan Mayen 48

Itzehoe (Germany) 107, 124, 160 
Jackson, G. 28, 46-47

Jacobs, E.M. 83

Jan en Albert 147

Jan Mayen 28, 35, 39, 48, 56, 93, 111, 112, 126, 127, 128,

$143,144,146,161,205,208,209,241,258$

Jansen, M.H. 154

Jansen, Michael 159, 160, 225, 238, 253

Jansz. Dz., L. 192

Japan $71,83,167$

Japanese Sea 70,82

Jaski, F.C. 192

Java (Dutch East Indies) 77, 80, 89

Johanna Cornelia 76, 237

Johnson, A.O. 22

Jong, C. de 19-23, 29, 32, 35, 39, 146, 153, 157, 172, 183 , 250, 262-263

Jong \& Son, Pieter de 44, 294

Jongewaard Jr., Simon 43, 293

Jonker, Joost 69, 78, 85, 224

Jonkhert, J. 192

Julian 50

Kall, Peter Julius 161

Kallenborn, Pieter 191, 323

Kampen 229

Kater, K. 147

Katoen, Wesselius 195

Keller, Jacob 121-123, 297

Ketelaar, J. 146

Ketelsen, Erik 127

Keulen, Hendrik van 183

Keulen, Jacob van 183

Keulen, Willem Hendrik van 183

Kirkaldy (Scotland) 163

klapmutsen 112, 205-206

klauwduiker 152

Knodsen, Sören 16, 206

Knudsen, N. 142

Koch (also spelled Kok), C. 142

kofschip 99, 126, 130, 131, 147

Kok Houwink, Herman 192

Koningsberg 35

Koog aan de Zaan 97

Koophandel 174

Korff, A. 106

Kupang (Timor) 83, 85, 168

Kraijer, D. 191

Kreulen, G. 122, 188

Krijt, Gijsbert 98, 99

Kroese, Johan 112

Krooshof, Paul 193

Kuijper, Claas 99

Kuijper, Cornelis 97

Kuijper, Lijsbeth see also: Vas, Weduwe Jan 97, 98-99

Kutschura, Julius 201

Kwade Hoek (Spitsbergen) 111, 205

Kweekschool voor de Zeevaart see: Nautical College in Amsterdam
Laan, A. van der 134

Labrador 26

land stations see also: shore stations 31, 41, 150, 241

Landberg, P. 69, 70, 166

Landswelvaren (also spelled sLandsWelvaren) 43, 44, 293, 294

Larsen, L.A. 146,305

Lautenbach, Dirk 192

laws

- Corn Laws 58

- foreign ships under Dutch flag 167

- Laws of Navigation also: Navigation Acts 58

- restriction on seal hunt $144-145$

Le Havre (France) 48, 49

Ledeboer, Jean Louis 118

Leemkoel, Bernardus 222, 223

Leinenga, J.R. 20, 21, 241, 243

Leith (Scotland) 126

Lerwick (Shetlands) 151, 183

lighthouses 224-225

Lilliendahl, G.A. 147,148

Lindeman, M. 46, 50, 199, 201-202, 258

Lively (Greenland) 161

Liverpool 172

Logan 69-74, 76, 88, 160, 162, 165, 166, 169, 170, 217, $235,236,238,239$

London $46,47,72,80$

lookout see also: crow's nest 208, 211

Lootsma, S. 243

losses 36, 52, 75, 76, 86, 87, 99, 118, 123, 236, 237, 239, 241, 265

Lottum, Jelle van 210

Louis XVI 48, 69

Louis-Philippe 49

Louisa Augusta 75

Lübbers, W. 50

Luden \& Van Geuns 85

Luden, J.H. 85

Lund, J. Navas 70

Lynx 77

Maasstroom 109, 121-123, 183, 297, 298

Maatschappij tot Nut van het Algemeen 190-191

Madou, Jean Baptiste 189

Magdalena Bay (Mexico) 87

Magdalena Bay (Spitsbergen) 117, 206

Mandell, Thomas 235

Manheim, J.H. $108,188,190$

Manila 73,78

Mansvelt, W.M.F. 159

Maria 144, 145, 146, 160, 163, 164, 174, 175, 185, 261, 304, 305

Maria Reigersbergen 77

Marselis, J. \& Th. van 84, 233

Martens, Friedrich 33

Martha 144

Martha's Vineyard (Massachusetts) 69

May, Jan Jacobsz. 28

May, William 171 
Mazarin 48

Mediterranean 19, 34, 35

Meer, W.J. van der 137

Mees \& Zoonen, R. 123

Mees, A. 68-69

Mehlen, Otto 130-136, 139-141, 176, 209, 301, 302, 303, 304

Meij, Simon van der 110

Mein, L. 127

Meinsma, Meindert 195

Melville Bay (Baffin Bay) 107, 108

Menado (Celebes present day Sulawesi) 168

Mennonites 97-98

mercantilism see: subsidies - mercantilism

Mercurius 137

Metzelaar, Tjerk Pieters 110

Mey van Streefkerk, J.G. de 104

Mey, J. van der 88, 90, 168

Meyer, A.J. 87, 88, 90, 169

Middelburg 29, 186

Miller, Peter 172

Minde, Adam van der 223

Moelen, Otto 127

Molk, Hendrik van der 183

Molk, Jan van der 183

Mollema, C. 113

Mollema, Jarig Cornelis 101, 113, 117, 219, 221

Moluccan islands (Dutch East Indies) also: Moluccas $80-82$

Mooij, Marten (also spelled Maarten) 44, 294, 295

Moreen, Carel J. 172

Mörzer Bruyns, W.F.J. 185

Muller Fzn., S. 21

Murk, H. 143

Muscovy Company 27

Musschenbroek, S.C.J.W. van 22-23, 69, 88-90, 164, $169,175,182,239,240,259$

Muyden, Willem van 27

Nagel, P. 134, 140, 303

Nahuys van Burgst, H.G. baron 81

Nantucket (Massachusetts) 46, 50, 69, 70, 72, 88

narwhals 35, 112, 128, 206, 207, 209

Nautical College in Amsterdam 109, 121-122, 166, 167, 169-170, 186-190, 187, 189, 191, 192

- list of pupils 188,190

Nautical College in Harlingen 186, 190-197, 323-324

- careers of whalemen educated at 195, 330-335

- list of pupils 196-197, 323-329

navigational education $185-186,191,192$

Nederland 61, 63, 64, 107-120, 124, 180, 188, 190, 206, 253, 255-257, 260, 297, 298, 299

Nederlandsch Aardrijkskundig Genootschap (Dutch Geographical Society) 153,154

Nederlandsche Handel-Maatschappij (NHM) 19, 53, $69-74,79,81,84,88,90,102,159,160,165,166,170$, 195,235

Nederlandsche Maatschappij ter Bevordering van Nijverheid 154
Nederlandsche Maatschappij voor Walvischvangst 69, 121-123, 187, 188, 297, 298

Nederlandsche Stoomboot Maatschappij 56, 79

Nederlandsche Walvischvaart N.V. 149-153, 165, 183, 264-265, 305

Nederlandsche Walvischvisscherij Maatschappij 8184

Nellie 165

Neptune 165

Netscher, Johannes Theodorus 55,80

New Bedford (Massachusetts) 50-51, 70, 235, 236

New London (Connecticut) 51

New York 70-74, 167, 170, 217, 235

Newcastle upon Tyne 150, 160

Newfoundland 26

NHM see: Nederlandsche Handel-Maatschappij (NHM)

Nieuwe Noordsche Compagnie ter uitoefening van de Robben- en Walvischvangst in de Noordelijke IJszee 154,258

Nijburg, Simon 221, 222, 223

Noord- en Zuid-Hollandsche Redding Maatschappij (NZHRM) 95, 96, 106

Noordkaper 149, 150, 151, 153, 154, 160, 165, 183, 185, 264, 305

Noordpool (ex-Cameleon) 142-143

Noordsche Compagnie see: Groenlandsche Compagnie

North Pacific 46

Norway $35,96,99,116,126,132,137,143,144,162,163$, $174,206,207,258,263$

Novaya Zemlya $26,27,29$

off-season activities see also: wages - additional income oil

- cole seed 225

- seal 113, 114, 126, 129, 131, 218, 219, 220, 221, 222, 223, $224,225,246,306-307$

- sperm see: sperm oil

- turnip 225, 226

- use of 52, 224-226

- whale $26,27,28,46,75,77,80,87,88,114,116,129$, $131,150,151,165,167,170,217,218,219,220,221,222$, 223, 224-226, 229-231, 236, 237, 244-246, 306-307

oil prices $47,74,75,76,115,133,170,236,242,244-246$, 259, 264

oil producers 96-98, 99, 119

oil production see: trying-out

Okken, J. 128

Oldenburg (Germany) 132, 172, 178, 202

Onderneming 43, 44, 293, 294

Oom, Frans 98, 99, 100, 105, 173, 250, 296, 297

Oosterling, J.E. 21

Oosterloo, Arend 208

Oregon 50

Ortt, H.J. 95

Osenburgen, Christoffer 132

Osy, P. 68-69

Osy \& Son, Joan 69

Ouendag, Hermanus 224, 228 
Ouwehand, D. 98

Ouwerkerk de Vries, Jan van 41

Pacific Ocean 52, 77, 86

Parma, S. 135

partenrederij see: fractional ownership

partgeld see: wages-payment system 200

Pauline 49

Peace of Amiens also: Treaty of Amiens 23, 24, 40, 41, 42

Pearl River (China) 78

Peereboom, Willem 192

pelagic-whaling see: whaling - pelagic

Perseverance 208

Peru 78

Peterhead (Scotland) 46, 47, 163, 208

Petermann, A. 258, 259

Pierce, Abraham Wilcox 86-87

Plas, W. van der 21

Pleasant Island present day Nauru 71

Point Belcher (Hudson Bay) 52

polar bears 46, 112, 136, 205

Pollux 77

Ponsilius (also spelled Bonfillios), H. 127

Poppe, Christian 128, 208

Posthumus, N.W. 76, 115, 241-245, 260

premium system see: subsidies

processing the whale see: whaling - processing

profitability $39,49,233-265$

Pronker, Pieter Douwes 179

Proserpina 76, 77, 79, 160, 237, 239

Providence (Rhode Island) 51

provisions 201, 203-204, 212

Purmerend 143, 144, 171, 175, 261, 263

Pyttersen, Barius 192

Rab, Willem 101, 296

recruiting see: crews - recruiting

Reederij voor de Zuidzee Walvischvangst (Reelfs Bro-

thers) $84-88,90,168,169,238,239$

Reelfs, Johann Anton and Johann Hayen 84

Rees, Cornelis van 180, 183

Rees, Dirk van 183

Rees, Kees van 180

religious holidays and Sundays see: crews - activities in spare time

Resolution 46

results see: catch results

Retgers, J.W. 122, 188

revenues see: costs and revenues of whaling expeditions

Ricard, J.P. 243

Richelieu 48

Rickmers, Hendrik (originally Hinrich) 107, 111-120, 125-130, 132, 137-139176, 189, 205, 206, 207, 252, 297, 298, 299, 300, 301

Rickmers, Hinrich Braren 128-130, 138-139, 208

Riel, A. van 19, 53

Riga 35

rivalry see also: whaling-competition 27,29 rocket bomb harpoon gun see: vuurpijlbomharpoenkanon

Rodenhuis \& Son 137

Rodenhuis \& Sons, Weduwe 222, 223

Rodenhuis, Bouwe 219, 220, 221, 222, 224, 228

Rodenhuis, Pieter 101, 104, 117, 123, 241

Rodenhuis, Ype Jetzes 101, 104, 117

Rodenhuis, Ysen Pieterszoon 191, 192

Roentgen, Gerard Moritz 159

Roggeveen, Jacob 77

Roma (inn) 116, 129, 132, 218, 221, 234

Roopaard, Het (shipyard) 85

Rosenthal, F.W.A. $163,164,262$

Rotterdam 29, 68-69, 70, 75, 101, 105, 109, 121, 122, 151, $159,167,171,186,187,226,229,230,237$

- City Council 121, 123

Rotterdam 121-123, 183, 297

Royal Netherlands Navy 19, 77, 79, 80, 84, 159, 160, 186,334

Roys, Thomas Welcome 147, 148, 152

Rügen (Germany) 137, 162

Ruig, Pieter Cornelisz. 43, 44, 294

Ruygh, Ymke Jansz. 101, 102, 105, 106, 118, 176, 178, 179, 182, 296, 297

Saar, first name unknown Du 204

Saint-Jean-de-Luz (France) 48

Samoa Islands 87

San Francisco $53,87,169,180$

Sandefjord (Norway) 143, 174

Sandwich Islands present day Hawai'i 71, 73, 79

Schaik, J.W. van 109, 188, 190

Schenk, H.P. 192

Schenk, Willem 192

Schere, Simon Jansz. 110

Schermerts, H.H.V.N. 108, 188, 190

Schieland, Hinrich 115, 206

Schiermonnikoog 177,190

Schiphorst, Jacob 127, 128, 207, 208

Schippers, J.H. 188,190

Schols, A. 21

Scholten, Jan Reinhart 41

School voor Wis- en Zeevaartkunde see: HarlingenNautical College

Schoor \& Sons, Frank van den 93, 294, 295

Schöder, Jan 115

Scoresby Jr., William 28, 94

Scroo, Willem 180

Sea of Okhotsk 51

seal hunters see: sealing

sealing

- Arctic 49, 102, 111-112, 195, 205-213, 217, 293-305, 306-307

- British 126, 144

- German 49

- Norwegian 144-145, 258

- products see: furs-seal and oil-seal

- Scottish 164, 183, 258

- slaughtery 212 
Senus, Willem van 54,55

Seydisfjördur (Iceland) 147, 148, 150, 151, 152

Sexbierum 214

shipbuilding $26,30,38,74,86,88,89,126,157,158-165$, $169,234,236,238,253$

shipbuilding in Harlingen 101, 105, 108

shipbuilding in the Zaanstreek 29-30, 31

shipwrights

- American 160, 162

- Dutch 74,105,162

- English 160, 162

- German 160, 162, 163, 262

- Norwegian 162

- Scottish 162

shore stations see also: land stations 147, 148, 153

Siderius, Herman 107

Sileno 148

Singapore 89

Sissingh, Albertus J. 191

Sjollema (shipyard) 130

Slee, A. van 191

Slooten, Sipke van 222, 224

Slooten, T.H. van 195

Sluyterman, K. 69, 85

Smeden, Bauke van 195

Smeer, Frans 68-69, 121, 187

Smeerenburg (Spitsbergen) 28, 39, 241

Smith, J.P. 76, 77, 90

soap 219, 225

Souter, first name unknown 46

South America 51

spare time activities see: crews - activities in spare time

sperm oil 53, 72, 73, 75, 76, 77, 86, 87, 170, 236, 237

- price $74,76,170,225,236$

sperm whales $52,71,72,80,90,146,167,226$

spermaceti $52,86,240$

spermaceti candles 225, 226

Spes et Fides 163

Spits (also spelled Spitz), Jacob 182

Spits, Jacob Jelle 180, 182

Spitsbergen $26,28,29,32,35,39,40,46,48,56,93,96$ $98,100,105,111,112,115,127,128,146,162,205,206$, $208,209,241,258$

Spitsbergen 59, 61, 62, 63, 101, 103, 105, 107, 108, 110, 118, $179,184,255,259,260,296,297$

Spitsbergen (II) 63, 64, 65, 66, 110-120, 124-141, 142, 160, 176, 179, 195, 205, 206, 207, 208, 209, 253, 255$257,298,299,300,301,302,303$

- crew lists 180, 189

Spreekens, Barend van 93-96, 171, 172, 173, 185, 219, 220, 221, 222, 223, 234, 246-249, 261, 265, 295, 296

Spreekens, Schelte van 94

St Helena 167

St. Martin \& Co. $74-77,90,237,238$

Staperaider 148

Starbuck, Alexander 72, 74

States Gereral 27, 29, 33, 36, 40, 45-46

States of Friesland see: Friesland-States of

States of Holland 36
Stavanger (Norway) 42

steam ships also: steamers 47-48, 49-50, 144, 145, 149, $154,159,162-165,231,262,264,265$

stearine 226

Stedinge (Germany) 49

Stedinger Company 49

Stellmann, Hermann 128, 208

Stellwagen, A.W. 144, 175

Stephens \& Son 162

Stinstra, Simon 224

Stockfleet (also spelled Stockfleth and Stokvleet), Her-

man $127,135,140,142,208,303$

Stoffels, Simon 192

Stratenus, A.A. 55

street lightning 224, 226

Storck, Abraham 37

Stuijt, Maria 143

subsidies $53-66$

- application procedures 57

- bounties 46-47, 49

- British 36

- French 36

- governmental 36-37, 40-41, 46-47, 48, 53-66, 75, 84, $86,102,103,113,115,128,129,131,132,134,142,144$, $234,237,242,248,249,253,254$

- mercantilism 36,48

- parties involved in the granting of 59

- premium system 37, 40, 53-66, 67, 93, 94-95, 101, $113,122,123,134,137,159,177,248$

- regulations 40

- shipbuilding 159

Suft (also spelled Sinft), Mathijs 115, 116, 206

Surabaya (Dutch East Indies) 168

surgeons see: crews - health and medical care

Swart, J. 77

Sydney $87,166,169$

Sytzama, Maurits Pico Diederik baron van 130

Taats, Dirk B. 173

taxes 40, 54, 223, 254

Telsemeijer, Gerardus 224

Templeman Brown, James 47

Ternate (Moluccas) 80, 86

Terschelling 101, 173, 177, 178, 179, 180, 182, 183, 190, $192,198,209,218$

Teves, M.C. 154

Texel 105, 108, 177, 178, 179, 250

Teyler van Hall, Adriaan 41

Thijssen Pals, Cornelis 183

Thorbecke, Jan Rudolph 57, 186

Tieman, F. 167

Tindal, G.A. 77

Tønnessen, J.N. 22

Tønsberg (Norway) 143, 163, 164, 174

Tot, Klaas 180

traan see: oil

traankokerijen see: cookeries

transportation see: distribution of whaling and sealing products 
Treking, Harmen 178

Trident 70

Triton (ex-Spitsbergen (II)) 135

Tromp, G.C. 192

Tromp, Tjelling 43, 293

Trondheim (Norway) 42

trying-out 28, 29, 133, 148, 150, 212, 213, 224, 228, 253

try-works see also: cookeries 28, 29, 31, 38, 224

- on deck 150, 165, 212

Tuckermann, L.H.F. 154

Tynemouth (England) 149, 165

Tzummarum 214

Umbgrove, Johan Lumbert 41

unicorns see: narwhals

Utrecht 229

Valckenier, Jan 224

Valparaiso (Chile) 87

Vas \& Co. 96-100, 97, 105, 172, 173-174, 234, 249-251, 261, 265, 296

Vas \& Company, Jan see: Vas \& Co.

Vas \& Dekker 43, 44, 97, 293, 295

Vas, Aaltje 98-99

Vas, Jan 96-97

Vas, Vastert Claasz. 96-97

Vas, Weduwe Jan 98-99, 297

Veder, Hendrik 149

Veendam 186

Veenhuizen, J.H. 188,190

Veenstra, W.C. 122, 188

Vellinga, Tjeerd Jacobs 112, 113

Veltkamp, P. 122

Vereeniging tot Walvischvangst om de Zuid 75, 162

Verhoeff, J.M. 243

Vervoort, Hendrik 224

Ville de Dieppe 48

Visser \& Son, Barend 57, 62, 65, 100-103, 124-142, 179, 191, 198, 200, 205, 218, 219, 220, 221, 222, 223, 228,

234, 257-262, 265, 296, 297, 300-305

Visser, Barend 101, 118, 125, 142, 160, 176

Visser, Dirk 99

Visser, Klaas 201

Visser, Vastert Vas 99

Visschershoop 44, 294, 295

Vlieland $177,178,180,190$

Vlierboom, C. \& A. 75

Vliet, A.P. van 30

VOC (Vereenigde Oostindische Compagnie) see: Dutch East India Company

Vollenhove, H. van

Voorland (Spitsbergen) 205, 208

Voort, J.P. van der 185

Vrede 145

Vriendschap 43, 44, 97, 293, 295

Vries, first name unknown De 121, 188

Vries, J. de 30

Vries, Sietse de 204

Vriesland 134
Vrolicq, Jean 48

Vroom, W. 20

Vrouw Catharina (ex-Dorothea) 99

Vrouwe Jantina 108

vuurpijlbomharpoenkanon 148-149, 151, 152

wages $157,161,170,172,188,189,198,199-203,234,236$, $242,246,247,257$

- additional income 201-203

- Arctic whaling 199-203

- payment system 200

- South Seas whaling 170

Walkes (also spelled Walker), P.T. 121

Wallen van Vollenhoven, J. van der 69, 237

walruses 46, 103, 211

wanvangst $40,41,56-57,60,67,102,113,122,123,126$,

$128,129,130,131,132,133,134,135,241,248,249,250$

Ward, S. 86,168

wars

- American Civil War (1861-1865) 52

- American War of Independence (1776-1783) 38

- Belgian Revolt (1830) also: Ten Days' War 75, 79

- Fourth Anglo-Dutch War (1780-1784) 38

- Franco-Prussian War (1870-1871) 50

- Napoleonic Wars (1795-1802; 1803-1813) 39, 48, 53, 93, 100

- War of 1812 50,51

Waterloo 102, 125

Weerd, M.J. de 137

Weerd(t), H. de 130

Weide Bzn., J. van der 22, 198, 200, 211, 228

Welgelegen see also: Alta's wharf 105, 111, 161, 253

Wellinga, Daan 192

Wells, Moses L. 74

Westermeijer, J.H. 50

Wever, Jan 137, 180, 198, 200, 211, 212, 214

whale fishery and whale hunting see: whaling

whale oil see: oil-whale (see also Greenland oil and Holland oil)

whalebone see: baleen

whalemen see: crews

whaleship construction see: shipbuilding

whales

- baleen whales 28, 212, 226

- bowhead whales 52, 226

- Greenland right whales (Balaena mysticetus) 28, 239,240

- Noordkapers 149, 226

- right whales 28, 226, 239

- sperm whales see: sperm whales

whaling

- American 50-53, 74, 83, 88, 146, 148, 156, 212-213

- Arctic 26-41, 42, 46-48, 56, 171-185, 195, 199, 217, 234, 240-265, 293-305, 306-307

- Basque 26, 48

- British 27-28, 45-48, 52, 126, 156

- competition see also: rivalry 27, 29, 45, 46

- dangers 32-33

- Dutch East Indies 82-83, 88-89 
- French 48-49, 69, 156

- German 49, 156

- in times of war 38,52

- Indian Ocean 52,82

- new methods of 148-153

- North Pacific 46

- Norwegian 163

- Norwegian in the Viking Era 26

- pelagic 29, 79, 150

- processing 28,31,33,37, 212, 224

- products see: baleen, oil -whale, sperm oil and spermaceti

- results see: catch results

- Scottish 46-48, 52, 156, 163, 164, 183, 258

- South Seas 41, 46, 48, 49, 53, 56, 68-91, 165-170, 233 , 235-240

whaling grounds

- Alaska and Siberia 51

- Arctic 56, 205-213, 210

- Bering Sea 51

- Iceland 149-152

- Japan 51,72, 82-83

- Norway 144

- Peru 51

- search for $35-36,46,51$

whaling procedures

- American 212-213

- Dutch 28, 212-213

Whitby Steam Ship Company 165

Wiarda, Ids 224

Wiarda, Simon 224

Wieringen, Cornelis Claesz. van 33, 34

Wijga, Inne Innes 102

Wijk, Jan A. van der 127

Wijma, Sjoerd Simons 104, 114, 117

Wildst, Hendrik 136, 137, 141-142, 193, 195, 198, 201, 204, 214, 304, 305

Wilhemina \& Maria (ex-Euterpe) 77,78
Willem I 45, 53-54, 54, 62, 68, 79, 93, 95, 102, 103, 104, $113,121,158,159,186,226,229,250,253$

Willem II $57,62,83,86$

Willem III 154

Willem 137

Willem de Eerste 59, 60, 62, 63, 105, 106, 118, 160, 161, $176,178,179,253,297$

Willem de Eerste (II) 108, 118-119, 122, 253, 255, 297, 298 Willem Eggerts 174

William Hamilton 86-87

Willinck, J.P.M. 77

Winter, Hendrik 110

Witveld, Cornelia 94

Wormerveer 96, 97, 99, 171, 249

Woude, A.M. van der 20

Wumkes, G.A. 179

Wyk auf Föhr 111, 125, 176

Yzenbeek, Jan Sikkes 101

Zaandam and vicinity (Zaanstreek) 29-30, 38, 97, 98, 229

Zaandam 43, 94, 294, 295

Zadelberg (Spitsbergen) 208

Zanden, J.L. van 19, 53

Zappey, W.M. 56

Zegers Veeckens, L. 188

Zeilmaker \& Company 135, 142-143, 174

Zeilmaker, Reindert Jans 135,142

Zijlstra, Dirk Cornelis 101, 104, 110, 117, 118, 124, 219, 221, 222, 224

Zorgdrager, Cornelis 28,33

Zuidpool (ex-Proserpina) 86-87, 88, 160, 166, 169, 238, 239

Zutphen 230

Zuylen van Nyevelt, Jan Adriaan baron van 124, 129130, 189

Zwaal, Lolke 192 